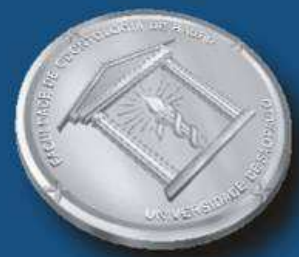

\title{
ज1 10
}

\section{Estudo Eomparativo dos efoitos} do tratamento da má oclusäid de Classe II, P divistio EOm os apardilios

\section{Jasper Jumper o Bionator, assobiados a0 aparallo fixo}

\section{Leniana Santios Neves}

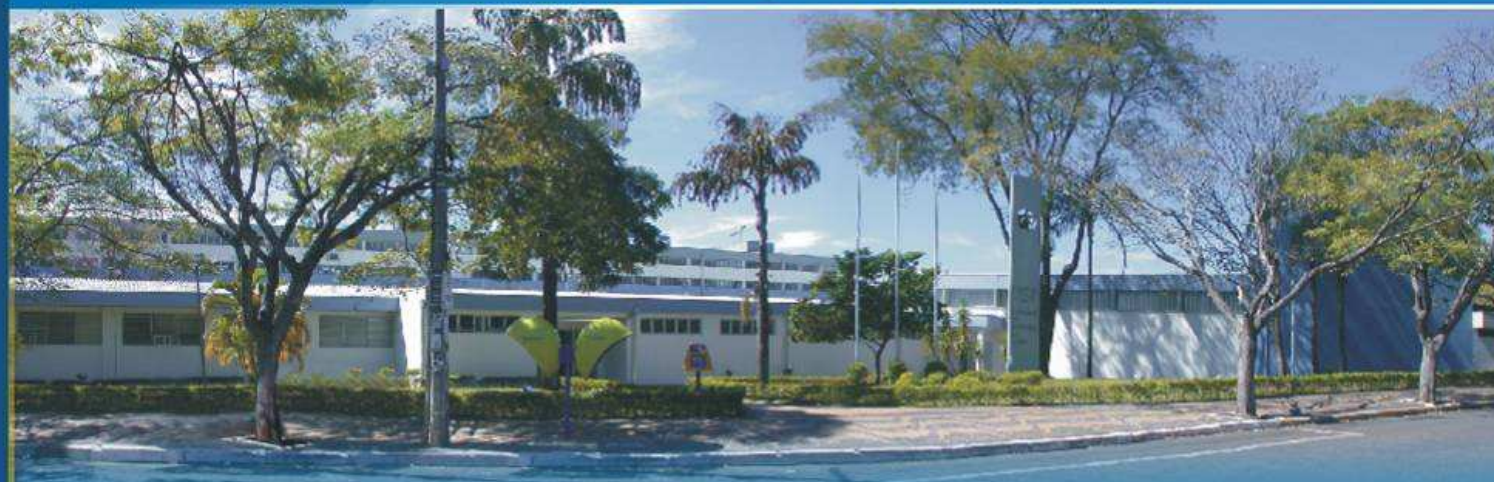

Tese apresentada à Faculdade de Odontologia de Bauru, da Universidade de São Paulo, como parte dos requisitos para obtenção do título de Doutora em Odontologia, área de Ortodontia. 



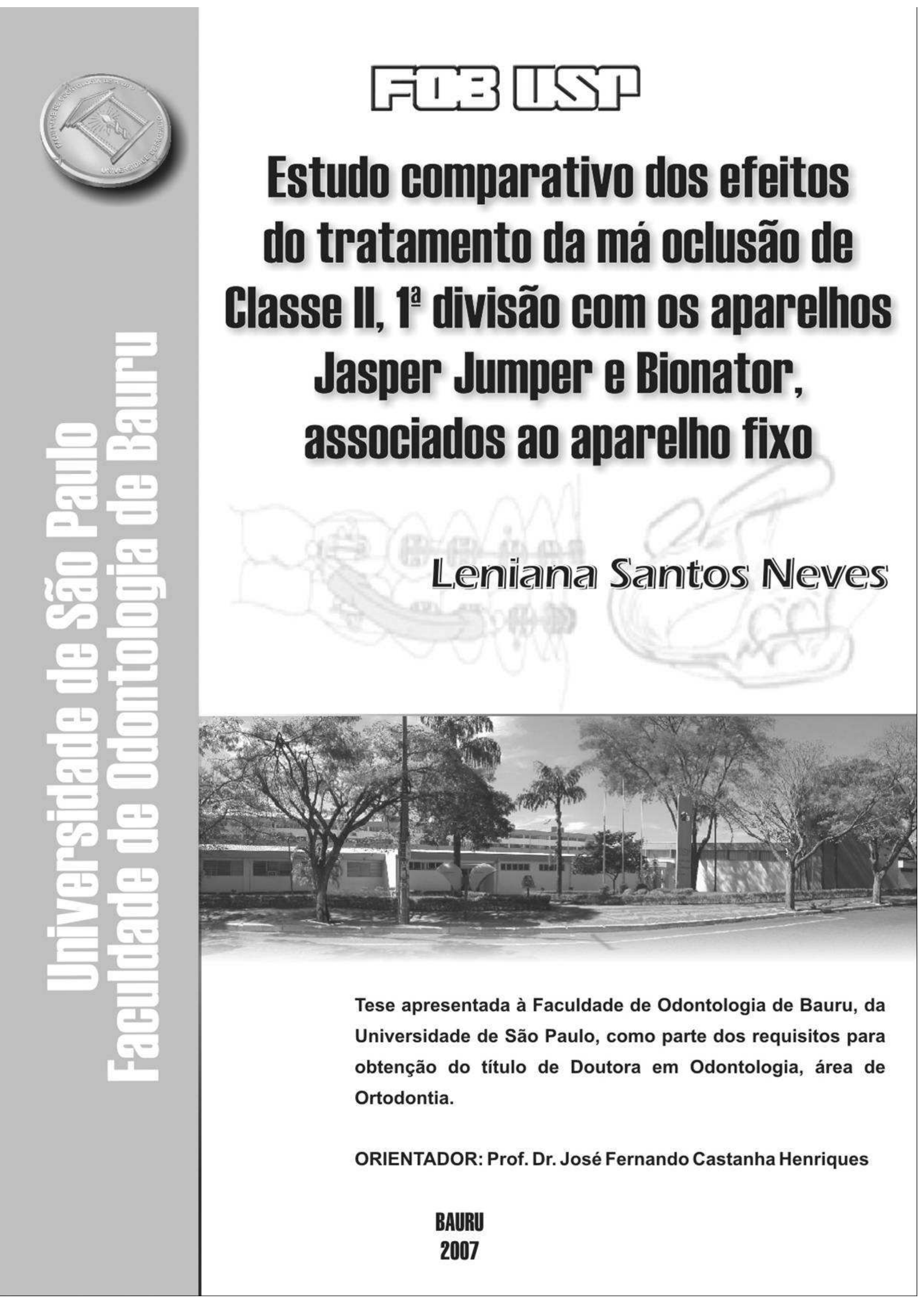




\begin{tabular}{|c|c|}
\hline \multirow[t]{3}{*}{ N414e } & $\begin{array}{l}\text { Neves, Leniana Santos } \\
\text { Estudo comparativo dos efeitos do tratamento da má oclusão de } \\
\text { Classe II, } 1 \text { a divisão com os aparelhos Jasper Jumper e Bionator, } \\
\text { associados ao aparelho fixo / Leniana Santos Neves. -- Bauru, } 2007 \text {. } \\
263 \text { p. : il. ; } 29,7 \mathrm{~cm} \text {. }\end{array}$ \\
\hline & Tese (Doutorado) -- Faculdade de Odontologia de Bauru. USP. \\
\hline & Orientador: Prof. Dr. José Fernando Castanha Henriques \\
\hline
\end{tabular}

Autorizo, exclusivamente para fins acadêmicos e científicos, a reprodução total ou parcial desta dissertação, por processos fotocopiadores e outros meios eletrônicos.

Bauru, 06 de fevereiro de 2007.

Assinatura:

Projeto de Pesquisa aprovado pelo Comitê de Ética em Pesquisa da Faculdade de Odontologia de Bauru, Universidade de São Paulo. Processo no 100/2003 


\section{LENIANA SANTOS NEVES}

06 de outubro de 1973

Diamantina - MG

Filiação

$1993-1996$

$1999-2001$

$2001-2003$

$2003-2007$

$2005-$

$2005-$

Associações
Nascimento

Amauri José Neves

Maria Helena Santos Neves

Curso de Graduação em Odontologia pela

Faculdade Federal de Odontologia de

Diamantina (atual UFVJM - Universidade

Federal dos Vales do Jequitinhonha e Mucuri).

Curso de Aperfeiçoamento em Ortodontia pela ACOPEN - Bauru - SP.

Curso de Pós-Graduação em Ortodontia, ao nível de Mestrado, pela Faculdade de Odontologia de Bauru - Universidade de São Paulo.

Curso de Pós-Graduação em Ortodontia, ao nível de Doutorado, pela Faculdade de Odontologia de Bauru - Universidade de São Paulo.

Consultora científica da revista "American Journal of Orthodontics and Dentofacial Orthopedics"

Professora do Curso de Especialização em Ortodontia da Universidade Federal dos Vales do Jequitinhonha e Mucuri (Diamantina - MG).

- AMEO - Associação Mineira de Especialistas em Ortodontia e Ortopedia Facial

- Sociedade Brasileira de Pesquisa Odontológica (SBPqO) 
"Sei que o meu trabalho é uma gota no oceano, mas sem ele, $\sigma$ oceano seria menor."

(Madre Teresa de Calcutá)

"Dar menos que seu methor é sacrificar o dom que você recebew."

(Steve Prefontaine) 


\section{DEDICO ESTE TRABALHO}

A $\underline{\text { Deus }}$, por Sua presença iluminada em minha vida, permitindo que eu tivesse saúde, tranqüilidade e força para seguir o meu caminho. Agradeço pelas pessoas maravilhosas que o Senhor colocou ao meu lado. Agradeço pelo dia de hoje, pela conclusão deste trabalho. Enfim, agradeço por ser uma pessoa feliz e abençoada por Ti!

“A Deus, que nos deu o dom da vida,

$\mathcal{N}$ os presenteou com a liberdade,

Nos abençoou com a inteligência,

$\mathcal{N}$ os deu a graça de lutarmos

Para a conquista das nossas realizações

Cabe o louvor e a glória.

$\mathcal{A}$ nós só cabe agradecer"

(Rui Barbosa)

Aos meus queridos pais, Amauri e Maria Helena, não existem palavras que possam expressar fielmente os meus sentimentos de gratidão e amor por vocês. Hoje estou aqui, concluindo este grande sonho, graças ao incentivo e apoio que sempre me proporcionaram. Agradeço por estarem sempre ao meu

lado, vibrarem a cada conquista minha, e serem a minha fortaleza nos momentos mais difíceis.

"Você pode sonhar, criar, desenhar e construir o lugar mais maravíthoso do mundo... Mas é necessárío ter pessoas para transformar seu sonho em realidade..."

(Walter Elias Disney) 
Aos meus irmãos, Janeysa, Lucyla e Rodrigo:

A minha vida não teria a mesma alegria sem vocês! Agradeço por serem tão companheiros e amigos. Agradeço por estarem sempre presentes em minha vida, vivendo as minhas alegrias e conquistas, e dividindo as minhas dificuldades ou tristezas. Amo vocês!

"Uma amizade verdadeira é como uma alma em dois corpos" (Aristóteles)

\section{Ao meu noivo Rodrigo:}

Agradeço por estar sempre ao meu lado, por ser uma pessoa em quem posso sempre confiar e contar... agradeço por todo amor e carinho... você é um grande profissioanal, uma pessoa maravilhosa, que tenho o privilégio de conviver desde que nos conhecemos em Bauru. Você é um exemplo de força, de perseverança e garra. Saiba que te admiro muito, você é especial em minha vida. AMO VOCÊ!

Não poderia deixar de te agradecer por todo apoio e auxílio durante o curso de Doutorado, durante o desenvolvimento deste trabalho, inclusive na elaboração da análise estatística desta pesquisa.

"Há momentos na vida em que se devería calar... e deixar que o siềncio falasse ao coração; poís há sentimentos que a linguagem não expressa... e há emoções que as palavras não sabem traduzir..."

(Autor Desconhecido)

A todos vocês, dedico este trabalho. 


\section{AGRADECIMENTO ESPECIAL}

Ao estimado Prof. Dr. José Fernando Castanha Henriques, meu orientador e coordenador do nosso Curso de Doutorado, agradeço pelo apoio e confiança durante toda a realização deste trabalho. Agradeço por ter estado sempre disponível para me receber, apesar de todas as suas atribuições enquanto ocupou o cargo de Prefeito do Campus desta Faculdade, respondendo tão prontamente aos meus questionamentos, sempre com palavras confortantes e incentivadoras. A sua orientação e auxílio foram determinantes e imprescindíveis para constituir a amostra do Jasper Jumper. O senhor estará sempre em minha memória como um exemplo de Mestre, Orientador e Administrador. Extendo os meus agradecimentos à sua família, que sempre me tratou com muito carinho e amizade.

"Feliz aquele que transfere o que sabe, e aprende o que ensina." (Cora Coralina) 


\section{AGRADECIMENTO ESPECIAL}

A minha grande amiga Karina Lima:

Você é mais que uma amiga, é uma irmã que Deus me presenteou. Agradeço por ter compartilhado comigo tantos momentos felizes, como também por estar em meu lado nos mais estressantes... agradeço por ter assumido junto de mim a montagem da amostra do Jasper Jumper, tarefa árdua, mas recompensadora, e que com certeza se tornou mais amena com o seu auxílio. Agradeço por ter dividido até mesmo o apartamento que moramos durante todo o curso de Doutorado. Você e Rodrigo foram a minha família em Bauru, e com certeza continuarão a fazer parte da minha vida sempre. Obrigada por me compreender e respeitar durante todo o nosso convívio, e peço desculpas pelas vezes que não te correspondi. Você é uma das pessoas mais íntegras, bondosas e iluminadas que já conheci. Vou sentir muito a sua ausência (física), mas sei que nossa amizade é eterna e abençoada por Deus. Você estará sempre em meu coração! Obrigada por tudo!!!!

"Todo o mundo sabe compadecer o sofrimento de um amigo, mas é preciso ter uma alma realmente bonita para se apreciar o sucesso de um amigo" (Oscar Wilde)

"O amigo autêntico é o que sabe tudo sobre tí e continua a ser teu amigo"

(Kurt D. Cobain) 


\section{AGRADECIMENTOS}

Ao Prof, Dr. Arnaldo Pinzan, meu orientador do Mestrado, com quem muito aprendi desde os meus primeiros passos na Ortodontia, ainda na SPO e ACOPEN. Agradeço por ter incentivado o meu gosto pela docência e pela pesquisa e ter contribuído de forma determinante para o meu desenvolvimento profissional. O senhor é um exemplo de competência, dedicação e seriedade com a profissão, além de ser um homem íntegro, honesto e de grande coração.

Meus sinceros agradecimentos.

Aos docentes da Disciplina de Ortodontia, Professores Doutores Décio Rodriques Martins, Guilherme Janson, Marcos Roberto de Freitase

Renato Rodrigues de Almeida , agradeço pela oportunidade da convivência e aprendizagem com pessoas tão capazes e experientes. A excelência dos cursos de Pós-Graduação em Ortodontia da FOB-USP e o reconhecimento nacional e, até mesmo internacional, são frutos de todo trabalho honesto que esta maravilhosa equipe vem desempenhando com seriedade ao longo dos anos. Tenho muito orgulho em tê-los como meus Mestres. Obrigada por tudo!

Aos Professores da Disciplina de Cirurgia Ortognática, Professores Doutores Eduardo Sant'Ana e Júlio Gurgel, pelos conhecimentos transmitidos e pela convivência agradável.

À Professora Ana Lúcia Alvares Capelozza, pela solicitude e presteza em me atender, respondendo minhas dúvidas e questionamentos no âmbito da Radiologia e Estomatologia. 


\section{AGRADECIMENTOS}

A todos os meus familiares, em especial Tia Nádia, Mene e Tê, pelo carinho e amizade. Eu sei que poderei sempre contar com o apoio de vocês.

À minha sogra Sheila, que sempre me recebeu como uma filha, só tenho a agradecer. Você acompanhou toda minha caminhada por Bauru, e as vezes que esteve aqui, trouxe muita alegria, apoio e carinho maternal.

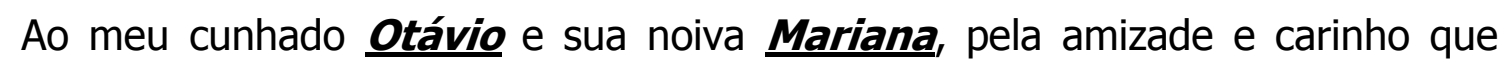
demonstram por mim. Vocês são admiráveis!

\section{À Profa Dra Mireile São Geraldo dos Santos Souza, Reitora da} Universidade Federal dos Vales do Jequitinhonha e Mucuri (UFVJM), agradeço por ter me incentivado na busca pelo aprimoramento profissional, desde os tempos da minha graduação. A senhora sempre foi um exemplo de Mestre para mim, e semeou em meu coração o amor pela docência e pela profissão. Hoje a senhora é merecidamente reconhecida pela brilhante atuação a frente da UFVJM. Obrigada pela sua amizade e pelas sábias palavras que sempre me orientaram e aconselharam.

À Profa Dra Conceição Eunice Canuto, Professora Titular da Disciplina de Ortodontia da UFVJM, agradeço por ter me despertado o interesse pela Ortodontia. Hoje sou muito feliz pelo caminho que segui! Obrigada pela sua amizade e pela confiança que deposita em mim. Admiro muito sua humildade, simplicidade e dedicação com a sua família e com a sua profissão. Agradeço por tudo que fez por mim e pelo Rodrigo. Seremos eternamente gratos.

Aos amigos Anísio e Eliane, agradeço pelas oportunidades que me concederam, pelo carinho, respeito e confiança que demonstram por mim. Obrigada pelo convívio alegre e harmonioso, e acima de tudo, pela amizade sincera. 
Aos Professores do Curso de Odontologia da UFVJM, pela competência, dedicação e amizade demonstradas durante a minha formação acadêmica, e pelo incentivo e apoio na minha qualificação profissional.

Aos amigos da FUNDAEPE e da UFVJM, por torcerem por mim e vibrarem comigo a cada conquista.

Aos amigos do curso de Doutorado, Analu, Célia, Fabrício, Fernanda, José Eduardo, Karina Freitas, Karina Lima, Rejane, Rodrigo e Ricardo, pela convivência e momentos agradáveis que passamos juntos.

Aos colegas do Doutorado "antigo", Adriano, Ana Carla, Ana Cláudia, Daniela, Danilo, Fausto, Karina Cruz, Karyna Valle, Paulo e Renata, pelos auxílios prestados e conhecimentos compartilhados.

Aos colegas do Doutorado "novo", Alexandre, Carlos Alberto Cabrera, Carlos Henrique, Darwin, Fernando Pedrin, Fernando Torres, Kelly, Lívia, Marcos Crepaldi, Marise, Paula, Rafael e Sérgio, pelo companheirismo e amizade ao longo do curso, e em especial à Renata Castro, amiga leal e sincera, grande companheira, a quem tenho muita admiração e respeito. Tenho certeza que nossa amizade se perpetuará até o fim de nossas existências. Agradeço também à sua mãe, Dona Célia, que sempre me alegrou com sua presença, nas suas vindas a Bauru.

Aos colegas do Curso de Mestrado, Caio, Danilo, Douglas, Luiz Fernando, Tassiana e Vladimir, pela convivência alegre e harmoniosa, e em especial aos amigos Eduardo, Janine, Leonardo, Luiz Filiphe, Mavara e Patrícia, pelo apoio, pela torcida, disponibilidade e pelos momentos prazerosos que passamos juntos.

Aos colegas dos demais cursos de Pós-graduação da FOB-USP, pela convivência saudável e coleguismo. 
Ao amigo Nilo Lima, tão atencioso e dedicado. Obrigada pelo apoio, pelos momentos maravilhosos que passamos juntos e pela torcida. Você é uma pessoa admirável, de grande coração. Você e Karina formam um casal iluminado, e estarão sempre em minha memória e em meu coração.

Aos amigos Celso e Angela, pela alegria da convivência e pelas experiências compartilhadas desde o nosso curso de Mestrado.

Aos meus amigos do curso de Graduação, em especial Luciana e Grace, e seus respectivos esposos, pela força e amizade.

À Minha grande amiga Ana Paula, por fazer parte da minha história, pela alegria sempre que nos encontramos, e pela certeza do apoio, da confiança e da torcida mesmo estando distante. Esses agradecimentos são extensivos a todos os seus familiares, e em especial ao Rogério, Ana Luiza e Ana Clara.

À Raquel (cunha) e Alê, pela presença alegre e fraternal.

'A Deusa, pela dedicação e carinho, cuidando tão bem de mim, de Karina, e do nosso apartamento.

À Faculdade de Odontologia de Bauru, Universidade de São Paulo, representada pelo Diretor Prof, Dr. Luiz Fernando Pegoraro

À Profa, Dra, Maria Aparecida de Andrade Moreira Machado, , Presidente da Comissão de Pós-Graduação da Faculdade de Odontologia de Bauru, Universidade de São Paulo. 
Aos funcionários da Disciplina de Ortodontia da FOB - USP, Neide, Cristina, Sérgio, Vera e Luciana, pela dedicação, carinho e atenção com que sempre me atenderam. Agradeço ao Daniel (Bonné) pela presteza em me atender e auxiliar no campo da informática.

Aos funcionários da ACOPEN, Sônia, Walter, César e Luciana, pela disponibilidade em me atender sempre que precisei, e pela convivência agradável.

Aos funcionários da Biblioteca e da Pós-Graduação, pela atenção e disponibilidade com que sempre me atenderam.

À equipe do SDO , em especial ao Fabrício e a Léia, pelo auxílo importante e indispensável na obtenção da documentação dos pacientes da amostra do Jasper Jumper. $\mathrm{O}$ apoio de vocês foi fundamental. Muito obrigada.

Aos meus pacientes, em especial aos pacientes da amostra do Jasper Jumper, imprescindíveis para a realização deste estudo, agradeço pela preciosa colaboração, pela oportunidade de aprendizado e pelo convívio sempre bem-humorado.

\section{À Coordenação de Aperfeiçoamento de Pessoal de Nível Superior} (CAPES), pela concessão da bolsa de estudo. 


\section{SUMÁRIO}

\section{LISTA DE FIGURAS}

\section{LISTA DE TABELAS}

\section{RESUMO}

\section{ABSTRACT}

1. INTRODUÇÃO.

2. REVISÃO DA LITERATURA................................................ 35

2.1. Características da má oclusão de Classe II, 1a divisão......... 35

2.2. Tratamento da má oclusão de Classe II, 1a divisão com 0 aparelho Jasper Jumper associado ao aparelho fixo.

2.3. Tratamento da má oclusão de Classe II, $1^{\text {a }}$ divisão com o aparelho Bionator.

3. PROPOSIÇÃO.................................................................... 93

4. MATERIAL E MÉTODOS............................................................ 97

4.1. Material................................................................. 97

4.1.1. Amostra.................................................... 97

4.1.1.1 Grupo Experimental 1......................... 97

4.1.1.2 Grupo Experimental 2........................... 98

4.1.1.3 Grupo Controle................................... 99

4.1.2. Critério para a seleção das amostras...................... 100

4.1.2.1. Grupo Experimental 1........................... 100

4.1.2.2. Grupo Experimental 2......................... 101

4.1.2.3. Grupo Controle.................................... 102

4.2. Descrição dos aparelhos utilizados nos Grupos Experimentais........................................................ 102

4.2.1. Jasper Jumper associado ao aparelho fixo.............. 102

4.2.2. Bionator e aparelho fixo...................................... 106

4.2.2.1. Aparelho Bionator................................. 106

4.2.2.2. Aparelho Ortodôntico Fixo...................... 107 


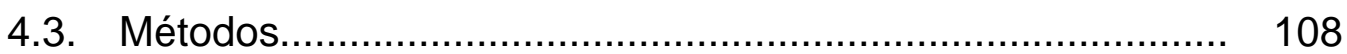

4.3.1. Método Radiográfico............................................... 108

4.3.2. Elaboração do cefalograma e medição das telerradiografias........................................................ 109

4.3.3. Traçado anatômico................................................. 109

4.3.4. Pontos de referência, linhas e planos....................... 110

4.3.5. Grandezas cefalométricas esqueléticas.................... 114

4.3.6. Grandezas cefalométricas dentárias......................... 117

4.3.7. Relações dentárias................................................ 120

4.3.8. Análise estatística................................................. 122

4.3.8.1. Erro do método........................................ 122

4.3.8.2. Comparações intra e intergrupos............... 122

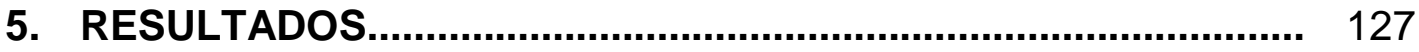

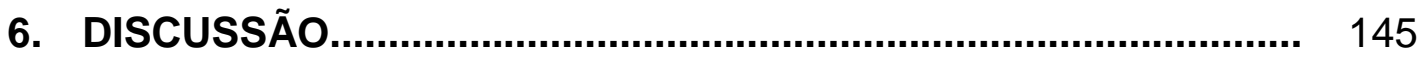

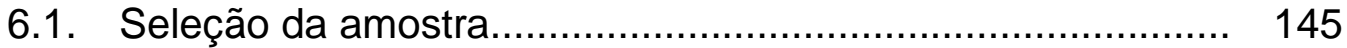

6.2. Compatibilidade dos grupos estudados............................... 149

6.3. Precisão da metodologia empregada (erro do método)......... 161

6.4. Resultados das comparações intra e intergrupos................... 164

6.5. Considerações finais.......................................................... 221

6.6. Sugestões para trabalhos futuros....................................... 226

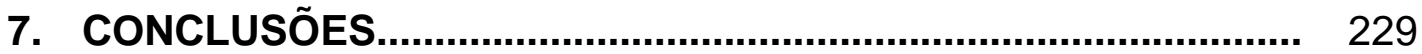

REFERÊNCIAS BIBLOGRÁFICAS................................................. 233

APÊNDICES

ANEXO 


\section{LISTA DE FIGURAS}

FIGURA 1 Componentes do aparelho Jasper Jumper.

FIGURA 2 Seleção do tamanho do aparelho Jasper Jumper. No exemplo, a distância foi de $20 \mathrm{~mm}$; adicionando-se os $12 \mathrm{~mm}$ preconizados $=32 \mathrm{~mm}$ (Jasper Jumper tamanho 4).

FIGURA 3 Jasper Jumper instalado.

FIGURA 4 Bionator modificado como contenção - uso noturno durante 1 ano.

FIGURA 5 Aparelho Bionator - componentes.

FIGURA 6 Aparelho Bionator modificado por Ascher ${ }^{28}$. 107

FIGURA 7 Aparelho ortodôntico fixo. 108

FIGURA 8 Pontos de referência, linhas e planos utilizados.

FIGURA 9 Grandezas cefalométricas esqueléticas

FIGURA 10 Grandezas cefalométricas dentárias superiores e inferiores

FIGURA 11 Grandezas cefalométricas referentes às relações dentárias

FIGURA 12 Valores médios da sobressaliência inicial, mensurada nos modelos de gesso.

FIGURA 13 Sobreposição em SN centrado em S dos cefalogramas médios iniciais dos três grupos estudados

FIGURA 14 Sobreposição em SN centrado em S dos cefalogramas médios iniciais dos três grupos estudados após a compatibilização dos mesmos quanto à idade inicial.......

FIGURA 15 Sobreposição em SN centrado em S dos cefalogramas médios finais dos três grupos avaliados

FIGURA 16 Sobreposição no Plano Palatino (PP) centrado na Espinha Nasal Anterior (ENA) dos cefalogramas médios finais dos três grupos avaliados.

FIGURA 17 Sobreposição no Plano Mandibular dos cefalogramas médios finais dos três grupos avaliados 
FIGURA 18 Sobreposição em SN centrado em S dos cefalogramas médios iniciais e finais do Grupo Experimental 1 (Jasper Jumper)

FIGURA 19 Sobreposição em SN centrado em S dos cefalogramas médios iniciais e finais do Grupo Experimental 2 (Bionator).

FIGURA 20 Sobreposição em SN centrado em S dos cefalogramas médios iniciais e finais do Grupo Controle

FIGURA 21 Sobreposição em PP centrado em ENA dos cefalogramas médios iniciais e finais do Grupo Experimental 1 (Jasper Jumper)...................................

FIGURA 22 Sobreposição em PP centrado em ENA dos cefalogramas médios iniciais e finais do Grupo Experimental 2 (Bionator)

FIGURA 23 Sobreposição em PP centrado em ENA dos cefalogramas médios iniciais e finais do Grupo Controle. 182

FIGURA 24 Sobreposição no Plano Mandibular dos cefalogramas médios iniciais e finais do Grupo Experimental 1 (Jasper Jumper).

FIGURA 25 Sobreposição no Plano Mandibular dos cefalogramas médios iniciais e finais do Grupo Experimental 2 (Bionator).

FIGURA 26 Sobreposição no Plano Mandibular dos cefalogramas médios iniciais e finais do Grupo Controle.

FIGURA 27 Valores médios das alterações das variáveis cefalométricas do Componente Maxilar nos três grupos estudados.

FIGURA 28 Valores médios das alterações das variáveis cefalométricas do Componente Mandibular nos três grupos estudados.

FIGURA 29 Valores médios das alterações das variáveis cefalométricas do Componente Relação Maxilomandibular nos três grupos estudados. 
FIGURA 30 Valores médios das alterações das variáveis SN.GoGn, FMA e SN.PP do Componente Padrão de Crescimento nos três grupos estudados.

FIGURA 31 Valores médios das alterações das variáveis SN.POF, AFAl e S-Go do Componente Padrão de Crescimento nos três grupos estudados.

FIGURA 32 Valores médios das alterações das variáveis 1.PP, 1.NA, 1-ENAperp e 1-NA do Componente Dentoalveolar Superior nos três grupos estudados.

FIGURA 33 Desenho esquemático representando a variação da inclinação da linha NA com a retrusão maxilar e sua influência na avaliação da posição do incisivo superior. As duas figuras são idênticas, apresentando apenas 0 posicionamento ântero-posterior da maxila alterado. Em A, a maxila encontra-se protruída; em $B$, após a retrusão, a linha NA ficou mais verticalizada, sugerindo que os incisivos superiores foram protruídos. No entanto, o posicionamento desses dentes em relação à maxila não foi alterado neste esquema.

FIGURA 34 Valores médios das alterações das variáveis 1-PP, 6-PP e 6-ENAperp do Componente Dentoalveolar Superior nos três grupos estudados.

FIGURA 35 Valores médios das alterações das variáveis IMPA, 1.NB, 1-Pogperp e 1-NB do Componente Dentoalveolar Inferior nos três grupos estudados

FIGURA 36 Valores médios das alterações das variáveis IMPA, 1.NB, 1-Pogperp e 1-NB do Componente Dentoalveolar Inferior nos três grupos compatibilizados quanto à idade inicial.

FIGURA 37 Valores médios das alterações das variáveis 1-PM, 6-PM e 6-Pogperp do Componente Dentoalveolar Inferior nos três grupos estudados

FIGURA 38 Valores médios das alterações das variáveis do Componente Relações Dentárias nos três grupos estudados 


\section{LISTA DE TABELAS}

TABELA 1 Severidade inicial da má oclusão no Grupo Experimental 1 .

TABELA 2 Severidade inicial da má oclusão no Grupo Experimental 2 99

TABELA 3 Severidade inicial da má oclusão no Grupo Controle..... 100

TABELA 4 Idades médias iniciais e finais e os períodos médios de avaliação dos três grupos estudados

TABELA 5 Avaliação do erro intra-examinador. Resultados da avaliação do erro sistemático (teste t dependente) e do erro casual (Dahlberg).

TABELA 6 Avaliação da compatibilidade entre os grupos considerando a idade inicial média, a distribuição por gêneros, a severidade inicial da relação ânteroposterior dos arcos dentários - relação molar, relação dos caninos, e sobressaliência. Avaliou-se também o tempo médio de avaliação e a idade final.

TABELA 7 Avaliação da compatibilidade entre os grupos experimentais quanto à severidade inicial da relação ântero-posterior dos arcos dentários - relação molar e relação dos caninos.

TABELA 8 Resultados da Análise de Variância (ANOVA) e do teste de comparações múltiplas de Tukey para avaliar a compatibilidade cefalométrica dos Grupos Experimentais 1 e 2 e Grupo Controle na fase inicial do tratamento (T1).

TABELA 9 Resultados da comparação das variáveis cefalométricas entre os três grupos estudados, na fase final do tratamento (T2), por meio da Análise de Variância (ANOVA) e do teste de comparações múltiplas de Tukey.

TABELA 10 Resultados da comparação das variáveis cefalométricas entre as fases inicial e final do Grupo Experimental 1 (Jasper Jumper), por meio do teste $t$ dependente. 
TABELA 11 Resultados da comparação das variáveis cefalométricas entre as fases inicial e final do Grupo Experimental 2 (Bionator), por meio do teste $t$ dependente.

TABELA 12 Resultados da comparação das variáveis cefalométricas entre as fases inicial e final do Grupo Controle, por meio do teste $t$ dependente

TABELA 13 Resultados da comparação das alterações das variáveis cefalométricas dos Grupos Experimental $1 \mathrm{e}$ Controle e das alterações anualizadas do Grupo Experimental 2, por meio da Análise de Variância (ANOVA) e do teste de comparações múltiplas de Tukey

TABELA 14 Comparação da idade inicial média, da distribuição por gêneros, da severidade inicial da relação ânteroposterior dos arcos dentários - relação molar, relação dos caninos, e sobressaliência, do tempo médio de avaliação e idade final, após a compatibilização dos grupos em relação à idade inicial.

TABELA 15 Resultados da Análise de Variância (ANOVA) e do teste de comparações múltiplas de Tukey para comparar as variáveis cefalométricas entre os Grupos Experimentais 1 e 2 e Grupo Controle na fase inicial (T1), após a compatibilização dos mesmos em relação à idade inicial.

TABELA 16 Comparação das alterações das variáveis cefalométricas dos Grupos Experimental 1 e Controle e das alterações anualizadas do Grupo Experimental 2, por meio da Análise de Variância e do teste de comparações múltiplas de Tukey, após a compatibilização dos grupos quanto à idade inicial........ 


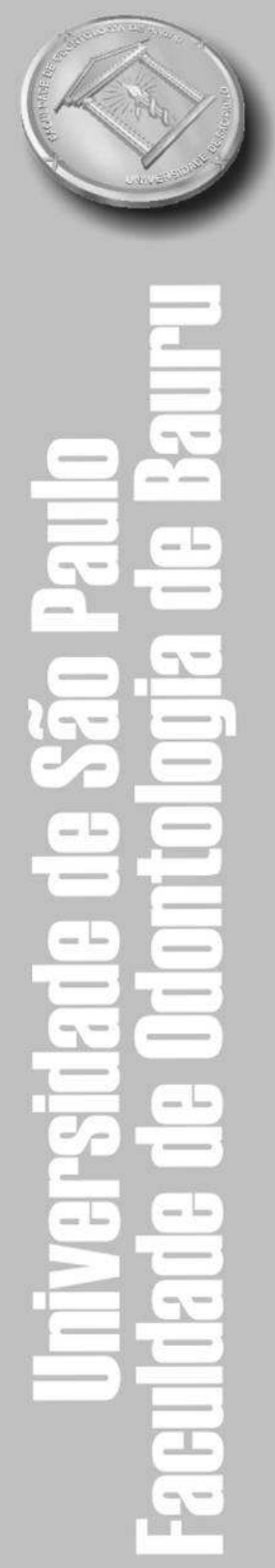

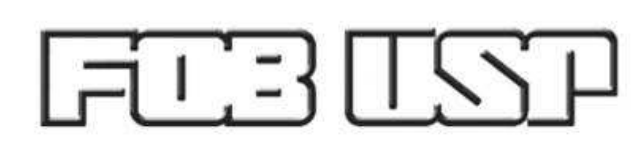

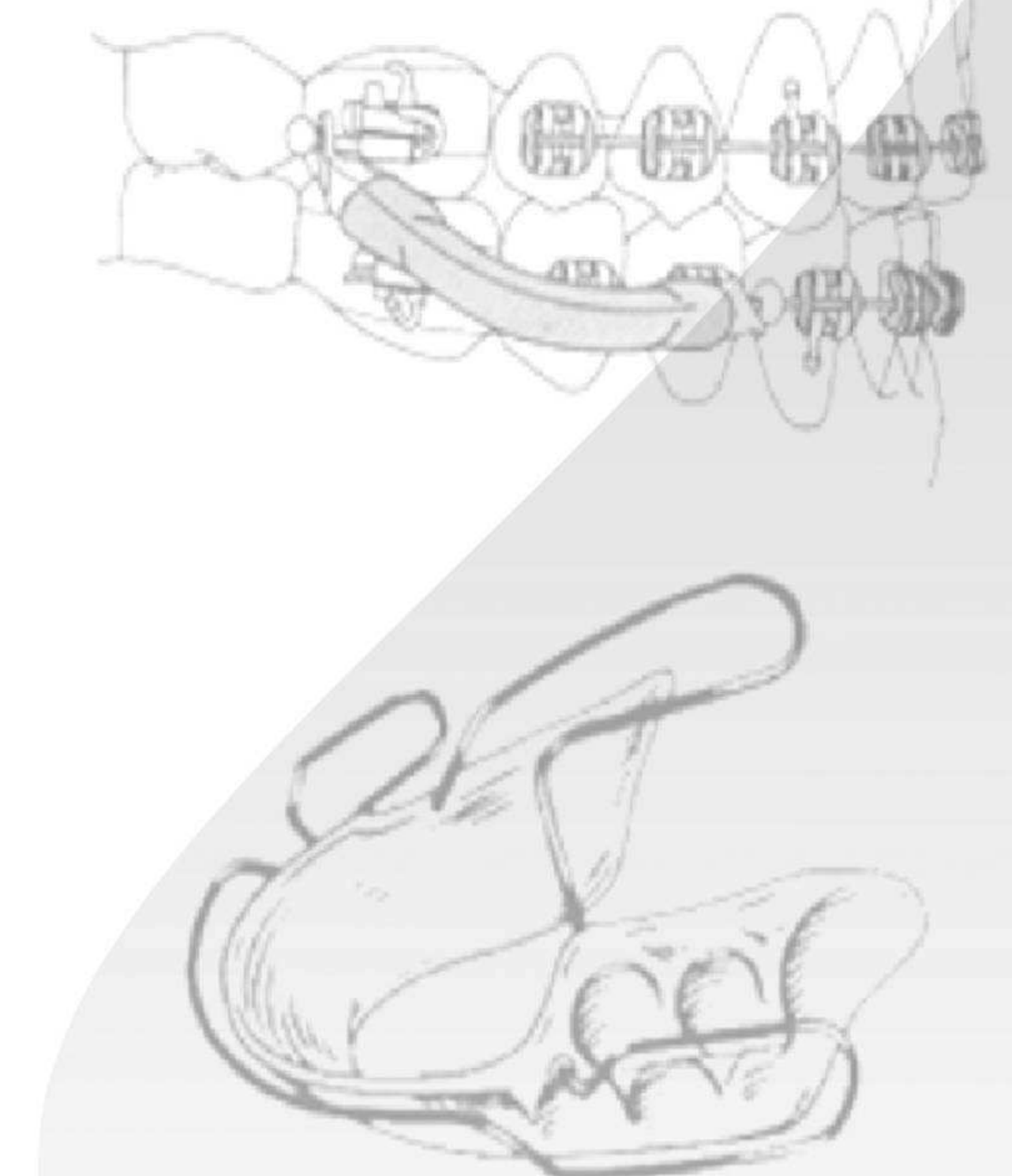

Resumo 
NEVES, L.S. Estudo comparativo dos efeitos do tratamento da má oclusão de Classe II, $1^{\text {a }}$ divisão com os aparelhos Jasper Jumper e Bionator, associados ao aparelho fixo. Bauru, 2007. 263p. Tese (Doutorado) - Faculdade de Odontologia de Bauru - Universidade de São Paulo.

O objetivo deste estudo foi comparar os efeitos do tratamento da má oclusão de Classe II, 1aㅡ divisão por meio dos aparelhos Jasper Jumper e Bionator, associados ao aparelho ortodôntico fixo. Para tanto, utilizou-se uma amostra de 77 jovens, divididos em três grupos: Grupo Experimental 1, constituído por 25 pacientes com idade inicial média de 12,72 anos, tratados por meio do aparelho Jasper Jumper associado ao aparelho ortodôntico fixo, por um período médio de 2,15 anos; Grupo Experimental 2, contendo 30 pacientes com idade inicial média de 11,31 anos, tratados por meio do aparelho Bionator e aparelho ortodôntico fixo, e o tempo médio de tratamento foi de 3,92 anos; Grupo Controle, composto por 22 jovens, com idade inicial média de 12,67 anos, e observados por um período médio de 2,13 anos. Avaliou-se as telerradiografias em norma lateral iniciais e finais dos indivíduos dos três grupos estudados. As variáveis cefalométricas dentoesqueléticas foram comparadas entre os grupos por meio da Análise de Variância, nas fases inicial e final. As alterações de todas as variáveis cefalométricas no grupo tratado por meio do Bionator foram anualizadas e, posteriormente, comparadas às alterações das variáveis dos demais grupos. Observou-se que ambos os tratamentos apresentaram um efeito restritivo na maxila e não alteraram o desenvolvimento mandibular. O tratamento com o Jasper Jumper ocasionou a rotação horária da mandíbula, o aumento da altura facial ântero-inferior, e menor rotação anti-horária do plano oclusal funcional em relação ao grupo tratado pelo Bionator. Os incisivos superiores foram retruídos nos grupos experimentais e extruídos no grupo do Jasper Jumper, que também apresentou uma distalização dos molares superiores. Os incisivos inferiores protruíram e vestibularizaram no grupo tratado por meio do Bionator e apresentaram uma tendência de protrusão e limitação do desenvolvimento vertical nos pacientes tratados com o Jasper Jumper. Os molares inferiores foram extruídos em ambos os grupos experimentais e mesializados no grupo tratado pelo Jasper Jumper. Ambos os aparelhos melhoraram significantemente o trespasse horizontal, vertical e a relação molar.

Palavras-chave: Maloclusão de Angle Classe II; Aparelhos Ativadores; Ortodontia Corretiva 


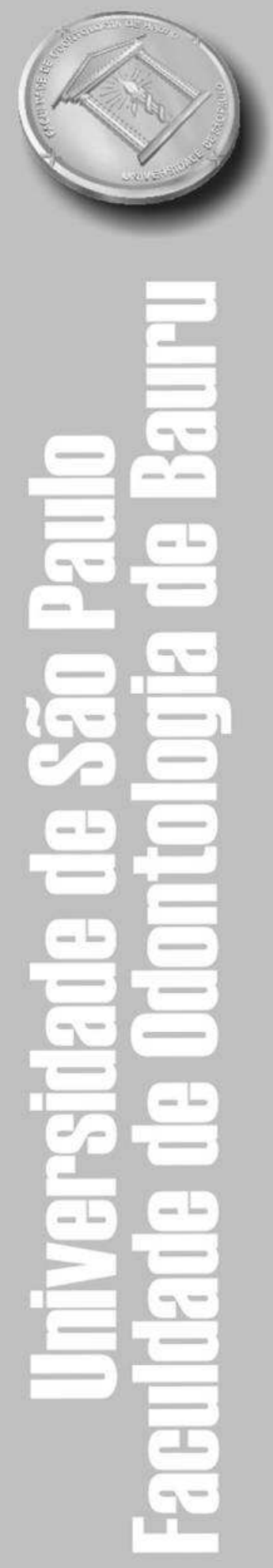

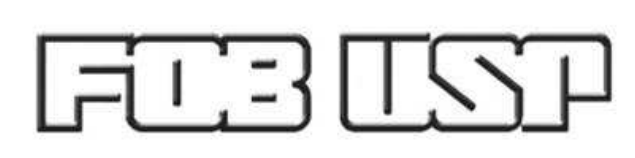

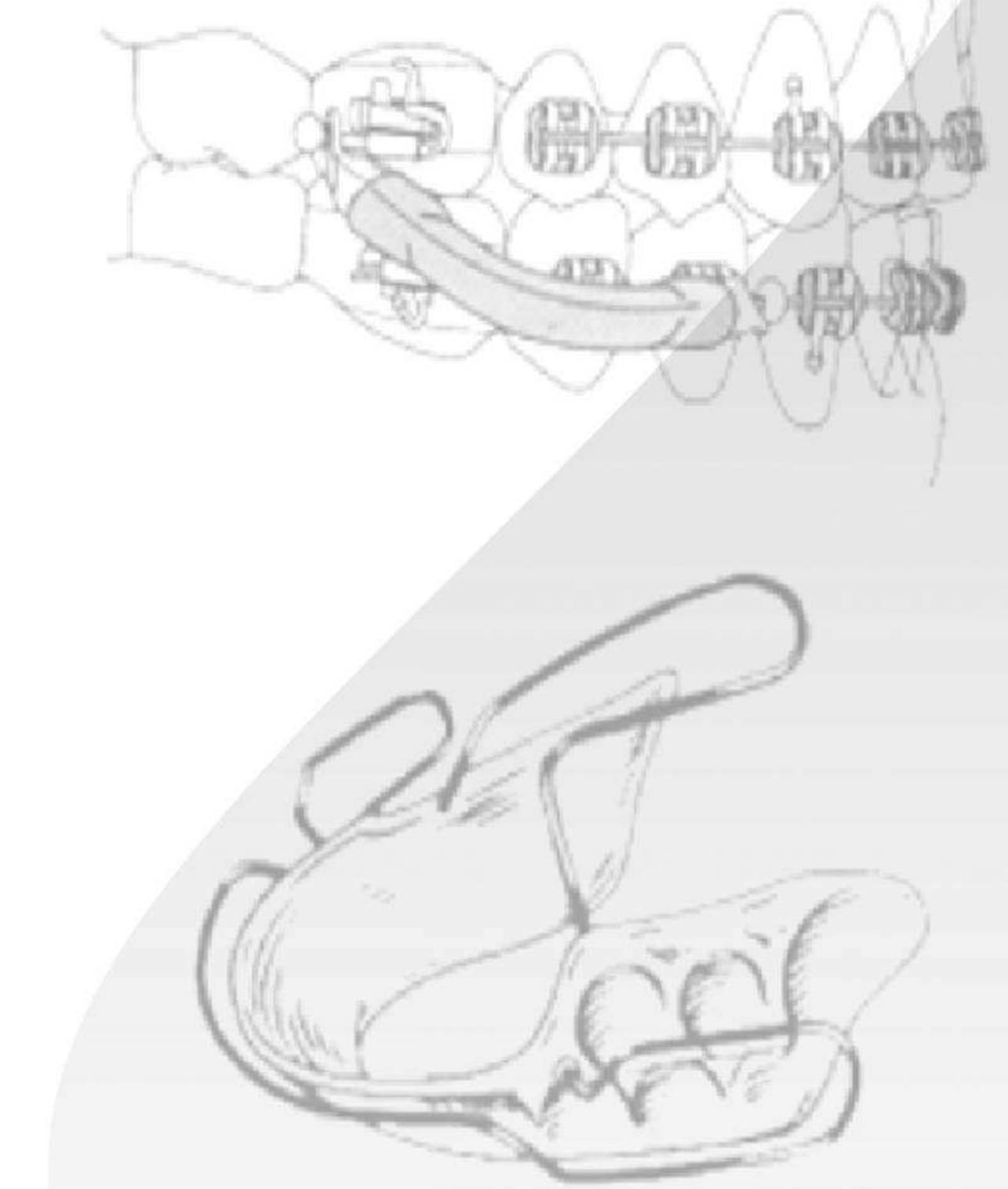

Abstract 
NEVES, L.S. Comparative study of the treatment effects of Class II division 1 malocclusion with the appliances Jasper Jumper and Bionator, associated with fixed appliances. Bauru, 2007. 263p. Thesis (PhD) - Bauru Dental School University of São Paulo.

This study compared the treatment effects of Class II division 1 malocclusion with the appliances Jasper Jumper and Bionator, associated with fixed appliances. The study sample was composed of 77 young individuals, divided into three groups: Study Group 1, comprising 25 patients with initial mean age of 12.72 years, treated with the Jasper Jumper appliance associated with fixed appliances for a mean period of 2.15 years; Study Group 2, composed of 30 patients with initial mean age of 11.31 years, treated with the Bionator and fixed appliances, with a mean treatment time of 3.92 years; and the Control Group, including 22 young individuals, with initial mean age of 12.67 years and followed for a mean period of 2.13 years. The initial and final lateral cephalograms of individuals in the three groups were evaluated. The cephalometric dentoskeletal variables were compared among groups at the initial and final periods by analysis of variance. The changes of all cephalometric variables in the Bionator group were annualized and compared to the changes observed for the other groups. It was observed that both treatments presented a restrictive effect on the maxilla and did not change the mandibular development. Treatment with the Jasper Jumper appliance produced clockwise mandibular rotation, increase in lower anterior facial height, and smaller counterclockwise rotation of the functional occlusal plane compared to treatment with Bionator. The maxillary incisors were retruded in the study groups and extruded in the Jasper Jumper group, which also exhibited distalization of maxillary molars. The mandibular incisors presented protrusion and buccal tipping in the group treated with the Bionator appliance and a tendency to protrusion and relative intrusion in individuals treated with the Jasper Jumper appliance. The mandibular molars exhibited extrusion in both study groups and mesial movement in the Jasper Jumper group. Both appliances allowed significant improvement of overjet, overbite and molar relationship.

Keywords: Malocclusion, Angle Class II; Activator Appliances; Orthodontics, Corrective 


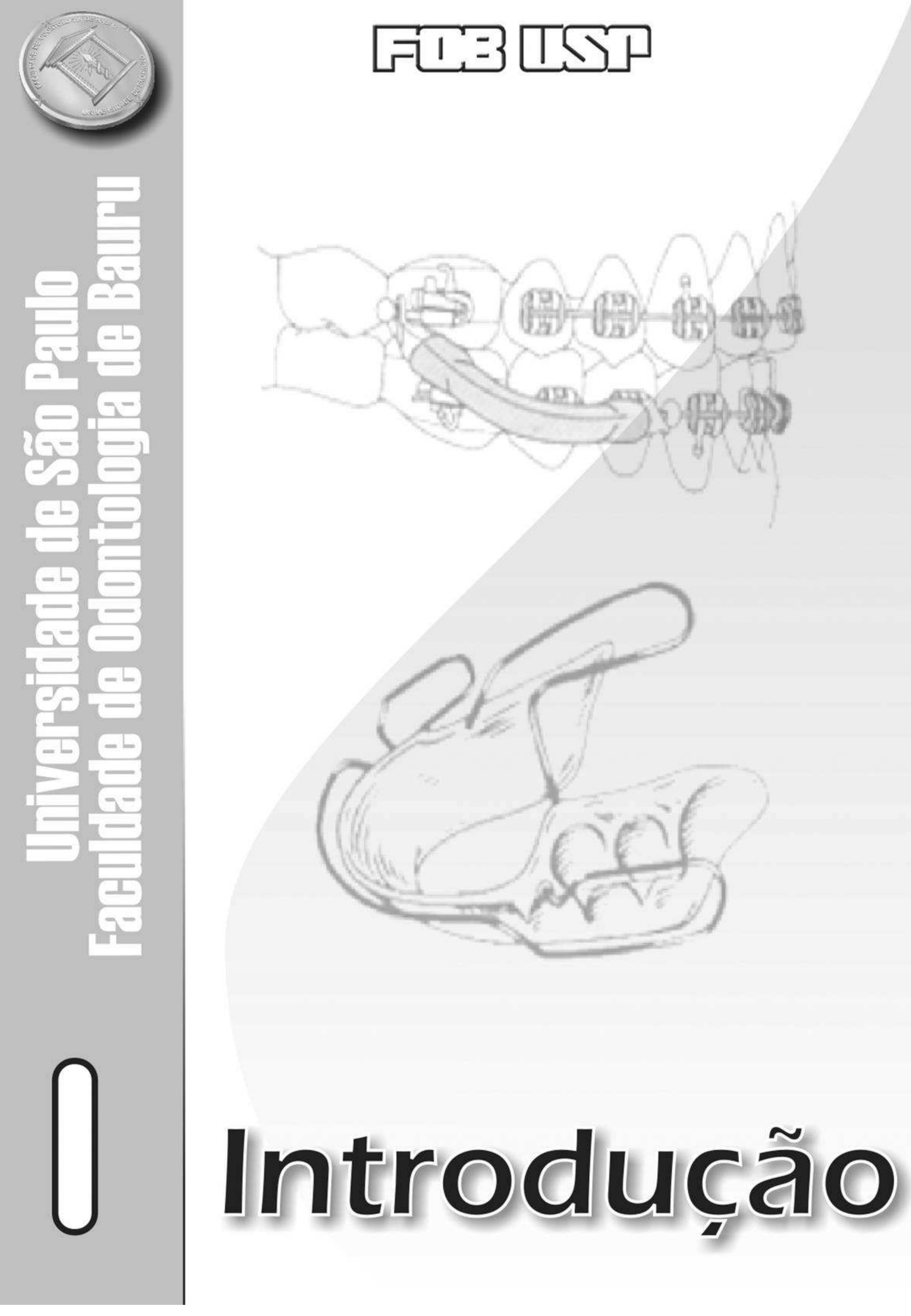




\section{INTRODUÇÃO}

A má oclusão de Classe II caracteriza-se por um relacionamento deficiente entre os arcos dentários superior e inferior, e pode apresentar origem dentoalveolar, esquelética ou uma combinação de ambas ${ }^{292}$. Esta má oclusão pode estar relacionada a uma protrusão da maxila, bem como dos dentes superiores, a uma retrusão da mandíbula e/ou dos dentes inferiores, ou a uma combinação destes fatores $^{292}$.

Apesar da má oclusão de Classe I ser a mais prevalente na população, os aspectos antiestéticos da Classe II provocam o maior afluxo de pacientes em busca das correções estéticas e funcionais desta má oclusão ${ }^{122}$. Dentre os dois tipos de Classe II, a $1^{\underline{a}}$ divisão consiste na mais freqüente no consultório ortodôntico $^{109,122,338}$, sendo causada na maioria das vezes pela retrusão da mandíbula ${ }^{205}$. Assim, torna-se bem indicada a utilização dos aparelhos ortopédicos funcionais, que redirecionam o crescimento mandibular e atuam durante a fase de crescimento e desenvolvimento craniofacial, propiciando uma boa oclusão e harmonia do perfil facial ${ }^{226,227}$.

Existem vários tipos de aparelhos ortopédicos funcionais, sendo a maioria deles semelhantes entre si no modo de ação. Muitos destes aparelhos são removíveis, o que requer uma boa cooperação e motivação por parte do paciente. Entretanto, alguns estudos revelam que a colaboração dos pacientes com o tratamento ortopédico funcional apresenta-se deficiente ${ }^{25,287,288}$.

Em 1905, EMIL HERBST idealizou um aparelho fixo para realizar o avanço mandibular, conhecido como Aparelho de Herbst, mas esse aparelho ficou esquecido pela comunidade ortodôntica por vários anos, devido ao grande desenvolvimento dos aparelhos ortopédicos funcionais removíveis na Europa e ao apogeu dos elásticos intermaxilares Estados Unidos ${ }^{305}$. Em 1979, o aparelho de Herbst foi reintroduzido por HANS PANCHERZ ${ }^{234}$ no intuito de minimizar o problema de colaboração do paciente, uma vez que o avanço mandibular passou a ser realizado por um dispositivo fixo, promovendo uma força contínua 24 horas por dia. Apesar dessas vantagens, surgiram alguns problemas como a dificuldade na mastigação, fonação e higienização, devido à rigidez do aparelho. 
Em 1987, JAMES JASPER ${ }^{162}$ buscou o aperfeiçoamento da técnica do avanço mandibular com aparelhos fixos e desenvolveu o aparelho Jasper Jumper ${ }^{\mathrm{a}}$, composto por dois módulos flexíveis de força, que minimizam os problemas causados pela rigidez do aparelho Herbst e reduzem o tempo de tratamento, pois o aparelho Jasper Jumper é utilizado juntamente com o aparelho fixo ${ }^{226,227}$. Além disto, não necessita da fase laboratorial e apresenta grande facilidade na instalação, ativação e remoção do aparelho ${ }^{47,226,227}$.

Deste modo, pretende-se investigar se as alterações decorrentes do tratamento com os aparelhos ortopédicos funcionais fixos associados ao aparelho ortodôntico fixo (aqui representados pelo aparelho Jasper Jumper) se equivalem àquelas dos aparelhos ortopédicos funcionais removíveis (no caso, - Bionator, por ser um dos mais utilizados pela comunidade ortodôntica $^{102,166,207,208,213}$ ) sucedidos pelo tratamento ortodôntico corretivo, no intuito de fornecer maiores informações ao Ortodontista no momento da planificação dos tratamentos das más oclusões de Classe II, $1^{\text {a}}$ divisão. Buscase também ressaltar as principais vantagens e desvantagens de cada um desses tipos de aparelho, para que o Ortodontista selecione conscientemente 0 recurso terapêutico adequado, podendo usufruir ao máximo das vantagens que cada aparelho pode fornecer ao paciente individualmente.

a Jasper Jumper®, American Orthodontics, Sheboygan, Wisc. 


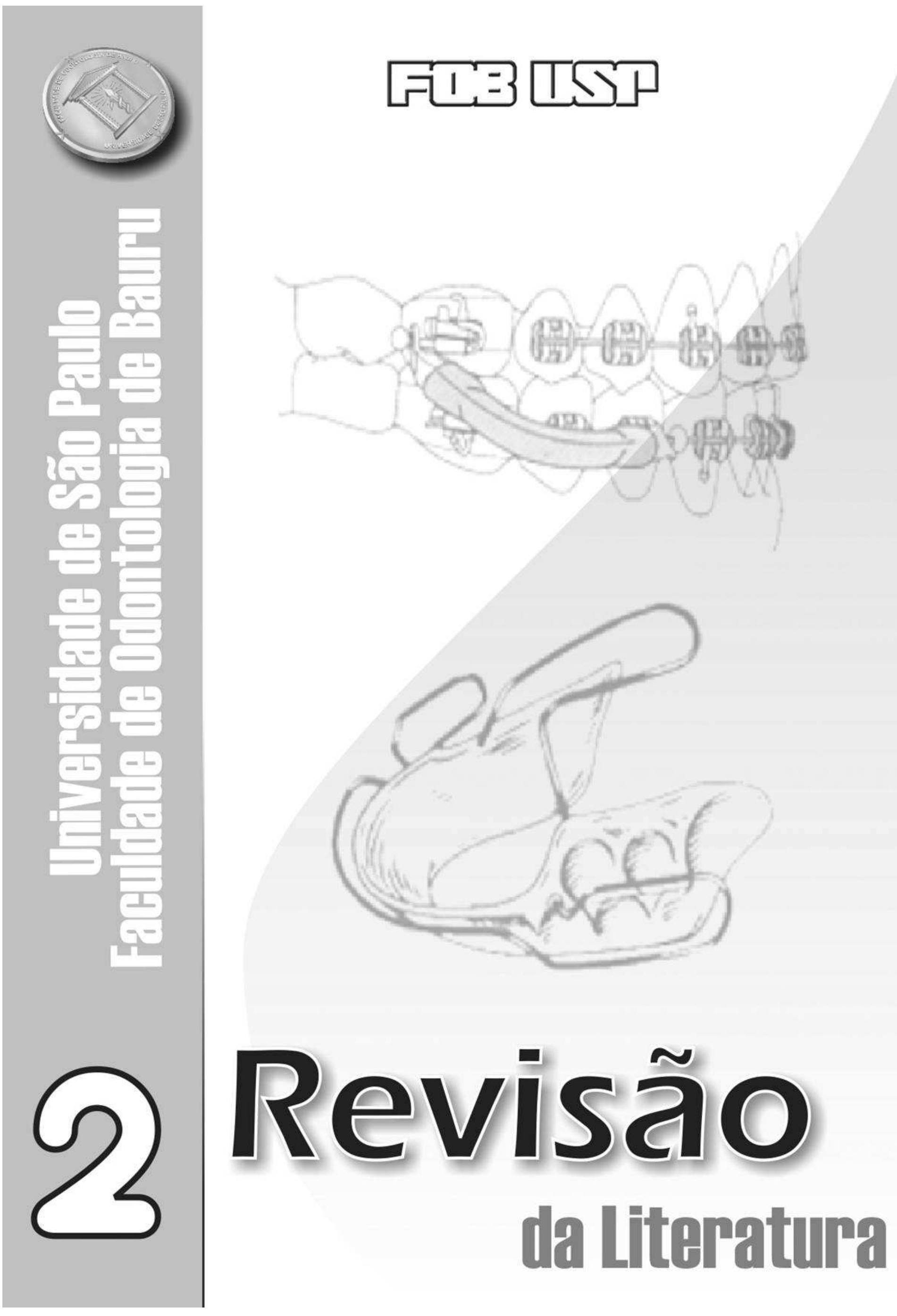




\section{REVISÃO DA LITERATURA}

Objetivando uma melhor leitura e compreensão, a revisão da literatura foi desenvolvida de maneira a oferecer informações quanto às principais características da má oclusão de Classe II, 1a divisão, e a respeito das duas modalidades de tratamento da referida má oclusão a serem avaliadas nesta pesquisa, que consistem no tratamento por meio do aparelho Jasper Jumper associado ao aparelho fixo e com o aparelho Bionator.

\subsection{Características da má oclusão de Classe II, $1^{\text {a }}$ divisão}

\section{Classificação das más oclusões}

Existem várias maneiras de classificação das más oclusões, porém a mais difundida e utilizada pelos Ortodontistas até os dias atuais é a classificação proposta por $\mathrm{ANGLE}^{22}$, no final do século XIX. De acordo com esta classificação, o primeiro molar superior encontrava-se em uma posição fixa, imutável em relação ao inferior e, a partir deste ponto, as variações determinavam os três tipos de má oclusão no sentido ântero-posterior. Entretanto, apesar de simples e objetiva, esta classificação considerava apenas as alterações da oclusão no sentido ântero-posterior, desprezando as alterações nos sentidos vertical e transversal que poderiam estar associadas, além de ser uma classificação essencialmente dentária, sem correlacionar o mau posicionamento dentário com as estruturas esqueléticas adjacentes. Portanto, o autor definiu a má oclusão de Classe II, 1a divisão como uma relação mesiodistal deficiente dos arcos dentários, com todos os dentes inferiores ocluindo distalmente em relação ao padrão normal, propiciando uma desarmonia acentuada dos incisivos e linhas faciais.

Posteriormente, alguns autores propuseram outros tipos de classificação das más oclusões, ou mesmo, buscaram aprimorar a classificação proposta por ANGLE $^{22}$. Neste sentido, ACKERMAN; PROFFIT ${ }^{1}$, em 1969, observaram que as más oclusões incluídas em uma mesma classificação de ANGLE poderiam ser análogas, ou seja, poderiam apresentar um relacionamento oclusal semelhante, porém, muitas vezes suas características esqueléticas não se 
equivaliam, e nesses casos, a forma de intervenção deveria ser diferente. Em 1975, SERVOSS ${ }^{300}$ acrescentou quatro termos à classificação de ANGLE. Os termos prognatismo ou retrognatismo referem-se ao posicionamento anterior ou posterior, respectivamente, das bases ósseas em relação à base do crânio. Adicionalmente, os termos protrusão ou retrusão descrevem o posicionamento anterior e posterior dos dentes em relação às bases ósseas. Estas condições são distintas, porém podem apresentar-se combinadas. Essencialmente, existem quatro componentes independentes que deveriam ser observados: maxila, mandíbula, dentes superiores e dentes inferiores.

\section{Prevalência da má oclusão de Classe II}

De acordo com SILVA FILHO; FREITAS; CAVASSAN ${ }^{304}$, em 1990, a prevalência da má oclusão de Classe II em escolares de Bauru - SP é de $42 \%$ do total das más oclusões encontradas. Mais da metade dos casos de Classe II (27\%) não apresentaram comprometimento facial, o que significa dizer que as bases ósseas encontram-se bem posicionadas, apesar dos arcos dentários relacionarem-se em Classe II. Das más oclusões de Classe II consideradas esqueléticas, que somam 15\%,11,5\% apresentaram características peculiares da $1^{\underline{a}}$ divisão, com discrepância notória entre a maxila e a mandíbula, ausência de selamento labial passivo, hipotonicidade do lábio superior e vestibuloversão dos incisivos superiores. Apenas $3,5 \%$ das más oclusões apresentaram as características da Classe II, $2^{\underline{a}}$ divisão. ALMEIDA et al. ${ }^{15}$ encontraram, em 1970, uma prevalência para a população bauruense de $12,7 \%$ das más oclusões atribuídas à Classe II, $1^{\underline{a}}$ divisão e 1,5\% à Classe II, $2^{2}$ divisão. Mais recentemente, FREITAS et al. ${ }^{109}$ (2002) estudaram a prevalência das principais más oclusões e irregularidades dentoalveolares na população que costuma procurar tratamento ortodôntico na Faculdade de Odontologia de Bauru - USP. Examinou-se os modelos de estudo de 520 pacientes no final da dentadura mista e início da dentadura permanente. Observou-se as seguintes prevalências de más oclusões: Classe II, 1ํㅡㄹ divisão: 50\%; Classe I: $44 \%$ para o gênero masculino e $40 \%$ para o feminino; Classe II, $2^{a}$ divisão: $4 \%$ para 0 gênero masculino e $8 \%$ para o feminino; e Classe III: $2 \%$. BISHARA et al. ${ }^{44}$, em 1997, relataram uma prevalência da má oclusão de Classe II em 34\% da amostra avaliada, oriunda do "Facial Growth Study" da Universidade de lowa. Em 2004, PHELAN et al. ${ }^{263}$ consideraram que, aproximadamente, 15 a $20 \%$ da 
população norte-americana apresenta má oclusão de Classe II, sendo que em 75\% desses casos ocorrem discrepâncias esqueléticas.

\section{Etiologia e componentes da má oclusão de Classe II}

Etiologicamente, as más oclusões de Classe II caracterizam-se por um forte componente hereditário, aparente tanto no exame de famílias com indivíduos apresentando a alteração, que tendem a apresentar padrões faciais semelhantes, e na avaliação da prevalência da condição nos vários grupos étnicos e raciais ${ }^{263,324}$.

A má oclusão de Classe II, 1a divisão pode apresentar variados componentes $^{292,293}$. SASSOUNI ${ }^{293}$, em 1970, subdividiu a má oclusão de Classe II, 1a divisão em 128 tipos de variações, pela análise dos componentes esqueléticos e dentários da maxila e da mandíbula, nos sentidos horizontal e vertical.

A maioria dos autores observou que a mandíbula encontra-se freqüentemente retruída nos indivíduos com este tipo de má oclusão $^{23,29,34,38,41,44,54,71,103,110,121,140,197,205,222,231,260,271,290,324,328,333}$ e muitas vezes apresenta-se também com seu tamanho diminuído em relação aos padrões normais $23,29,62,63,96,110,172,222,290,333$. Já a maxila, na maioria das vezes apresenta-se ou bem posicionada $38,54,71,103,110,121,197,205,222,260,290,324,328$ ou com uma tendência à protrusão $23,71,113,121,271,277,278,324,328$; no entanto, algumas vezes pode até mesmo encontrar-se retruída em relação à base do crânio, mas em menor magnitude que a retrusão mandibular ${ }^{34,38,121,205}$. Além disto, alguns autores consideram a presença de atresia maxilar neste tipo de má oclusão $^{23,29,42,61,270,307}$ e a presença de um palato mais profundo ${ }^{61}$. REJMAN et al. ${ }^{270}$, em 2006, observaram que de um modo geral, jovens com má oclusão de Classe II, $1^{\underline{a}}$ divisão apresentam tendência para deficiência transversal posterior dos arcos dentários, principalmente quando essa má oclusão encontra-se associada ao apinhamento dentário. Em relação aos componentes dentoalveolares da má oclusão de Classe II, $1^{\text {a }}$ divisão, os incisivos superiores normalmente apresentam-se vestibularizados e/ou protruídos na maxila 23,38,54,71,96,103,110,172,197,205,260,278,290,328, podendo observar também extrusão dos mesmos ${ }^{140,324}$, enquanto que os incisivos inferiores podem apresentar-se lingualizados e/ou retruídos na mandíbula ${ }^{23,140,328}$, bem 
posicionados $^{71,205,260}$, ou vestibularizados e/ou protruídos ${ }^{34,54,110,113,197,290,324}$, além de poderem estar extruídos ${ }^{324}$.

$\mathrm{Na}$ literatura consultada observou-se uma ausência de dimorfismo entre os gêneros em relação às características dentoalveolares e esqueléticas da má oclusão de Classe II, $1^{\text {a }}$ divisão ${ }^{110,277,290,328}$. ROTHSTEIN; YOON-TARLIE ${ }^{277}$ (2000) observaram que apenas a altura da sínfise mandibular foi maior no gênero masculino. Em 2004, PHELAN et al. ${ }^{263}$ avaliaram as diferenças étnicas, etárias e de gênero em indivíduos com má oclusão de Classe II não tratados e verificaram que as diferenças em relação ao gênero ocorreram apenas no tamanho da mandíbula (gênero masculino maior) e posicionamento dos incisivos superiores (gênero masculino mais protruídos). Concluíram que, em geral, o gênero exerce pouco efeito no posicionamento dentário e esquelético na má oclusão de Classe II.

Em relação ao padrão de crescimento facial, há uma variação individual muito grande ${ }^{71,140,205}$, e na literatura os autores observaram a associação dos diferentes tipos faciais com a má oclusão de Classe II, 1a divisão. A maior parte dos estudos encontrou uma maior participação do vetor de crescimento vertical nos indivíduos com este tipo de má oclusão $38,71,96,110,197,205,222,290,324,328$, com conseqüente aumento da altura facial ântero-inferior (AFAI) ${ }^{96,324,328}$. Porém, outros estudos indicaram o predomínio de indivíduos com má oclusão de Classe II, 1ํ- divisão com padrão de crescimento equilibrado ${ }^{62,103,277,307}$ ou com predomínio do vetor de crescimento horizontal ${ }^{271,278}$. HENRIQUES et al. ${ }^{140}$, em 1998, observaram uma distribuição uniforme de indivíduos com predominância de crescimento vertical, horizontal e equilíbrio dos vetores.

As discrepâncias esqueléticas ântero-posteriores e verticais podem associar-se ${ }^{103,222}$; assim, SASSOUNI ${ }^{292}$ (1969) descreveu a Classe II esquelética com mordida aberta ou com sobremordida profunda. Na Classe II esquelética com mordida aberta, a retrusão mandibular pode ser puramente posicional, geralmente devido à rotação horária da mandíbula, e esta rotação associa-se com uma excessiva extrusão dos molares. Na Classe II esquelética com sobremordida profunda, a rotação da mandíbula para trás agrava o padrão de Classe II, embora possa melhorar a sobremordida profunda. Durante o crescimento pode-se esperar alguma melhora neste tipo, já que a mandíbula apresenta maior crescimento vertical e ântero-posterior que a maxila. 
Percebe-se então que os problemas do desenvolvimento ânteroposterior e vertical mandibulares constituem os principais componentes esqueléticos da má oclusão da Classe II, $1^{\underline{a}}$ divisão, sugerindo que os aparelhos que alteram ou redirecionam o crescimento mandibular sejam os mais apropriados na maioria dos $\operatorname{casos}^{205,231}$.

\section{Relação entre a base do crânio e a má oclusão de Classe II}

Alguns autores investigaram o relacionamento entre o comprimento e a flexão da base do crânio com o padrão esquelético das bases ósseas nos casos de má oclusão de Classe II, 1a divisão. Sendo assim, alguns deles observaram que nos casos desta má oclusão, há um maior comprimento craniano ântero-posterior ${ }^{172,278,324}$ acompanhado por uma espessura aumentada do osso frontal ao nível do seio ${ }^{278}$, um ângulo da base do crânio mais obtuso ${ }^{278,292}$, e um maior comprimento da base do crânio anterior (selanásio) $)^{277,278,292}$ e posterior ${ }^{324}$. De acordo com os seus resultados, URSI; MCNAMARA JR. ${ }^{324}$ concluíram que se existem diferenças entre os componentes cranianos de indivíduos Classe I e Classe II, estas se encontram localizadas posteriormente à sela turca (base do crânio posterior). PROFFIT; WHITE $^{267}$ e DIBBETS ${ }^{94}$ consideram que devido à arquitetura da base do crânio, mais especificamente o ângulo básio-sela-násio, sob forte influência genética, ser mais obtuso nos casos de má oclusão de Classe II, há um favorecimento do posicionamento mais posterior da mandíbula e, conseqüentemente, do relacionamento deficiente entre esta base óssea e a maxila. Entretanto, o estudo desenvolvido por ROTHSTEIN; YOON-TARLIE ${ }^{277}$ não suportou a afirmativa de que um aumento na flexão da base do crânio (ângulo básio-sela-násio) contribui para uma posição mais retruída da mandíbula ${ }^{94,267}$, uma vez que nos jovens que apresentaram este ângulo aumentado a mandíbula não se encontrava posicionada posteriormente.

No ano de 2002, KLOCKE; NANDA; KAHL-NIEKE ${ }^{178}$ investigaram as características esqueléticas em pacientes com ângulos da base do crânio diminuídos e aumentados. Formou-se dois grupos de indivíduos não tratados de acordo com o ângulo da base do crânio (násio-sela-articular), se diminuído ou aumentado, em uma idade de 5 anos. Analisou-se os dados cefalométricos dos 2 grupos com os indivíduos nas idades de 5 e 12 anos. Em ambas as idades, os grupos revelaram diferenças significantes das variáveis SNA, SNB, 
ANB individualizado e eixo Y. O ângulo ANB não ajustado e o ângulo da convexidade NAP não apresentaram diferenças significantes entre os 2 grupos. De acordo com a norma individualizada do ângulo ANB, os indivíduos com ângulo da base do crânio aumentado na dentadura decídua demonstraram uma tendência a Classe II esquelética tanto na observação inicial como no momento da $2^{\text {a }}$ observação. Observou-se uma constância do padrão esquelético durante o período da avaliação longitudinal. Assim, o relacionamento entre a flexão da base do crânio e o padrão esquelético dos maxilares parece ser estabelecido antes dos 5 anos de idade.

BUSCHANG et al. ${ }^{63}$ verificaram que a velocidade média de crescimento da base do crânio (básio-násio) foi significantemente maior para jovens com má oclusão de Classe II, 1a divisão, em relação aos jovens com oclusão normal e com má oclusão de Classe II, $2^{\text {a }}$ divisão. ROTHSTEIN ${ }^{278}$ observou que a direção do movimento mandibular tende a acompanhar proximamente aquele observado na base do crânio.

Ainda a respeito da relação entre a base do crânio e o padrão esquelético da Classe II, $1^{\text {a }}$ divisão, outros estudos não encontraram diferença do comprimento e da flexão da base craniana entre jovens com a referida má oclusão e com oclusão normal ou má oclusão de Classe I $^{44,222}$. ROTHSTEIN; $\mathrm{PHAN}^{276}$, em 2001, observaram que a flexão da base do crânio não exerce

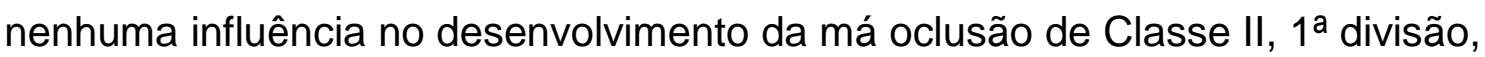
e que as alterações do crescimento no ângulo da base do crânio foram similares àquelas dos jovens com oclusão de Classe $\mathrm{l}$.

\section{Características clínicas da má oclusão de Classe II}

Clinicamente, as principais características da má oclusão de Classe II, $1^{\underline{a}}$ divisão são um posicionamento posterior aparente dos primeiros molares inferiores $^{29,278}$ e dos caninos inferiores ${ }^{29}$, protrusão dos incisivos superiores ${ }^{278,304}$, tendência à mordida cruzada posterior ${ }^{29,307}$, sobressaliência acentuada $^{29,41,54,110,172,197,290,307}$, sobremordida que pode se apresentar normal ${ }^{197,307}$, moderada ${ }^{54}$, profunda ${ }^{41,103,292}$, ou até mesmo negativa ${ }^{292}$. O perfil facial apresenta-se convexo ${ }^{44,197}$, acompanhando a convexidade esquelética que normalmente se faz presente ${ }^{41,44,96}$, e normalmente há uma falta de selamento passivo dos lábios ${ }^{103,304}$. 
Estudos indicam que os sinais clínicos da má oclusão de Classe II são evidentes na dentadura decídua e persistem na dentadura mista e permanente ${ }^{29,140}$, bem como o padrão esquelético, que se estabelece precocemente e se mantém até a dentadura permanente ${ }^{140,222}$, não havendo portanto, uma auto-correção desta condição ${ }^{27,42,43,140}$. ARYA; SAVARA; THOMAS $^{27}$ observaram que todos os pacientes avaliados que apresentavam uma relação de degrau distal dos segundos molares decíduos posteriormente demonstravam uma relação de Classe II dos molares permanentes. Essas observações foram confirmadas por BACCETTI et al. ${ }^{29}$, que verificaram que todas as características oclusais da Classe II foram mantidas ou se acentuaram durante a transição da dentadura decídua para a mista nos indivíduos avaliados, e por BISHARA et al. ${ }^{43}$, que concluíram que a má oclusão de Classe II, quando diagnosticada com base nas características oclusais, nunca se autocorrige nos pacientes em crescimento.

Todavia, FELDMANN; LUNDSTROM; PECK ${ }^{103}$ estudaram longitudinalmente as alterações oclusais naturais da adolescência à idade adulta em indivíduos não tratados, com má oclusão de Classe II, 1a divisão, apresentando sobremordida de moderada a profunda. Os resultados revelaram uma melhora estatisticamente significante (mas não correção) da má oclusão da adolescência à idade adulta para todas as variáveis oclusais avaliadas, exceto para o desenvolvimento de um apinhamento discreto em ambos os arcos dentários. As evidências indicaram que a ausência da correção ortodôntica nos pacientes adolescentes com má oclusão de Classe II, 1aㅡ divisão e sobremordida de moderada a profunda não levará normalmente à deterioração oclusal na idade adulta. Posteriormente, CHUNG; WONG ${ }^{77}$ avaliaram longitudinalmente jovens com má oclusão de Classe II esquelética não tratada aos 9 e aos 18 anos, e verificaram que houve uma tendência de melhora da relação de Classe II esquelética com a idade, com diminuição da convexidade facial.

Tratamento precoce (duas fases) x tratamento em uma fase da má oclusão de Classe II

A persistência das características oclusais e esqueléticas da má oclusão de Classe II, 1a divisão desde a dentadura decídua até a permanente, observada por muitos autores $27,29,42,43,140,222$, justifica o planejamento de uma 
intervenção precoce, embora outros fatores devam ser considerados, como a conduta terapêutica mais adequada a ser instituída e aceitação e cooperação do paciente com o tratamento ${ }^{29}$. Muitos justificam essa intervenção precoce considerando que a correção das alterações da oclusão podem prevenir problemas dentários posteriores, como: aumento da sobremordida e desenvolvimento de apinhamento anterior ${ }^{145}$ maior inclinação vestibular dos dentes superiores ou seqüelas periodontais ${ }^{145}$, injúrias traumáticas devido à inclinação vestibular dos incisivos superiores e ausência de selamento labial passivo ${ }^{213,229}$, além dos aspectos psicológicos envolvidos decorrentes do comprometimento estético, ocasionado pela má oclusão de Classe II, 1aㅡ divisão ${ }^{122,136,175,213,266,324}$, que seriam corrigidos em uma etapa precoce da vida da criança, melhorando sua auto-estima ${ }^{136,264}$. Este problema estético talvez seja a motivação mais importante que leva o paciente a procurar tratamento, principalmente nas sociedades ocidentais, onde a aparência dentofacial exerce um papel fundamental nas inter-relações pessoais, e que o público em geral seja positivamente tendencioso para indivíduos com faces bem proporcionadas $^{324}$. PROFFIT; TULLOCH ${ }^{266}$ recomendam ainda o tratamento precoce para indivíduos que apresentam maturidade esquelética bem a frente do desenvolvimento dentário, e para crianças que apresentam problemas verticais associados à Classe II.

Em 2005, MIGUEL et al. ${ }^{213}$ apontaram as principais vantagens e desvantagens da indicação do tratamento precoce da má oclusão de Classe II. Foram citadas como maiores vantagens: aumento da auto-estima do paciente, redução da incidência de trauma nos incisivos e menor duração da terapia ortodôntica na segunda fase do tratamento. Por outro lado, a principal desvantagem citada foi a saturação de cooperação do paciente. Além desta, também foram apontadas como desvantagens: incapacidade do paciente em cooperar com o tratamento por falta de maturidade; mínimos benefícios ortopédicos pelo fato do paciente ainda não ter iniciado o surto de crescimento pubescente; aumento do tempo total, bem como do custo do tratamento; menor estabilidade dos resultados obtidos; além dos mesmos resultados poderem ser alcançados em um menor tempo de tratamento.

Tradicionalmente, a redução na incidência de traumas nos incisivos superiores consiste em uma importante razão para se considerar o tratamento 
em 2 fases. Entretanto, investigando a incidência de traumas na região dos incisivos em indivíduos com trespasse horizontal maior ou igual a $7 \mathrm{~mm}$ ao início do tratamento, KOROLUK; TULLOCH; PHILLIPS ${ }^{181}$ (2003) avaliaram a influência do tratamento precoce da Classe II na diminuição dessas injúrias aos tecidos dentários. No início da pesquisa, 29,1\% dos pacientes relataram já terem sofrido algum tipo de trauma na região dos incisivos. Durante 0 tratamento, houve um aumento do trauma nesta região, no entanto, este aumento não foi significantemente maior no grupo em que o tratamento foi realizado somente após a completa erupção dos dentes permanentes. Os resultados sugerem que o tratamento da Classe II com o objetivo de diminuir a incidência de traumas na região dos incisivos deve se iniciar tão logo se complete a erupção dos incisivos superiores na cavidade bucal. No entanto, os autores consideraram que os traumas foram de pequena magnitude e que os custos com o tratamento destes traumas são pequenos, quando comparados aos custos de um tratamento ortodôntico em duas fases, com o intuito de diminuir a protrusão dentária. Em 2006, WHEELER et al. ${ }^{342}$, comparando pacientes tratados em 1 e 2 fases, observaram que, após um período de avaliação de 3 anos, não houve correlações estatisticamente significantes entre a existência de novas injúrias aos dentes incisivos e idade, sobressaliência, alteração da sobressaliência, ou tempo de tratamento.

Com o objetivo de avaliar a influência do tratamento precoce da má oclusão de Classe II, $1^{\text {a }}$ divisão na melhora da auto-estima dos pacientes, DANN et al. ${ }^{88}$ avaliaram a auto-estima de 208 pacientes com má oclusão de Classe II e sobressaliência aumentada, variando dos 7 aos 15 anos de idade, antes do início do tratamento, por meio da escala de auto-estima de PIERS; HARRIS $^{264}$. Avaliou-se novamente a auto-estima após o tratamento ortopédico de 87 desses pacientes, que durou em média de 15 meses. Os autores verificaram que não houve associação entre o escore de auto-estima do paciente e a magnitude da sobressaliência ou a idade. Além disso, não houve alteração no escore médio de auto-estima desses jovens durante o tratamento precoce, como também não houve associação entre a redução das principais características morfológicas da Classe II e uma melhora da auto-estima do paciente. Os resultados deste estudo sugerem que os jovens com má oclusão de Classe II que procuram tratamento ortodôntico não apresentam 
necessariamente uma baixa auto-estima e que, em média, não há uma melhora da auto-estima do paciente após o tratamento precoce desta má oclusão.

Avaliando a duração da fase ortodôntica entre pacientes tratados em uma e em duas fases, WHEELER et al. ${ }^{342}$ (2006) observaram que aqueles que se submeteram à primeira fase (ortopédica), finalizaram a segunda (ortodôntica) cerca de 6 meses mais rápido do que aqueles tratados em uma única fase (ortodôntica). Entretanto, ao se considerar o tempo total de tratamento (fase 1 + fase 2 no grupo tratado em 2 fases; fase 1 naquele tratado em uma única fase), o tratamento em 2 fases mostrou-se significantemente mais longo que o tratamento em uma fase ${ }^{66,67,266,342}$; além disto, ao final do tratamento, os resultados alcançados foram semelhantes para os pacientes tratados em uma fase e aqueles tratados em duas fases ${ }^{66,67,266,342}$. De acordo com WHEELER et al. ${ }^{342}$, aproximadamente 3 anos pós-tratamento, não houve diferenças estatisticamente significantes na estabilidade dos resultados do tratamento realizado em uma fase e em duas fases.

PROFFIT; TULLOCH ${ }^{266}$ consideraram que o tratamento precoce não reduz a porcentagem de indivíduos que necessitam de extrações de prémolares ou outros dentes durante a segunda fase do tratamento, nem influencia uma eventual necessidade de cirurgia ortognática.

\section{Má oclusão x mastigação}

Com o propósito de avaliar a hipótese não testada até o momento de que a má oclusão afeta negativamente o desempenho mastigatório, ENGLISH; BUSCHANG; THROCKMORTON ${ }^{99}$ (2002) avaliaram 185 indivíduos não tratados, dos 7 aos 37 anos de idade, divididos em grupos com oclusão normal ( $n=38)$, má oclusão de Classe I $(n=56)$, má oclusão de Classe II $(n=45)$ e má oclusão de Classe III $(n=46)$. O desempenho mastigatório foi avaliado objetivamente, utilizando-se alimentos artificiais (para avaliar tamanho médio das partículas e amplitude de distribuição) e reais (avaliando o número de ciclos mastigatórios até a deglutição), e subjetivamente, utilizando uma escala visual análoga. Os indivíduos com oclusão normal apresentaram tamanhos de partículas significantemente menores e maior amplitude de distribuição das partículas durante a mastigação do que os indivíduos com má oclusão, o que indica melhor desempenho mastigatório. Comparando com o grupo de oclusão 
normal, o tamanho médio das partículas para os grupos com má oclusão de Classe I, Classe II e Classe III foi aproximadamente 9\%, 15\%, e 34\% maiores, respectivamente. Houve também diferenças significantes entre os grupos na habilidade de mastigar cenouras frescas, aipo (ou salsão) e carne firme. Os indivíduos com má oclusão de Classe III relataram maiores dificuldades, seguidos pelos indivíduos com má oclusão de Classe II, Classe I e oclusão normal, respectivamente. A má oclusão não afeta o número de ciclos mastigatórios realizados até que ocorra a deglutição, mas afeta a percepção do indivíduo de como ele pode mastigar bem. Os autores concluíram que a má oclusão afeta negativamente a habilidade do indivíduo de processar e mastigar os alimentos. Posteriormente, TORO et al. ${ }^{312}$ (2006) avaliaram prospectivamente a performance mastigatória em crianças e adolescentes com oclusão normal, más oclusões de Classe I e Classe II. Foram examinados 335 indivíduos nas idades médias de 6, 9, 12 e 15 anos. A performance mastigatória foi quantificada por meio do tamanho médio da partícula e da amplitude da distribuição da partícula utilizando alimento artificial. Observou-se que a performance mastigatória melhora significantemente com a idade; houve diferenças estatisticamente significantes na performance mastigatória entre crianças com oclusão normal e aquelas com má oclusão de Classe I, entretanto, não se encontrou diferenças entre indivíduos com oclusão normal e má oclusão de Classe II.

\section{Crescimento craniofacial em jovens com má oclusão de Classe II}

Nos próximos parágrafos serão abordados aspectos relacionados às alterações decorrentes do crescimento craniofacial e dentoalveolar nos indivíduos com má oclusão de Classe II, 1ํㅡㄹ divisão, suas diferenças entre os gêneros, e as diferenças e/ou semelhanças do crescimento nesta má oclusão quando comparadas com o crescimento em jovens com oclusão normal ou com má oclusão de Classe I.

Em 1986, BUSCHANG et al. ${ }^{63}$ avaliaram o crescimento craniofacial em 40 jovens do gênero masculino, sendo 20 apresentando má oclusão de Classe II não tratada (12 com má oclusão de Classe II, $1^{\text {a }}$ divisão e 8 com 2ª divisão) e 20 apresentando oclusão normal. Os resultados revelaram relativamente poucas diferenças no crescimento craniofacial de jovens dos 11 aos 14 anos de idade com oclusão normal e com má oclusão de Classe II não tratada. A 
velocidade do crescimento mandibular e as reduções anuais do ângulo ANB foram comparáveis para os jovens com oclusão normal e com má oclusão de Classe II. A maxila apresentou mínimo crescimento; seu relacionamento com a base do crânio, definido pelos ângulos do plano palatino e SNA, permaneceu estável ao longo do período avaliado. A velocidade de crescimento mandibular aumentou com a idade, sugerindo que os jovens (gênero masculino) encontravam-se no período do surto de crescimento pubescente. Como o crescimento mandibular acelerou, a discrepância entre a maxila e a mandíbula foi reduzida e a convexidade facial diminuiu. Para a maioria das variáveis (80\%), os jovens com oclusão normal e com má oclusão de Classe II não apresentaram diferenças significantes. Os grupos foram semelhantes nos incrementos e aceleração do crescimento, indicando que as diferenças do tamanho foram estabelecidas antes dos 11 anos de idade e se mantiveram durante a adolescência.

CARTER $^{71}$, em 1987, observou 30 jovens com má oclusão de Classe II, $1^{\text {a }}$ divisão (15 do gênero masculino e 15 do feminino) por um período médio de 5 anos, sendo a primeira avaliação em uma idade média de 12 anos e 1 mês e a segunda, aos 17 anos e 5 meses em média, abrangendo assim o período durante 0 qual normalmente se realiza o tratamento ortodôntico. Durante 0 período observado, o ângulo ANB reduziu em $1^{\circ}$ no gê nero masculino, mas não no feminino. Isto ocorreu provavelmente devido ao crescimento anterior tardio da mandíbula. O aumento médio nas dimensões lineares no grupo masculino foi mais do triplo do aumento observado no grupo feminino, pois a probabilidade do período de observação incluir o surto de crescimento pubescente é bem mais considerável para o gênero masculino do que para o feminino, e também porque o crescimento continua por mais tempo no gênero masculino do que no feminino. Observou-se que o gênero feminino apresentou um padrão de rotação mandibular mais para baixo e para trás do que o gênero masculino. Apesar de haver considerável variação individual, houve uma tendência da sobressaliência reduzir-se suavemente no gênero masculino, mas não no feminino. A sobremordida em média se manteve constante em ambos os gêneros. As diferenças no crescimento facial entre os gêneros enfatizam a importância de parear o número de cada gênero nos estudos cefalométricos. 
De acordo com BUSCHANG et al. ${ }^{62}$ (1988), a predição dos efeitos do tratamento relaciona-se intimamente à compreensão das alterações do crescimento, que seriam esperadas sem a intervenção ortodôntica. Os autores utilizaram modelos matemáticos para estimar e comparar o crescimento mandibular em jovens dos 6 aos 15 anos de idade, com oclusão normal e má oclusão de Classe II, $1^{\text {a }}$ divisão, não tratados. Com exceção da velocidade de crescimento anual, as curvas que descrevem a quantidade e direção do crescimento do ponto cefalométrico gnátio são comparáveis para os jovens com oclusão normal e má oclusão. Observou-se nos jovens com má oclusão uma deficiência de crescimento mandibular de aproximadamente 0,4 cm por ano para o gênero masculino e de $0,2 \mathrm{~cm}$ por ano para o gênero feminino, em relação aos jovens com oclusão normal, nivelando-se com o passar dos anos. Estimou-se que os picos de crescimento da infância e da puberdade ocorrem em média aos 8,7 e 14,1 anos para o gênero masculino e aos 7,7 e 12,9 anos para o gênero feminino, respectivamente.

Com o objetivo de verificar longitudinalmente se a tendência de crescimento no comprimento e largura dos arcos dentários superior e inferior em indivíduos com má oclusão de Classe II, $1^{\text {a }}$ divisão se difere daquela dos indivíduos com oclusão normal, BISHARA; BAYATI; JAKOBSEN ${ }^{42}$, em 1996, avaliaram modelos de gesso de 37 indivíduos com má oclusão de Classe II, 1aㅡ divisão e de 55 com oclusão normal, em três estágios do desenvolvimento (dentadura decídua - idade média = 5 anos; dentadura mista - idade média = 8 anos; e dentadura permanente - idade média = 12,5 anos). Mensurou-se 18 parâmetros relativos ao comprimento e largura dos arcos dentários superior e inferior. Os resultados indicaram que a tendência de crescimento dos parâmetros avaliados nos arcos dentários foi similar nos grupos de oclusão normal e de má oclusão de Classe II, $1^{\text {a }}$ divisão tanto para o gênero masculino quanto para o feminino. Os autores concluíram que o clínico pode assumir que as alterações no comprimento e largura dos arcos dentários tanto em indivíduos com má oclusão de Classe II, 1a divisão como em indivíduos com oclusão normal seguem um mesmo padrão geral.

Buscando determinar se os padrões craniofaciais estabelecidos na dentadura decídua de pacientes com má oclusão de Classe II são mantidos, melhorados ou piorados durante a transição para a dentadura mista, 
BACCETTI et al. ${ }^{29}$, em 1997, compararam um grupo de 25 crianças não tratadas, apresentando má oclusão de Classe II, 1a divisão na dentadura decídua com um grupo controle constituído por 22 crianças com oclusão normal no mesmo estágio de desenvolvimento da dentição. As crianças foram observadas durante um período de 2 anos e meio na transição da dentadura decídua para a mista. As alterações cefalométricas consistiram de um crescimento maxilar significantemente maior (aumento da protrusão maxilar) e menores incrementos nas dimensões mandibulares (no comprimento total e no corpo mandibular) no grupo de Classe II. Além disto, observou-se uma rotação posterior da mandíbula nas crianças com má oclusão de Classe II.

De acordo com BISHARA et al. ${ }^{44}$, em 1997, o potencial de crescimento em indivíduos com má oclusão de Classe II é de interesse do Ortodontista, devido ao fato de que esta má oclusão constitui uma porcentagem significante dos casos tratados. O propósito deste estudo foi comparar longitudinalmente as alterações que ocorrem nas estruturas dentofaciais em indivíduos não tratados com má oclusão de Classe II, $1^{\text {ạ }}$ divisão e com oclusão normal entre as dentaduras decídua e permanente. Selecionou-se a documentação completa de 65 indivíduos em três estágios de desenvolvimento: dentadura decídua completa (média de 5 anos), após a completa irrupção dos primeiros molares permanentes (média de 7,7 anos), e após a completa irrupção dos dentes permanentes (exceto terceiros molares) (média de 12,2 anos). A comparação das alterações totais da dentadura decídua à permanente indicou a presença de um número de diferenças significantes entre os indivíduos com má oclusão de Classe II e com oclusão normal, incluindo uma magnitude maior dos comprimentos mandibulares e maxilares no grupo controle e maior convexidade esquelética e tegumentar no grupo de Classe II. Nos indivíduos com má oclusão de Classe II, $1^{\text {a }}$ divisão o ângulo da convexidade esquelética diminuiu, enquanto a convexidade do tecido mole aumentou com o crescimento quando comparados com indivíduos com oclusão normal.

Em 1997, URSI; MCNAMARA JR. ${ }^{324}$ compararam longitudinalmente 0 crescimento craniofacial de pacientes apresentando má oclusão de Classe II com um grupo controle constituído de indivíduos com oclusão "normal", entre as idades de 10,6 e 12,6 anos, a fim de estabelecer as peculiaridades inerentes aos pacientes que apresentam esta má oclusão, no que se refere ao 
crescimento. Todos os jovens foram selecionados dos arquivos de documentação do "Elementary Growth Study" do Centro de Crescimento Humano da Universidade de Michigan, e todos apresentavam inicialmente dentadura permanente completa. $\mathrm{O}$ crescimento dos dois grupos foi, durante 0 período avaliado de 24 meses, muito semelhante em todos os seus aspectos, não havendo diferenças nos incrementos verificados, indicando que as diferenças encontradas devem ser atribuídas ao crescimento na primeira década de vida.

A fim de descrever as alterações esqueléticas ântero-posteriores e verticais durante a infância e a adolescência, BUSCHANG; MARTINS ${ }^{60}$, em 1998, realizaram um estudo em jovens apresentando más oclusões de Classe I e II que não receberam tratamento ortodôntico. De acordo com os resultados, as relações ântero-posteriores e verticais não se mostraram estáveis durante o crescimento craniofacial. As alterações na relação ântero-posterior ocorreram principalmente devido ao crescimento diferencial da mandíbula. Os jovens que apresentaram um maior aumento na discrepância vertical denotaram também um menor movimento inferior do ponto gônio e um maior movimento inferior do ponto pogônio. O deslocamento inferior dos pontos pogônio e gônio foram maiores durante a adolescência.

HENRIQUES et al. ${ }^{140}$, em 1998, avaliaram as características dentoesqueléticas e as alterações da má oclusão de Classe II, 1a divisão, sem tratamento, em 25 jovens acompanhados por um período médio de 3 anos e 4 meses (em média, dos 9 anos e 4 meses aos 12 anos e 8 meses). A altura facial ântero-inferior aumentou em decorrência do crescimento facial. A relação maxilomandibular demonstrou melhora insignificante, proporcionando a manutenção da discrepância esquelética. Houve manutenção do padrão esquelético de Classe II, bem como do dentário, uma vez que molares e incisivos superiores acompanharam o crescimento maxilar, com mesialização e extrusão; os molares e incisivos inferiores também extruíram, porém com mesialização apenas dos molares, enquanto os incisivos foram retruídos, agravando o trespasse horizontal.

No ano de 2001, ROTHSTEIN; PHAN ${ }^{276}$ apresentaram as diferenças no crescimento entre jovens com má oclusão de Classe II, 1a divisão e aqueles com oclusão de Classe I. De acordo com os autores, o conhecimento das 
diferenças na magnitude e direção de crescimento em jovens com má oclusão de Classe II, 1ํㅡㄹ divisão pode, algumas vezes, possibilitar o clínico controlar o resultado do tratamento. Observou-se que os jovens dos gêneros feminino e masculino diferem entre si na magnitude e direção de crescimento pubescente. Comparado com o controle, o arco dentário superior no gênero feminino com má oclusão de Classe II, $1^{\text {a }}$ divisão cresce mais horizontalmente, os incisivos superiores vestibularizam-se mais (mas não os inferiores), e a mandíbula cresce mais horizontalmente; apresentam também menor crescimento da AFAI e da altura facial anterior total. A convexidade da face média no gênero masculino com má oclusão de Classe II, $1^{\text {a }}$ divisão aumentou marcantemente, devido ao crescimento mais horizontal no ponto $A$ e menos horizontal no násio e pogônio, e os dentes anteriores superiores e inferiores vestibularizaram-se mais; apresentaram também uma diminuição do ângulo goníaco e menor crescimento do comprimento total mandibular. Os jovens tanto do gênero masculino como feminino com má oclusão de Classe II, $1^{\text {a }}$ divisão demonstraram uma diminuição do ângulo do plano mandibular, menor crescimento na altura facial anterior total, e maior inclinação vestibular dos dentes ântero-superiores. Para os autores, os dados sugerem que nos indivíduos em crescimento do gênero feminino, a correção da má oclusão de Classe II, $1^{\text {a }}$ divisão pode ser mais facilmente conseguida devido ao maior crescimento horizontal mandibular, que parece ocorrer entre as idades de $10 \mathrm{e}$ 14 anos. Nos jovens do gênero masculino com má oclusão de Classe II, $1^{\text {a }}$ divisão, deseja-se restringir o crescimento anterior do arco dentário superior, pois pode-se esperar que a mandíbula no gênero masculino apresente um maior componente vertical de crescimento.

Objetivando investigar as alterações dentoalveolares relacionadas com o crescimento mandibular em jovens com má oclusão de Classe II não tratados, YOU et al. ${ }^{350}$, em 2001, avaliaram cefalometricamente 40 jovens antes e após o surto de crescimento pubescente, e compararam com indivíduos com oclusão normal. O crescimento mandibular dos jovens com má oclusão foi semelhante aos com oclusão normal. Entretanto, o efeito do crescimento anterior da mandíbula, que teria um potencial de levar os dentes inferiores para anterior, não ocorreu devido aos movimentos adaptativos do complexo dentoalveolar por meio do travamento da intercuspidação. Isto poderia explicar a razão pela 
qual as más oclusões de Classe II não se auto-corrigem em jovens em crescimento, sem tratamento. Os autores sugeriram que a desarticulação da oclusão, para minimizar os efeitos do mecanismo adaptativo, obtendo-se vantagem com o crescimento normal anterior da mandíbula, facilitaria enormemente o tratamento da má oclusão de Classe II em pacientes na fase de crescimento.

CHUNG; WONG ${ }^{77}$, em 2002, estudaram longitudinalmente 0 crescimento craniofacial em jovens com má oclusão de Classe II esquelética sem tratamento. Avaliou-se as telerradiografias em norma lateral de cada jovem aos 9 e 18 anos de idade e realizou-se comparações entre grupos divididos de acordo com os padrões de crescimento (vertical, equilibrado e horizontal). Os autores concluíram que, aos 9 anos de idade houve diferenças significantes entre os grupos vertical e horizontal, com relação ao SNA, SNB, ANB, convexidade facial, comprimento mandibular e inclinação dos incisivos superiores. Entretanto, dos 9 aos 18 anos, ocorreu aumento do SNA e SNB em todos os grupos, com diminuição do ANB, em virtude de um maior avanço do ponto B. Em todos os grupos, observou-se uma rotação mandibular para frente, com maior significância para o grupo horizontal. Os incisivos inferiores ficaram mais lingualizados no grupo horizontal e mais vestibularizados no grupo vertical. O padrão de crescimento esquelético foi semelhante entre os gêneros, com relação às medidas angulares. Porém, notou-se grande dimorfismo entre os gêneros em algumas medidas lineares, especialmente no grupo vertical.

Em 2002, KLOCKE; NANDA; KAHL-NIEKE ${ }^{179}$ observaram 23 jovens com má oclusão de Classe II dos 5 aos 12 anos de idade, e dividiram esses jovens em dois grupos, de acordo com o comportamento do ângulo ANB. Um grupo de 13 jovens que apresentou uma diminuição do ângulo ANB (pelo menos 1,59 durante o período de avaliação foi deno minado como grupo de crescimento favorável. No outro grupo, denominado de crescimento desfavorável, os 10 jovens apresentaram um aumento do ângulo ANB. Neste último grupo, observou-se algumas características: aumento do ângulo SN.PP, do ângulo goníaco e da distância násio-mentoniano, além de uma diminuição da proporção das alturas facial posterior e anterior. Na avaliação longitudinal, os grupos mostraram diferenças significativas nas medidas SNB e ANB. A 
melhora no relacionamento maxilomandibular no grupo de crescimento favorável ocorreu devido à alteração da posição mandibular.

KIM; NIELSEN ${ }^{176}$, em 2002, propuseram-se a avaliar longitudinalmente a intensidade do crescimento condilar, a rotação mandibular e a associação entre ambos em 32 jovens com má oclusão de Classe II, não tratados. Avaliou-se o crescimento condilar em uma série de telerradiografias tomadas anualmente, dos 8 aos 13 anos de idade. Em média, o gênero feminino cresceu menos que o masculino. Nenhum dos indivíduos manteve uma velocidade consistente de crescimento por mais de 2 anos consecutivos. A média da intensidade de crescimento condilar foi de 2 a $3 \mathrm{~mm}$ por ano, durante o período avaliado, para ambos os gêneros, com o gênero masculino crescendo suavemente mais rápido do que feminino em algumas idades. A maior velocidade de crescimento observada foi $8 \mathrm{~mm}$ em um ano, observada em um jovem do gênero masculino. Três jovens do gênero feminino apresentaram $6 \mathrm{~mm}$ de crescimento condilar em um ano. Em 95\% dos casos, houve rotação mandibular para anterior com o crescimento, com grande variação individual. Não se observou associação entre intensidade de crescimento condilar e rotação mandibular. Os resultados mostraram que a intensidade de crescimento dos côndilos variou consideravelmente entre os jovens, e de ano para ano.

A compreensão dos eventos relacionados ao desenvolvimento físico dos indivíduos é de suma importância na Ortodontia clínica. Assim, o crescimento corporal do adolescente e sua relação com a aceleração do crescimento craniofacial foram investigados por THIESEN et al. ${ }^{311}$ em 2004. Avaliou-se 30 indivíduos com Classe II esquelética, não tratados ortodonticamente, acompanhados longitudinalmente junto ao Centro de Crescimento de Burlington, no Canadá. As documentações (telerradiografias laterais e fichas clínicas) foram obtidas aos 6, 9, 12, 14 e 16 anos de idade cronológica. Os resultados indicaram que o pico de crescimento estatural, bem como o maior incremento médio da maioria das medidas mandibulares avaliadas ocorreram, para o gênero feminino, no período entre os 9 e 12 anos, e para o gênero masculino, entre 12 e 14 anos. 


\section{Conclusão da revisão da literatura sobre a má oclusão de Classe II}

Finalizando esse tópico da revisão de literatura, conclui-se que é de extrema importância o conhecimento das características, das particularidades e do comportamento com o crescimento da má oclusão de Classe II, $1^{a}$ divisão. Desta maneira, o Ortodontista pode realizar um diagnóstico correto da má oclusão e, então, optar pelo tratamento mais adequado ${ }^{1,260,277}$, tendo em vista a grande variabilidade estrutural que acomete os indivíduos com esta alteração oclusal $^{197,293,300}$ e os variados tipos de aparelhos existentes para sua correção ${ }^{260}$. Assim, de acordo com ROTHSTEIN; YOON-TARLIE ${ }^{277}$, o correto diagnóstico de uma má oclusão dita os objetivos do tratamento e a mecanoterapia a ser utilizada.

\subsection{Tratamento da má oclusão de Classe II, $1^{\text {a }}$ divisão com 0 aparelho Jasper Jumper associado ao aparelho fixo}

\section{Aparelho de Herbst - o precursor}

EMIL HERBST (1872 - 1940) foi um ortodontista alemão e o primeiro chefe de um Departamento de Ortodontia na Europa. Nascido em Bremen, idealizou, nos idos de 1900, o primeiro aparelho ortopédico funcional fixo, indicado para a correção da deficiência mandibular. O sistema lançava mão de um mecanismo telescópico bilateral, composto por tubos e pistões. Esse aparelho foi apresentado pela primeira vez em um Congresso Internacional de Odontologia em Berlim, em 1905, com o nome de Herbst-Schanier ${ }^{241,305}$.

$\mathrm{Na}$ mesma época em que HERBST idealizou seu aparelho para o reposicionamento mandibular, destacavam-se na Europa os conceitos e os expoentes da ortopedia funcional dos maxilares, que prometiam resultados satisfatórios com o emprego de aparelhos removíveis, muito mais fáceis de serem confeccionados e adaptados, e com custos operacionais reduzidos. Assim, os aparelhos ortopédicos funcionais removíveis se desenvolveram e firmaram de forma notável na Europa. Por outro lado, vivia-se nos Estados Unidos o apogeu dos elásticos intermaxilares, aplicados com extrema facilidade e sem nenhuma manobra especial para a sua instalação nos aparelhos fixos. Além disso, os Estados Unidos ofereceram particularmente 
muita resistência à aceitação dos aparelhos ortopédicos para avanço mandibular ${ }^{305}$.

Pelas razões supracitadas, o aparelho de Herbst caiu no esquecimento da comunidade ortodôntica por vários anos, até que em 1979, o sueco HANS PANCHERZ ${ }^{234}$ o reintroduziu, despertando grande interesse clínico por parte dos Ortodontistas ${ }^{241}$. A partir daí, PANCHERZ $Z^{235-240,244-254}$ e outros

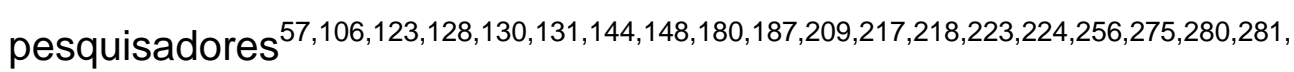

283,325,327,336,337 realizaram inúmeras investigações que proporcionaram um embasamento científico mais sólido a respeito da utilização e dos efeitos terapêuticos do aparelho de Herbst ${ }^{203}$.

\section{Efeitos do tratamento com o aparelho de Herbst}

Os efeitos do tratamento com 0 aparelho de Herbst têm sido amplamente investigados. Em relação à maxila, grande dos autores concorda que há uma restrição do seu deslocamento anterior ${ }^{83,84,234,237,238,248,251,252,327 . ~}$ PANCHERZ; ANEHUS-PANCHERZ ${ }^{246}$, em 1993, avaliaram cefalometricamente os efeitos do tratamento com o aparelho de Herbst no complexo maxilar, e observaram que houve um crescimento ântero-posterior, porém, menor que no grupo controle, composto por jovens com má oclusão de Classe II não tratados. Os autores concluíram que o aparelho de Herbst apresenta um efeito similar ao do extrabucal de tração occipital no complexo maxilar, especialmente em relação à distalização dos primeiros molares superiores, que foi em média de 2,1mm. Em 1997, PANCHERZ ${ }^{240}$ chegou a conclusões similares. Porém, a magnitude desta restrição do deslocamento anterior da maxila é menos significante que a encontrada nos pacientes tratados com aparelhos extrabucais, ou mesmo com outros aparelhos funcionais ${ }^{240,322,325,327}$. Já NAHÁS ${ }^{218}$ e ALMEIDA et al. ${ }^{10,11}$ não observaram nenhuma influência significante do tratamento com o aparelho de Herbst no crescimento maxilar.

Considerando-se o componente mandibular, há uma grande concordância na literatura consultada em relação aos efeitos do aparelho de Herbst. Os autores relatam um aumento no comprimento mandibular logo após a remoção do aparelho, o que indica um aumento no crescimento ânteroposterior mandibular quando comparado aos grupos 
controle ${ }^{10,11,130,180,187,209,223,234,235,237,238,248,251,253,256,257,281,282,303,327}$. A posição mais anterior da mandíbula após o tratamento ocorre devido a uma estimulação do crescimento do côndilo em resposta ao avanço mandibular $^{131,209,235-237,248,251,256,257,282,284,285,303,327}$, combinada a uma remodelação da fossa articular $^{236,282,284}$, observadas também em experimentos em animais ${ }^{335,336,347}$.

A restrição do deslocamento maxilar para anterior e a estimulação do crescimento mandibular resultam em uma melhora considerável no perfil facial e na relação maxilomandibular ${ }^{83,127,234,238,240,247,248,295,327 . ~}$

Avaliando os efeitos do aparelho de Herbst no componente vertical, há uma tendência do plano mandibular apresentar um comportamento semelhante ao do plano palatino, deslocando-se de maneira paralela, similarmente aos grupos controle, indicando uma harmonia no aumento das dimensões verticais anterior e posterior $209,234,236,280,295,327$. PANCHERZ ${ }^{237}$ demonstrou que 0 aparelho de Herbst ocasionou um aumento da altura facial ântero-inferior, o que veio a ser confirmado posteriormente em outro estudo ${ }^{238}$. MCNAMARA JR.; HOWE; DISCHINGER ${ }^{209}$ e URSI; MCNAMARA JR.; MARTINS ${ }^{322,325}$ verificaram um aumento tanto na altura facial ântero-inferior como na posterior, não influenciando negativamente o ângulo do plano mandibular. De acordo com PANCHERZ ${ }^{237}$, esse aumento na AFAI com o tratamento contra-indica seu uso em pacientes com altura facial excessiva. Entretanto, VALANT; SINCLAIR $^{327}$ não verificaram esse aumento, e atribuíram esse fato a um melhor controle vertical dos molares inferiores, utilizando-se uma cobertura de resina acrílica sobre os dentes. NAHÁS ${ }^{218}$ e ALMEIDA et al. ${ }^{10,11}$ concluíram que o tratamento com o aparelho de Herbst não influencia significantemente 0 padrão de crescimento craniofacial.

O aparelho de Herbst proporciona grandes alterações dentoalveolares. Em relação aos incisivos superiores, algumas pesquisas indicam que não ocorrem alterações significantes em suas posições $234,235,237,238,251,325,327$, enquanto outras demonstraram uma maior inclinação lingual ${ }^{10,11,209,218}$, retrusão ${ }^{10,11,218}$ e extrusão ${ }^{209}$. Já para os molares superiores, há um consenso na literatura de que o tratamento com o aparelho de Herbst induz alterações significantes. Muitos autores verificaram uma distalização desses dentes $^{83,209,218,234,238,251,327}$ e restrição de desenvolvimento no sentido 
vertical $^{10,11,218}$. MCNAMARA JR.; HOWE; DISCHINGER ${ }^{209}$ e VALANT; SINCLAIR ${ }^{327}$ observaram uma manutenção da posição vertical desses dentes, enquanto PANCHERZ ${ }^{234}$ relatou a intrusão relativa dos molares superiores.

Considerando-se os incisivos inferiores, os autores são unânimes em afirmar que 0 aparelho de Herbst promove uma vestibularização, porém, em graus variados ${ }^{10,11,83,209,218,234-238,240,242,248,250,251,325,327}$. Entretanto, após a remoção do aparelho, os incisivos inferiores tendem a recidivar na direção lingual ${ }^{129}$, principalmente nos primeiros seis meses, quando então assumem suas posições estáveis no arco dentário. RUF; HANSEN; PANCHERZ ${ }^{279}$ avaliaram os efeitos da vestibularização dos incisivos inferiores no periodonto a longo prazo, e verificaram que este se manteve sadio. Além da vestibularização, o aparelho de Herbst tende a intruir os incisivos inferiores, provavelmente devido ao componente de força do aparelho e à vestibularização dos mesmos ${ }^{209,218,327}$. Os molares inferiores também são significantemente influenciados pela terapia com 0 aparelho de Herbst, havendo uma mesialização desses dentes com 0 tratamento $209,218,234$ 237,250,251,322,325,327. Pode haver também uma tendência de extrusão desses dentes, apresentando uma variação na magnitude em decorrência do modelo do aparelho utilizado ${ }^{10,11,209,234,322,325}$.

Com relação ao perfil mole, as principais alterações proporcionadas pelo tratamento com o aparelho de Herbst são uma discreta retrusão do lábio superior $^{59,247,322,325}$, protrusão do lábio inferior $r^{59,247,322,325}$, projeção anterior do pogônio $^{322,325}$, diminuição da convexidade facial ${ }^{59,247,322,325}$ e conseqüente melhora do perfil facial ${ }^{59,218,247,322,325}$. NAHÁS ${ }^{218}$ (2004) concluiu que o perfil facial foi influenciado positivamente, de modo significante, em decorrência das alterações dentárias induzidas pelo tratamento com este aparelho.

\section{Época de tratamento com o aparelho de Herbst}

Há uma controvérsia na literatura em relação à época ideal para iniciar o tratamento com o aparelho de Herbst. Segundo PANCHERZ ${ }^{243}$, HANSEN; PANCHERZ; HÄGG ${ }^{131}$, KONIK; PANCHERZ; HANSEN ${ }^{180}$, a época ideal de tratamento com o Herbst seria na dentadura permanente ou logo após o pico de crescimento pubescente (em torno dos 14 a 16 anos para o gênero masculino e 12 a 14 anos para o feminino). O limite superior de idade ainda é desconhecido ${ }^{242,243}$. As imagens de ressonância magnética da ATM 
demonstraram que é possível reativar o crescimento no côndilo e fossa articular mesmo em pacientes com idades mais avançadas ${ }^{242,243}$. O tempo de tratamento ativo com esse aparelho é de 6 a 8 meses, e nos indivíduos com idades mais avançadas é um pouco maior. PANCHERZ ${ }^{243}$ afirmou que não há vantagens em se utilizar o aparelho de Herbst na dentadura decídua ou mista. Nestes pacientes não seria possível obter uma intercuspidação estável dos dentes após o tratamento e, portanto, os resultados deveriam ser mantidos até que todos os dentes permanentes tivessem irrompido.

SILVA FILHO et al. ${ }^{305}$ acreditam que a época oportuna para se tratar uma deficiência mandibular deveria coincidir com a época de grande potencial de crescimento mandibular. Normalmente, os autores não iniciam o tratamento ortopédico funcional antes do segundo período transitório da dentadura mista, entretanto, quando há uma severa deficiência mandibular, iniciam o tratamento no período intertransitório da dentadura mista. Há um predomínio de compensações dentárias quando se instala o aparelho depois do pico de crescimento pubescente, em detrimento dos efeitos ortopédicos, que são mais evidentes quando se realiza o tratamento durante o surto de crescimento ${ }^{123,250}$. Todavia, ALMEIDA et al. ${ }^{10,11}$ avaliaram os efeitos esqueléticos e dentoalveolares produzidos pelo aparelho de Herbst na dentadura mista; os autores observaram a predominância dos efeitos de natureza dentoalveolar na correção da Classe II. Observaram ainda que os efeitos esqueléticos mandibulares obtidos foram de menor magnitude que aqueles observados em outros estudos com pacientes adolescentes, utilizando o mesmo protocolo de tratamento. PAULSEN ${ }^{256}$ utiliza o aparelho de Herbst mesmo depois da adolescência, com relatos de pequena remodelação da ATM.

\section{Vantagens e desvantagens do aparelho de Herbst}

De acordo com PANCHERZ ${ }^{241}$, as principais vantagens do aparelho de Herbst são: é fixo aos dentes; não necessita da cooperação do paciente para a sua correta função; atua 24 horas por dia e o tempo de tratamento é menor (aproximadamente de 6 a 8 meses). Por outro lado, COELHO FILHO ${ }^{78}$, em 1995, relatou que o aparelho de Herbst apresentava algumas desvantagens, como: a rigidez (que limita parcialmente os movimentos mandibulares, principalmente de lateralidade ${ }^{163-165}$ ), a necessidade de trabalhos laboratoriais, 
a utilização de coroas ou bandas especiais, a grande possibilidade de quebras e o alto custo do aparelho.

\section{O aparelho Jasper Jumper}

Numa tentativa de superar estes problemas do aparelho de Herbst, JAMES JASPER ${ }^{162}$, em 1987, desenvolveu um novo dispositivo flexível para o avanço mandibular, o Jasper Jumper, composto por dois módulos flexíveis de força que minimizam os problemas causados pela rigidez do aparelho de Herbst, permitindo ao paciente muito mais liberdade dos movimentos mandibulares. Além disto, há uma redução do tempo total de tratamento, pois, o aparelho Jasper Jumper é utilizado juntamente com o aparelho fixo. Assim, o tratamento é realizado em apenas uma fase, não necessitando de duas fases, uma ortopédica e outra ortodôntica corretiva, como ocorre com a maioria aparelhos ortopédicos funcionais. É um aparelho fixo flexível que libera força leve e contínua ${ }^{47}$.

O aparelho Jasper Jumper é relativamente novo, e pouco foi publicado até o momento a respeito da sua utilização, principalmente se comparado à vasta documentação envolvendo o aparelho de Herbst. Porém, há uma razoável similaridade entre os estudos encontrados na literatura no que tange os efeitos do Jasper Jumper. Estes assemelham-se bastante aos efeitos produzidos pelo aparelho de Herbst, devido à equivalência dos seus mecanismos de ação ${ }^{163-165}$.

O aparelho Jasper Jumper produz um vetor de força com ação de pressão, forçando um distanciamento, entre si, dos pontos de apoio da força. Esta força resultante contrasta-se com a ação de tração observada nos elásticos intermaxilares, que tendem a aproximar os seus pontos de apoio ${ }^{163-}$ 165. As forças geradas pelos módulos apresentam direção ântero-posterior, intrusiva e expansiva. As forças ântero-posteriores distalizam as unidades de ancoragem posteriores superiores $\left(1^{\circ}\right.$ molar superior ou $1^{\circ}$ e $2^{\circ}$ molares superiores) e geram uma força anterior na mandíbula e seus dentes. Produzse uma força intrusiva nas regiões póstero-superior e ântero-inferior, além da força vestibular, que também é produzida pelo módulo na região pósterosuperior $^{163-165,171}$. 


\section{Efeitos do tratamento com o aparelho Jasper Jumper}

Os principais resultados esperados com o uso do Jasper Jumper nos casos de má oclusão de Classe II são: a restrição do deslocamento anterior da maxila5,6,79,80,183,184,215,219,310; protrusão mandibular significante $5,6,171,183,184,310$, embora outros estudos não evidenciaram nenhuma alteração significante no crescimento mandibular $80,170,219,226,227$; algum indício de crescimento condilar $^{47,171}$; a intrusão e distalização dos molares superiores ${ }^{47,79,80,163-}$ $165,171,183,184,215,219,310,338,340$, com abertura ocasional da mordida posterior ${ }^{47}$ e expansão dos molares superiores (se não utilizar ancoragem) ${ }^{47,171}$. KARACAY et al. $^{171}$ relataram a expansão dos arcos dentários superior e inferior, mesmo tendo inserido torque lingual de coroa na região póstero-superior; segundo os autores, o arco inferior expandiu como resultado da intercuspidação com o arco superior. Além disto, há a distalização dos incisivos superiores (retrusão e/ou inclinação distal) $5,6,79,80,171,183,184,215,219,310,338,339$ e extrusão dos mesmos $^{80,171,183,184,219}$; movimento anterior dos dentes inferiores ao longo do osso alveolar (molares e incisivos) 5,6,47,79,80,170,171,183,184,215,219,226,227,310,338-340; intrusão dos incisivos inferiores ${ }^{47,79,80,171,183,184,219,310,340}$ e extrusão dos molares inferiores $^{79,80,171,183,184,226,227}$.

Há uma melhora significante do relacionamento maxilomandibular ${ }^{171,184,219,226,227}$. As alterações dentárias resultam em uma rotação horária do plano oclusal ${ }^{80,171,183,184,219}$ (considerando-se a telerradiografia em norma lateral com o perfil voltado para a direita), sem que haja uma rotação do plano mandibular ${ }^{80,183,184}$. Entretanto, alguns autores citam uma ligeira tendência de rotação horária da mandíbula ${ }^{79,171}$. Enfim, de uma maneira geral não ocorrem alterações verticais significantes $5,6,170,183,219,226,227$. Há uma melhora do perfil mole dos pacientes ${ }^{171,183,219}$.

Observando os efeitos do tratamento com o Jasper Jumper percebe-se que a correção da má oclusão de Classe II ocorre principalmente devido às alterações dentoalveolares em vez das alterações esqueléticas, apesar da utilização de métodos para minimizar esses efeitos e potencializar os esqueléticos $^{5,6,79,80,170,171,183,196,219,226,227}$. WEILAND; BANTLEON ${ }^{338}$ (1995) observaram que esta correção deveu-se $40 \%$ às alterações esqueléticas e $60 \%$ às alterações dentárias após 6 meses de uso do Jasper Jumper em pacientes na fase de crescimento. As alterações esqueléticas foram predominantemente mandibulares. KÜÇÜKKELES; ILHAN; ORGUN ${ }^{183}$ (2007) comprovaram a 
efetividade do Jasper Jumper em corrigir a má oclusão de Classe II, entretanto, $80 \%$ das alterações ocorridas foram de natureza dentoalveolar.

COPE et al. ${ }^{79}$ (1994) consideraram que o aparelho Jasper Jumper produz resultados semelhantes aos demais aparelhos funcionais, com a vantagem de propiciar um maior controle pelo profissional, sendo bastante efetivo nos casos de pacientes não colaboradores.

\section{Indicações do aparelho Jasper Jumper}

Considerando-se os efeitos proporcionados pelo tratamento com 0 aparelho Jasper Jumper, pode-se constatar que a principal indicação desse aparelho consiste nos casos de Classe II, $1^{\underline{a}}$ divisão, em crescimento, preferencialmente quando se diagnostica a retrusão mandibular ${ }^{74}$. Utiliza-se esse aparelho para reposicionar a mandíbula em uma oclusão de Classe I por meio do avanço mandibular ${ }^{74}$. Idealmente, não deve haver sobremordida profunda, e o padrão de crescimento deve ser favorável (equilibrado ou horizontal) para assegurar o sucesso do tratamento ${ }^{74}$. Quando se deseja o avanço mandibular, a magnitude de força gerada pelo módulo (que deve ser ativado $4 \mathrm{~mm}$ ) deve ser geralmente maior ( 6 a 8 onças, que equivalem a 170,1 a 226,8 gramas) que o gerado quando se deseja apenas a distalização do molar. Como conseqüência do aumento da força nos módulos, o paciente tende a posicionar sua mandíbula para frente ${ }^{163-165}$.

Outra indicação desse aparelho constitui alguns casos de má oclusão de Classe II, onde se deseja distalizar e intruir os primeiros molares superiores (efeito extrabucal) $^{74,163-165}$. Este tipo de movimento é alcançado quando não se conjuga os dentes superiores em bloco ou quando não se dobram as extremidades distais do arco, permitindo que o mesmo permaneça reto e sobre ligeiramente na distal dos tubos ${ }^{163-165}$. Os módulos devem produzir forças leves (2 a 4 onças, que equivalem a 56,7 a 113,4 gramas) para distalizar os molares superiores. Como a força é distribuída por toda a arcada inferior, observa-se pouca alteração inferior ${ }^{163-165}$. O efeito extrabucal pode ser produzido não apenas em pacientes em crescimento, mas também em adultos ${ }^{163-165}$. Após a distalização dos molares, o módulo pode ser deixado no local para ancorar a retração dos pré-molares e caninos. Também pode ser utilizado para aumentar a ancoragem durante a retração dos dentes ântero-superiores, em casos com ou sem extrações, mesmo em pacientes com má oclusão de Classe $1^{47,74,163-165}$. 
Nesses casos, os dentes póstero-superiores são contidos pela ação dos módulos de força. Além disto, pode-se utilizar uma mola de níquel-titânio ou elástico intramaxilar (elástico corrente) preso ao gancho que fixa o Jasper Jumper ao tubo do molar superior para retrair os dentes anteriores. A ancoragem do molar contra a ação desta força de tração é dada pela ação do módulo e pelo arco dentário inferior ${ }^{163-165}$.

ZIMMER; ROTTWINKEL ${ }^{352}$, em 2002, consideraram a utilização do Jasper Jumper nos casos de fechamento de espaços decorrentes da agenesia de segundos pré-molares inferiores, sem extrações no arco superior. Optou-se pelo Jasper Jumper com o intuito de promover uma ancoragem para a mesialização dos molares inferiores, minimizando os efeitos secundários. 0 aparelho transfere a ancoragem ântero-inferior para o arco superior. Os autores relataram a utilização do Jasper Jumper em seis pacientes com agenesia dos segundos pré-molares inferiores por um período de seis meses, onde se observou uma relação molar de Classe III desejável, com sobremordida e sobressaliência normais. Um significante ganho de espaço distalmente aos segundos molares confirmou a relevante mesialização dos molares inferiores, possibilitando aos terceiros molares inferiores funcionarem como "substitutos" naturais dos segundos pré-molares ausentes.

O Jasper Jumper pode ser utilizado também em pacientes que apresentam assimetrias dentárias ântero-posteriores, como nos casos de má oclusão de Classe II, subdivisão ${ }^{100,163-165}$. Deve-se conjugar em bloco o lado onde há a relação molar de Classe I. Assim, pode-se alcançar também efeitos ortopédicos assimétricos ${ }^{163-165}$.

Pode-se indicar a utilização do Jasper Jumper em pacientes com má oclusão de Classe III, especialmente nos casos cuja má oclusão se caracteriza mais pela retrusão maxilar esquelética em vez do prognatismo mandibular ${ }^{111,163-165}$. Nesses casos, o aparelho é utilizado com sua posição invertida $^{111}$. PHAM et al. $^{262}$, em 1996 e FULY; OLIVEIRA; URSI ${ }^{111}$ em 2000, descreveram casos clínicos de jovens com má oclusão de Classe III tratados satisfatoriamente por meio do aparelho Jasper Jumper invertido.

Outras aplicações potenciais deste sistema incluem a correção das mordidas cruzadas em pacientes com pseudo-Classe III ou Classe III funcional, a estabilização pós-cirúrgica das más oclusões de Classe II e III e o 
condicionamento muscular pré-cirúrgico nos pacientes com má oclusão de Classe II $^{163-165}$.

\section{Época de tratamento com o aparelho Jasper Jumper}

Normalmente, o Jasper Jumper é utilizado na dentadura permanente, em pacientes na fase de crescimento, por volta dos 10 a 14 anos $^{51,74,79,80,338}$, podendo também ser utilizado em pacientes adultos ${ }^{72,183,219,310}$. De acordo com KÜÇÜKKELES; ILHAN; ORGUN ${ }^{183}$, pelo fato dos efeitos proporcionados pelo tratamento serem predominantemente dentoalveolares (aproximadamente 80\%), o Jasper Jumper pode ser utilizado em pacientes com má oclusão de Classe II, mesmo após o final do crescimento. Em 2005, NALBANTGIL et al. ${ }^{219}$ sugeriram que o tratamento com o Jasper Jumper em pós-adolescentes poderia ser uma alternativa à cirurgia ortognática nos casos limítrofes de Classe II. WEILAND; DROSCHL ${ }^{339}$ utilizaram o Jasper Jumper em um dos seus casos no qual o paciente se recusou a submeter à cirurgia ortognática, obtendo resultados bastante satisfatórios.

Porém, o Jasper Jumper também pode ser utilizado na dentadura mista, utilizando-se bandas nos molares e acessórios colados nos incisivos (4 x 2). Nesses casos, torna-se indispensável a utilização de recursos de ancoragem (barra palatina e arco lingual fixo) para controlar o potencial dos efeitos colaterais desfavoráveis produzidos pelo aparelho (como a inclinação de molares e incisivos), uma vez que não apresenta a ancoragem proporcionada pelo aparelho fixo colado em todos os dentes ${ }^{163-165}$. Uma outra variação do aparelho Jasper Jumper que permite seu uso na dentadura mista foi descrita por MILLS; MCCULLOCH ${ }^{215}$, em 1997. O caso clínico relatado apresentava indicação prévia de expansão rápida da maxila. Assim, as molas do Jasper Jumper foram fixadas ao aparelho expansor e a um arco lingual inferior. Como nos casos tratados com o Jasper Jumper de maneira convencional, as alterações obtidas com o tratamento também foram predominantemente dentoalveolares.

Uma outra modificação do emprego do Jasper Jumper foi relatada em 2003 por SARI et al. ${ }^{291}$. Trata-se do Jasper Jumper removível "splintado" em placas de acrílico superior e inferior, associado ao extrabucal. Os autores sugerem que a indicação ideal para o tratamento com o Jasper Jumper removível associado ao extrabucal consiste nos casos com ângulos altos 
(padrão de crescimento vertical), particularmente com excesso maxilar e deficiência mandibular.

Aspectos mecânicos do uso do aparelho Jasper Jumper Ancoragem

Para se obter resultados satisfatórios com o Jasper Jumper torna-se relevante 0 entendimento das forças geradas pelo aparelho e, conseqüentemente, a utilização de uma adequada ancoragem para minimizar os efeitos indesejados no tratamento e potencializar os efeitos desejados. Os Jasper Jumpers devem ser instalados em arcos retangulares pesados ${ }^{74,163-}$ 165,196,226,227. Para controlar a força expansiva na região póstero-superior e minimizar a movimentação dos dentes póstero-superiores, indica-se a utilização de barra palatina ${ }^{47,74,163-165,171,196,219,226,227}$ e/ou a utilização de arco pesado constrito nessa região ${ }^{47,74,163-165,183}$, no qual pode ser incorporado torque lingual de coroa ${ }^{74,163-165,183}$, a menos que se deseje uma expansão lenta ${ }^{47}$. Entretanto, no estudo de KARACAY et al. ${ }^{171}$, apenas o torque lingual de coroa não foi adequado para controlar a expansão do arco superior. Segundo KÜÇÜKKELES; ILHAN; ORGUN ${ }^{183}$, a maioria dos casos de Classe II com retrognatismo mandibular apresenta maxila atrésica em relação à mandíbula posicionada após o avanço; esses casos poderiam se beneficiar da força expansiva gerada pelo Jasper Jumper. Por este motivo, os autores não utilizaram a barra palatina nos pacientes avaliados, utilizando apenas o arco constrito e torque lingual de coroa na região posterior do arco superior. CHAMPAGNE $^{74}$ recomenda também incluir os segundos molares superiores no arco para compensar a inclinação e vestibularização dos primeiros molares superiores, entretanto, na maioria das vezes, os tubos nos segundos molares superiores impedem a colocação e remoção dos Jasper Jumpers ${ }^{163-165}$.

Sugere-se incluir um torque vestibular nos dentes ântero-superiores para contrabalancear os efeitos de lingualização ou verticalização desses dentes $^{74,183}$. Para minimizar o efeito de vestibularização e/ou protrusão dos incisivos inferiores, recomenda-se a instalação de um arco retangular o mais espesso possível, adicionando torque lingual nesta região do arco ${ }^{47,50-52,74,163-}$ 165,219,226,227. Também pode-se utilizar braquetes ântero-inferiores com torques linguais incorporados ${ }^{47,163-165,183,219}$. Além disto, para aumentar a ancoragem, 
deve-se incorporar os segundos molares inferiores no arco, se possível ${ }^{74}$; dobrar o fio na extremidade distal do último molar inferior incluído no sistema ou amarrar o fio ao tubo por meio de dobras em ômega ${ }^{74,163-165,226,227}$.

JASPER; MCNAMARA JR. ${ }^{163}$ e JASPER; MCNAMARA JR.; MOLLENHAUER ${ }^{164,165}$ relataram que quando se deseja promover o avanço mandibular, o fator clínico mais importante é preparação da unidade de ancoragem maxilar. $\mathrm{O}$ movimento dos dentes póstero-superiores deve ser minimizado para maximizar a alteração mandibular. $\mathrm{O}$ arco deve ser amarrado (por meio da dobra ômega) ou dobrado na extremidade distal ${ }^{74,163-165,226,227 . ~}$ Essa extremidade apenas deverá ser reta quando se desejar distalizar os primeiros molares superiores ${ }^{74,163-165}$. Além disso, deve-se utilizar uma barra palatina para se obter ancoragem intra-arco e minimizar o movimento dos dentes posteriores.

\section{Tempo de tratamento com o Jasper Jumper}

O Jasper Jumper é capaz de produzir alterações rápidas no relacionamento oclusal ${ }^{47}$. O tempo de tratamento é normalmente encurtado devido ao seu uso 24 horas por dia, com a aplicação ininterrupta das forças ${ }^{47,162}$. JASPER ${ }^{162}$ recomenda 6 meses para o alinhamento e preparo de ancoragem, 6 a 9 meses para o uso do Jasper Jumper (com visitas de controle agendadas a cada 4 a 6 semanas $^{74}$ ), e 12 meses para a finalização. BLACKWOOD $1 \mathrm{II}^{47}$ considera este tempo bastante apropriado, e o tempo adicional para a finalização e detalhamento constituiu uma grande vantagem.

Grande parte dos autores concorda que o Jasper Jumper pode produzir uma resposta apropriada em, aproximadamente, 6 meses de tratamento $^{74,80,171,183,184,310,338,340,352}$. COPE et al. ${ }^{79}$ relataram que, de uma maneira geral, este tempo de tratamento com o Jasper Jumper varia de 3 a 7 meses. Para OLIVEIRA JR. ${ }^{226}$ (2002) e OLIVEIRA JR.; ALMEIDA ${ }^{227}$ (2004), o tempo médio de utilização do Jasper Jumper pelos pacientes avaliados foi de 8 meses.

\section{Contenção e estabilidade do tratamento com o Jasper Jumper}

Por ser um aparelho relativamente novo, pouco se publicou até 0 momento sobre protocolos de contenção e a estabilidade do tratamento da Classe II por meio do Jasper Jumper. 
JASPER $^{162}$ recomenda que após a obtenção de uma relação molar de Classe I, O Jasper Jumper deve permanecer passivamente no local como contenção por 3 ou 4 meses, a fim de aumentar a estabilidade dos resultados. KÜÇÜKKELES; ILHAN; ORGUN ${ }^{183}$ recomendam a realização de uma sobrecorreção no sentido ântero-posterior, alcançando uma relação de "superClasse I". De acordo com CHAMPAGNE ${ }^{74}$, deve-se realizar uma sobrecorreção, aproximadamente, em topo (1/2 Classe III) ao final do período do tratamento ativo. Só então deve-se remover o Jasper Jumper e utilizar elásticos de Classe II apenas durante a noite, como contenção dos resultados do tratamento ${ }^{74,171}$. Deve-se aguardar um mês e controlar a recidiva, guiando para uma relação dentária de Classe $\mathrm{I}^{74}$.

Em 1998, STUCKI; INGERVALL avaliaram os efeitos da correção da má oclusão de Classe II na dentadura permanente precoce com o Jasper Jumper, bem como a estabilidade desses efeitos após um período mediano de observação de 7 meses (variando de 4 a 12,5 meses). Após a remoção dos Jasper Jumpers, utilizou-se elásticos de Classe II como contenção em 18 pacientes, em 5 casos utilizou-se o ativador, enquanto que em três pacientes não se utilizou nenhuma contenção. $O$ tempo mediano de uso da contenção foi de 5 meses (variando de 2 a 9 meses). Após o período de observação, houve uma recidiva parcial dos efeitos dentoalveolares obtidos. $O$ efeito que mais contribuiu para a manutenção dos resultados alcançados foi o efeito esquelético na mandíbula (aumento do prognatismo mandibular). Esse efeito esquelético mandibular foi semelhante tanto nos indivíduos mais jovens como naqueles com idade mais avançada (uma vez que este estudo avaliou jovens com idades iniciais dos 13 anos e 1 mês aos 24 anos e 8 meses, com mediana de 14 anos e 8 meses). Ao final do período de observação, aproximadamente $60 \%$ da redução da sobressaliência e $75 \%$ da correção da relação molar foram mantidas. Este estudo demonstrou que o Jasper Jumper é um aparelho efetivo para a correção da má oclusão de Classe II, 1a divisão na dentadura permanente precoce, e que a recidiva parcial dos efeitos dentários obtidos torna clara a necessidade de uma sobrecorreção moderada.

O protocolo de contenção utilizado por OLIVEIRA JR. ${ }^{226}$ (2002) e OLIVEIRA JR.; ALMEIDA ${ }^{227}$ (2004) foi uma placa de Hawley modificada no arco superior e o $3 \times 3$ inferior após a remoção dos aparelhos fixos. 


\section{Vantagens do tratamento com o Jasper Jumper}

Uma grande vantagem do aparelho Jasper Jumper consiste no controle direcional que ele permite ao profissional, principalmente quando comparado aos elásticos intermaxilares, com suas forças extrusivas e constritoras nos molares inferiores e extrusiva nos dentes ântero-superiores ${ }^{47}$. Apresenta também maior controle da quantidade de força aplicada pelos módulos em relação ao aparelho de Herbst ${ }^{163-165}$. Além disto, apresenta uma grande facilidade para a sua instalação, ativação e remoção $0^{47,183,196,310}$. Outra grande vantagem que estimula os Ortodontistas quanto à utilização do Jasper Jumper é o reduzido tempo em que ocorre a correção da discrepância ânteroposterior ${ }^{47,80,163-165}$, sem aumentar significantemente 0 vetor de crescimento vertical $^{80}$, permitindo assim, um tempo adicional para a finalização do caso ${ }^{47}$. $O$ tempo total de tratamento também é reduzido, pois não há a fase ortopédica previamente à fase corretiva ${ }^{162}$. Comparando com a maioria dos aparelhos funcionais, o Jasper Jumper se adapta bem aos aparelhos fixos. A correção de maus posicionamentos dentários, tais como, rotações e dentes não alinhados, pode ser perfeitamente integrada à terapia ortopédica. Assim, toda a correção pode ser realizada em uma única fase de atuação ${ }^{50-52,163-165,196}$. A literatura atual propõe, exceto para $10 \%$ dos pacientes que necessitam de uma intervenção precoce, a utilização de uma abordagem de tratamento que envolva uma só fase $49,66,67,114,116,169,191$.

Uma outra vantagem desse sistema de força refere-se ao fato dele poder ser acrescentado ao aparelho fixo já existente. Assim, os Jasper Jumpers podem ser utilizados como um método primário de tratamento ou serem adicionados posteriormente, após tentativas sem sucesso de tratamentos anteriores (por exemplo: aparelho extrabucal, aparelho ortopédico funcional removível, elásticos de Classe II) ${ }^{163-165,310}$. Não é necessário que se remova o aparelho fixo total para que os módulos sejam instalados, nem se requer qualquer custo adicional com laboratório (fase laboratorial), a não ser que seja indicada a utilização da barra palatina soldada ${ }^{163-165}$. Além disto, o Jasper Jumper exige menor tempo clínico, tornando-o assim menos oneroso ${ }^{310}$.

Outra característica positiva do Jasper Jumper é sua flexibilidade ${ }^{47,163-}$ 165, que facilita a higienização bucal ${ }^{47,163-165}$, e devido às curvas do aparelho para fora do contato oclusal durante o fechamento (em direção à bochecha), 
ele não interfere na mastigação ${ }^{47,163-165}$. Ainda, a curvatura do módulo em direção vestibular produz um modesto efeito de escudo ao mecanismo de força do músculo bucinador ${ }^{163-165}$. Além disto, o Jasper Jumper, por meio da realização de uma pressão flexível em vez de rígida, permite maior liberdade de movimento mandibular, principalmente de lateralidade ${ }^{74,163-165}$, o que o torna mais confortável para o paciente ${ }^{51,163-165}$. Para tanto, deve-se remover os braquetes dos primeiros pré-molares inferiores, e às vezes dos segundos também, para permitir uma liberdade de 6 a $8 \mathrm{~mm}$ de movimento para o Jasper Jumper, deslizando pelo arco ${ }^{74,163-165}$.

A aceitação do aparelho por parte dos pacientes é excelente ${ }^{47,100,183,310}$, uma vez que suas únicas responsabilidades são manter o aparelho limpo e evitar quebras ${ }^{47}$.

Entretanto, o ponto alto do aparelho é o fato de não depender da colaboração do paciente, já que consiste em um dispositivo intrabucal fixo que produz força contínua ${ }^{47,50-52,74,79,80,100,163-165,262,310,340}$. Segundo CHAMPAGNE $^{74}$, torna-se difícil obter a cooperação por parte dos adolescentes para a utilização de aparelhos removíveis. Freqüentemente, o Ortodontista deseja substituir os aparelhos removíveis por aparelhos fixos. O autor conclui que os pacientes que não colaboram com a fase ortopédica dos tratamentos com aparelho funcional em uma idade precoce podem agora se beneficiar do avanço mandibular durante a fase corretiva do tratamento, sem nenhum problema de colaboração.

BLACKWOOD III ${ }^{47}$, em 1991, considerou que a colaboração do paciente é um problema para os Ortodontistas. Os aparelhos removíveis deixam o Ortodontista totalmente dependente do paciente, e os aparelhos ortopédicos colados apresentam problemas de higiene e limpeza.

\section{Desvantagens do tratamento com o Jasper Jumper}

Como em qualquer sistema fixo de força, existem desvantagens associadas ao uso dos módulos de força ${ }^{163-165}$. O Jasper Jumper pode ocasionar alguns efeitos adversos, como: a vestibularização dos incisivos inferiores $^{50-52,72,74,163-165}$; aumento do ângulo do plano oclusal ${ }^{72}$; inclinação e vestibularização dos primeiros molares superiores ${ }^{74,163-165}$. No entanto, esses efeitos podem ser controlados por meio da utilização de uma ancoragem 
adequada, como descrito anteriormente, ou até mesmo corrigidos após a remoção do Jasper Jumper ${ }^{74,80}$.

Outro problema que pode ocorrer com esse aparelho é a quebra ${ }^{74,163-}$ 165,183,262. O Jasper Jumper não é um aparelho tão frágil, mas o paciente deve ser avisado para não resistir ao avanço proporcionado por ele ${ }^{74}$. O paciente deve deixar a mandíbula mover livremente na direção ântero-posterior. Devese evitar a torção lateral excessiva do aparelho ${ }^{74}$. A mola do Jasper Jumper eventualmente pode quebrar, e se isso ocorrer, normalmente será na extremidade superior da mola ${ }^{74}$. A quebra do aparelho prolonga o tempo do tratamento ${ }^{74}$. A utilização desses módulos em pacientes não colaboradores aumenta a probabilidade de fratura ${ }^{163-165}$. O sistema do aparelho tem sido melhorado nos últimos anos; os módulos são mais resistentes à fratura do que quando foram desenvolvidos e começaram ser utilizados ${ }^{163-165}$. É indicada uma dieta restrita. O paciente deve ser repetidamente alertado para não ficar mordendo os módulos como se fossem goma de mascar ${ }^{163-165}$. Os pacientes devem ser instruídos a não realizarem movimentos que impliquem em grande abertura da boca. A causa mais comum de quebra do Jasper Jumper é a excessiva abertura da boca associada ao comprimento do módulo de força ${ }^{163-}$ 165. A excessiva abertura da boca traciona a mola para fora do seu tubo. $O$ ideal seria que o Jasper Jumper fosse longo o suficiente para não permitir isto $^{163-165}$. O índice de fratura dos Jasper Jumpers observado por STUCKI; INGERVALL ${ }^{310}$ foi de $9 \%$, enquanto HEINING; GÖZ ${ }^{135}$ relataram um índice de 10\%. KARACAY et al. ${ }^{171}$ citaram a quebra de 2 Jasper Jumpers dentre os utilizados nos 16 pacientes da pesquisa, enquanto que KÜÇÜKKELES; ILHAN; ORGUN ${ }^{183}$ relataram a quebra desse aparelho em 4 dos 25 pacientes tratados.

WEILAND; BANTLEON ${ }^{338}$ (1995) e HEINING; GÖZ ${ }^{135}$ observaram que o material do Jasper Jumper freqüentemente sofre fadiga ou perde a elasticidade após, aproximadamente, 3 meses, devendo substituí-los por novos módulos para continuar o tratamento. HEINING; GÖZ $Z^{135}$ consideraram também que o material plástico que envolve as molas do Jasper Jumper é susceptível à colonização pela placa bacteriana e por outras bactérias, fazendo com que o aparelho se torne poroso e frágil.

Muitos clínicos consideram o custo um fator muito importante quando se refere ao Jasper Jumper. Contudo, o custo desse aparelho se torna 
insignificante quando comparado com o custo de um tratamento prolongado ${ }^{163-}$ 165

\section{Conclusão da revisão da literatura sobre o aparelho Jasper Jumper}

Ao final deste tópico, pode-se concluir, de acordo com a literatura compulsada, que o Jasper Jumper consiste em um dispositivo eficiente para a correção da má oclusão de Classe II, 1a divisão, desde que se utilize adequadamente os sistemas de ancoragem disponíveis, com o intuito de controlar os movimentos dentários indesejáveis que podem ocorrer com 0 tratamento. É um aparelho intrabucal fixo, flexível, que minimiza a necessidade de colaboração do paciente, e proporciona efeitos predominantemente dentoalveolares em um período de tempo bastante reduzido, facilitando assim a atuação do Ortodontista. Como em qualquer outro tipo de aparelho, podem ocorrer alguns problemas com sua utilização, como, por exemplo, a ocorrência de fraturas dos módulos do aparelho. Como este dispositivo é relativamente novo, muito pouco foi estudado até o momento em relação à estabilidade dos resultados obtidos.

\subsection{Tratamento da má oclusão de Classe II, $1^{\text {a }}$ divisão com 0 aparelho Bionator}

\section{O desenvolvimento do aparelho Bionator e a filosofia de Balters}

O Bionator consiste em um aparelho funcional derivado do Ativador de Andresen, que foi desenvolvido na década de cinqüenta pelo médico alemão WILHELM BALTERS ${ }^{31,117-120}$, que viveu em Bonn, Alemanha, de 1893 a $1973^{98}$. Entretanto, a publicação do "Guia de la técnica del Bionator"31 só ocorreu em 1969. Balters considerava que o equilíbrio entre a língua e os músculos circundantes influenciava a forma dos arcos dentários e a intercuspidação adequada, sendo a língua considerada o centro da atividade reflexa da cavidade bucal, e, portanto, o fator essencial ao desenvolvimento da dentição. Assim, a má oclusão deveria ser considerada como um distúrbio desse equilíbrio ${ }^{117-120}$. Segundo Balters, as más oclusões de Classe II ocorriam devido a um posicionamento posterior da língua. Desta forma, a língua deveria ser levada mais para anterior por meio da estimulação da parte posterior do 
dorso lingual. Além disso, a estimulação do crescimento mandibular, com o intuito de estabelecer a correção da má oclusão de Classe II, também traria reflexos positivos tanto para as vias respiratórias como para a deglutição. Para Balters, o Bionator levaria a uma normalização da função e a relações anatômicas harmoniosas ${ }^{117,118}$.

A técnica de Balters priorizava o selamento labial para o tratamento de todos os tipos de más oclusões, condição considerada indispensável para o livre desenvolvimento do potencial de crescimento, que foi impedido pela função anormal ${ }^{117,118}$.

De acordo com Balters, os pontos essenciais do tratamento eram: obter o selamento dos lábios e trazer o dorso da língua em contato com o palato mole; 2) aumentar o espaço bucal e treinar sua função; 3) trazer os incisivos para um relacionamento topo-a-topo; 4) realizar alongamento da mandíbula, que, por sua vez, aumentaria o espaço bucal, tornando possível uma melhor posição da língua; 5) obter um melhor relacionamento das bases ósseas, da língua e dos dentes, como também dos tecidos moles circundantes ${ }^{28,117,118}$. Posteriormente, EIREW ${ }^{98}$ (1981) enumerou os principais objetivos do tratamento com o Bionator da seguinte maneira: 1) eliminar a interposição do lábio e a relação anormal entre lábios e incisivos; 2) eliminar o trauma à mucosa palatina em decorrência da sobremordida profunda; 3) corrigir a retrusão mandibular e a má posição da língua; 4) obter um plano oclusal correto, quando necessário, pela ação impedidora da interposição lingual e da musculatura jugal. Esses objetivos são alcançados com a construção do aparelho com os incisivos em posição de topo ou o mais próximo possível desta relação.

Nos anos 80, a escola de Balters ainda era representada por um pequeno grupo de profissionais seguidores de sua filosofia, como ROBERTS $S^{274}$ que, em 1985, destacou que a má oclusão de Classe II resultava da posição posterior da língua, gerando deglutição atípica e respiração bucal. Atualmente, este mecanismo de ação alegado por Balters não encontra suporte, por nunca ter sido comprovado cientificamente ${ }^{84}$.

\section{Tipos de aparelho}

Quanto à classificação, há três tipos de Bionator que se destinam à correção das diferentes anomalias esqueléticas e alterações funcionais: o 
Bionator base ${ }^{101,118}$, também conhecido como Bionator padrão ${ }^{98,120}$; o Bionator invertido $^{101}$, ou de inversão ${ }^{118}$, ou reverso ${ }^{120}$, ou Classe III ${ }^{118,120}$; e o Bionator de proteção $^{118}$, ou fechado ${ }^{101}$, ou protetor ${ }^{120}$, ou de mordida aberta ${ }^{118,120}$. O Bionator base ou padrão é utilizado para o tratamento do retrognatismo mandibular (Classe II); o invertido, para corrigir o prognatismo mandibular (Classe III) e o fechado, para a correção das mordidas abertas com ou sem alterações esqueléticas ${ }^{101,118}$.

Cabe ressaltar que as considerações a serem descritas daqui por diante a respeito do aparelho Bionator referir-se-ão ao tipo base ou padrão, por se tratar do aparelho a ser avaliado neste estudo.

\section{Indicações e contra-indicações do Bionator padrão}

$\mathrm{Na}$ seleção dos casos a serem tratados com o Bionator, um correto diagnóstico diferencial torna-se essencial para um tratamento bem sucedido, e os casos passíveis de tratamento com esse aparelho devem apresentar retrusão mandibular e potencial de crescimento suficiente para permitir as alterações favoráveis ${ }^{19,46,117-120,160,204}$.

Desta maneira, as indicações do Bionator são similares às do Ativador ${ }^{98}$, e consistem em casos de Classe II moderada $98,119,120,160$, com arcos bem alinhados ou pouco apinhamento ${ }^{98,119,120,315}$, padrão de crescimento favorável $^{137,160,204}$, altura facial inferior normal ou reduzida ${ }^{19,98,119,120,315}$, e presença de retrusão mandibular ou mandíbula subdesenvolvida ${ }^{9,19,39,48,98,107,119,120,199,204,225,315}$. Os casos de Classe II com sobressaliência acentuada normalmente apresentam maxilas estreitas ${ }^{19}$. Nesses casos, ao se posicionar a mandíbula anteriormente com o Bionator, a largura das bases ósseas superior e inferior devem ser compatíveis. Se houver uma discrepância entre essa relação (a maxila cruzar com o avanço mandibular), o arco superior deve ser expandido inicialmente, antes da instalação do aparelho funcional ${ }^{19,39}$.

De acordo com BISHARA; ZIAJA ${ }^{46}$, em 1989, os casos de Classe II, $1^{\text {a }}$ divisão ideais para a utilização de aparelhos funcionais seriam aqueles em que os pacientes se encontrassem na fase de crescimento, nos quais as extrações dentárias prejudicariam a estética facial, com os incisivos superiores protruídos e inferiores retruídos, sobremordida acentuada, padrão de crescimento horizontal ou equilibrado, e retrusão mandibular esquelética. 
Em 2001, AHN; KIM; $\mathrm{NAHM}^{4}$ pesquisaram as características cefalométricas iniciais dos pacientes que apresentaram sucesso na correção da má oclusão de Classe II, 1ำ divisão com a utilização do Bionator na fase da dentadura mista. Para isto, os autores dividiram os 40 jovens avaliados em dois grupos, um contendo pacientes que apresentaram bons resultados e no outro, os resultados não foram tão satisfatórios após o tratamento. O padrão cefalométrico que respondeu melhor ao tratamento com o Bionator foi caracterizado por apresentarem inicialmente um predomínio do vetor de crescimento horizontal, relação ântero-posterior entre as bases ósseas próxima do normal, incisivos inferiores verticalizados e retrusão do lábio inferior. Os autores concluíram que a indicação do Bionator e a eficácia do tratamento relacionam-se intimamente às características morfológicas faciais dos pacientes.

Em contrapartida, GRABER; RAKOSI; PETROVIC ${ }^{119,120}$ relataram que o Bionator torna-se contra-indicado se houver as seguintes condições: relacionamento de Classe II por prognatismo maxilar, padrão de crescimento predominantemente vertical e inclinação vestibular evidente dos incisivos inferiores.

\section{Época de tratamento com o Bionator}

Em relação à época ideal para se iniciar o tratamento ortopédico funcional com o Bionator, a maioria dos autores concorda que o paciente deve se encontrar na fase de crescimento craniofacial ${ }^{9,19,25,46,137,139,166,204,221,318,320,346, ~}$ durante a dentadura mista ${ }^{4,39,69,221,315,318,320 .}$

JANSON $^{158,159}$, JANSON; HASUND ${ }^{161}$ investigaram os efeitos do tratamento com o Bionator em jovens nos estágios de crescimento prépubescente e pubescente (identificado por meio de radiografias carpais) e observaram que as alterações dentoalveolares foram mais pronunciadas durante o estágio pré-pubescente, enquanto que as alterações esqueléticas foram mais evidentes no estágio pubescente. FALTIN JR. et al. ${ }^{102}$, em 2003, realizaram um estudo semelhante, onde dividiram a amostra experimental, composta por 23 pacientes, em dois grupos, de acordo com a idade esquelética avaliada pela maturidade das vértebras cervicais. Os resultados indicaram que o tratamento com o Bionator seguido da terapia com aparelho fixo é mais efetivo e estável quando instituído durante o pico de crescimento 
pubescente, em comparação a um tratamento mais precoce (no estágio prépubescente). Os autores concluíram que a época ideal para o início do tratamento ortopédico funcional é determinada pela visualização da concavidade das bordas inferiores da segunda e terceira vértebras cervicais. JENA; DUGGAL; PARKASH ${ }^{166}$ (2006) descreveram que a época do tratamento ortopédico funcional (no caso, com os aparelhos Twin-block e Bionator) - no pico do surto de crescimento pubescente - desempenha um papel crucial, contribuindo para que haja uma predominância dos efeitos esqueléticos na correção da relação molar e da sobressaliência no tratamento da má oclusão de Classe II, 1ำ divisão. Os autores encontraram mais de $57 \%$ de contribuição esquelética na correção da Classe II com os aparelhos avaliados.

Em 1980, PFEIFFER ${ }^{259}$ sugeriu que o tratamento ortopédico funcional deve ser iniciado em jovens do gênero feminino por volta dos 10 anos de idade e finalizado próximo aos 13 anos, e nos pacientes do gênero masculino, devese iniciar aos 11 anos e 6 meses aproximadamente, e finalizar aos 14 anos. Assim, inicia-se o tratamento antes do surto de crescimento e finaliza-o um ano após esse surto.

MAMANDRAS; ALLEN ${ }^{199}$, em 1990, observaram que pacientes com mandíbulas pequenas se beneficiam mais do tratamento com o Bionator do que aqueles com mandíbulas de tamanho normal. Os pacientes que apresentam crescimento tardio podem experimentar mais desenvolvimento durante o tratamento em função do ambiente favorável de crescimento, propiciado pela terapia com o aparelho funcional.

\section{Efeitos do tratamento com o Bionator}

Os efeitos proporcionados pelo tratamento com o Bionator assemelhamse àqueles oriundos da terapia com o Ativador ${ }^{84}$, e são predominantemente dentoalveolares $8,9,12,95,160$. Entretanto, alguns efeitos esqueléticos também podem ser observados. Em relação à maxila, grande parte dos trabalhos revela que o tratamento com o Bionator não altera nem a sua posição nem o seu comprimento efetivo $^{13}$, ou seja, o referido aparelho não promove alterações no desenvolvimento maxilar ${ }^{7-9,12,13,17,48,69,115,137,158,159,161,166,173,318,319,346}$. Por outro lado, alguns autores $46,118,133,142,188,211,225,260,315,316,331,344$ demonstraram que 0 Bionator promove uma restrição do deslocamento anterior da maxila, além de uma expansão transversal da mesma ${ }^{200,315,342}$. Considerando a mandíbula, a 
grande maioria dos autores acredita que o Bionator produz um aumento na sua protrusão $7-9,12,13,16,17,35,36,46,48,69,86,89,107,108,115,137,139,158,159,173,188,199,211,225$,

$230,297,315,318,319,344$ e nos comprimentos efetivo $7,8,12,13,16,35,36,48,89,107,108,115,137,139$, $147,158,159,173,188,199,225,266,297,318,319$ e do corpo mandíbular ${ }^{7-9,12,13,16,297}$. Segundo MARSCHNER; HARRIS ${ }^{201}$ (1966), o potencial de crescimento genético é importante. Eles advogam que a terapia com aparelho funcional pode apenas alterar o crescimento dentro de limites do potencial de crescimento genético do indivíduo. Da mesma maneira, TSAMTSOURIS; VEDRENNE ${ }^{315}$, em 1983, relataram que a correção do padrão do comportamento muscular anormal no complexo bucofacial permitirá um crescimento irrestrito da mandíbula para 0 tamanho geneticamente pré-determinado. MELO et al. ${ }^{211}$, em 2006, avaliaram três pacientes (dois do gênero masculino e um do feminino, com idades variando dos 7 aos 9 anos) que foram acompanhados sem tratamento por um período de um ano e, posteriormente, tratados com o Bionator por um período de dois anos. Os autores observaram que durante o período de acompanhamento sem tratamento, os níveis de crescimento da mandíbula e maxila eram equivalentes; entretanto, após a utilização do Bionator, o grau de crescimento mandibular se manteve superior durante todo o período de observação. Os autores consideraram ainda que o Bionator teve um efeito positivo no sentido de correção da relação ântero-posterior entre maxila e mandíbula; contudo, não pode ser afirmado se houve realmente um aumento do crescimento mandibular ou se houve apenas uma aceleração de seu crescimento no período de uso do aparelho. Todavia, alguns autores ${ }^{133,331,346}$ não evidenciaram alterações na protrusão e incrementos mandibulares.

O tratamento com o Bionator melhora significantemente a relação maxilomandibular e o ângulo da convexidade facial esquelética $^{7,9,12,13,16,17,84,86,115,137,139,188,211,266,318,319,346}$. Alguns pesquisadores ${ }^{7-}$ 9,12,13,16,17,56,69,138,188,198 mostraram que a terapia com o Bionator não altera o padrão de crescimento craniofacial, entretanto, outros ${ }^{48,297,346}$ identificaram um aumento do vetor de crescimento vertical. Da mesma maneira, alguns autores $^{48,56,73,84,137,138,142,147,188,198,225,315,346}$ afirmam que esta terapia leva a um aumento significante na altura facial ântero-inferior, enquanto outros ${ }^{7,9,12,13,16,17}$ não verificaram uma alteração significante desta altura em relação a indivíduos não tratados (grupo controle). Pode haver um aumento da altura facial posterior 
em decorrência da utilização do Bionator ${ }^{7-9,12,13,188}$, além de rotação no sentido horário do plano palatino ${ }^{7,9,13}$ e rotação do plano oclusal ${ }^{315}$.

Alguns trabalhos ${ }^{40,46,331}$ apontam que há uma remodelação da fossa articular, bem como do côndilo $24,142,211,230,268$, em decorrência da terapia ortopédica funcional. MELO et al. ${ }^{211}$ relataram uma alteração no crescimento condilar após a utilização do Bionator nos três casos estudados, caracterizada por uma direção mais posterior, fato que, de acordo com os autores, contribuiu para a correção da relação ântero-posterior entre a maxila e a mandíbula. RABIE; SHE; HÄGG ${ }^{268}$, em 2003, observaram, por meio de um estudo em ratas, que os aparelhos ortopédicos de avanço mandibular aceleram e aumentam o crescimento condilar. Segundo os autores, isto ocorre devido a uma maior diferenciação de células mesenquimais em condrócitos, induzindo a uma maior quantidade de matriz cartilaginosa. Posteriormente, em 2004, ARAÚJO; BUSCHANG; MELO ${ }^{24}$ objetivaram descrever as alterações do crescimento condilar e da remodelação mandibular ocorridas com a terapia por meio do Bionator. Os resultados revelaram alterações significantes na direção (mais posterior), mas não na quantidade total de crescimento condilar. $O$ Bionator produziu um deslocamento posterior das variáveis avaliadas nas regiões condilar e goníaca, maior que o esperado. A sobreposição na base do crânio revelou um deslocamento mandibular anterior maior do que esperado, e uma rotação mandibular para anterior discreta ou praticamente inexistente. Assim, o Bionator produz alterações na direção do crescimento condilar e no deslocamento mandibular.

Em relação aos efeitos dentoalveolares, o Bionator promove uma inclinação para lingual e/ou retrusão dos incisivos superiores ${ }^{4,7-}$ $9,12,13,16,17,35,36,46,48,69,86,95,107,108,118,137,147,158,159,161,211,297,315,331,346$ e uma inclinação para vestibular e/ou protrusão dos incisivos inferiores ${ }^{4,7-}$ $9,12,13,16,17,46,95,118,137,158,159,161,166,211,225,297,315$, apesar de alguns investigadores $^{48,107,108,346}$ não terem observado essa alteração na inclinação dos incisivos inferiores. BOLMGREN; MOSHIRI ${ }^{48}$ ressaltam que a cobertura de acrílico sobre os incisivos inferiores preveniu a inclinação para vestibular desses dentes. MELO et al. ${ }^{211}$, em 2006, observaram a inclinação vestibular dos incisivos inferiores nos três casos apresentados (apesar da cobertura de acrílico); entretanto, ao observarem a inclinação vestibular dos incisivos 
inferiores durante o período de avaliação sem tratamento, constataram que mesmo sem tratamento os incisivos apresentam tendência natural de vestibularização, e o tratamento com o Bionator teria apenas intensificado esta tendência. Os molares superiores não sofrem alteração em sua posição vertical $^{13,17,48,315}$ nem ântero-posterior ${ }^{46,297}$, enquanto que os molares inferiores são extruídos com o uso do Bionator ${ }^{7,9,13,16,17,46,48,107,108,118,133,315}$, além de movimentarem-se para mesial ${ }^{16,17,46,166,297,315}$.

As alterações tegumentares advindas da terapia com o Bionator resumem-se em retrusão do lábio superior ${ }^{7,9,13,16}$ e protrusão do lábio inferior $^{7,9,13,16,138,147,198}$. Entretanto, LANGE et al. ${ }^{188}$, BRANGELI ${ }^{56,198}$ e HENRIQUES et al. ${ }^{138}$ demonstraram que o lábio superior não sofreu efeito significante com o uso de Bionator; FREITAS ${ }^{107}$ e FREITAS; VIGORITO ${ }^{108}$ relataram que a posição do lábio inferior se manteve inalterada. Alguns autores $^{7,9,13,16,188}$ consideram que esse aparelho não induz alterações substanciais no ângulo nasolabial, enquanto outros ${ }^{192,225}$ relatam um aumento deste ângulo em decorrência da lingualização dos incisivos superiores. LANGE et al. ${ }^{188}$ observaram um aumento no ângulo mentolabial (ou diminuição da sua profundidade) em decorrência do tratamento funcional com o Bionator, também verificado por BRANGELI56,198, em 2000 e 2004; PROFFIT; TULLOCH ${ }^{266}$ (2002) relataram uma projeção do queixo após o tratamento com o Bionator. Em 2006, FLORES-MIR; MAJOR ${ }^{104}$ realizaram uma revisão sistemática da literatura, objetivando elucidar as alterações tegumentares decorrentes do tratamento da má oclusão de Classe II, 1a divisão por meio dos aparelhos Ativador e Bionator; os autores verificaram que há grandes controvérsias a esse respeito, e ponderaram que alterações tegumentares relatadas como sendo estatisticamente significantes apresentam significância clínica questionável. Assim, os autores ressaltaram a necessidade do desenvolvimento de estudos clínicos duplo-cegos, prospectivos, randomizados, a fim de confirmarem os resultados encontrados.

De acordo com BISHARA; ZIAJA ${ }^{46}$, em 1989, a combinação dos efeitos dentoalveolares (60\% a $70 \%)$ e esqueléticos $(30 \%$ a $40 \%)$ permite a correção efetiva da má oclusão de Classe II por meio dos aparelhos ortopédicos funcionais removíveis (os autores avaliaram o Ativador e o Regulador Funcional). 
CARELS; REYCHLER; VAN DER LINDEN ${ }^{69}$, em 1997, não observaram diferenças significantes nos efeitos do tratamento com o Bionator em pacientes com tendências aos padrões esqueléticos de mordida aberta e de sobremordida profunda.

TULLOCH; PHILLIPS; PROFFIT ${ }^{319}$ (1998) alegaram que a variabilidade no padrão de crescimento esquelético parece ser o grande contribuinte para as variações nas respostas ao tratamento ortopédico.

Com o propósito de verificar se os aparelhos ortopédicos funcionais (Bionator, Bass, Fränkel, Twin-block) aumentam o crescimento mandibular, CHEN; WILL; NIEDERMAN ${ }^{76}$, em 2002, realizaram uma revisão sistemática em busca de publicações de estudos randomizados e que utilizaram grupos controle. Seis artigos foram considerados adequados para avaliação por meio de 12 variáveis cefalométricas. Não houve diferença significante entre os jovens não tratados, pertencentes ao grupo controle, e os pacientes tratados pelos aparelhos funcionais, em relação às variáveis condílio-pogônio, condíliognátio, SNB, ângulo do incisivo inferior, além de outras variáveis horizontais. Entretanto, para as variáveis articular-pogônio e articular-gnátio, houve diferenças estatisticamente significantes entre os grupos tratados e controle. De acordo com os autores, os resultados sugerem a necessidade de reavaliação quanto à utilização dos aparelhos funcionais com a finalidade de aumentar o crescimento mandibular.

Com objetivos semelhantes, COZZA et al. ${ }^{81}$, em 2006, realizaram uma revisão sistemática da literatura, buscando as respostas de alguns questionamentos: "a mandíbula cresce mais em indivíduos Classe II tratados com aparelhos funcionais do que em indivíduos Classe II não tratados?"; "os efeitos dos aparelhos funcionais no comprimento mandibular são clinicamente significantes?" e "quais aparelhos funcionais são mais eficientes?". Para isto, os autores qualificaram e selecionaram 22 artigos dentre os 704 encontrados na literatura. Os aparelhos avaliados foram: Ativador, Bass, Bionator, FR-2 de Fränkel, MARA, Twin-block e Herbst. Os autores concluíram que: 2/3 das amostras nos 22 estudos considerados apresentaram aumento clinicamente significante no comprimento total da mandíbula, como um resultado especialmente do tratamento ativo com aparelhos funcionais; a curto prazo, a quantidade de crescimento mandibular parece ser significantemente maior 
quando o tratamento funcional é realizado no pico de crescimento pubescente, e o aparelho de Herbst mostrou o maior coeficiente de eficiência $(0,28 \mathrm{~mm}$ por mês) seguido pelo Twin-block (0,23mm por mês).

\section{Confecção da mordida construtiva}

Os efeitos obtidos com o Bionator encontram-se intimamente relacionados à construção da mordida ${ }^{315}$. O correto registro da mordida em cera é um dos fatores mais importantes no tratamento com aparelhos funcionais $^{19,126}$. A mandíbula deverá ser avançada até que o perfil esteja esteticamente agradável, para auxiliar e assegurar a cooperação do paciente em relação à utilização do aparelho ${ }^{19}$. A mordida construtiva determina o grau dos deslocamentos ântero-posterior e vertical da mandíbula e, conseqüentemente, a ativação proporcionada pelo aparelho ${ }^{46,225}$.

GRABER; NEUMANN ${ }^{117,118}$ enfatizaram a importância da correta mordida construtiva e relataram que vários fatores devem ser considerados na construção do Bionator para o tratamento da má oclusão de Classe II, 1aㅡ divisão, como a magnitude da sobressaliência, a distância que o paciente poderá mover a mandíbula para anterior confortavelmente e a sobremordida.

Há uma controvérsia na literatura sobre os procedimentos a serem seguidos para se obter a mordida construtiva, principalmente no que tange a quantidade de avanço mandibular e a abertura da mordida no sentido vertical. No sentido ântero-posterior, a maioria dos autores ${ }^{7,9,13,16,24,56,69,70,73,98,117-}$ 120,138,188,204,225 preconiza um avanço único da mandíbula até a posição de topo entre os incisivos, ou o mais próximo disto que o paciente conseguir alcançar ${ }^{98}$. Entretanto, quando o paciente apresentar uma sobressaliência maior que 7 $\mathrm{mm}$, recomenda-se a correção parcial numa primeira mordida construtiva (em um primeiro aparelho) e a realização posterior de novo (s) avanço (s) até a posição de topo entre os incisivos ${ }^{7,9,13,14,16,119,120,138}$. Outros autores ${ }^{199,261}$ recomendam um avanço de 2 a $3 \mathrm{~mm}$ aquém da máxima protrusão da mandíbula, que em média equivale a $7 \mathrm{~mm}^{261}$. BIGLIAZZI; KESSNER; FALTIN JÚNIOR ${ }^{39}$, assim como ALTUNA; NIEGEL ${ }^{19}$ recomendam que o contato de topo a topo entre os incisivos deve ser promovido com um único aparelho, desde que o trespasse horizontal não ultrapasse $4 \mathrm{~mm}$, caso contrário, o avanço mandibular deve ser alcançado utilizando-se dois ou mais aparelhos. 
DE VINCENZO; WINN ${ }^{90}$, em 1989, compararam os efeitos ortopédicos e ortodônticos do tratamento com aparelho funcional utilizando três variados protocolos de avanço mandibular (um avanço único, avanços a cada $1 \mathrm{~mm}$, e avanços a cada $3 \mathrm{~mm}$ ), e observaram que não houve diferenças desses efeitos entre os grupos tratados com um grande avanço e com pequenos avanços sucessivos.

Com o intuito de comparar os efeitos do tratamento com o Bionator por meio de avanços progressivos e por um único avanço da mandíbula, KUMAR; SIDHU; KHARBANDA ${ }^{185}$, em 1996, avaliaram três grupos distintos: o primeiro tratado com o Bionator utilizando avanços progressivos; o segundo tratado com o Bionator confeccionado com um único avanço até a posição de topo entre os incisivos e o terceiro grupo composto por jovens sem nenhum tratamento (grupo controle). A redução da discrepância entre as bases ósseas foi significante para os dois grupos tratados, porém, ocorreu de forma distinta. No grupo de avanços progressivos essa redução relacionou-se a um maior deslocamento anterior da mandíbula, enquanto que no grupo de avanço único houve uma maior evidência da restrição do deslocamento anterior da maxila. Não houve diferenças entre os grupos em relação ao posicionamento ânteroposterior dos côndilos. Além disto, o grupo de avanços progressivos apresentou um maior aumento da altura facial ântero-inferior e a redução da sobressaliência ocorreu predominantemente devido aos efeitos esqueléticos nesse grupo (79\% efeitos esqueléticos e $21 \%$ efeitos dentários). Em contrapartida, o grupo de avanço único apresentou a correção da sobressaliência devido a uma combinação de $59 \%$ de efeitos esqueléticos e $41 \%$ de efeitos dentários. Os autores concluíram que a magnitude dos efeitos mandibulares foi maior no grupo de avanços progressivos e que esta diferença pode ser explicada com base na resposta tecidual que, provavelmente, resultou de uma adaptação neuromuscular inicial ao avanço induzido, posteriormente substituída por adaptações esqueléticas e ressaltaram que a estabilidade dos resultados obtidos com os dois protocolos de avanço mandibular precisa ser averiguada em estudos futuros.

No sentido vertical, deve-se realizar uma abertura entre os incisivos dentro do espaço funcional livre $(2 \text { a } 4 \mathrm{~mm})^{14,230}$. Segundo MAMANDRAS; ALLEN $^{199}$ e PFEIFFER; GROBETY ${ }^{261}$, a mordida construtiva deve ser 
elaborada com abertura vertical na região posterior de 3 a $4 \mathrm{~mm}$, além da posição de repouso ou espaço funcional livre. De acordo com LANGE et al. ${ }^{188}$, a abertura vertical deve ser de 4 a $5 \mathrm{~mm}$ na região dos molares, enquanto ARAÚJO; BUSCHANG; MELO ${ }^{24}$ realizam uma abertura de $2 \mathrm{~mm}$ entre os dentes posteriores. BIGLIAZZI; KESSNER; FALTIN JÚNIOR ${ }^{39}$ consideram que a dimensão vertical da mordida de construção deve-se basear na altura de desoclusão posterior decorrente do contato de topo a topo entre os incisivos. Alguns autores ${ }^{7,9,13,16,56,73,138}$ advogam uma abertura da mordida no sentido vertical de aproximadamente $5 \mathrm{~mm}$, ou até que se corrija a sobremordida ${ }^{138}$. OLIVEIRA et al. ${ }^{225}$ elucidaram que o deslocamento vertical além do espaço livre é realizado para que o aparelho seja mantido em posição pelos músculos elevadores da mandíbula, evitando o retorno da mesma à sua posição inicial.

No sentido transversal, deve-se manter a coincidência das linhas médias $^{9,13,14}$. Nos casos de desvio da linha média dentária, deve-se manter o desvio durante a confecção da mordida construtiva ${ }^{9,13,14}$. Entretanto, se o desvio da linha média for de natureza esquelética, a mordida construtiva deve ser realizada com as linhas médias coincidentes ${ }^{14}$ quando o desvio for de até 3 $\mathrm{mm}^{332}$. Se for maior, provavelmente o tratamento cirúrgico será mais adequado $^{332}$.

\section{Tempo diário de uso do Bionator}

Para se obter o máximo de benefícios, o Bionator deve ser utilizado durante o dia e a noite (uso intenso) ${ }^{9,13,19,56,70,117-120,137,138,230,315}$, exceto durante as refeições ${ }^{9,13,39,70,117,118,137,138,315}$, prática de esportes ${ }^{9,13,39,117,118,137,138}$, onde houver perigo de trauma bucal ${ }^{39}$, e em situações onde a melhor dicção do paciente for necessária ${ }^{39}$. É perfeitamente viável seu uso na escola ${ }^{117,118}$. Inicialmente, o paciente deverá usar o aparelho apenas à noite. Deve-se checar a adaptação após uma semana, e observar se apareceu alguma ferida na boca do paciente. Só após esse período inicial de adaptação o aparelho deverá ser utilizado intensamente ${ }^{19,39,117,118,225}$. O intervalo entre as consultas é de 3 a 6 semanas, dependendo do estágio de irrupção dos dentes ${ }^{117-120,166}$.

\section{Manipulação clínica do Bionator}

Em relação à manipulação clínica do Bionator, vários fatores devem ser considerados. Durante os estágios iniciais do tratamento, o arco vestibular não deverá entrar em contato com a superfície vestibular dos dentes ântero- 
superiores $^{19}$. Uma vez o paciente ter se ajustado ao aparelho, ter acostumado a abrir e fechar a boca e falar com o aparelho, o arco vestibular poderá ser ativado para lingualizar os incisivos superiores nos casos onde isto for indicado $^{19}$. O arco vestibular deve ser ajustado a cada consulta, se necessário, para assegurar que ele toque os dentes ântero-superiores novamente ${ }^{119,120}$. As alças do bucinador devem estar afastadas das áreas dos primeiros e segundos molares decíduos, mas ela não deve ferir a mucosa jugal ${ }^{119,120}$. Se a estabilidade vertical não estiver satisfatória, o aparelho poderá bascular na cavidade bucal toda vez que o paciente abrir e fechar a boca ${ }^{19}$.

Durante a primeira fase do tratamento, torna-se comum a ocorrência de rápidas alterações horizontais e verticais na posição mandibular ${ }^{119,120}$. Essas rápidas alterações levam a uma mordida aberta nos segmentos posteriores ${ }^{98,119,120}$. As adaptações articulares e dentoalveolares ocorrem em um segundo estágio, seguindo a adaptação neuromuscular ${ }^{119,120}$.

A mordida aberta posterior persiste até que os pré-molares possam ser guiados a uma completa oclusão ${ }^{98,119,120}$. Para isto, deve-se realizar desgastes seletivos no acrílico que ocupa a superfície oclusal dos dentes pósteroinferiores, com o objetivo de permitir uma maior irrupção desses dentes $^{13,19,70,119,120,166,225}$ e manter o plano oclusal superior ao mesmo nível (já que os dentes póstero-superiores continuam em contato com o acrílico) ${ }^{19}$, além de permitir o movimento mesial desses dentes póstero-inferiores ${ }^{225}$. Este tipo de erupção controlada auxilia a correção ântero-posterior e vertical da má oclusão de Classe II, $1^{\text {a }}$ divisão ${ }^{13,19,69,225}$. De acordo com ALTUNA; NIEGEL ${ }^{19}$, deve-se iniciar os desgastes no acrílico assim que os molares decíduos se esfoliarem e os pré-molares iniciarem sua irrupção, entretanto, na região anterior, o acrílico deve ser mantido para prevenir a extrusão dos incisivos ${ }^{19,98}$. Alguns autores ${ }^{69,70}$ recomendam a remoção do acrílico da superfície oclusal dos molares inferiores no primeiro estágio do tratamento (após aproximadamente 1 a 3 meses), e somente em um estágio posterior (próximo ao final do tratamento ortopédico) remove-se o acrílico da superfície oclusal dos pré-molares inferiores. HENRIQUES et al. ${ }^{138}$ apenas iniciam os desgastes seletivos quando os pacientes já se acostumaram com o aparelho; esses desgastes devem ser realizados mensalmente, até a eliminação total do acrílico da superfície oclusal dos dentes posteriores. 
Em casos com altura facial ântero-inferior excessiva, o acrílico entre os dentes superiores e inferiores pode ser deixado sem desgastes para evitar um aumento desta altura ${ }^{19}$.

Os casos de sobremordida profunda podem ser administrados com sucesso por meio do Bionator, após o desgaste do acrílico. Essa correção será bem sucedida especialmente se a sobremordida profunda for causada pela infra-oclusão dos molares e pré-molares ${ }^{119,120}$.

\section{Tempo de tratamento com o Bionator}

BISHARA; ZIAJA ${ }^{46}$ sugerem que os aparelhos ortopédicos devem ser utilizados por um período de tempo prolongado, geralmente de um ano e meio a dois anos, para assegurar uma completa adaptação condilar, após a remodelação da fossa articular.

$\mathrm{Na}$ literatura consultada, o tempo médio de tratamento com o Bionator variou de 10,8 meses $^{225}$ a 24 meses $^{211}$. A grande maioria dos autores relata um tempo médio de uso desse aparelho entre um ano (12 meses) e um ano e meio (18 meses) ${ }^{7-9,13,16,48,56,117,118,137-139,158,159,188,204,221,230}$. De acordo com JENA; DUGGAL; PARKASH ${ }^{166}$ (2006), o tempo de tratamento varia consideravelmente, dependendo do nível de cooperação do paciente e da velocidade de esfoliação dos dentes decíduos. Já para segunda fase do tratamento, realizada com aparelhos fixos (às vezes associados com 0 aparelho extrabucal ${ }^{221}$ ), os autores relatam um tempo variando de 9 meses $^{137}$ a 18 meses $^{221}$.

\section{Segunda fase do tratamento - aparelho ortodôntico fixo}

Embora existam casos nos quais o tratamento apenas com o Bionator é possível, na maioria das vezes torna-se necessária uma combinação de medidas terapêuticas para produzir melhores resultados ${ }^{119,120}$. Movimentos dentários especiais (por exemplo: rotações, torque, movimentos de corpo para fechamento de espaço, distalizações para abrir espaço) não podem ser realizados pelo Bionator ${ }^{119,120}$. Nestes casos, os aparelhos fixos promovem um melhor controle individual dos dentes ${ }^{119,120}$, permitindo 0 alinhamento, nivelamento e acabamento final dos arcos dentários ${ }^{221}$. A associação das terapias ortopédica e ortodôntica objetiva a correção dos problemas esqueléticos e dentários, modificando o relacionamento maxilomandibular, bem 
como, movimentando os dentes para suas posições ideais em relação às bases ósseas, a fim de obter oclusão estática e funcional ideais ${ }^{137}$.

A seqüência mais racional para o tratamento das más oclusões, sob o ponto de vista de PFEIFFER; GROBETY261, consiste primeiramente na remodelação óssea, seguida da obtenção da harmonia muscular e, finalmente, as movimentações dentárias. O tratamento ortopédico prévio favorece uma harmonia entre as bases ósseas, alterando a forma e posição dos maxilares para posteriormente atingir uma oclusão satisfatória com a ortodontia corretiva. Com o aparelho fixo corrige-se as angulações, as inclinações e as rotações dentárias ${ }^{261}$.

Após comprovar a efetividade da associação ortopédica-ortodôntica, BASS $^{35,36}$ concluiu que a técnica ortopédica permite a correção funcional dos tecidos moles e a coordenação do desenvolvimento facial e dentário quando utilizada em associação com a ortodontia corretiva, permitindo consideráveis vantagens no tratamento da má oclusão de Classe II esquelética.

De acordo com HENRIQUES et al. ${ }^{139}$, a associação dos tratamentos ortodônticos e ortopédicos constitui-se num dos principais procedimentos clínicos para a correção das más oclusões de Classe II, $1^{a \underline{a}}$ divisão, com discrepância ântero-posterior entre as bases apicais. Assim, a primeira fase do tratamento visa o estabelecimento de uma relação normal entre as bases ósseas, eliminando desta forma, as possíveis interferências dos tecidos moles nas estruturas dentárias ${ }^{139}$. Somente após este procedimento, inicia-se a movimentação ortodôntica para, enfim, obter uma oclusão satisfatória ${ }^{139}$. A finalidade da utilização dos aparelhos fixos posteriormente à terapia ortopédica funcional é movimentar os dentes para suas posições ideais em relação às respectivas bases e obter a oclusão ideal, tanto anatômica como funcional ${ }^{139}$. Os autores consideram que a combinação do tratamento ortopédicoortodôntico para os casos de Classe II, $1^{\text {a }}$ divisão é de suma importância para a obtenção de uma melhor estética e estabilidade, e concluem que este protocolo de tratamento proporciona as seguintes vantagens, também observadas por BASS $^{35,36}$ em 1983: 1) coordenação do crescimento maxilomandibular; 2) adaptação precoce da musculatura bucofacial; 3) a motivação do paciente e familiares se eleva em decorrência da rápida mudança da posição mandibular; 4) redução significante da necessidade de extrações; 5) proporciona 
movimentações dentárias menores durante a fase com aparelho fixo; 6) menor tempo de utilização dos aparelhos fixos e 7) maior estabilidade, com menor risco de recidiva.

ARAÚJO et al. ${ }^{25}$, ao discorrerem a respeito do tratamento da Classe II em duas fases, relataram que a ortopedia facial permite uma correção inicial no sentido ântero-posterior, vertical e transversal, diminuindo ou até mesmo corrigindo a discrepância esquelética existente. A utilização dos aparelhos ortopédicos irá facilitar a segunda fase do tratamento, que consiste na fase corretiva com aparelho fixo.

NASCIMENTO; CARVALHO ${ }^{221}$ (2003) ressaltaram a conveniência do tratamento por meio da junção dos recursos disponíveis da ortodontia e ortopedia facial em benefício do paciente. Com um correto diagnóstico e planejamento, as alterações esqueléticas e dentárias conseguidas com a ortodontia e a ortopedia facial não demandam de tempo de tratamento exorbitante $^{221}$.

\section{Contenção e estabilidade do tratamento com o Bionator}

O estudo da recidiva da sobremordida e da sobressaliência após 0 tratamento da Classe II, 1ํ divisão com o Ativador realizado por PANCHERZ ${ }^{233}$, em 1977, mostrou que essa recidiva poderia ser uma recuperação fisiológica da condição original do paciente e que algumas explicações parciais para este problema seriam métodos impróprios de tratamento, contenções insuficientes, alterações desfavoráveis de crescimento após o tratamento e persistência de hábitos de interposição lingual. Entretanto, a interceptação do desenvolvimento maxilomandibular desfavorável com a conseqüente normalização das condições oclusal e muscular podem influenciar favoravelmente o padrão de crescimento, tanto da maxila quanto da mandíbula no período pós-tratamento, de acordo com WIESLANDER; LAGERSTROM ${ }^{346}$, em 1979.

Para minimizar ou evitar que ocorra essa recidiva, torna-se de suma importância a utilização de contenções após o tratamento ortopédico funcional. Assim, GRABER; NEUMANN ${ }^{117,118}$ recomendam que, após o tratamento com o Bionator, o mesmo aparelho seja utilizado somente durante a noite como contenção. O período de contenção pode variar de 6 meses a 1 ano, ou mais. 
aparelho passa a ser utilizado gradualmente por menos tempo à noite e menos vezes. O paciente deverá ser instruído a usar novamente o aparelho com mais freqüência, se depois de certo intervalo houver tensão muscular ao ser inserido o aparelho ${ }^{117,118}$.

Outro protocolo de contenção após a terapia com o Bionator foi utilizado por HENRIQUES e colaboradores ${ }^{137,139}$, em 1991 e 1997. Refere-se à utilização do aparelho extrabucal tipo Kloehn, durante 12 horas por dia, juntamente com o aparelho fixo (durante a $2^{\mathrm{a}}$ fase do tratamento combinado ortopédico-ortodôntico), com o objetivo de conter o deslocamento anterior da maxila e aprimorar a relação molar de Classe I. Após a conclusão da $2^{a}$ fase do tratamento, instalou-se uma placa de Hawley superior e um arco lingual colado de canino a canino no arco inferior (3x3).

Pesquisando os fatores que podem levar à recidiva da correção da sobressaliência por meio de aparelhos funcionais, DRAGE; HUNT ${ }^{95}$ (1990) compararam cefalometricamente as alterações do tratamento e pós-tratamento entre jovens tratados com Ativador ou Bionator e jovens não tratados (grupo controle). Os autores concluíram que a redução da sobressaliência ocorreu, principalmente, em decorrência de alterações dentoalveolares. As alterações das inclinações dos incisivos superiores para vestibular e em menor grau dos incisivos inferiores para lingual contribuíram para a recidiva da sobressaliência. Não houve evidências de que um padrão de crescimento vertical pudesse influenciar a recidiva. Observou-se que os jovens que sofreram uma grande redução da sobressaliência durante o tratamento apresentaram maior recidiva. Embora a inclinação vestibular dos incisivos superiores após o tratamento tenha se associado com a quantidade de inclinação para lingual desses dentes durante o tratamento, não se verificou nenhuma relação entre as alterações do tratamento e pós-tratamento na inclinação dos incisivos inferiores.

Em 1991, DE VINCENZO ${ }^{89}$ analisou as alterações no comprimento mandibular antes, após a correção da má oclusão de Classe II por meio de um aparelho ortopédico funcional seguido do tratamento com aparelho ortodôntico fixo e após um período de contenção e observação. Os resultados revelaram um aumento inicial marcante no comprimento mandibular durante a fase ortopédica. No entanto, durante a fase ortodôntica a velocidade de crescimento mandibular diminuiu significantemente em relação aos pacientes do grupo 
controle (não tratados). A quantidade de crescimento no comprimento mandibular, desde a instalação do aparelho até o período de observação final, permaneceu similar entre os grupos tratado e controle. $O$ autor concluiu que $o$ comprimento mandibular aumenta de modo significante até 2 anos após o final do tratamento; porém, não ocorrem diferenças significantes em relação a jovens não tratados após o quarto ano.

KEELING et al. ${ }^{173}$ (1998) propuseram-se a avaliar se as alterações proporcionadas pela terapia ortopédica funcional se perpetuam com 0 crescimento normal posterior, se ocorre recidiva, a natureza da mesma (dentária ou esquelética), e se a contenção entre as fases de tratamento (ortopédica e ortodôntica) é necessária. Os autores avaliaram 70 jovens com má oclusão de Classe II tratados com o Bionator, nas fases pré-tratamento, pós-tratamento, pós-contenção e controle de 6 meses após a remoção da contenção. Concluíram que o crescimento facial é alterado pelo tratamento, e que o tempo de contenção de 6 meses não influenciou as alterações obtidas. A recidiva observada no período de 6 meses após a remoção da contenção foi de origem dentária. Assim, ressaltaram a importância do Ortodontista estar ciente que a contenção é necessária para prevenir recidivas dentárias, mas não esqueléticas.

\section{Principais vantagens do tratamento com o Bionator}

Muitos autores ${ }^{9,19,28,84,98,117-120,204,315}$ consideram vantajoso o tamanho reduzido do Bionator em relação ao Ativador, o que possibilita seu uso contínuo, durante os períodos do dia e da noite, e o torna mais adequado durante a fala. Assim, observa-se normalmente uma boa aceitação pelo paciente ${ }^{84,98,299}$. Apesar de sua aparência mais frágil, o Bionator bem confeccionado é resistente, e pode ser utilizado com segurança por bastante tempo ou por pacientes menos cuidadosos ${ }^{98}$. É um aparelho de simples confecção, boa adaptabilidade e grande facilidade de uso ${ }^{28,138,139}$, causando pouco ou nenhum desconforto ao paciente ${ }^{28}$. Além disto, a utilização desse aparelho na dentadura mista protege os incisivos de possíveis fraturas ${ }^{315}$, elimina danos na mucosa devido à sobremordida profunda traumática ${ }^{315} \mathrm{e}$ permite o selamento labial ${ }^{315}$. Ele melhora, sobremaneira, a estética facial do paciente $^{315}$. Alguns autores ${ }^{13,25,139}$ relatam que o tratamento bem realizado com aparelhos ortopédicos funcionais, no caso o Bionator, diminui sensivelmente a 
necessidade de extrações dentárias futuras. Além disto, pode diminuir o tempo da fase ortodôntica corretiva e, até mesmo, evitar a cirurgia ortognática ${ }^{25}$. Todavia, se o diagnóstico for impreciso ou o paciente não apresentar motivação, os resultados são pobres ou quase nulos ${ }^{25}$.

\section{Desvantagens do tratamento com o Bionator}

Deve-se salientar que, como acontece com todos os aparelhos, 0 sucesso com o Bionator não é universal. Ocorrem falhas com qualquer aparelho, removível ou fixo ${ }^{117,118}$. Um sucesso parcial é o mais provável, o que pode ser atribuído à falta de cooperação do paciente, diagnóstico duvidoso, padrão de crescimento desfavorável, surtos de crescimento inadequados, e à mesma multiplicidade de fatores que interferem na correção das variadas más oclusões morfofuncionais ${ }^{117,118}$.

O êxito do tratamento com o Bionator depende da cooperação do paciente em relação ao uso do aparelho ${ }^{19,25,39,46,137,211,221,315}$, que somente poderá ser obtida se o aparelho estiver confortável e bem adaptado ${ }^{19}$. Um bom relacionamento entre o Ortodontista e o paciente torna-se especialmente útil no início do tratamento ${ }^{315}$. Observa-se uma melhor aceitação do aparelho quando o paciente é preparado para as dificuldades na fonação e deglutição que serão encontradas durante os primeiros (poucos) dias ${ }^{315}$. O paciente deve ser estimulado a usar o aparelho durante todo o tempo ${ }^{315}$. Um reforço verbal, como elogios, e o agendamento de visitas de acompanhamento constantes auxiliam a conquistar a boa cooperação do paciente ${ }^{315}$. ALTUNA; NIEGEL ${ }^{19}$ sugerem que tanto os pacientes como seus pais devem entender o que se deseja alcançar com os aparelhos funcionais. É importante mostrá-los em um espelho como os tecidos moles e o perfil facial melhoram com o aparelho instalado ${ }^{19}$. Deve-se conversar com o paciente enquanto ele estiver usando o aparelho, pois assim ele ganha confiança na fala ${ }^{19}$.

Outra limitação do tratamento com o Bionator, assim como com os demais aparelhos ortopédicos funcionais, consiste na inclinação vestibular dos incisivos inferiores ${ }^{228}$. Para minimizar esta inclinação, alguns autores ${ }^{7-}$ 9,12,13,16,48,56,73,160,188,199,211,225,228 incorporam uma proteção de acrílico cobrindo as faces incisal e parte da vestibular desses dentes.

Se a estabilidade vertical do aparelho estiver incorreta, ele poderá bascular na cavidade bucal quando o paciente realizar os movimentos 
mandibulares; as forças oclusais poderão ser distribuídas desigualmente sobre os tecidos moles e causar pontos de irritação, além de uma pobre adaptação ${ }^{19}$.

De acordo com BOLMGREN; MOSHIRI ${ }^{48}$, a variação individual é provavelmente, $\mathrm{O}$ aspecto mais frustrante do tratamento com aparelhos funcionais, assim como ocorre na maioria dos tratamentos ortodônticos. Alguns pacientes alcançam resultados altamente positivos em um tempo reduzido, enquanto outros pouco se beneficiam do tratamento.

GRABER; RAKOSI; PETROVIC ${ }^{119,120}$ consideram que a desvantagem do Bionator encontra-se na dificuldade de manejá-lo corretamente, principalmente, devido à necessidade simultânea de estabilização do aparelho e do desgaste seletivo para promover a irrupção diferencial dos dentes pósteroinferiores. Além disto, os autores relatam que a normalização da função somente ocorrerá se o padrão inerente de crescimento for favorável, sem influências negativas do meio ambiente a este padrão. Ainda, nos casos de distúrbios esqueléticos, a eficácia do Bionator é limitada, como também acontece para diversos aparelhos funcionais. Os mesmos autores referem-se a uma desvantagem potencial adicional, que pode ocorrer também com outros aparelhos funcionais com estruturas em fio de aço (o aparelho de Bimler, particularmente), que é a vulnerabilidade à distorção.

\section{Conclusão da revisão da literatura sobre o Bionator}

Finalizando este tópico relacionado ao aparelho Bionator padrão, conclui-se que é um aparelho de simples utilização, largamente indicado pela classe ortodôntica ${ }^{166,204,213}$, visto o grande número de publicações a esse respeito e a eficácia da correção da má oclusão de Classe II, 1aㅡ divisão, predominantemente por alterações dentoalveolares. Para alcançar a estabilidade da correção, torna-se importante um diagnóstico correto, utilizando-o em uma época oportuna (fase de crescimento ativo) e utilizando uma contenção adequada após o tratamento. Como este aparelho não corrige as más posições dentárias individuais, é comum que se realize o tratamento em duas fases, instalando o aparelho ortodôntico fixo após a correção ânteroposterior com o propósito de alinhar, nivelar os arcos dentários e refinar a oclusão do paciente. Sua principal desvantagem advém do fato de ser um 
aparelho removível, e assim, depender substancialmente da colaboração do paciente para o sucesso do tratamento. 


\section{(28) Gं3पS}
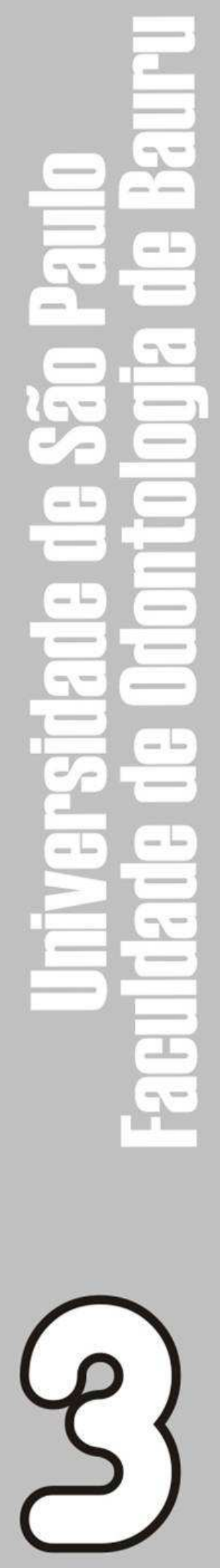

Proposição 


\section{PROPOSIÇÃO}

O propósito deste trabalho é comparar cefalometricamente as alterações dos componentes dentoesqueléticos de jovens com má oclusão de Classe II, $1^{\text {a }}$ divisão, tratados por meio do aparelho Jasper Jumper associado ao aparelho ortodôntico fixo bem como do Bionator e a aparelhagem fixa. 


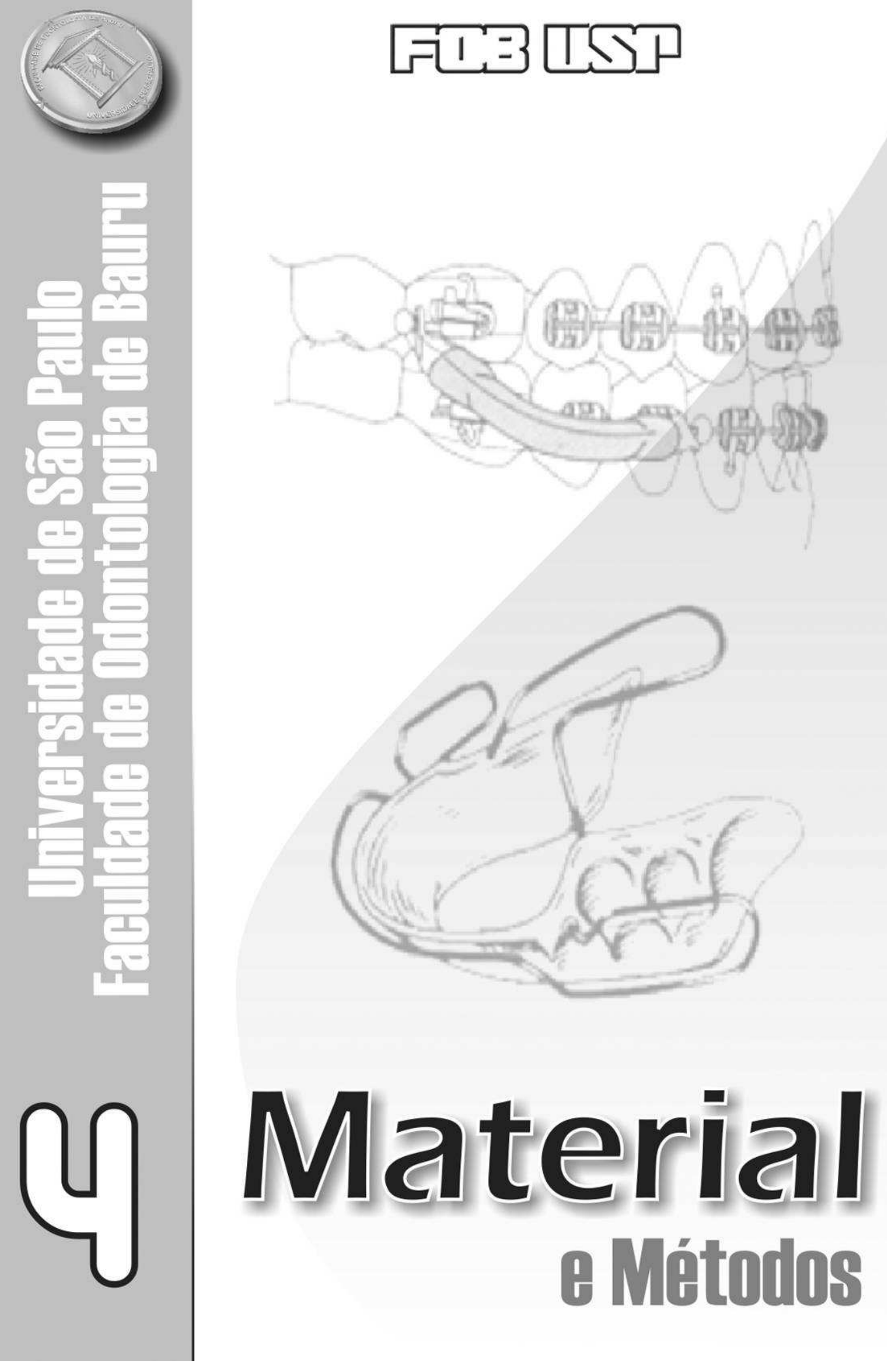




\section{MATERIAL E MÉTODOS}

\subsection{MATERIAL}

\subsubsection{Amostra}

A amostra utilizada no presente estudo constituiu-se de 154 telerradiografias em norma lateral e 77 modelos de estudo referentes a 77 jovens, os quais foram distribuídos em três grupos:

\subsubsection{Grupo Experimental 1}

Composto pelas documentações de 25 pacientes, sendo 13 do gênero masculino e 12 do gênero feminino, com má oclusão inicial de Classe II, $1^{\text {a }}$ divisão e idade inicial média de 12,72 anos (D.P.= 1,21, variando de 10,32 a 14,84 anos), tratados por meio do aparelho Jasper Jumper associado ao aparelho ortodôntico fixo, por um período total médio de 2,15 anos (D.P. $=0,30$, variando de 1,81 a 3,32). Assim, a idade média final dos pacientes foi de 14,88 anos (D.P. $=1,20$, variando de 12,74 a 16,90).

O tempo médio de uso do aparelho Jasper Jumper foi de 0,61 ano (D.P. $=0,17$, variando de 0,37 a 0,97 )

Os jovens foram selecionados em Escolas do Ensino Fundamental da cidade de Bauru - SP e foram tratados por duas alunas do Curso de Doutorado em Odontologia, área de Ortodontia, na clínica de Ortodontia da Faculdade de Odontologia de Bauru - Universidade de São Paulo.

Avaliou-se a severidade inicial da má oclusão nos modelos de gesso iniciais por meio da relação molar, relação dos caninos e da sobressaliência. Quando houve diferença na relação molar e/ou dos caninos entre os lados direito e esquerdo, considerou-se o lado mais severo (TABELA 1). A média da sobressaliência ao início do tratamento foi de 7,38 mm (D.P.= 2,22, variando de $4,50$ a $13,50 \mathrm{~mm})$. 
TABELA 1- Severidade inicial da má oclusão no Grupo Experimental 1

\begin{tabular}{l|cc}
\hline \multicolumn{1}{c|}{ Severidade Inicial } & Relação Molar & Relação dos Caninos \\
\hline Classe II completa & 12 pacientes & 4 pacientes \\
$3 / 4$ de Classe II & 9 pacientes & 17 pacientes \\
$1 / 2$ Classe II & 4 pacientes & 4 pacientes \\
$1 / 4$ de Classe II & 0 pacientes & 0 pacientes \\
\hline
\end{tabular}

\subsubsection{Grupo Experimental 2}

Constituído pelas documentações de 30 pacientes, sendo 16 do gênero masculino e 14 do gênero feminino, com má oclusão inicial de Classe II, $1^{\text {a }}$ divisão e idade inicial média de 11,31 anos (D.P.= 1,19, variando de 9,27 a 14,00 anos), tratados por meio do aparelho Bionator e aparelho ortodôntico fixo. O tempo médio de tratamento ortopédico-ortodôntico foi de 3,92 anos (D.P.= 1,62, variando de 1,45 a 7,82 anos), e a idade média final dos pacientes foi de 15,23 anos (D.P.=1,16, variando de 12,99 a 17,60 anos). Considerandose individualmente as fases de tratamento, a terapia ortopédica funcional durou em média 1,27 ano (D.P.= 0,53, variando de 0,38 a 2,31 anos), e a duração média da fase ortodôntica foi de 1,76 ano (D.P.=0,94, variando de 0,56 a 4,45 anos). O intervalo médio entre as fases do tratamento combinado foi de 0,41 ano (D.P. = 0,75, variando de $-1,37$ a 2,40 anos. $O$ valor negativo indica que 0 tratamento ortodôntico iniciou-se durante a terapia ortopédica funcional).

Os pacientes foram previamente tratados por alunos dos cursos de Pósgraduação na área de Ortodontia da Faculdade de Odontologia de Bauru Universidade de São Paulo.

Da mesma maneira do Grupo Experimental 1, avaliou-se a severidade inicial da má oclusão nos modelos de gesso iniciais por meio da relação molar, relação dos caninos (TABELA 2) e da sobressaliência. A média da sobressaliência ao início do tratamento foi de 8,70 mm (D.P.=2,58, variando de $4,50$ a $15,00 \mathrm{~mm})$. 
TABELA 2 - Severidade inicial da má oclusão no Grupo Experimental 2

\begin{tabular}{l|cc}
\hline \multicolumn{1}{c|}{ Severidade Inicial } & Relação Molar & Relação dos Caninos \\
\hline Classe II completa & 12 pacientes & 4 pacientes \\
$3 / 4$ de Classe II & 9 pacientes & 13 pacientes \\
$1 / 2$ Classe II & 9 pacientes & 12 pacientes \\
$1 / 4$ de Classe II & 0 pacientes & 1 paciente \\
\hline
\end{tabular}

\subsubsection{Grupo Controle}

Composto pelas documentações de 22 jovens, 12 do gênero masculino e 10 do feminino, com má oclusão de Classe II, 1a divisão, não submetidos a qualquer tipo de tratamento ortodôntico ou ortopédico funcional, com idade inicial média de 12,67 anos (D.P.= 0,75, variando de 11,21 a 13,98 anos) e observados por um período médio de 2,13 anos (D.P.=1,64, variando de 0,56 a 6,58 anos). A idade média da segunda observação (idade final) foi de 14,80 anos (D.P.= 1,71, variando de 12,32 a 19,11 anos).

Selecionou-se estes jovens a partir da amostra longitudinal do Centro de Estudo de Crescimento da Faculdade de Odontologia de Bauru, Universidade de São Paulo ${ }^{153}$, onde um grupo de jovens era anualmente controlado, obtendo radiografias e modelos de gesso dos mesmos, desde a dentadura decídua até a permanente completa.

Todos os jovens foram encaminhados para o tratamento ortodôntico, porém alguns optaram pela intervenção mais tardia ou não se interessaram pelo tratamento, viabilizando assim a constituição de um grupo controle.

Assim como nos Grupos Experimentais, avaliou-se a severidade inicial da má oclusão nos modelos de gesso iniciais por meio da relação molar, relação dos caninos (TABELA 3) e da sobressaliência. A média da sobressaliência ao início do período de observação foi de 5,95 mm (D.P.= 1,86, variando de 4,00 a 11,50 $\mathrm{mm}$ ). 
TABELA 3 - Severidade inicial da má oclusão no Grupo Controle

\begin{tabular}{l|cc}
\hline \multicolumn{1}{c|}{ Severidade Inicial } & Relação Molar & Relação dos Caninos \\
\hline Classe II completa & 3 jovens & 1 jovem \\
$3 / 4$ de Classe II & 5 jovens & 6 jovens \\
$1 / 2$ Classe II & 10 jovens & 13 jovens \\
$1 / 4$ de Classe II & 4 jovens & 2 jovens \\
\hline
\end{tabular}

As idades médias iniciais e finais e os períodos médios de avaliação dos três grupos estudados encontram-se dispostos na TABELA 4, a fim de permitir uma visualização global das amostras.

TABELA 4 - Idades médias iniciais e finais e os períodos médios de avaliação dos três grupos estudados

\begin{tabular}{l|cccccc}
\hline \multirow{2}{*}{ GRUPOS } & \multicolumn{2}{|c}{ Idade Inicial } & \multicolumn{2}{c}{ Idade Final } & \multicolumn{2}{c}{ Período de Avaliação } \\
\cline { 2 - 7 } & Média & D.P. & Média & D.P. & Média & D.P. \\
\hline $\begin{array}{l}\text { Experimental 1 } \\
\text { (Jasper Jumper) }\end{array}$ & 12,72 & 1,21 & 14,88 & 1,20 & 2,15 & 0,30 \\
$\begin{array}{l}\text { Experimental 2 } \\
\text { (Bionator) }\end{array}$ & 11,31 & 1,19 & 15,23 & 1,16 & 3,92 & 1,62 \\
Controle & 12,67 & 0,75 & 14,80 & 1,71 & 2,13 & 1,64 \\
\hline
\end{tabular}

\subsubsection{Critérios para a seleção das amostras}

\subsubsection{Grupo Experimental 1}

Os pacientes desta amostra prospectiva foram selecionados em quatro Escolas Públicas de Ensino Fundamental do município de Bauru - SP, mediante autorização dos Diretores dessas escolas. De um total aproximado de 1.800 jovens examinados clinicamente, selecionou-se 36 para iniciarem o tratamento ortopédico-ortodôntico por meio do aparelho Jasper Jumper, com base nos seguintes critérios:

$>$ todos os jovens deveriam apresentar:

- má oclusão de Classe II, 1a divisão bilateral, avaliada clinicamente;

- ausência de agenesias ou perdas de dentes permanentes;

- ausência de dentes supranumerários; 
- perfil facial convexo;

- arco inferior com mínimo ou nenhum apinhamento;

- não terem sido submetidos a nenhum tipo de tratamento ortodôntico prévio.

Dos 36 pacientes selecionados inicialmente para se submeterem ao referido tratamento, apenas 25 apresentaram condições para constituir esse grupo experimental, por motivos diversos como: desistência do tratamento e compatibilização das amostras deste estudo.

Não se realizou extrações dentárias ou desgastes interproximais em nenhum dos pacientes desta amostra. Os pacientes foram tratados até a obtenção da relação molar e de caninos de Classe I, redução satisfatória da sobressaliência, e adequado alinhamento e nivelamento dos arcos dentários.

\subsubsection{Grupo Experimental 2}

Os pacientes desta amostra retrospectiva foram selecionados do acervo da Disciplina de Ortodontia da Faculdade de Odontologia de Bauru Universidade de São Paulo, tendo sido submetidos a um tratamento em duas fases, sendo a primeira por meio do aparelho Bionator, e a segunda fase por meio de aparelhos ortodônticos fixos. A seleção desses pacientes obedeceu aos seguintes critérios:

> todos os jovens deveriam apresentar inicialmente:

- má oclusão de Classe II, $1^{\underline{a}}$ divisão bilateral, avaliada por meio de modelos de estudo;

- ausência de agenesias ou perdas de dentes permanentes;

- ausência de dentes supranumerários;

- arco inferior com mínimo ou nenhum apinhamento;

- não terem sido submetidos a nenhum tipo de tratamento ortodôntico prévio.

Nenhum paciente se submeteu a realização de extrações dentárias ou desgastes interproximais. Os pacientes apresentaram ao final do tratamento uma relação molar e de caninos de Classe I, uma redução satisfatória da sobressaliência, e um adequado alinhamento e nivelamento dos arcos dentários. 


\subsubsection{Grupo Controle}

A partir da amostra longitudinal para estudos de crescimento da Disciplina de Ortodontia da Faculdade de Odontologia de Bauru - USP ${ }^{153}$, selecionou-se os 22 jovens para comporem o grupo controle deste estudo, apresentando as seguintes características:

- procedência: parques infantis municipais da cidade de Bauru;

- filhos de pais brasileiros, italianos, espanhóis, portugueses;

- má oclusão de Classe II, 1ำ divisão bilateral, avaliada por meio de modelos de estudo;

- ausência de agenesias ou perdas de dentes permanentes;

- ausência de dentes supranumerários;

- nunca submetidos a tratamento ortopédico ou ortodôntico até o final do período de avaliação.

Durante a seleção desses jovens, levou-se em consideração as idades inicial e final, o período médio de avaliação e o gênero, a fim de compatibilizálos com os pacientes do Grupo Experimental 1.

\subsection{Descrição dos aparelhos utilizados nos Grupos Experimentais}

\subsubsection{Jasper Jumper associado ao aparelho fixo}

O aparelho Jasper Jumper foi desenvolvido por JAMES JASPER ${ }^{162}$ em 1987, sendo constituído por dois módulos flexíveis de força, direito e esquerdo, pinos com extremidade esférica que promovem a fixação do dispositivo no arco superior e esferas de acrílico que promovem o "stop" do aparelho no arco inferior (FIGURA 1). Os Jasper Jumpers encontram-se disponíveis em 7 diferentes comprimentos, de $26 \mathrm{~mm}$ (tamanho 1) a $38 \mathrm{~mm}$ (tamanho 7), com intervalos de $2 \mathrm{~mm}$. 


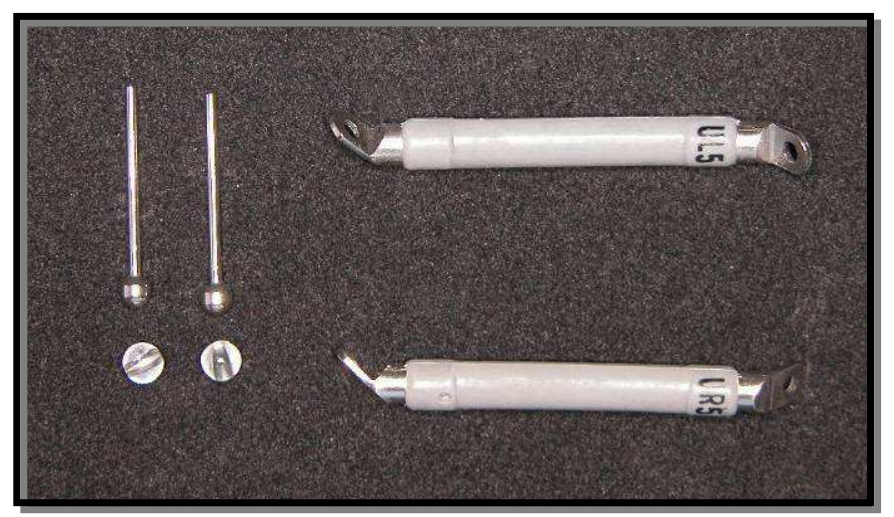

FIGURA 1 - Componentes do aparelho Jasper Jumper

O aparelho fixo utilizado em todos os pacientes da amostra seguiu os princípios da mecânica do arco reto (pré-ajustado), de acordo com a prescrição de Roth, com braquetes que apresentavam ranhura .022" x .030". Instalou-se barra palatina em todos os pacientes para reforço da ancoragem pósterosuperior, objetivando potencializar os efeitos esqueléticos do tratamento em detrimento dos dentários. Inicialmente, realizou-se o alinhamento e nivelamento dos arcos dentários. Finalizou-se essa fase com a instalação de arcos retangulares de aço .018” x .025", que foram dobrados por distal dos tubos dos molares.

Para a instalação do Jasper Jumper, confeccionou-se baionetas no fio retangular de aço inferior por distal dos caninos, onde foram inseridas as esferas de acrílico para a realização do "stop" anterior dos módulos de força do aparelho. Realizou-se torque lingual de coroa na região ântero-inferior, com o intuito de minimizar o efeito de vestibularização dos incisivos inferiores. Posteriormente, selecionou-se e instalou-se os módulos de força, os Jasper Jumpers, para a correção da discrepância ântero-posterior. Para selecionar o comprimento adequado do aparelho para cada paciente, mediu-se a distância da mesial da secção redonda do tubo do primeiro molar até a distal da esfera de acrílico do arco inferior, e a essa distância adicionou-se $12 \mathrm{~mm}$ (4 mm referentes ao comprimento do tubo, $4 \mathrm{~mm}$ de espaço que deve ser deixado na distal do tubo e $4 \mathrm{~mm}$ de ativação do aparelho) (FIGURA 2). Quando o resultado foi um número ímpar, selecionou-se o Jasper Jumper de tamanho maior. Durante a instalação do Jasper Jumper, os braquetes dos primeiros prémolares inferiores foram removidos, e em alguns casos, dos segundos pré- 
molares inferiores também, objetivando liberar os módulos de força durante os movimentos mandibulares. Os pinos com extremidades esféricas foram introduzidos nas secções redondas dos tubos dos primeiros molares superiores, de distal para mesial, e dobrados na mesial dos tubos, permitindo assim a instalação do aparelho Jasper Jumper associado ao aparelho fixo (FIGURA 3).

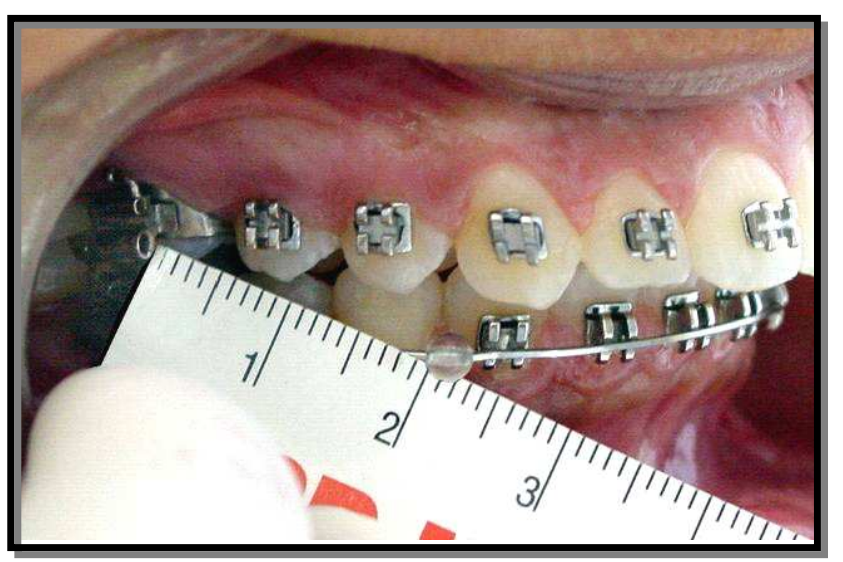

FIGURA 2 - Seleção do tamanho do aparelho Jasper Jumper. No exemplo, a distância foi de $20 \mathrm{~mm}$; adicionando-se os $12 \mathrm{~mm}$ preconizados = $32 \mathrm{~mm}$ (Jasper Jumper tamanho 4).

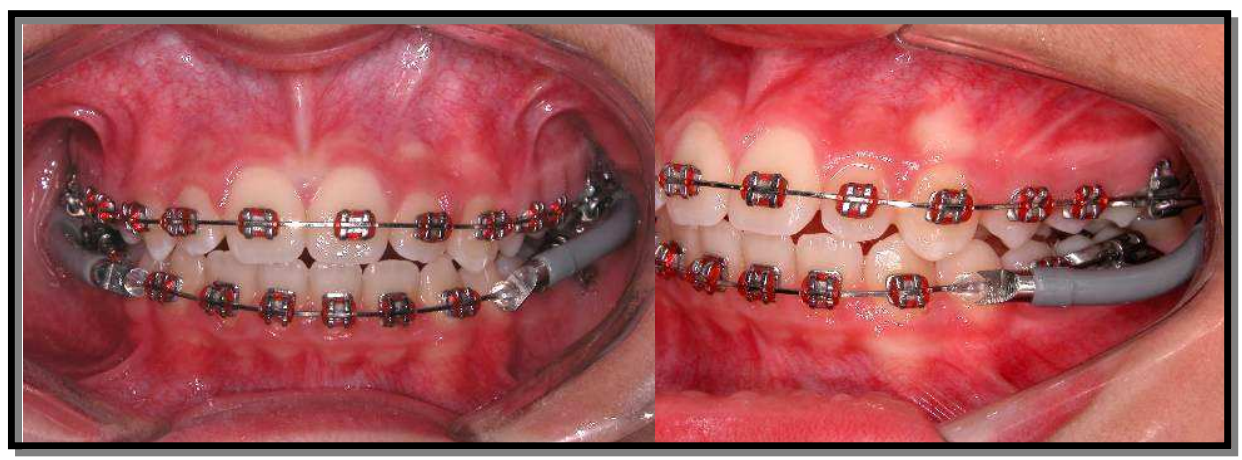

FIGURA 3 - Jasper Jumper instalado

Deve-se orientar o paciente a não ocluir sobre o aparelho, evitar a abertura excessiva da boca durante a mastigação, o bocejar, e não resistir à protrusão inferior proporcionada pelos módulos de força. Essas recomendações são efetuadas na tentativa de minimizar o risco de quebra do sistema. Na amostra utilizada o índice de quebra foi de $35,14 \%$ dos aparelhos 
instalados, tendo a quebra mais precoce ocorrido após 2 meses de uso do aparelho e a mais tardia após 9 meses de uso.

As ativações do aparelho Jasper Jumper foram realizadas adicionandose esferas de acrílico no arco inferior.

Após um período médio de 0,61 ano de tratamento com o Jasper Jumper, a relação ântero-posterior foi sobrecorrigida. Assim, os Jasper Jumpers foram removidos e realizou-se a intercuspidação dentária e finalização do tratamento. Durante esta fase de finalização, todos os pacientes foram orientados a utilizar elásticos de Classe II por, aproximadamente, 10 horas/dia (apenas para dormir) como contenção ativa da correção ântero-posterior. Em algumas situações solicitou-se o uso desses elásticos por um período diário maior, de acordo com a necessidade do caso. Com a remoção do aparelho fixo, instalou-se como contenção a placa de Hawley modificada no arco superior para uso diurno, o $3 \times 3$ inferior, e um Bionator modificado (com espessura de acrílico delgada entre os dentes posteriores e sem recobrimento dos incisivos inferiores) para uso noturno, por um período de um ano (FIGURA 4).

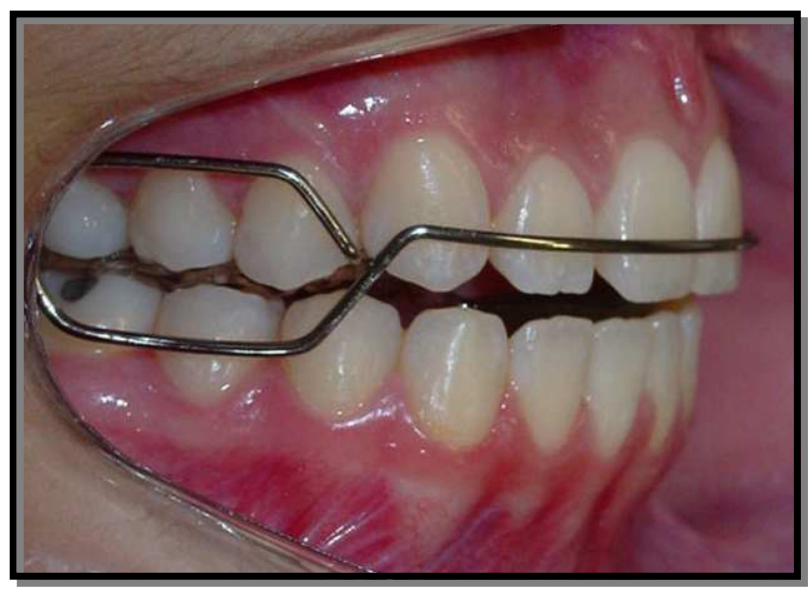

FIGURA 4 - Bionator modificado como contenção - uso noturno durante 1 ano. 


\subsubsection{Bionator e aparelho fixo}

\subsubsection{Aparelho Bionator}

O aparelho Bionator utilizado na clínica de Pós-graduação em Ortodontia da Faculdade de Odontologia de Bauru - USP apresenta algumas modificações considerando-se o aparelho original proposto por Balters. Essas modificações foram propostas por Ascher ${ }^{28}$, em 1977. O Bionator apresenta em sua constituição quatro componentes básicos: uma base de acrílico, alça palatina, arco vestibular e dobras do bucinador (FIGURA 5). Algumas características deste aparelho diferiram da forma original proposta por Balters, como o recobrimento acrílico dos incisivos inferiores, com o intuito de minimizar a protrusão e extrusão dos mesmos ${ }^{160}$. Além disto, a alça palatina manteve-se passiva, não agindo como um posicionador postural da língua, e o arco vestibular, construído originalmente afastado dos incisivos superiores com 0 objetivo de guiar ou facilitar o selamento labial, passou a tocar os incisivos superiores, exercendo uma suave pressão nos mesmos, agindo assim como um elemento ativo do tratamento (FIGURA 6).

A mordida construtiva para a confecção do Bionator buscou a relação de topo-a-topo entre os incisivos, desde que 0 avanço mandibular não ultrapassasse $7 \mathrm{~mm}$, observando concomitantemente as relações de normalidade dos caninos e primeiros molares permanentes. Para os casos que apresentaram uma sobressaliência maior que $7 \mathrm{~mm}$, realizou-se um avanço mandibular gradual, ou seja, a cada 3 meses respeitando o limite de 2 a $3 \mathrm{~mm}$ a cada avanço ${ }^{7}$. No sentido vertical, realizou-se uma abertura entre os dentes posteriores de, aproximadamente, $5 \mathrm{~mm}$, ou até que se corrigisse a sobremordida ${ }^{56}$. No sentido transversal, manteve-se a coincidência das linhas medianas esqueléticas superior e inferior. Nos casos de desvio da linha média dentária, manteve-se o desvio durante a confecção da mordida construtiva ${ }^{7}$.

Recomendou-se a utilização do Bionator por período integral, removendo-o apenas para as refeições, higienização e prática de esportes. Os desgastes seletivos póstero-inferiores só foram iniciados depois que os pacientes se acostumaram com o aparelho ${ }^{56}$. Esta fase ortopédica durou, em média, 1,27 ano. 


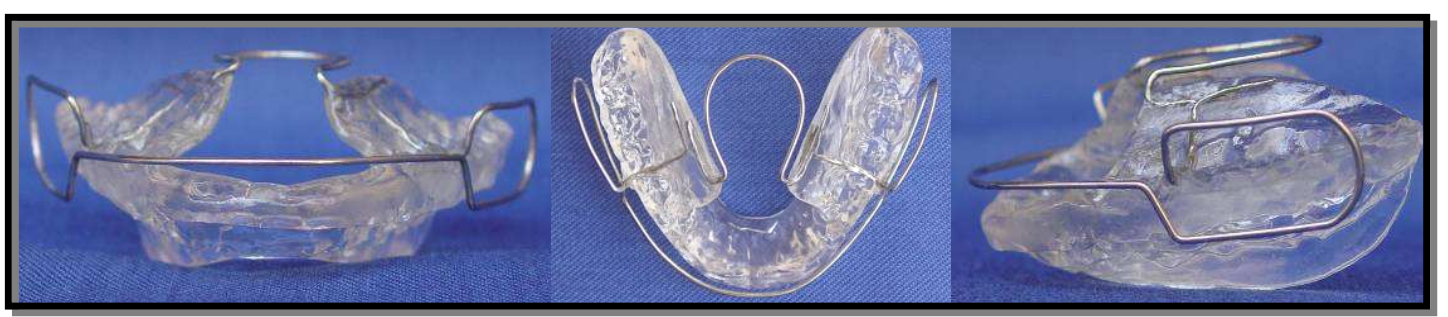

FIGURA 5 - Aparelho Bionator - componentes

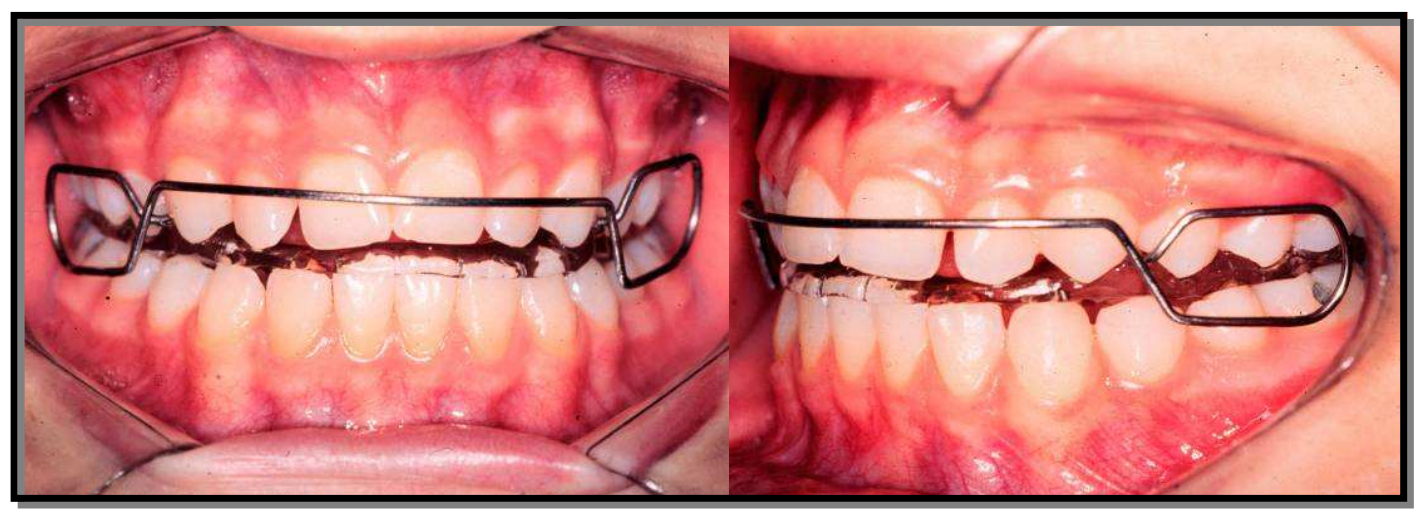

FIGURA 6 - Aparelho Bionator modificado por Ascher ${ }^{28}$

\subsubsection{Aparelho Ortodôntico Fixo}

Após a obtenção de uma relação ântero-posterior normal por meio do aparelho Bionator, os pacientes se submeteram ao tratamento ortodôntico corretivo para o alinhamento e nivelamento dos arcos dentários, visando uma boa oclusão estática e funcional (FIGURA 7). Alguns pacientes utilizaram braquetes "Edgewise" enquanto em outros seguiu-se os princípios da mecânica do arco reto (pré-ajustado), de acordo com a prescrição de Roth. Todos os braquetes utilizados apresentavam ranhura .022" x .030", independentemente da especificação. Observou-se que a grande maioria utilizou o aparelho extrabucal (KHG) como contenção ativa da correção ântero-posterior por, aproximadamente, 14 horas/dia, durante a fase ortodôntica. Dos 32 pacientes dessa amostra, 10 utilizaram o próprio Bionator para dormir, como contenção da correção ântero-posterior. Além disto, os elásticos de Classe II foram freqüentemente utilizados ao final do tratamento ortodôntico. Esta fase ortodôntica corretiva durou, em média, 1,76 ano. Após a finalização do 
tratamento, utilizou-se como contenção a placa de Hawley modificada no arco superior e o $3 \times 3$ inferior.

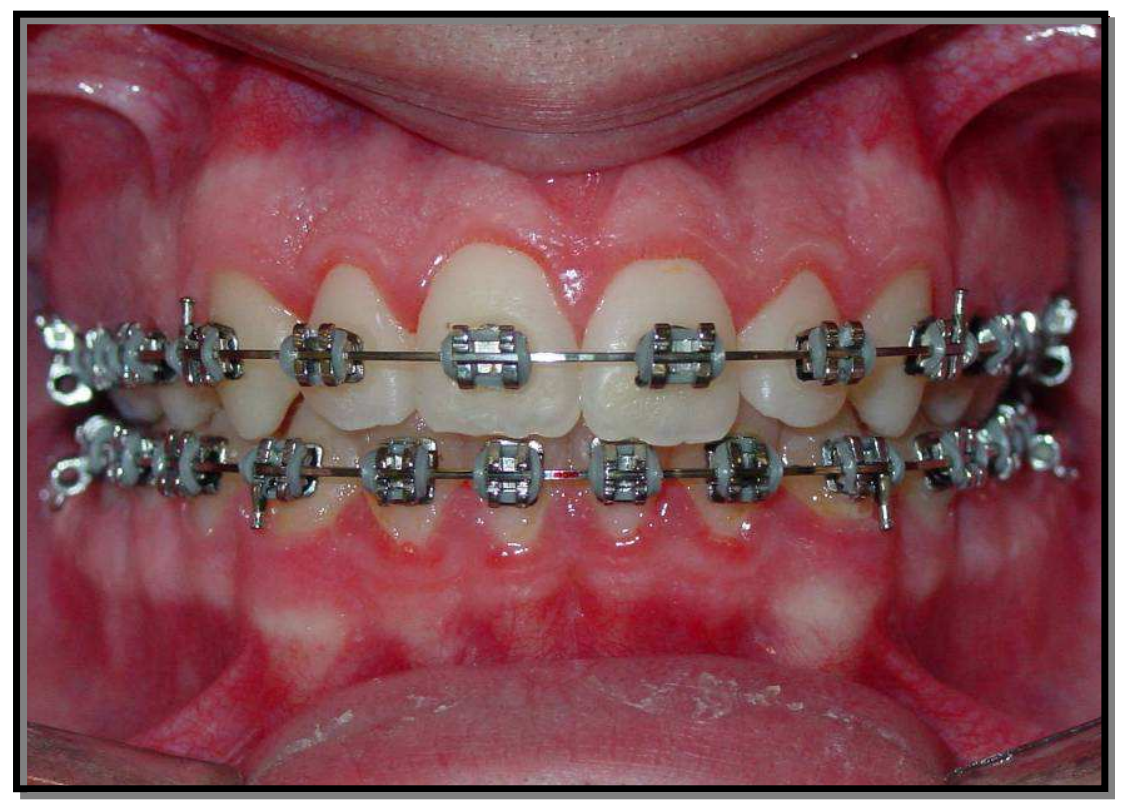

FIGURA 7 - Aparelho ortodôntico fixo

\subsection{MÉTODOS}

\subsubsection{Método Radiográfico}

Para a realização deste estudo, utilizou-se duas telerradiografias em norma lateral de cada jovem, consideradas T1 (inicial) e T2 (final). Essas radiografias foram tomadas com os lábios em repouso e na posição de máxima intercuspidação habitual, com 0 auxílio do cefalostato de Broadbent ${ }^{58}$. As radiografias foram obtidas em diferentes aparelhos, porém, em todas as tomadas radiográficas respeitou-se as normas técnicas de obtenção e processamento preconizadas pela Disciplina de Radiologia da Faculdade de Odontologia de Bauru, da Universidade de São Paulo. Os fatores de magnificação foram determinados em 9,8\% para o Grupo Experimental 1 (todas as radiografias desse grupo foram realizadas em um mesmo aparelho); em 6\%, 7,9\% e 9,8\% para o Grupo Experimental 2 (essa amostra é de caráter retrospectivo, e as radiografias foram realizadas em diferentes centros de documentação, apresentando diferentes fatores de magnificação); e em $6 \%$ 
para o Grupo Controle (todas as radiografias desse grupo foram tomadas em um único aparelho).

\subsubsection{Elaboração do cefalograma e medição das telerradiografias}

Para a realização do cefalograma, adaptou-se em cada telerradiografia uma folha de papel de acetato transparente "ultraphan" de 0,07mm de espessura e 17,5 x 17,5 cm. O traçado anatômico e a demarcação dos pontos de referência dentoesqueléticos foram efetuados manualmente pela autora sobre um negatoscópio, com lapiseira de $0,3 \mathrm{~mm}$, em uma sala obscurecida. Após a realização dos traçados anatômicos, os mesmos foram verificados por outro examinador, para conferir maior precisão da avaliação cefalométrica. Seqüencialmente, o traçado anatômico e os pontos demarcados foram digitalizados em uma mesa digitalizadora Numonics AccuGrid XNT, modelo A30TL.F ${ }^{\mathrm{b}}$ (Austin, Texas - USA), acoplada a um microcomputador AMD K6-II $500 \mathrm{MHZ}$.

O programa utilizado para a medição das variáveis cefalométricas foi 0 Dentofacial Planner $7.02^{\mathrm{C}}$ (Toronto, Ontário - Canadá), com o qual a magnificação da imagem radiográfica já é corrigida.

\subsubsection{Traçado anatômico}

Foram delimitadas as seguintes estruturas dentoesqueléticas:

- perfil mole;

- perfil do osso frontal e dos ossos nasais;

- sela turca;

- meato acústico externo;

- limite póstero-inferior da cavidade orbitária;

- maxila;

- mandíbula;

\footnotetext{
${ }^{\mathrm{b}}$ Numonics Corporation - Montgomeryville - PA, USA.

${ }^{c}$ Dentofacial Planner Software Inc., Toronto, Ontario, Canada.
} 
- incisivos centrais superiores e inferiores;

- primeiros molares superiores e inferiores.

Para todas as imagens duplas das estruturas bilaterais traçou-se a média.

\subsubsection{Pontos de referência, linhas e planos (FIGURA 8)}

Demarcou-se os pontos de referência anatômicos de acordo com as especificações de KROGMAN; SASSOUNI ${ }^{182}$, RIOLO ${ }^{273}$, MCNAMARA JR. ${ }^{206}$, JACOBSON $^{149}$, LEGAN $^{190}$, STEINER ${ }^{309}$ e RICKETTS ${ }^{272}$ :

1. S (sela turca): ponto mais central da sela turca;

2. $N$ (násio): ponto mais anterior da sutura frontonasal;

3. Or (orbitário): a média dos pontos mais inferiores das margens inferiores das órbitas;

4. ENA (espinha nasal anterior): ponto mais anterior da espinha nasal anterior;

5. ENP (espinha nasal posterior): ponto mais posterior do assoalho da fossa nasal;

6. Ponto A (subespinhal): ponto mais profundo da concavidade anterior da maxila;

7. Ponto B (supramentoniano): ponto mais profundo da concavidade da sínfise mentoniana;

8. Pog (pogônio): ponto mais anterior do contorno do mento ósseo;

9. Gn (gnátio): ponto mais inferior e anterior do contorno do mento ósseo, determinado pela bissetriz das linhas NPog e o plano mandibular (GoMe);

10. Me (mentoniano): ponto mais inferior da sínfise mentoniana;

11. Go (gônio): ponto determinado pela intersecção da bissetriz do ângulo formado pelas tangentes às bordas posterior e inferior da mandíbula;

12. Po (pório anatômico): ponto mais superior do meato acústico externo;

13. Co (condílio): ponto mais posterior e superior do côndilo mandibular; 
14. BIS (borda do incisivo superior): ponto mais inferior da borda incisal do incisivo central superior;

15. AIS (ápice do incisivo superior): ponto mais superior do ápice radicular do incisivo central superior;

16. Bll (borda do incisivo inferior): ponto mais superior da borda incisal do incisivo central inferior;

17. All (ápice do incisivo inferior): ponto mais inferior do ápice radicular do incisivo central inferior;

18. SMPMS (superfície mesial do primeiro molar superior): ponto mais anterior da coroa do primeiro molar permanente superior;

19. CMPMS (cúspide mesial do primeiro molar superior): ponto mais inferior da cúspide mesial do primeiro molar permanente superior;

20. SMPMI (superfície mesial do primeiro molar inferior): ponto mais anterior da coroa do primeiro molar permanente inferior;

21. CMPMI (cúspide mesial do primeiro molar inferior): ponto mais superior da cúspide mesial do primeiro molar permanente inferior;

22. COM (contato oclusal molar): o ponto médio da superfície de intercuspidação dos primeiros molares;

23. COPM (contato oclusal pré-molar): ponto médio da superfície de intercuspidação dos primeiros pré-molares ou dos primeiros molares decíduos;

Além desses pontos descritos, relacionados com estruturas anatômicas, construiu-se dois pontos para efeitos de digitalização:

24. Pogperp (ponto pogônio perpendicular): ponto localizado arbitrariamente ao nível dos incisivos superiores, porém perpendicular ao plano Go-Me, a partir do ponto Pog;

25. ENAperp (ponto espinha nasal anterior perpendicular): ponto localizado arbitrariamente ao nível dos incisivos inferiores, porém perpendicular ao plano palatino, a partir do ponto ENA; 


\section{Linhas e planos}

\section{Horizontais}

A. Linha SN: do ponto sela ao násio;

B. FH (plano horizontal de Frankfurt): do ponto pório ao orbitário;

C. PP (plano palatino): do ponto ENA ao ENP;

D. POF (plano oclusal funcional): do contato oclusal pré-molar ao contato oclusal molar;

E. GoGn (plano mandibular): do ponto gônio ao gnátio;

F. GoMe (plano mandibular): do ponto gônio ao mentoniano.

\section{Verticais}

G. Linha NA: une o ponto násio ao ponto $A$;

H. Linha NB: une o ponto násio ao ponto B;

I. Linha BIS-AIS (longo eixo do incisivo superior): une os pontos correspondentes da borda incisal ao ápice dos incisivos centrais superiores;

J. Linha Bll-All (longo eixo do incisivo inferior): une os pontos correspondentes da borda incisal ao ápice dos incisivos centrais inferiores;

K. Linha Nperp: linha perpendicular ao plano de Frankfurt, passando pelo ponto násio;

L. Linha Pogperp: linha perpendicular ao plano mandibular Go-Me, passando pelo ponto pogônio;

M. Linha ENAperp: linha perpendicular ao plano palatino, passando pela espinha nasal anterior;

N. Plano CoGo: do ponto condílio ao ponto gônio. 


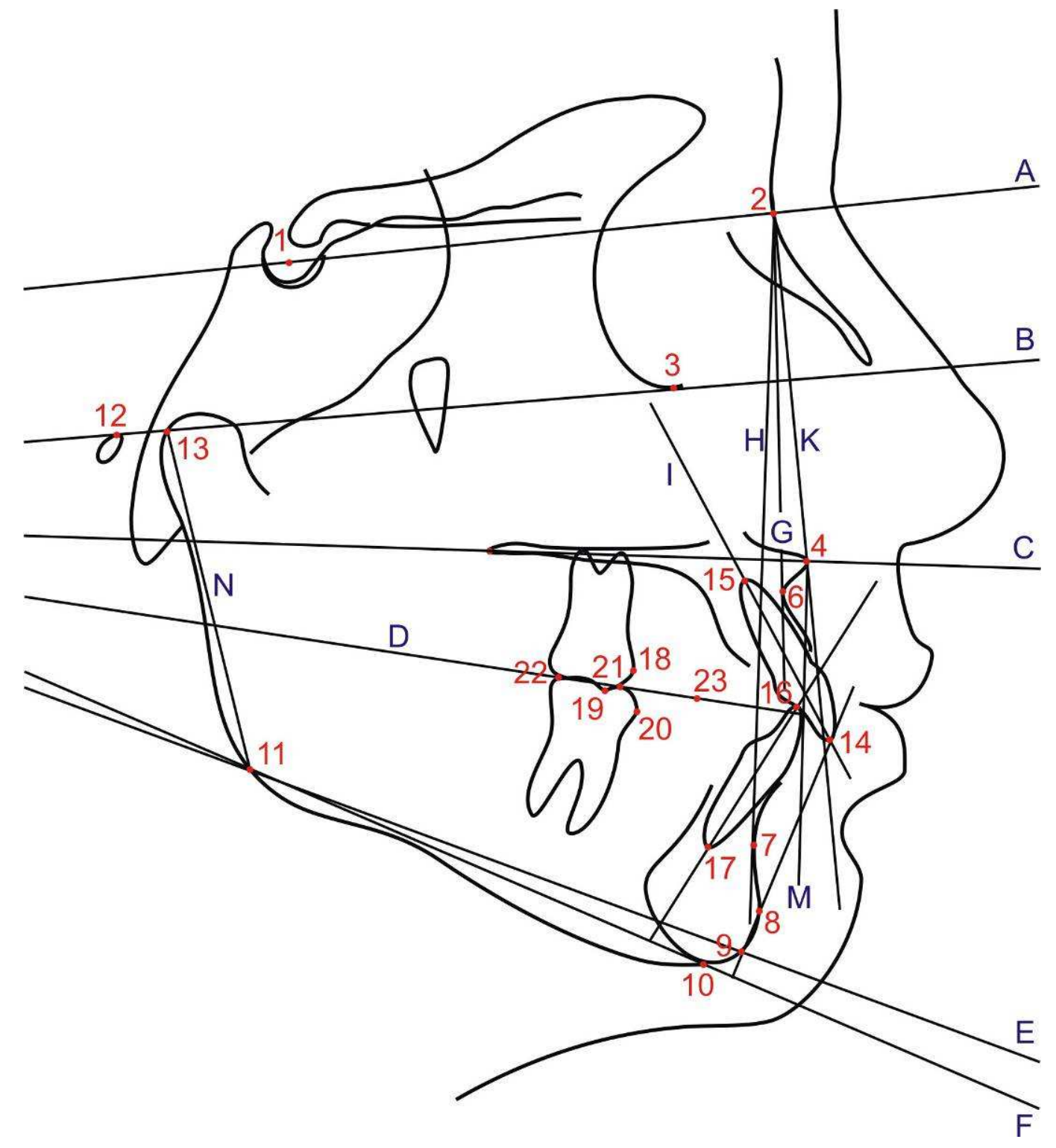

FIGURA 8 - Pontos de referência, linhas e planos utilizados 


\subsubsection{Grandezas cefalométricas esqueléticas (FIGURA 9)}

\section{Maxilares}

1. SNA (9: ângulo formado pelas linhas SN e NA. Indic a a relação ânteroposterior da maxila em relação à base do crânio, e seu aumento indica um aumento da protrusão maxilar;

2. Co-A (mm): distância entre os pontos condílio e A. Representa o comprimento efetivo da maxila;

3. A-Nperp (mm): distância entre o ponto $A$ e a linha násio perpendicular. Define a posição ântero-posterior da maxila e seu aumento também indica um aumento da protrusão maxilar.

\section{Mandibulares}

4. SNB (9: ângulo formado pelas linhas SN e NB. Indica a relação ânteroposterior da mandíbula em relação à base do crânio, e seu aumento indica um aumento da protrusão mandibular;

5. Co-Gn (mm): distância entre os pontos condílio e gnátio. Define o comprimento efetivo mandibular;

6. Go-Gn $(\mathrm{mm})$ : distância entre os pontos gônio e gnátio. Avalia o comprimento do corpo mandibular;

7. Co-Go (mm): distância entre os pontos condílio e gônio. Representa a altura do ramo mandibular;

8. Pog-Nperp $(\mathrm{mm})$ : distância entre o ponto pogônio e a linha násio perpendicular. Representa a posição ântero-posterior da mandíbula, e seu aumento indica um aumento da protrusão mandibular.

\section{Maxilomandibulares}

9. ANB (9: ângulo entre as linhas NA e NB. Representa o grau de discrepância ântero-posterior entre a maxila e mandíbula; sua diminuição indica um melhor relacionamento maxilomandibular;

10. NAP (9: ângulo entre as linhas NA e APog. Descreve o grau de 
convexidade do perfil ósseo;

11. Wits $(\mathrm{mm})$ : distância entre as projeções perpendiculares dos pontos $A$ e B sobre o plano oclusal funcional. Define o relacionamento ânteroposterior entre a maxila e mandíbula e sua diminuição indica um melhor relacionamento maxilomandibular;

12. Co-A/Co-Gn (mm): proporção entre os comprimentos maxilar e mandibular. Avalia o crescimento diferencial da mandíbula em relação à maxila.

\section{Padrão de crescimento}

13. FMA (9: ângulo formado pelos planos horizontal de Frankfurt e mandibular (GoMe). Define a orientação do padrão de crescimento facial;

14. SN.GoGn (9: ângulo formado pela linha $S N$ e o plano mandibular GoGn. Utilizando-se pontos cefalométricos diferentes, também define a orientação do padrão de crescimento facial;

15. SN.PP (9: ângulo formado pela linha SN e o plano palatino. Indica o posicionamento da porção basal maxilar;

16. SN.POF (9: ângulo formado entre a linha $\mathrm{SN}$ e o plano oclusal funcional. Relaciona a inclinação do plano oclusal com a base do crânio;

17. AFAl (mm): distância entre os pontos espinha nasal anterior e mentoniano. Indica a altura do terço inferior da face;

18. S-Go (mm): Distância entre os pontos sela e gônio. Indica a altura posterior da face. 


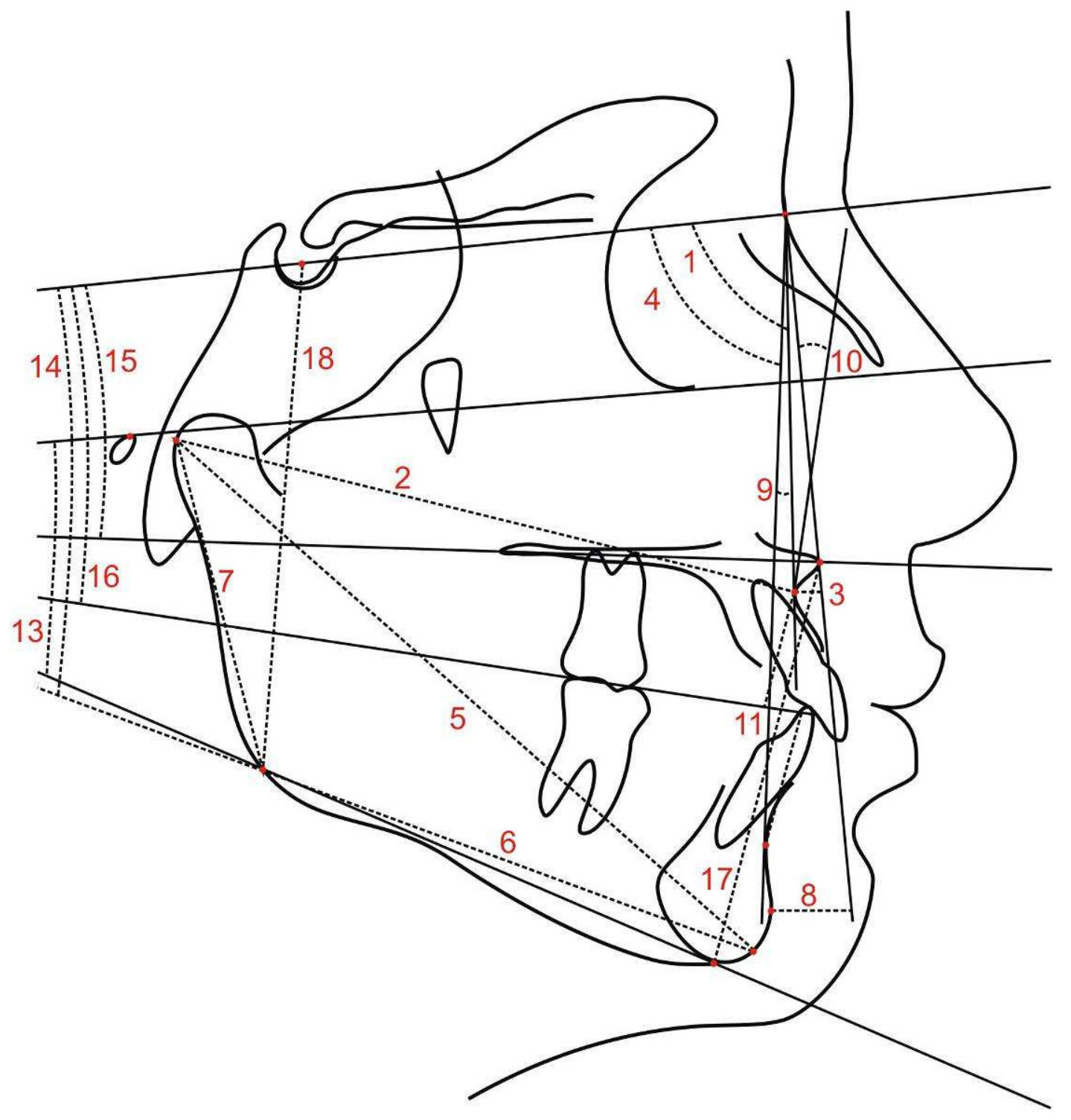

FIGURA 9 - Grandezas cefalométricas esqueléticas 


\subsubsection{Grandezas cefalométricas dentárias (FIGURA 10)}

\section{Dentárias superiores}

1. 1.PP (9: ângulo entre o longo eixo do incisivo cen tral superior e o plano palatino. Avalia a inclinação do incisivo superior em relação à maxila;

2. 1.NA (9: ângulo entre o longo eixo do incisivo cen tral superior e a linha NA. Define o grau de inclinação do incisivo central em relação à maxila e ao násio;

3. 1-NA (mm): distância entre o ponto mais anterior da coroa do incisivo central superior e a linha NA. Avalia a posição ântero-posterior do incisivo superior em relação à maxila e ao násio e seu aumento indica uma protrusão do incisivo;

4. 1-ENAperp $(\mathrm{mm})$ : distância entre o ponto mais anterior da coroa do incisivo central superior e a linha espinha nasal anterior perpendicular. Determina a posição ântero-posterior do incisivo superior em relação à maxila. Valores posteriores a essa linha são negativos, anteriores, positivos, seguindo o mesmo raciocínio de 1-NA;

5. 1-PP (mm): distância entre a borda incisal do incisivo central superior e o plano palatino. Determina a altura do processo alveolar superior em sua região anterior;

6. 6-PP $(\mathrm{mm})$ : distância entre a cúspide mesiovestibular do primeiro molar superior e o plano palatino. Avalia a altura do processo alveolar em sua região posterior;

7. 6-ENAperp $(\mathrm{mm})$ : distância entre a face mesial do primeiro molar superior e a linha espinha nasal anterior perpendicular. Determina a posição ântero-posterior do primeiro molar superior em relação à maxila, sendo que seu aumento (ou diminuição do valor absoluto) indica uma mesialização do molar; 


\section{Dentárias inferiores}

8. IMPA (9: ângulo entre o longo eixo do incisivo central inferior e o plano mandibular GoMe. Indica a inclinação desse dente em relação à mandíbula;

9. 1.NB (9: ângulo entre o longo eixo do incisivo inferior e a linha NB. Relaciona a inclinação desse dente com a mandíbula e o násio;

10. 1-NB (mm): distância entre o ponto mais anterior da coroa do incisivo central inferior e a linha NB. Avalia a posição ântero-posterior do incisivo inferior em relação à mandíbula e ao násio;

11. 1-Pogperp $(\mathrm{mm})$ : distância entre o ponto mais anterior da coroa do incisivo central inferior e a linha pogônio perpendicular. Determina a posição ântero-posterior do incisivo central inferior em relação à mandíbula, sendo que seu aumento indica uma protrusão do incisivo;

12. 1-PM $(\mathrm{mm})$ : distância entre a borda incisal do incisivo central inferior e o plano mandibular GoMe. Determina a altura do processo alveolar inferior em sua região anterior;

13. 6-Pogperp $(\mathrm{mm})$ : distância entre a face mesial do primeiro molar inferior e a linha pogônio perpendicular. Determina a posição ântero-posterior do primeiro molar inferior em relação à mandíbula, sendo que seu aumento (ou diminuição do valor absoluto) indica uma mesialização do molar;

14. 6-PM $(\mathrm{mm})$ : distância entre a cúspide mesiovestibular do primeiro molar inferior e o plano mandibular GoMe. Determina a altura do processo alveolar inferior em sua região posterior. 


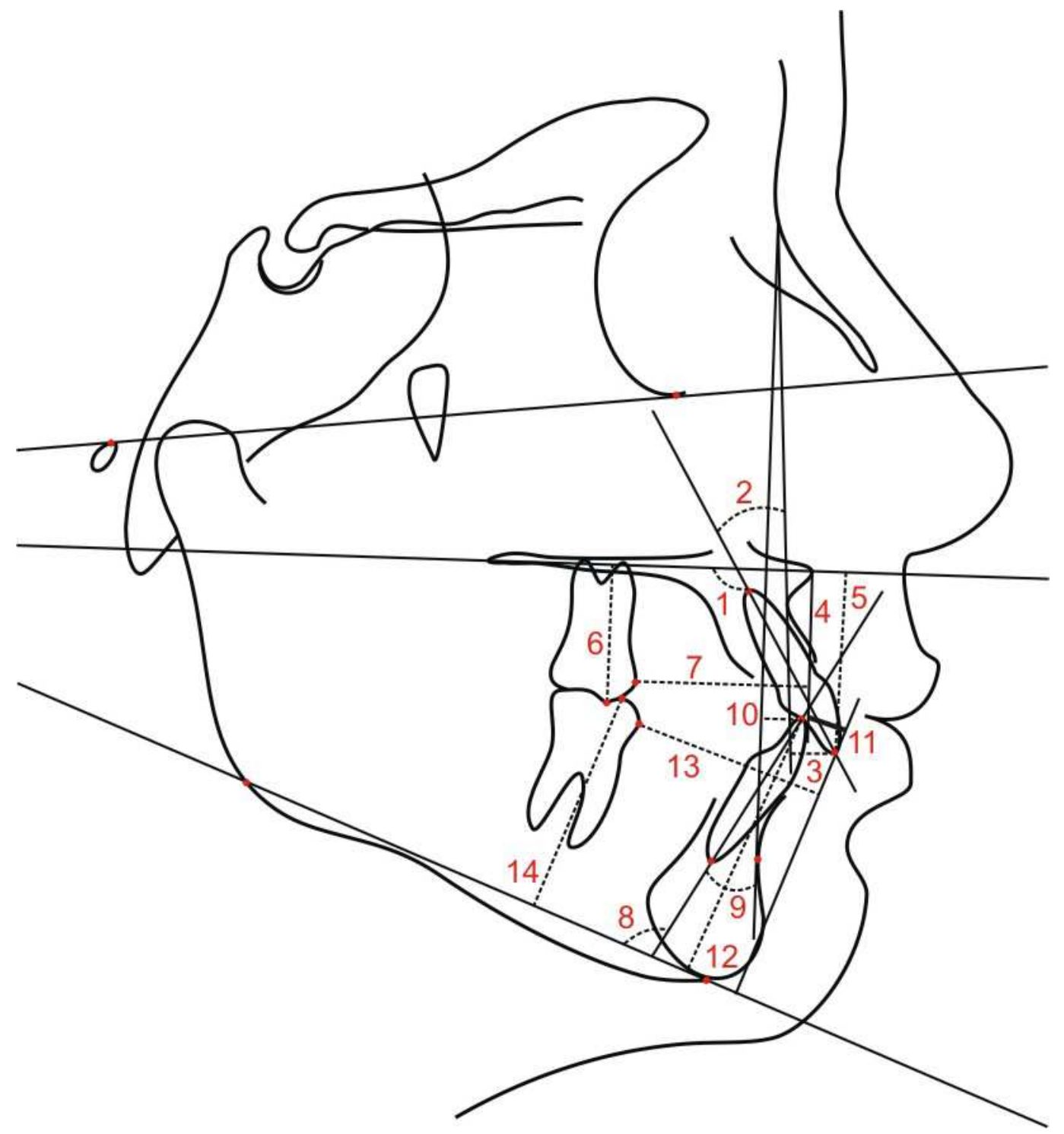

FIGURA 10 - Grandezas cefalométricas dentárias superiores e inferiores 


\subsubsection{Relações dentárias (FIGURA 11)}

1. TRESPASSE HORIZONTAL - T.H. (mm): distância da borda incisal do incisivo inferior à borda incisal do incisivo superior, medida paralelamente ao plano oclusal funcional;

2. TRESPASSE VERTICAL - T.V. (mm): distância da borda incisal do incisivo inferior à borda incisal do incisivo superior, medida perpendicularmente ao plano oclusal funcional;

3. RELAÇÃO MOLAR - Rel. molar (mm): distância da superfície mesial do primeiro molar superior à superfície mesial do primeiro molar inferior, medida paralelamente ao plano oclusal funcional. Seu aumento indica uma maior mesialização do molar inferior em relação ao superior. 


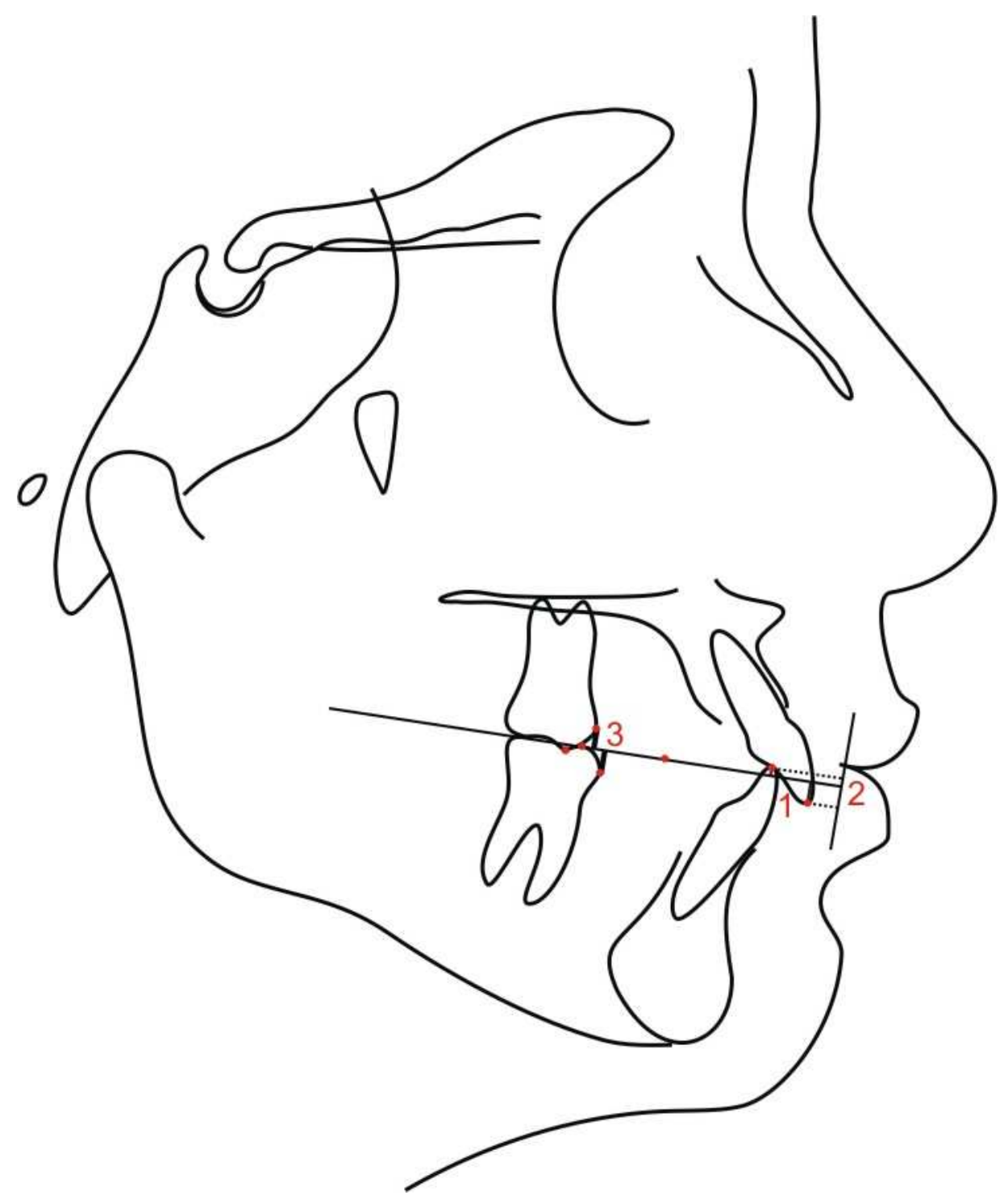

FIGURA 11 - Grandezas cefalométricas referentes às relações dentárias 


\subsubsection{Análise estatística}

\subsubsection{Erro do método}

Para a avaliação do erro intra-examinador, foram traçadas e mensuradas novamente 30 telerradiografias selecionadas ao acaso, após um intervalo de 3 semanas. Aplicou-se $o$ teste $t$ dependente com o objetivo de estimar o erro sistemático. Para a avaliação do erro casual, empregou-se o teste de DAHLBERG ${ }^{87}$, por meio da seguinte fórmula: $\mathrm{Se}^{2}=\sum \mathrm{d}^{2} / 2 \mathrm{n}$, onde $\mathrm{Se}^{2}$ representa o erro de Dahlberg; $\Sigma \mathrm{d}^{2}$ corresponde ao somatório dos quadrados das diferenças entre as primeiras e segundas medições e $2 n$ representa 0 dobro do número de casos em que as medidas foram repetidas.

\subsubsection{Comparações intra e intergrupos}

Para as comparações intra e intergrupos aplicou-se os seguintes testes estatísticos:

a) Estatística descritiva: médias, desvios-padrão, valor mínimo e valor máximo das idades iniciais, finais, tempo de tratamento e sobressaliência inicial (medida nos modelos de gesso) nos grupos estudados, nas fases inicial e final;

b) Teste de Kolmogorov-Smirnov: para verificar se todas as variáveis estudadas seguem uma distribuição normal, em todos os grupos avaliados, o que permite a aplicação dos testes estatísticos paramétricos;

c) Teste não paramétrico qui-quadrado: para avaliar a compatibilidade dos grupos estudados em relação à severidade inicial da má oclusão (relação molar e relação dos caninos), e em relação à distribuição dos gêneros nos 3 grupos;

d) Análise de Variância a um critério (ANOVA): para avaliar a compatibilidade cefalométrica nas fases inicial e final, além das idades inicial, final e tempo de avaliação nos 3 grupos avaliados, bem como 
para avaliar a compatibilidade da sobressaliência inicial (medida nos modelos de estudo) entre os grupos estudados;

e) Teste t dependente: para a comparação dos valores das grandezas cefalométricas entre as fases inicial e final (intragrupo), nos grupos experimentais e controle, a fim de determinar se ocorreram alterações estatisticamente significantes derivadas do tratamento e/ou crescimento entre estas duas fases;

f) Determinou-se as diferenças entre as mensurações nas fases final e inicial de cada variável cefalométrica, estabelecendo assim as alterações reais ocorridas no período de avaliação, nos três grupos estudados (alteração = valor final - valor inicial). Como os períodos médios de tratamento foram consideravelmente diferentes entre os grupos experimentais, torna-se impraticável uma comparação direta entre esses grupos, uma vez que os resultados inevitavelmente estariam influenciados pelo fator tempo de avaliação. De modo a possibilitar a comparação direta entre os grupos experimentais e o grupo controle, as alterações ocorridas em cada variável, para cada paciente do Grupo Experimental 2 (tratados por meio do Bionator e aparelhagem fixa) foram então anualizadas, ou seja, divididas pelo tempo de tratamento do paciente e multiplicadas pelo tempo médio de tratamento do Grupo Experimental 1 (2,15 anos), equiparando assim os grupos tratados em relação ao tempo de avaliação. As alterações anualizadas do Grupo Experimental 2 foram então comparadas com as alterações dos Grupos Experimental 1 e Controle (que já estavam previamente compatibilizados quanto ao tempo de avaliação), por meio da Análise de Variância a um critério;

g) Teste de Tukey: para determinar entre quais grupos houve diferença estatisticamente significante quando detectada previamente pela Análise de Variância. 
Toda a análise estatística foi realizada com o programa Statistica for $W_{i n d o w s}{ }^{d}$. Foram considerados estatisticamente significantes resultados com valor de $p<0,05$.

${ }^{\mathrm{d}}$ Statistica for Windows - Release 6.0 - Copyright Statsoft, Inc. 2001. 


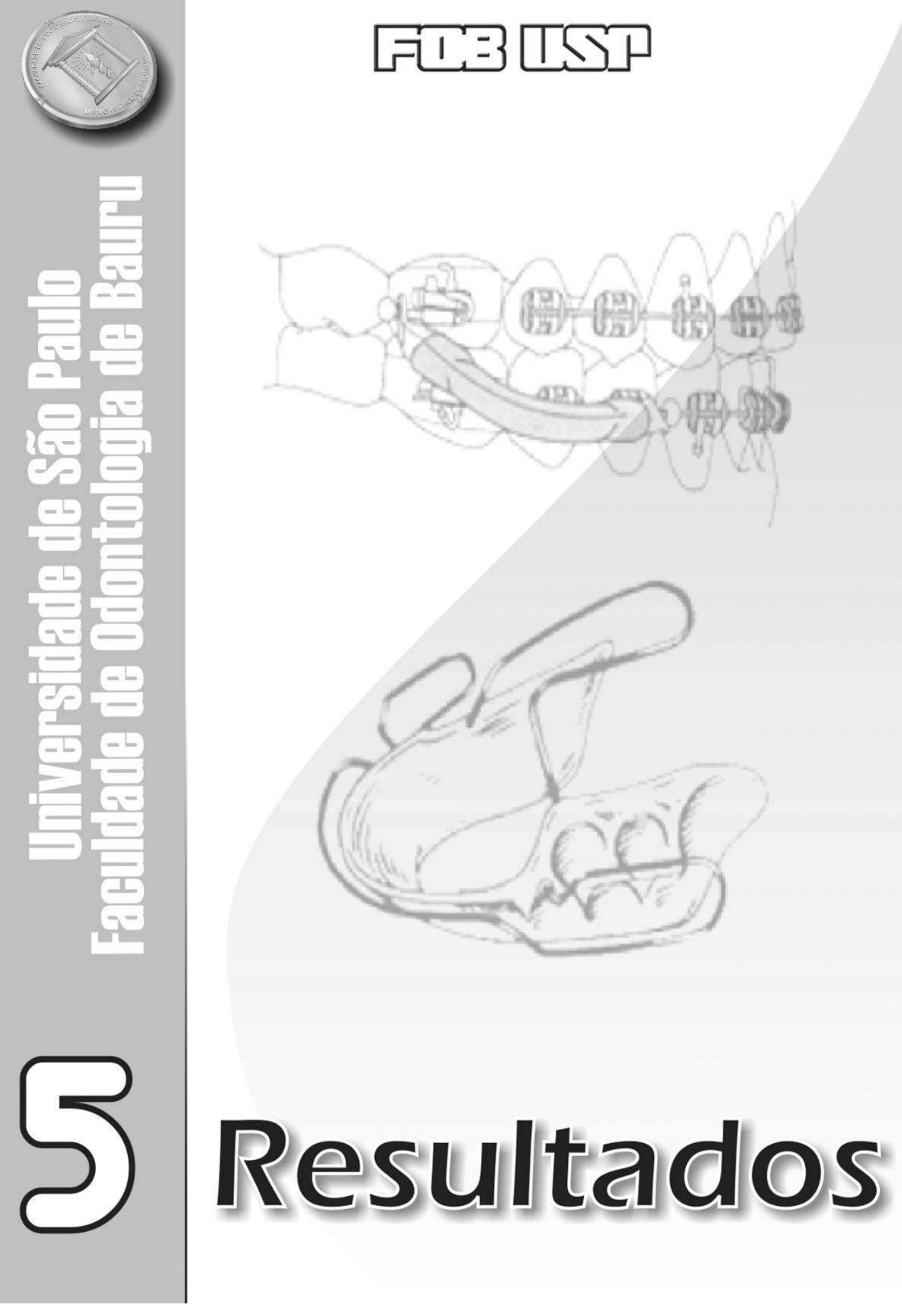




\section{RESULTADOS}

Os resultados deste trabalho estão apresentados sob a forma de tabelas.

A TABELA 5 apresenta os resultados da avaliação do erro intraexaminador nas telerradiografias em norma lateral, sendo que a magnitude dos erros casuais foi verificada por meio da fórmula de Dahlberg e os erros sistemáticos por meio da aplicação do teste t dependente.

De acordo com o teste Kolmogorov-Smirnov (utilizado para verificar se todas as variáveis, dos três grupos avaliados, nas fases inicial e final, seguiam uma distribuição normal), nenhuma variável apresentou resultado estatisticamente significante, indicando que os testes estatísticos paramétricos podem ser aplicados a essas variáveis.

A TABELA 6 contém os resultados da avaliação da compatibilidade entre os grupos quanto à idade inicial média (ANOVA a um critério e teste de Tukey), distribuição por gêneros (teste do qui-quadrado) e quanto à severidade inicial da má oclusão no sentido ântero-posterior, analisada por meio da relação molar, relação dos caninos (teste do qui-quadrado) e sobressaliência inicial, medida nos modelos de gesso (ANOVA a um critério e teste de Tukey). Esta tabela traz também a comparação entre os grupos do tempo médio de avaliação e da idade final (ANOVA a um critério e teste de Tukey). Já a TABELA 7 apresenta os resultados do teste qui-quadrado comparando a severidade inicial da má oclusão, por meio da relação molar e relação dos caninos, somente entre os grupos experimentais.

Os resultados da verificação da compatibilidade cefalométrica dos Grupos Experimentais e o Grupo Controle na fase inicial do tratamento estão dispostos na TABELA 8 (ANOVA a um critério e teste de Tukey).

A TABELA 9 apresenta os resultados da comparação das variáveis cefalométricas entre os três grupos estudados, na fase final do tratamento (ANOVA a um critério e teste de Tukey).

Os resultados da comparação dos valores das grandezas cefalométricas entre as fases inicial e final (intragrupo), nos grupos Experimental 1, 
Experimental 2 e Controle, por meio do teste $t$ dependente, encontram-se representados nas TABELAS 10, 11 e 12, respectivamente.

Determinou-se as alterações ocorridas entre as fases inicial e final de cada variável cefalométrica (alteração $=$ valor $\mathrm{T} 2$ - valor $\mathrm{T} 1$ ), para cada indivíduo dos três grupos avaliados. Como o tempo médio de tratamento do Grupo Experimental 2 foi consideravelmente maior que 0 do Grupo Experimental 1 e que o tempo médio de observação do Grupo Controle, as alterações desse grupo (tratado por meio do Bionator e aparelhagem fixa) foram então anualizadas:

$$
\text { Alteração anualizada }=\frac{\text { alteração variável }}{\text { tempo de tratamento do paciente }} \times \begin{gathered}
2,15 \quad \begin{array}{c}
\text { (tempo médio de } \\
\text { tratamento do Grupo } \\
\text { Experimental } 1 \text { ) }
\end{array}
\end{gathered}
$$
2,15 (tempo médio de tratamento do Grupo
Experimental 1)

Assim, as médias das alterações das variáveis cefalométricas do Grupo Experimental 1 e do Grupo Controle foram comparadas com as médias das alterações anualizadas das variáveis cefalométricas do Grupo Experimental 2, por meio da Análise de Variância a um critério e do teste de comparação múltipla de Tukey. Os resultados dessas comparações encontram-se na TABELA 13.

Como o Grupo Experimental 2 diferiu dos demais grupos tanto em relação à idade inicial quanto ao período de avaliação, compatibilizou-se os três grupos em relação à idade inicial, a fim de eliminar possíveis interferências dessa variável na avaliação dos resultados dos tratamentos; não foi possível compatibilizá-los em relação ao período de avaliação, pelas características próprias de cada um dos tipos de tratamento (o grupo Experimental 1 foi tratado em 1 fase enquanto o Experimental 2, em 2 fases). Os resultados da comparação das idades inicial e final, do período de avaliação, da severidade inicial da má oclusão e da distribuição dos gêneros entre os grupos compatibilizados encontram-se na TABELA 14 (ANOVA a um critério, teste de Tukey e teste do qui-quadrado). A TABELA 15 apresenta os resultados da comparação cefalométrica inicial (em T1) entre os grupos compatibilizados quanto à idade inicial (ANOVA a um critério e teste de Tukey). A comparação das alterações das variáveis cefalométricas dos grupos Experimental $1 \mathrm{e}$ Controle com as alterações anualizadas do Grupo Experimental 2, após a 
compatibilização dos grupos quanto à idade inicial, encontra-se disposta na TABELA 16.

As variáveis em destaque foram estatisticamente significantes para $\mathrm{p}<0,05$. 
TABELA 5 - Avaliação do erro intra-examinador. Resultados da avaliação do erro sistemático (teste t dependente) e do erro casual (Dahlberg).

\begin{tabular}{|c|c|c|c|c|c|c|}
\hline \multirow{2}{*}{ Variáveis } & \multicolumn{2}{|c|}{$\begin{array}{c}1 \text { Medição } \\
(n=30)\end{array}$} & \multicolumn{2}{|c|}{ 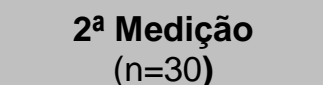 } & \multirow{2}{*}{$\begin{array}{c}\text { Dahlberg } \\
\text { (erro casual) }\end{array}$} & \multirow[b]{2}{*}{$\mathbf{p}$} \\
\hline & Média & D.P. & Média & D.P. & & \\
\hline \multicolumn{7}{|c|}{ Componente Maxilar } \\
\hline SNA () & 82,24 & 2,59 & 82,22 & 2,45 & 0,5618 & 0,8930 \\
\hline A-Nperp (mm) & 0,19 & 2,51 & 0,33 & 2,56 & 0,4370 & 0,2437 \\
\hline Co-A (mm) & 84,52 & 4,26 & 84,61 & 4,19 & 0,5984 & 0,5406 \\
\hline \multicolumn{7}{|c|}{ Componente Mandibular } \\
\hline SNB () & 77,73 & 3,05 & 77,60 & 3,01 & 0,4935 & 0,3156 \\
\hline Pog-Nperp (mm) & $-5,48$ & 4,86 & $-5,54$ & 5,22 & 0,8079 & 0,7790 \\
\hline Co-Gn (mm) & 104,09 & 4,44 & 104,10 & 4,34 & 0,4211 & 0,9048 \\
\hline Go-Gn (mm) & 69,07 & 3,65 & 69,07 & 3,64 & 0,8410 & 1,0000 \\
\hline Co-Go (mm) & 48,70 & 3,41 & 48,56 & 3,19 & 1,0002 & 0,5962 \\
\hline \multicolumn{7}{|c|}{ Relação Maxilomandibular } \\
\hline ANB ( $(\%)$ & 4,51 & 1,89 & 4,61 & 1,96 & 0,2699 & 0,1407 \\
\hline Wits (mm) & $-0,13$ & 2,05 & 0,18 & 2,10 & 0,7476 & 0,1093 \\
\hline $\operatorname{NAP}(\stackrel{\circ}{)}$ & 7,33 & 5,14 & 7,66 & 5,19 & 0,5820 & 0,0238 \\
\hline Co-A/Co-Gn (mm) & 81,19 & 2,45 & 81,35 & 2,40 & 0,3585 & 0,0771 \\
\hline \multicolumn{7}{|c|}{ Padrão de Crescimento } \\
\hline SN.GoGn (o) & 31,30 & 4,51 & 31,45 & 4,46 & 0,6086 & 0,3375 \\
\hline FMA (ㅇ) & 25,73 & 3,98 & 25,70 & 3,88 & 0,6436 & 0,8296 \\
\hline SN.PP ( $\left({ }^{\circ}\right)$ & 7,42 & 3,02 & 7,61 & 3,15 & 0,5520 & 0,1951 \\
\hline SN.POF () & 19,91 & 4,18 & 20,02 & 4,36 & 1,2571 & 0,7484 \\
\hline AFAl (mm) & 60,63 & 4,11 & 60,85 & 4,20 & 0,4997 & 0,0882 \\
\hline S-Go (mm) & 68,36 & 4,15 & 68,48 & 4,10 & 0,7391 & 0,5615 \\
\hline \multicolumn{7}{|c|}{ Componente dentoalveolar superior } \\
\hline 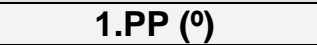 & 114,44 & 6,35 & 114,10 & 5,80 & 1,4373 & 0,3636 \\
\hline 1-ENAperp (mm) & $-3,41$ & 2,50 & $-3,11$ & 2,17 & 0,6828 & 0,0852 \\
\hline 1-PP $(\mathrm{mm})$ & 26,00 & 2,25 & 26,07 & 2,17 & 0,3168 & 0,3788 \\
\hline 6-PP (mm) & 20,10 & 2,36 & 20,14 & 2,23 & 0,4231 & 0,7659 \\
\hline 6-ENAperp (mm) & $-32,78$ & 2,42 & $-32,06$ & 2,29 & 1,0123 & 0,0041 \\
\hline 1.NA $\left({ }^{\circ}\right)$ & 24,79 & 6,80 & 24,28 & 6,69 & 1,4261 & 0,1727 \\
\hline 1-NA (mm) & 3,91 & 2,13 & 3,76 & 2,15 & 0,3793 & 0,1108 \\
\hline \multicolumn{7}{|c|}{ Componente dentoalveolar inferior } \\
\hline IMPA () & 95,29 & 5,23 & 94,73 & 6,15 & 1,5120 & 0,1572 \\
\hline 1-Pogperp (mm) & $-7,97$ & 1,82 & $-8,09$ & 1,97 & 0,4713 & 0,3190 \\
\hline 1-PM $(\mathrm{mm})$ & 36,95 & 2,38 & 37,20 & 2,50 & 0,3828 & 0,0111 \\
\hline 1.NB () & 26,66 & 5,48 & 26,11 & 6,05 & 1,4338 & 0,1350 \\
\hline 1-NB (mm) & 4,48 & 1,96 & 4,48 & 2,04 & 0,3452 & 0,9709 \\
\hline 6-Pogperp (mm) & $-30,35$ & 2,32 & $-30,10$ & 2,25 & 0,5342 & 0,0730 \\
\hline 6-PM $(\mathrm{mm})$ & 27,09 & 2,02 & 27,47 & 2,06 & 0,4031 & 0,0000 \\
\hline \multicolumn{7}{|c|}{ Relações dentárias } \\
\hline T.H. (mm) & 5,03 & 2,17 & 5,02 & 2,31 & 0,3207 & 0,9062 \\
\hline T.V. (mm) & 3,98 & 1,55 & 4,04 & 1,50 & 0,2843 & 0,3974 \\
\hline Rel. molar (mm) & 0,20 & 1,75 & 0,06 & 1,87 & 0,5495 & 0,3321 \\
\hline
\end{tabular}


TABELA 6 - Avaliação da compatibilidade entre os grupos considerando a idade inicial média ${ }^{\mathrm{ANOVA}}$, a distribuição por gêneros ${ }^{q}$, a severidade inicial da relação ântero-posterior dos arcos dentários - relação molar $^{q}$, relação dos caninos $^{q}$, e sobressaliência ${ }^{A N O V A}$. Avaliou-se também o tempo médio de avaliação e a idade final ${ }^{\text {ANOVA }}$.

$q$ - teste do qui-quadrado

\begin{tabular}{|c|c|c|c|c|}
\hline Variáveis & $\begin{array}{c}\text { Grupo } \\
\text { Experimental } 1 \\
(n=25)\end{array}$ & $\begin{array}{c}\text { Grupo } \\
\text { Experimental } 2 \\
(n=30)\end{array}$ & $\begin{array}{l}\text { Grupo } \\
\text { Controle } \\
(n=22)\end{array}$ & p \\
\hline $\begin{array}{l}\text { Idade Inicial } \\
\text { Média (D.P.) }\end{array}$ & $12,72(1,21)^{A}$ & $11,31(1,19)^{B}$ & $12,67(0,75)^{A}$ & 0,0000 \\
\hline $\begin{array}{l}\text { Gênero } \\
\text { Masculino } \\
\text { Feminino }\end{array}$ & $\begin{array}{l}13 \\
12 \\
\end{array}$ & $\begin{array}{l}16 \\
14\end{array}$ & $\begin{array}{l}12 \\
10 \\
\end{array}$ & $\begin{array}{c}0,9848^{9} \\
\chi^{2}=0,0306\end{array}$ \\
\hline $\begin{array}{l}\text { Relação molar } \\
\text { 1/4 Classe II } \\
\text { 1/2 Classe II } \\
\text { 3/4 Classe II } \\
\text { Classe II completa }\end{array}$ & $\begin{array}{c}0 \\
4 \\
9 \\
12 \\
\end{array}$ & $\begin{array}{c}0 \\
9 \\
9 \\
12 \\
\end{array}$ & $\begin{array}{c}4 \\
11 \\
4 \\
3 \\
\end{array}$ & $\begin{array}{c}0,0028^{q} \\
\chi^{2}=19,9793\end{array}$ \\
\hline $\begin{array}{l}\text { Relação dos caninos } \\
\text { 1/4 Classe II } \\
\text { 1/2 Classe II } \\
\text { 3/4 Classe II } \\
\text { Classe II completa } \\
\end{array}$ & $\begin{array}{c}0 \\
4 \\
17 \\
4 \\
\end{array}$ & $\begin{array}{c}1 \\
12 \\
13 \\
4 \\
\end{array}$ & $\begin{array}{c}2 \\
13 \\
6 \\
1 \\
\end{array}$ & $\begin{array}{c}0,0289^{q} \\
\chi^{2}=14,0649\end{array}$ \\
\hline $\begin{array}{l}\text { Sobressaliência } \\
\text { inicial (mm) } \\
\text { (Modelos de gesso) }\end{array}$ & $7,38(2,22)^{A, B}$ & $8,70(2,58)^{A}$ & $5,86(1,88)^{B}$ & 0,0002 \\
\hline $\begin{array}{l}\text { Tempo médio de } \\
\text { avaliação (anos) }\end{array}$ & $2,15(0,30)^{A}$ & $3,92(1,62)^{B}$ & $2,13(1,64)^{A}$ & 0,0000 \\
\hline $\begin{array}{l}\text { Idade Final } \\
\text { Média (D.P.) }\end{array}$ & $14,88(1,20)^{A}$ & $15,23(1,17)^{A}$ & $14,80(1,71)^{\mathrm{A}}$ & 0,4534 \\
\hline
\end{tabular}

* Letras diferentes representam diferença estatisticamente significante no teste de Tukey 
TABELA 7 - Avaliação da compatibilidade entre os grupos experimentais quanto à severidade inicial da relação ântero-posterior dos arcos dentários - relação molar ${ }^{q}$ e relação dos caninos ${ }^{q}$.

\begin{tabular}{|c|c|c|c}
\hline Variáveis & $\begin{array}{c}\text { Grupo } \\
\text { Experimental 1 } \\
(n=25)\end{array}$ & $\begin{array}{c}\text { Grupo } \\
\text { Experimental 2 } \\
(n=30)\end{array}$ & $\mathbf{p}$ \\
\hline Relação molar & 0 & 0 & \\
$\mathbf{1 / 4}$ Classe II & 4 & 9 & $0,4769^{9}$ \\
$\mathbf{1 / 2}$ Classe II & 9 & 9 & $\chi^{2}=1,4808$ \\
3/4 Classe II & 12 & 12 & \\
Classe II completa & 0 & 1 & $0,1631^{9}$ \\
\hline Relação dos caninos & 4 & 12 & $\chi^{2}=5,1211$ \\
$\mathbf{1 / 4}$ Classe II & 17 & 13 & \\
$\mathbf{1 / 2}$ Classe II & 4 & 4 & \\
3/4 Classe II & & & \\
Classe II completa & &
\end{tabular}

$q$ - teste do qui-quadrado 
TABELA 8 - Resultados da Análise de Variância (ANOVA) e do teste de comparações múltiplas de Tukey para avaliar a compatibilidade cefalométrica dos Grupos Experimentais 1 e 2 e Grupo Controle na fase inicial do tratamento (T1).

*Letras diferentes representam diferença estatisticamente significante no teste de Tukey

\begin{tabular}{|c|c|c|c|c|}
\hline \multirow[t]{2}{*}{ Variáveis } & $\begin{array}{c}\text { Grupo Experimental } 1 \\
(n=25)\end{array}$ & $\begin{array}{c}\text { Grupo Experimental } 2 \\
(\mathrm{n}=30)\end{array}$ & $\begin{array}{l}\text { Grupo Controle } \\
\qquad(n=22)\end{array}$ & \multirow{2}{*}{$\begin{array}{l}\text { ANOVA } \\
p\end{array}$} \\
\hline & Média (D.P.) & Média (D.P.) & Média (D.P.) & \\
\hline \multicolumn{5}{|c|}{ Componente Maxilar } \\
\hline SNA $\left({ }^{\circ}\right)$ & $82,58(3,38)^{A}$ & $82,15(2,92)^{A}$ & $81,65(3,29)^{A}$ & 0,6090 \\
\hline A-Nperp (mm) & $1,34(3,63)^{A}$ & $0,09(3,05)^{A}$ & $0,69(2,55)^{A}$ & 0,3375 \\
\hline Co-A $(\mathrm{mm})$ & $85,87(4,47)^{A}$ & $82,53(3,54)^{B}$ & $87,01(4,42)^{A}$ & 0,0005 \\
\hline \multicolumn{5}{|c|}{ Componente Mandibular } \\
\hline SNB () & $77,21(2,56)^{A}$ & $76,11(2,80)^{A}$ & $77,54(3,67)^{A}$ & 0,1940 \\
\hline Pog-Nperp (mm) & $-4,74(5,01)^{A, B}$ & $-7,76(5,54)^{A}$ & $-4,12(4,15)^{B}$ & 0,0206 \\
\hline Co-Gn $(\mathrm{mm})$ & $106,30(5,13)^{A}$ & $100,22(3,65)^{B}$ & $106,80(5,81)^{A}$ & 0,0000 \\
\hline Go-Gn $(\mathrm{mm})$ & $70,50(3,98)^{A}$ & $66,11(3,60)^{B}$ & $70,24(3,80)^{A}$ & 0,0000 \\
\hline Co-Go (mm) & $51,04(3,77)^{A}$ & $46,52(3,14)^{B}$ & $50,52(4,06)^{A}$ & 0,0000 \\
\hline \multicolumn{5}{|c|}{ Relação Maxilomandibular } \\
\hline$A N B(\stackrel{\circ}{)}$ & $5,38(2,87)^{A, B}$ & $6,04(2,09)^{A}$ & $4,11(1,83)^{B}$ & 0,0147 \\
\hline Wits $(\mathrm{mm})$ & $1,75(2,52)^{A}$ & $1,43(2,27)^{A, B}$ & $-0,16(2,58)^{B}$ & 0,0206 \\
\hline NAP () & $8,97(7,30)^{A}$ & $10,18(5,31)^{A}$ & $6,91(4,70)^{A}$ & 0,1469 \\
\hline Co-A/Co-Gn (mm) & $80,84(3,42)^{A}$ & $82,40(2,95)^{A}$ & $81,50(2,23)^{A}$ & 0,1457 \\
\hline \multicolumn{5}{|c|}{ Padrão de Crescimento } \\
\hline SN.GoGn () & $31,12(4,01)^{A}$ & $32,95(5,75)^{A}$ & $30,83(4,58)^{A}$ & 0,2321 \\
\hline FMA $(\stackrel{\circ}{\circ})$ & $24,72(3,85)^{A, B}$ & $27,13(4,77)^{A}$ & $24,17(2,83)^{B}$ & 0,0186 \\
\hline 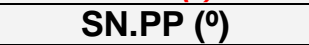 & $7,41(2,90)^{A}$ & $7,44(2,98)^{A}$ & $8,14(3,46)^{A}$ & 0,6624 \\
\hline SN.POF $(\stackrel{\circ}{)}$ & $18,90(3,99)^{\mathrm{A}}$ & $20,82(4,64)^{A}$ & $19,77(4,68)^{A}$ & 0,2867 \\
\hline AFAl $(\mathrm{mm})$ & $61,81(4,22)^{A}$ & $59,49(4,64)^{A}$ & $60,70(3,95)^{A}$ & 0,1459 \\
\hline S-Go $(\mathrm{mm})$ & $69,34(4,93)^{A}$ & $65,37(4,55)^{B}$ & $69,65(4,88)^{A}$ & 0,0019 \\
\hline \multicolumn{5}{|c|}{ Componente dentoalveolar superior } \\
\hline 1.PP $(\stackrel{\circ}{)}$ & $114,48(6,91)^{A}$ & $1119,28(6,96)^{B}$ & $113,11(6,06)^{A}$ & 0,0030 \\
\hline 1-ENAperp (mm) & $-1,85(2,64)^{A}$ & $-2,73(2,99)^{A}$ & $-3,56(2,56)^{A}$ & 0,1118 \\
\hline 1-PP $(\mathrm{mm})$ & $26,51(2,61)^{A}$ & $25,06(2,16)^{A}$ & $26,58(2,53)^{A}$ & 0,0367 \\
\hline 6-PP $(\mathrm{mm})$ & $20,95(2,12)^{A}$ & $19,50(1,90)^{B}$ & $20,57(2,06)^{A, B}$ & 0,0256 \\
\hline 6-ENAperp $(\mathrm{mm})$ & $-30,65(2,82)^{A}$ & $-32,98(2,89)^{B}$ & $-32,57(2,31)^{B}$ & 0,0060 \\
\hline 1.NA $(\stackrel{o}{)})$ & $24,49(7,30)^{A}$ & $29,69(7,03)^{B}$ & $23,30(6,02)^{A}$ & 0,0022 \\
\hline 1-NA (mm) & $4,64(2,57)^{A}$ & $4,95(2,40)^{A}$ & $3,46(1,76)^{A}$ & 0,0670 \\
\hline \multicolumn{5}{|c|}{ Componente dentoalveolar inferior } \\
\hline IMPA $(\stackrel{\circ}{)})$ & $97,88(7,52)^{A}$ & $92,62(7,39)^{B}$ & $94,95(4,71)^{A, B}$ & 0,0206 \\
\hline 1-Pogperp (mm) & $-7,62(2,80)^{A}$ & $-9,37(3,00)^{B}$ & $-8,23(1,99)^{A, B}$ & 0,0552 \\
\hline 1-PM $(\mathrm{mm})$ & $38,63(2,84)^{A}$ & $36,12(2,60)^{B}$ & $37,20(2,40)^{A, B}$ & 0,0031 \\
\hline 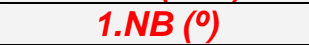 & $28,65(5,83)^{A}$ & $23,76(7,33)^{B}$ & $25,66(5,08)^{A, B}$ & 0,0196 \\
\hline 1-NB (mm) & $5,10(2,06)^{A}$ & $3,67(2,53)^{B}$ & $3,98(1,80)^{A, B}$ & 0,0511 \\
\hline 6-Pogperp (mm) & $-29,21(2,19)^{A}$ & $-29,88(1,98)^{A}$ & $-30,15(2,09)^{A}$ & 0,2768 \\
\hline 6-PM $(\mathrm{mm})$ & $27,91(2,31)^{A}$ & $25,76(1,93)^{B}$ & $27,45(2,10)^{A}$ & 0,0007 \\
\hline \multicolumn{5}{|c|}{ Relações dentárias } \\
\hline T.H. $(\mathrm{mm})$ & $6,24(2,21)^{A}$ & $8,42(2,93)^{B}$ & $4,70(1,60)^{A}$ & 0,0000 \\
\hline T.V. (mm) & $4,94(1,68)^{A}$ & $4,64(2,25)^{A}$ & $4,62(1,71)^{A}$ & 0,8011 \\
\hline Rel. molar (mm) & $-1,38(1,15)^{A}$ & $-0,98(1,22)^{A}$ & $0,69(1,23)^{B}$ & 0,0000 \\
\hline
\end{tabular}


TABELA 9 - Resultados da comparação das variáveis cefalométricas entre os três grupos estudados, na fase final do tratamento (T2), por meio da Análise de Variância (ANOVA) e do teste de comparações múltiplas de Tukey.

*Letras diferentes representam diferença estatisticamente significante no teste de Tukey

\begin{tabular}{|c|c|c|c|c|}
\hline \multirow[t]{2}{*}{ Variáveis } & $\begin{array}{l}\text { Grupo Experimental } 1 \\
(n=25)\end{array}$ & $\begin{array}{c}\text { Grupo Experimental } 2 \\
(n=30)\end{array}$ & $\begin{array}{l}\text { Grupo Controle } \\
\qquad(\mathrm{n}=22)\end{array}$ & \multirow{2}{*}{$\begin{array}{l}\text { ANOVA } \\
p\end{array}$} \\
\hline & Média (D.P.) & Média (D.P.) & Média (D.P.) & \\
\hline \multicolumn{5}{|c|}{ Componente Maxilar } \\
\hline SNA (ㅇ) & $81,35(3,27)^{A}$ & $81,30(2,92)^{A}$ & $82,55(3,66)^{A}$ & 0,3322 \\
\hline A-Nperp (mm) & $0,09(4,84)^{A}$ & $-0,30(3,25)^{A}$ & $2,22(3,15)^{A}$ & 0,0543 \\
\hline Co-A $(\mathrm{mm})$ & $86,48(4,94)^{A}$ & $86,07(4,29)^{A}$ & $89,64(3,63)^{B}$ & 0,0108 \\
\hline \multicolumn{5}{|c|}{ Componente Mandibular } \\
\hline SNB (ํ) & $77,30(2,43)^{A}$ & $77,54(3,29)^{A}$ & $78,16(4,04)^{A}$ & 0,6547 \\
\hline Pog-Nperp (mm) & $-4,84(6,38)^{A}$ & $-4,64(6,93)^{A}$ & $-1,73(5,79)^{A}$ & 0,1878 \\
\hline Co-Gn (mm) & $110,35(5,21)^{A}$ & $108,92(5,83)^{A}$ & $111,25(5,50)^{A}$ & 0,3156 \\
\hline Go-Gn (mm) & $73,37(3,90)^{A}$ & $71,21(4,78)^{A}$ & $73,02(4,15)^{A}$ & 0,1456 \\
\hline Co-Go (mm) & $53,48(4,40)^{A}$ & $51,17(5,06)^{A}$ & $53,40(3,46)^{A}$ & 0,0978 \\
\hline \multicolumn{5}{|c|}{ Relação Maxilomandibular } \\
\hline ANB () & $4,05(2,83)^{A}$ & $3,76(2,32)^{A}$ & $4,40(1,34)^{A}$ & 0,6054 \\
\hline Wits (mm) & $0,59(2,78)^{A}$ & $1,42(1,77)^{A}$ & $1,02(2,18)^{A}$ & 0,3996 \\
\hline NAP ( $(9)$ & $5,91(7,48)^{A}$ & $4,70(6,64)^{\mathrm{A}}$ & $7,12(3,76)^{A}$ & 0,3908 \\
\hline Co-A/Co-Gn (mm) & $78,39(3,57)^{A}$ & $79,09(2,86)^{A, B}$ & $80,64(2,26)^{B}$ & 0,0356 \\
\hline \multicolumn{5}{|c|}{ Padrão de Crescimento } \\
\hline SN.GoGn () & $31,69(4,35)^{A}$ & $32,37(6,38)^{A}$ & $30,40(5,17)^{A}$ & 0,4343 \\
\hline FMA (ㅇ) & $25,43(4,83)^{A}$ & $26,16(5,96)^{A}$ & $23,10(3,11)^{A}$ & 0,0828 \\
\hline SN.PP () & $7,79(3,01)^{A}$ & $8,08(3,16)^{A}$ & $8,50(3,41)^{A}$ & 0,7455 \\
\hline SN.POF (o) & $18,25(3,65)^{A}$ & $16,23(5,13)^{A}$ & $17,60(4,55)^{A}$ & 0,2433 \\
\hline AFAI (mm) & $65,44(4,58)^{\mathrm{A}}$ & $64,11(5,84)^{\mathrm{A}}$ & $62,77(4,77)^{A}$ & 0,2158 \\
\hline S-Go (mm) & $73,04(5,50)^{A}$ & $72,67(6,26)^{A}$ & $72,41(4,94)^{A}$ & 0,9286 \\
\hline \multicolumn{5}{|c|}{ Componente dentoalveolar superior } \\
\hline 1.PP $(\stackrel{\circ}{)}$ & $111,53(5,84)^{\mathrm{A}}$ & $114,08(6,43)^{A}$ & $113,27(6,36)^{A}$ & 0,3164 \\
\hline 1-ENAperp (mm) & $-3,87(2,39)^{A}$ & $-4,24(3,01)^{A}$ & $-2,62(2,29)^{A}$ & 0,0864 \\
\hline 1-PP $(\mathrm{mm})$ & $27,99(2,67)^{A}$ & $26,99(2,67)^{A}$ & $27,25(2,57)^{A}$ & 0,3686 \\
\hline 6-PP (mm) & $21,92(1,98)^{A}$ & $22,00(2,45)^{A}$ & $22,26(2,37)^{A}$ & 0,8706 \\
\hline 6-ENAperp (mm) & $-31,38(2,74)^{A}$ & $-31,74(3,09)^{A}$ & $-31,90(2,35)^{A}$ & 0,8028 \\
\hline 1.NA (o $)$ & $22,38(8,10)^{A}$ & $24,70(7,19)^{A}$ & $22,22(6,17)^{A}$ & 0,3691 \\
\hline 1-NA (mm) & $3,75(3,04)^{A}$ & $3,97(2,40)^{A}$ & $3,45(1,90)^{A}$ & 0,7590 \\
\hline \multicolumn{5}{|c|}{ Componente dentoalveolar inferior } \\
\hline IMPA $(\stackrel{\circ}{)}$ & $100,13(7,10)^{A}$ & $98,15(4,73)^{A, B}$ & $95,04(4,91)^{B}$ & 0,0110 \\
\hline 1-Pogperp (mm) & $-6,45(3,06)^{A}$ & $-8,60(2,83)^{B}$ & $-8,69(2,41)^{B}$ & 0,0080 \\
\hline 1-PM (mm) & $38,80(2,82)^{A}$ & $38,34(3,45)^{A}$ & $38,58(2,63)^{A}$ & 0,8549 \\
\hline $1 . N B(\stackrel{\circ}{)}$ & $31,57(5,63)^{A}$ & $30,27(5,92)^{A}$ & $25,94(5,49)^{B}$ & 0,0032 \\
\hline $1-N B(m m)$ & $6,66(2,55)^{A}$ & $5,81(2,31)^{A, B}$ & $4,39(2,08)^{B}$ & 0,0052 \\
\hline 6-Pogperp (mm) & $-28,38(2,55)^{A}$ & $-29,41(2,47)^{A, B}$ & $-30,45(2,30)^{B}$ & 0,0193 \\
\hline 6-PM $(\mathrm{mm})$ & $30,91(2,37)^{A}$ & $29,66(3,21)^{A, B}$ & $28,55(2,28)^{B}$ & 0,0145 \\
\hline \multicolumn{5}{|c|}{ Relacões dentárias } \\
\hline T.H. $(\mathrm{mm})$ & $2,51(0,41)^{A}$ & $3,10(0,97)^{A}$ & $4,86(1,71)^{B}$ & 0,0000 \\
\hline$T . V .(\mathrm{mm})$ & $2.10(0.77)^{A}$ & $2,37(1,09)^{A}$ & $4,36(1,69)^{B}$ & 0,0000 \\
\hline Rel. molar (mm) & $2,04(0,59)^{A}$ & $2,02(0,95)^{A}$ & $0,51(1,38)^{B}$ & 0,0000 \\
\hline
\end{tabular}


TABELA 10 - Resultados da comparação das variáveis cefalométricas entre as fases inicial e final do Grupo Experimental 1 (Jasper Jumper), por meio do teste t dependente.

\begin{tabular}{|c|c|c|c|c|c|}
\hline \multirow{2}{*}{ Variáveis } & \multicolumn{2}{|c|}{ Inicial (T1) } & \multicolumn{2}{|c|}{ Final (T2) } & \multirow[b]{2}{*}{$\mathbf{p}$} \\
\hline & Média & D.P. & Média & D.P. & \\
\hline \multicolumn{6}{|c|}{ Componente Maxilar } \\
\hline SNA $(\stackrel{\circ}{*})$ & 82,58 & 3,38 & 81,35 & 3,27 & 0,0070 \\
\hline$A-\operatorname{Nperp}(\mathrm{mm})$ & 1,34 & 3,63 & 0,09 & 4,84 & 0,0444 \\
\hline Co-A (mm) & 85,87 & 4,47 & 86,48 & 4,94 & 0,2131 \\
\hline \multicolumn{6}{|c|}{ Componente Mandibular } \\
\hline SNB () & 77,21 & 2,56 & 77,30 & 2,43 & 0,6378 \\
\hline Pog-Nperp (mm) & $-4,74$ & 5,01 & $-4,84$ & 6,38 & 0,9066 \\
\hline Co-Gn $(\mathrm{mm})$ & 106,30 & 5,13 & 110,35 & 5,21 & 0,0000 \\
\hline Go-Gn (mm) & 70,50 & 3,98 & 73,37 & 3,90 & 0,0000 \\
\hline Co-Go $(\mathrm{mm})$ & 51,04 & 3,77 & 53,48 & 4,40 & 0,0000 \\
\hline \multicolumn{6}{|c|}{ Relação Maxilomandibular } \\
\hline ANB ( $\left.{ }^{\circ}\right)$ & 5,38 & 2,87 & 4,05 & 2,83 & 0,0003 \\
\hline Wits $(\mathrm{mm})$ & 1,75 & 2,52 & 0,59 & 2,78 & 0,0185 \\
\hline$N A P(\stackrel{o}{)}$ & 8,97 & 7,30 & 5,91 & 7,48 & 0,0004 \\
\hline Co-A/Co-Gn (mm) & 80,84 & 3,42 & 78,39 & 3,57 & 0,0000 \\
\hline \multicolumn{6}{|c|}{ Padrão de Crescimento } \\
\hline SN.GoGn (ํ) & 31,12 & 4,01 & 31,69 & 4,35 & 0,0680 \\
\hline FMA (ㅇ) & 24,72 & 3,85 & 25,43 & 4,83 & 0,1720 \\
\hline SN.PP () & 7,41 & 2,90 & 7,79 & 3,01 & 0,2594 \\
\hline SN.POF ( $\left.{ }^{\circ}\right)$ & 18,90 & 3,99 & 18,25 & 3,65 & 0,2299 \\
\hline $\operatorname{AFAl}(\mathrm{mm})$ & 61,81 & 4,22 & 65,44 & 4,58 & 0,0000 \\
\hline S-Go $(\mathrm{mm})$ & 69,34 & 4,93 & 73,04 & 5,50 & 0,0000 \\
\hline \multicolumn{6}{|c|}{ Componente dentoalveolar superior } \\
\hline 1.PP $(\stackrel{\circ}{)})$ & 114,48 & 6,91 & 111,53 & 5,84 & 0,0705 \\
\hline 1-ENAperp $(\mathrm{mm})$ & $-1,85$ & 2,64 & $-3,87$ & 2,39 & 0,0002 \\
\hline $1-P P(\mathrm{~mm})$ & 26,51 & 2,61 & 27,99 & 2,67 & 0,0000 \\
\hline 6-PP $(\mathrm{mm})$ & 20,95 & 2,12 & 21,92 & 1,98 & 0,0007 \\
\hline 6-ENAperp (mm) & $-30,65$ & 2,82 & $-31,38$ & 2,74 & 0,0965 \\
\hline 1.NA ( $(\stackrel{)}{)}$ & 24,49 & 7,30 & 22,38 & 8,10 & 0,2251 \\
\hline 1-NA (mm) & 4,64 & 2,57 & 3,75 & 3,04 & 0,1310 \\
\hline \multicolumn{6}{|c|}{ Componente dentoalveolar inferior } \\
\hline IMPA (ํ) & 97,88 & 7,52 & 100,13 & 7,10 & 0,0626 \\
\hline 1-Pogperp (mm) & $-7,62$ & 2,80 & $-6,45$ & 3,06 & 0,0068 \\
\hline 1-PM (mm) & 38,63 & 2,84 & 38,80 & 2,82 & 0,5764 \\
\hline 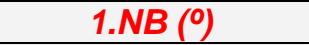 & 28,65 & 5,83 & 31,57 & 5,63 & 0,0129 \\
\hline $1-N B(m m)$ & 5,10 & 2,06 & 6,66 & 2,55 & 0,0000 \\
\hline 6-Pogperp (mm) & $-29,21$ & 2,19 & $-28,38$ & 2,55 & 0,0013 \\
\hline 6-PM $(\mathrm{mm})$ & 27,91 & 2,31 & 30,91 & 2,37 & 0,0000 \\
\hline \multicolumn{6}{|c|}{ Relações dentárias } \\
\hline T.H. $(\mathrm{mm})$ & 6,24 & 2,21 & 2,51 & 0,41 & 0,0000 \\
\hline$T . V .(\mathrm{mm})$ & 4,94 & 1,68 & 2,10 & 0,77 & 0,0000 \\
\hline Rel. molar (mm) & $-1,38$ & 1,15 & 2,04 & 0,59 & 0,0000 \\
\hline
\end{tabular}


TABELA 11 - Resultados da comparação das variáveis cefalométricas entre as fases inicial e final do Grupo Experimental 2 (Bionator), por meio do teste $t$ dependente.

\begin{tabular}{|c|c|c|c|c|c|}
\hline \multirow{2}{*}{ Variáveis } & \multicolumn{2}{|c|}{ Inicial (T1) } & \multicolumn{2}{|c|}{ Final (T2) } & \multirow[b]{2}{*}{$\mathbf{p}$} \\
\hline & Média & D.P. & Média & D.P. & \\
\hline \multicolumn{6}{|c|}{ Componente Maxilar } \\
\hline SNA $(\stackrel{\circ}{)}$ & 82,15 & 2,92 & 81,30 & 2,92 & 0,0097 \\
\hline A-Nperp (mm) & 0,09 & 3,05 & $-0,30$ & 3,25 & 0,2523 \\
\hline $\mathrm{Co}-A(\mathrm{~mm})$ & 82,53 & 3,54 & 86,07 & 4,29 & 0,0000 \\
\hline \multicolumn{6}{|c|}{ Componente Mandibular } \\
\hline SNB $\left(^{\circ}\right)$ & 76,11 & 2,80 & 77,54 & 3,29 & 0,0003 \\
\hline Pog-Nperp (mm) & $-7,76$ & 5,54 & $-4,64$ & 6,93 & 0,0001 \\
\hline Co-Gn $(\mathrm{mm})$ & 100,22 & 3,65 & 108,92 & 5,83 & 0,0000 \\
\hline Go-Gn (mm) & 66,11 & 3,60 & 71,21 & 4,78 & 0,0000 \\
\hline Co-Go $(\mathrm{mm})$ & 46,52 & 3,14 & 51,17 & 5,06 & 0,0000 \\
\hline \multicolumn{6}{|c|}{ Relação Maxilomandibular } \\
\hline$A N B\left({ }^{\circ}\right)$ & 6,04 & 2,09 & 3,76 & 2,32 & 0,0000 \\
\hline Wits (mm) & 1,43 & 2,27 & 1,42 & 1,77 & 0,9936 \\
\hline$N A P(\stackrel{o}{)}$ & 10,18 & 5,31 & 4,70 & 6,64 & 0,0000 \\
\hline Co-A/Co-Gn (mm) & 82,40 & 2,95 & 79,09 & 2,86 & 0,0000 \\
\hline \multicolumn{6}{|c|}{ Padrão de Crescimento } \\
\hline SN.GoGn (ํ) & 32,95 & 5,75 & 32,37 & 6,38 & 0,2065 \\
\hline FMA (o $)$ & 27,13 & 4,77 & 26,16 & 5,96 & 0,0269 \\
\hline SN.PP (ํ) & 7,44 & 2,98 & 8,08 & 3,16 & 0,1002 \\
\hline SN.POF $(\stackrel{\circ}{)})$ & 20,82 & 4,64 & 16,23 & 5,13 & 0,0000 \\
\hline $\operatorname{AFAl}(\mathrm{mm})$ & 59,49 & 4,64 & 64,11 & 5,84 & 0,0000 \\
\hline S-Go $(\mathrm{mm})$ & 65,37 & 4,55 & 72,67 & 6,26 & 0,0000 \\
\hline \multicolumn{6}{|c|}{ Componente dentoalveolar superior } \\
\hline $1 . P P(\stackrel{o}{)}$ & 119,28 & 6,96 & 114,08 & 6,43 & 0,0002 \\
\hline 1-ENAperp $(\mathrm{mm})$ & $-2,73$ & 2,99 & $-4,24$ & 3,01 & 0,0078 \\
\hline $1-P P(\mathrm{~mm})$ & 25,06 & 2,16 & 26,99 & 2,67 & 0,0000 \\
\hline 6-PP $(\mathrm{mm})$ & 19,50 & 1,90 & 22,00 & 2,45 & 0,0000 \\
\hline 6-ENAperp ( $\mathrm{mm})$ & $-32,98$ & 2,89 & $-31,74$ & 3,09 & 0,0220 \\
\hline 1.NA $(\stackrel{\circ}{)})$ & 29,69 & 7,03 & 24,70 & 7,19 & 0,0006 \\
\hline 1-NA (mm) & 4,95 & 2,40 & 3,97 & 2,40 & 0,0304 \\
\hline \multicolumn{6}{|c|}{ Componente dentoalveolar inferior } \\
\hline IMPA $(\stackrel{\circ}{)})$ & 92,62 & 7,39 & 98,15 & 4,73 & 0,0011 \\
\hline 1-Pogperp (mm) & $-9,37$ & 3,00 & $-8,60$ & 2,83 & 0,2599 \\
\hline 1-PM $(\mathrm{mm})$ & 36,12 & 2,60 & 38,34 & 3,45 & 0,0000 \\
\hline 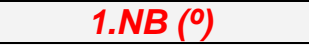 & 23,76 & 7,33 & 30,27 & 5,92 & 0,0004 \\
\hline $1-\mathrm{NB}(\mathrm{mm})$ & 3,67 & 2,53 & 5,81 & 2,31 & 0,0000 \\
\hline 6-Pogperp (mm) & $-29,88$ & 1,98 & $-29,41$ & 2,47 & 0,1408 \\
\hline 6-PM $(\mathrm{mm})$ & 25,76 & 1,93 & 29,66 & 3,21 & 0,0000 \\
\hline \multicolumn{6}{|c|}{ Relações dentárias } \\
\hline T.H. $(\mathrm{mm})$ & 8,42 & 2,93 & 3,10 & 0,97 & 0,0000 \\
\hline$T . V .(\mathrm{mm})$ & 4,64 & 2,25 & 2,37 & 1,09 & 0,0000 \\
\hline Rel. molar (mm) & $-0,98$ & 1,22 & 2,02 & 0,95 & 0,0000 \\
\hline
\end{tabular}


TABELA 12 - Resultados da comparação das variáveis cefalométricas entre as fases inicial e final do Grupo Controle, por meio do teste $t$ dependente.

\begin{tabular}{|c|c|c|c|c|c|}
\hline \multirow{2}{*}{ Variáveis } & \multicolumn{2}{|c|}{ Inicial (T1) } & \multicolumn{2}{|c|}{ Final (T2) } & \multirow[b]{2}{*}{$\mathbf{p}$} \\
\hline & Média & D.P. & Média & D.P. & \\
\hline \multicolumn{6}{|c|}{ Componente Maxilar } \\
\hline SNA () & 81,65 & 3,29 & 82,55 & 3,66 & 0,1156 \\
\hline$A-\operatorname{Nperp}(\mathrm{mm})$ & 0,69 & 2,55 & 2,22 & 3,15 & 0,0268 \\
\hline Co-A $(\mathrm{mm})$ & 87,01 & 4,42 & 89,64 & 3,63 & 0,0006 \\
\hline \multicolumn{6}{|c|}{ Componente Mandibular } \\
\hline SNB () & 77,54 & 3,67 & 78,16 & 4,04 & 0,1732 \\
\hline Pog-Nperp (mm) & $-4,12$ & 4,15 & $-1,73$ & 5,79 & 0,0251 \\
\hline Co-Gn $(\mathrm{mm})$ & 106,80 & 5,81 & 111,25 & 5,50 & 0,0001 \\
\hline Go-Gn (mm) & 70,24 & 3,80 & 73,02 & 4,15 & 0,0000 \\
\hline Co-Go $(\mathrm{mm})$ & 50,52 & 4,06 & 53,40 & 3,46 & 0,0017 \\
\hline \multicolumn{6}{|c|}{ Relação Maxilomandibular } \\
\hline ANB () & 4,11 & 1,83 & 4,40 & 1,34 & 0,2789 \\
\hline Wits $(\mathrm{mm})$ & $-0,16$ & 2,58 & 1,02 & 2,18 & 0,0103 \\
\hline NAP () & 6,91 & 4,70 & 7,12 & 3,76 & 0,7103 \\
\hline Co-A/Co-Gn (mm) & 81,50 & 2,23 & 80,64 & 2,26 & 0,0303 \\
\hline \multicolumn{6}{|c|}{ Padrão de Crescimento } \\
\hline SN.GoGn (ํ) & 30,83 & 4,58 & 30,40 & 5,17 & 0,2511 \\
\hline FMA $(\stackrel{o}{*})$ & 24,17 & 2,83 & 23,10 & 3,11 & 0,0207 \\
\hline SN.PP (ํ) & 8,14 & 3,46 & 8,50 & 3,41 & 0,3072 \\
\hline SN.POF $(\stackrel{\circ}{*})$ & 19,77 & 4,68 & 17,60 & 4,55 & 0,0033 \\
\hline $\operatorname{AFAl}(\mathrm{mm})$ & 60,70 & 3,95 & 62,77 & 4,77 & 0,0030 \\
\hline S-Go $(\mathrm{mm})$ & 69,65 & 4,88 & 72,41 & 4,94 & 0,0016 \\
\hline \multicolumn{6}{|c|}{ Componente dentoalveolar superior } \\
\hline 1.PP $(\stackrel{\circ}{)})$ & 113,11 & 6,06 & 113,27 & 6,36 & 0,7516 \\
\hline 1-ENAperp $(\mathrm{mm})$ & $-3,56$ & 2,56 & $-2,62$ & 2,29 & 0,0357 \\
\hline $1-P P(\mathrm{~mm})$ & 26,58 & 2,53 & 27,25 & 2,57 & 0,0040 \\
\hline 6-PP $(\mathrm{mm})$ & 20,57 & 2,06 & 22,26 & 2,37 & 0,0000 \\
\hline 6-ENAperp (mm) & $-32,57$ & 2,31 & $-31,90$ & 2,35 & 0,0872 \\
\hline 1.NA (o $)$ & 23,30 & 6,02 & 22,22 & 6,17 & 0,0372 \\
\hline 1-NA (mm) & 3,46 & 1,76 & 3,45 & 1,90 & 0,9629 \\
\hline \multicolumn{6}{|c|}{ Componente dentoalveolar inferior } \\
\hline IMPA () & 94,95 & 4,71 & 95,04 & 4,91 & 0,9151 \\
\hline 1-Pogperp (mm) & $-8,23$ & 1,99 & $-8,69$ & 2,41 & 0,1229 \\
\hline 1-PM $(\mathrm{mm})$ & 37,20 & 2,40 & 38,58 & 2,63 & 0,0063 \\
\hline 1. NB $\left({ }^{\circ}\right)$ & 25,66 & 5,08 & 25,94 & 5,49 & 0,7597 \\
\hline $1-\mathrm{NB}(\mathrm{mm})$ & 3,98 & 1,80 & 4,39 & 2,08 & 0,2340 \\
\hline 6-Pogperp (mm) & $-30,15$ & 2,09 & $-30,45$ & 2,30 & 0,2929 \\
\hline 6-PM $(\mathrm{mm})$ & 27,45 & 2,10 & 28,55 & 2,28 & 0,0149 \\
\hline \multicolumn{6}{|c|}{ Relações dentárias } \\
\hline T.H. (mm) & 4,70 & 1,60 & 4,86 & 1,71 & 0,5427 \\
\hline T.V. (mm) & 4,62 & 1,71 & 4,36 & 1,69 & 0,5775 \\
\hline Rel. molar (mm) & 0,69 & 1,23 & 0,51 & 1,38 & 0,5178 \\
\hline
\end{tabular}


TABELA 13 - Resultados da comparação das alterações das variáveis cefalométricas dos Grupos Experimental 1 e Controle e das alterações anualizadas do Grupo Experimental 2, por meio da Análise de Variância (ANOVA) e do teste de comparações múltiplas de Tukey.

*Letras diferentes representam diferença estatisticamente significante no teste de Tukey

\begin{tabular}{|c|c|c|c|c|}
\hline \multirow[t]{2}{*}{ Variáveis } & $\begin{array}{c}\text { Grupo Experimental } 1 \\
(n=25)\end{array}$ & $\begin{array}{c}\text { Grupo Experimental } 2 \\
(n=30)\end{array}$ & $\begin{array}{l}\text { Grupo Controle } \\
\qquad(n=22)\end{array}$ & \multirow{2}{*}{$\begin{array}{c}\text { ANOVA } \\
p\end{array}$} \\
\hline & Média (D.P.) & Média (D.P.) & Média (D.P.) & \\
\hline \multicolumn{5}{|c|}{ Componente Maxilar } \\
\hline SNA (ㅇ) & $-1,23(2,09)^{A}$ & $-0,64(1,26)^{A}$ & $0,90(2,56)^{B}$ & 0,0014 \\
\hline A-Nperp (mm) & $-1,26(2,96)^{A}$ & $-0,27(1,21)^{A}$ & $1,53(3,01)^{B}$ & 0,0009 \\
\hline Co-A $(\mathrm{mm})$ & $0,61(2,39)^{A}$ & $1,91(1,59)^{A, B}$ & $2,63(3,07)^{B}$ & 0,0141 \\
\hline \multicolumn{5}{|c|}{ Componente Mandibular } \\
\hline SNB () & $0,09(0,96)^{A}$ & $0,85(0,95)^{A}$ & $0,62(2,07)^{A}$ & 0,1261 \\
\hline Pog-Nperp (mm) & $-0,10(4,22)^{A}$ & $1,89(2,50)^{A}$ & $2,39(4,65)^{A}$ & 0,0579 \\
\hline Co-Gn (mm) & $4,05(2,81)^{A}$ & $5,01(2,66)^{A}$ & $4,45(4,39)^{A}$ & 0,5536 \\
\hline Go-Gn (mm) & $2,87(2,42)^{A}$ & $2,69(1,60)^{A}$ & $2,79(2,26)^{A}$ & 0,9508 \\
\hline Co-Go (mm) & $2,44(2,28)^{A}$ & $2,91(2,49)^{A}$ & $2,88(3,75)^{A}$ & 0,8066 \\
\hline \multicolumn{5}{|c|}{ Relação Maxilomandibular } \\
\hline$A N B\left({ }^{\circ}\right)$ & $-1,32(1,58)^{A}$ & $-1,49(1,34)^{A}$ & $0,29(1,21)^{B}$ & 0,0000 \\
\hline Wits $(\mathrm{mm})$ & $-1,16(2,29)^{A}$ & $-0,12(1,58)^{A}$ & $1,18(1,97)^{B}$ & 0,0005 \\
\hline $\operatorname{NAP}(\stackrel{o}{)}$ & $-3,06(3,69)^{A}$ & $-3,38(3,02)^{A}$ & $0,21(2,66)^{B}$ & 0,0002 \\
\hline Co-A/Co-Gn ( $\mathrm{mm})$ & $-2,44(2,02)^{A}$ & $-2,05(1,72)^{A, B}$ & $-0,86(1,74)^{B}$ & 0,0120 \\
\hline \multicolumn{5}{|c|}{ Padrão de Crescimento } \\
\hline SN.GoGn () & $0,57(1,50)^{A}$ & $-0,28(1,36)^{A}$ & $-0,43(1,72)^{A}$ & 0,0483 \\
\hline FMA ( $(\stackrel{)}{)}$ & $0,72(2,54)^{A}$ & $-0,58(1,35)^{B}$ & $-1,07(2,01)^{B}$ & 0,0076 \\
\hline SN.PP ( $\stackrel{9}{ })$ & $0,38(1,64)^{A}$ & $0,62(1,41)^{A}$ & $0,37(1,65)^{A}$ & 0,7970 \\
\hline SN.POF $(\stackrel{\circ}{*})$ & $-0,65(2,65)^{A}$ & $-2,53(2,41)^{B}$ & $-2,17(3,07)^{A, B}$ & 0,0322 \\
\hline AFAl $(\mathrm{mm})$ & $3,63(2,03)^{A}$ & $2,49(1,24)^{A, B}$ & $2,06(2,88)^{B}$ & 0,0302 \\
\hline S-Go $(\mathrm{mm})$ & $3,70(2,36)^{A}$ & $4,32(2,00)^{A}$ & $2,75(3,58)^{A}$ & 0,1154 \\
\hline \multicolumn{5}{|c|}{ Componente dentoalveolar superior } \\
\hline 1.PP (ㅇ) & $-2,95(7,79)^{\AA}$ & $-3,67(6,02)^{A}$ & $0,15(2,26)^{A}$ & 0,0657 \\
\hline 1-ENAperp $(\mathrm{mm})$ & $-2,02(2,27)^{A}$ & $-0,90(1,57)^{A}$ & $0,94(1,97)^{B}$ & 0,0000 \\
\hline 1-PP $(\mathrm{mm})$ & $1,48(1,21)^{A}$ & $1,05(1,06)^{A, B}$ & $0,67(0,98)^{B}$ & 0,0455 \\
\hline 6-PP $(\mathrm{mm})$ & $0,97(1,24)^{A}$ & $1,28(0,96)^{A}$ & $1,69(1,30)^{A}$ & 0,1121 \\
\hline 6-ENAperp $(\mathrm{mm})$ & $-0,73(2,12)^{A}$ & $0,61(1,48)^{B}$ & $0,67(1,75)^{B}$ & 0,0093 \\
\hline 1.NA $\left({ }^{\circ}\right)$ & $-2,11(8,48)^{A}$ & $-3,64(6,04)^{A}$ & $-1,08(2,28)^{A}$ & 0,3352 \\
\hline 1-NA (mm) & $-0,88(2,83)^{A}$ & $-0,83(1,61)^{A}$ & $-0,01(1,36)^{A}$ & 0,2668 \\
\hline \multicolumn{5}{|c|}{ Componente dentoalveolar inferior } \\
\hline IMPA $(\stackrel{\circ}{)}$ & $2,26(5,78)^{A, B}$ & $4,90(9,53)^{A}$ & $0,08(3,56)^{B}$ & 0,0551 \\
\hline 1-Pogperp (mm) & $1,17(1,98)^{A}$ & $1,16(3,46)^{A}$ & $-0,46(1,34)^{A}$ & 0,0466 \\
\hline 1-PM $(\mathrm{mm})$ & $0,16(1,45)^{A}$ & $1,06(1,03)^{A, B}$ & $1,38(2,14)^{B}$ & 0,0216 \\
\hline $1 . N B(\stackrel{o}{)}$ & $2,92(5,44)^{A, B}$ & $5,55(10,11)^{A}$ & $0,28(4,27)^{B}$ & 0,0450 \\
\hline $1-\mathrm{NB}(\mathrm{mm})$ & $1,56(1,39)^{A}$ & $1,63(2,29)^{A}$ & $0,41(1,57)^{A}$ & 0,0420 \\
\hline 6-Pogperp $(\mathrm{mm})$ & $0,82(1,13)^{A}$ & $0,37(1,00)^{A, B}$ & $-0,30(1,32)^{B}$ & 0,0048 \\
\hline 6-PM $(\mathrm{mm})$ & $3,00(1,14)^{A}$ & $2,29(1,06)^{A}$ & $1,09(1,93)^{B}$ & 0,0001 \\
\hline \multicolumn{5}{|c|}{ Relações dentárias } \\
\hline T.H. (mm) & $-3,73(2,29)^{A}$ & $-3,89(4,16)^{A}$ & $0,16(1,24)^{B}$ & 0,0000 \\
\hline T.V. $(\mathrm{mm})$ & $-2,84(1,36)^{A}$ & $-1,77(2,05)^{A}$ & $-0,25(2,11)^{B}$ & 0,0001 \\
\hline Rel. molar (mm) & $3,42(1,16)^{A}$ & $2,19(1,83)^{B}$ & $-0,18(1,30)^{c}$ & 0,0000 \\
\hline
\end{tabular}


TABELA 14 - Comparação da idade inicial médiaANOVA da distribuição por gêneros $q$, da severidade inicial da relação ântero-posterior dos arcos dentários - relação molar ${ }^{q}$, relação dos caninos ${ }^{q}$, e sobressaliênciaANOVA, do tempo médio de avaliação e idade final $^{\mathrm{ANOVA}}$, após a compatibilização dos grupos em relação à idade inicial.

\begin{tabular}{|c|c|c|c|c|}
\hline Variáveis & $\begin{array}{c}\text { Grupo } \\
\text { Experimental } 1 \\
(n=18)\end{array}$ & $\begin{array}{c}\text { Grupo } \\
\text { Experimental } 2 \\
(n=18)\end{array}$ & $\begin{array}{c}\text { Grupo } \\
\text { Controle } \\
(n=18)\end{array}$ & p \\
\hline $\begin{array}{l}\text { Idade Inicial } \\
\text { Média (D.P.) }\end{array}$ & $12,18(0,93)^{A}$ & $12,07(0,83)^{\mathrm{A}}$ & $12,41(0,55)^{\mathrm{A}}$ & 0,4195 \\
\hline $\begin{array}{l}\text { Gênero } \\
\text { Masculino } \\
\text { Feminino }\end{array}$ & $\begin{array}{l}9 \\
9\end{array}$ & $\begin{array}{c}10 \\
8\end{array}$ & $\begin{array}{l}9 \\
9\end{array}$ & $\begin{array}{r}0,1484^{9} \\
\chi^{2}=0,9285\end{array}$ \\
\hline $\begin{array}{l}\text { Relação molar } \\
\text { 1/4 Classe II } \\
\text { 1/2 Classe II } \\
3 / 4 \text { Classe II } \\
\text { Classe II completa }\end{array}$ & $\begin{array}{l}0 \\
3 \\
6 \\
9\end{array}$ & $\begin{array}{l}0 \\
6 \\
6 \\
6\end{array}$ & $\begin{array}{l}3 \\
8 \\
4 \\
3\end{array}$ & $\begin{array}{c}0,0681^{q} \\
\chi^{2}=11,7353\end{array}$ \\
\hline $\begin{array}{l}\text { Relação dos caninos } \\
\text { 1/4 Classe II } \\
\text { 1/2 Classe II } \\
\text { 3/4 Classe II } \\
\text { Classe II completa }\end{array}$ & $\begin{array}{c}0 \\
3 \\
13 \\
2 \\
\end{array}$ & $\begin{array}{l}0 \\
8 \\
8 \\
2 \\
\end{array}$ & $\begin{array}{c}1 \\
10 \\
6 \\
1 \\
\end{array}$ & $\begin{array}{c}0,1734^{9} \\
\chi^{2}=9,0032\end{array}$ \\
\hline $\begin{array}{l}\text { Sobressaliência } \\
\text { inicial (mm) } \\
\text { (Modelos de gesso) }\end{array}$ & $7,53(2,33)^{A, B}$ & $8,39(2,75)^{A}$ & $6,14(1,98)^{B}$ & 0,0220 \\
\hline $\begin{array}{l}\text { Tempo médio de } \\
\text { avaliação (anos) }\end{array}$ & $2,13(0,34)^{A}$ & $3,15(1,22)^{B}$ & $2,34(1,73)^{A, B}$ & 0,0400 \\
\hline $\begin{array}{l}\text { Idade Final } \\
\text { Média (D.P.) }\end{array}$ & $14,31(0,89)^{A}$ & $15,23(1,18)^{A}$ & $14,75(1,87)^{\mathrm{A}}$ & 0,1465 \\
\hline
\end{tabular}

$q$ - teste do qui-quadrado

*Letras diferentes representam diferença estatisticamente significante no teste de Tukey 
TABELA 15 - Resultados da Análise de Variância (ANOVA) e do teste de comparações múltiplas de Tukey para comparar as variáveis cefalométricas entre os Grupos Experimentais 1 e 2 e Grupo Controle na fase inicial (T1), após a compatibilização dos mesmos em relação à idade inicial.

\begin{tabular}{|c|c|c|c|c|}
\hline \multirow[t]{2}{*}{ Variáveis } & $\begin{array}{l}\text { Grupo Experimental } 1 \\
(n=18)\end{array}$ & $\begin{array}{c}\text { Grupo Experimental } 2 \\
(n=18)\end{array}$ & $\begin{array}{l}\text { Grupo Controle } \\
\qquad(n=18)\end{array}$ & \multirow{2}{*}{$\begin{array}{l}\text { ANOVA } \\
p\end{array}$} \\
\hline & Média (D.P.) & Média (D.P.) & Média (D.P.) & \\
\hline \multicolumn{5}{|c|}{ Componente Maxilar } \\
\hline SNA () & $82,64(3,16)^{A}$ & $82,00(3,19)^{A}$ & $81,86(3,58)^{A}$ & 0,7522 \\
\hline A-Nperp (mm) & $1,98(3,36)^{A}$ & $0,66(3,15)^{A}$ & $0,75(2,73)^{A}$ & 0,3627 \\
\hline Co-A $(\mathrm{mm})$ & $85,37(4,24)^{A, B}$ & $83,22(3,77)^{A}$ & $86,81(4,60)^{B}$ & 0,0446 \\
\hline \multicolumn{5}{|c|}{ Componente Mandibular } \\
\hline SNB (ㅇ) & $77,08(2,23)^{A}$ & $76,15(3,02)^{A}$ & $77,57(3,99)^{A}$ & 0,4010 \\
\hline Pog-Nperp (mm) & $-4,14(4,81)^{A}$ & $-6,33(5,44)^{A}$ & $-4,28(4,43)^{A}$ & 0,3344 \\
\hline Co-Gn (mm) & $105,19(4,94)^{A, B}$ & $101,49(3,64)^{A}$ & $106,72(6,34)^{B}$ & 0,0103 \\
\hline Go-Gn (mm) & $69,54(3,78)^{A}$ & $67,33(2,98)^{A}$ & $70,19(4,13)^{A}$ & 0,0576 \\
\hline Co-Go $(\mathrm{mm})$ & $50,68(3,78)^{A}$ & $47,33(3,02)^{B}$ & $50,52(3,97)^{A}$ & 0,0111 \\
\hline \multicolumn{5}{|c|}{ Relação Maxilomandibular } \\
\hline ANB (ㅇ) & $5,58(2,50)^{A}$ & $5,85(2,39)^{A}$ & $4,29(1,89)^{A}$ & 0,1002 \\
\hline Wits (mm) & $1,57(2,40)^{A}$ & $1,65(2,55)^{A}$ & $-0,14(2,71)^{A}$ & 0,0689 \\
\hline NAP $(\stackrel{\circ}{)}$ & $9,83(6,55)^{A}$ & $9,69(5,83)^{A}$ & $7,24(4,62)^{A}$ & 0,3213 \\
\hline Co-A/Co-Gn (mm) & $81,20(3,27)^{A}$ & $82,06(3,34)^{A}$ & $81,38(1,83)^{A}$ & 0,6488 \\
\hline \multicolumn{5}{|c|}{ Padrão de Crescimento } \\
\hline SN.GoGn () & $31,44(3,69)^{A}$ & $32,55(5,94)^{A}$ & $31,05(4,79)^{A}$ & 0,6368 \\
\hline FMA () & $24,37(3,85)^{A}$ & $26,04(4,66)^{A}$ & $24,55(2,75)^{A}$ & 0,3665 \\
\hline SN.PP (ํ) & $7,32(2,70)^{A}$ & $7,87(3,03)^{A}$ & $7,94(3,49)^{A}$ & 0,8031 \\
\hline SN.POF () & $19,69(2,77)^{A}$ & $20,31(4,61)^{A}$ & $20,01(5,03)^{A}$ & 0,9099 \\
\hline $\operatorname{AFAI}(\mathbf{m m})$ & $61,52(4,20)^{A}$ & $59,43(4,05)^{A}$ & $60,99(3,86)^{A}$ & 0,2834 \\
\hline S-Go (mm) & $68,58(4,84)^{A}$ & $66,47(4,98)^{A}$ & $69,60(5,08)^{A}$ & 0,1664 \\
\hline \multicolumn{5}{|c|}{ Componente dentoalveolar superior } \\
\hline 1.PP (ㅇ) & $114,63(6,81)^{A}$ & $117,97(8,01)^{A}$ & $113,09(6,37)^{A}$ & 0,1183 \\
\hline 1-ENAperp (mm) & $-2,24(2,50)^{A}$ & $-2,42(2,95)^{A}$ & $-3,64(2,73)^{A}$ & 0,2559 \\
\hline 1-PP $(\mathrm{mm})$ & $26,51(2,46)^{A}$ & $25,34(1,83)^{A}$ & $26,73(2,39)^{A}$ & 0,1486 \\
\hline 6-PP $(\mathrm{mm})$ & $20,87(2,25)^{A}$ & $20,01(1,80)^{A}$ & $20,59(2,26)^{A}$ & 0,4630 \\
\hline 6-ENAperp (mm) & $-30,94(2,32)^{A}$ & $-32,17(2,47)^{A}$ & $-32,53(2,37)^{A}$ & 0,1218 \\
\hline 1.NA $(\stackrel{\circ}{)})$ & $24,67(6,73)^{A}$ & $28,09(8,25)^{A}$ & $23,26(6,53)^{A}$ & 0,1282 \\
\hline 1-NA (mm) & $4,53(2,12)^{A}$ & $4,71(2,68)^{A}$ & $3,49(1,83)^{A}$ & 0,2229 \\
\hline \multicolumn{5}{|c|}{ Componente dentoalveolar inferior } \\
\hline IMPA (ํ) & $98,33(8,26)^{A}$ & $92,07(8,36)^{B}$ & $94,92(5,15)^{A, B}$ & 0,0478 \\
\hline 1-Pogperp (mm) & $-7,36(2,79)^{A}$ & $-9,89(3,20)^{B}$ & $-8,26(2,09)^{A, B}$ & 0,0253 \\
\hline 1-PM (mm) & $38,03(2,75)^{A}$ & $36,17(2,61)^{A}$ & $37,21(2,59)^{A}$ & 0,1161 \\
\hline 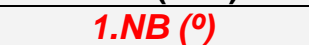 & $29,26(5,95)^{A}$ & $22,91(8,62)^{B}$ & $25,89(5,47)^{A, B}$ & 0,0265 \\
\hline $1-\mathrm{NB}(\mathrm{mm})$ & $5,02(1,82)^{A}$ & $3,21(2,75)^{B}$ & $4,19(1,84)^{A, B}$ & 0,0527 \\
\hline 6-Pogperp (mm) & $-28,93(2,20)^{A}$ & $-30,06(2,20)^{A}$ & $-30,12(2,24)^{A}$ & 0,2019 \\
\hline 6-PM (mm) & $27,43(2,24)^{A}$ & $25,94(2,05)^{A}$ & $27,49(2,20)^{A}$ & 0,0614 \\
\hline \multicolumn{5}{|c|}{ Relações dentárias } \\
\hline T.H. $(\mathrm{mm})$ & $6,45(2,26)^{A}$ & $8,55(3,27)^{B}$ & $4,76(1,75)^{A}$ & 0,0002 \\
\hline T.V. $(\mathrm{mm})$ & $4,72(1,73)^{A}$ & $4,92(2,37)^{A}$ & $4,52(1,87)^{A}$ & 0,8334 \\
\hline Rel. molar (mm) & $-1,51(1,22)^{A}$ & $-1,25(1,27)^{A}$ & $0,56(1,29)^{B}$ & 0,0000 \\
\hline
\end{tabular}

${ }^{*}$ Letras diferentes representam diferença estatisticamente significante no teste de Tukey 
TABELA 16 - Comparação das alterações das variáveis cefalométricas dos Grupos Experimental 1 e Controle e das alterações anualizadas do Grupo Experimental 2, por meio da Análise de Variância e do teste de comparações múltiplas de Tukey, após a compatibilização dos grupos quanto à idade inicial.

*Letras diferentes representam diferença estatisticamente significante no teste de Tukey

\begin{tabular}{|c|c|c|c|c|}
\hline \multirow[t]{2}{*}{ Variáveis } & $\begin{array}{l}\text { Grupo Experimental } 1 \\
\qquad(\mathrm{n}=18)\end{array}$ & $\underset{(n=18)}{\text { Grupo Experimental } 2}$ & $\begin{array}{l}\text { Grupo Controle } \\
\qquad(n=18)\end{array}$ & \multirow{2}{*}{$\begin{array}{l}\text { ANOVA } \\
\mathbf{p}\end{array}$} \\
\hline & Média (D.P.) & Média (D.P.) & Média (D.P.) & \\
\hline \multicolumn{5}{|c|}{ Componente Maxilar } \\
\hline SNA ( $\stackrel{o}{ })^{\prime}$ & $-1,24(1,93)^{A}$ & $-0,81(1,56)^{A}$ & $0,94(2,71)^{B}$ & 0,0076 \\
\hline$A-\operatorname{Nperp}(\mathrm{mm})$ & $-1,66(3,21)^{A}$ & $-0,34(1,50)^{A, B}$ & $1,64(3,25)^{B}$ & 0,0032 \\
\hline Co-A (mm) & $0,54(2,71)^{A}$ & $1,89(1,87)^{A, B}$ & $2,68(3,05)^{B}$ & 0,0509 \\
\hline \multicolumn{5}{|c|}{ Componente Mandibular } \\
\hline SNB () & $0,02(0,70)^{A}$ & $0,90(1,07)^{A}$ & $0,69(2,27)^{A}$ & 0,1936 \\
\hline Pog-Nperp (mm) & $-0,98(4,48)^{A}$ & $2,18(3,04)^{A, B}$ & $2,63(5,11)^{B}$ & 0,0296 \\
\hline Co-Gn (mm) & $4,02(3,16)^{A}$ & $5,39(3,23)^{A}$ & $4,47(4,84)^{A}$ & 0,5544 \\
\hline Go-Gn (mm) & $3,32(2,45)^{A}$ & $2,32(1,80)^{A}$ & $2,84(2,47)^{A}$ & 0,4189 \\
\hline Co-Go (mm) & $2,13(2,21)^{A}$ & $3,61(2,88)^{A}$ & $2,79(4,14)^{A}$ & 0,3864 \\
\hline \multicolumn{5}{|c|}{ Relação Maxilomandibular } \\
\hline 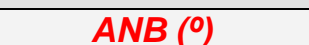 & $-1,27(1,64)^{A}$ & $-1,73(1,59)^{A}$ & $0,27(1,10)^{B}$ & 0,0004 \\
\hline Wits $(\mathrm{mm})$ & $-0,84(1,97)^{A}$ & $-0,20(1,82)^{A, B}$ & $1,16(2,05)^{B}$ & 0,0106 \\
\hline $\operatorname{NAP}(\stackrel{\circ}{)}$ & $-3,03(3,99)^{A}$ & $-3,86(3,58)^{A}$ & $0,17(2,57)^{B}$ & 0,0022 \\
\hline Co-A/Co-Gn (mm) & $-2,53(2,19)^{A}$ & $-2,35(2,03)^{A, B}$ & $-0,82(1,67)^{B}$ & 0,0224 \\
\hline \multicolumn{5}{|c|}{ Padrão de Crescimento } \\
\hline SN.GoGn $(\stackrel{\circ}{)})$ & $0,69(0,96)^{A}$ & $-0,29(1,58)^{A, B}$ & $-0,55(1,82)^{B}$ & 0,0393 \\
\hline 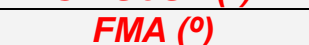 & $1,28(2,44)^{A}$ & $-0,68(1,56)^{B}$ & $-1,24(2,18)^{B}$ & 0,0018 \\
\hline 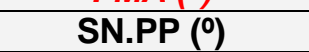 & $0,53(1,62)^{A}$ & $0,86(1,63)^{A}$ & $0,42(1,81)^{A}$ & 0,7210 \\
\hline SN.POF ( $(9)$ & $-1,02(2,12)^{A}$ & $-2,68(2,80)^{A}$ & $-2,32(3,35)^{A}$ & 0,1858 \\
\hline AFAl (mm) & $3,65(1,82)^{A}$ & $2,60(1,32)^{A}$ & $1,89(3,09)^{A}$ & 0,0651 \\
\hline S-Go $(\mathrm{mm})$ & $3,61(1,86)^{A}$ & $4,87(2,24)^{A}$ & $2,61(3,89)^{A}$ & 0,0631 \\
\hline \multicolumn{5}{|c|}{ Componente dentoalveolar superior } \\
\hline 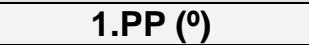 & \begin{tabular}{|l|l|}
$-3,98(8,21)^{\AA}$ \\
\end{tabular} & $-4,21(7,20)^{\mathrm{A}}$ & $0,27(2,17)^{A}$ & 0,0720 \\
\hline 1-ENAperp (mm) & $-2,29(2,18)^{A}$ & $-1,18(1,56)^{A}$ & $1,14(2,01)^{B}$ & 0,0000 \\
\hline 1-PP $(\mathrm{mm})$ & $1,48(0,99)^{A}$ & $0,88(1,21)^{A}$ & $0,68(1,03)^{A}$ & 0,0820 \\
\hline 6-PP $(\mathrm{mm})$ & $1,09(1,27)^{A}$ & $1,22(1,13)^{A}$ & $1,78(1,37)^{A}$ & 0,2246 \\
\hline 6-ENAperp (mm) & $-0,69(2,03)^{A}$ & $0,37(1,60)^{A, B}$ & $0,80(1,69)^{B}$ & 0,0427 \\
\hline 1.NA () & $-3,28(9,10)^{A}$ & $-4,24(7,06)^{A}$ & $-1,05(1,84)^{A}$ & 0,3537 \\
\hline 1-NA (mm) & $-1,24(3,04)^{A}$ & $-1,08(1,71)^{\mathrm{A}}$ & $0,10(1,16)^{A}$ & 0,1264 \\
\hline \multicolumn{5}{|c|}{ Componente dentoalveolar inferior } \\
\hline IMPA $(\stackrel{\circ}{)}$ & $1,46(6,02)^{A, B}$ & $7,00(11,84)^{A}$ & $-0,30(3,81)^{B}$ & 0,0222 \\
\hline 1-Pogperp (mm) & $0,97(2,18)^{A, B}$ & $1,95(4,22)^{A}$ & $-0,44(1,45)^{B}$ & 0,0506 \\
\hline 1-PM (mm) & $0,32(1,38)^{A}$ & $1,03(1,12)^{A}$ & $1,38(2,32)^{A}$ & 0,1710 \\
\hline 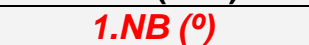 & $2,21(5,66)^{A, B}$ & $7,68(12,58)^{A}$ & $-0,15(4,58)^{B}$ & 0,0218 \\
\hline 1-NB (mm) & $1,42(1,56)^{A, B}$ & $2,14(2,81)^{A}$ & $0,42(1,73)^{B}$ & 0,0580 \\
\hline 6-Pogperp (mm) & $0,91(1,11)^{A}$ & $0,63(1,02)^{A, B}$ & $-0,31(1,36)^{B}$ & 0,0083 \\
\hline 6-PM $(\mathrm{mm})$ & $3,01(1,10)^{A}$ & $2,50(1,22)^{A}$ & $0,96(2,03)^{B}$ & 0,0004 \\
\hline \multicolumn{5}{|c|}{ Relações dentárias } \\
\hline T.H. $(\mathrm{mm})$ & $-3,89(2,31)^{A}$ & $-4,94(5,01)^{A}$ & $0,25(1,29)^{B}$ & 0,0000 \\
\hline T.V. $(\mathrm{mm})$ & $-2,64(1,41)^{A}$ & $-2,35(2,35)^{A}$ & $-0,06(2,26)^{B}$ & 0,0006 \\
\hline Rel. molar (mm) & $3,39(1,19)^{A}$ & $2,78(2,04)^{A}$ & $-0,26(1,35)^{B}$ & 0,0000 \\
\hline
\end{tabular}




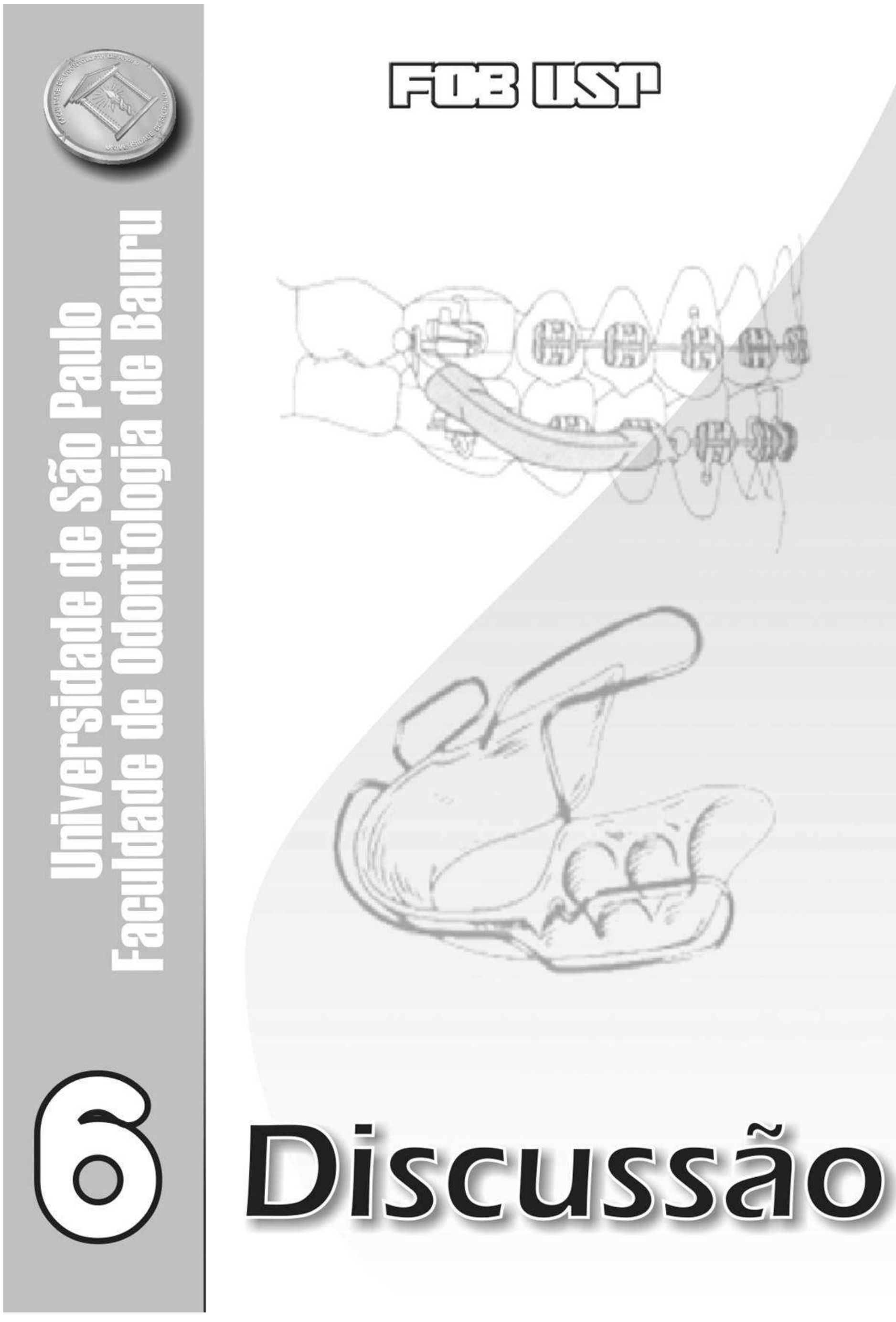




\section{DISCUSSÃO}

Com o objetivo de facilitar a interpretação e análise dos resultados obtidos, este capítulo foi dividido em tópicos considerando-se os vários aspectos envolvidos na execução deste trabalho. Inicialmente, serão discutidos os critérios relacionados à seleção da amostra e compatibilidade dos grupos estudados. Em seguida, discutir-se-á a precisão da metodologia empregada (erro do método). Posteriormente, serão discutidos os resultados das comparações intra e intergrupos e, concluindo, serão apresentadas as considerações finais.

Serão apresentadas ao longo deste capítulo sobreposições cefalométricas totais e parciais dos traçados médios dos Grupos Experimentais e do Grupo Controle, com finalidade ilustrativa. Traçado médio refere-se a uma média de todos os traçados dos Grupos Experimentais 1 e 2 e do Grupo Controle, em cada fase estudada. As sobreposições dos traçados médios dos grupos avaliados objetivam facilitar a visualização das características cefalométricas desses grupos nas fases inicial e final, e das alterações decorrentes do crescimento craniofacial, bem como do tratamento ortopédicoortodôntico. $\mathrm{O}$ traçado médio e as sobreposições foram efetuados pelo próprio programa Dentofacial Planner 7.02.

\subsection{Seleção da amostra}

A seleção da amostra foi realizada com base no objetivo do trabalho, que consistiu em comparar dois tipos de tratamento ortopédico-ortodôntico da má oclusão de Classe II, $1^{1}$ divisão, utilizando ainda um grupo controle com a finalidade de evidenciar os efeitos reais do tratamento instituído, daqueles advindos do crescimento e desenvolvimento craniofacial ${ }^{8,71,218,324}$.

Todos os jovens selecionados para este estudo apresentavam inicialmente má oclusão de Classe II, 1a divisão bilateral. Os pacientes que apresentavam má oclusão de Classe II, $2^{\mathrm{a}}$ divisão foram excluídos do estudo com a finalidade de se obter uma amostra o mais homogênea possível. A 
possibilidade das características distintas inerentes a Classe II, 2 ${ }^{\text {a }}$ divisão influenciar os resultados determinou a exclusão destes pacientes ${ }^{255}$.

A presença de dentes supranumerários, irrompidos ou não, e a ocorrência de agenesias ou perda de dentes permanentes foram critérios de exclusão dos pacientes da amostra, uma vez que estas condições podem interferir no desenvolvimento normal da oclusão, acarretando más oclusões que podem exigir recursos terapêuticos diferenciados, que vão além do propósito deste trabalho ${ }^{53,294}$.

As discrepâncias de tamanho dentário, avaliadas por meio da análise de Bolton, não foram consideradas neste trabalho em razão de sua ocorrência não interferir significativamente nos resultados finais ${ }^{141,269}$; além disto, a presença desta discrepância nos grupos estudados tende a ser semelhante, uma vez que não há nenhum fator que favoreça uma maior ocorrência da mesma em determinado grupo. Ainda, dentre os grupos de más oclusões de Angle, a má oclusão de Classe II apresenta a menor prevalência de discrepâncias de tamanho dentário ${ }^{26}$.

Os pacientes do Grupo Experimental 1, tratados por meio do Jasper Jumper associado ao aparelho fixo, constituíram uma amostra de caráter prospectivo, e foram tratados por apenas duas alunas do curso de PósGraduação em Ortodontia, em nível de Doutorado, da Faculdade de Odontologia de Bauru - Universidade de São Paulo. Desta maneira, todas as etapas do tratamento foram pré-determinadas e as profissionais calibradas. Entretanto, devido a sua característica prospectiva, o número de pacientes desta amostra reduziu-se consideravelmente. Inicialmente, dos aproximados 1800 jovens examinados em quatro escolas públicas de Bauru, foram selecionados 36 com base nos critérios de seleção deste estudo, como descrito no capítulo de Material e Métodos. Outro fator que contribui para este número relativamente reduzido da amostra inicial $(n=36)$ foi a dificuldade financeira dos pais ou responsáveis por alguns jovens selecionados em arcar com os custos do tratamento (no caso, o pagamento das documentações ortodônticas inicial e final). Isto significa que inicialmente, de acordo com os critérios de seleção das amostras deste estudo, mais de 36 jovens apresentavam condições de participar do estudo, no entanto, foram excluídos pelas questões financeiras consideradas. 
Vale ressaltar que este número de jovens selecionados (36 em 1800, o que representa $2 \%$ de todos os jovens examinados) não representa a prevalência da má oclusão de Classe II, $1^{\text {a }}$ divisão na população, que de acordo com SILVA FILHO et al. ${ }^{304}$, em 1990, corresponde a 11,5\%. O motivo desta prevalência reduzida foi a obediência aos critérios de seleção adotados.

Posteriormente, dos 36 pacientes que iniciaram o tratamento, 2 abandonaram antes mesmo da instalação do Jasper Jumper; duas pacientes foram excluídas por apresentarem impacção de um segundo molar inferior, o que causou o prolongamento do tempo de tratamento. Este fato poderia influenciar os resultados, pois a correção ântero-posterior foi obtida, além de um correto alinhamento e engrenamento dos dentes, e o aparelho ortodôntico não foi removido até a desimpacção e alinhamento dos segundos molares. Além disto, uma paciente apresentava características da má oclusão de Classe II, $2^{\text {a }}$ divisão, e não foi incluída no estudo apesar do seu tratamento ter sido concluído satisfatoriamente. Finalmente, os 6 pacientes restantes foram excluídos deste estudo por terem seus tratamentos prolongados em virtude de intercorrências, tais como: falta de cooperação com a higienização, o que acarretou em hiperplasia gengival e necessidade de realização de cirurgia periodontal durante o tratamento ortodôntico; falta de colaboração com o tratamento, constatado por repetidas quebras dos acessórios ortodônticos e/ou com o uso de elásticos intermaxilares. Assim, restaram 25 pacientes que preencheram os requisitos para inclusão neste trabalho.

O tamanho da amostra $(n=25)$, apesar de ter sido reduzido, apresentase suficiente para conferir confiabilidade aos resultados, considerando-se também 0 fato de outros estudos terem utilizado amostras de tamanho

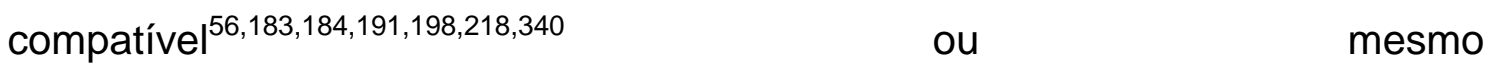
reduzido $8,12,21,64,102,129,154,166,170,171,180,198,219,230,298$. Além disto, pelo fato de ser uma amostra prospectiva, apresenta maior valor científico em decorrência da maior confiabilidade dos resultados e maior poder avaliativo ${ }^{317}$, pois minimiza as variações que podem ocorrer durante o tratamento ${ }^{21}$. Ainda, AELBERS; DERMAUT $^{3}$ (1996) ponderaram que grupos experimentais contendo grande número de pacientes são, infelizmente, difíceis de serem encontrados na literatura. 
O Grupo Experimental 2 foi selecionado a partir do arquivo de documentações da Disciplina de Ortodontia da Faculdade de Odontologia de Bauru - Universidade de São Paulo. Os pacientes que constituíram esse grupo foram tratados pelos alunos dos cursos de Pós-Graduação da referida instituição, sob orientação dos docentes responsáveis. Os pacientes foram selecionados retrospectivamente de acordo com os critérios impostos previamente e enumerados na seção de Material e Métodos, buscando ainda uma compatibilidade com o Grupo Experimental 1 em relação à severidade da má oclusão e distribuição quanto ao gênero. Assim, foram selecionados 30 pacientes, um número maior que o do Grupo Experimental 1, de acordo com a disponibilidade de documentações com as características almejadas no referido arquivo.

Apesar de apresentar caráter retrospectivo, provavelmente houve poucas variações nos métodos de tratamento utilizados entre os grupos experimentais, visto que são provenientes da mesma instituição de ensino, com a mesma filosofia de tratamento e, ambos, supervisionados pelos mesmos docentes responsáveis. Além disto, o maior número de pacientes do Grupo Experimental $2(n=30)$ compensou as possíveis variações ocorridas durante 0 tratamento ortopédico-ortodôntico dos pacientes ${ }^{21}$.

O Grupo Controle foi selecionado retrospectivamente a partir da amostra longitudinal para estudos de crescimento da Disciplina de Ortodontia da Faculdade de Odontologia de Bauru - USP ${ }^{153}$, e foi composto por 22 jovens que satisfizeram os requisitos previamente determinados para inclusão nesta amostra. O número de jovens da amostra foi considerado satisfatório para essa investigação, considerando a dificuldade em se obter uma amostra com as características desejadas e visto que esse mesmo número já foi utilizado em grupos controle de outros estudos ${ }^{8,12,29} \mathrm{e}$, em outros utilizou-se amostra controle com tamanho menor ${ }^{64,102,154,166,170,171,183,184,218,219}$.

Durante a seleção desses jovens, levou-se em consideração as idades inicial e final, o período médio de avaliação e o gênero, a fim de compatibilizálos com os pacientes do Grupo Experimental 1. Buscou-se essa compatibilização do Grupo Controle com o grupo tratado com o Jasper Jumper pelo fato do Grupo Experimental 2 ter sido tratado em duas fases, uma ortopédica (Bionator) e outra ortodôntica e, conseqüentemente, o tempo de 
tratamento ter sido consideravelmente maior do que o do Grupo Experimental 1. Assim, pretendia-se realizar a comparação entre os grupos por meio da anualização das alterações das variáveis, e julgou-se mais adequado compatibilizar o Grupo Controle com o Grupo Experimental 1, e anualizar as alterações do Grupo Experimental 2, que apresentava maior tempo de tratamento.

Este tipo de amostra longitudinal de pacientes com má oclusão de Classe II, $1^{\underline{a}}$ divisão não tratada torna-se extremamente importante para a comparação com os grupos experimentais, possibilitando distinguir os efeitos dos aparelhos testados daqueles decorrentes do crescimento craniofacial $^{8,71,324}$.

\section{2 - Compatibilidade dos grupos estudados}

A confiabilidade dos resultados de qualquer estudo cefalométrico comparativo depende diretamente do grau de semelhança das amostras estudadas ao início do período de observação ${ }^{322}$. Esta compatibilidade parece ser mais difícil de ser obtida quando se utiliza grupo controle, composto por jovens com a má oclusão não tratada ${ }^{3}$. A constituição de um grupo controle de jovens com má oclusão de Classe II, 1a divisão não submetidos a nenhum tipo de tratamento, é extremamente difícil ${ }^{64,86,93,154,248}$. Esta dificuldade justifica-se em parte pelo fato da maioria dos jovens necessitar do tratamento ortodôntico, principalmente pelos envolvimentos estético e funcional, e este tratamento ser negligenciado ou adiado, muitas vezes deixando de ser realizado na fase ideal para grande parte dos protocolos de tratamento (fase do pico de crescimento pubescente), onde seriam obtidos melhores resultados. Outro fato seria a questão ética que, muitas vezes, desaprova a coleta longitudinal dos dados desses jovens, uma vez que eles seriam examinados, radiografados apenas com a finalidade de pesquisa, sem se beneficiarem com o tratamento de suas más oclusões ${ }^{18,64,93,324}$.

De acordo com URSI; MCNAMARA JR. ${ }^{324}$ (1997), idealmente, para se distinguir as alterações derivadas do crescimento das correspondentes ao tratamento, deveria ser realizado um acompanhamento paralelo e contemporâneo de um grupo de jovens com estrutura craniofacial similar ao 
grupo submetido à terapia a ser avaliada. Por razões éticas, isto não seria possível, uma vez que o grupo controle poderia estar se beneficiando do tratamento nesta época. Resta, portanto, a utilização das documentações de jovens não tratados, obtidas em décadas passadas em Centros de Crescimento e Desenvolvimento Humano de instituições nacionais, como o de Bauru $^{153}$ e internacionais, como os de Burlington, Bolton e Michigan. Estes estudos não são mais repetidos e, há muito tempo, foram interrompidos, especialmente na América do Norte e Europa, em função de normas restringindo a utilização de radiografias para outros fins que não sejam de diagnóstico. No presente estudo, utilizou-se documentações de jovens com má oclusão de Classe II, $1^{\text {a }}$ divisão não tratados, provenientes de um desses centros, o Centro de Estudo de Crescimento da Faculdade de Odontologia de Bauru, Universidade de São Paulo, como já foi descrito anteriormente.

Em prol de um maior rigor científico, as amostras utilizadas em pesquisas como esta, onde se realizam comparações cefalométricas entre grupos, devem ser selecionadas criteriosamente, observando além das características da má oclusão, o gênero e a idade. Uma diferença considerável entre os grupos em relação a esses fatores poderia influenciar os resultados do tratamento, pois a efetividade da correção da má oclusão de Classe II está diretamente relacionada com a severidade inicial da discrepância ânteroposterior ${ }^{177,343}$ e o crescimento craniofacial relaciona-se ao gênero e à idade dos indivíduos ${ }^{3}$.

\section{Compatibilidade da severidade inicial da má oclusão}

A severidade inicial da má oclusão foi averiguada nos modelos de gesso por meio da relação molar, relação dos caninos e sobressaliência. Alguns jovens encontravam-se inicialmente na fase da dentadura mista, e estes parâmetros associados poderiam refletir melhor a severidade da má oclusão, uma vez que somente a avaliação da relação molar poderia induzir a erros ao considerar, por exemplo, uma relação do primeiro molar permanente de topo (em decorrência do plano terminal reto do segundo molar decíduo) como uma má oclusão de $1 / 2$ Classe II de Andrews ${ }^{20}$. Assim, considerou-se como má oclusão de Classe II o caso que além do molar, apresentasse relação dos caninos em Classe II e uma sobressaliência aumentada. 
Neste estudo, observou-se que a severidade inicial da má oclusão (os três parâmetros avaliados) foi significantemente diferente entre os grupos (TABELA 6). A sobressaliência diferiu significantemente entre o Grupo Experimental 2 (Bionator) e o Grupo Controle, que apresentou o menor valor médio (FIGURA 12), de acordo com os resultados da Análise de Variância, e posteriormente do teste de Tukey. No entanto, comparou-se a relação molar e dos caninos na fase inicial apenas entre os grupos experimentais (TABELA 7), e pôde-se verificar uma compatibilidade entre os mesmos, indicando uma semelhança da severidade inicial da má oclusão entre os Grupos Experimentais e uma menor severidade do Grupo Controle. Esta menor severidade da má oclusão inicial do Grupo Controle, apesar de não ser o ideal, pode ser perfeitamente compreensível, uma vez que jovens com Classe II, $1^{\text {a }}$ divisão severa (de $3 / 4$ de Classe II a Classe II completa) não deveriam ser deixados sem tratamento até por volta dos 15 anos, pois a época ideal de tratamento teria passado, resultando em tratamento futuro mais complexo, contrariando os princípios éticos nos quais uma pesquisa deve se fundamentar ${ }^{44,64}$. Além disto, outros estudos relataram também essa menor severidade do grupo controle para a relação molar $r^{64,93,154,345}$ e para a sobressaliência $64,65,95,154,214$.

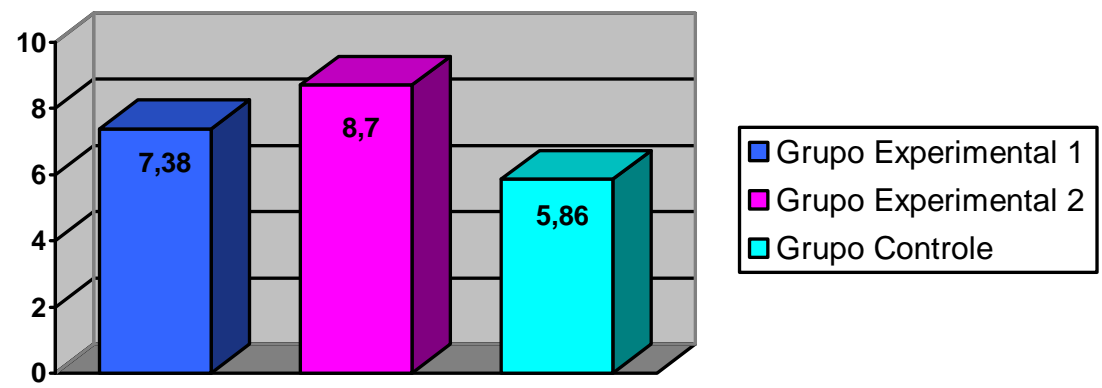

FIGURA 12 - Valores médios da sobressaliência inicial, mensurada nos modelos de gesso.

\section{Compatibilidade da distribuição dos gêneros}

Em relação à distribuição dos gêneros entre os grupos, torna-se fundamental que esteja compatível a fim de evitar influências nos resultados desse estudo, uma vez que é reconhecida a existência de diferenças importantes entre os gêneros masculino e feminino no que diz respeito à época de maturação esquelética e dentária e às respostas biológicas a alguns 
protocolos de tratamento ortopédico-ortodôntico ${ }^{45,105,124,202,341}$. O gênero feminino apresenta a maturação mais precoce e um ritmo de crescimento mais acelerado; isso faz com que se espere que as melhores respostas ao tratamento ortopédico-ortodôntico ocorram em uma idade cronológica menor no gênero feminino do que no masculino $45,105,124,202,341$. Além disso, alguns autores observaram que há diferença entre os gêneros em relação ao nível de colaboração com o tratamento, o que poderia influenciar os resultados da terapia instituída ${ }^{55,85,112,308}$; neste contexto, os resultados desta pesquisa poderiam ser influenciados se houvesse uma distribuição heterogênea dos gêneros entre os grupos, principalmente pelo fato do Grupo Experimental 2 (Bionator) depender mais da colaboração dos pacientes do que o Grupo Experimental 1 (Jasper Jumper), podendo assim ser influenciado positiva ou negativamente por essa suposta incompatibilidade.

Assim, a semelhança dos grupos estudados em relação à distribuição dos gêneros, verificada na TABELA 6 , foi de grande importância para a confiabilidade dos resultados obtidos, considerando que o potencial de crescimento presente é um fator importante na correção da Classe II, e a época do potencial máximo varia de acordo com o gênero, como também, o sucesso dos diversos protocolos de correção desta má oclusão dependem, em algum grau, da cooperação do paciente ${ }^{33,46,152,157,167,169,343}$.

\section{Compatibilidade das idades iniciais}

A TABELA 6 mostra os resultados da comparação das idades iniciais entre os grupos estudados, por meio da Análise de Variância. O Grupo Experimental 2 diferiu significantemente dos demais, fato este que já era esperado, devido às características inerentes de cada um dos protocolos de tratamento. O Grupo Experimental 1 foi tratado em apenas uma fase (o Jasper Jumper é utilizado juntamente com o aparelho ortodôntico fixo), e os jovens selecionados para esta modalidade de tratamento já deveriam apresentar inicialmente todos os dentes permanentes, com exceção dos segundos e terceiros molares, pois o aparelho fixo seria instalado imediatamente. Já para o Grupo Experimental 2, tratado com o Bionator e o aparelho ortodôntico fixo (tratamento realizado em duas fases), os jovens deveriam estar idealmente no início do surto de crescimento pubescente ao início do tratamento, o que 
geralmente coincide com o segundo período transitório da dentadura

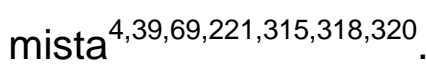

A incompatibilidade dos grupos quanto à idade inicial provavelmente iria influenciar os resultados deste trabalho no sentido de favorecer maiores alterações cefalométricas no grupo tratado em duas fases, visto que este grupo apresentava uma idade inicial média menor ao início do tratamento e, por conseguinte, um maior potencial de crescimento, favorecendo a correção da má oclusão de Classe $\|^{60,97,132,326}$. De acordo com TULLOCH; PROFFIT; PHILLIPS ${ }^{320}$, a influência da idade nos resultados do tratamento pode ser direta, considerando a magnitude de crescimento presente ou a resposta biológica à movimentação, ou indireta, em decorrência do nível de cooperação do paciente com o tratamento. Já foi relatada a relação da idade do paciente e o nível de colaboração com o tratamento ortopédico-ortodôntico ${ }^{55,314}$.

Alguns autores também já se propuseram a comparar protocolos de tratamento que, em razão de suas características e indicações, os levaram a evidenciar esta diferença entre as idades iniciais médias dos grupos avaliados $^{66,67,191,321,334}$.

No entanto, com o intuito de verificar a influência da idade inicial nos resultados desta investigação, compatibilizou-se os grupos quanto à idade inicial (TABELA 14) e, posteriormente, realizou-se uma segunda comparação de todas as variáveis estudadas entre os grupos compatibilizados. Após a compatibilização em relação à idade inicial, cada grupo apresentou 18 indivíduos; sabe-se que é um número reduzido para se realizar comparações, mas foi considerado um número razoável para permitir resultados confiáveis, eliminando a influência da variação da idade inicial entre os grupos, visto que outros estudos já utilizaram amostras de tamanho compatível ou menor ${ }^{170,171,219,230}$. Além disto, HOUSTON ${ }^{143}$ considerou que para a validade de qualquer estudo longitudinal, a amostra deve apresentar pelo menos 15 componentes, afirmativa essa que suporta a confiabilidade dos resultados das comparações entre os grupos compatibilizados do presente estudo. Verificouse novamente a compatibilidade entre os grupos em relação à distribuição dos gêneros, à severidade da má oclusão inicial, ao tempo médio de avaliação e idade após o tratamento, mas agora após a compatibilização dos mesmos em relação à idade inicial (TABELA 14). Observou-se que todos os parâmetros, 
com exceção do tempo médio de observação e sobressaliência inicial, foram compatíveis. Em relação à sobressaliência (já discutida anteriormente), a diferença das médias entre os grupos diminuiu e o valor do $p$ (erro probabilístico) que era de 0,0002, passou a ser de 0,0400.

\section{Compatibilidade do tempo médio de avaliação}

A idade final foi compatível entre os três grupos pesquisados (TABELAS 6 e 14).

Como era de se esperar, o tempo médio de observação foi estatisticamente maior para o Grupo Experimental 2 (TABELA 6). Isso ocorreu porque esse grupo foi tratado em duas fases, uma ortopédica, por meio do aparelho Bionator, e a segunda fase com o aparelho ortodôntico fixo. O Grupo Experimental 1 foi tratado em apenas uma fase, e o Grupo Controle foi compatibilizado com esse grupo em relação à idade inicial, final e ao tempo médio de observação. Essa diferença significante para mais no tempo de tratamento do Grupo Experimental 2 provavelmente influenciaria os resultados desse estudo, pois, na idade em que os pacientes se encontravam, ocorreriam certamente maiores alterações decorrentes do crescimento facial, o que poderia gerar a falsa impressão de uma maior eficácia de tal protocolo. Desta maneira, um paciente tratado por 3,5 anos, por exemplo, provavelmente apresentaria um crescimento facial maior durante o período do tratamento que um outro paciente tratado por 2,15 anos, mesmo que ambos tenham sido tratados de maneira semelhante.

Mesmo após a compatibilização dos grupos em relação à idade média inicial, essa diferença no tempo médio de avaliação entre os grupos continuou sendo significante, apesar de ter sido reduzida (TABELA 14).

Devido a essa falta de compatibilidade do tempo médio de observação entre o Grupo Experimental 2 e os demais grupos, as medidas cefalométricas obtidas foram anualizadas nesse grupo (grupo tratado por meio do Bionator e aparelho fixo), que apresentava idade inicial média significantemente menor, e conseqüentemente, um maior tempo de observação. Assim, para cada paciente do Grupo Experimental 2 calculou-se a alteração de cada variável cefalométrica (alteração = valor final - valor inicial); a alteração de cada variável foi então dividida pelo tempo de tratamento do próprio paciente e, posteriormente, foi multiplicada pelo tempo médio de tratamento do Grupo 
Experimental 1 (2,15 anos). Esse cálculo foi realizado para cada variável cefalométrica de cada paciente. Ao final, obteve-se as alterações médias dessas variáveis no tempo médio de 2,15 anos de tratamento, tornando-se assim, os três grupos compatíveis em relação ao tempo médio de observação, possibilitando a comparação direta das alterações das variáveis cefalométricas entre os grupos estudados.

Obviamente, o ideal seria que esse tempo médio de observação fosse semelhante e compatível entre os três grupos, porém, devido às características inerentes aos protocolos de tratamento estudados, não foi possível obter essa homogeneidade. Assim, decidiu-se anualizar as variáveis selecionadas para esse estudo, a fim de permitir a comparação entre os protocolos de tratamento propostos. A anualização dos dados tem sido utilizada em vários estudos $^{8,12,21,30,102,173,194,195,209,216,313,319,320,322,325}$ e consiste em um recurso cientificamente aceito e confiável, proporcionando situações próximas da realidade $8,21,173,209,216,322,325$.

\section{Compatibilidade cefalométrica inicial}

Idealmente, os grupos a serem comparados devem apresentar características morfológicas semelhantes, a fim de se obter resultados mais confiáveis e fidedignos. Assim, os grupos devem apresentar uma boa compatibilidade das variáveis cefalométricas na fase inicial (T1). No presente estudo, houve diferenças estatisticamente significantes entre os grupos em um número considerável de variáveis cefalométricas (TABELA 8 e FIGURA 13). De uma maneira geral, essas diferenças ocorreram principalmente em virtude de dois fatores: 1) a diferença da idade inicial entre os grupos, com uma precocidade significante do Grupo Experimental 2 (em média, 1,41 ano mais jovem que o Grupo Experimental 1); e 2) a menor severidade da má oclusão de Classe II para o Grupo Controle em comparação aos Grupos Experimentais.

Quando os grupos foram compatibilizados em relação à idade inicial, houve uma compatibilidade cefalométrica satisfatória ao início do tratamento, sendo que das 35 variáveis cefalométricas avaliadas, apenas 8 apresentaram diferenças estatisticamente significantes (TABELA 15 e FIGURA 14). 


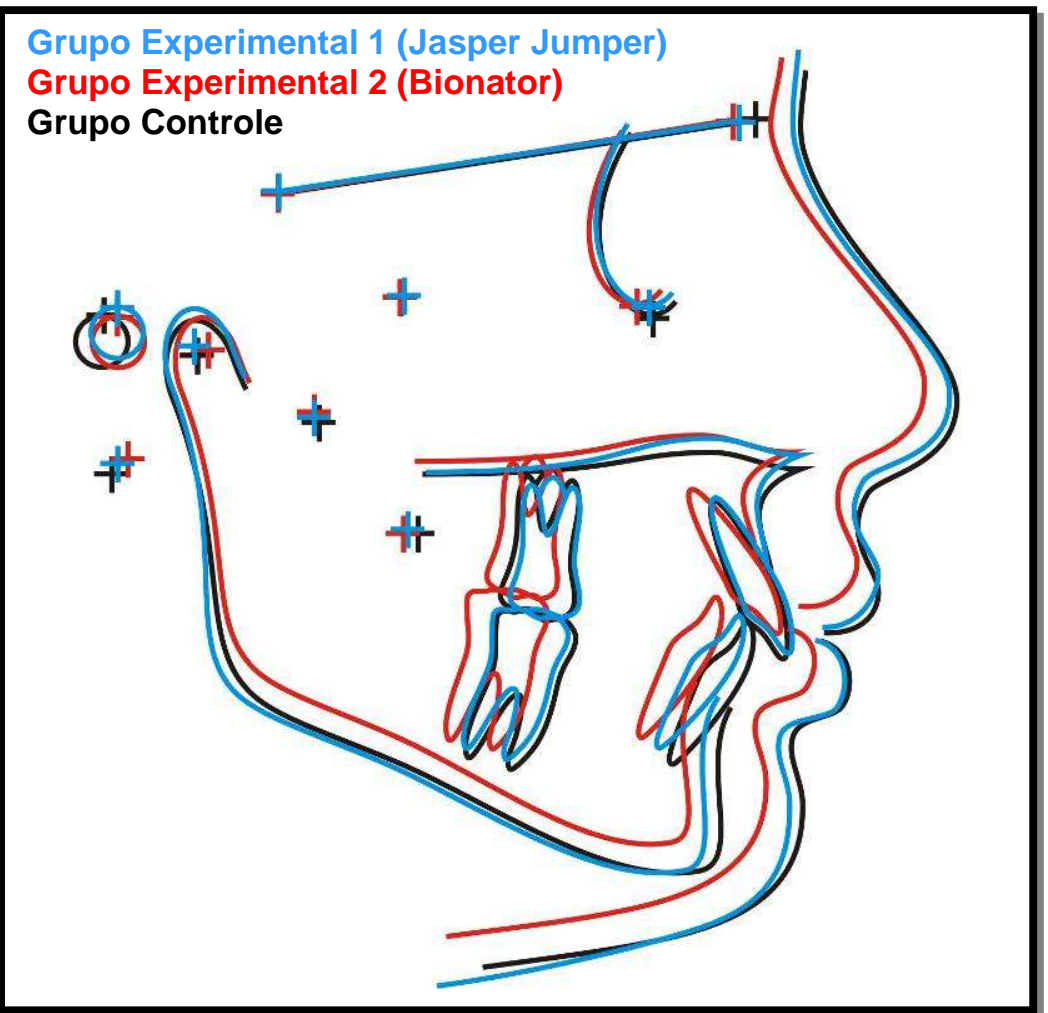

FIGURA 13 - Sobreposição em SN centrado em S dos cefalogramas médios iniciais dos três grupos estudados.

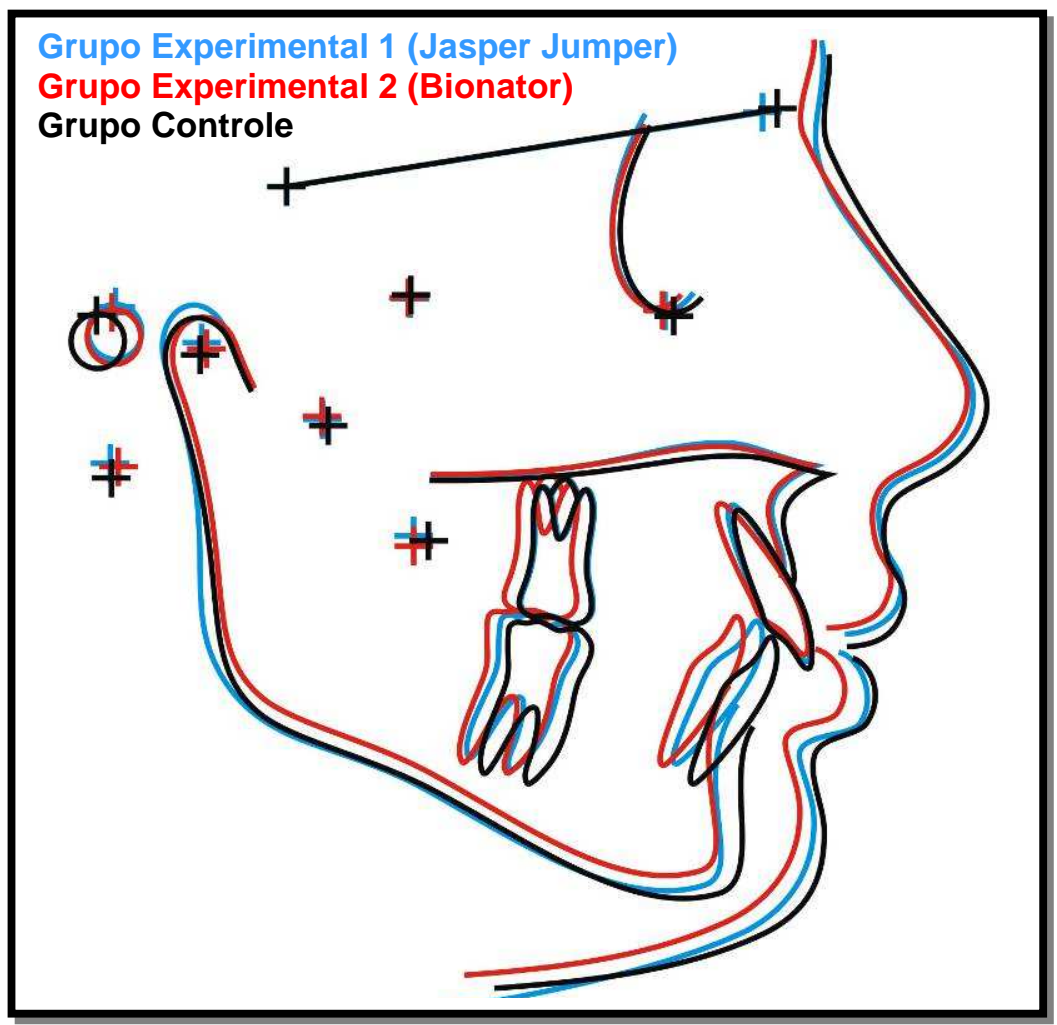

FIGURA 14 - Sobreposição em SN centrado em S dos cefalogramas médios iniciais dos três grupos estudados após a compatibilização dos Componente Maxilar

mesmos quanto à idade inicial. 
No componente maxilar, apenas a variável Co-A não foi compatível entre os grupos (TABELA 8), indicando que ao início do tratamento os pacientes tratados com o Bionator apresentavam um comprimento efetivo da maxila significantemente menor que os pacientes dos demais grupos. Isso poderia ter ocorrido porque os pacientes desse grupo eram em média 1,41 ano mais jovens que os pacientes tratados com o Jasper Jumper e 1,36 ano mais jovens que os indivíduos do Grupo Controle. Assim, até o momento da fase inicial (T1), os pacientes do Grupo Experimental 2 haveriam apresentado menor crescimento facial. Entretanto, mesmo após a compatibilização da idade inicial entre os grupos, a variável Co-A continuou apresentando um valor significantemente menor para o grupo tratado com o Bionator, apesar desta diferença ter diminuído (TABELA 15).

\section{Componente Mandibular}

Todas as variáveis cefalométricas lineares do componente mandibular apresentaram diferença estatisticamente significante entre os grupos na fase T1 (TABELA 8). Ao início do tratamento, a mandíbula apresentava-se significantemente mais retruída no Grupo Experimental 2 em relação ao Grupo Controle (avaliada pela variável Pog-Nperp). Além disto, as mensurações referentes ao comprimento efetivo da mandíbula (Co-Gn), comprimento do corpo mandibular (Go-Gn) e altura do ramo mandibular (Co-Go) apresentaram valores significantemente menores para o Grupo Experimental 2. Isto ocorreu, provavelmente, em decorrência da diferença entre as idades médias iniciais dos grupos. Após a compatibilização dos grupos quanto à idade inicial (TABELA 15), apenas o comprimento efetivo da mandíbula (Co-Gn) e a altura do ramo mandibular (Co-Go) continuaram significantemente menores para 0 grupo tratado em duas fases (Bionator e aparelho fixo).

\section{Componente Relação Maxilomandibular}

$\mathrm{Na}$ avaliação da relação maxilomandibular, as variáveis ANB e Wits apresentaram diferença estatisticamente significante entre os grupos na fase inicial (TABELA 8). O ângulo ANB foi estatisticamente semelhante entre os grupos experimentais, entretanto, o grupo controle apresentou valor significantemente menor em relação ao Grupo Experimental 2. Já para a medida linear Wits, constatou-se também uma semelhança estatística entre os grupos experimentais, mas essa medida foi significantemente menor para 0 
Grupo Controle em relação ao Grupo Experimental 1. Esses valores menores para o Grupo Controle caracterizam uma relação de Classe II, 1a divisão mais suave nesses jovens não submetidos ao tratamento ortopédico/ortodôntico. Esse fato é compreensível, pois um jovem com uma má oclusão severa de Classe II, $1^{\underline{a}}$ divisão, com um maior envolvimento esquelético, apresentaria por conseqüência um maior comprometimento estético e funcional, o que justificaria a instituição imediata do tratamento, e contrariaria a postergação ou a não realização do mesmo com o intuito de constituir um grupo controle. Essa relação de Classe II mais suave para o Grupo Controle já foi observada em outros estudos ${ }^{64,93,154,345}$. Após a compatibilização dos três grupos avaliados quanto à idade inicial, os valores das variáveis cefalométricas do componente maxilomandibular continuaram sendo menores, porém, não apresentaram diferença estatisticamente significante em T1 (TABELA 15). Esperava-se que 0 Grupo Controle continuasse apresentando uma relação de Classe II significantemente mais suave que os grupos experimentais, mas isto não ocorreu provavelmente em decorrência do número reduzido de componentes nas amostras compatibilizadas $(n=18)$.

\section{Componente Padrão de Crescimento}

Das 6 variáveis do componente padrão de crescimento, duas apresentaram diferença estatisticamente significante entre os grupos na fase T1, a saber, FMA e a altura posterior da face (S-Go) (TABELA 8). O ângulo FMA apresentou valor maior para o Grupo Experimental 2 do que para os demais grupos, entretanto, essa diferença foi significante apenas em relação ao Grupo Controle. Já a altura posterior da face (S-Go) foi significantemente menor para o Grupo Experimental 2 em relação aos demais grupos. Estas diferenças ocorreram provavelmente devido à idade significantemente menor do Grupo Experimental 2 em relação aos demais grupos ao início do período de avaliação. Com a idade e, por conseqüência, com o crescimento, há uma tendência do ângulo FMA diminuir ${ }^{202}$. De acordo com MARTINS et al. ${ }^{202}$, dos 11 aos 12 anos de idade o FMA diminui em aproximadamente $2^{\circ}$, tanto para 0 gênero masculino quanto para o feminino. Já a altura posterior da face tende a aumentar com a idade ${ }^{202}$. Após a compatibilização dos Grupos em relação à idade inicial, não houve diferenças estatisticamente significantes em nenhuma variável do componente padrão de crescimento na fase inicial (TABELA 15), o 
que comprova a suposição da influência da idade inicial nos resultados da comparação da compatibilidade cefalométrica inicial entre os grupos.

\section{Componente Dentoalveolar Superior}

Em relação às variáveis do componente dentoalveolar superior, observase que ao início do período de avaliação o Grupo Experimental 2 apresentava incisivos superiores mais inclinados para vestibular quando comparado aos demais grupos, o que pode ser verificado pelos valores significantemente maiores para as variáveis 1.PP e 1.NA (TABELA 8). Houve diferença estatisticamente significante entre os grupos, na fase inicial, das alturas alveolares superiores anterior (1-PP) e posterior (6-PP). Para a medida 1-PP a Análise de Variância revelou uma diferença estatisticamente significante, porém, o teste de Tukey não acusou tal diferença entre os grupos. Isto pode ocorrer pelo fato de se tratar de testes estatísticos diferentes, com precisões diferentes. De uma maneira geral, a Análise de Variância é mais sensível que o teste de Tukey ${ }^{189,193,351}$. Independente desta discordância entre os dois testes estatísticos, pode-se observar que o Grupo Experimental 2 apresentou o menor valor para a altura alveolar anterior (1-PP). Para a altura alveolar posterior (6PP), o Grupo Experimental 2 apresentou medida menor que os demais grupos, porém, esta diferença foi significante apenas em relação ao Grupo Experimental 1. Estes valores menores das alturas alveolares para o grupo tratado com o Bionator ocorreram provavelmente em virtude da idade inicial significantemente menor em relação aos outros grupos, o que permitiu menores alterações decorrentes do crescimento facial até o momento da fase T1. Esse fato pode ser confirmado pela compatibilidade dessas variáveis após a compatibilização da idade inicial entre os grupos (TABELA 15).

Ainda em relação ao componente dentoalveolar superior (TABELA 8), o molar superior apresentou-se significantemente mais mesializado ao início do tratamento no Grupo Experimental 1 (maior valor - ou menor valor absoluto da variável 6-ENAperp).

Após a compatibilização dos grupos em relação à idade inicial, o Grupo Experimental 2 continuou apresentando valores maiores para as variáveis 1.PP e 1.NA e o Grupo Experimental 1 continuou apresentando maior mensuração (ou menor valor absoluto) para a variável 6-ENAperp (TABELA 15), porém, nenhuma destas medidas continuou apresentando diferença estatisticamente 
significante em relação aos outros grupos. Isto, provavelmente, deve-se ao número reduzido de indivíduos nos grupos compatibilizados $(n=18)$.

\section{Componente Dentoalveolar Inferior}

Ao se comparar as mensurações das variáveis do componente dentoalveolar inferior entre os grupos na fase T1 (TABELA 8) pôde-se observar que os incisivos inferiores encontravam-se significantemente mais inclinados para vestibular no Grupo Experimental 1 em relação ao Grupo Experimental 2 (observado pelas variáveis IMPA e 1.NB), e essa diferença se manteve mesmo após a compatibilização dos grupos quanto à idade inicial (TABELA 15). Pôdese observar também, de acordo com o teste de Tukey, que os incisivos inferiores encontravam-se significantemente mais protruídos (1-Pogperp) no Grupo Experimental 1 em relação ao Grupo Experimental 2 (TABELA 8), porém, esta diferença não foi significante de acordo com a Análise de Variância ( $p=0,0552)$. Após a compatibilização dos grupos quanto à idade inicial, esta tendência de maior protrusão do incisivo inferior no grupo tratado com o Jasper Jumper quando comparado ao tratado com o Bionator se manteve, e passou a ser significante tanto pela Análise de Variância quanto pelo teste de Tukey (TABELA 15). Confirmando esta tendência de maior protrusão dos incisivos inferiores na fase T1 no grupo tratado com o Jasper Jumper, a variável 1-NB apresentou valores maiores para este grupo quando comparado ao grupo tratado por meio do Bionator e a terapia ortodôntica corretiva, porém, esta diferença foi significante apenas pelo teste de Tukey (TABELAS 8 e 15). As alturas alveolares inferiores anterior (1-PM) e posterior (6-PM) apresentaram diferença estatisticamente significante entre os grupos ao início do período de avaliação (TABELA 8). Em relação à variável 1-PM, o Grupo Experimental 2 apresentou medida menor que os demais grupos, porém, esta diferença foi significante apenas em relação ao Grupo Experimental 1. Já para a variável 6PM, o Grupo Experimental 2 apresentou valor significantemente menor que os demais grupos. Como descrito para as alturas alveolares superiores, estas diferenças se devem, provavelmente, ao menor crescimento experimentado pelos jovens do Grupo Experimental 2 quando comparados aos jovens dos outros dois grupos na fase inicial, devido à idade inicial significantemente menor desse grupo. Assim, após a compatibilização dos grupos em relação à 
idade inicial, não houve mais diferenças estatisticamente significantes das alturas alveolares inferiores anterior e posterior (TABELA 15).

\section{Componente Relações Dentárias}

Ao avaliar as relações dentárias na fase inicial (T1), observou-se que o Grupo Experimental 2 apresentava um trespasse horizontal significantemente maior que os demais grupos, e o Grupo Controle apresentava uma relação molar de Classe II significantemente menos severa que os demais grupos (TABELA 8). Essas diferenças se mantiveram mesmo após a compatibilização dos grupos quanto à idade inicial (TABELA 15). Como já foi considerado anteriormente, é perfeitamente compreensível e aceitável que o Grupo Controle apresente uma má oclusão menos severa que os grupos experimentais, como já foi evidenciado em trabalhos prévios ${ }^{64,93,154,345}$. De uma maneira geral, a avaliação das relações dentárias por meio das telerradiografias em norma lateral seguiu a mesma tendência das avaliações efetuadas nos modelos de gesso iniciais (TABELA 6).

Enfim, de acordo com PETROVIC ${ }^{258}$, torna-se extremamente difícil a obtenção de grupos totalmente compatíveis, pois o crescimento não ocorre de forma linear e constante, e apresenta grandes variações individuais. Além disto, serão comparadas as alterações das variáveis entre os grupos, o que faz com que os resultados sejam menos susceptíveis à influência da incompatibilidade de algumas variáveis entre os grupos ${ }^{345}$.

\subsection{Precisão da metodologia empregada (erro do método) (TABELA 5)}

O estudo do erro do método (avaliação do erro intra-examinador) é um recurso importante em qualquer pesquisa científica, e visa minimizar e controlar os erros operacionais que invariavelmente surgem quando a metodologia envolve medições em telerradiografias ${ }^{37,143}$. A dificuldade na identificação de estruturas anatômicas e, conseqüentemente na demarcação e digitalização de pontos cefalométricos, imprime uma maior dificuldade e subjetividade nas medições radiográficas, acarretando uma imprecisão dos valores obtidos ${ }^{66}$.

Idealmente, é necessário que a metodologia empregada seja suficientemente precisa para permitir sua reprodução. Quando esta precisão encontra-se comprometida por algum motivo, surgem os erros que podem ser 
de natureza sistemática ou casual. Estes erros, quando significativos e de grande magnitude, afetam a confiabilidade dos resultados, aumentando ou diminuindo as verdadeiras diferenças entre as variáveis estudadas ${ }^{66}$.

O erro sistemático ocorre quando há uma tendência do operador subestimar ou superestimar continuamente uma determinada medida. Se as medições são realizadas por um único examinador, este tipo de erro geralmente resulta de uma modificação no conceito da demarcação de alguma estrutura ou ponto cefalométrico, modificação na técnica de mensuração ou ainda, pode resultar de uma tendenciosidade inconsciente do examinador em direcionar os resultados de acordo com as próprias expectativas ${ }^{143}$. Por outro lado, HOUSTON ${ }^{143}$ considera que a principal fonte de erros casuais é representada pela dificuldade e pela imprecisão em identificar ou definir certos pontos, que podem ser demarcados em diferentes direções.

Para uma análise adequada da precisão da metodologia, HOUSTON ${ }^{143}$ preconiza a reavaliação de, pelo menos, 25 telerradiografias. Assim, procedeuse a avaliação do erro intra-examinador, realizando novas medidas em 30 telerradiografias selecionadas aleatoriamente dos três grupos estudados, após um intervalo de três semanas.

O erro sistemático foi verificado por meio do teste t dependente ao nível de significância de $5 \%(p<0,05)$. Para o cálculo do erro casual, empregou-se a fórmula de DAHLBERG e, como referência, foram seguidas as recomendações de HOUSTON ${ }^{143}$ e SANDLER ${ }^{289}$, que estipularam como aceitáveis as medidas que apresentassem uma variação de até $1 \mathrm{~mm}$ para as grandezas lineares e $1,5^{\circ}$ para as angulares.

$\mathrm{Na}$ avaliação do erro sistemático, 4 das 35 variáveis cefalométricas avaliadas apresentaram diferença estatisticamente significante entre as duas medições: NAP ( $p=0,0238), 6$-ENAperp ( $p=0,0041), 1$-PM $(p=0,0111)$, e 6-PM $(p=0,0000)$ e as diferenças entre as primeiras e as segundas medições foram, respectivamente, $0,33^{\circ}, 0,72 \mathrm{~mm}, 0,25 \mathrm{~mm}$ e $0,38 \mathrm{~mm}$. Esses valores das diferenças entre as duas medições foram de pequena magnitude e, portanto, sem implicações clínicas.

Das 35 variáveis cefalométricas, apenas três apresentaram valores acima do preconizado na avaliação do erro casual: Co-Go (1,0002), 6-ENAperp $(1,0123)$, e IMPA $(1,5120)$. Observa-se que nas três variáveis o valor 
encontrado pela fórmula de Dahlberg ficou bem próximo do valor preconizado, e as diferenças entre a primeira e segunda medições foram de $-0,14 \mathrm{~mm}$ para a variável Co-Go, de 0,72mm para 6-ENAperp, e de -0,56ํㅜ para o IMPA. Esses valores são considerados clinicamente insignificantes, e não alterariam ou invalidariam os resultados obtidos.

Vale ressaltar que a variável 6-ENAperp apresentou erro casual e sistemático significantes, apesar da diferença entre as medições ser de 0,72mm, valor considerado aceitável. Entretanto, foi a maior diferença observada dentre as variáveis que apresentaram erro sistemático e casual. Os erros sistemático e casual da variável 6-ENAperp podem ter ocorrido em função da freqüente dificuldade na visualização da espinha nasal anterior. Além disto, pode haver certa dificuldade na delimitação da superfície mesial do primeiro molar superior, em virtude da sobreposição do primeiro molar do lado oposto e dos segundos pré-molares superiores. Apesar da ocorrência dos erros sistemático e casual para esta variável, a metodologia e os resultados não foram comprometidos, devido à mínima ou nenhuma repercussão clínica da diferença (considerada pequena) entre as 2 medições.

Assim sendo, os resultados do erro intra-examinador demonstram que houve precisão na marcação e digitalização dos pontos cefalométricos, garantindo a reprodutibilidade e confiabilidade dos resultados obtidos nessa pesquisa. 


\subsection{Resultados das comparações intra e intergrupos}

Comparação entre os grupos na fase final (T2) (TABELA 9)

Ao final do período de avaliação, os grupos mostraram-se semelhantes especialmente em relação às características esqueléticas (FIGURA 15).

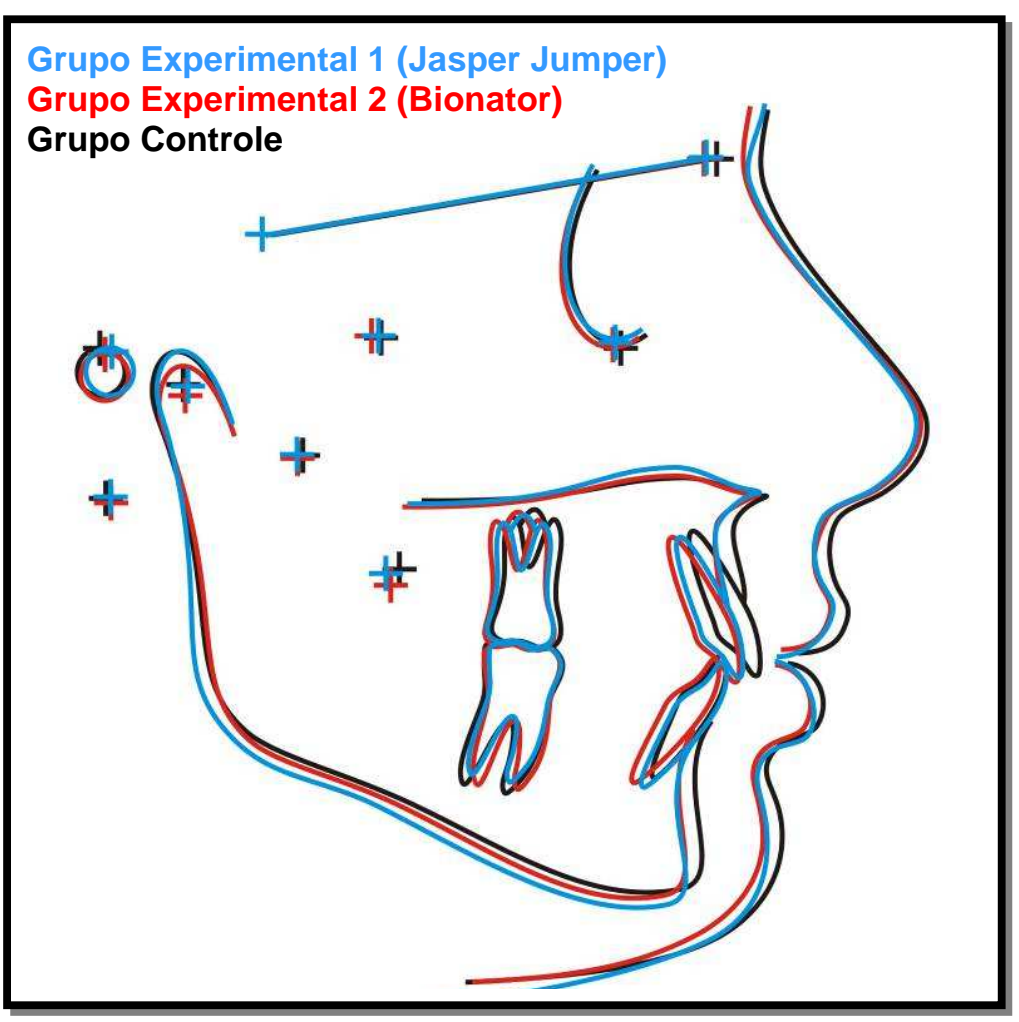

FIGURA 15 - Sobreposição em SN centrado em S dos cefalogramas médios finais dos três grupos avaliados.

\section{Componente Maxilar}

Dentre as variáveis que constituem o componente maxilar, apenas o comprimento efetivo da maxila (Co-A) apresentou diferença estatisticamente significante entre os grupos na fase T2, sendo que o Grupo Controle apresentou maior comprimento maxilar que os Grupos Experimentais. Isto ocorreu, possivelmente, em decorrência da restrição do crescimento maxilar no Grupo Experimental 1 (Jasper Jumper) (FIGURA 15), efeito já observado anteriormente por outros pesquisadores $5,6,79,80,183,184,215,219,310$. Em relação ao Grupo Experimental 2 (Bionator), ainda não se pode afirmar que houve uma restrição do crescimento maxilar, pois, ao início do tratamento, o comprimento efetivo da maxila já se encontrava significantemente menor em relação ao Grupo Controle (TABELAS 8 e 15), e isto foi mantido no final do tratamento, justificando o valor da variável Co-A significantemente menor quando 
comparado ao controle. Além disto, observa-se que inicialmente o comprimento efetivo da maxila era significantemente menor no Grupo Experimental 2 em relação ao Grupo Experimental 1 (TABELA 8) e, após a compatibilização dos grupos em relação à idade inicial, esse comprimento maxilar continuou sendo menor para o Grupo Experimental 2 (TABELA 15), apesar de não mais com significância estatística (provavelmente pelo reduzido número da amostra, uma vez que a diferença foi de mais de $2 \mathrm{~mm}$ ). Já ao final do tratamento (T2), o comprimento efetivo da maxila foi semelhante entre os grupos experimentais, 0 que leva a crer que o tratamento com o Bionator e o aparelho ortodôntico fixo ou não causou uma restrição do crescimento maxilar, ou se causou, essa restrição foi menor do que a ocorrida no grupo tratado pelo Jasper Jumper com o aparelho fixo.

\section{Componente Mandibular}

No componente mandibular, não houve diferenças estatisticamente significantes entre os grupos ao final do período de avaliação. Este seja talvez um dos pontos mais controversos quando se estuda os efeitos de aparelhos ortopédicos funcionais. De acordo com MEIKLE ${ }^{210}$ (2005), vários estudos clínicos randomizados foram desenvolvidos com o propósito de responder essa questão, sobre a habilidade dos aparelhos funcionais em modificar significantemente o crescimento facial, em especial o crescimento mandibular, entretanto, até o momento, a questão não foi claramente definida. $O$ autor ${ }^{210}$ atribuiu esta indefinição à variabilidade da época, magnitude e duração do surto de crescimento facial pubescente, aos diferentes níveis de motivação e colaboração dos pacientes, às limitações inerentes à cefalometria, bem como à questionável validade e precisão das próprias variáveis utilizadas para quantificar as alterações ocorridas.

De uma maneira geral, as terapias ortopédico-ortodônticas instituídas não produziram maiores efeitos esqueléticos mandibulares do que aqueles esperados pelo crescimento, observados no Grupo Controle deste estudo, ou seja, ao final do período de avaliação não é possível diferenciar, somente pelo crescimento mandibular, os pacientes submetidos a tratamento e os jovens do Grupo Controle. Vale ressaltar que, antes do período de avaliação, os três grupos eram compatíveis em relação à variável SNB (TABELAS 8 e 15), permanecendo semelhantes mesmo após o tratamento, indicando um 
posicionamento mandibular semelhante nos grupos tratados e controle antes e após o período avaliado. Para as demais variáveis do componente mandibular, o Grupo Experimental 1 e o Grupo Controle apresentavam-se compatíveis antes do período de observação; já o Grupo Experimental 2 (Bionator) apresentou valores significantemente menores em relação aos outros dois grupos, com exceção da variável Pog-Nperp que foi estatisticamente semelhante ao Grupo Experimental 1 e menor que o Grupo Controle (TABELA 8). Após a compatibilização dos grupos em relação à idade inicial, o Grupo Experimental 2 apresentou apenas duas variáveis do componente mandibular com diferença significante entre os grupos na fase inicial: o comprimento efetivo da mandíbula (Co-Gn) era inicialmente menor para os pacientes do grupo tratado com o Bionator em comparação ao Grupo Controle, e a altura do ramo mandibular (Co-Go), que foi significantemente menor para o Grupo Experimental 2 em relação aos demais grupos (TABELA 15). Como ao final do tratamento (T2) todas as variáveis mandibulares foram estatisticamente semelhantes, sugere-se que, a exemplo de outros estudos ${ }^{80,170,219,226,227}$, o tratamento com o Jasper Jumper não produziu efeitos esqueléticos mandibulares significantes; já o tratamento com o Bionator e aparelho ortodôntico fixo parece ter propiciado o aumento do comprimento efetivo da mandíbula e da altura do ramo mandibular de tal maneira que, ao final do tratamento, ambas se apresentaram semelhantes aos demais grupos, os quais inicialmente tinham valores maiores. Entretanto, esses possíveis efeitos serão melhor avaliados quando as tabelas que comparam as alterações das variáveis entre os grupos (TABELAS 13 e 16) forem estudadas e discutidas.

\section{Componente Relação Maxilomandibular}

O ângulo ANB e a avaliação de Wits apresentaram na fase inicial (T1) valores significantemente menores para o Grupo Controle quando comparados aos grupos experimentais (TABELA 8), e após a compatibilização dos grupos quanto à idade inicial essas variáveis continuaram apresentando valores menores, apesar de estatisticamente não significantes (TABELA 15). Entretanto, ao final do período de avaliação (T2), as variáveis ANB e Wits apresentaram valores semelhantes entre os grupos experimentais e controle, indicando que houve uma melhora do relacionamento maxilomandibular nos grupos tratados, tornando-os semelhantes ao Grupo Controle, que apresentava 
uma menor severidade da má oclusão inicialmente. O grau de convexidade facial, avaliado por meio do ângulo NAP, apresentou valores estatisticamente semelhantes entre os três grupos na fase T2. De acordo com as TABELAS 8 e 15, este ângulo apresentou-se semelhante entre os grupos também na fase T1. A única variável do componente relação maxilomandibular que ao final do período de avaliação se mostrou estatisticamente diferente entre os grupos foi Co-A/Co-Gn, que avalia o crescimento diferencial da mandíbula em relação à maxila. De acordo com os resultados deste estudo, o Grupo Experimental 1 (Jasper Jumper) apresentou valor significantemente menor em relação ao Grupo Controle. Vale considerar que em T1 esta variável apresentava-se compatível entre os três grupos (TABELAS 8 e 15). Esta diferença em T2 ocorreu, provavelmente, em decorrência da restrição do crescimento da maxila observada no Grupo Experimental 1, que fez com que o valor da variável CoA/Co-Gn tivesse uma maior redução com o tratamento neste grupo do que no grupo não submetido a nenhum tipo de tratamento ortodôntico/ortopédico.

\section{Componente Padrão de Crescimento}

Todas as variáveis que avaliam o padrão de crescimento apresentaramse estatisticamente semelhantes entre os grupos ao final do período de avaliação (T2). Como já discutido anteriormente, os grupos eram semelhantes entre si também na fase inicial de avaliação, no que diz respeito ao padrão de crescimento craniofacial (TABELA 15).

\section{Componente Dentoalveolar Superior}

As sete variáveis do componente dentoalveolar superior apresentaram mensurações estatisticamente semelhantes entre os três grupos na fase final, T2 (FIGURA 16). Entretanto, na fase T1 algumas variáveis revelaram diferenças significantes entre os grupos. Como já foi discorrido anteriormente, 0 Grupo Experimental 2 apresentava inicialmente os incisivos superiores (1.PP e 1.NA) mais vestibularizados que os demais grupos, e o Grupo Experimental 1 apresentava os molares superiores (6-ENAperp) mais mesializados que os outros dois grupos (TABELA 8). Após a compatibilização dos grupos quanto à idade inicial, essas variáveis continuaram apresentando a mesma tendência, com mensurações semelhantes às dos grupos não compatibilizados, mas as diferenças não foram mais estatisticamente significantes, provavelmente em virtude do número reduzido da amostra (TABELA 15). Assim, para que ao final 
do período de avaliação todas as variáveis do componente dentoalveolar superior apresentassem semelhança entre os grupos, provavelmente, 0 Bionator + aparelho fixo promoveram um maior efeito de lingualização nos incisivos superiores que o Jasper Jumper e a ação do crescimento no Grupo Controle. Já o Jasper Jumper ocasionou a distalização, ou talvez a restrição da mesialização dos molares superiores quando comparados aos demais grupos.

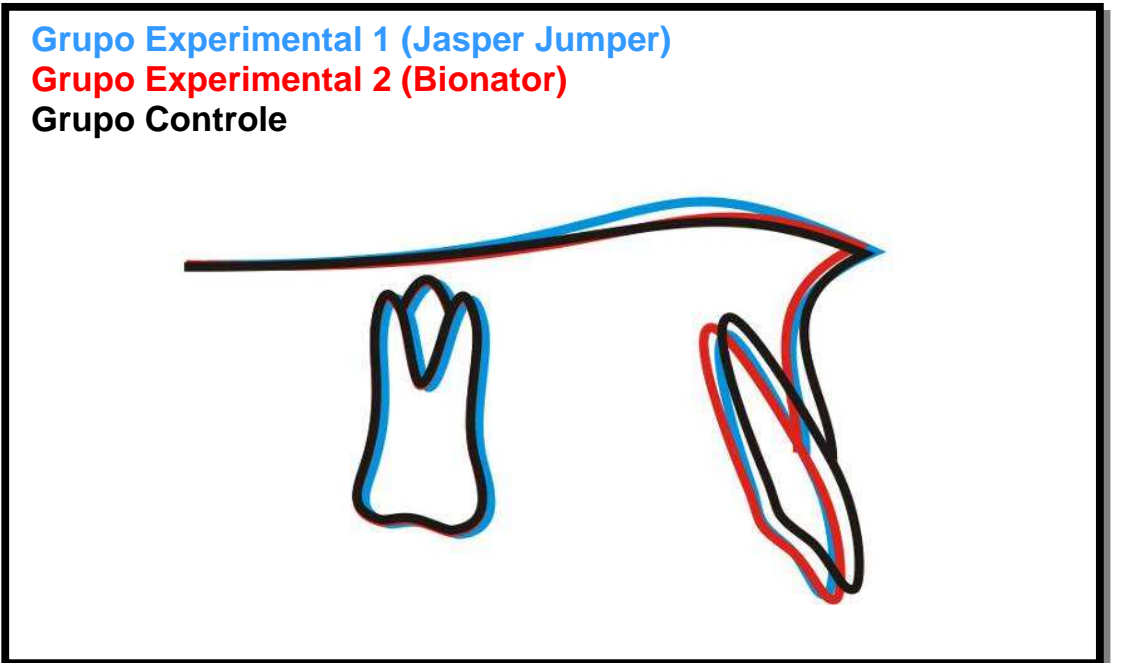

FIGURA 16 - Sobreposição no Plano Palatino (PP) centrado na Espinha Nasal Anterior (ENA) dos cefalogramas médios finais dos três grupos avaliados.

\section{Componente Dentoalveolar Inferior}

Inicialmente (T1) os incisivos inferiores dos pacientes do Grupo Experimental 1 encontravam-se mais vestibularizados (IMPA e 1.NB) e protruídos (1-Pogperp e 1-NB) em relação àqueles dos pacientes do Grupo Experimental 2, porém encontravam-se estatisticamente semelhantes aos dos jovens do Grupo Controle (TABELAS 8 e 15). Após o período de avaliação, a inclinação dos incisivos inferiores (IMPA e 1.NB) apresentou-se semelhante entre os grupos experimentais, e maior que o Grupo Controle, ou seja, ao final, os incisivos dos pacientes submetidos aos protocolos de tratamento ortopédico/ortodôntico apresentaram-se mais vestibularizados em relação aos pacientes não tratados (FIGURA 17). Já para as variáveis que avaliam 0 posicionamento dos incisivos inferiores, observa-se que, de acordo com a medida 1-Pogperp, os incisivos inferiores encontraram-se significantemente mais protruídos ao final do tratamento com o Jasper Jumper quando 
comparados aos valores em T2 dos demais grupos; já para a variável 1-NB, o Grupo Experimental 1 apresentou valor médio significantemente maior que o Grupo Controle, enquanto que o Grupo Experimental 2 mostrou-se estatisticamente semelhante aos demais grupos, lembrando que inicialmente este era o grupo que apresentava menor valor para esta variável (FIGURA 17). Todas as considerações anteriores sobre o componente dentoalveolar inferior levam a crer que os incisivos foram significantemente influenciados pelas terapias instituídas, fato este já esperado, pois a grande maioria das pesquisas sobre os aparelhos ortopédicos funcionais revela estes efeitos ${ }^{4-9,12,13,16,17,46,47,79}$, 80,95,118,137,158,159,161,166,170,171,183,184,211,215,219,225-227,297,310,315,338-340. Em relação aos molares inferiores, observa-se em T2 que eles se encontram significantemente mais mesializados e extruídos (com maior altura alveolar - 6-PM) no Grupo Experimental 1 quando comparados ao Grupo Controle (FIGURA 17). O Grupo Experimental 2 encontra-se estatisticamente semelhante aos demais grupos.

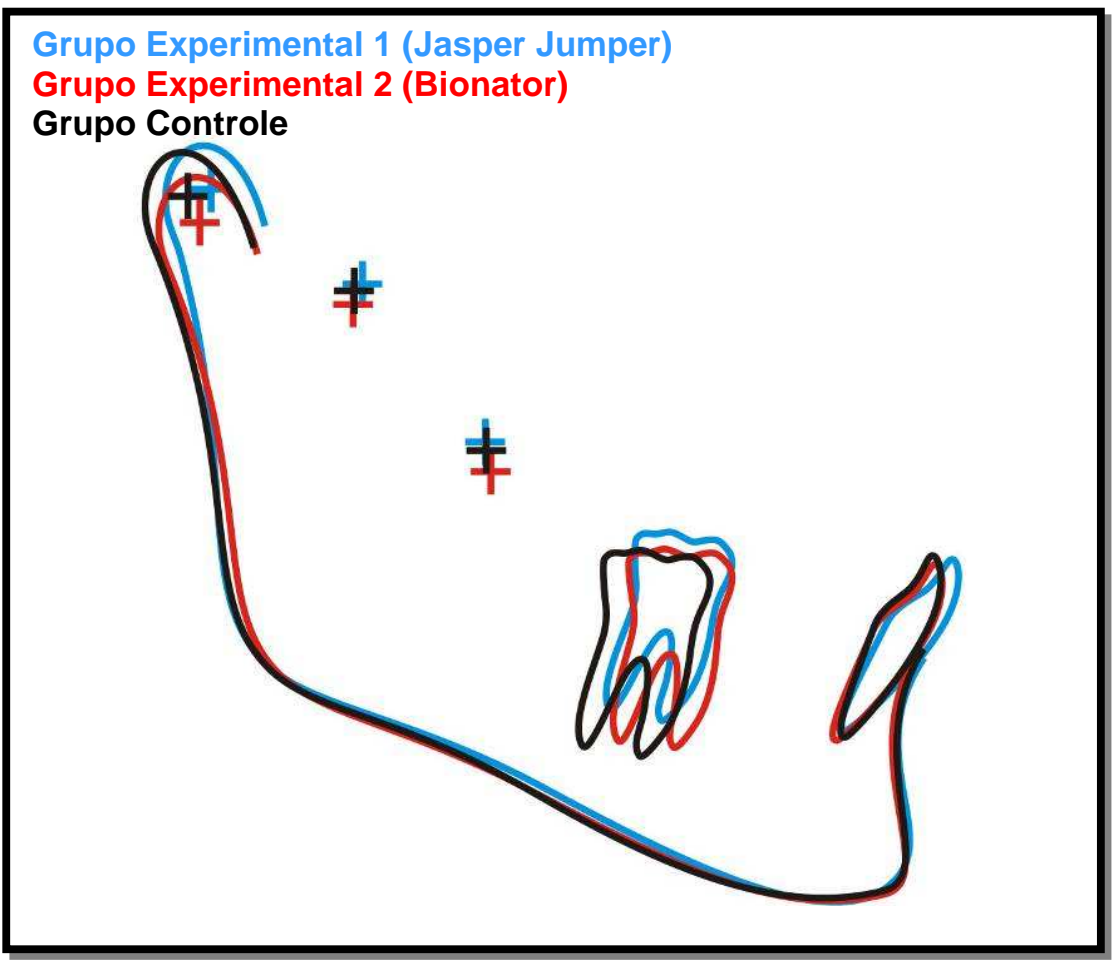

FIGURA 17 - Sobreposição no Plano Mandibular dos cefalogramas médios finais dos três grupos avaliados.

\section{Componente Relações Dentárias}

Observa-se que as três variáveis deste componente apresentaram o mesmo comportamento, revelando valores estatisticamente semelhantes para 
os grupos experimentais, e significantemente diferentes do Grupo Controle. Observa-se que o trespasse horizontal (T.H.), que inicialmente apresentava maiores valores para os grupos experimentais, em T2 apresentou valores significantemente menores para os grupos experimentais em relação ao Grupo Controle. Inicialmente o trespasse vertical (T.V.) era compatível entre os três grupos; já em T2, ambos os grupos experimentais apresentaram valores significantemente menores que o Grupo Controle. A relação molar (Rel. molar), que em $\mathrm{T} 1$ os grupos experimentais apresentaram mensurações significantemente menores em relação ao controle, mostrou o inverso ao final do período de avaliação; os grupos experimentais revelaram valores significantemente maiores que o Grupo Controle, indicando que houve uma correção da relação molar após os tratamentos realizados. Vale relembrar que um aumento da variável Rel. molar indica maior mesialização do molar inferior em relação ao superior. Era esperado que ao final dos tratamentos realizados os trespasses horizontal e vertical se apresentassem menor que o grupo não tratado, e que a relação molar fosse corrigida nos grupos tratados.

Comparações intragrupos: Grupo Experimental 1 (TABELA 10), Grupo Experimental 2 (TABELA 11) e Grupo Controle (TABELA 12)

Comparou-se todas as variáveis cefalométricas nas fases inicial (T1) e final (T2) por meio do teste $t$ dependente, nos três grupos estudados, com 0 objetivo de avaliar quais variáveis apresentariam valores significantemente diferentes entre as duas fases comparadas, seja como um resultado do tratamento, do próprio crescimento craniofacial, ou uma combinação de ambos.

\section{Componente Maxilar}

Avaliando as mensurações do componente maxilar, observa-se que a variável SNA diminuiu significantemente seu valor nos grupos experimentais, enquanto que no Grupo Controle houve um aumento do seu valor, porém este aumento não foi significante. Isto indica que houve uma significante retrusão maxilar nos grupos tratados, enquanto que o Grupo Controle não alterou a relação ântero-posterior da maxila significantemente. Ainda em relação à posição ântero-posterior da maxila, a variável A-Nperp mostrou um comportamento similar ao ângulo SNA, havendo uma diminuição do seu valor nos grupos experimentais e um aumento no Grupo Controle. Porém, a 
diminuição desta variável no Grupo Experimental 2 não foi estatisticamente significante. Observa-se que, na fase final T2, estas duas variáveis que avaliam o posicionamento ântero-posterior da maxila não apresentaram diferenças significantes entre os grupos (TABELA 9); entretanto, o comportamento dessas variáveis da fase inicial para a fase final diferiu entre os grupos experimentais e o Grupo Controle, onde houve uma diminuição das mensurações de T1 para T2 nos grupos experimentais e um aumento de T1 para T2 no Grupo Controle. Por isso, na comparação entre os grupos na fase final não houve diferenças significantes e nas comparações intragrupos pôde-se observar diferenças com significância estatística. Desta maneira, apesar dos valores de SNA e A-Nperp na fase final serem semelhantes entre os grupos, o comportamento destas variáveis diferiu da fase inicial para a final. Comparando o comprimento efetivo da maxila (Co-A) entre as fases inicial e final, observa-se que no Grupo Experimental 1 não houve diferenças significantes entre as fases, enquanto que no Grupo Experimental 2 e no Grupo Controle houve um aumento significante de T1 para T2. Isto indica que, como discutido anteriormente, houve uma restrição do crescimento maxilar no grupo tratado por meio do Jasper Jumper, enquanto que nos demais grupos a maxila continuou seu crescimento, havendo um aumento significante do seu comprimento efetivo (FIGURAS 18, 19 e 20). Na literatura consultada, vários trabalhos relatam a restrição do deslocamento anterior da maxila após a terapia com o Jasper Jumper ${ }^{5,6,79,80,183,184,215,219,310}$ em concordância com os resultados do presente estudo. Em relação ao Bionator, grande parte dos trabalhos ${ }^{8,9,12,13,16,17,69,166,173,319}$ relata que 0 tratamento não altera 0 posicionamento ântero-posterior da maxila, nem o seu comprimento efetivo. Por outro lado, alguns autores ${ }^{48,95,188,225,230,260,315,344}$ demonstraram que 0 Bionator promove um efeito retrusivo na maxila, verificado principalmente pela diminuição do ângulo SNA, como observado nesta pesquisa. OLIVEIRA et al. ${ }^{225}$ (1997) encontraram resultados semelhantes a esta investigação em relação à maxila; observou-se uma diminuição significante da variável A-Nperp, e o comprimento efetivo da maxila (Co-A) não alterou significantemente. Já MELO et al. ${ }^{211}$ (2006) observaram uma restrição do crescimento maxilar (Co-A). 


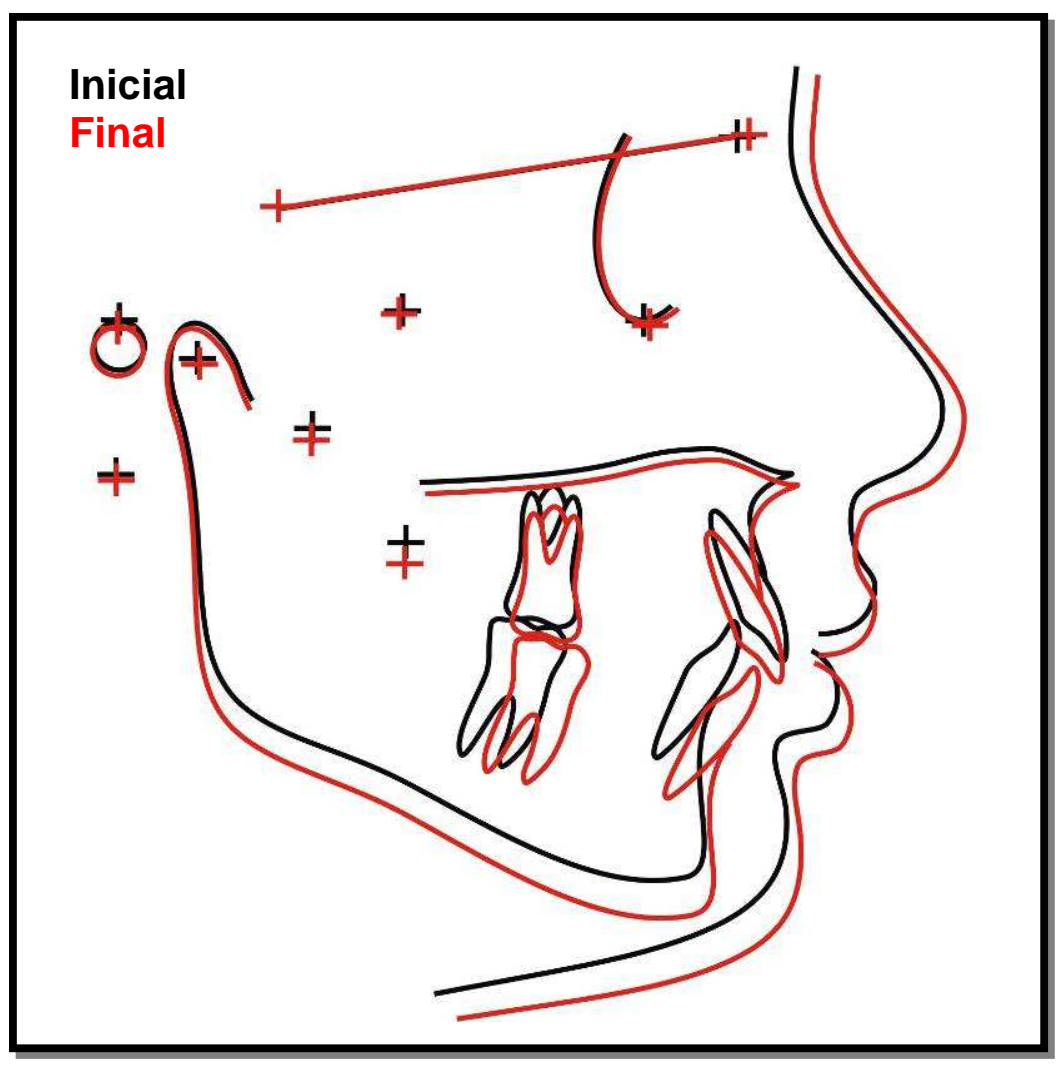

FIGURA 18 - Sobreposição em SN centrado em S dos cefalogramas médios iniciais e finais do Grupo Experimental 1 (Jasper Jumper).

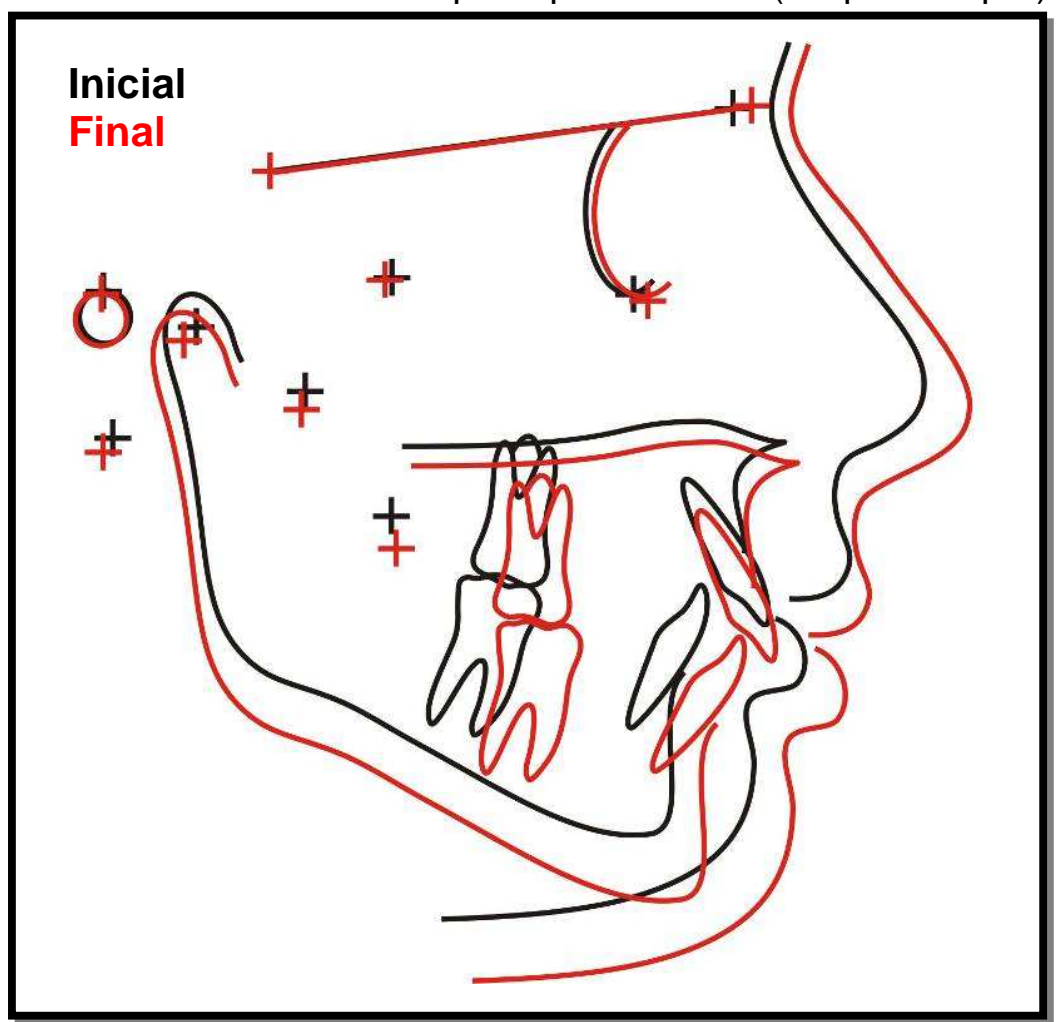

FIGURA 19 - Sobreposição em SN centrado em S dos cefalogramas médios iniciais e finais do Grupo Experimental 2 (Bionator). 


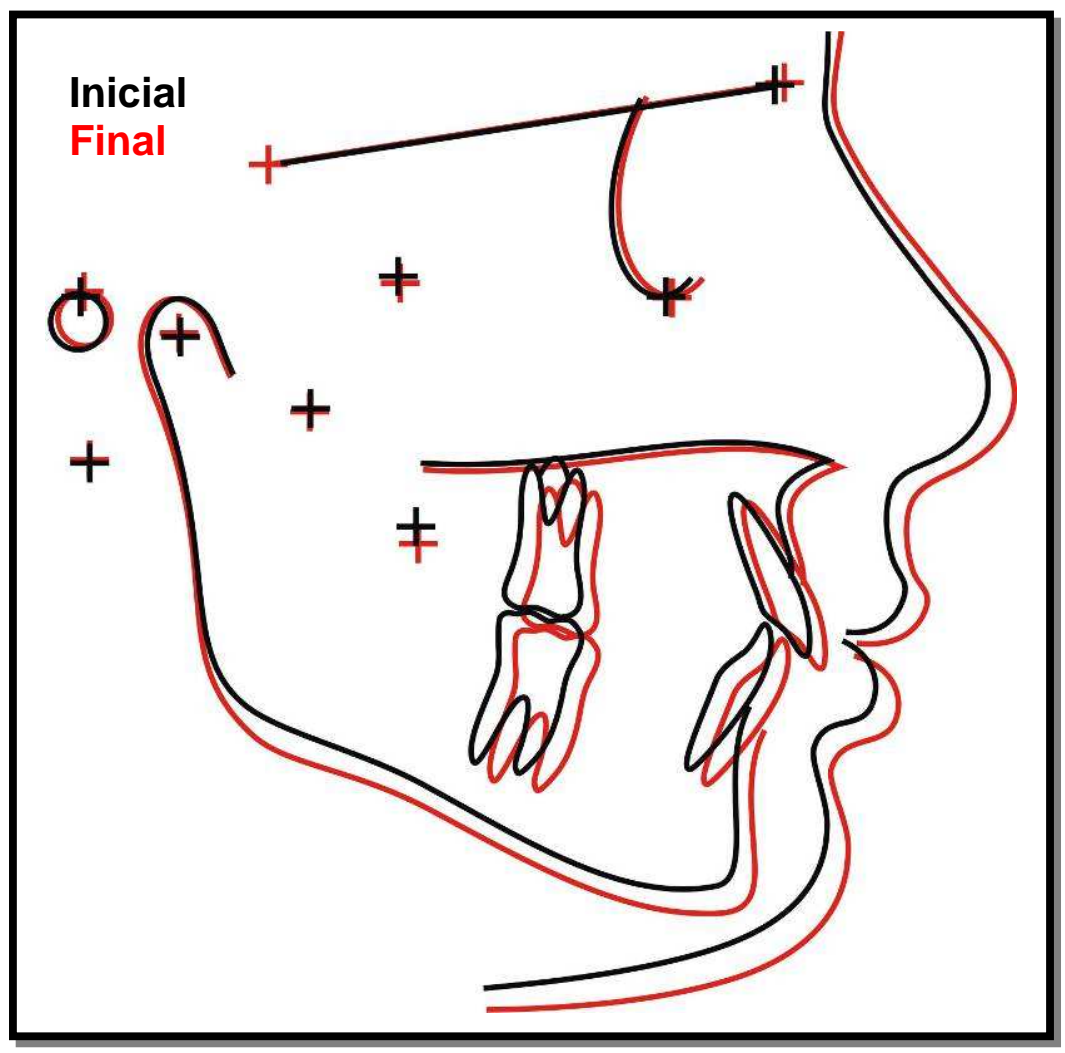

FIGURA 20 - Sobreposição em SN centrado em S dos cefalogramas médios iniciais e finais do Grupo Controle.

\section{Componente Mandibular}

Ao se avaliar o componente mandibular, observa-se que 0 posicionamento ântero-posterior da mandíbula (SNB e Pog-Nperp) não modificou significantemente de T1 para T2 no Grupo Experimental 1 (FIGURA 18). Já no Grupo Experimental 2 houve uma protrusão mandibular significante no período de avaliação (FIGURA 19). O Grupo Controle revelou a mesma tendência de protrusão mandibular entre as fases estudadas, porém, apenas variável Pog-Nperp apresentou diferença significante (FIGURA 20). Isto sugere que a protrusão mandibular observada no Grupo experimental 2 e no Grupo Controle tenha sido conseqüência do crescimento facial. Em relação às variáveis lineares que avaliam o comprimento efetivo da mandíbula (Co-Gn), o comprimento do corpo mandibular (Go-Gn) e a altura do ramo mandibular (CoGo), os três grupos mostraram comportamento semelhante. Houve um aumento significante desses comprimentos nos grupos estudados, fato que pode ser atribuído ao crescimento facial, uma vez que os pacientes não 
tratados exibiram aumentos compatíveis aos dos grupos tratados. Cabe ressaltar que o Grupo Experimental 2 apresentou uma diferença maior entre o valor dessas variáveis nas fases inicial e final porque o tempo médio de avaliação foi significantemente maior (3,92 anos) quando comparado aos demais grupos (2,15 anos e 2,13 anos para os Grupos Experimental $1 \mathrm{e}$ Controle, respectivamente). Sendo assim, os pacientes do grupo tratado por meio do Bionator e aparelho fixo experimentaram maior manifestação do crescimento facial e, conseqüentemente, maior aumento dos comprimentos mandibulares entre as fases inicial e final. Como os três grupos apresentaram aumento significante dos comprimentos mandibulares e apenas o Grupo Experimental 1 não apresentou protrusão mandibular no período de avaliação, especula-se que isto ocorreu devido à provável tendência de rotação horária da mandíbula em decorrência do tratamento com o Jasper Jumper, já reportada anteriormente em outros estudos ${ }^{79,171}$. Esta rotação horária mandibular provavelmente mascarou o crescimento normal da mandíbula, também observado nos demais grupos, fazendo com que o seu posicionamento ânteroposterior não fosse alterado durante o período de avaliação. Corroborando com esta justificativa, CREEKMORE; RADNEY ${ }^{82}$ (1983) avaliaram os efeitos do tratamento com o aparelho de Fränkel e relataram que o aumento no comprimento mandibular ocorrido durante a terapia ortopédica funcional não contribui de maneira significativa para a correção da Classe II devido à rotação horária da mandíbula induzida pelo aparelho.

\section{Componente Relação Maxilomandibular}

No componente relação maxilomandibular, observa-se que houve uma melhora da relação entre as bases ósseas nos grupos tratados, expressa pela redução significante do valor da variável ANB em relação ao Grupo Controle. Esta redução ocorreu em virtude dos tratamentos realizados, e encontra-se suportada na literatura consultada tanto para o tratamento com o Jasper Jumper ${ }^{171,184,219,226,227}$ quanto com

Bionator $7,9,12,13,16,17,84,86,115,137,139,188,211,266,318,319,346$. A outra variável que avalia 0 relacionamento maxilomandibular (Wits) revelou um comportamento diferente entre os grupos. No Grupo Experimental 1 houve uma redução significante entre as fases inicial e final, indicando uma melhora no relacionamento maxilomandibular. Já no Grupo Experimental 2 esta variável não alterou 
significantemente no período avaliado e no Grupo Controle houve um aumento significante do valor de Wits entre as fases T1 e T2. Assim, observa-se que em jovens com má oclusão de Classe II, 1a divisão não tratada, há a tendência do valor de Wits aumentar com o tempo, pelo menos entre as idades de 12,67 e 14,80, como observado no Grupo Controle deste estudo. Estudos prévios como os de HALL-SCOTT ${ }^{125}$, HURMERINTA et al. ${ }^{146}$ e CAFFER ${ }^{64}$ observaram este aumento do valor de Wits com a idade, em jovens não tratados ortodonticamente. Como o crescimento mandibular que ocorre durante o surto de crescimento pubescente favorece a diminuição da severidade da má oclusão de Classe II, que pode ser constatado pela diminuição do ANB com a idade (durante a fase de crescimento) ${ }^{202}$, poderia ser esperado que o valor de Wits diminuísse também, já que é uma variável que avalia o relacionamento maxilomandibular assim como o ângulo ANB. Entretanto, esse aumento do Wits com a idade (durante a fase de crescimento) parece estar associado à rotação do plano oclusal funcional no sentido anti-horário (diminuição do ângulo SN.POF) que, geralmente, ocorre com o crescimento facial ${ }^{92,125,202,302}$.

Os grupos tratados do presente estudo não evidenciaram este aumento do valor de Wits entre as fases inicial e final, esperado nos jovens não submetidos a nenhum tipo de tratamento ortodôntico/ortopédico. Isto indica que as terapias instituídas favoreceram a melhora no relacionamento entre as bases ósseas. No Grupo Experimental 1 houve uma redução significante na mensuração de Wits, enquanto que o Grupo Experimental 2 não modificou seu valor significantemente. Esta diferença observada nos grupos experimentais pode ter ocorrido em virtude da variação do comportamento do plano oclusal funcional (POF) entre ambos. No grupo tratado por meio do Jasper Jumper, o POF não acompanhou a tendência normal de rotação anti-horária já descrita anteriormente, não alterando significantemente no período de avaliação (de acordo com o ângulo SN.POF), enquanto nos demais grupos houve uma rotação anti-horária significante do POF em relação à base do crânio (linha $\mathrm{SN})$. A rotação anti-horária do POF leva a uma interpretação de Wits tendendo mais para a Classe II, pois favorece a demarcação do ponto $A O$ (projeção do ponto $\mathrm{A}$ no $\mathrm{POF}$ ) mais anteriormente em relação ao ponto $\mathrm{BO}^{146}$. Estudos anteriores já relataram que 0 tratamento com o Jasper Jumper pode alterar 0 plano oclusal, levando a uma rotação horária do mesmo $80,171,183,184,219$, o que 
certamente exerce influência sobre a variável Wits, no sentido de potencializar a ação do tratamento realizado em relação à melhora do relacionamento das bases ósseas. RUSHTON et al. ${ }^{286}$ relataram que uma pequena variação no ângulo do plano oclusal causa uma grande repercussão na mensuração de Wits. Vários autores concordam que a inclinação do plano oclusal influencia a avaliação de Wits ${ }^{68,75,92,134,150,151,220,302}$.

Ainda sobre o componente relação maxilomandibular, o grau de convexidade do perfil ósseo (NAP) diminuiu significantemente nos grupos experimentais entre as fases inicial e final, em decorrência dos tratamentos realizados; já o Grupo Controle não apresentou diferença estatisticamente significante entre as fases avaliadas. O maior crescimento da mandíbula em relação à maxila pode ser verificado pela redução estatisticamente significante da proporção Co-A/Co-Gn entre as fases $\mathrm{T} 1$ e T2 nos três grupos estudados. Esta é uma tendência natural, pois a mandíbula tende a crescer mais que a maxila pós-nascimento ${ }^{202,265}$. Entretanto, observa-se que nos grupos experimentais o valor absoluto da diferença entre as mensurações de Co-A/CoGn nas fases inicial e final foi maior que no Grupo Controle.

\section{Componente Padrão de Crescimento}

Em relação ao componente padrão de crescimento, não se verificou diferenças estatisticamente significantes entre as fases inicial e final para as variáveis SN.GoGn e SN.PP nos três grupos estudados. O ângulo FMA apresentou um aumento entre T1 e T2, porém não significante, no Grupo Experimental 1; nos demais grupos houve uma redução significante desse ângulo no período avaliado. Com o crescimento, o ângulo FMA tende a fechar, ou diminuir ${ }^{202,273}$, uma vez que a altura facial posterior se desenvolve mais que a AFAI, como verificado por diversos estudos ${ }^{48,71,140,156,232,248}$, e comprovado pela alteração observada no grupo que não recebeu nenhum tipo de tratamento no presente estudo (Grupo Controle). Logo, o tratamento com o Bionator não modifica significantemente o padrão de crescimento existente, como observado por vários autores ${ }^{7-9,12,13,16,17,56,69,138,188,198}$, permitindo que ocorram as alterações normais do crescimento.

Porém, verifica-se que os jovens tratados com o Jasper Jumper não apresentaram essa rotação anti-horária da mandíbula esperada como um resultado normal do crescimento facial, o que permite concordar com os 
trabalhos de COPE et al. ${ }^{79}$ e KARACAY et al. ${ }^{171}$, que observaram a tendência de rotação horária da mandíbula após o tratamento com o Jasper Jumper. Alguns autores ${ }^{32,248,327}$ já evidenciaram também uma suave tendência de rotação horária mandibular em decorrência do tratamento com o aparelho de Herbst. De acordo com PANCHERZ; FACKEL ${ }^{248}$, o aumento do ângulo do plano mandibular durante o tratamento com 0 aparelho de Herbst pode ser explicado pelo fato do crescimento condilar ser redirecionado posteriormente; após o tratamento há uma diminuição desse ângulo como resultado da modificação do crescimento condilar em uma direção mais vertical. Assim, os autores concluíram que o tratamento ortopédico com o aparelho de Herbst apresenta um impacto temporário no padrão de crescimento craniofacial. Especula-se que o Jasper Jumper produz efeitos e resultados dentoalveolares e esqueléticos equivalentes aos do aparelho de Herbst, por apresentarem mecanismos de ação semelhantes. Entretanto, torna-se necessário o desenvolvimento de pesquisas para confirmarem algumas suposições e especulações, como esta relacionada ao padrão de crescimento facial, visto que é um aparelho pouco investigado até o momento, até mesmo por ser novo em comparação ao aparelho de Herbst e aos demais aparelhos ortopédicos funcionais removíveis.

Em relação à inclinação do plano oclusal funcional, o grupo tratado por meio do Jasper Jumper não apresentou alteração significante entre as fases inicial e final, enquanto que o grupo tratado com o Bionator e o grupo que não recebeu nenhum tipo de tratamento ortopédico/ortodôntico mostraram uma rotação anti-horária do ângulo SN.POF entre as fases estudadas. Esta diminuição semelhante do ângulo do plano oclusal funcional entre os Grupos Experimental 2 e Controle indica que $o$ tratamento com o Bionator e o aparelho fixo não acarreta alterações significantes no plano oclusal funcional, além daquelas esperadas pelo crescimento e desenvolvimento normais. Na literatura consultada, as investigações sobre os efeitos do tratamento com o Bionator não avaliaram o comportamento do plano oclusal, assim, buscou-se comparar a alteração do ângulo do plano oclusal funcional observada no presente estudo com as alterações evidenciadas em estudos utilizando outros aparelhos ortopédicos funcionais. Alguns trabalhos ${ }^{64,154,232}$ revelaram uma rotação antihorária do ângulo do plano oclusal, compatível com a rotação de jovens sem 
tratamento (constituindo grupo controle), semelhantemente aos resultados desta pesquisa, enquanto que outros ${ }^{174,186}$ verificaram que o plano oclusal permaneceu inalterado com o tratamento.

A grande maioria dos autores que avaliaram os efeitos dentoesqueléticos do tratamento por meio do Jasper Jumper evidenciaram uma rotação horária do plano oclusal ${ }^{80,171,183,184,219}$.

A altura facial ântero-inferior aumentou significantemente nos três grupos no período avaliado; entretanto, observa-se que a diferença das mensurações entre as fases final e inicial é maior nos grupos experimentais, sugerindo que ambos os tratamentos induziram um aumento da AFAl maior que o esperado com o crescimento craniofacial, conforme reportado anteriormente em relação ao tratamento com o Bionator ${ }^{48,56,73,84,137,138,142,147,188,198,225,315,346}$. Todavia, poucas publicações ${ }^{171}$ envolvendo o aparelho Jasper Jumper relatam o aumento significante da AFAl; alguns estudos utilizando o aparelho de Herbst evidenciaram esse efeito ${ }^{237,238}$. MCNAMARA JR.; HOWE; DISCHINGER ${ }^{209}$ e URSI; MCNAMARA JR.; MARTINS ${ }^{322,325}$ verificaram um aumento tanto na altura facial ântero-inferior como na posterior após o tratamento com o aparelho de Herbst, não influenciando negativamente o ângulo do plano mandibular. Pode haver também um aumento da altura facial posterior em decorrência da utilização do Bionator $^{7-9,12,13,188}$. No presente estudo, a altura facial posterior (S-Go) aumentou significantemente nos três grupos entre as fases T1 e T2; o grupo tratado pelo Bionator apresentou maior magnitude desse aumento, entretanto, esse aumento mais acentuado da altura facial posterior no Grupo Experimental 2 provavelmente está relacionado ao tempo de avaliação significantemente maior deste grupo. As alterações das alturas faciais serão melhor discutidas posteriormente, quando forem consideradas as tabelas das comparações intergrupos das alterações das variáveis cefalométricas, onde as alterações do grupo do Bionator, que apresentou período de avaliação maior, foram anualizadas, eliminando esta possível interferência nos resultados obtidos. 


\section{Componente Dentoalveolar Superior}

De acordo com PANCHERZ; HANSEN ${ }^{251}$, a extensão das alterações dentárias varia consideravelmente entre os indivíduos.

A inclinação dos incisivos superiores, avaliada pelas variáveis 1.PP e 1.NA, apresentou uma tendência de diminuir sua magnitude (lingualização) entre as fases inicial e final no Grupo Experimental 1, porém, esta diminuição observada nos valores médios das variáveis em questão não foi estatisticamente significante. Houve também uma tendência de retrusão desses dentes, verificada pela diminuição estatisticamente significante do valor da variável 1-ENAperp, e pela diminuição, apesar de não significante estatisticamente, da variável 1-NA (FIGURA 21). Esta tendência de lingualização e retrusão dos incisivos superiores, já reportada previamente na literatura tanto como conseqüência do tratamento com 0 Jasper Jumper ${ }^{5,6,79,80,171,183,184,215,219,310,338,339}$, quanto com 0 aparelho de Herbst $^{10,11,130,209,218,330}$, parece relacionar-se com o sistema de forças que 0 aparelho libera sobre os dentes ${ }^{203}$. Deste modo, o mecanismo telescópico do aparelho de Herbst e a mola do aparelho Jasper Jumper produzem uma força direcionada para trás sobre a maxila e os dentes superiores, algumas vezes reportada como "headgear effect" ou "efeito extrabucal" ${ }^{13,183,240,246,327}$ dos aparelhos ortopédicos funcionais. Entretanto, no intuito de minimizar os efeitos dessa força distal nos dentes ântero-superiores, foram incorporados torques vestibulares nessa região dos arcos retangulares (mesmo utilizando braquetes pré-torqueados), ora resistentes, ora ativos, durante o tratamento com o Jasper Jumper nos pacientes desta pesquisa, a não ser nos casos onde o paciente apresentasse incisivos superiores com inclinações vestibulares acentuadas. Provavelmente, esta é a razão pela qual a lingualização dos incisivos superiores entre as fases T1 e T2 não foi estatisticamente significante no grupo tratado por meio do Jasper Jumper, embora tenha ocorrido retrusão significante desses dentes (FIGURA 21). Ainda, alguns pesquisadores observaram que 0 tratamento com o aparelho de Herbst não alterou significantemente a posição dos incisivos superiores ${ }^{234,235,237,238,251,325,327 .}$ 


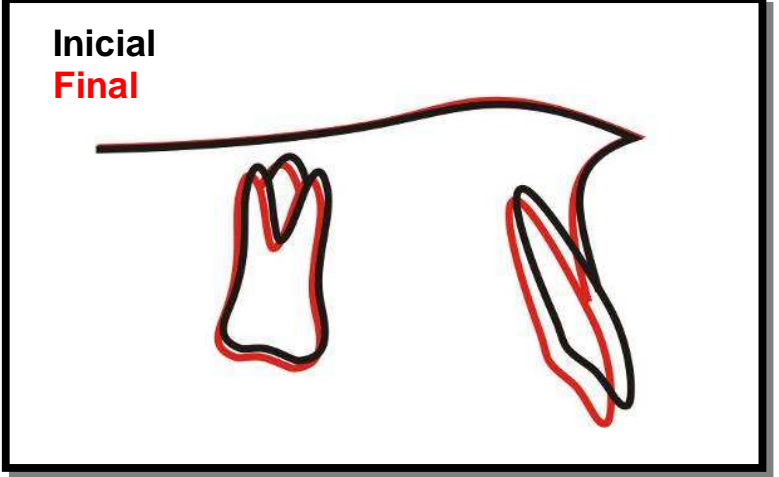

FIGURA 21 - Sobreposição em PP centrado em ENA dos cefalogramas médios iniciais e finais do Grupo Experimental 1 (Jasper Jumper).

No grupo tratado por meio do Bionator, os incisivos superiores foram significantemente lingualizados e retruídos durante o período de avaliação (FIGURA 22). Vale ressaltar que essas alterações dentoalveolares foram mais acentuadas neste grupo, entretanto, o tempo de tratamento foi significantemente maior, o que propiciou que os jovens estivessem por mais tempo sob a ação dos aparelhos utilizados e do crescimento craniofacial. Enfim, muitos autores já relataram a lingualização e/ou retrusão dos incisivos superiores em decorrência da utilização do Bionator ${ }^{4,7-}$ $9,12,13,16,17,35,36,46,48,69,86,95,107,108,118,137,147,158,159,161,211,297,315,331,346$, que pode ocorrer em virtude do contato do arco vestibular com os incisivos superiores e do "efeito extrabucal" dos aparelhos ortopédicos funcionais ${ }^{166}$.

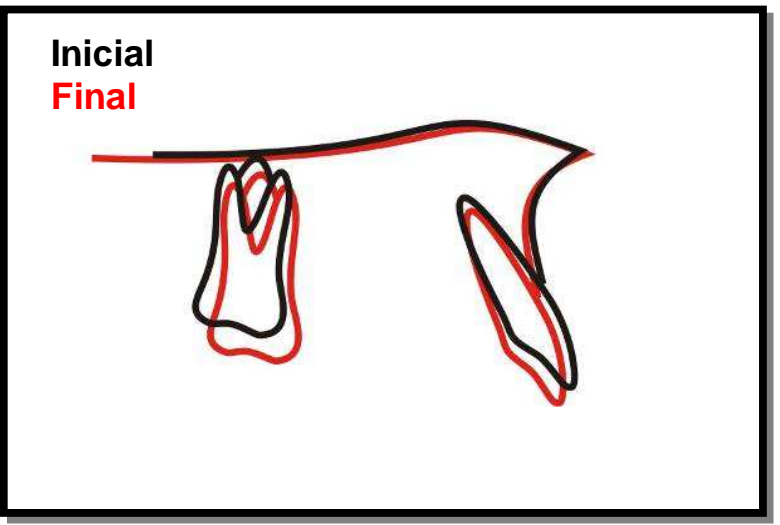

FIGURA 22 - Sobreposição em PP centrado em ENA dos cefalogramas médios iniciais e finais do Grupo Experimental 2 (Bionator).

Já no Grupo Controle (FIGURA 23), não houve uma concordância no comportamento das variáveis que avaliam a inclinação dos incisivos 
superiores; de acordo com a variável 1.PP, a inclinação dos incisivos superiores manteve-se inalterada durante o período de avaliação, ao contrário da variável 1.NA, que revelou uma lingualização estatisticamente significante desses dentes entre as fases avaliadas. Apesar de estatisticamente significante essa lingualização foi pequena $\left(1,08^{\circ}\right)$ e de pouca significância clínica. Semelhantemente, houve uma discordância entre as variáveis que avaliam o posicionamento dos incisivos superiores; de acordo com a variável 1-NA, a posição dos incisivos superiores não alterou entre as fases T1 e T2, enquanto que a variável 1-ENAperp revelou uma protrusão estatisticamente significante (apesar de ter sido de pequena magnitude, 0,94mm) desses dentes no período de avaliação. Estas divergências entre as variáveis que avaliam a inclinação e o posicionamento dos incisivos superiores podem ter ocorrido pelo fato dessas variáveis apresentarem grande variabilidade entre os indivíduos, conjuntamente ao restrito número de indivíduos na amostra $(n=22)$. A variabilidade das grandezas cefalométricas em questão pode ser observada pelos altos valores dos desvios-padrão neste estudo (variáveis 1.PP, 1ENAperp, 1.NA e 1-NA nas TABELAS 10, 11 e 12), e também pode ser verificada nas mensurações apresentadas no Atlas de Crescimento Craniofacial $^{202}$. Sabe-se que, idealmente, quanto maior a variabilidade da variável estudada maior deverá ser a amostra, para que esta represente mais fidedignamente o comportamento da variável na população ${ }^{189,193,351}$. Entretanto, já foi discutida anteriormente a dificuldade em se obter amostras de pacientes com má oclusão sem tratamento, com finalidade de compor um grupo controle.

Em relação à altura alveolar anterior (1-PP) e posterior (6-PP), houve aumento significante entre as fases inicial e final nos três grupos estudados. É esperado o aumento das alturas alveolares anterior e posterior em decorrência do crescimento e desenvolvimento craniofacial; porém, a possível influência das terapias instituídas no aumento dessas alturas alveolares será melhor avaliada e discutida posteriormente, quando forem comparadas as alterações dessas grandezas entre os grupos. 


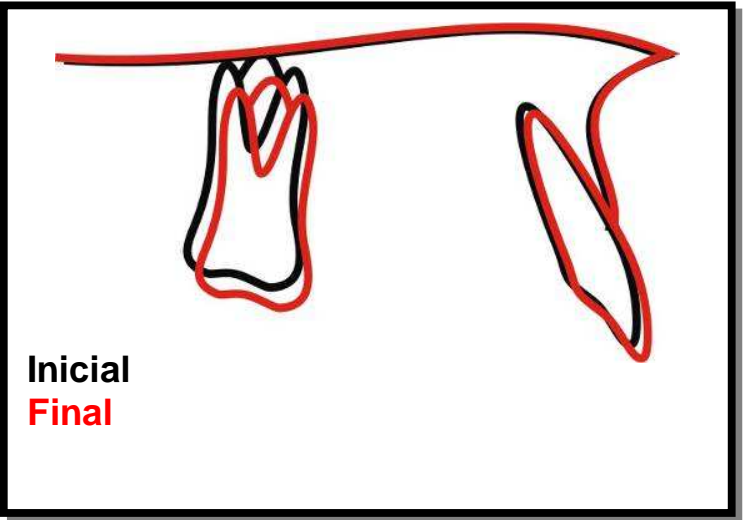

FIGURA 23 - Sobreposição em PP centrado em ENA dos cefalogramas médios iniciais e finais do Grupo Controle.

O posicionamento do molar superior não se alterou significantemente entre as fases T1 e T2 nos Grupos Experimental 1 e Controle, apesar de que houve uma tendência de distalização do molar superior no grupo tratado com o Jasper Jumper, verificada pela diminuição (não significante estatisticamente) do valor da grandeza 6-ENAperp (ou aumento do valor absoluto). Provavelmente, esta tendência de distalização do molar ocorreu em virtude da força distal gerada pela mola do aparelho Jasper Jumper tanto na maxila como nos dentes superiores. Já no Grupo Controle pode-se observar uma tendência de mesialização desse dente, como resultado do desenvolvimento normal da face. O Grupo Experimental 2 apresentou uma mesialização estatisticamente significante do molar superior durante o período de observação (o molar mesializou em média 1,24mm). Esta mesialização do molar superior pode ter sido uma conseqüência do desenvolvimento facial normal, pois observou-se uma tendência de mesialização no grupo que não recebeu nenhum tipo de tratamento; o movimento mesial do grupo tratado com o Bionator foi maior provavelmente devido ao maior tempo de avaliação desse grupo, onde os pacientes estiveram por mais tempo sob a manifestação do crescimento e desenvolvimento facial. Além disto, já foi reportado previamente que o tratamento com o Bionator não altera significantemente 0 posicionamento ântero-posterior do molar superior ${ }^{46,297}$. 


\section{Componente Dentoalveolar Inferior}

Um consenso amplamente aceito na literatura é que os aparelhos ortopédicos funcionais, de uma maneira geral, causam vestibularização dos incisivos inferiores. Este efeito é possivelmente uma conseqüência da força mesial resultante nos incisivos inferiores induzida pela protrusão mandibular.

Assim, ambos os grupos experimentais apresentaram um aumento na inclinação (vestibularização) e na protrusão dos incisivos inferiores entre as fases inicial e final do tratamento, verificado pelo aumento dos valores das variáveis IMPA, 1-Pogperp, 1.NB e 1-NB. Apesar de todas essas variáveis aumentarem suas mensurações em ambos os grupos experimentais, as diferenças entre as fases T1 e T2 não foram estatisticamente significantes apenas para a variável IMPA no Grupo Experimental 1, e 1-Pogperp no Grupo Experimental 2. Este aumento observado na inclinação vestibular e protrusão dos incisivos inferiores já foi reportado previamente, tanto como uma conseqüência do tratamento com 0 Jasper Jumper $5,6,47,79,80,170,171,183,184,215,219,226,227,310,338-340$ quanto com o Bionator ${ }^{4,7-}$ $9,12,13,16,17,46,95,118,137,158,159,161,166,211,225,297,315$. Já no Grupo Controle, tanto a inclinação quanto o posicionamento ântero-posterior dos incisivos inferiores mantiveram-se inalterados durante o período de avaliação.

A altura alveolar inferior anterior, avaliada pela variável 1-PM, não apresentou diferença estatisticamente significante entre as fases T1 e T2 no Grupo Experimental 1, entretanto, no Grupo Experimental 2 e no Grupo Controle houve aumento significante dessa grandeza entre as fases avaliadas, possivelmente em decorrência do processo normal de crescimento e desenvolvimento facial. Assim, nota-se que houve uma restrição desse desenvolvimento vertical normal da altura alveolar inferior na região dos incisivos, como possível efeito do tratamento com o aparelho Jasper Jumper (FIGURA 24). Corroborando este resultado, alguns autores observaram a intrusão dos incisivos inferiores como efeito do tratamento com o Jasper Jumper ${ }^{47,79,80,171,183,184,219,310,340}$, provavelmente em decorrência da direção da força aplicada pela mola do Jasper Jumper na região ântero-inferior (para frente e para baixo). Em relação à altura alveolar inferior posterior (6-PM), houve um aumento significante entre as fases inicial e final nos três grupos estudados (FIGURAS 24, 25 e 26). Nota-se que nos grupos experimentais esse 
aumento foi de magnitude consideravelmente maior que no Grupo Controle (3,0mm, 3,9mm, e 1,10mm, respectivamente). Nesse caso, houve uma ação do processo de crescimento e desenvolvimento facial nos três grupos, mas também houve uma possível influência dos tratamentos ortopédicoortodônticos realizados nos grupos experimentais, induzindo a extrusão dos molares inferiores, como descrito previamente na literatura como um esperado efeito do tratamento por meio do Jasper Jumper ${ }^{79,80,171,183,184,226,227}$ e do Bionator $7,9,13,16,46,48,107,108,118,133,315$.

Considerando o posicionamento do molar inferior no sentido ânteroposterior (6-Pogperp), houve um movimento mesial estatisticamente significante entre as fases avaliadas no Grupo Experimental 1. Esta mesialização do molar inferior ocorre possivelmente em virtude da direção da força (para anterior) que a mola do Jasper Jumper imprime na mandíbula e nos dentes inferiores, e já foi verificada também em estudos anteriores $^{5,6,47,79,80,170,171,183,184,215,219,226,227,310,338-340}$. No Grupo Experimental 2 houve também uma suave tendência de mesialização dos molares inferiores entre as fases T1 e T2, no entanto, sem significância estatística. No Grupo Controle, observa-se uma suave tendência de movimento contrário aos grupos experimentais durante o período de avaliação. O valor da variável 6-Pogperp diminuiu entre as fases (ou aumentou seu valor absoluto), indicando um posicionamento mais distal, porém, não foi estatisticamente significante.

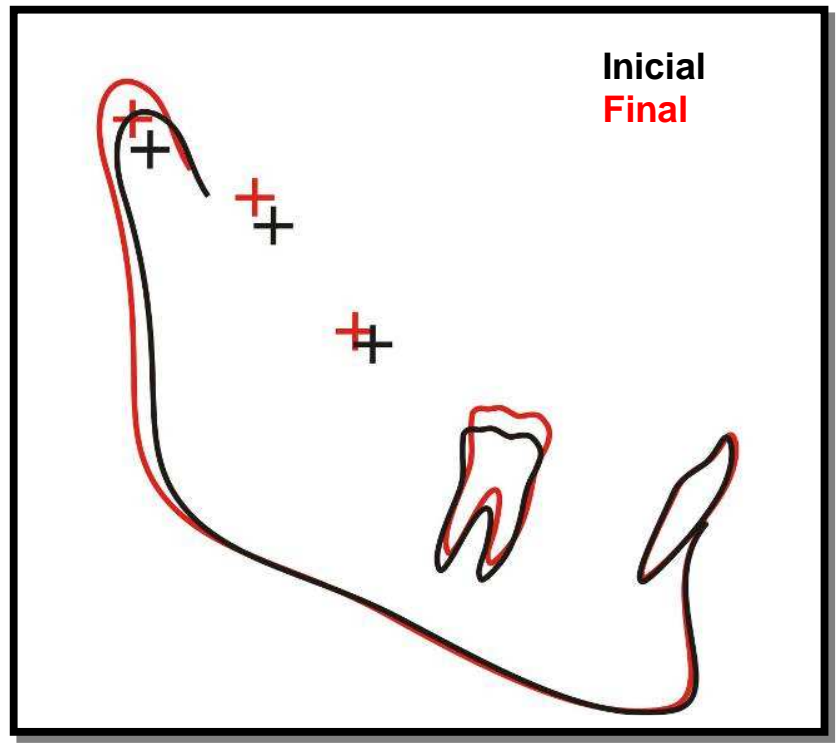

FIGURA 24 - Sobreposição no Plano Mandibular dos cefalogramas médios iniciais e finais do Grupo Experimental 1 (Jasper Jumper). 


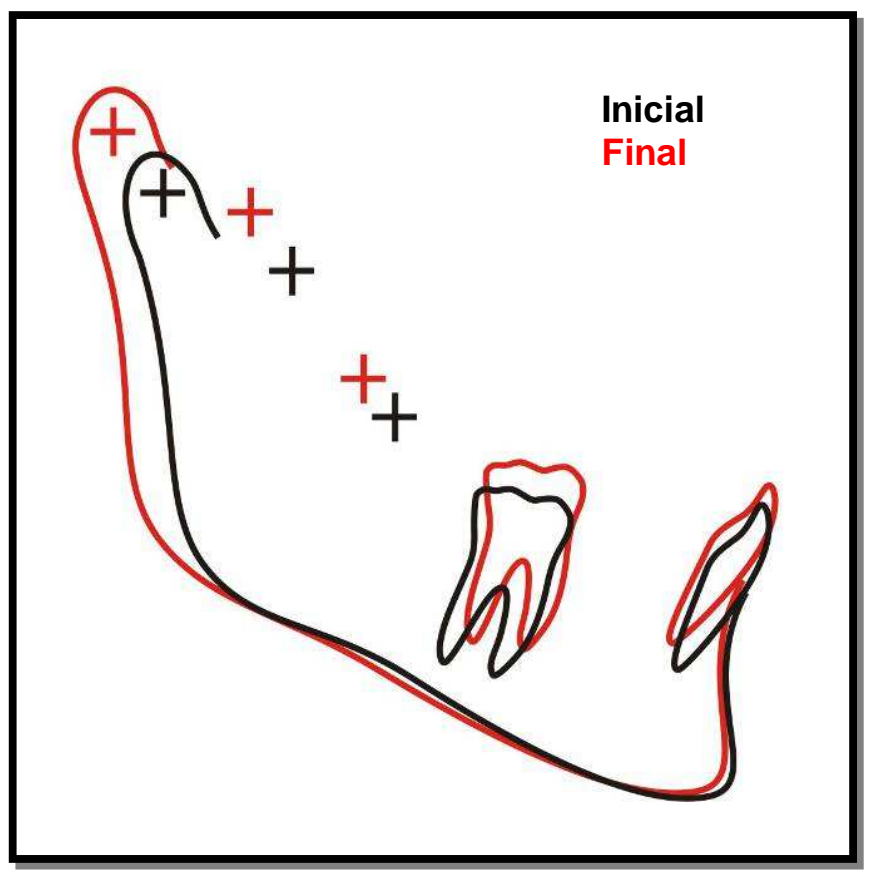

FIGURA 25 - Sobreposição no Plano Mandibular dos cefalogramas médios iniciais e finais do Grupo Experimental 2 (Bionator).

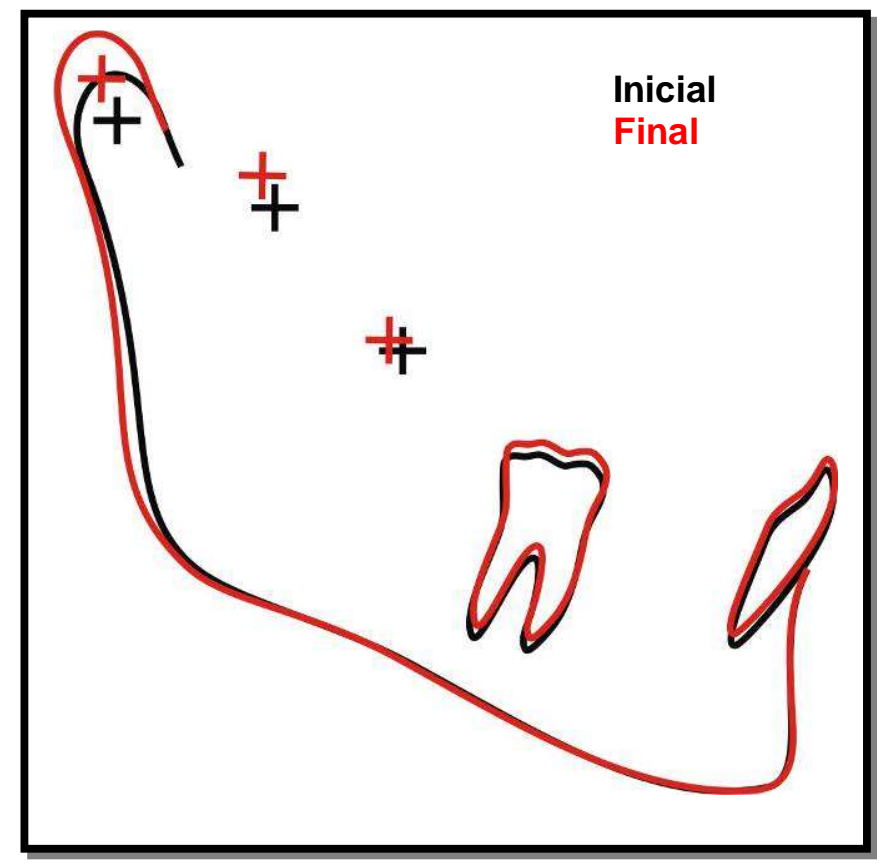

FIGURA 26 - Sobreposição no Plano Mandibular dos cefalogramas médios iniciais e finais do Grupo Controle. 


\section{Componente Relações Dentárias}

Houve diminuição estatisticamente significante do trespasse horizontal e do trespasse vertical nos grupos experimentais entre as fases inicial e final do tratamento. Além disto, houve um aumento significante da variável relação molar durante o período de avaliação nos grupos experimentais, indicando uma correção desta relação que, inicialmente, era de Classe II. Já no Grupo Controle, nenhuma das três variáveis deste componente alterou significantemente durante o período avaliado. Desta maneira, fica clara a influência dos tratamentos realizados na normalização das relações dentárias consideradas. Esta correção da relação molar e dos trespasses horizontal e vertical provavelmente ocorreu devido a um somatório de alterações esqueléticas e dentoalveolares que, conjuntamente, contribuíram para a obtenção dos resultados observados.

\section{Comparações das alterações das variáveis cefalométricas entre os grupos (TABELAS 13 e 16)}

As alterações de todas as variáveis cefalométricas estudadas do Grupo Experimental 1, do Grupo Controle, e as alterações anualizadas do Grupo Experimental 2 foram comparadas entre si e serão discutidas a seguir.

\section{Componente Maxilar}

Na comparação do posicionamento ântero-posterior da maxila (SNA e ANperp) entre os grupos, observa-se que houve uma significante retrusão nos grupos experimentais em relação ao Grupo Controle (FIGURA 27). Mesmo após a compatibilização dos grupos quanto à idade inicial, essa retrusão maxilar continuou sendo observada, revelando que não houve influência da diferença da média da idade inicial nos resultados obtidos. Entretanto, apesar da diminuição observada no valor da variável A-Nperp no Grupo Experimental 2 (TABELA 16), não houve diferença estatisticamente significante entre este grupo e o Grupo Controle, nem entre este grupo e o Grupo Experimental 1 após a compatibilização das idades iniciais, provavelmente em decorrência no número de indivíduos na amostra, que ficou reduzido. 
Grupo Experimental 1 (Jasper Jumper) $\square$ Grupo Experimental 2 (Bionator) $\square$ Grupo Controle

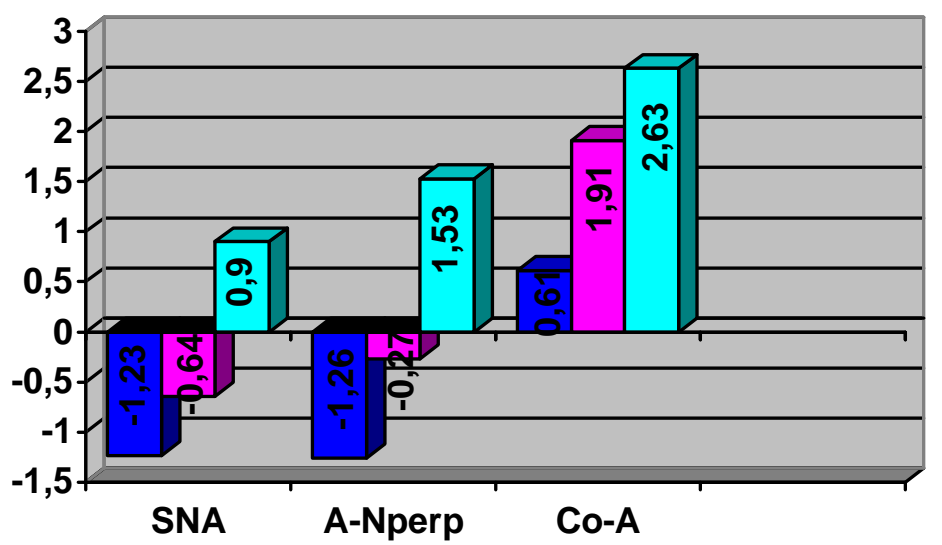

FIGURA 27 - Valores médios das alterações das variáveis cefalométricas do Componente Maxilar nos três grupos estudados.

Em relação ao comprimento efetivo da maxila, houve uma restrição estatisticamente significante do crescimento maxilar entre 0 Grupo Experimental 1 (Jasper Jumper) e o Grupo Controle, porém, o Grupo Experimental 2 apresentou-se estatisticamente semelhante aos demais grupos (FIGURA 27). Após a compatibilização dos grupos quanto à idade inicial (TABELA 16), não houve mais diferença estatisticamente significante entre os grupos de acordo com a Análise de Variância, entretanto, o tese de comparação múltipla de Tukey revelou 0 mesmo resultado obtido anteriormente, na TABELA 13.

Esta diminuição do ângulo SNA e da variável A-Nperp e a posição posterior do ponto A em relação ao Grupo Controle indicam que os aparelhos apresentam um efeito esquelético restritivo na maxila.

No tratamento com o Jasper Jumper associado ao aparelho ortodôntico fixo, os dentes superiores e os inferiores encontram-se unidos, ancorados em um arco retangular espesso, formando uma unidade ${ }^{183}$. Assim, a força direcionada para cima e para trás transmitida pelas molas do aparelho na região dos molares superiores é repercutida em toda região dentoalveolar superior; essa força distal no complexo dentoalveolar superior possivelmente é a responsável pela restrição do deslocamento anterior da maxila, bem como pela sua retrusão após o tratamento. Este é um provável efeito do tratamento com o aparelho Jasper Jumper e já foi observado por diversos autores $5,6,79,80,171,183,184,215,219,310$. Além disto, após a remoção do Jasper Jumper, 
todos os pacientes deste grupo utilizaram elásticos de Classe II como contenção ativa. Assim, mesmo após a fase ortopédica, a maxila continuou recebendo uma força distal ${ }^{2}$.

NALBANTGIL et al. $^{219}$ relataram que a restrição do deslocamento anterior da maxila foi a única alteração esquelética proporcionada pelo Jasper Jumper em seu estudo.

No caso da utilização do Bionator, 0 avanço da mandíbula proporcionado pelo aparelho cria uma força intermaxilar. A força proveniente da musculatura ativada (principalmente dos músculos retrusores) é transmitida aos dentes superiores pelo aparelho e exerce um efeito inibitório no deslocamento anterior da maxila, redirecionando seu crescimento ${ }^{166,315}$. Entretanto, este efeito nem sempre é observado; na literatura consultada a maioria dos autores relataram que o tratamento com o Bionator não alterou

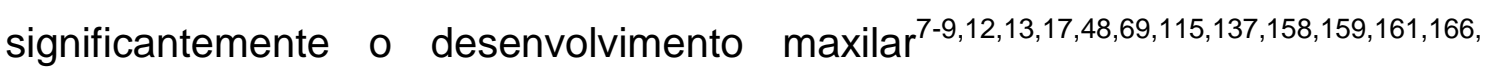
$173,318,319,346$. Por outro lado, outros trabalhos revelaram um efeito restritivo do Bionator na maxila ${ }^{46,118,133,142,188,211,225,260,315,316,331,344}$.

Sabe-se que a maioria das variáveis cefalométricas que avaliam o posicionamento e o comprimento efetivo da maxila leva em consideração o ponto A. Devido à ampla utilização deste ponto, alguns autores ${ }^{69,171,206,322,338}$ ressaltaram que o mesmo está sujeito a variações em decorrência de alterações na posição dos incisivos superiores, podendo assim, mascarar a interpretação do posicionamento e comprimento maxilar. De acordo com CARELS; REYCHLER; VAN DER LINDEN ${ }^{69}$, o ponto A geralmente é avançado em decorrência das alterações na região dos incisivos após o tratamento ortopédico funcional, uma vez que a inclinação lingual dos incisivos que normalmente ocorre, vem acompanhada pelo deslocamento vestibular dos seus ápices. Isto poderia mascarar um possível efeito restritivo no crescimento maxilar. Esta poderia ser a razão de, em vários estudos, não ter ocorrido alterações esqueléticas significantes na maxila. Neste sentido, KARACAY et al. ${ }^{171}$ ressaltaram que apesar da retrusão maxilar observada, o deslocamento do ponto $\mathrm{A}$ não foi observado, e os autores acreditam que o posicionamento deste ponto foi mascarado devido às alterações dentárias ocorridas. Entretanto, no presente estudo a inclinação dos incisivos superiores não alterou significantemente nos grupos experimentais em relação ao Grupo 
Controle (TABELAS 13 e 16) e, conseqüentemente, esta remodelação na região do ponto $A$ foi menor, minimizando a chance de ocorrer uma interpretação equivocada das alterações esqueléticas da maxila.

Somado a isto, no presente estudo avaliou-se o tratamento da má oclusão de Classe II em duas fases no Grupo Experimental 2, ou seja, os pacientes foram tratados primeiramente por meio do Bionator, e posteriormente, na fase corretiva, por meio do aparelho fixo. A maioria das pesquisas $^{7-9,12,13,17,69,115,158,159,161,166,173,318,346}$ que indica que o Bionator não apresenta um efeito restritivo na maxila avaliou apenas o tratamento ortopédico funcional, e obviamente o tempo total de avaliação foi consideravelmente inferior ao desta pesquisa. Assim, a probabilidade de ocorrerem efeitos esqueléticos na maxila em um tempo consideravelmente menor de avaliação, também se torna reduzida. Ainda, na segunda fase de tratamento deste estudo a grande maioria dos pacientes utilizou como contenção ativa ou o aparelho extrabucal (25 pacientes), algumas vezes associados aos elásticos de Classe II na fase dos arcos retangulares (15 pacientes); 2 pacientes utilizaram apenas os elásticos de Classe II como contenção ativa e apenas 3 pacientes não utilizaram contenção ativa. Sabe-se que o aparelho extrabucal e os elásticos intermaxilares de Classe II são dispositivos que também exercem uma força distal no complexo dentoalveolar superior ${ }^{2,218,318}$, reforçando a ação do Bionator na primeira fase do tratamento, o que também contribuiu para que a maxila fosse significantemente influenciada pelo tratamento realizado. No entanto, neste estudo torna-se difícil separar as alterações provocadas pelo aparelho ortopédico e pelo aparelho ortodôntico, já que a proposta do estudo foi avaliar o tratamento completo, englobando as duas fases.

Enfim, ambos os protocolos de tratamento avaliados produziram efeitos esqueléticos significantes na maxila. $O$ tratamento por meio do Jasper Jumper associado ao aparelho fixo ocasionou retrusão maxilar e restrição no seu crescimento. Já o tratamento com o Bionator e aparelho fixo proporcionou a retrusão maxilar, no entanto, não houve diferença estatisticamente significante nas alterações do comprimento efetivo da maxila entre esse grupo e os demais. 


\section{Componente Mandibular}

Nenhuma das variáveis do componente mandibular apresentou diferença estatisticamente significante de suas alterações entre os três grupos estudados (TABELA 13, FIGURA 28). Após a compatibilização dos grupos quanto à idade inicial, a variável Pog-Nperp passou a apresentar diferença estatisticamente significante, indicando uma retrusão mandibular do Grupo Experimental 1 em relação ao Grupo Controle; entretanto, esta diferença estatística possivelmente ocorreu em virtude da amostra ter sido reduzida. Independentemente da significância estatística, observa-se uma tendência das variáveis que avaliam o posicionamento ântero-posterior da mandíbula (SNB e Pog-Nperp) diminuírem seu valor no grupo tratado por meio do Jasper Jumper, quando o efeito esperado seria exatamente o oposto, de protrusão mandibular. Observa-se ainda que as variáveis que medem os incrementos do crescimento mandibular, ou seja, que quantificam o comprimento efetivo da mandíbula (CoGn), o comprimento do corpo mandibular (Go-Gn) e a altura do ramo mandibular (Co-Go) apresentaram alterações semelhantes entre os grupos (TABELAS 13, 16 e FIGURA 28). Contudo, esse crescimento mandibular normal muito contribui para a correção da má oclusão de Classe $\|^{133}$.

Grupo Experimental 1 (Jasper Jumper) $\square$ Grupo Experimental 2 (Bionator) $\square$ Grupo Controle

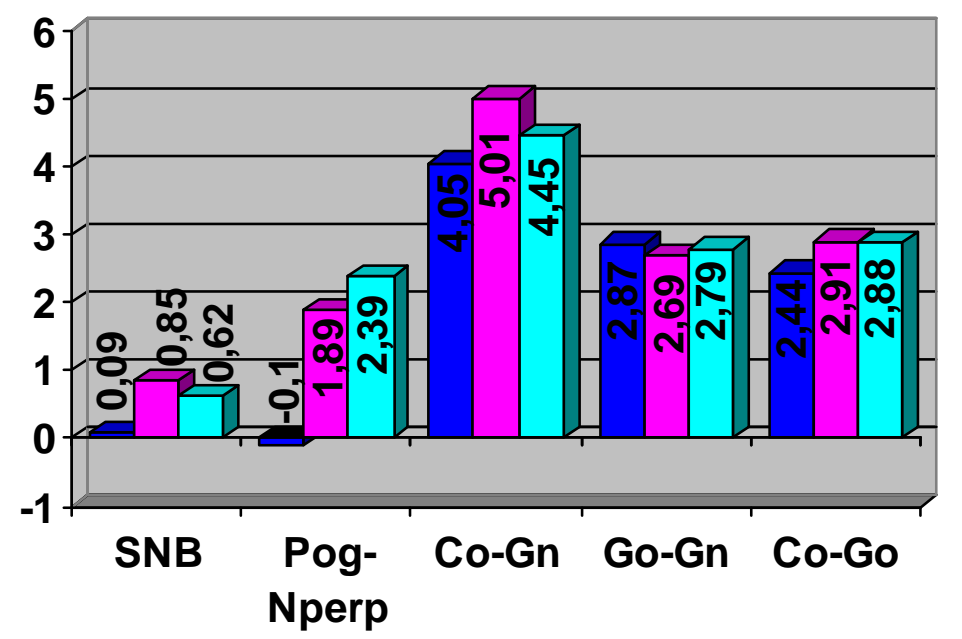

FIGURA 28 - Valores médios das alterações das variáveis cefalométricas do Componente Mandibular nos três grupos estudados. 
Como já foi aventado anteriormente, esse aparente efeito retrusivo mandibular no grupo tratado com o Jasper Jumper se deve, possivelmente, à rotação horária da mandíbula que ocorreu com o tratamento, como pode ser observado nas TABELAS 13 e 16, uma vez que ocorreu o crescimento normal mandibular, e apenas o posicionamento ântero-posterior da mandíbula apresentou uma tendência de retrusão.

O efeito da terapia com aparelhos ortopédicos funcionais no crescimento mandibular é o que apresenta maiores controvérsias e divergências entre os autores $^{166}$.

Diversos autores relatam uma protrusão mandibular significante após 0 tratamento por meio do Jasper Jumper ${ }^{5,6,171,183,184,310}$, enquanto outros estudos não evidenciaram nenhuma alteração significante no crescimento e/ou posicionamento ântero-posterior mandibular ${ }^{80,170,219,226,227}$. De acordo com os resultados desta investigação, COVELL JR. et al. ${ }^{80}$ relataram que os pacientes tratados com o Jasper Jumper apresentaram restrição do deslocamento anterior da maxila e não revelaram nenhuma alteração significante mandibular. Em relação ao tratamento com o Bionator, diversos autores acreditam que há um aumento na protrusão mandibular ${ }^{7}$ $9,12,13,16,17,35,36,46,48,69,86,89,107,108,115,137,139,158,159,173,188,199,211,225,230,297,315,318,319,344$ e nos comprimentos efetivo $7,8,12,13,16,35,36,48,89,107,108,115,137,139,147,158,159,173,188,199$, $225,266,297,318,319$ e do corpo da mandíbula ${ }^{7-9,12,13,16,297}$. Entretanto, outros autores $^{133,166,331,346}$ não evidenciaram alterações na protrusão e incrementos mandibulares. Além disto, autores que estudaram outros aparelhos ortopédicos funcionais também não evidenciaram efeitos significantes na mandíbula $64,65,91,133,154,186,331,346$.

De acordo com JOHNSTON ${ }^{168}$ (1996), os aparelhos funcionais promovem um deslocamento mandibular anterior rápido durante a primeira fase do tratamento, sendo este de natureza temporária. Posteriormente, os côndilos deverão crescer em direção à fossa articular, repondo estruturalmente o deficit de crescimento deixado por este rápido avanço mandibular. Mais recentemente (2000), VOUDOURIS; KUFTINEC ${ }^{335}$ demonstraram os efeitos dos aparelhos ortopédicos funcionais (mais precisamente, Twin-block e Herbst) no côndilo e fossa articular. Segundo os autores, o posicionamento anterior da mandíbula proporcionado pelos aparelhos ortopédicos funcionais estende os tecidos 
retrodiscais que, por sua vez, transmitem as forças para o côndilo e fossa articular, estimulando o processo de remodelação óssea nesta região. Removido o estímulo, o processo gradativamente perde a intensidade, até alcançar os níveis basais. Assim, após a remoção dos Jasper Jumpers nos pacientes do Grupo Experimental 1, procedeu-se a finalização do caso com o aparelho fixo; durante este período, que durou em média 0,73 ano, essa remodelação do côndilo e fossa articular pode ter diminuído sua intensidade, chegando próximo aos níveis basais.

Nos pacientes do Grupo Experimental 2 do presente estudo, as alterações promovidas pelos aparelhos ortopédicos e ortodônticos foram avaliadas conjuntamente, como já foi ressaltado anteriormente. Assim, não foi possível avaliar o comportamento das variáveis do componente mandibular logo após a fase ortopédica. O que se pode afirmar é que ao final do tratamento completo não houve diferenças estatisticamente significantes das alterações das variáveis do componente mandibular entre os grupos experimentais e o grupo controle (TABELAS 13 e 16). Além disto, essas variáveis apresentaram valores semelhantes entre os grupos na fase final de avaliação (TABELA 9), não sendo possível diferenciar, considerando apenas o crescimento mandibular, os pacientes submetidos ao tratamento ortopédico/ortodôntico e os jovens que não receberam nenhum tipo de tratamento. Porém, não se sabe se durante a fase ortodôntica houve recidiva das alterações esqueléticas mandibulares ocorridas na fase ortopédica do tratamento. DE VINCENZO ${ }^{89}$ observou em seu estudo que a principal recidiva do aumento do comprimento mandibular em decorrência do tratamento ortopédico funcional ocorre durante o início da fase ortodôntica.

Assim, ao final do período de avaliação, nenhum dos protocolos de tratamento avaliados promoveu alterações significantes na mandíbula, nem no seu posicionamento ântero-posterior, nem nos seus incrementos. Houve uma tendência de um posicionamento mandibular mais retruído no grupo tratado por meio do Jasper Jumper, possivelmente em decorrência da rotação horária da mandíbula neste grupo. 


\section{Componente Relação Maxilomandibular}

Houve uma melhora significante do relacionamento entre as bases ósseas, bem como da convexidade do perfil ósseo nos grupos experimentais em relação ao Grupo Controle (FIGURA 29).

Q Grupo Experimental 1 (Jasper Jumper) $\square$ Grupo Experimental 2 (Bionator) $\square$ Grupo Controle

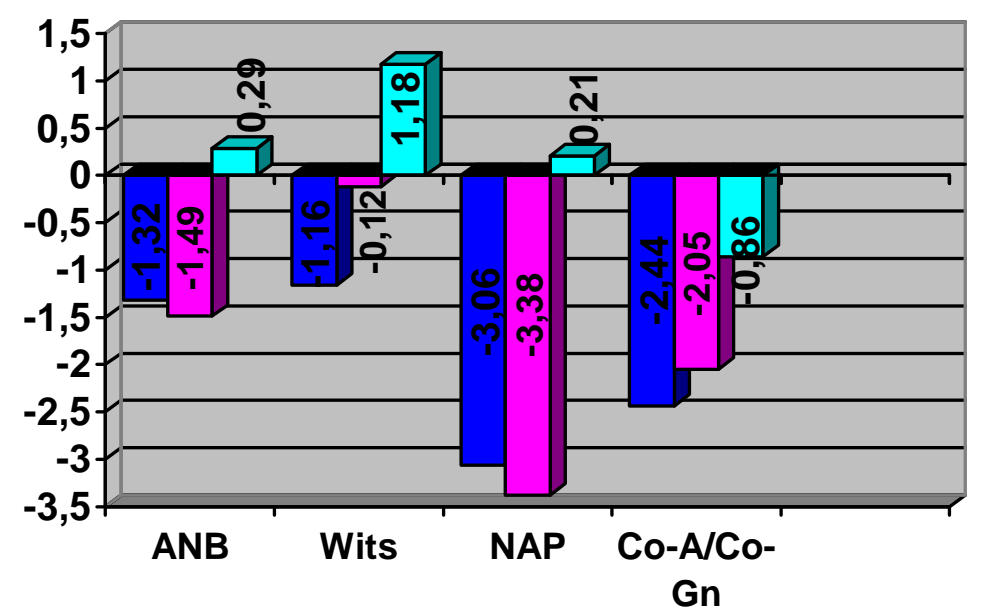

FIGURA 29 - Valores médios das alterações das variáveis cefalométricas do Componente Relação Maxilomandibular nos três grupos estudados.

As alterações no relacionamento maxilomandibular podem ocorrer em virtude da combinação de vários efeitos nas estruturas dentoesqueléticas, associada ao crescimento normal craniofacial dos indivíduos ${ }^{7,323}$.

Nesta pesquisa, a melhora no relacionamento entre as bases ósseas e na convexidade facial parece ter ocorrido como resultado da retrusão maxilar nos grupos experimentais, associada ao crescimento e deslocamento normal da mandíbula para anterior. $O$ Grupo Experimental 1 beneficiou-se mais da restrição do crescimento maxilar e da retrusão desta base óssea, enquanto que o grupo tratado por meio do Bionator foi influenciado, em parte, pela retrusão maxilar e, por outro lado, pela protrusão mandibular decorrente do crescimento normal. Além disto, alguns efeitos dentoalveolares podem ter influenciado esses resultados. Suportando os resultados obtidos, vários autores já reportaram a melhora no relacionamento maxilomandibular após o tratamento com o Jasper Jumper ${ }^{171,184,219,226,227}$ e Bionator $^{7,9,12,13,16,17,84,86,115,137,139,188,211,266,318,319,346 . ~}$ 
Normalmente, o ajuste ântero-posterior entre as bases ósseas ocorre pelo crescimento diferencial entre a maxila e a mandíbula ${ }^{16}$, aqui avaliado pela variável Co-A/Co-Gn. Houve uma diminuição estatisticamente significante da proporção Co-A/Co-Gn no Grupo Experimental 1 em relação ao Grupo Controle; no Grupo Experimental 2 verificou-se uma diminuição nesta proporção, menor que a do Grupo Experimental 1 e maior que a do Grupo Controle, porém sem significância estatística com esses dois grupos. Cabe ressaltar que no Grupo Controle também houve uma redução na proporção entre o crescimento maxilar e mandibular, porém, de menor magnitude que a apresentada nos grupos experimentais. Isto indica que houve um crescimento diferencial da mandíbula em relação à maxila em todos os grupos (os incrementos do comprimento efetivo da mandíbula foram consideravelmente maiores que os do comprimento efetivo maxilar, em decorrência do crescimento mandibular normal). Assim, observa-se que, apesar dos tratamentos realizados não demonstrarem alterações significantes no componente mandibular em relação ao Grupo Controle, eles diminuíram a proporção entre os comprimentos maxilar e mandibular em maior magnitude do que verificado nos jovens sem tratamento. Isto ocorreu principalmente em decorrência da restrição do crescimento maxilar nos grupos experimentais, já descrita previamente. Logo, os menores valores das alterações da variável CoA/Co-Gn nos grupos experimentais relacionam-se às menores alterações do comprimento efetivo da maxila nesses grupos em relação ao controle, somado ao crescimento mandibular normal.

Enfim, as duas terapias empregadas foram efetivas na melhora da relação maxilomandibular e na redução da convexidade facial, verificadas pelas diferenças apresentadas em relação ao Grupo Controle.

\section{Componente Padrão de Crescimento}

O comportamento do padrão de crescimento craniofacial influencia diretamente a relação ântero-posterior entre as bases ósseas ${ }^{206}$. Desta maneira, torna-se importante o conhecimento das alterações verticais decorrentes dos tratamentos realizados, as quais podem favorecer ou não a correção da má oclusão de Classe II. 
De acordo com as variáveis que avaliam a orientação do padrão de crescimento da face, os grupos experimentais exibiram comportamentos diferentes. Houve uma tendência de rotação horária na mandíbula dos jovens tratados por meio do Jasper Jumper, enquanto os pacientes tratados com o Bionator apresentaram a mesma tendência dos jovens não tratados, ou seja, a rotação mandibular no sentido anti-horário, indicando que este tratamento não alterou significantemente o padrão de crescimento da face (FIGURA 30). Desta maneira, o Grupo Experimental 1 apresentou um aumento da variável SN.GoGn, enquanto os demais grupos revelaram uma diminuição da mesma, porém, estas diferenças foram estatisticamente significantes de acordo com a Análise de Variância, mas ao se aplicar o teste de comparação múltipla de Tukey, não foi possível detectar diferenças significantes. Esta divergência entre os testes estatísticos pode ocorrer, como já discutida anteriormente, por se tratar de testes diferentes, com precisões diferentes e, geralmente, ocorre quando o valor do "p" encontra-se próximo ao nível de significância adotado (no caso, $p<0,05$ ). Ao se compatibilizar os grupos quanto à idade inicial (TABELA 16), além da significância estatística para a Análise de Variância, pôde-se observar diferenças acusadas pelo teste de Tukey, onde o Grupo Experimental 1 apresentou um aumento significante de SN.GoGn em relação ao Grupo Controle. O Grupo Experimental 2 apresentou uma suave diminuição do valor de SN.GoGn, e foi estatisticamente semelhante aos demais grupos.

Confirmando estas tendências, a variável FMA apresentou aumento estatisticamente significante no Grupo Experimental 1 em relação aos demais grupos, que apresentaram diminuição do valor desta variável e foram estatisticamente semelhantes entre si (TABELAS 13 e 16, FIGURA 30). 
口 Grupo Experimental 1 (Jasper Jumper) $\square$ Grupo Experimental 2 (Bionator) $\square$ Grupo Controle

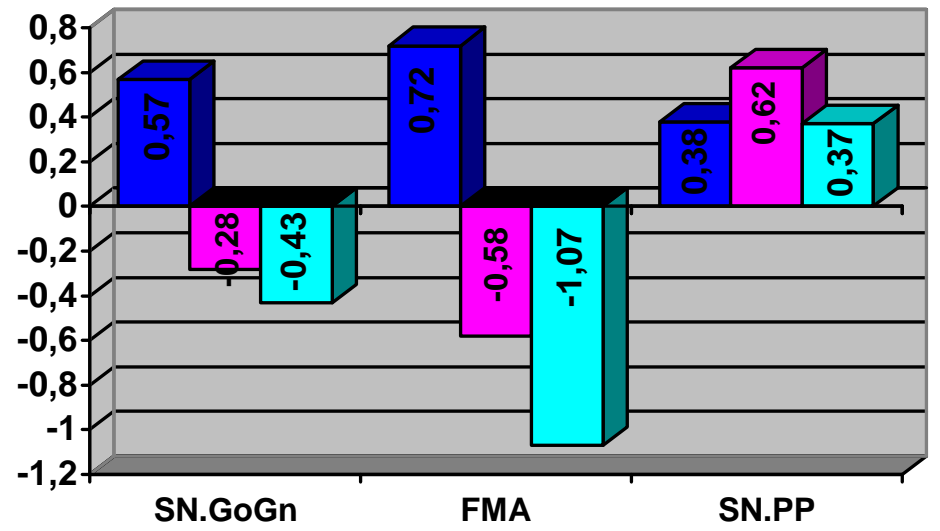

FIGURA 30 - Valores médios das alterações das variáveis SN.GoGn, FMA e SN.PP do Componente Padrão de Crescimento nos três grupos estudados.

$\mathrm{Na}$ literatura consultada, alguns autores ${ }^{79,171}$ também observaram essa rotação horária da mandíbula como resultado do tratamento com o Jasper Jumper, enquanto outros ${ }^{7-9,12,13,16,17,56,69,138,188,198}$ relataram que o tratamento por meio do Bionator não alterou significantemente o padrão de crescimento dos pacientes, de acordo com os resultados aqui apresentados. Em contrapartida, outros investigadores ${ }^{48,297,346}$ observaram um aumento do vetor de crescimento vertical após o tratamento por meio do Bionator, e alguns trabalhos não verificaram alterações verticais significantes em decorrência do

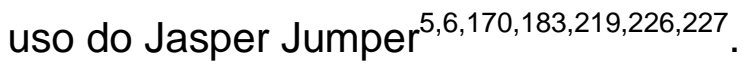

Com o crescimento normal, há uma tendência de rotação mandibular no sentido anti-horário ${ }^{202,273}$, como observado nos jovens não tratados deste estudo, uma vez que a altura facial posterior se desenvolve mais que a anterior $^{48,71,140,156,232,248}$. Os principais fatores que podem alterar 0 posicionamento vertical mandibular são: a direção do crescimento condilar e o desenvolvimento vertical maior na região dos molares, o que leva a uma rotação no sentido horário, aumentando a $\mathrm{AFAl}^{296}$. No presente estudo, o desenvolvimento vertical dos molares superiores (6-PP) foi semelhante entre os três grupos estudados, entretanto, o desenvolvimento vertical dos molares inferiores foi significantemente maior nos grupos experimentais em relação ao controle, indicando extrusão destes dentes. Observa-se um maior desenvolvimento vertical dos molares inferiores no grupo tratado por meio do 
Jasper Jumper, seguido do grupo tratado pelo Bionator, porém, estatisticamente, estes grupos foram semelhantes. Acredita-se que mesmo sem significância estatística, a diferença do desenvolvimento vertical dos molares inferiores entre os dois grupos experimentais, de $0,71 \mathrm{~mm}$ a mais para o Grupo Experimental 1, apresenta uma repercussão clínica de maior rotação mandibular no sentido horário para este grupo. Este maior aumento no processo alveolar posterior inferior no grupo tratado por meio do Jasper Jumper certamente contribui para a rotação horária da mandíbula. Em relação ao grupo tratado por meio do Bionator, apesar de ter ocorrido um aumento no processo dentoalveolar posterior significantemente maior que o do Grupo Controle, este aumento não foi suficiente para promover a rotação horária da mandíbula; houve uma rotação mandibular anti-horária neste grupo, seguindo a mesma tendência do controle, porém esta rotação foi um pouco menos expressiva que a ocorrida no Grupo Controle. Provavelmente, o grupo do Bionator apresentou menor rotação anti-horária que o controle, apesar de não significante estatisticamente, por influência desse aumento significante da variável 6-PM.

Considerando o aparelho Jasper Jumper, acredita-se que o aparelho imprime uma força na mandíbula em direção anterior e inferior, ocasionando uma leve rotação posterior ${ }^{171}$. Especula-se que devido à direção de força dos módulos do aparelho, o Jasper Jumper promove um componente de força vertical maior que os aparelhos ortopédicos funcionais removíveis, que seria um fator a mais contribuindo para a significante rotação mandibular horária em decorrência desta terapia.

Além deste fator, o crescimento condilar provavelmente foi influenciado pelas terapias instituídas $24,47,64,142,171,211,230,236,253,268,282,284$, fato que repercute diretamente na rotação mandibular. BALTROMEJUS; RUF; PANCHERZ ${ }^{32}$, em 2002, avaliaram o efeito na articulação têmporo-mandibular (ATM) do tratamento com dois tipos de aparelhos ortopédicos funcionais, um fixo (Herbst) e um removível (Ativador). Os autores observaram que os efeitos do tratamento na ATM foram significantemente diferentes entre os grupos. Enquanto as alterações efetivas no crescimento da ATM no grupo do Ativador foram direcionadas verticalmente e anteriormente, verificou-se um desenvolvimento mais para posterior no grupo do Herbst. Assim, a análise dos efeitos do tratamento, de acordo com os autores, sugere uma forte estimulação do 
crescimento condilar vertical induzido pela terapia com o Ativador. Ainda, o aumento no componente vertical do crescimento condilar poderia ter ocorrido devido às forças intermitentes geradas pelo Ativador, em contraste às forças contínuas liberadas pelo aparelho de Herbst. Em relação à rotação mandibular, os autores observaram que o fato do crescimento condilar ter sido estimulado predominantemente em uma direção vertical durante o tratamento com 0 Ativador foi responsável pela significante rotação mandibular para anterior neste grupo. No grupo do Herbst, houve uma suave rotação mandibular para posterior em decorrência das alterações predominantemente em direção posterior na ATM. Analogamente, no presente estudo, observou-se a rotação mandibular para posterior no grupo tratado pelo aparelho ortopédico funcional fixo (Jasper Jumper), e para anterior no grupo tratado com o aparelho ortopédico funcional removível (Bionator). Acredita-se que as alterações na ATM induzida pelos aparelhos desta pesquisa tenham sido equivalentes às observadas por BALTROMEJUS; RUF; PANCHERZ ${ }^{32}$, pela semelhança dos mecanismos de ação dos aparelhos em questão. Desta maneira, as alterações na ATM contribuíram para os resultados obtidos nesta investigação em relação ao padrão de crescimento.

Entretanto, PANCHERZ; FACKEL ${ }^{248}$ acreditam que 0 efeito desses aparelhos ortopédicos funcionais, no caso o aparelho de Herbst, no padrão de crescimento craniofacial apresenta apenas um impacto temporário.

As alterações da inclinação do plano palatino foram estatisticamente semelhantes entre os três grupos avaliados (FIGURA 30), concordando com os trabalhos averiguados na literatura, que relatam que os tratamentos ortopédicos ou ortopédico/ortodônticos realizados não alteram significantemente a inclinação do plano palatino em relação à base do crânio $(\mathrm{SN} . P P)^{80,183,209,226,227}$. ALMEIDA e colaboradores ${ }^{7,9,13}$, em seus estudos sobre o Bionator, encontraram diferenças estatisticamente significantes da inclinação do plano palatino em relação ao controle; entretanto, observa-se que, de acordo com a presente pesquisa, houve uma discreta rotação horária do ângulo SN.PP no grupo do Bionator, e o que diferiu nos trabalhos dos referidos autores foi o comportamento do grupo controle, que apresentou uma rotação anti-horária deste ângulo, responsável pela diferença estatisticamente significante entre os grupos. 
As alterações da inclinação do plano oclusal funcional (POF) em relação à base do crânio (SN.POF) diferiram significantemente entre os grupos (FIGURA 31). Houve uma menor rotação anti-horária do POF no grupo tratado por meio do Jasper Jumper em relação ao grupo do Bionator, com significância estatística. Já em relação ao Grupo Controle, apesar da diferença das alterações neste ângulo entre os grupos ser grande, não foi estatisticamente significante de acordo com o teste de Tukey. Após a compatibilização dos grupos quanto à idade inicial, observa-se as mesmas tendências aqui apresentadas, porém, de acordo com a Análise de Variância, as diferenças das alterações da grandeza SN.POF entre os grupos não foram significantes. Isto ocorreu possivelmente devido ao número de indivíduos em cada grupo, que foi reduzido para viabilizar a referida compatibilização.

口 Grupo Experimental 1 (Jasper Jumper) $\square$ Grupo Experimental 2 (Bionator) $\square$ Grupo Controle

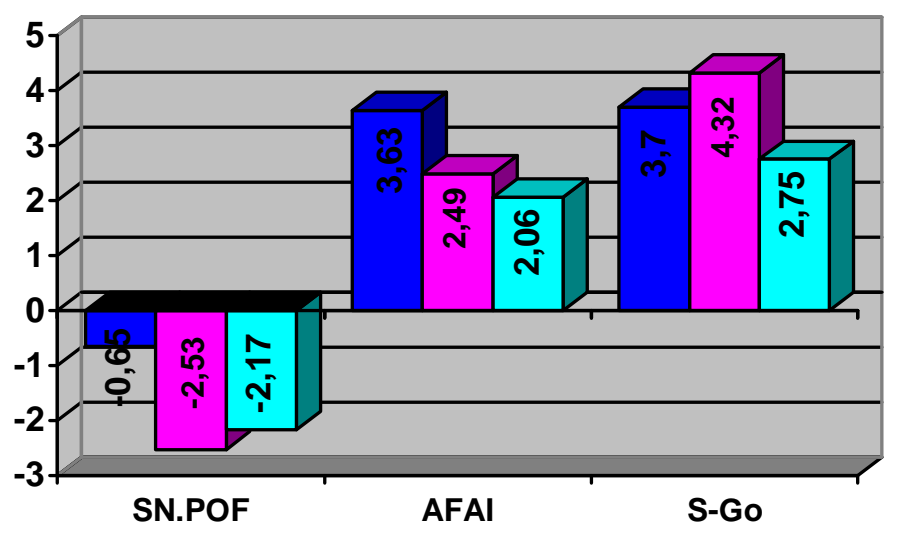

FIGURA 31 - Valores médios das alterações das variáveis SN.POF, AFAl e S-Go do Componente Padrão de Crescimento nos três grupos estudados.

Cabe ressaltar que a rotação do plano oclusal funcional no sentido antihorário consiste em uma alteração normal do crescimento facial ${ }^{92,125,202,302}$.

Provavelmente, o acrílico do Bionator em contato com os dentes superiores foi o responsável pela semelhança deste grupo com o Grupo Controle em relação ao ângulo do plano oclusal funcional, pois os desgastes póstero-inferiores no acrílico permitiram a extrusão apenas dos dentes inferiores em direção aos superiores, sem que houvesse alterações no plano oclusal dos dentes superiores e na posição vertical de grupos de dentes. Logo, o tratamento não influenciou esse ângulo significativamente, ocorrendo apenas 
as alterações normais do desenvolvimento facial. Como no tratamento com o Jasper Jumper não há acrílico em contato com os dentes superiores, e o aparelho exerce força intrusiva nos molares superiores ${ }^{47,79,80,163-}$ $165,171,183,184,215,219,310,338,340$ e nos incisivos inferiores ${ }^{47,79,80,171,183,184,219,310,340}$, e força extrusiva nos incisivos superiores ${ }^{80,171,183,184,219}$ e molares inferiores $^{79,80,171,183,184,226,227}$, essas alterações dentárias resultam em restrição da rotação anti-horária do plano oclusal, como verificado na presente pesquisa, ou em rotação horária do plano oclusal, evidenciada em estudos anteriores $^{80,171,183,184,219}$.

Avaliando as alterações ocorridas na mensuração da altura facial ânteroinferior (AFAI), verifica-se um aumento estatisticamente significante para 0 Grupo Experimental 1 (Jasper Jumper) em relação ao Grupo Controle (FIGURA 31). O Grupo Experimental 2 apresentou-se estatisticamente semelhante aos demais grupos, apesar do aumento da AFAl neste grupo ter sido consideravelmente menor que o do grupo tratado com o Jasper Jumper. Após a compatibilização dos grupos em relação à idade inicial, não houve diferenças estatisticamente significantes entre os grupos, embora as mesmas tendências fossem observadas no comportamento da AFAI. Isto provavelmente ocorreu em conseqüência, mais uma vez, do número reduzido da amostra após a compatibilização.

Segundo KARACAY et al. ${ }^{171}$, o giro da mandíbula no sentido horário no grupo dos pacientes tratados por meio do Jasper Jumper foi o principal responsável pelo aumento significante da AFAl em relação aos jovens que não

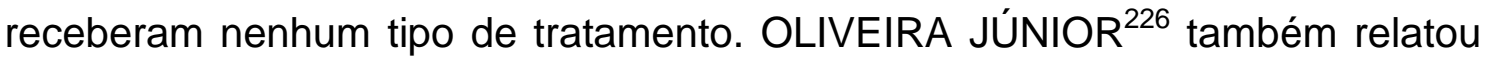
um aumento da AFAl nos pacientes tratados por meio do Jasper Jumper, porém, sem significância estatística.

Acredita-se que o maior desenvolvimento dentoalveolar vertical na região dos molares inferiores (6-PM) no Grupo Experimental 1 também contribuiu para este aumento significante da AFAI. Houve também um aumento vertical significante na região dentoalveolar dos molares inferiores no grupo tratado pelo Bionator (de menor magnitude que o observado no grupo do Jasper Jumper), no entanto, este aumento não foi suficiente para alterar significantemente a AFAI, uma vez que não se constatou o giro horário da mandíbula neste grupo. Pelo contrário, houve uma rotação anti-horária, 
semelhante à ocorrida no Grupo Controle, compensando em parte o desenvolvimento vertical dos molares inferiores dos pacientes do grupo do Bionator.

KÜÇÜKKELES; ILHAN; ORGUN ${ }^{183}$ descreveram que as alterações na AFAl foram mínimas durante a fase ativa do tratamento com o Jasper Jumper, tanto no grupo experimental como no controle. O único aumento significante na AFAl ocorreu durante o nivelamento, o que pode ser atribuído à extrusão dos dentes posteriores. A presente investigação avaliou o tratamento total com 0 Jasper Jumper associado ao aparelho fixo, portanto, possíveis alterações da AFAl ocorridas durante a fase do nivelamento foram consideradas nos resultados obtidos.

Assim, corroborando os resultados desta pesquisa, vários autores $^{7,9,12,13,16,17}$ não verificaram uma alteração significante da AFAl em decorrência da utilização do aparelho Bionator em relação a indivíduos não tratados, embora outros $48,56,73,84,137,138,142,147,188,198,225,315,346$ verificaram aumento significante na altura facial ântero-inferior. Entretanto, muitos trabalhos que relatam aumento da AFAl após o uso do Bionator ou outros aparelhos ortopédicos funcionais removíveis, ou tratam de relatos de casos clínicos ou não utilizam um grupo controle, dificultando a interpretação precisa do comportamento dessa altura como um resultado do tratamento, e não do crescimento normal e esperado.

A altura facial posterior (S-Go) aumentou de maneira semelhante nos três grupos avaliados, não ocorrendo diferenças com significância estatística entre os mesmos (FIGURA 31). Entretanto, observa-se que o Grupo Controle apresentou menor magnitude de aumento desta variável. Estes resultados foram observados ainda mesmo após a compatibilização dos grupos quanto à idade inicial (TABELA 16). De acordo com KARACAY et al. ${ }^{171}$, o aumento da altura facial posterior está relacionado ao crescimento condilar.

Em suma, o tratamento por meio do Jasper Jumper associado ao aparelho fixo apresentou uma suave, porém significante rotação horária da mandíbula, uma restrição da rotação anti-horária do plano oclusal e aumento da AFAI, denotando uma influência vertical deste tratamento nas estruturas faciais. Este pode ser um fator limitante deste protocolo de tratamento em pacientes dolicofaciais. Já o tratamento com o Bionator e aparelho ortodôntico 
fixo não ocasionou alterações verticais significantes em relação ao Grupo Controle.

\section{Componente Dentoalveolar Superior}

As diferenças entre os grupos são mais pronunciadas para as variáveis dentoalveolares, como observado por ALMEIDA et al. ${ }^{8}$.

Inicialmente foram avaliadas as alterações da inclinação (1.PP e 1.NA) e do posicionamento ântero-posterior (1-ENAperp e 1-NA) dos incisivos superiores nos grupos estudados. Observa-se que, embora os grupos experimentais tenham apresentado maiores alterações, em especial o Grupo Experimental 2 (Bionator), os três grupos foram estatisticamente semelhantes em relação à alteração da inclinação dos incisivos superiores, considerando as duas variáveis selecionadas para esta finalidade. Avaliando o posicionamento ântero-posterior destes dentes, houve uma discordância entre as duas variáveis utilizadas. De acordo com a grandeza 1-ENAperp, os grupos experimentais apresentaram uma retrusão estatisticamente significante em relação a Grupo Controle. Entretanto, de acordo com a variável 1-NA, os grupos foram estatisticamente semelhantes (FIGURA 32). Após a compatibilização dos grupos quanto à idade inicial (TABELA 16), resultados semelhantes foram observados.

Acredita-se que, apesar da divergência entre as variáveis, houve a retrusão dos incisivos superiores nos grupos experimentais em relação ao controle. Ainda, esta retrusão foi mais expressiva no grupo tratado por meio do Jasper Jumper, observada pelas maiores magnitudes das alterações ocorridas neste grupo. Especula-se que, para a avaliação do posicionamento ânteroposterior dos incisivos, a variável 1-ENAperp torna-se mais confiável, pois esta utiliza como referência o plano palatino, que não foi significantemente alterado durante o período de avaliação em nenhum grupo, e a espinha nasal anterior. No caso da grandeza cefalométrica 1-NA, utiliza-se como referência um ponto na base de crânio e, portanto, mais distante da região avaliada, que é o ponto $\mathrm{N}$, e outro na maxila, o ponto $\mathrm{A}$. Sabe-se que o ponto $\mathrm{A}$ é altamente passível de variações em decorrência de tratamentos ortopédicos e/ou ortodônticos, principalmente quando há movimentações ou inclinações extensas dos incisivos superiores ${ }^{69,171,206,322,338}$. Apesar de que neste estudo a inclinação dos 
incisivos superiores não alterou significantemente numa comparação entre os grupos, clinicamente a inclinação lingual ocorrida nos grupos experimentais pode ser significativa, uma vez que a magnitude das alterações variou de 2,11응 a $3,67^{\circ}$ (de acordo com as variáveis 1.PP e 1.NA - FIGURA 32). O fato de estatisticamente não ter ocorrido diferença significante pode estar relacionado à grande variabilidade na população do comportamento das grandezas cefalométricas relacionadas aos incisivos, como já considerado previamente ${ }^{251}$. Somado a isto, houve um efeito inibitório na maxila nos grupos experimentais, mais intenso no Grupo Experimental 1. Obviamente, supõe-se que os dentes superiores acompanham a retrusão maxilar, tornando-se retruídos também, mas não em relação à maxila, pois há uma retrusão em bloco, da base óssea juntamente com os dentes nela contidos. Sendo assim, as variáveis que avaliam o posicionamento dos incisivos superiores e utilizam pontos ou planos de referência apenas na maxila, como é o caso de 1-ENAperp, quantificam as alterações puramente dos incisivos, sem interferência das alterações ocorridas na própria base óssea. Por outro lado, quando se utiliza pontos de referências longe das bases ósseas, como o caso de 1-NA, pode haver interferência das alterações ocorridas na maxila. Considerando a linha NA, com a retrusão maxilar esta linha fica mais inclinada para posterior, ou mais verticalizada, acompanhando neste sentido o movimento de lingualização e retrusão dos incisivos superiores. Com isto, a mensuração de 1-NA fica alterada, no sentido de revelar um valor maior que o real, mascarando a possível retrusão dos incisivos, podendo até mesmo passar uma impressão de protrusão destes dentes (FIGURA 33).

No entanto, optou-se por manter a variável 1-NA neste estudo devido à sua ampla utilização nas pesquisas científicas com avaliações por meio da cefalometria. Assim, seria possível obter mais parâmetros na literatura para comparações aos resultados alcançados com esta investigação. 
Grupo Experimental 1 (Jasper Jumper) $\square$ Grupo Experimental 2 (Bionator) $\square$ Grupo Controle

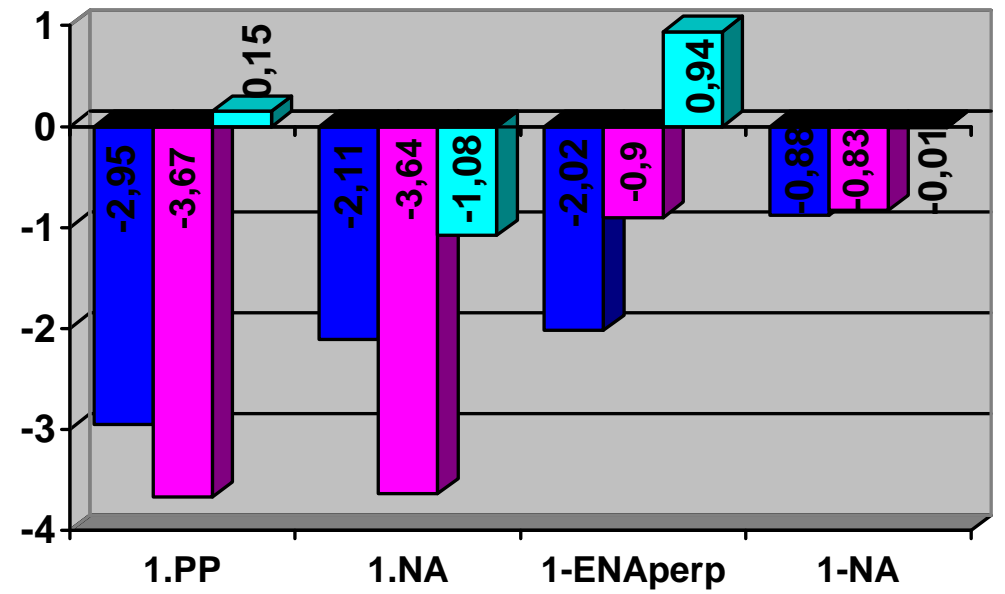

FIGURA 32 - Valores médios das alterações das variáveis 1.PP, 1.NA, 1-ENAperp e 1-NA do Componente Dentoalveolar Superior nos três grupos estudados.

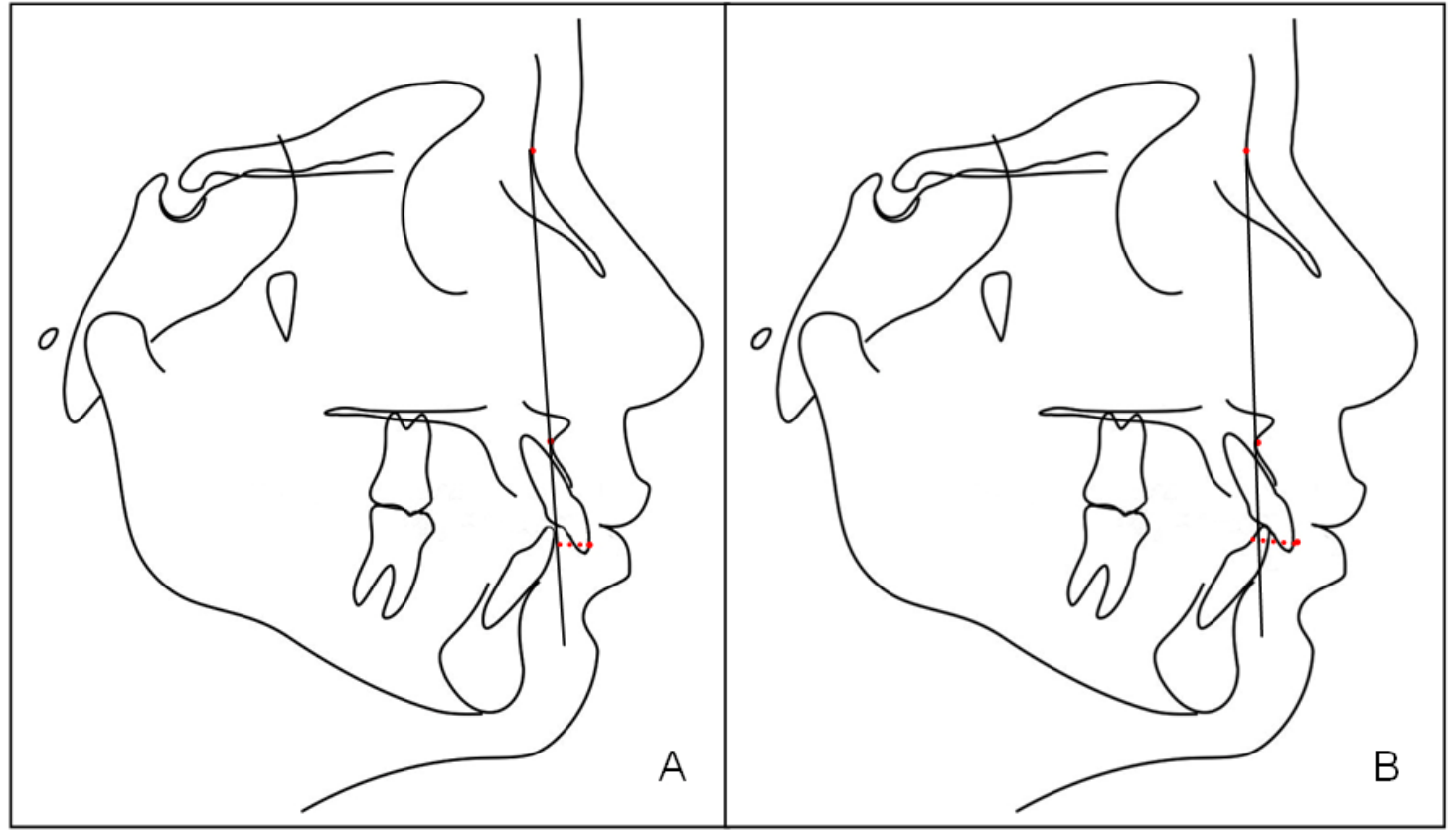

FIGURA 33 - Desenho esquemático representando a variação da inclinação da linha NA com a retrusão maxilar e sua influência na avaliação da posição do incisivo superior. As duas figuras são idênticas, apresentando apenas o posicionamento ântero-posterior da maxila alterado. Em $A$, a maxila encontra-se protruída; em $B$, após a retrusão, a linha NA ficou mais verticalizada, sugerindo que os incisivos superiores foram protruídos. No entanto, o posicionamento desses dentes em relação à maxila não foi alterado neste esquema. 
Neste estudo, verificou-se a retrusão estatisticamente significante e a retroinclinação clinicamente significante (apesar de estatisticamente não significante) dos incisivos superiores nos grupos experimentais em relação ao controle.

No caso do Jasper Jumper, estes efeitos ocorrem em virtude do "efeito extrabucal" do aparelho, já descrito anteriormente e relatado na literatura ${ }^{171,183,219}$. Assim, quando a força direcionada para cima e para trás proveniente das molas do aparelho Jasper Jumper é aplicada na região posterior superior, normalmente ocorre a distalização e intrusão dos molares superiores, e os efeitos conseqüentes na região anterior do arco superior são a extrusão e verticalização dos incisivos ${ }^{183}$.

OLIVEIRA JÚNIOR ${ }^{226}$; OLIVEIRA JÚNIOR ; ALMEIDA ${ }^{227}$ observaram que o grupo que utilizou o Jasper Jumper apresentou uma suave inclinação para vestibular dos incisivos superiores (1.NA) e uma discreta retrusão dos mesmos (1-NA e 1-FHp), embora sem significância estatística. Estes resultados podem ter ocorrido em razão das variáveis utilizadas para avaliação dos incisivos superiores.

COVELL JR. et al. ${ }^{80}$ avaliaram cefalometricamente o tratamento com o Jasper Jumper, e constituíram para isto dois grupos, um considerando o tratamento completo, constando de radiografias antes da instalação do aparelho fixo e após a remoção do mesmo, incluindo a fase ortopédica com o Jasper Jumper. O outro grupo constou de radiografias obtidas ao início e final da fase do tratamento com o Jasper Jumper. Os autores observaram que enquanto os Jasper Jumpers estavam sendo utilizados, os incisivos superiores foram retroinclinados. Porém, durante a finalização ortodôntica, essa retroinclinação foi corrigida. Este pode ter sido um dos fatores que contribuiu para que, no atual estudo, a alteração da inclinação dos incisivos superiores não tenha sido estatisticamente significante. Resultados semelhantes foram descritos por STUCKI; INGERVALL ${ }^{310}$, em 1998, onde os incisivos superiores foram moderadamente retroinclinados quando os Jasper Jumpers foram usados. Ao final do período de observação (em média 7 meses após a remoção do Jasper Jumper) não houve diferença significante em relação à inclinação inicial. 
Pelo fato dos pacientes continuarem com o aparelho fixo após a remoção dos Jasper Jumpers, a não significância da alteração da inclinação dos incisivos superiores poderia ser atribuída à expressão da prescrição do aparelho ortodôntico ${ }^{80}$. Além disto, um componente de correção pode ocorrer devido à tendência de recidiva das correções dentoalveolares ${ }^{80,215,310}$. De acordo com STUCKI; INGERVALL ${ }^{310}$, a recidiva parcial dos efeitos dentoalveolares da terapia após o uso do Jasper Jumper torna clara a indicação de uma sobrecorreção moderada.

Além disto, uma outra razão para que neste estudo o tratamento com o Jasper Jumper tenha promovido a retrusão, mas mantido a inclinação dos incisivos superiores foi a utilização de arcos retangulares com torques vestibulares de coroa inseridos ao fio $^{183}$, mesmo utilizando braquetes préajustados, como já discutido anteriormente. De acordo com esses resultados, KARACAY et al. ${ }^{171}$ relataram que o "efeito extrabucal" do aparelho influenciou os incisivos superiores, de maneira que eles foram extruídos, retruídos e inclinados para lingual. No entanto, a inclinação lingual dos incisivos centrais não foi significante no grupo do Jasper Jumper quando comparado ao controle.

Com a utilização do Bionator, a força retrusiva da musculatura em decorrência do avanço mandibular atua diretamente sobre os incisivos superiores, que tendem a verticalizar e retruir em suas bases ósseas. Alguns autores, como ALMEIDA ${ }^{7}$ e ALMEIDA et al. ${ }^{8}$, atribuem os efeitos nos incisivos superiores ao arco vestibular do aparelho Bionator, que entra em contato com os incisivos durante o uso do aparelho, particularmente durante o sono. Entretanto, esta participação primordial do arco vestibular nos movimentos dos incisivos superiores foi questionada por MCNAMARA JR.; HOWE; DISCHINGER ${ }^{209}$, em 1990. Os autores compararam os efeitos dos tratamentos com o aparelho de Herbst e com o de Fränkel, e observaram que, com a utilização de ambos os aparelhos, houve a retroinclinação dos incisivos superiores. Os autores ressaltaram que o aparelho de Fränkel possui um arco vestibular que toca a região ântero-superior, enquanto que o aparelho de Herbst não apresenta esse arco. Assim, o papel do arco vestibular superior na inclinação lingual dos incisivos superiores foi questionado.

O que parece mesmo acontecer com o uso do Bionator é a atuação de uma força para trás na maxila, que também é transmitida aos dentes 
superiores, em especial, os anteriores, fazendo com que se movimentem nesta mesma direção; desta maneira os incisivos são lingualizados e/ou retruídos. Alguns autores ${ }^{166}$ referem-se a este efeito como o "efeito extrabucal", como já dito previamente. Acredita-se que, mesmo que o arco vestibular do aparelho não seja o principal responsável pelos efeitos promovidos nos incisivos superiores, ele contribui com esses efeitos transmitindo a força retrusiva da musculatura, gerada pelo avanço mandibular, aos dentes ântero-superiores.

Enfim, a verticalização e retrusão dos incisivos superiores são altamente favoráveis nos casos com trespasse horizontal acentuado e incisivos superiores vestibularizados e protruídos, características estas freqüentemente observadas na má oclusão de Classe II, $1^{\text {a }}$ divisão ${ }^{46,71,96,328}$. Por outro lado, a lingualização excessiva desses dentes pode limitar o avanço mandibular ${ }^{322}$.

Ao se avaliar as alterações da altura do processo alveolar superior em sua região anterior (1-PP), observa-se que houve um aumento estatisticamente significante no grupo tratado pelo Jasper Jumper em relação ao Grupo Controle, indicando que houve extrusão dos incisivos superiores com 0 tratamento. O grupo tratado pelo Bionator apresentou um suave aumento desta distância, porém, não houve diferenças estatisticamente significantes na comparação entre os grupos (FIGURA 34). Após a compatibilização dos grupos em relação à idade inicial, as mesmas tendências foram reveladas, entretanto, não houve diferenças estatisticamente significantes entre os grupos. Mais uma vez isto pode ter ocorrido em decorrência da redução da amostra, uma vez que a diferença das alterações da variável 1-PP nos Grupos Experimental $1 \mathrm{e}$ Controle entre a comparação inicial (TABELA 13) e a comparação após a compatibilização foi de apenas $0,01 \mathrm{~mm}$.

Como ja foi considerado anteriormente, até mesmo neste tópico da discussão, a extrusão dos incisivos superiores é um efeito esperado do tratamento por meio do Jasper Jumper, como conseqüência da força decorrente do aparelho Jasper Jumper, causando na região anterior maxilar a extrusão e verticalização dos incisivos ${ }^{80,171,183,184,219}$.

Os molares superiores foram significantemente distalizados no Grupo Experimental 1 (Jasper Jumper) em relação aos demais grupos, e no sentido vertical não foram significantemente alterados em nenhum dos grupos estudados (FIGURA 34). 
Grupo Experimental 1 (Jasper Jumper) $\square$ Grupo Experimental 2 (Bionator) $\square$ Grupo Controle

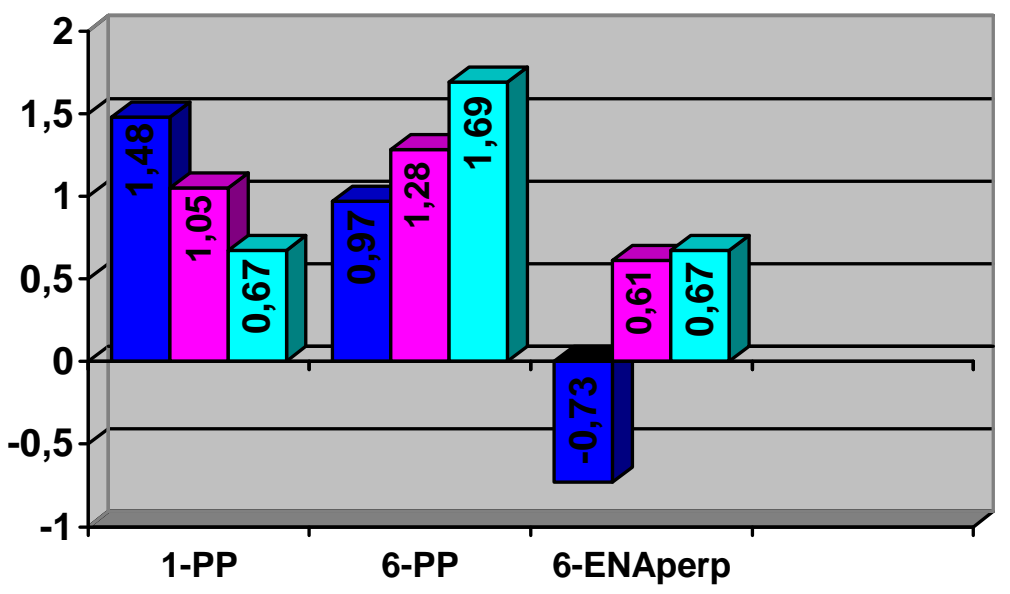

FIGURA 34 - Valores médios das alterações das variáveis 1-PP, 6-PP e 6-ENAperp do Componente Dentoalveolar Superior nos três grupos estudados.

A distalização dos molares superiores com a utilização do Jasper Jumper é compreensível, pois as molas do aparelho exercem uma força para distal e para cima nesta região, que é repercutida em toda estrutura dentoalveolar da maxila; entretanto, o dente que recebe diretamente a força que posteriormente é transmitida à maxila é o $1^{\circ}$ molar superior. Com o uso do Bionator, a força de origem muscular não apresenta um ponto de aplicação; ela é distribuída na maxila por meio do acrílico e dos fios do aparelho.

Segundo NALBANTGIL et al. $^{219}$, pelo fato dos molares e incisivos superiores estarem unidos por meio do aparelho fixo, formando uma unidade, os incisivos são retroinclinados e os molares distalizados como um resultado do "efeito extrabucal" do aparelho. KARACAY et al. ${ }^{171}$ verificaram que os primeiros molares superiores foram significantemente intruídos e distalizados, devido ao vetor de força, que passava abaixo e atrás do centro de resistência dentoalveolar da maxila.

Porém, no presente estudo, os molares superiores foram significantemente distalizados após a terapia com o Jasper Jumper; no sentido vertical, observa-se que este grupo apresentou menor alteração da variável 6PP, revelando uma tendência de restrição da extrusão natural dos molares superiores, mas, no entanto, sem significância estatística. Isto pode ter ocorrido, em parte, pela utilização da barra palatina soldada aos molares 
superiores, desde a montagem do aparelho fixo, permanecendo durante quase todo o tratamento. Além disto, o componente horizontal (de distalização) da força exercida pelos módulos do aparelho parece ser maior que o componente vertical (de intrusão). Assim, somente a barra palatina não foi suficiente para impedir a distalização dos molares superiores, mas limitou a intrusão (ou restrição da extrusão) dos mesmos. Neste sentido, NALBANTGIL et al. ${ }^{219}$ modificaram o vetor de força do Jasper Jumper, tornando-o mais vertical, por meio da utilização de arcos segmentados; conseqüentemente, este vetor de força mais vertical intruiu e inclinou os molares superiores significantemente.

OLIVEIRA JÚNIOR ${ }^{226}$; OLIVEIRA JÚNIOR ; ALMEIDA $^{227}$ relataram a extrusão dos molares superiores, no entanto, sem significância estatística em relação ao controle.

A intrusão e distalização dos molares superiores proporcionadas pelo tratamento com o Jasper Jumper foram amplamente relatadas na literatura consultada $47,79,80,163-165,171,183,184,215,219,310,338,340$.

Em relação ao tratamento com o Bionator, o acrílico mantido sempre em contato com os molares superiores não impediu o desenvolvimento vertical natural, observado pelo aumento da variável 6-PP estatisticamente semelhante ao aumento ocorrido nos jovens que não receberam nenhum tratamento. Ainda, o posicionamento ântero-posterior desses dentes não alterou significantemente no grupo do Bionator. Estes resultados encontram-se suporte na literatura, onde alguns autores relatam que os molares superiores não sofreram alteração em sua posição vertical ${ }^{13,17,48,315}$ nem ântero-posterior ${ }^{46,297}$.

Ao final da avaliação das alterações ocorridas no componente dentoalveolar superior, verifica-se que os incisivos superiores foram significantemente retruídos nos grupos experimentais e extruídos no grupo tratado por meio do Jasper Jumper. Os molares superiores foram significantemente distalizados no grupo do Jasper Jumper, e não foram alterados no sentido vertical em nenhum dos grupos avaliados.

\section{Componente Dentoalveolar Inferior}

Os efeitos ântero-posteriores do tratamento nos incisivos inferiores foram mais marcantes no Grupo Experimental 2 (Bionator) (FIGURAS 35 e 36). Os incisivos inferiores inclinaram significantemente para vestibular nos pacientes tratados com o Bionator e aparelho fixo quando comparados aos 
jovens que não se submeteram a nenhum tipo de tratamento. $O$ grupo do Jasper Jumper apresentou um aumento da inclinação dos incisivos inferiores, porém, sem significância estatística em relação aos demais grupos (FIGURA 35). Todos estes resultados foram descritos de acordo com a variável 1.NB; segundo a Análise de Variância, a grandeza IMPA não apresentou diferença significante entre os grupos, no entanto, de acordo com o teste de Tukey, as diferenças foram significantes, fornecendo os mesmos resultados já descritos para a variável 1.NB. Entretanto, após a compatibilização dos grupos quanto à idade inicial (TABELA 16 e FIGURA 36), as diferenças em relação à grandeza IMPA foram significantes tanto para a ANOVA quanto para o teste de comparações múltiplas de Tukey, e resultados semelhantes aos descritos anteriormente puderam ser observados.

Avaliando as alterações do posicionamento ântero-posterior dos incisivos inferiores (1-Pogperp e 1-NB), observou-se uma tendência de protrusão nos grupos experimentais, com significância estatística de acordo com a Análise de Variância, porém, o teste de comparações múltiplas de Tukey não detectou diferenças significantes entre os grupos (TABELA 13 e FIGURA 35). Após a compatibilização dos grupos de acordo com a idade inicial, a Análise de Variância não apresentou diferenças significantes entre os grupos para as variáveis em questão, já o teste de Tukey revelou diferenças significantes entre o grupo tratado com o Bionator e o controle; o grupo tratado pelo Jasper Jumper apresentou-se semelhante aos demais de acordo com este teste post hoc (TABELA 16 e FIGURA 36). Observa-se que nestes casos 0 valor do "p" esteve sempre próximo ao nível de significância adotado (5\%), o que favoreceu esta discordância entre os testes estatísticos. 
Grupo Experimental 1 (Jasper Jumper) $\square$ Grupo Experimental 2 (Bionator) $\square$ Grupo Controle

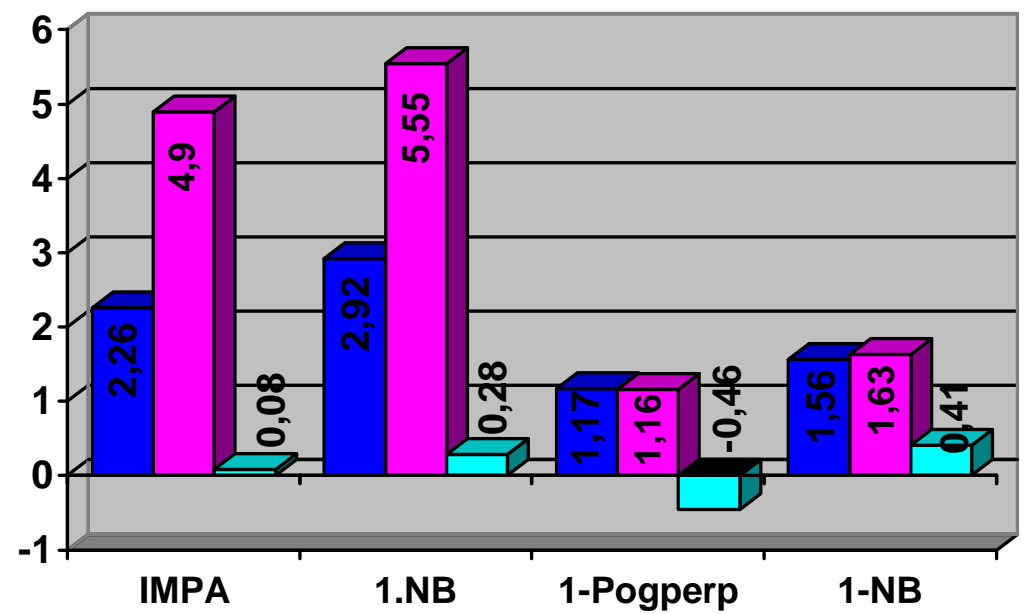

FIGURA 35 - Valores médios das alterações das variáveis IMPA, 1.NB, 1-Pogperp e 1-NB do Componente Dentoalveolar Inferior nos três grupos estudados.

— Grupo Experimental 1 (Jasper Jumper) $\square$ Grupo Experimental 2 (Bionator) $\square$ Grupo Controle

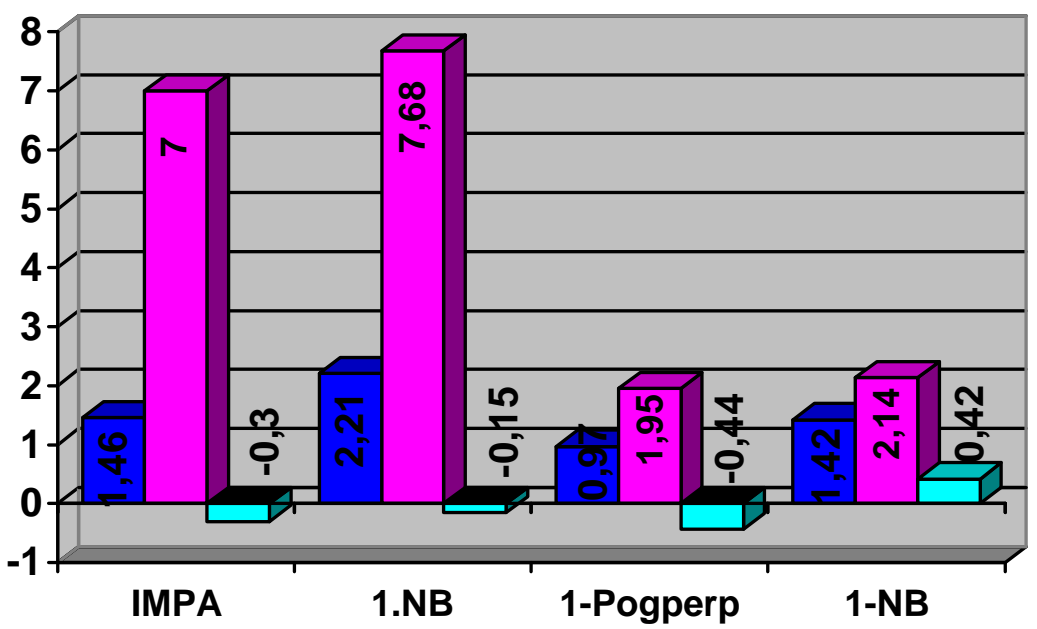

FIGURA 36 - Valores médios das alterações das variáveis IMPA, 1.NB, 1-Pogperp e 1-NB do Componente Dentoalveolar Inferior nos três grupos compatibilizados quanto à idade inicial.

Deve-se ressaltar o grande valor dos desvios-padrão verificados para as variáveis que avaliam o comportamento horizontal dos incisivos inferiores, demonstrando grande variabilidade destas variáveis nos indivíduos. Um grande desvio-padrão para essas variáveis também foi averiguado por CAFFER ${ }^{64}$. 
Alguns autores ${ }^{64,310}$ consideram o comportamento dos incisivos inferiores bastante variável em decorrência à terapia ortopédica funcional.

O aparelho Jasper Jumper aplica uma força para anterior e para baixo no arco inferior ${ }^{171}$, o que pode levar à vestibularização e à protrusão dos incisivos. No entanto, no presente estudo, os pacientes tratados por meio deste dispositivo apresentaram tendência de vestibularização e protrusão dos incisivos inferiores, porém, estatisticamente foram semelhantes tanto com o grupo que não recebeu nenhum tipo de tratamento ortopédico e/ou ortodôntico, quanto com o grupo tratado por meio do Bionator, que por sua vez apresentou grandes alterações nos incisivos inferiores. $O$ fato dos dois grupos experimentais terem apresentado semelhança de acordo com os testes estatísticos deixa claro uma influência, mesmo que discreta, do tratamento com o Jasper Jumper nos incisivos inferiores. Se não houvesse nenhuma influência, provavelmente o teste de comparações múltiplas de Tukey revelaria semelhança do grupo do Jasper Jumper com o Grupo Controle e diferença com o grupo do Bionator, e isto não ocorreu.

A grande variabilidade do comportamento dos incisivos inferiores, averiguada pelos grandes desvios-padrão das variáveis consideradas, pode ter influenciado os resultados desta pesquisa. Desta maneira, se o número de pacientes do grupo do Jasper Jumper fosse aumentado, possivelmente seriam observadas diferenças no posicionamento ântero-posterior e inclinação dos incisivos inferiores com significância estatística. Devido à grande variabilidade reportada anteriormente, uma amostra maior representaria mais fielmente 0 comportamento da população.

Ainda, deve-se lembrar que todas as alterações dentoalveolares resultam da interação da terapia ortopédica e ortodôntica.

COVELL JR. et al. ${ }^{80}$ relatou a vestibularização dos incisivos inferiores tanto na fase ortopédica com o Jasper Jumper, quanto após a sua remoção e finalização do caso com aparelho fixo, evidenciando que o aparelho fixo não corrigiu esta vestibularização. Entretanto, STUCKI; INGERVALL ${ }^{310}$ observaram uma marcante vestibularização dos incisivos durante o uso do Jasper Jumper, no entanto, estes dentes foram amplamente verticalizados quando os Jasper Jumpers foram removidos. De acordo com os autores, em média apenas 30\% da vestibularização ocorrida durante a fase da utilização do Jasper Jumper 
permaneceu ao final do período de observação (em média 7 meses após a remoção do Jasper Jumper). Assim, o efeito residual do tratamento consiste em uma moderada vestibularização dos incisivos inferiores.

No presente estudo, pode ter ocorrido também a vestibularização e posteriormente esta acentuada retroinclinação dos incisivos inferiores após a remoção do Jasper Jumper, tanto pela tendência natural de recidiva ${ }^{310}$, quanto pela utilização de torque lingual de coroa inserido na região ântero-inferior do arco retangular, durante a fase ativa do Jasper Jumper e na fase de finalização com aparelho fixo.

Desta maneira, todos estes fatores considerados atuaram conjuntamente fazendo com que, ao final do período de avaliação, não houvesse diferença estatisticamente significante entre o grupo tratado por meio do Jasper Jumper e os demais grupos.

Com relação ao uso do Bionator, as significantes protrusão e vestibularização observadas em relação ao Grupo Controle são, provavelmente, conseqüência da resultante de força mesial nos incisivos inferiores induzida pela protrusão mandibular ${ }^{8,147,158,166,313,315}$. Estes efeitos são amplamente citados na literatura 4,7-9,12,13,16,17,46,95,118,137,158,159, 161,166,211,225,297,315, apesar de alguns investigadores ${ }^{48,107,108,346}$ não terem relatado a vestibularização e protrusão dos incisivos inferiores. Nesta pesquisa, em concordância com 0 descrito anteriormente por outros autores ${ }^{7-}$ 9,12,13,16,17,211,225,315, o recobrimento dos incisivos inferiores com acrílico no Bionator não preveniu a vestibularização desses dentes, como relatado por BOLMGREN; MOSHIRI ${ }^{48}$. Desta maneira, de acordo com os resultados do presente estudo, deve-se ter cautela em utilizar o Bionator em pacientes que apresentam incisivos inferiores vestibularizados antes do início do tratamento.

A vestibularização dos incisivos normalmente é considerada um efeito desfavorável da terapia funcional ${ }^{219}$.

Entretanto, COVELL JR. et al. $^{80}$ ponderam que, levando em consideração a proporção dos efeitos esqueléticos e dentoalveolares dos aparelhos funcionais, nota-se que apesar dos incisivos inferiores não apresentarem ao final do tratamento a inclinação e posicionamento ideais em relação à base óssea, de acordo com as normas cefalométricas ${ }^{273}$, a vestibularização dos mesmos representa, em parte, uma compensação 
dentoalveolar necessária para mascarar a discrepância esquelética das bases ósseas persistente ao final do tratamento ${ }^{309}$.

A possível recessão gengival proporcionada pela vestibularização dos incisivos inferiores foi objeto de vários estudos ${ }^{212,279,348,349}$. De acordo com RUF; HANSEN; PANCHERZ ${ }^{279}$, não há uma correlação entre a quantidade de inclinação vestibular dos incisivos inferiores e o desenvolvimento de recessão gengival em crianças e adolescentes. MELSEN; ALLAIS ${ }^{212}$ evidenciaram em seus estudos que a recessão gengival na região dos incisivos inferiores não aumentou significantemente durante o tratamento ortodôntico. De acordo com os autores, os principais fatores predisponentes são o biotipo gengival, presença de placa visível e inflamação. YARED; ZENOBIO; PACHECO ${ }^{348,349}$ relacionam o desenvolvimento de recessões gengivais ântero-inferiores com a magnitude da inclinação final dos incisivos inferiores (e não a alteração da inclinação) e, com mais relevância, com a espessura da gengiva marginal livre que, de acordo com os autores, não deve ser menor que $0,5 \mathrm{~mm}$.

Além disto, a vestibularização dos incisivos inferiores não leva ao apinhamento ântero-inferior após o tratamento ortopédico funcional. Em uma análise a longo prazo, o desenvolvimento do apinhamento nos incisivos inferiores associa-se com as alterações do crescimento craniofacial normal ${ }^{129}$.

Avaliando a alteração do posicionamento vertical dos incisivos inferiores, observa-se que houve uma significante restrição do seu desenvolvimento vertical no grupo tratado por meio do Jasper Jumper em relação ao Grupo Controle. O grupo tratado pelo Bionator apresentou-se estatisticamente semelhante aos demais (TABELA 13 e FIGURA 37). Entretanto, após os grupos terem sido compatibilizados em função da idade inicial, esta diferença da alteração da variável 1-PM entre o Grupo Experimental 1 e o Grupo Controle não foi mais estatisticamente significante (TABELA 16). Como os grupos continuaram apresentando a mesma tendência após a compatibilização, acredita-se que a não significância estatística se deu em função da redução da amostra.

A intrusão dos incisivos inferiores pode ocorrer em decorrência da direção de força aplicada pelas molas do aparelho Jasper Jumper nesta região, para baixo e para anterior ${ }^{171}$, e também como uma conseqüência do aumento da inclinação desses incisivos para vestibular ${ }^{209,219,306}$, ainda que não 
significante estatisticamente, diminuindo a distância da borda incisal do incisivo inferior ao plano mandibular. Cabe ressaltar que esta alteração média dos incisivos inferiores nos pacientes tratados com o Jasper Jumper, de acordo com a variável 1.NB, foi de quase $3^{\circ}$. A intrusão dos incisivos inferiores como um resultado da terapia com o Jasper Jumper foi verificada por vários

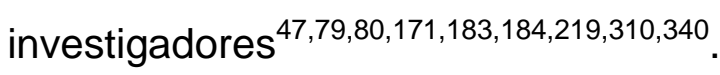

No caso do Bionator, o recobrimento dos incisivos inferiores com acrílico parece ter sido eficiente em restringir o desenvolvimento vertical destes dentes, como observado por outros autores ${ }^{7,8,64,329}$, o que contribuiu também para a correção da sobremordida profunda.

Os molares inferiores extruíram significantemente nos grupos experimentais em relação ao controle, e foram significativamente mesializados no Grupo Experimental 1 (Jasper Jumper) em relação ao Grupo Controle. O Grupo Experimental 2, apesar de ter verificado um aumento da variável 6Pogperp, o que poderia indicar uma mesialização dos molares inferiores, apresentou-se estatisticamente semelhante aos outros dois grupos em relação ao posicionamento ântero-posterior desses dentes (TABELAS 13 e 16, FIGURA 37).

$\square$ Grupo Experimental 1 (Jasper Jumper) $\square$ Grupo Experimental 2 (Bionator) $\square$ Grupo Controle

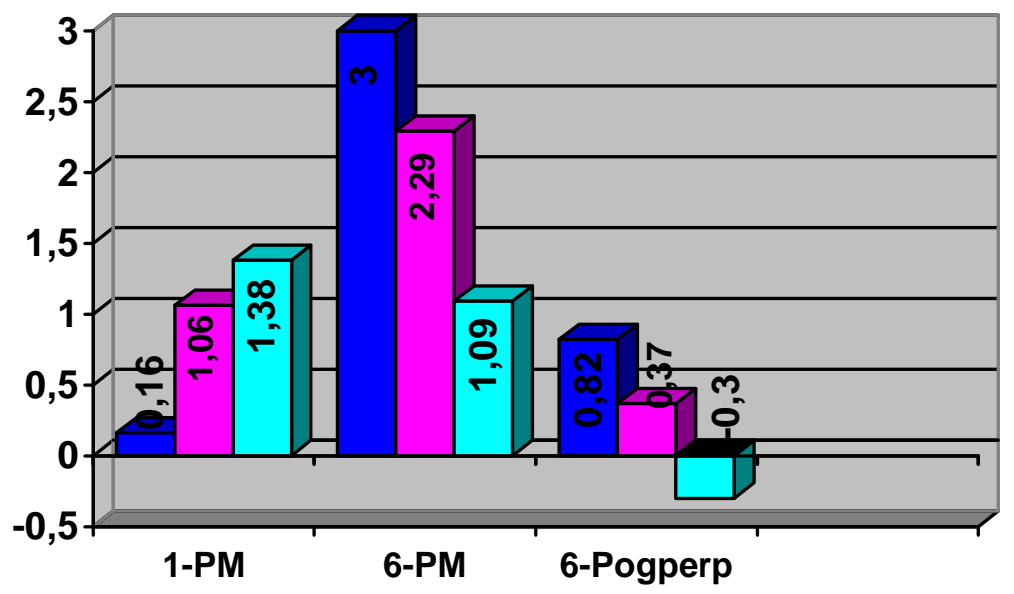

FIGURA 37 - Valores médios das alterações das variáveis 1-PM, 6-PM e 6-Pogperp do Componente Dentoalveolar Inferior nos três grupos estudados. 
De acordo com KARACAY et al. ${ }^{171}$, o aparelho Jasper Jumper exerce força para frente e para baixo nos dentes ântero-inferiores, e em conseqüência a este efeito, os molares inferiores extruem e movimentam-se para mesial. Estes efeitos já foram também relatados em diversos estudos $^{5,6,79,80,170,171,183,184,215,219,226,227,310,338-340 .}$.

Encontra-se bem fundamentado na literatura que a correção da relação molar de Classe II é facilitada quando se inibe a irrupção do molar superior e estimula-se a irrupção do molar inferior, que tende a extruir e mesializar ${ }^{80,133}$, de acordo com o princípio da erupção diferencial de HARVOLD ${ }^{133}$. Este efeito pode ser obtido tanto com os aparelhos ortopédicos funcionais fixos ${ }^{80,234,236,327}$ como com os removíveis ${ }^{17,46,166,297,315}$.

Além disto, a extrusão dos dentes póstero-inferiores auxilia a correção da sobremordida profunda e o nivelamento da Curva de Spee, visto que em grande parte dos casos de má oclusão de Classe II, $1^{1}$ divisão há sobremordida e Curva de Spee acentuadas.

No caso dos aparelhos ortopédicos funcionais removíveis, como o Bionator, estes movimentos dos molares inferiores são proporcionados pelo desgaste do acrílico na sua porção póstero-inferior. A extrusão significante dos molares inferiores como resultado do tratamento com o Bionator foi verificada por vários autores $7,9,13,16,17,46,48,107,108,118,133,315$, em concordância aos resultados do presente estudo. Porém, o tratamento não influenciou significantemente o posicionamento ântero-posterior desses dentes, considerando que não houve diferença estatisticamente significante entre o Grupo Experimental 2 e o Grupo Controle. Verifica-se na literatura que poucos trabalhos avaliaram 0 posicionamento ântero-posterior dos molares inferiores após o tratamento ortopédico funcional. Dentre eles, alguns também não revelaram a mesialização significante dos molares inferiores ${ }^{64,154,155,186,313,331}$, embora outros descreveram a movimentação para mesial desses dentes ${ }^{16,17,46,166,297,315}$.

Enfim, de acordo com as alterações observadas no componente dentoalveolar inferior, os incisivos inferiores protruíram e vestibularizaram significantemente nos pacientes tratados por meio do Bionator e apresentaram uma tendência de protrusão nos pacientes tratados com o Jasper Jumper quando comparados ao controle. Os molares inferiores foram significantemente 
extruídos nos grupos experimentais e mesializados no grupo tratado pelo Jasper Jumper em relação ao controle.

\section{Componente Relações Dentárias}

Os trespasses horizontal e vertical foram significantemente reduzidos pelos tratamentos realizados quando comparados aos jovens que não receberam nenhum tipo de tratamento. A variável relação molar, por sua vez, aumentou significantemente nos grupos experimentais em relação ao Grupo Controle, indicando uma correção da relação molar inicial de Classe II (FIGURA 38). Estas correções resultam de um somatório de alterações de natureza esquelética e dentoalveolar.

Q Grupo Experimental 1 (Jasper Jumper) $\square$ Grupo Experimental 2 (Bionator) $\square$ Grupo Controle

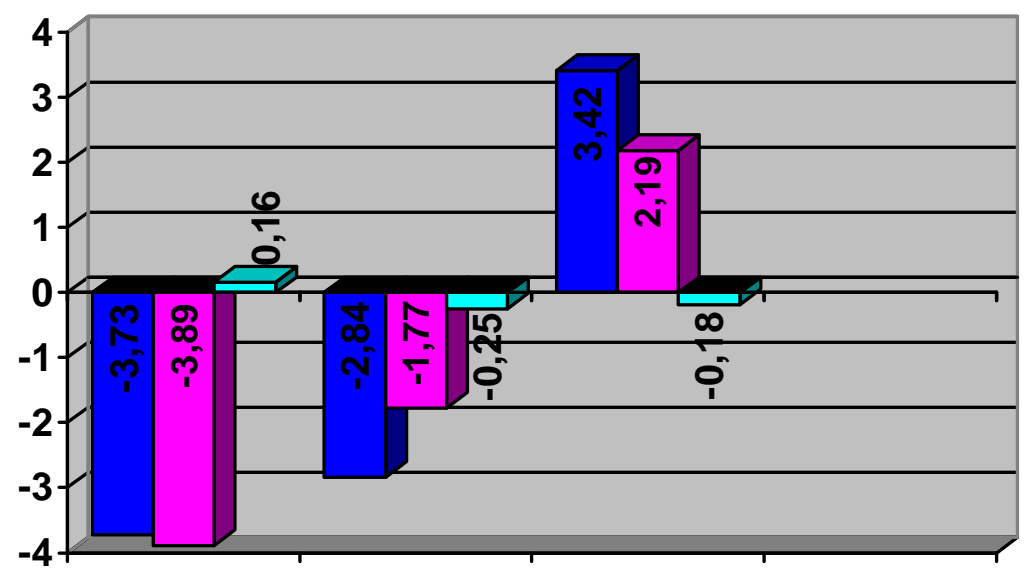

$\begin{array}{lll}\text { T.H. } & \text { T.V. } & \text { Rel. molar }\end{array}$

FIGURA 38 - Valores médios das alterações das variáveis do Componente Relações Dentárias nos três grupos estudados.

A correção do trespasse horizontal no Grupo Experimental 1 (Jasper Jumper) ocorreu em virtude da retrusão dos incisivos superiores, da tendência de protrusão observada nos incisivos inferiores e da retrusão e restrição do crescimento maxilar. $\mathrm{O}$ crescimento mandibular normal poderia contribuir para esta correção, no entanto, parece que este crescimento foi compensado pelo menos em parte pela rotação horária da mandíbula neste grupo, como pode ser verificado pelos menores valores, apesar de não significantes, das variáveis SNB e Pog-Nperp no Grupo Experimental 1 em relação aos demais.

KÜÇÜKKELES; ILHAN; ORGUN ${ }^{183}$ descreveram que a redução do trespasse horizontal foi observada tanto na fase de nivelamento quanto durante 
a utilização do Jasper Jumper. Durante o nivelamento, esta redução ocorreu em conseqüência das alterações nas inclinações dos incisivos, enquanto que durante a fase do Jasper Jumper, diversos fatores levaram a esta redução, incluindo o "efeito extrabucal" do aparelho, a conseqüente retrusão dos incisivos superiores e a protrusão dos incisivos inferiores. Os autores indicaram que mais de $80 \%$ da redução do trespasse horizontal foi de origem dentoalveolar. KARACAY et al. ${ }^{171}$ concordam que os principais componentes responsáveis pela redução do trespasse horizontal são dentoalveolares. De acordo com WEILAND et al. ${ }^{340}$, nenhuma alteração no trespasse horizontal é esperada em um período de 6 meses com o crescimento normal, entretanto, com o uso do Jasper Jumper houve uma extensa e significante redução deste trespasse. Menos da metade destas alterações foram atribuídas aos efeitos esqueléticos.

No Grupo Experimental 2 (Bionator), a redução do trespasse horizontal ocorreu em conseqüência da retrusão dos incisivos superiores, vestibularização e protrusão dos incisivos inferiores, da retrusão maxilar em conjunto ao crescimento normal da mandíbula. Alguns autores ${ }^{95}$ relataram o predomínio das alterações dentoalveolares na correção do trespasse horizontal por meio do Bionator, entretanto, JENA; DUGGAL; PARKASH ${ }^{166}$ encontraram $57,77 \%$ de contribuição esquelética para a referida correção. Os autores justificaram esta elevada participação das alterações esqueléticas na redução do trespasse horizontal em função da época em que o tratamento foi realizado, no pico de velocidade do surto de crescimento pubescente.

No grupo tratado pelo Jasper Jumper, a correção do trespasse vertical ocorreu devido a um conjunto e fatores: rotação horária da mandíbula e aumento da AFAl; restrição do desenvolvimento vertical dos incisivos inferiores; desenvolvimento vertical normal dos molares superiores e extrusão significante dos molares inferiores. Já no grupo tratado por meio do Bionator, os principais fatores que contribuíram para a redução do trespasse vertical foram, basicamente, dentários: desenvolvimento vertical normal dos molares superiores e extrusão significante dos molares inferiores, além da vestibularização dos incisivos inferiores, que favorece esta redução ${ }^{219}$. Além dos fatores citados para ambos os grupos, a acentuação e reversão da Curva de Spee nos arcos de aço utilizados nos grupos experimentais, durante a fase 
corretiva nos casos que ainda apresentaram sobremordida profunda após a fase ortopédica, também contribuíram para esta correção. Observa-se que apesar dos três grupos apresentarem trespasses verticais semelhantes inicialmente (TABELA 8), o tratamento com o Jasper Jumper foi mais efetivo na sua redução, apresentando uma correção de $1,07 \mathrm{~mm}$ a mais que a terapia com o Bionator, apesar desta diferença não apresentar significância estatística.

No Grupo Experimental 1, a correção da relação molar ocorreu em decorrência da distalização do molar superior, da mesialização do molar inferior e da retrusão e restrição do crescimento maxilar. Da mesma maneira que a correção do trespasse horizontal, o crescimento mandibular normal poderia contribuir para a correção da relação molar, porém, foi compensado pelo giro horário da mandíbula verificado neste grupo. No Grupo Experimental 2, a correção da relação molar ocorreu mais em conseqüência das alterações esqueléticas, uma vez os molares superiores e inferiores não demonstraram alterações estatisticamente significantes em seu posicionamento ânteroposterior em relação ao Grupo Controle. Assim, a retrusão maxilar associada ao crescimento mandibular normal possibilitou a correção da relação molar, pois os molares acompanham o deslocamento de suas respectivas bases ósseas. Resultados semelhantes a esses, porém obtidos em decorrência do tratamento da Classe II por meio do Ativador associado ao extrabucal, foram observados por JANSON et al. ${ }^{154}$, em 2004. LAGERSTROM et al. ${ }^{186}$ relataram que o crescimento mandibular normal em direção anterior foi importante para a correção da relação molar.

O Grupo Experimental 1 (Jasper Jumper) apresentava inicialmente uma relação molar mais acentuada que o Grupo Experimental 2, porém, sem significância estatística (TABELA 8). A correção desta relação molar, que inicialmente era de Classe II, foi mais efetiva no grupo tratado pelo Jasper Jumper em relação ao grupo tratado pelo Bionator, e esta diferença foi estatisticamente significante. Esta maior efetividade do tratamento com 0 Jasper Jumper na correção da relação molar, provavelmente relaciona-se aos efeitos dentoalveolares nos molares superiores (distalização) e inferiores (mesialização) observados neste grupo e não observados no grupo do Bionator. Entretanto, após a compatibilização dos grupos quanto à idade inicial (TABELA 16), não houve mais diferença estatisticamente significante entre os 
mesmos das alterações da relação molar, apesar do grupo tratado com o Jasper Jumper continuar apresentando maiores alterações. Mais uma vez, isto pode ter ocorrido devido à redução da amostra, com a finalidade de compatibilização dos grupos.

Em relação ao tratamento com o Jasper Jumper, KÜÇÜKKELES; ILHAN; ORGUN $^{183}$ relataram que $80,03 \%$ dos efeitos que contribuíram para a correção da relação molar foram de natureza dentoalveolar. Avaliando apenas o intervalo de uso do Jasper Jumper, COVELL JR. et al. ${ }^{80}$ demonstraram que a correção da discrepância ântero-posterior dos molares ocorreu principalmente devido aos movimentos dentários (97\%). WEILAND et al. ${ }^{340}$ compararam os efeitos do tratamento com o Jasper Jumper aos efeitos de dois tipos de Ativador. Os autores ressaltaram que os pacientes tratados com o Jasper Jumper apresentaram correções da relação molar mais pronunciadas, semelhantemente ao presente estudo. Além disto, os autores discorreram que a correção da relação molar ocorreu mais rapidamente e foi devido, principalmente, aos efeitos dentoalveolares, enquanto que os grupos tratados pelos Ativadores apresentaram correções menores, mais lentas, que ocorreram principalmente devido às alterações esqueléticas. Assim, estes resultados sustentam a opinião de que compensações dentoalveolares rápidas impedem correções mais expressivas da discrepância esquelética na má oclusão de Classe $\|^{117,118,340}$.

Em virtude dos efeitos do tratamento com o Jasper Jumper serem predominantemente dentoalveolares $5,6,79,80,170,171,183,196,219,226,227$, KÜÇÜKKELES; ILHAN; ORGUN ${ }^{183}$ concluíram que este aparelho pode ser utilizado mesmo em pacientes que não apresentam mais potencial de crescimento.

Considerando o tratamento com o Bionator, JENA; DUGGAL; PARKASH ${ }^{166}$ revelaram que a correção da relação molar ocorre, em grande parte, devido ao crescimento diferencial da mandíbula em relação à maxila, corroborando os resultados desta pesquisa. Os autores observaram que as alterações esqueléticas contribuíram em $73,3 \%$ na correção da relação molar com o Bionator.

ALMEIDA et al. ${ }^{8}$ relataram que os principais efeitos do tratamento com o Bionator são dentoalveolares, com menores efeitos esqueléticos significantes. 
Enfim, os tratamentos realizados foram efetivos em corrigir os trespasses horizontal e vertical, bem como a relação molar, apresentando alterações significantes em relação ao Grupo Controle.

\subsection{Considerações Finais}

Ambos os protocolos de tratamento avaliados foram efetivos na correção da má oclusão de Classe II, promovendo a melhora significante no relacionamento maxilomandibular e nas relações dentárias. Entretanto, algumas diferenças nos efeitos obtidos entre os dois tipos de aparelhos ortopédicos utilizados devem ser consideradas.

O Jasper Jumper associado ao aparelho fixo proporcionou alterações mais expressivas na maxila, restringindo o seu crescimento, além da retrusão que foi observada também nos pacientes tratados em duas fases por meio do Bionator e aparelho fixo. Houve também uma importante diferença entre os dois tipos de tratamento em relação ao padrão de crescimento. O Jasper Jumper induziu a uma rotação horária da mandíbula e aumento significante na AFAI, o que limita sua indicação nos casos de pacientes dolicofaciais. Ainda, o Jasper Jumper produziu efeitos significantes nos molares superiores (distalização) e inferiores (mesialização), o que não foi observado após o tratamento com o Bionator, porém, os incisivos inferiores foram significantemente mais influenciados pelo tratamento com o Bionator e aparelho fixo, principalmente em relação à inclinação destes dentes para vestibular, mesmo realizando o capeamento dos incisivos com a resina acrílica. Isto sugere que se deve ter cautela em iniciar um tratamento em duas fases, utilizando o Bionator na primeira fase, em pacientes que apresentam incisivos inferiores com inclinação vestibular acentuada.

Os protocolos de tratamento avaliados não produziram alterações mandibulares significantes, o que permite questionar o fato de que a principal indicação para o tratamento combinado ortopédico funcional e ortodôntico, em especial com os aparelhos Bionator e Jasper Jumper, seja a presença da má oclusão de Classe II, $1^{\text {a }}$ divisão, com retrognatismo mandibular, como descrito por vários autores $9,19,39,48,74,98,107,119,120,199,204,225,315$. Assim, de acordo com os resultados deste estudo, a retrusão mandibular não deve ser a principal 
indicação do tratamento combinado ortopédico/ortodôntico, e não se deve esperar um maior crescimento ou protrusão mandibular do que os advindos do crescimento normal, após este tratamento.

Além das diferenças das alterações cefalométricas entre os tipos de tratamento, outros dois importantes fatores devem ser considerados: o tempo de tratamento e a necessidade de colaboração do paciente.

Como o tratamento com o Jasper Jumper é realizado em uma fase (a fase ortopédica é integrada à terapia ortodôntica), o tempo de tratamento é consideravelmente menor quando comparado ao tratamento realizado em duas fases, uma ortopédica, utilizando o Bionator, e outra ortodôntica. Atualmente, há uma tendência em se optar por protocolos de tratamento mais eficientes, ou seja, que alcancem bons resultados em um tempo de tratamento razoável. Neste sentido, pesquisas recentes ${ }^{67,321,334}$ demonstram que 0 tratamento realizado em uma fase é mais eficiente, uma vez que obtém resultados oclusais semelhantes ao protocolo em duas fases, em um tempo significantemente menor. Assim, CANÇADO et al. ${ }^{67}$ destacaram que o tempo total de tratamento foi a variável responsável por conferir uma maior eficiência ao protocolo de tratamento em uma fase. Seria necessário o desenvolvimento de uma pesquisa para investigar se os resultados oclusais nos dois protocolos de tratamento avaliados neste estudo promovem resultados oclusais semelhantes, e avaliar a eficiência de ambas as terapias. No entanto, especula-se que o tratamento realizado por meio do Jasper Jumper associado ao aparelho fixo seja mais eficiente que o tratamento com o Bionator e a aparelhagem fixa, baseado na diferença do tempo de tratamento entre ambos.

Outra importante vantagem do tratamento realizado pelo Jasper Jumper associado ao aparelho fixo sobre a terapia utilizando o Bionator na primeira fase e o aparelho fixo na segunda, consiste na redução da necessidade de colaboração do paciente com o tratamento. Como o Jasper Jumper é fixo, não há a dependência da motivação e cooperação do paciente em usar o aparelho, fato que acontece com o Bionator, apesar de ser um dos aparelhos ortopédicos funcionais removíveis mais aceitos por parte dos pacientes ${ }^{299}$. SAHM; BARTSCH; WITT ${ }^{287}$ monitoraram, por meio de um dispositivo eletrônico, o tempo real de uso do Bionator em 53 pacientes (com idade variando de 9 a 14 anos), e verificaram que o aparelho foi usado em média 7,65 horas por dia, 0 
que correspondeu a 50 a 60\% do recomendado pelo Ortodontista. A dificuldade na fala e na mastigação são fatores que podem levar o paciente a não usar o aparelho de acordo com a recomendação ${ }^{167}$. Por outro lado, um bom relacionamento profissional-paciente, a informação ao paciente dos objetivos do tratamento, métodos, e o seu papel para se obter um bom resultado, além de oferecer informações a respeito do uso do aparelho podem aumentar potencialmente a colaboração do paciente ${ }^{167}$. Desta maneira, torna-se clara a dependência da colaboração do paciente para se obter sucesso do tratamento com o Bionator, além do que, a regularidade de uso do aparelho relaciona-se com a duração do tratamento ${ }^{288}$. Ainda, após a remoção do Bionator deve-se utilizar como contenção ativa ou o próprio aparelho (apenas para dormir), ou dispositivos removíveis como o aparelho extrabucal e o elástico de Classe II, aumentando a necessidade de colaboração do paciente. Apesar do Jasper Jumper ser um dispositivo fixo, ele não elimina completamente a dependência da cooperação do paciente com o tratamento, uma vez que é necessário manter o aparelho limpo, evitar a abertura excessiva da boca para evitar quebras $^{47}$, e após a remoção do Jasper Jumper, torna-se necessário o uso dos elásticos de Classe II como contenção ativa, o que depende da colaboração do paciente. No entanto, esta necessidade de colaboração é muito menor quando comparado com o tratamento em duas fases por meio do Bionator e aparelho fixo. Enfim, diferentemente dos aparelhos funcionais removíveis, os dispositivos fixos que promovem o avanço mandibular aplicam forças leves e contínuas, minimizando assim a necessidade de cooperação do paciente e encurtando o tempo de tratamento ${ }^{183}$.

Estes aparelhos funcionais fixos podem ser categorizados em dois grupos: os semi-elásticos (por exemplo, o Eureca Spring, Twin Force e Jasper Jumper) e os rígidos (por exemplo, o Herbst, MARA e APM) ${ }^{183}$. Apesar da melhor aceitação pelos pacientes e facilidade de aplicação dos aparelhos semielásticos, ambos os grupos demonstraram resultados similares a respeito da correção dentoesquelética ${ }^{183}$. De acordo com KARACAY et al. ${ }^{171}$, os aparelhos ortopédicos funcionais fixos semi-elásticos e rígidos utilizam os mesmo princípios biomecânicos; no entanto, a rigidez do aparelho de Herbst, do MARA limita os movimentos laterais da mandíbula, mas ao mesmo tempo, proporciona estimulação do crescimento mandibular por posicionar a 
mandíbula mais anteriormente em relação aos aparelhos flexíveis. Seria necessário desenvolver uma pesquisa para verificar se realmente os dispositivos fixos rígidos induzem o maior crescimento mandibular quando comparados aos flexíveis. No momento, sabe-se que durante a utilização do Jasper Jumper, todos os pacientes se adaptaram rapidamente ao aparelho ${ }^{183}$, a grande maioria considerou o aparelho confortável, e nenhum se queixou de limitação de movimento de lateralidade. Poucos pacientes se queixaram da limitação da abertura de boca; nestes casos, os braquetes dos segundos prémolares inferiores foram removidos, satisfazendo a queixa desses pacientes. Assim, a flexibilidade do Jasper Jumper é um importante fator para oferecer conforto ao paciente durante o tratamento, e constitui em uma grande vantagem deste aparelho em relação aos funcionais rígidos. Além disto, a facilidade de instalação e manipulação do Jasper Jumper diminuiu o "tempo de cadeira" do paciente ${ }^{310}$ e estimula o Ortodontista a utilizá-lo. Em contrapartida, o índice de quebra do aparelho nos pacientes desta pesquisa foi considerado alto $(35,14 \%$ dos aparelhos instalados), o que foi considerado uma desvantagem do tratamento com o Jasper Jumper.

O tratamento com o Bionator e aparelho fixo também apresenta suas indicações e vantagens. Uma indicação para o tratamento em duas fases que é freqüentemente citada na literatura consiste na presença de uma estética facial desagradável que afeta negativamente o convívio social e a auto-estima da criança ou adolescente ${ }^{136,301}$, o que justificaria uma intervenção ainda na fase da dentadura mista. Outro fator a ser considerado é a diminuição da incidência de traumas aos incisivos superiores ${ }^{315}$. Pacientes com trespasse horizontal aumentado e excessiva vestibularização dos incisivos superiores apresentam um risco aumentado para sofrerem traumatismos nestes dentes ${ }^{181}$; assim, a realização do tratamento em duas fases, iniciando na fase da dentadura mista, poderia contribuir para a diminuição da incidência de traumas nestes dentes. Contudo, KOROLUK; TULLOCH; PHILLIPS ${ }^{181}$ argumentam que a maioria dos traumatismos são pequenos e as possibilidades terapêuticas apresentam menor custo quando comparadas a um tratamento ortopédico/ortodôntico realizado em duas fases.

Dentre os aparelhos ortopédicos funcionais removíveis, o Bionator apresenta boa aceitação pelo paciente ${ }^{98,299}$. É um aparelho de simples 
confecção, boa adaptabilidade e grande facilidade de uso e manipulação $28,138,139$, causando pouco ou nenhum desconforto ao paciente ${ }^{28}$.

Sendo assim, a escolha por um determinado protocolo de tratamento deve se basear no conhecimento dos efeitos esperados de cada terapia, bem como da correta indicação e das vantagens inerentes a cada tipo de aparelho.

Tão importante quanto se obter bons resultados, é manter os resultados alcançados a longo prazo. Neste contexto, observa-se na literatura a escassez de estudos avaliando a estabilidade a longo prazo do tratamento da Classe II por meio de aparelhos ortopédicos funcionais, mais especificamente o Jasper Jumper e o Bionator. CAFFER ${ }^{64}$ estudou a estabilidade do tratamento da Classe II, $1^{\text {a }}$ divisão por meio do Ativador associado ao aparelho extrabucal, seguido do aparelho ortodôntico fixo, e considerou que o tratamento ortopédico da Classe II, deve ser finalizado com aparelhos fixos completos para se obter uma melhor oclusão estática e funcional. Durante esta fase, a autora recomendou a utilização do aparelho extrabucal ou o ativador para melhorar o prognóstico da estabilidade do tratamento; afirmou ainda que o ideal é deixar o próprio aparelho ortopédico como contenção por aproximadamente 1 ano, reduzindo seu uso paulatinamente. Após o tratamento corretivo, o protocolo de contenção recomendado pela autora foi a placa de Hawley por aproximadamente 1 ano e o $3 \times 3$. Estudando a estabilidade a longo prazo do tratamento da má oclusão de Classe II por meio do aparelho de Herbst, HANSEN; PANCHERZ; HÄGG ${ }^{131}$ observaram que quando a maxila e a mandíbula encontram-se bem relacionadas em uma relação estável e Classe I, a força do crescimento maxilar pode ser transmitida à mandíbula e vice-versa. Para tanto, torna-se fundamental finalizar o tratamento com a melhor intercuspidação possível ${ }^{239,248,250}$. 


\subsection{Sugestões para trabalhos futuros}

- Comparar os resultados oclusais e a eficiência do tratamento da má oclusão de Classe II, $1^{\text {a }}$ divisão por meio dos aparelhos Jasper Jumper e Bionator, associados ao aparelho fixo.

- Comparar as alterações cefalométricas do tratamento da má oclusão de Classe II, $1^{\text {a }}$ divisão por meio do Jasper Jumper e um dispositivo funcional fixo, como o MARA ou o Herbst;

- Comparar a estabilidade do tratamento da má oclusão de Classe II, 1a divisão por meio do Jasper Jumper e do Bionator, associados ao aparelho fixo. 


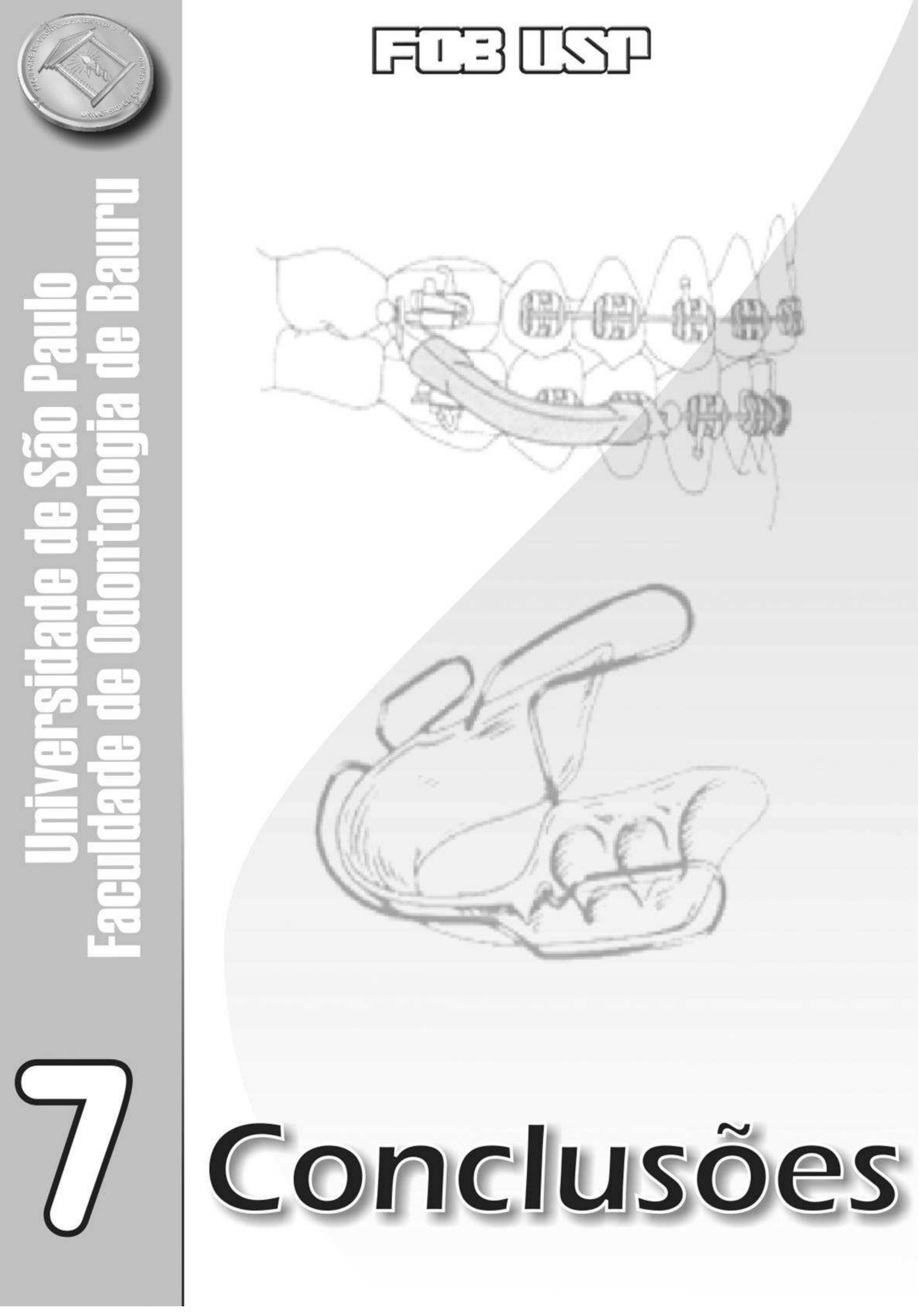




\section{CONCLUSÕES}

Com base na metodologia utilizada e nos resultados obtidos, julga-se lícito concluir que:

- ambos os tratamentos influenciaram significantemente a maxila, promovendo uma retrusão desta base óssea; o grupo tratado por meio do Jasper Jumper associado ao aparelho fixo ocasionou ainda a restrição do crescimento maxilar;

- os grupos experimentais não propiciaram alterações significantes no posicionamento e crescimento mandibular;

- houve melhora significante da relação maxilomandibular nos dois protocolos de tratamento avaliados;

- o tratamento com o Bionator e aparelho fixo não alterou significantemente o padrão de crescimento existente; porém, o tratamento com o Jasper Jumper associado ao aparelho fixo ocasionou a rotação horária da mandíbula, o aumento da altura facial ântero-inferior, e uma menor rotação anti-horária do plano oclusal funcional em relação ao grupo tratado pelo Bionator;

- os incisivos superiores foram retruídos nos grupos experimentais e extruídos no grupo tratado por meio do Jasper Jumper associado ao aparelho fixo. Os molares superiores foram distalizados no grupo do Jasper Jumper;

- os incisivos inferiores protruíram e vestibularizaram no grupo tratado por meio do Bionator e apresentaram uma tendência de protrusão e restrição do seu desenvolvimento vertical nos pacientes tratados com o Jasper Jumper quando comparados ao controle. Os molares inferiores foram extruídos em ambos os grupos experimentais e mesializados no grupo tratado pelo Jasper Jumper;

- ambos os aparelhos melhoraram significantemente as relações dentárias (trespasse horizontal, vertical e relação molar). Observa-se que a correção da relação molar foi mais efetiva no grupo tratado por meio do Jasper Jumper, apesar do grupo do Bionator também apresentar melhora significante em relação ao controle. 

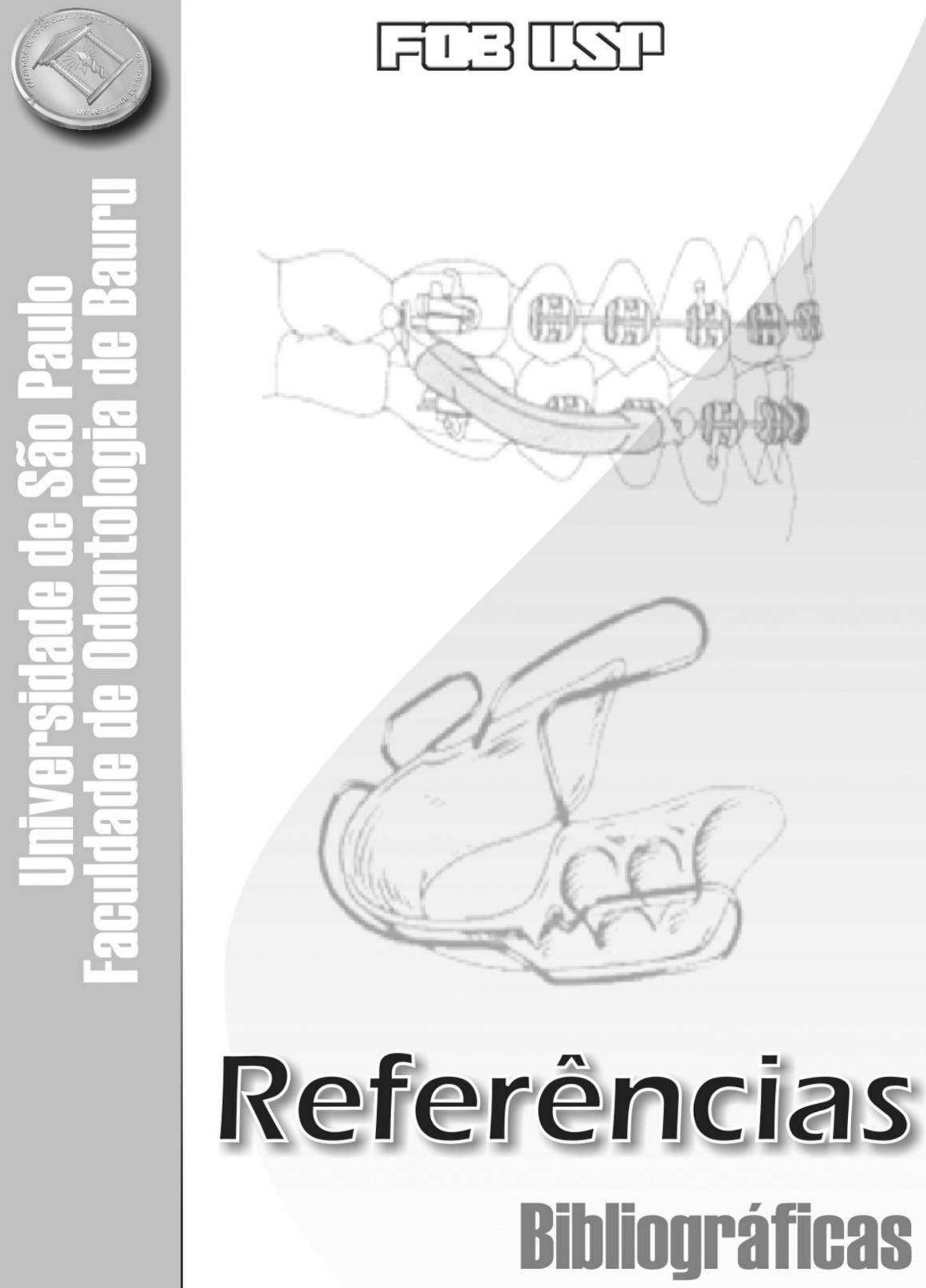


\section{REFERÊNCIAS BIBLIOGRÁFICAS*}

1. ACKERMAN, J.L.; PROFFIT, W.R. The characteristics of malocclusion: a modern approach to classification and diagnosis. Am J Orthod, v.56, n.5, p.443-54, Nov. 1969.

2. ADAMS, C.D. et al. Dentofacial remodelling produced by intermaxillary forces in Macaca mulatta. Arch Oral Biol, v.17, n.11, p.1519-35, Nov 1972.

3. AELBERS, C.M.; DERMAUT, L.R. Orthopedics in orthodontics: Part I, Fiction or reality--a review of the literature. Am J Orthod Dentofacial Orthop, v.110, n.5, p.513-9, Nov 1996.

4. AHN, S.J.; KIM, J.T.; NAHM, D.S. Cephalometric markers to consider in the treatment of Class II Division 1 malocclusion with the bionator. Am J Orthod Dentofacial Orthop, v.119, n.6, p.578-86, June 2001.

5. ALMADA, R.O. Avaliação cefalométrica das alterações dentárias e esqueléticas promovidas pelo aparelho Jasper Jumper em pacientes portadores de displasia esquelética por restrusão mandibular. Lavras, 1999. 71p. Monografia (Especialização) - Universidade do Estado de Minas Gerais. Curso de Odontologia. Campus de Lavras.

6. ALMADA, R.O. et al. Avaliação cefalométrica das alterações dentárias e esqueléticas promovidas pelo aparelho Jasper Jumper em pacientes portadores de displasia esquelética por retrusão mandibular. J Bras Ortodon Ortop Facial, v.4, n.21, p.193-208, maio-jun. 1999.

7. ALMEIDA, M.R. Avaliação cefalométrica comparativa da interceptação da má oclusão de Classe II, $1^{\text {a }}$ divisão utilizando o aparelho de Fränkel e o Bionator de Balters. Bauru, 2000. 237p. Tese (Doutorado) - Faculdade de Odontologia de Bauru - Universidade de São Paulo.

8. ALMEIDA, M.R. et al. Treatment effects produced by the Bionator appliance. Comparison with an untreated Class II sample. Eur J Orthod, v.26, n.1, p.65-72, Feb. 2004.

9. ALMEIDA, M.R. et al. Efeitos do Bionator de Balters sobre o complexo dentoesquelético-facial comparado a uma amostra não tratada de classe II. J Bras Ortodon Ortop Facial, v.5, n.30, p.38-48, nov.-dez. 2000.

\footnotetext{
* Normas recomendadas para uso no âmbito da Universidade de São Paulo, com base no documento "Referências bibliográficas: exemplos", emanado do Conselho Supervisor do Sistema Integrado de bibliotecas da USP, em reunião de 20 de setembro de 1990.
} 
10. ALMEIDA, M.R. et al. Efeitos dentoesqueléticos produzidos pelo aparelho de Herbst na dentadura mista. Rev Dent Press Ortodon Ortoped Facial, v.11, n.5, p.21-34, set./out. 2006.

11. ALMEIDA, M.R. et al. Short-term treatment effects produced by the Herbst appliance in the mixed dentition. Angle Orthod, v.75, n.4, p.540-7, Jul 2005.

12. ALMEIDA, M.R.; HENRIQUES, J.F.C.; URSI, W. Comparative study of the Fränkel (FR-2) and bionator appliances in the treatment of Class II malocclusion. Am J Orthod Dentofacial Orthop, v.121, n.5, p.458-66, May 2002.

13. ALMEIDA, M.R.D. et al. Avaliação cefalométrica comparativa da interceptação da má oclusão de classe II, $1^{\text {a }}$ divisão utilizando os aparelhos de Fränkel e Bionator de Balters. Rev Dent Press Ortodon Ortoped Facial, v.6, n.6, p.11-27, nov.-dez. 2001.

14. ALMEIDA, R.R. et al. Mordida construtiva para a confecção do ativador para a Classe II, Divisão 1, com sobremordida profunda. Rev Dent Press Ortodon Ortoped Maxilar, v.1, n.2, p.72-7, nov.-dez. 1996.

15. ALMEIDA, R.R. et al. Influência da fluoretação na prevalência de más oclusões. Estomat Cult, v.4, n.1, p.35-42, jan.-jun. 1970.

16. ALMEIDA-PEDRIN, R.R. Efeitos cefalométricos do aparelho extrabucal conjugado (Splint Maxilar) e do bionator, no tratamento da má oclusão de classe II, 1a divisão. Bauru, 2003. 209p. Tese (Doutorado) Faculdade de Odontologia de Bauru - Universidade de São Paulo.

17. ALMEIDA-PEDRIN, R.R. et al. Efeitos do AEB conjugado e do Bionator no tratamento da Classe II, $1^{\underline{a}}$ divisão. Rev Dent Press Ortodon Ortoped Facial, v.10, n.5, p.37-54, set.-out. 2005.

18. ALTENBURGER, E.; INGERVALL, B. The initial effects of the treatment of Class II, division 1 malocclusions with the van Beek activator compared with the effects of the Herren activator and an activator-headgear combination. Eur J Orthod, v.20, n.4, p.389-97, Aug. 1998.

19. ALTUNA, G.; NIEGEL, S. Bionators in Class II treatment. J Clin Orthod, v.19, n.3, p.185-91, Mar. 1985.

20. ANDREWS, L.F. The straight wire appliance. Syllabus of philosophy and techniques. p.109-41, 1975.

21. ANGELIERI, F. Comparação dos efeitos cefalométricos promovidos pelos aparelhos extrabucal cervical e pendulum. Bauru, 2005. 142p. 
Tese (Doutorado) - Faculdade de Odontologia de Bauru - Universidade de São Paulo.

22. ANGLE, E.H. Classification of malocclusion. Dent Cosmos, v.41, n.3, p.248-64, Mar. 1899.

23. ANGLE, E.H. Treatment of malocclusion of the teeth. 7th ed. Philadelphia, SSWhite, 1907.

24. ARAÚJO, A.M.; BUSCHANG, P.H.; MELO, A.C.M. Adaptive condylar growth and mandibular remodelling changes with bionator therapy-an implant study. Eur J Orthod, v.26, n.5, p.515-22, Oct. 2004.

25. ARAÚJO, A.M. et al. Tratamento da má-oclusão de Classe II, divisão 1, em paciente não-colaborador: relato de caso clínico. J Bras Ortodon Ortop Facial, v.6, n.35, p.358-68, set.-out. 2001.

26. ARAÚJO, E.; SOUKI, M. Bolton anterior tooth size discrepancies among different malocclusion groups. Angle Orthod, v.73, n.3, p.307-13, June 2003.

27. ARYA, B.S.; SAVARA, B.S.; THOMAS, D.R. Prediction of first molar occlusion. Am J Orthod, v.63, n.6, p.610-21, June 1973.

28. ASCHER, F. The bionator. In: Graber, T.M.; Neumann, B. Removable orthodontic appliances. Philadelphia, Saunders, 1977, p.229-46.

29. BACCETTI, T. et al. Early dentofacial features of Class II malocclusion: a longitudinal study from the deciduous through the mixed dentition. Am $\mathbf{J}$ Orthod Dentofacial Orthop, v.111, n.5, p.502-9, May 1997.

30. BACCETTI, T. et al. Treatment timing for Twin-block therapy. Am J Orthod Dentofacial Orthop, v.118, n.2, p.159-70, Aug 2000.

31. BALTERS, W. Guia de la técnica del Bionator. Buenos Aires, Círculo Argentino de Odontologia, 1969.

32. BALTROMEJUS, S.; RUF, S.; PANCHERZ, H. Effective temporomandibular joint growth and chin position changes: Activator versus Herbst treatment. A cephalometric roentgenographic study. Eur $\mathbf{J}$ Orthod, v.24, n.6, p.627-37, Dec 2002.

33. BARTON, S.; COOK, P.A. Predicting functional appliance treatment outcome in Class II malocclusions - a review. Am J Orthod Dentofacial Orthop, v.112, n.3, p.282-6, Sept. 1997.

34. BASS, N.M. Dento-facial orthopaedics in the correction of class II malocclusion. Br J Orthod, v.9, n.1, p.3-31, Jan. 1982. 
35. BASS, N.M. Orthopedic coordination of dentofacial development in skeletal Class II malocclusion in conjunction with edgewise therapy. Part I. Am J Orthod, v.84, n.5, p.361-83, Nov. 1983.

36. BASS, N.M. Orthopedic coordination of dentofacial development in skeletal Class II malocclusion in conjunction with edgewise therapy. Part II. Am J Orthod, v.84, n.6, p.466-90, Dec 1983.

37. BAUMRIND, S.; FRANTZ, R.C. The reliability of head film measurements. 1. Landmark identification. Am J Orthod, v.60, n.2, p.111-27, Aug. 1971.

38. BERTOZ, F.A. et al. Características cefalométricas de pacientes com má oclusão Classe II. Rev APEO, v.1, n.1, p.35-41, jan.-mar. 2003.

39. BIGLIAZZI, R.; KESSNER, C.A.; FALTIN JÚNIOR, K. Estudos das alterações anatômicas e morfológicas em pacientes Classe II, divisão 1르, com retrognatismo mandibular tratados com o bionator de Balters, empregando-se a análise das contrapartes de enlow. Rev Dent Press Ortodon Ortopedi Facial, v.5, n.2, p.9-19, mar.-abr. 2000.

40. BIRKEBAEK, L.; MELSEN, B.; TERP, S. A laminagraphic study of the alterations in the temporo-mandibular joint following activator treatment. Eur J Orthod, v.6, n.4, p.257-66, Nov. 1984.

41. BISHARA, S.E. Mandibular changes in persons with untreated and treated Class II division 1 malocclusion. Am J Orthod Dentofacial Orthop, v.113, n.6, p.661-73, June 1998.

42. BISHARA, S.E.; BAYATI, P.; JAKOBSEN, J.R. Longitudinal comparisons of dental arch changes in normal and untreated Class II, Division 1 subjects and their clinical implications. Am J Orthod Dentofacial Orthop, v.110, n.5, p.483-9, Nov. 1996.

43. BISHARA, S.E. et al. Changes in the molar relationship between the deciduous and permanent dentitions: a longitudinal study. Am J Orthod Dentofacial Orthop, v.93, n.1, p.19-28, Jan. 1988.

44. BISHARA, S.E. et al. Changes in dentofacial structures in untreated Class II division 1 and normal subjects: a longitudinal study. Angle Orthod, v.67, n.1, p.55-66, 1997.

45. BISHARA, S.E. et al. Longitudinal changes in standing height and mandibular parameters between the ages of 8 and 17 years. Am J Orthod, v.80, n.2, p.115-35, Aug. 1981. 
46. BISHARA, S.E.; ZIAJA, R.R. Functional appliances: a review. Am J Orthod Dentofacial Orthop, v.95, n.3, p.250-8, Mar. 1989.

47. BLACKWOOD III, H.O. Clinical management of the Jasper Jumper. J Clin Orthod, v.25, n.12, p.755-60, Dec 1991.

48. BOLMGREN, G.A.; MOSHIRI, F. Bionator treatment in Class II, division 1. Angle Orthod, v.56, n.3, p.255-62, July 1986.

49. BOWMAN, S.J. One-stage versus two-stage treatment: are two really necessary? Am J Orthod Dentofacial Orthop, v.113, n.1, p.111-6, Jan. 1998.

50. BOWMAN, S.J. Class II combination therapy (distal jet and Jasper Jumpers): a case report. J Orthod, v.27, n.3, p.213-8, Sept. 2000.

51. BOWMAN, S.J. Os Jasper Jumpers na correção da Classe II: um relato de caso. Rev Dental Press Ortod Ortop Facial, v.5, n.2, p.54-8, 2000.

52. BOWMAN, S.J. Terapia combinada para Classe II (Distal Jet e Jasper Jumper): um relato de caso. Rev Dental Press Ortod Ortop Facial, v.5, n.6, p.73-8, 2000.

53. BRAND, A. et al. Orthodontic, genetic, and periodontal considerations in the treatment of impacted maxillary central incisors: A study of twins. Am J Orthod Dentofacial Orthop, v.117, n.1, p.68-74, Jan. 2000.

54. BRANDÃO, A.M.B.; DOMíNGUEZ-RODRÍGUEZ, G.C.; CAPELOZZA FILHO, L. Avaliação comparativa entre as características da má oclusão Classe II, divisão 1 obtidas pela cefalometria e análise facial subjetiva. Rev Dent Press Ortodon Ortoped Facial, v.6, n.2, p.33-40, mar./abr. 2001.

55. BRANDÃO, M.; PINHO, H.S.; URIAS, D. Clinical and quantitative assessment of headgear compliance: a pilot study. Am $\mathbf{J}$ Orthod Dentofacial Orthop, v.129, n.2, p.239-44, Feb 2006.

56. BRANGELI, L.A.M. Avaliação comparativa da influência do tratamento com ortopedia nas estruturas faciais esqueléticas e tegumentares, de jovens com classe II, 1a divisão de Angle. Bauru, 2000. 257p. Tese (Doutorado) - Faculdade de Odontologia de Bauru - Universidade de São Paulo.

57. BREADS, P.R.; ABRUZZO, M. The Herbst appliance. Quintessence Dent Technol, v.8, n.4, p.249-53, Apr. 1984.

58. BROADBENT, B.H. A new X-ray technique and its application to orthodontia. Angle Orthod, v.1, n.2, p.45-66, Apr. 1931. 
59. BURKHARDT, D.R.; MCNAMARA JR., J.A.; BACCETTI, T. Maxillary molar distalization or mandibular enhancement: a cephalometric comparison of comprehensive orthodontic treatment including the pendulum and the Herbst appliances. Am J Orthod Dentofacial Orthop, v.123, n.2, p.108-16, Feb. 2003.

60. BUSCHANG, P.H.; MARTINS, J. Childhood and adolescent changes of skeletal relationships. Angle Orthod, v.68, n.3, p.199-206; discussion 2078, June 1998.

61. BUSCHANG, P.H.; STROUD, J.; ALEXANDER, R.G. Differences in dental arch morphology among adult females with untreated Class I and Class II malocclusion. Eur J Orthod, v.16, n.1, p.47-52, Feb. 1994.

62. BUSCHANG, P.H. et al. Mathematical models of longitudinal mandibular growth for children with normal and untreated Class II, division 1 malocclusion. Eur J Orthod, v.10, n.3, p.227-34, Aug. 1988.

63. BUSCHANG, P.H. et al. A polynomial approach to craniofacial growth: description and comparison of adolescent males with normal occlusion and those with untreated Class II malocclusion. Am J Orthod Dentofacial Orthop, v.90, n.5, p.437-42, Nov. 1986.

64. CAFFER, D.D.C. Estabilidade da correeção da classe II, divisão 1 com o aparelho extrabucal conjugado ao ativador seguido da mecânica "Edgewise". Bauru, 2002. 210p. Dissertação (Mestrado) - Faculdade de Odontologia de Bauru - Universidade de São Paulo.

65. CALVERT, F.J. An assessment of Andresen therapy on class II division 1 malocclusion. Br J Orthod, v.9, n.3, p.149-53, Jul 1982.

66. CANÇADO, R.H. Estudo comparativo dos resultados oclusais e da eficiência dos protocolos de tratamento em uma e duas fases da má oclusão Classe II, Divisão 1. Bauru, 2005. 176p. Tese (Doutorado) Faculdade de Odontologia de Bauru - Universidade de São Paulo.

67. CANÇADO, R.H. et al. Occlusal outcomes and efficiency of 1- and 2-phase protocols in Class II, division 1 malocclusion treatment. Am J Orthod Dentofacial Orthop, no prelo, 2006.

68. CANUTO, C.E.; MARTINS, D.R.; PINZAN, A. A influência do traçado do plano oclusal sobre a avaliação Wits. Ortodontia, v.35, n.2, p.49-54, abr.jun. 2002. 
69. CARELS, C.; REYCHLER, A.; VAN DER LINDEN, F.P. Cephalometric evaluation of dento-skeletal changes during treatment with the Bionator type 1. J Oral Rehabil, v.24, n.11, p.841-8, Nov. 1997.

70. CARELS, C.; VAN STEENBERGHE, D. Changes in neuromuscular reflexes in the masseter muscles during functional jaw orthopedic treatment in children. Am J Orthod Dentofacial Orthop, v.90, n.5, p.410-9, Nov. 1986.

71. CARTER, N.E. Dentofacial changes in untreated Class II division 1 subjects. Br J Orthod, v.14, n.4, p.225-34, Nov. 1987.

72. CASH, R.G. Adult nonextraction treatment with a Jasper Jumper. J Clin Orthod, v.25, n.1, p.43-7, Jan. 1991.

73. CAVALCANTI, C.T. Alterações verticais decorrentes da interceptação da classe II com o aparelho bionator. Bauru, 2003. 132p. Dissertação (Mestrado) - Faculdade de Odontologia de Bauru - Universidade de São Paulo.

74. CHAMPAGNE, M. The Jasper Jumper technique. Funct Orthod, v.9, n.2, p.19-21, 24-5, Mar.-Apr. 1992.

75. CHANG, H.P. Assessment of anteroposterior jaw relationship. Am $\mathbf{J}$ Orthod Dentofacial Orthop, v.92, n.2, p.117-22, Aug 1987.

76. CHEN, J.Y.; WILL, L.A.; NIEDERMAN, R. Analysis of efficacy of functional appliances on mandibular growth. Am J Orthod Dentofacial Orthop, v.122, n.5, p.470-6, Nov. 2002.

77. CHUNG, C.H.; WONG, W.W. Craniofacial growth in untreated skeletal Class II subjects: a longitudinal study. Am J Orthod Dentofacial Orthop, v.122, n.6, p.619-26, Dec 2002.

78. COELHO FILHO, C.M. Mandibular protraction appliances for Class II treatment. J Clin Orthod, v.29, n.5, p.319-36, May 1995.

79. COPE, J.B. et al. Quantitative evaluation of craniofacial changes with Jasper Jumper therapy. Angle Orthod, v.64, n.2, p.113-22, 1994.

80. COVELL JR., D.A. et al. A cephalometric study of class II Division 1 malocclusions treated with the Jasper Jumper appliance. Angle Orthod, v.69, n.4, p.311-20, Aug. 1999.

81. COZZA, P. et al. Mandibular changes produced by functional appliances in Class II malocclusion: a systematic review. Am J Orthod Dentofacial Orthop, v.129, n.5, p.599 e1-12; discussion e1-6, May 2006. 
82. CREEKMORE, T.D.; RADNEY, L.J. Fränkel appliance therapy: orthopedic or orthodontic? Am J Orthod, v.83, n.2, p.89-108, Feb 1983.

83. CROFT, R.S. et al. A cephalometric and tomographic evaluation of Herbst treatment in the mixed dentition. Am J Orthod Dentofacial Orthop, v.116, n.4, p.435-43, Oct. 1999.

84. CRUZ, K.S. et al. Efeitos dos aparelhos funcionais na correção da má oclusão de classe II. Rev Dent Press Ortodon Ortopedi Facial, v.5, n.4, p.43-52, jul.-ago. 2000.

85. CUCALON, A.; SMITH, R.J. Relationship between compliance by adolescent orthodontic patients and performance on psychological tests. Angle Orthod, v.60, n.2, p.107-14, Apr. 1990.

86. CURA, N. et al. Orthodontic and orthopedic effects of Activator, ActivatorHG combination, and Bass appliances: a comparative study. Am J Orthod Dentofacial Orthop, v.110, n.1, p.36-45, July 1996.

87. DAHLBERG, G. Statistical methods for medical and biological students. New York, Interscience, 1940.

88. DANN, C.T. et al. Self-concept, Class II malocclusion, and early treatment. Angle Orthod, v.65, n.6, p.411-6, 1995.

89. DE VINCENZO, J.P. Changes in mandibular length before, during, and after successful orthopedic correction of Class II malocclusions, using a functional appliance. Am J Orthod Dentofacial Orthop, v.99, n.3, p.241-57, Mar. 1991.

90. DE VINCENZO, J.P.; WINN, M.W. Orthopedic and orthodontic effects resulting from the use of a functional appliance with different amounts of protrusive activation. Am J Orthod Dentofacial Orthop, v.96, n.3, p.18190, Sept. 1989.

91. DEGUCHI, T. Skeletal, dental, and functional effects of headgear-activator therapy on Class II malocclusion in Japanese: a clinical case report. Am J Orthod Dentofacial Orthop, v.100, n.3, p.274-85, Sept. 1991.

92. DEL SANTO, M., JR. Influence of occlusal plane inclination on ANB and Wits assessments of anteroposterior jaw relationships. Am J Orthod Dentofacial Orthop, v.129, n.5, p.641-8, May 2006.

93. DERMAUT, L.R.; VAN DEN EYNDE, F.; DE PAUW, G. Skeletal and dentoalveolar changes as a result of headgear activator therapy related to 
different vertical growth patterns. Eur J Orthod, v.14, n.2, p.140-6, Apr. 1992.

94. DIBBETS, J.M. Morphological associations between the Angle classes. Eur J Orthod, v.18, n.2, p.111-8, Apr. 1996.

95. DRAGE, K.J.; HUNT, N.P. Overjet relapse following functional appliance therapy. Br J Orthod, v.17, n.3, p.205-13, Aug. 1990.

96. DRELICH, R. A cephalometric study of untreated Class II, division 1 malocclusion. Angle Orthod, v.18, n.3-4, p.70-5, July-Oct. 1948.

97. DYER, G.S.; HARRIS, E.F.; VADEN, J.L. Age effects on orthodontic treatment: adolescents contrasted with adults. Am J Orthod Dentofacial Orthop, v.100, n.6, p.523-30, Dec. 1991.

98. EIREW, H.L. The Bionator. Brit J Orthod, v.8, n.1, p.33-6, 1981.

99. ENGLISH, J.D.; BUSCHANG, P.H.; THROCKMORTON, G.S. Does malocclusion affect masticatory performance? Angle Orthod, v.72, n.1, p.21-7, Feb. 2002.

100. ERDOGAN, E. Asymmetric application of the Jasper Jumper in the correction of midline discrepancies. J Clin Orthod, v.32, n.3, p.170-80, Mar. 1998.

101. FALTIN, C.O.; FALTIN JUNIOR, K. Bionator de Balters. Rev Dent Press Ortodon Ortopedi Facial, v.3, n.6, p.70-95, nov.-dez. 1998.

102. FALTIN JR., K. et al. Long-term effectiveness and treatment timing for Bionator therapy. Angle Orthod, v.73, n.3, p.221-30, June 2003.

103. FELDMANN, I.; LUNDSTROM, F.; PECK, S. Occlusal changes from adolescence to adulthood in untreated patients with Class II Division 1 deepbite malocclusion. Angle Orthod, v.69, n.1, p.33-8, Feb. 1999.

104. FLORES-MIR, C; MAJOR, P.W. A systematic review of cephalometric facial soft tissue changes with the Activator and Bionator appliances in Class II division 1 subjects. Eur J Orthod, v.28, n.6, p.586-93, Dec 2006.

105. FOLEY, T.F.; MAMANDRAS, A.H. Facial growth in females 14 to 20 years of age. Am J Orthod Dentofacial Orthop, v.101, n.3, p.248-54, Mar. 1992.

106. FRANCHI, L.; BACCETTI, T.; MCNAMARA JR., J.A. Treatment and posttreatment effects of acrylic splint Herbst appliance therapy. Am $\mathbf{J}$ Orthod Dentofacial Orthop, v.115, n.4, p.429-38, Apr. 1999.

107. FREITAS, B.V. Estudo das alterações esqueléticas e dentárias em pacientes do sexo feminino com má-oclusão de Classe II, divisão 1, 
com retrognatismo mandibular, tratados por meio do Bionator de Balters, no período pré-puberal. São Bernardo do Campo, 1996. 132p. Dissertação (Mestrado) - Faculdade de Ciências Biológicas e da Saúde do Instituto Metodista de Ensino Superior, da Federação de Escolas Speriores do $A B C$.

108. FREITAS, B.V.; VIGORITO, J.W. Estudo das alterações esqueléticas e dentárias em pacientes do sexo feminino com má-oclusão de Classe II, div. 1 com retrognatismo mandibular, tratados por meio do bionator de Balters, no periodo pré-puberal. Ortodontia, v.32, n.1, p.29-43, jan.-abr. 1999.

109. FREITAS, M.R. et al. Prevalência das más oclusões em pacientes inscritos para tratamento ortodôntico na Faculdade de Odontologia de Bauru-USP. Rev Fac Odontol Bauru, v.10, n.3, p.164-9, jul.-set. 2002.

110. FREITAS, M.R. et al. Cephalometric characterization of skeletal Class II, division 1 malocclusion in white Brazilian subjects. J Appl Oral Sci, v.13, n.2, p.198-203, Apr.-June 2005.

111. FULY, C.M.; OLIVEIRA, A.G.; URSI, W. Utilização do Jasper Jumper para correção da Maloclusão de Classe III. J Bras Ortodon Ortop Facial, v.5, n.30, p.21-7, 2000.

112. GABRIEL, H.F. Psychology of the use of the headgear. Angle Orthod, v.35, n.4, p.320-5, Oct. 1965.

113. GESCH, D. A longitudinal study on growth in untreated children with Angle Class II, Division 1 malocclusion. J Orofac Orthop, v.61, n.1, p.2033, 2000.

114. GHAFARI, J. Timing the early treatment of Class II, division 1 malocclusion - clinical and research considerations. Clin Orthod Res, v.1, n.2, p.118-29, Nov. 1998.

115. GHAFARI, J.; KING, G.J.; TULLOCH, J.F. Early treatment of Class II, division 1 malocclusion - comparison of alternative treatment modalities. Clin Orthod Res, v.1, n.2, p.107-17, Nov. 1998.

116. GIANELLY, A.A. One-phase versus two-phase treatment. Am J Orthod Dentofacial Orthop, v.108, n.5, p.556-9, Nov. 1995.

117. GRABER, T.M.; NEUMANN, B. Removable orthodontic appliances. 2nd ed. Philadelphia, Saunders, 1984.

118. GRABER, T.M.; NEUMANN, B. Aparelhos ortodônticos removíveis. 2. ed. São Paulo, Panameicana, 1987. 
119. GRABER, T.M.; RAKOSI, T.; PETROVIC, A.G. Dentofacial orthopedics with functional appliances. 2nd ed. St. Louis, Mosby, 1997.

120. GRABER, T.M.; RAKOSI, T.; PETROVIC, A.G. Ortopedia dentofacial com aparelhos funcionais. 2. ed. Rio de Janeiro, Guanabara Koogan, 1999.

121. GURGEL, J.A.; ALMEIDA, R.R.; PINZAN, A. Avaliação comparativa das dimensões maxilomandibulares entre jovens, do sexo masculino, com máoclusão de Classe II, 1a divisão, não tratados e com oclusão normal. Rev Dent Press Ortodon Ortoped Facial, v.5, n.2, p.20-8, mar.-abr. 2000.

122. GURGEL, J.A.; ALMEIDA, R.R.; PINZAN, A. Avaliação comparativa das alterações esqueléticas maxilomandibulares entre jovens, do sexo masculino, tratados ortodonticamente da má oclusão de Classe II, 1a divisão e com oclusão normal. Rev Dent Press Ortodon Ortoped Facial, v.6, n.1, p.39-50, jan.-fev. 2001.

123. HÄGG, U.; PANCHERZ, H. Dentofacial orthopaedics in relation to chronological age, growth period and skeletal development. An analysis of 72 male patients with Class II division 1 malocclusion treated with the Herbst appliance. Eur J Orthod, v.10, n.3, p.169-76, Aug. 1988.

124. HÄGG, U.; TARANGER, J. Maturation indicators and the pubertal growth spurt. Am J Orthod, v.82, n.4, p.299-309, Oct. 1982.

125. HALL-SCOTT, J. The maxillary-mandibular planes angle (MM degrees) bisector: a new reference plane for anteroposterior measurement of the dental bases. Am J Orthod Dentofacial Orthop, v.105, n.6, p.583-91, Jun 1994.

126. HAMANO, Y.; AHLGREN, J. A cephalometric study of the construction bite of the activator. Eur J Orthod, v.9, n.4, p.305-13, Nov. 1987.

127. HANSEN, K. Post-treatment effects of the Herbst appliance. A radiographic, clinical and biometric investigation. Swed Dent J Suppl, v.88, p.1-49, 1992.

128. HANSEN, K.; IEMAMNUEISUK, P.; PANCHERZ, H. Long-term effects of the Herbst appliance on the dental arches and arch relationships: a biometric study. Br J Orthod, v.22, n.2, p.123-34, May 1995.

129. HANSEN, K.; KOUTSONAS, T.G.; PANCHERZ, H. Long-term effects of Herbst treatment on the mandibular incisor segment: a cephalometric and 
biometric investigation. Am J Orthod Dentofacial Orthop, v.112, n.1, p.92103, July 1997.

130. HANSEN, K.; PANCHERZ, H. Long-term effects of Herbst treatment in relation to normal growth development: a cephalometric study. Eur $\mathbf{J}$ Orthod, v.14, n.4, p.285-95, Aug. 1992.

131. HANSEN, K.; PANCHERZ, H.; HÄGG, U. Long-term effects of the Herbst appliance in relation to the treatment growth period: a cephalometric study. Eur J Orthod, v.13, n.6, p.471-81, Dec 1991.

132. HARRIS, E.F.; DYER, G.S.; VADEN, J.L. Age effects on orthodontic treatment: skeletodental assessments from the Johnston analysis. Am J Orthod Dentofacial Orthop, v.100, n.6, p.531-6, Dec. 1991.

133. HARVOLD, E.P.; VARGERVIK, K.S. Morphogenetic response to activator treatment. Am J Orthod, v.60, n.5, p.478-90, Nov. 1971.

134. HAYNES, S.; CHAU, M.N. The reproducibility and repeatability of the Wits analysis. Am J Orthod Dentofacial Orthop, v.107, n.6, p.640-7, Jun 1995.

135. HEINIG, N.; GÖZ, G. Clinical application and effects of the Forsus spring. A study of a new Herbst hybrid. J Orofac Orthop, v.62, n.6, p.436-50, Nov. 2001.

136. HELM, S.; KREIBORG, S.; SOLOW, B. Psychosocial implications of malocclusion: a 15-year follow-up study in 30-year-old Danes. Am J Orthod, v.87, n.2, p.110-8, Feb. 1985.

137. HENRIQUES, J.F.C. et al. Tratamento da má oclusão de classe II, $1^{\text {a }}$ divisão, com retrusão mandibular, utilizando o bionator previamente à aparelhagem fixa: relato de um caso clínico. Ortodontia, v.30, n.3, p.74-81, set.-dez. 1997.

138. HENRIQUES, J.F.C. et al. Avaliação da influência do tratamento com bionator nas estruturas faciais tegumentares de jovens com Classe II $1^{\text {a }}$ Divisão de Angle. Ortodontia, v.34, n.3, p.57-64, set.-dez. 2001.

139. HENRIQUES, J.F.C. et al. Tratamento ortopédico ortodôntico: considerações gerais e relato de um caso clínico. Ortodontia, v.24, n.3, p.25-31, set.-dez. 1991.

140. HENRIQUES, J.F.C. et al. Estudo longitudinal das características da máoclusão de Classe II, 1a Divisão sem tratamento, em jovens brasileiros, leucodermas, por um período médio de 3 anos e 4 meses. Rev Dent Press Ortodon Ortoped Facial, v.3, n.3, p.52-66, mai.-jun. 1998. 
141. HEUSDENS, M.; DERMAUT, L.; VERBEECK, R. The effect of tooth size discrepancy on occlusion: An experimental study. Am J Orthod Dentofacial Orthop, v.117, n.2, p.184-91, Feb. 2000.

142. HIRZEL, H.; GREWE, J. Activators: a practical approach. Am J Orthod, v.66, n.5, p.557-70, Nov. 1974.

143. HOUSTON, W.J. The analysis of errors in orthodontic measurements. Am J Orthod, v.83, n.5, p.382-90, May 1983.

144. HOWE, R.P. The bonded Herbst appliance. J Clin Orthod, v.16, n.10, p.663-7, Oct. 1982.

145. HUG, H.U. Periodontal status and its relationship to variations in tooth position. An analysis of the findings reported in the literature. Helv Odont Acta, v.26, p.11-24, 1982.

146. HURMERINTA, K.; RAHKAMO, A.; HAAVIKKO, K. Comparison between cephalometric classification methods for sagittal jaw relationships. Eur $\mathbf{J}$ Oral Sci, v.105, n.3, p.221-7, Jun 1997.

147. ILLING, H.M.; MORRIS, D.O.; LEE, R.T. A prospective evaluation of Bass, Bionator and Twin Block appliances. Part I - The hard tissues. Eur J Orthod, v.20, n.5, p.501-16, Oct. 1998.

148. JACK, A. The Herbst appliance. Dent Tech, v.44, n.3, p.10-1, 15-6, Mar. 1991.

149. JACOBSON, A. The "Wits" appraisal of jaw disharmony. Am J Orthod, v.67, n.2, p.125-38, Feb 1975.

150. JACOBSON, A. Application of the "Wits" appraisal. Am J Orthod, v.70, n.2, p.179-89, Aug 1976.

151. JACOBSON, A. Update on the Wits appraisal. Angle Orthod, v.58, n.3, p.205-19, Jul 1988.

152. JANSON, G. et al. Class II treatment success rate in 2- and 4-premolar extraction protocols. Am J Orthod Dentofacial Orthop, v.125, n.4, p.472-9, Apr. 2004.

153. JANSON, G. et al. O Centro de Estudo de Crescimento da Faculdade de Odontologia de Bauru, Universidade de São Paulo. Rev Dent Press Ortodon Ortoped Facial, v.6, n.4, p.67-75, jul./ago. 2001.

154. JANSON, G. et al. Stability of Class II, division 1 treatment with the headgear-activator combination followed by the edgewise appliance. Angle Orthod, v.74, n.5, p.594-604, Oct 2004. 
155. JANSON, G. et al. Class II treatment effects of the Fränkel appliance. Eur J Orthod, v.25, n.3, p.301-9, Jun 2003.

156. JANSON, G.R.P. Estudo longitudinal e comparativo do crescimento facial - dos 13 aos 18 anos de idade - em jovens brasileiros leucodermas, utilizando a análise cefalométrica de McNamara Jr. Bauru, 1990. 138p. Tese (Doutorado) - Faculdade de Odontologia de Bauru. 157. JANSON, G.R.P. et al. Avaliação do grau de colaboração e aceitação dos pacientes na utilização de dois diferentes tipos de aparelhos removíveis. Rev Dental Press Ortod Ortop Facial, v.8, n.2, p.31-40, mar./abr. 2003.

158. JANSON, I. A cephalometric study of the efficiency of the bionator. Trans Europ Orthod Soc, v.28, p.283-98, 1977.

159. JANSON, I. Skelettale und dentoalveoläre veränderungen durch die bionatorbehandlung in der vorpubetären und pubertären wachstumszeit. Fortschr Kieferorthop, v.39, n.1, p.62-76, Jan. 1978.

160. JANSON, I.R.; NOACHTAR, R. Functional appliance therapy with the Bionator. Sem Orthod, v.4, n.1, p.33-45, 1998.

161. JANSON, M.; HASUND, A. Functional problems in orthodontic patients out of retention. Eur J Orthod, v.3, n.3, p.173-9, 1981.

162. JASPER, J.J. The Jasper Jumper - a fixed functional appliance. Sheboygan, Wisconsin, American Orthodontics, 1987.

163. JASPER, J.J.; MCNAMARA JR., J.A. The correction of interarch malocclusions using a fixed force module. Am $\mathbf{J}$ Orthod Dentofacial Orthop, v.108, n.6, p.641-50, Dec 1995.

164. JASPER, J.J.; MCNAMARA JR., J.A.; MOLLENHAUER, B. The modified Herbst appliance (Jasper Jumper). In: Graber, T.M.; Rakosi, T.; Petrovic, A.G. Dentofacial orthopedics with functional appliances. 2nd ed. St. Louis, Mosby, 1997. p.367-378.

165. JASPER, J.J.; MCNAMARA JR., J.A.; MOLLENHAUER, B. O aparelho modificado de Herbst (Jasper Jumper). In: Graber, T.M.; Rakosi, T.; Petrovic, A.G. Ortopedia dentofacial com aparelhos funcionais. 2. ed. Rio de Janeiro, Guanabara Koogan, 1999. p.358-69.

166. JENA, A.K.; DUGGAL, R.; PARKASH, H. Skeletal and dentoalveolar effects of Twin-block and bionator appliances in the treatment of Class II malocclusion: a comparative study. Am J Orthod Dentofacial Orthop, v.130, n.5, p.594-602, Nov 2006. 
167. JOHNSON, P.D. et al. Attitudes and compliance of pre-adolescent children during early treatment of Class II malocclusion. Clin Orthod Res, v.1, n.1, p.20-8, Aug. 1998.

168. JOHNSTON, L.E., JR. Functional appliances: a mortgage on mandibular position. Aust Orthod J, v.14, n.3, p.154-7, Oct 1996.

169. JOHNSTON, L.E., JR. Growth and the Class II patient: rendering unto Caesar. Semin Orthod, v.4, n.1, p.59-62, Mar. 1998.

170. KAMACHE, N.G. et al. Estudo cefalométrico comparativo dos efeitos esqueléticos e dentários promovidos pelos aparelhos APM3 (Aparelho de Protração Mandibular) e Jasper Jumper nas fases inicial e imediatamente após avanço mandibular. Rev Dent Press Ortodon Ortoped Facial, v.11, n.4, p.53-65, jul.-ago. 2006.

171. KARACAY, S. et al. Forsus Nitinol Flat Spring and Jasper Jumper corrections of Class II division 1 malocclusions. Angle Orthod, v.76, n.4, p.666-72, Jul 2006.

172. KEAN, M.R. Some aspects of facial depth in Class II, division 1 malocclusion. Angle Orthod, v.28, n.1, p.1-11, Jan. 1958.

173. KEELING, S.D. et al. Anteroposterior skeletal and dental changes after early Class II treatment with bionators and headgear. Am J Orthod Dentofacial Orthop, v.113, n.1, p.40-50, Jan. 1998.

174. KIGELE, E. Cephalometric changes from activator-headgear treatment of Class II, division 1 malocclusion. J Clin Orthod, v.21, n.7, p.466-9, July 1987.

175. KILPELAINEN, P.V.; PHILLIPS, C.; TULLOCH, J.F. Anterior tooth position and motivation for early treatment. Angle Orthod, v.63, n.3, p.171-4, Fall 1993.

176. KIM, J.; NIELSEN, I.L. A longitudinal study of condylar growth and mandibular rotation in untreated subjects with class II malocclusion. Angle Orthod, v.72, n.2, p.105-11, Apr. 2002.

177. KING, G.J. et al. Comparison of peer assessment ratings (PAR) from 1phase and 2-phase treatment protocols for Class II malocclusions. Am J Orthod Dentofacial Orthop, v.123, n.5, p.489-96, May 2003.

178. KLOCKE, A.; NANDA, R.S.; KAHL-NIEKE, B. Role of cranial base flexure in developing sagittal jaw discrepancies. Am J Orthod Dentofacial Orthop, v.122, n.4, p.386-91, Oct. 2002. 
179. KLOCKE, A.; NANDA, R.S.; KAHL-NIEKE, B. Skeletal Class II patterns in the primary dentition. Am J Orthod Dentofacial Orthop, v.121, n.6, p.596601, June 2002.

180. KONIK, M.; PANCHERZ, H.; HANSEN, K. The mechanism of Class II correction in late Herbst treatment. Am J Orthod Dentofacial Orthop, v.112, n.1, p.87-91, July 1997.

181. KOROLUK, L.D.; TULLOCH, J.F.; PHILLIPS, C. Incisor trauma and early treatment for Class II Division 1 malocclusion. Am J Orthod Dentofacial Orthop, v.123, n.2, p.117-25; discussion 125-6, Feb. 2003.

182. KROGMAN, W.M.; SASSOUNI, V. A syllabus in roentgenographic cephalometry. Philadelphia, 1957.

183. KÜÇÜKKELES, N.; ILHAN, I.; ORGUN, A. Treatment efficiency in skeletal Class II patients treated with the Jasper Jumper. Angle Orthod, v.77, n.3, p.449-56, May 2007 (available online).

184. KÜÇÜKKELES, N.; ORGUN, A. Correction of Class II malocclusions with a Jasper Jumper in growing patients. Eur J Orthod, v.17, n.5, p.445, Oct. 1995.

185. KUMAR, S.; SIDHU, S.S.; KHARBANDA, O.P. A cephalometric evaluation of the dental and facial-skeletal effects using the Bionator with stepwise protrusive activations. J Clin Pediatr Dent, v.20, n.2, p.101-8, Winter 1996.

186. LAGERSTROM, L.O. et al. Dental and skeletal contributions to occlusal correction in patients treated with the high-pull headgear-activator combination. Am J Orthod Dentofacial Orthop, v.97, n.6, p.495-504, June 1990.

187. LAI, M.; MCNAMARA JR., J.A. An evaluation of two-phase treatment with the Herbst appliance and preadjusted edgewise therapy. Semin Orthod, v.4, n.1, p.46-58, Mar. 1998.

188. LANGE, D.W. et al. Changes in soft tissue profile following treatment with the bionator. Angle Orthod, v.65, n.6, p.423-30, Mar. 1995.

189. LE, C.T. Fundamentals of biostatistical inference. New York, Dekker, 1992.

190. LEGAN, H.L.; BURSTONE, C.J. Soft tissue cephalometric analysis for orthognathic surgery. J Oral Surg, v.38, n.10, p.744-51, Oct 1980. 
191. LIVIERATOS, F.A.; JOHNSTON, L.E., JR. A comparison of one-stage and two-stage nonextraction alternatives in matched Class II samples. Am J Orthod Dentofacial Orthop, v.108, n.2, p.118-31, Aug. 1995.

192. LO, F.D.; HUNTER, W.S. Changes in nasolabial angle related to maxillary incisor retraction. Am J Orthod, v.82, n.5, p.384-91, Nov. 1982.

193. LOONEY, S.W. Biostatistical methods. Totowa, N.J., Humana Press, 2002.

194. LUND, D.I.; SANDLER, P.J. The effects of Twin Blocks: a prospective controlled study. Am J Orthod Dentofacial Orthop, v.113, n.1, p.104-10, Jan 1998.

195. MACDONALD, K.E.; KAPUST, A.J.; TURLEY, P.K. Cephalometric changes after the correction of class III malocclusion with maxillary expansion/facemask therapy. Am J Orthod Dentofacial Orthop, v.116, n.1, p.13-24, Jul 1999.

196. MACEDO, D.M.; AIDAR, L.A.A. Dispositivos intrabucais fixos para correção da relação molar de Classe II. Rev Dental Press Ortod Ortop Facial, v.8, n.2, p.63-72, mar.-abr. 2003.

197. MAIA, F.A. Estudo cefalométrico das características da má oclusão de Classe II/1, em brasileiros da região nordeste, em fase de dentadura mista (parte 1). Ortodontia, v.31, n.2, p.53-68, maio-ago. 1998.

198. MALTAGLIATI, L.A. et al. Influence of orthopedic treatment on hard and soft facial structures of individuals presenting with Class II, division 1 malocclusion. A comparative study. J Appl Oral Sci, v.12, n.2, p.164-70, 2004.

199. MAMANDRAS, A.H.; ALLEN, L.P. Mandibular response to orthodontic treatment with the Bionator appliance. Am J Orthod Dentofacial Orthop, v.97, n.2, p.113-20, Feb. 1990.

200. MAROTTA ARAUJO, A.; BUSChANG, P.H.; MELO, A.C. Transverse skeletal base adaptations with Bionator therapy: a pilot implant study. Am J Orthod Dentofacial Orthop, v.126, n.6, p.666-71, Dec 2004.

201. MARSCHNER, J.F.; HARRIS, J.E. Mandibular growth and class II treatment. Angle Orthod, v.36, n.1, p.89-93, Jan. 1966.

202. MARTINS, D.R. et al. Atlas de crescimento craniofacial. São Paulo, Ed. Santos, 1998. 
203. MARTINS, D.R.; URSI, W.J.S.; SCAVONE JÚNIOR, H. O aparelho de Herbst no tratamento ortopédico das más oclusões de Classe II. Odontomaster Ortodontia, v.1, n.4, p.90-104, 1994.

204. MARTINS, L.P. et al. Tratamento da Classe II, divisão 1, com o aparelho Bionator de Balters: relato de caso clínico. J Bras Ortodon Ortop Facial, v.6, n.31, p.59-63, jan.-fev. 2001.

205. MCNAMARA JR., J.A. Components of class II malocclusion in children 810 years of age. Angle Orthod, v.51, n.3, p.177-202, July 1981.

206. MCNAMARA JR., J.A. A method of cephalometric evaluation. Am J Orthod, v.86, n.6, p.449-69, Dec. 1984.

207. MCNAMARA JR., J.A. Tratamiento ortodóncico y ortopédico en la denticion mista. Ann Arbor: Needham Press, 1995.

208. MCNAMARA JR., J.A.; BRUDON, W. Orthodontic and orthopedic treatment in the mixed dentition. Ann Arbor: Needham Press, p.112-3, 1993.

209. MCNAMARA JR., J.A.; HOWE, R.P.; DISCHINGER, T.G. A comparison of the Herbst and Fränkel appliances in the treatment of Class II malocclusion. Am J Orthod Dentofacial Orthop, v.98, n.2, p.134-44, Aug. 1990.

210. MEIKLE, M.C. Guest editorial: what do prospective randomized clinical trials tell us about the treatment of class II malocclusions? A personal viewpoint. Eur J Orthod, v.27, n.2, p.105-14, Apr 2005.

211. MELO, A.C.M. et al. Avaliação cefalométrica do efeito do tratamento da má oclusão Classe II, divisão 1, com o bionator de Balters: estudo com implantes metálicos. Rev Dent Press Ortodon Ortoped Facial, v.11, n.3, p.18-31, maio-jun. 2006.

212. MELSEN, B.; ALLAIS, D. Factors of importance for the development of dehiscences during labial movement of mandibular incisors: a retrospective study of adult orthodontic patients. Am J Orthod Dentofacial Orthop, v.127, n.5, p.552-61; quiz 625, May 2005.

213. MIGUEL, J.A.M. et al. Rationale for referring Class II patients for early orthodontic treatment. J Appl Oral Sci, v.13, n.3, p.312-7, 2005.

214. MILLS, C.M.; HOLMAN, R.G.; GRABER, T.M. Heavy intermittent cervical traction in class II treatment: a longitudinal cephalometric assessment. Am J Orthod, v.74, n.4, p.361-79, Oct 1978. 
215. MILLS, C.M.; MCCULLOCH, K.J. Case report: modified use of the Jasper Jumper appliance in a skeletal Class II mixed dentition case requiring palatal expansion. Angle Orthod, v.67, n.4, p.277-82, 1997.

216. MILLS, C.M.; MCCULLOCH, K.J. Posttreatment changes after successful correction of Class II malocclusions with the twin block appliance. Am $\mathbf{J}$ Orthod Dentofacial Orthop, v.118, n.1, p.24-33, Jul 2000.

217. MORO, A. et al. Descrição passo-a-passo do aparelho de Herbst com coroas de aço superiores e "Splint" removível inferior. Rev Dent Press Ortodon Ortoped Facial, v.6, n.3, p.55-62, maio-jun. 2001.

218. NAHÁS, A.C.R. Estudo cefalométrico das alterações dentoesqueléticas da má oclusão de Classe II, divisão 1 tratada com 0 aparelho de Herbst e com o aparelho extrabucal de tração occipital. Bauru, 2004. 194p. Tese (Doutorado) - Faculdade de Odontologia de Bauru - Universidade de São Paulo.

219. NALBANTGIL, D. et al. Skeletal, dental and soft-tissue changes induced by the Jasper Jumper appliance in late adolescence. Angle Orthod, v.75, n.3, p.426-36, May 2005.

220. NANDA, R.S.; MERRILL, R.M. Cephalometric assessment of sagittal relationship between maxilla and mandible. Am $\mathbf{J}$ Orthod Dentofacial Orthop, v.105, n.4, p.328-44, Apr 1994.

221. NASCIMENTO, J.E.; CARVALHO, L.S. Tratamento da má oclusão de Classe II divisão 1aa através de recursos ortodônticos e ortopédicos faciais (funcionais e mecânicos): relato de caso. Rev Clin Ortodon Dent Press, v.2, n.4, p.81-91, ago.-set. 2003.

222. NGAN, P.W.; BYCZEK, E.; SCHEICK, J. Longitudinal evaluation of growth changes in Class II division 1 subjects. Semin Orthod, v.3, n.4, p.222-31, Dec 1997.

223. OBIJOU, C.; PANCHERZ, H. Herbst appliance treatment of Class II, division 2 malocclusions. Am J Orthod Dentofacial Orthop, v.112, n.3, p.287-91, Sept. 1997.

224. O'BRIEN, K. et al. Effectiveness of treatment for Class II malocclusion with the Herbst or twin-block appliances: a randomized, controlled trial. Am J Orthod Dentofacial Orthop, v.124, n.2, p.128-37, Aug. 2003.

225. OLIVEIRA, A.J. et al. Avaliação cefalométrica comparativa das alterações esqueléticas, dentárias e faciais ocorridas em pacientes com má oclusão de 
classe II, divisão 1, tratados com tração extra bucal ortopédica e com Bionator de Balters. J Bras Ortodon Ortop Facial, v.2, n.10, p.51-63, jul.ago. 1997.

226. OLIVEIRA JÚNIOR, J.N. Avaliação comparativa das alterações dentoesqueléticas promovidas pelos aparelhos Jasper Jumper e extrabucal com ancoragem cervical, ambos associados à aparelhagem fixa no tratamento da Classe II, Divisão 1, de Angle. Bauru, 2002. 235p. Dissertação (Mestrado) - Faculdade de Odontologia de Bauru Universidade de São Paulo.

227. OLIVEIRA JUNIOR, J.N.; ALMEIDA, R.R. Avaliação cefalométrica comparativa das alterações dentoesqueléticas promovidas pelos aparelhos Jasper Jumper e extrabucal com ancoragem cervical, ambos associados à aparelhagem fixa no tratamento da Classe II, divisão 1, de Angle. Rev Dent Press Ortodon Ortoped Facial, v.9, n.2, p.50-68, mar./abr. 2004.

228. OLIVEIRA, R.A. et al. Estudo cefalométrico comparativo entre 2 tipos de bionatores: com e sem alívio lingual dos incisivos inferiores. Rev Dent Press Ortodon Ortoped Facial, v.7, n.5, p.55-63, set.-out. 2002.

229. O'MULLANE, D.M. Some factors predisposing to injuries of permanent incisors in school children. Br Dent J, v.134, n.8, p.328-32, Apr. 1973.

230. OP HEIJ, D.G.; CALLAERT, H.; OPDEBEECK, H.M. The effect of the amount of protrusion built into the bionator on condylar growth and displacement: a clinical study. Am J Orthod Dentofacial Orthop, v.95, n.5, p.401-9, May 1989.

231. OPPENHEIM, A. Prognatism from the anthropological and orthodontic viewpoints. Dent Cosmos, v.70, n.12, p.1170-84, Dec. 1928.

232. ÖZTÜRK, Y.; TANKÜTER, N. Class II: a comparison of activator and activator headgear combination appliances. Eur J Orthod, v.16, n.2, p.14957, Apr. 1994.

233. PANCHERZ, H. Relapse after activator treatment. A biometric, cephalometric, and electromyographic study of subjects with and without relapse of overjet. Am J Orthod, v.72, n.5, p.499-512, Nov. 1977.

234. PANCHERZ, H. Treatment of class II malocclusions by jumping the bite with the Herbst appliance. A cephalometric investigation. Am J Orthod, v.76, n.4, p.423-42, Oct. 1979. 
235. PANCHERZ, $\mathrm{H}$. The effect of continuous bite jumping on the dentofacial complex: a follow-up study after Herbst appliance treatment of class II malocclusions. Eur J Orthod, v.3, n.1, p.49-60, 1981.

236. PANCHERZ, $\mathrm{H}$. The mechanism of Class II correction in Herbst appliance treatment. A cephalometric investigation. Am J Orthod, v.82, n.2, p.104-13, Aug. 1982.

237. PANCHERZ, H. Vertical dentofacial changes during Herbst appliance treatment. A cephalometric investigation. Swed Dent J Suppl, v.15, p.18996, 1982.

238. PANCHERZ, H. The Herbst appliance-its biologic effects and clinical use. Am J Orthod, v.87, n.1, p.1-20, Jan. 1985.

239. PANCHERZ, $\mathrm{H}$. The nature of Class II relapse after Herbst appliance treatment: a cephalometric long-term investigation. Am $\mathbf{J}$ Orthod Dentofacial Orthop, v.100, n.3, p.220-33, Sept. 1991.

240. PANCHERZ, $H$. The effects, limitations, and long-term dentofacial adaptations to treatment with the Herbst appliance. Semin Orthod, v.3, n.4, p.232-43, Dec 1997.

241. PANCHERZ, H. O novo aparelho de Herbst. In: Graber, T.M.; Rakosi, T.; Petrovic, A.G. Ortopedia dentofacial com aparelhos funcionais. 2. ed. Rio de Janeiro, Guanabara Koogan, 1999. p.327-57.

242. PANCHERZ, H. Dentofacial orthopedics or orthognathic surgery: is it a matter of age? Am J Orthod Dentofacial Orthop, v.117, n.5, p.571-4, May 2000.

243. PANCHERZ, H. Entrevista com o Prof. Hans Pancherz. Rev Dent Press Ortodon Ortoped Facial, v.5, n.4, p.1-3, jul./ago. 2000.

244. PANCHERZ, H.; ANEHUS-PANCHERZ, M. Muscle activity in class II, division 1 malocclusions treated by bite jumping with the Herbst appliance. An electromyographic study. Am J Orthod, v.78, n.3, p.321-9, Sept. 1980.

245. PANCHERZ, H.; ANEHUS-PANCHERZ, M. The effect of continuous bite jumping with the Herbst appliance on the masticatory system: a functional analysis of treated class II malocclusions. Eur J Orthod, v.4, n.1, p.37-44, Feb. 1982.

246. PANCHERZ, H.; ANEHUS-PANCHERZ, M. The headgear effect of the Herbst appliance: a cephalometric long-term study. Am J Orthod Dentofacial Orthop, v.103, n.6, p.510-20, June 1993. 
247. PANCHERZ, H.; ANEHUS-PANCHERZ, M. Facial profile changes during and after Herbst appliance treatment. Eur J Orthod, v.16, n.4, p.275-86, Aug. 1994.

248. PANCHERZ, H.; FACKEL, U. The skeletofacial growth pattern pre- and post-dentofacial orthopaedics. A long-term study of Class II malocclusions treated with the Herbst appliance. Eur J Orthod, v.12, n.2, p.209-18, May 1990.

249. PANCHERZ, H.; FISCHER, S. Amount and direction of temporomandibular joint growth changes in Herbst treatment: a cephalometric long-term investigation. Angle Orthod, v.73, n.5, p.493-501, Oct. 2003.

250. PANCHERZ, H.; HÄGG, U. Dentofacial orthopedics in relation to somatic maturation. An analysis of 70 consecutive cases treated with the Herbst appliance. Am J Orthod, v.88, n.4, p.273-87, Oct. 1985.

251. PANCHERZ, H.; HANSEN, K. Occlusal changes during and after Herbst treatment: a cephalometric investigation. Eur J Orthod, v.8, n.4, p.215-28, Nov. 1986.

252. PANCHERZ, H.; HANSEN, K. Mandibular anchorage in Herbst treatment. Eur J Orthod, v.10, n.2, p.149-64, May 1988.

253. PANCHERZ, H.; RUF, S.; KOHLHAS, P. "Effective condylar growth" and chin position changes in Herbst treatment: a cephalometric roentgenographic long-term study. Am J Orthod Dentofacial Orthop, v.114, n.4, p.437-46, Oct. 1998.

254. PANCHERZ, H.; RUF, S.; THOMALSKE-FAUBERT, C. Mandibular articular disk position changes during Herbst treatment: a prospective longitudinal MRI study. Am J Orthod Dentofacial Orthop, v.116, n.2, p.207-14, Aug. 1999.

255. PANCHERZ, H.; ZIEBER, K.; HOYER, B. Cephalometric characteristics of Class II division 1 and Class II division 2 malocclusions: a comparative study in children. Angle Orthod, v.67, n.2, p.111-20, Apr. 1997.

256. PAULSEN, H.U. Morphological changes of the TMJ condyles of 100 patients treated with the Herbst appliance in the period of puberty to adulthood: a long-term radiographic study. Eur J Orthod, v.19, n.6, p.65768, Dec 1997. 
257. PAULSEN, H.U. et al. CT-scanning and radiographic analysis of temporomandibular joints and cephalometric analysis in a case of Herbst treatment in late puberty. Eur J Orthod, v.17, n.3, p.165-75, June 1995.

258. PETROVIC, A.G.; STUTZMANN, J.J. Research methodology and findings in applied craniofacial growth studies. In: Graber, T.M.; Rakosi, T.; Petrovic, A.G. Dentofacial orthopedics with functional appliances. 2nd ed. St. Louis, Mosby, 1997. p.13-63.

259. PFEIFFER, J.P. Should orthopaedic treatment of severe class II malocclusions be related to growth? Eur J Orthod, v.2, n.4, p.249-56, 1980.

260. PFEIFFER, J.P.; GROBETY, D. The class II malocclusion: differential diagnosis and clinical application of activators, extraoral traction, and fixed appliances. Am J Orthod, v.68, n.5, p.499-544, Nov. 1975.

261. PFEIFFER, J.P.; GROBETY, D. A philosophy of combined orthopedicorthodontic treatment. Am J Orthod, v.81, n.3, p.185-201, Mar. 1982.

262. PHAM, T. et al. New clinical applications for the Jasper Jumper. J Orofac Orthop, v.57, n.6, p.366-71, Dec 1996.

263. PHELAN, T. et al. Variation in Class II malocclusion: comparison of Mexican mestizos and American whites. Am J Orthod Dentofacial Orthop, v.125, n.4, p.418-25, Apr. 2004.

264. PIERS, E.V.; HARRIS, D.B. Piers-Harris children's self-concept scale. Rev. manual /. Los Angeles, Calif., Western Psychological Services, 1984.

265. PROFFIT, W.R. Contemporary orthodontics. 2nd ed. St. Louis, Mosby, 1993.

266. PROFFIT, W.R.; TULLOCH, J.F. Preadolescent Class II problems: treat now or wait? Am J Orthod Dentofacial Orthop, v.121, n.6, p.560-2, June 2002.

267. PROFFIT, W.R.; WHITE, R.P. Surgical-orthodontic treatment. St. Louis, Mosby-Year Book, 1991.

268. RABIE, A.B.; SHE, T.T.; HÄGG, U. Functional appliance therapy accelerates and enhances condylar growth. Am $\mathbf{J}$ Orthod Dentofacial Orthop, v.123, n.1, p.40-8, Jan. 2003.

269. REDAHAN, S.; LAGERSTROM, L. Orthodontic treatment outcome: the relationship between anterior dental relations and anterior inter-arch tooth size discrepancy. J Orthod, v.30, n.3, p.237-44, Sept. 2003. 
270. REJMAN, R. et al. Estudo comparativo das dimensões transversais dos arcos dentários entre jovens com oclusão normal e má oclusão de Classe II, $1^{\text {a }}$ divisão. Rev Dent Press Ortodon Ortoped Facial, v.11, n.4, p.118-25, jul.-ago. 2006.

271. RENFROE, E.W. A study of the facial patterns associated with Class I, Class II, division 1, and Class II, division 2 malocclusions. Angle Orthod, v.18, n.1-2, p.12-5, Jan.-Apr. 1948.

272. RICKETTS, R.M. A four-step method to distinguish orthodontic changes from natural growth. J Clin Orthod, v.9, n.4, p.208-15, 218-28, Apr 1975.

273. RIOLO, M.L. An Atlas of craniofacial growth : cephalometric standards from the University school growth study, the University of Michigan. Ann Arbor, Center for Human Growth and Development University of Michigan, 1974.

274. ROBERTS, G.L. Functional appliances: which one, when? Part 1-Rationale for selection. Aust Orthod J, v.9, n.1, p.160-78, Mar. 1985.

275. ROGERS, M.B. Herbst appliance variations. J Clin Orthod, v.37, n.3, p.156-9; quiz 147, Mar. 2003.

276. ROTHSTEIN, T.; PHAN, X.L. Dental and facial skeletal characteristics and growth of females and males with Class II Division 1 malocclusion between the ages of 10 and 14 (revisited). Part II. Anteroposterior and vertical circumpubertal growth. Am J Orthod Dentofacial Orthop, v.120, n.5, p.542-55, Nov. 2001.

277. ROTHSTEIN, T.; YOON-TARLIE, C. Dental and facial skeletal characteristics and growth of males and females with class II, division 1 malocclusion between the ages of 10 and 14 (revisited)-part I: characteristics of size, form, and position. Am J Orthod Dentofacial Orthop, v.117, n.3, p.320-32, Mar. 2000.

278. ROTHSTEIN, T.L. Facial morphology and growth from 10 to 14 years of age in children presenting Class II, Division 1 Malocclusion: a comparative roentgenographic cephalometric study. Am J Orthod, v.60, n.6, p.619-20, Dec 1971.

279. RUF, S.; HANSEN, K.; PANCHERZ, H. Does orthodontic proclination of lower incisors in children and adolescents cause gingival recession? Am J Orthod Dentofacial Orthop, v.114, n.1, p.100-6, Jul 1998. 
280. RUF, S.; PANCHERZ, H. The effect of Herbst appliance treatment on the mandibular plane angle: a cephalometric roentgenographic study. Am J Orthod Dentofacial Orthop, v.110, n.2, p.225-9, Aug. 1996.

281. RUF, S.; PANCHERZ, H. The mechanism of Class II correction during Herbst therapy in relation to the vertical jaw base relationship: a cephalometric roentgenographic study. Angle Orthod, v.67, n.4, p.271-6, 1997.

282. RUF, S.; PANCHERZ, H. Temporomandibular joint growth adaptation in Herbst treatment: a prospective magnetic resonance imaging and cephalometric roentgenographic study. Eur J Orthod, v.20, n.4, p.375-88, Aug. 1998.

283. RUF, S.; PANCHERZ, H. Dentoskeletal effects and facial profile changes in young adults treated with the Herbst appliance. Angle Orthod, v.69, n.3, p.239-46, June 1999.

284. RUF, S.; PANCHERZ, H. Temporomandibular joint remodeling in adolescents and young adults during Herbst treatment: A prospective longitudinal magnetic resonance imaging and cephalometric radiographic investigation. Am J Orthod Dentofacial Orthop, v.115, n.6, p.607-18, June 1999.

285. RUF, S.; PANCHERZ, H. Does bite-jumping damage the TMJ? A prospective longitudinal clinical and MRI study of Herbst patients. Angle Orthod, v.70, n.3, p.183-99, June 2000.

286. RUSHTON, R.; COHEN, A.M.; LINNEY, A.D. The relationship and reproducibility of angle ANB and the Wits appraisal. Br J Orthod, v.18, n.3, p.225-31, Aug 1991.

287. SAHM, G.; BARTSCH, A.; WITT, E. Micro-electronic monitoring of functional appliance wear. Eur J Orthod, v.12, n.3, p.297-301, Aug. 1990.

288. SAHM, G.; BARTSCH, A.; WITT, E. Reliability of patient reports on compliance. Eur J Orthod, v.12, n.4, p.438-46, Nov. 1990.

289. SANDLER, P.J. Reproducibility of cephalometric measurements. $\mathbf{B r} \mathbf{J}$ Orthod, v.15, n.2, p.105-10, May 1988.

290. SANTOS, M.A.C. Caracterização cefalométrica da Classe II, 1a divisão, esquelética. Bauru, 2003. 87p. Dissertação (Mestrado) Universidade Estadual de Londrina e Faculdade de Odontologia de Bauru Universidade de São Paulo (Programa Interinstitucional). 
291. SARI, Z. et al. Comparative evaluation of a new removable Jasper Jumper functional appliance vs an activator-headgear combination. Angle Orthod, v.73, n.3, p.286-93, June 2003.

292. SASSOUNI, V. A classification of skeletal facial types. Am J Orthod, v.55, n.2, p.109-23, Feb. 1969.

293. SASSOUNI, V. The Class II syndrome: differential diagnosis and treatment. Angle Orthod, v.40, n.4, p.334-41, Oct. 1970.

294. SCHATZ, J.P.; JOHO, J.P. Indications of autotransplantation of teeth in orthodontic problem cases. Am J Orthod Dentofacial Orthop, v.106, n.4, p.351-7, Oct. 1994.

295. SCHIAVONI, R.; GRENGA, V.; MACRI, V. Treatment of Class II high angle malocclusions with the Herbst appliance: a cephalometric investigation. Am J Orthod Dentofacial Orthop, v.102, n.5, p.393-409, Nov. 1992.

296. SCHUDY, F.F. The Rotation of the Mandible Resulting from Growth: Its Implications in Orthodontic Treatment. Angle Orthod, v.35, p.36-50, Jan. 1965.

297. SCHULHOF, R.J.; ENGEL, G.A. Results of Class II functional appliance treatment. J Clin Orthod, v.16, n.9, p.587-99, Sept. 1982.

298. SCHÜTZ, T.C.B. et al. Avaliação cefalométrico-radiográfica das modificações dentoalveolares decorrentes do tratamento com o aparelho Herbst em adolescentes com maloclusão de Classe II, divisão $1^{\underline{a}}$ de Angle Parte I. Ortodontia, v.35, n.4, p.22-34, out.-dez. 2002.

299. SERGL, H.G.; ZENTNER, A. A comparative assessment of acceptance of different types of functional appliances. Eur J Orthod, v.20, n.5, p.517-24, Oct. 1998.

300. SERVOSS, J.M. Classification of occlusion. ASDC J Dent Child, v.42, n.1, p.28-30, Jan.-Feb. 1975.

301. SHAW, W.C. The influence of children's dentofacial appearance on their social attractiveness as judged by peers and lay adults. Am J Orthod, v.79, n.4, p.399-415, Apr 1981.

302. SHERMAN, S.L. et al. The longitudinal effects of growth on the Wits appraisal. Am J Orthod Dentofacial Orthop, v.93, n.5, p.429-36, May 1988. 
303. SIDHU, M.S.; KHARBANDA, O.P.; SIDHU, S.S. Cephalometric analysis of changes produced by a modified Herbst appliance in the treatment of Class II division 1 malocclusion. Br J Orthod, v.22, n.1, p.1-12, Feb. 1995.

304. SILVA FILHO, O.G.; FREITAS, S.F.; CAVASSAN, A.O. Prevalência de oclusão normal e má oclusão em escolares da Cidade de Bauru (São Paulo). Parte I: relação sagital. Rev Odontol Univ São Paulo, v.4, n.2, p.130-7, abr.-jun. 1990.

305. SILVA FILHO, O.G. et al. Aparelho de Herbst: variação para uso na dentadura mista. Rev Dent Press Ortodon Ortoped Facial, v.5, n.5, p.5867 , set.-out. 2000.

306. SIQUEIRA, D.F. Estudo comparativo, por meio de análise cefalométrica em norma lateral, dos efeitos dentoesqueléticos e tegumentares produzidos pelo aparelho extrabucal cervical e pelo aparelho de protração mandibular, associados ao aparelho fixo, no tratamento da Classe II, 1a divisão de Angle. Bauru, 2004. 189p. Tese (Doutorado) - Faculdade de Odontologia de Bauru - Universidade de São Paulo.

307. STALEY, R.N.; STUNTZ, W.R.; PETERSON, L.C. A comparison of arch widths in adults with normal occlusion and adults with class II, Division 1 malocclusion. Am J Orthod, v.88, n.2, p.163-9, Aug. 1985.

308. STARNBACH, H.K.; KAPLAN, A. Profile of an excellent orthodontic patient. Angle Orthod, v.45, n.2, p.141-5, Apr. 1975.

309. STEINER, C. Cephalometrics as a clinical tool. In: Kraus, B.; Riedel, R. Vistas in orthodontics. Philadelphia, Lea \& Fabiger, 1962. p.131-61.

310. STUCKI, N.; INGERVALL, B. The use of the Jasper Jumper for the correction of Class II malocclusion in the young permanent dentition. Eur $\mathbf{J}$ Orthod, v.20, n.3, p.271-81, June 1998.

311. THIESEN, G.; REGO, M.V.N.N.; LIMA, E.M.S. Estudo longitudinal da relação entre o crescimento mandibular e o crescimento estatural em indivíduos com Classe II esquelética. Rev Dent Press Ortodon Ortoped Facial, v.9, n.5, p.28-40, set.-out. 2004.

312. TORO, A. et al. Masticatory performance in children and adolescents with Class I and II malocclusions. Eur J Orthod, v.28, n.2, p.112-9, Apr 2006.

313. TOTH, L.R.; MCNAMARA, J.A., JR. Treatment effects produced by the twin-block appliance and the FR-2 appliance of Fränkel compared with an 
untreated Class II sample. Am J Orthod Dentofacial Orthop, v.116, n.6, p.597-609, Dec 1999.

314. TRULSSON, U. et al. Age dependence of compliance with orthodontic treatment in children with large overjet. An interview study. Swed Dent J, v.28, n.2, p.101-9, 2004.

315. TSAMTSOURIS, A.; VEDRENNE, D. The use of the bionator appliance in the treatment of Class II, division 1 malocclusion in the late mixed dentition. J Pedod, v.8, n.1, p.78-104, Fall 1983.

316. TULLEY, W.J. The scope and limitations of treatment with the activator. Am J Orthod, v.61, n.6, p.562-77, June 1972.

317. TULLOCH, J.F.; MEDLAND, W.; TUNCAY, O.C. Methods used to evaluate growth modification in Class II malocclusion. Am J Orthod Dentofacial Orthop, v.98, n.4, p.340-7, Oct. 1990.

318. TULLOCH, J.F. et al. The effect of early intervention on skeletal pattern in Class II malocclusion: a randomized clinical trial. Am J Orthod Dentofacial Orthop, v.111, n.4, p.391-400, Apr. 1997.

319. TULLOCH, J.F.; PHILLIPS, C.; PROFFIT, W.R. Benefit of early Class II treatment: progress report of a two-phase randomized clinical trial. Am J Orthod Dentofacial Orthop, v.113, n.1, p.62-72, quiz 73-4, Jan. 1998.

320. TULLOCH, J.F.; PROFFIT, W.R.; PHILLIPS, C. Influences on the outcome of early treatment for Class II malocclusion. Am J Orthod Dentofacial Orthop, v.111, n.5, p.533-42, May 1997.

321. TULLOCH, J.F.C.; PROFFIT, W.R.; PHILLIPS, C. Outcomes in a 2-phase randomized clinical trial of early class II treatment. Am J Orthod Dentofacial Orthop, v.125, n.6, p.657-67, June 2004.

322. URSI, W.J.S. Alteração clínica da face em crescimento: uma comparação cefalométrica entre os aparelhos extrabucal cervical, Fränkel (FR-2) e Herbst, no tratamento das más-oclusões de classe II, primeira divisão de Angle. Bauru, 1993. 168p. Tese (Doutorado) Faculdade de Odontologia de Bauru - Universidade de São Paulo.

323. URSI, W.J.S. Crescimento e alterações nas relações mandibulares dos 6 aos 18 anos de idade. Ortodontia, v.29, n.1, p.4-12, jan./abr. 1996.

324. URSI, W.J.S.; MCNAMARA JR., J.A. Crescimento craniofacial em pacientes apresentando maloclusões de Classe II e oclusão normal, entre 
os 10 e os 12 anos de idade. Rev Dent Press Ortodon Ortoped Facial, v.2, n.5, p.49-59, set.-out. 1997.

325. URSI, W.J.S.; MCNAMARA JR., J.A.; MARTINS, D.R. Alteração clínica da face em crescimento: uma comparação cefalométrica entre os aparelhos extrabucal cervical, Fränkel e Herbst, no tratamento das Classes II. Rev Dent Press Ortodon Ortoped Facial, v.4, n.5, p.77-108, set.-out. 1999.

326. VADEN, J.L.; HARRIS, E.F.; BEHRENTS, R.G. Adult versus adolescent Class II correction: a comparison. Am J Orthod Dentofacial Orthop, v.107, n.6, p.651-61, June 1995.

327. VALANT, J.R.; SINCLAIR, P.M. Treatment effects of the Herbst appliance. Am J Orthod Dentofacial Orthop, v.95, n.2, p.138-47, Feb. 1989.

328. VALE, D.M.V.D. Avaliação cefalométrica das estruturas dentoesqueléticas em jovens portadores de Classe II, divisão 1, brasileiros, leucodermas e de origem mediterrânea. Bauru, 1985. 94p. Dissertação (Mestrado) - Faculdade de Odontologia de Bauru - Universidade de São Paulo.

329. VAN BEEK, H. Combination headgear-activator. J Clin Orthod, v.18, n.3, p.185-9, Mar. 1984.

330. VANLAECKEN, R. et al. Treatment effects of the edgewise Herbst appliance: a cephalometric and tomographic investigation. Am $\mathbf{J}$ Orthod Dentofacial Orthop, v.130, n.5, p.582-93, Nov 2006.

331. VARGERVIK, K.; HARVOLD, E.P. Response to activator treatment in Class II malocclusions. Am J Orthod, v.88, n.3, p.242-51, Sept. 1985.

332. VIG, P.S.; VIG, K.W. Hybrid appliances: a component approach to dentofacial orthopedics. Am J Orthod Dentofacial Orthop, v.90, n.4, p.273-85, Oct 1986.

333. VIGORITO, J.W. Estudo comparativo de algumas características mandibulares em maloclusões de Classe I e Classe II, divisão 1, de Angle. Rev Fac Odont USP, v.11, n.1, p.75-82, jan.-jun. 1973.

334. VON BREMEN, J.; PANCHERZ, H. Efficiency of early and late Class II Division 1 treatment. Am J Orthod Dentofacial Orthop, v.121, n.1, p.31-7, Jan. 2002.

335. VOUDOURIS, J.C.; KUFTINEC, M.M. Improved clinical use of Twin-block and Herbst as a result of radiating viscoelastic tissue forces on the condyle 
and fossa in treatment and long-term retention: growth relativity. Am $\mathbf{J}$ Orthod Dentofacial Orthop, v.117, n.3, p.247-66, Mar. 2000.

336. VOUDOURIS, J.C. et al. Condyle-fossa modifications and muscle interactions during Herbst treatment, Part 2. Results and conclusions. Am J Orthod Dentofacial Orthop, v.124, n.1, p.13-29, July 2003.

337. VOUDOURIS, J.C. et al. Condyle-fossa modifications and muscle interactions during herbst treatment, part 1. New technological methods. Am J Orthod Dentofacial Orthop, v.123, n.6, p.604-13, June 2003.

338. WEILAND, F.J.; BANTLEON, H.P. Treatment of Class II malocclusions with the Jasper Jumper appliance-a preliminary report. Am J Orthod Dentofacial Orthop, v.108, n.4, p.341-50, Oct. 1995.

339. WEILAND, F.J.; DROSCHL, H. Treatment of a Class II, Division 1 malocclusion with the Jasper Jumper: a case report. Am J Orthod Dentofacial Orthop, v.109, n.1, p.1-7, Jan. 1996.

340. WEILAND, F.J. et al. Initial effects of treatment of Class II malocclusion with the Herren activator, activator-headgear combination, and Jasper Jumper. Am J Orthod Dentofacial Orthop, v.112, n.1, p.19-27, July 1997.

341. WEST, K.S.; MCNAMARA, J.A., JR. Changes in the craniofacial complex from adolescence to midadulthood: a cephalometric study. Am J Orthod Dentofacial Orthop, v.115, n.5, p.521-32, May 1999.

342. WHEELER, T.T. et al. The timing of Class II treatment. Am J Orthod Dentofacial Orthop, v.129, n.4 Suppl, p.S66-70, Apr 2006.

343. WHEELER, T.T. et al. Effectiveness of early treatment of Class II malocclusion. Am J Orthod Dentofacial Orthop, v.121, n.1, p.9-17, Jan. 2002.

344. WHITNEY, E.F.; SINCLAIR, P.M. An evaluation of combination second molar extraction and functional appliance therapy. Am $\mathbf{J}$ Orthod Dentofacial Orthop, v.91, n.3, p.183-92, Mar. 1987.

345. WIESLANDER, L. Long-term effect of treatment with the headgear-Herbst appliance in the early mixed dentition. Stability or relapse? Am J Orthod Dentofacial Orthop, v.104, n.4, p.319-29, Oct 1993.

346. WIESLANDER, L.; LAGERSTROM, L. The effect of activator treatment on class II malocclusions. Am J Orthod, v.75, n.1, p.20-6, Jan. 1979. 
347. WOODSIDE, D.G.; METAXAS, A.; ALTUNA, G. The influence of functional appliance therapy on glenoid fossa remodeling. Am $\mathbf{J}$ Orthod Dentofacial Orthop, v.92, n.3, p.181-98, Sept. 1987.

348. YARED, K.F.G.; ZENOBIO, E.G.; PACHECO, W. Periodontal status of mandibular central incisors after orthodontic proclination in adults. Am $\mathbf{J}$ Orthod Dentofacial Orthop, v.130, n.1, p.6 e1-8, Jul 2006.

349. YARED, K.F.G.; ZENOBIO, E.G.; PACHECO, W. Projeção ortodôntica de incisivos inferiores: um risco à recessão periodontal? Rev Dent Press Ortodon Ortoped Facial, v.11, n.5, p.35-41, set./out. 2006.

350. YOU, Z.H. et al. Dentoalveolar changes related to mandibular forward growth in untreated Class II persons. Am J Orthod Dentofacial Orthop, v.120, n.6, p.598-607, Dec 2001.

351. ZAR, J.H. Biostatistical analysis. 4th ed. Upper Saddle River, N.J., Prentice Hall, 1999.

352. ZIMMER, B.; ROTTWINKEL, Y. Orthodontic space closure without counterbalancing extractions in patients with bilateral aplasia of the lower second premolars. J Orofac Orthop, v.63, n.5, p.400-21, Sept. 2002. 


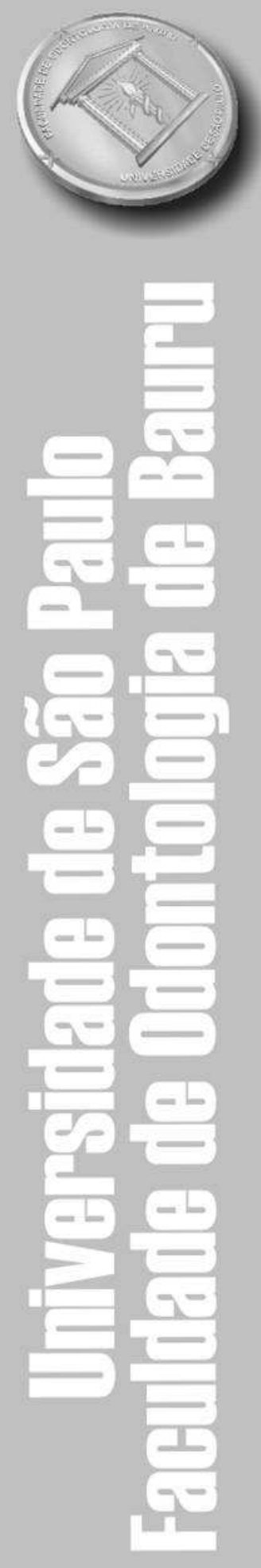

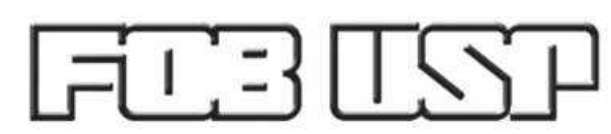

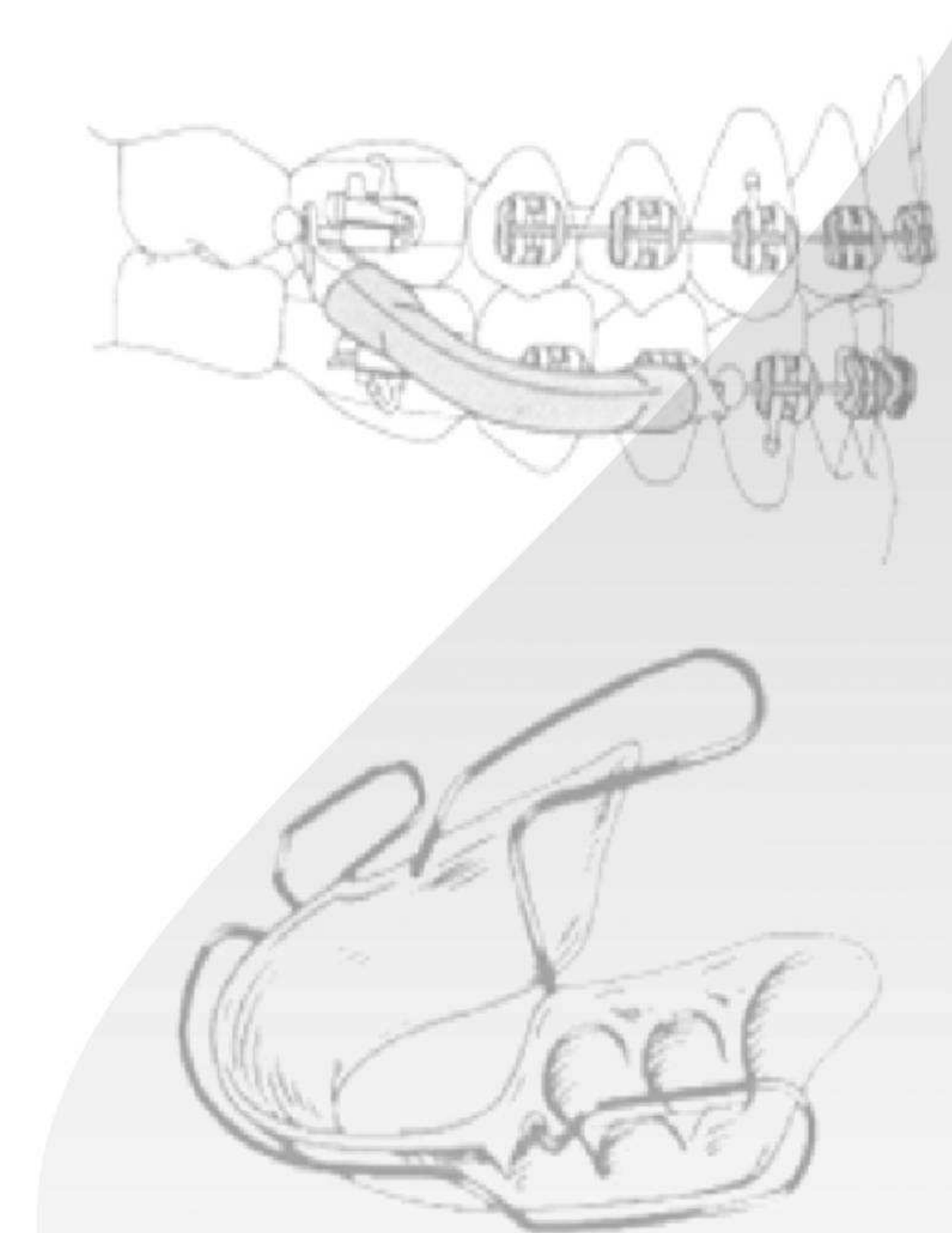

Apêndices 
APÊNDICE 1 - Valores individuais das idades inicial, final; do tempo de uso do Jasper Jumper, do tempo de tratamento total, e da severidade inicial da má oclusão medida nos modelos de gesso (relação molar*, relação dos caninos*, e sobressaliência) para os pacientes do Grupo Experimental 1 (Jasper Jumper).

\section{Paciente Gênero}

A. B. F. S.

B. N. A.

B. P. N.

C. C. Jr.

D.P.C.

D. L. F.

D. R. C. S.

G. C.

G. B. F. B.

J. R. B.

J. B. C.

J. T. A.

K. F. R.

L. C. B. S.

M. H. A.

M. F. S.

M. M. L.

M. T. M.

M. C. P.

M. P. P.

P. R. S.

R. C.

R. F. G.

V. F. F.

V.S.

\section{Idade} inicial

M 12,34a

M 11,36a

M 12,09a

M 11,01a

F 13,65a

F $10,32 a$

M 13,62a

F $\quad 11,77 a$

M 11,94a

F $14,84 a$

M 12,25a

F $12,62 \mathrm{a}$

F $13,43 a$

M 14,15a

M 14,55a

M 13,27a

M 12,78a

F $\quad 10,86 a$

F $11,39 a$

F $13,06 \mathrm{a}$

M $13,88 \mathrm{a}$

F $12,14 a$

M 13,78a

F 12,93a

F $13,97 a$

\section{Idade final}

$14,49 a$

$13,33 a$

$14,30 a$

$13,15 a$

$15,78 a$

$12,74 a$

$15,61 \mathrm{a}$

$13,71 a$

$15,26 a$

$16,68 \mathrm{a}$

$14,53 a$

$14,44 a$

$15,49 a$

$16,42 a$

$16,90 \mathrm{a}$

$15,16 a$

$14,90 a$

$13,07 a$

$13,50 \mathrm{a}$

$14,92 \mathrm{a}$

$16,15 a$

$14,07 a$

$15,97 a$

$14,95 a$

$16,37 a$
Tempo de Tempo de uso Jasper trat. total

$\begin{array}{ll}0,61 \mathrm{a} & 2,15 \mathrm{a} \\ 0,48 \mathrm{a} & 1,96 \mathrm{a} \\ 0,78 \mathrm{a} & 2,21 \mathrm{a} \\ 0,41 \mathrm{a} & 2,13 \mathrm{a} \\ 0,61 \mathrm{a} & 2,13 \mathrm{a} \\ 0,62 \mathrm{a} & 2,42 \mathrm{a} \\ 0,97 \mathrm{a} & 1,98 \mathrm{a} \\ 0,48 \mathrm{a} & 1,94 \mathrm{a} \\ 0,43 \mathrm{a} & 3,32 \mathrm{a} \\ 0,65 \mathrm{a} & 1,84 \mathrm{a} \\ 0,63 \mathrm{a} & 2,28 \mathrm{a} \\ 0,40 \mathrm{a} & 1,81 \mathrm{a} \\ 0,78 \mathrm{a} & 2,06 \mathrm{a} \\ 0,86 \mathrm{a} & 2,28 \mathrm{a} \\ 0,90 \mathrm{a} & 2,35 \mathrm{a} \\ 0,48 \mathrm{a} & 1,89 \mathrm{a} \\ 0,37 \mathrm{a} & 2,12 \mathrm{a} \\ 0,57 \mathrm{a} & 2,21 \mathrm{a} \\ 0,43 \mathrm{a} & 2,11 \mathrm{a} \\ 0,61 \mathrm{a} & 1,86 \mathrm{a} \\ 0,51 \mathrm{a} & 2,27 \mathrm{a} \\ 0,48 \mathrm{a} & 1,93 \mathrm{a} \\ 0,52 \mathrm{a} & 2,19 \mathrm{a} \\ 0,79 \mathrm{a} & 2,02 \mathrm{a} \\ 0,77 \mathrm{a} & 2,40 \mathrm{a}\end{array}$

Rel. mol

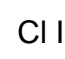

Cl II completa

CI II completa $1 / 2 \mathrm{Cl}$ II

Cl II completa $3 / 4 \mathrm{Cl}$ II $3 / 4 \mathrm{Cl} \mathrm{II}$

Cl II completa

Cl II completa

CI II completa

Cl II completa $3 / 4 \mathrm{Cl} \mathrm{II}$
Rel. can.

Sobres.

CI II completa
$1 / 2 \mathrm{CI} \mathrm{II}$
$3 / 4 \mathrm{CI} \mathrm{II}$
$3 / 4 \mathrm{CI} \mathrm{II}$
$1 / 2 \mathrm{CI}$ II
CI II completa
$3 / 4 \mathrm{Cl} \mathrm{II}$

$9,5 \mathrm{~mm}$

$7 \mathrm{~mm}$

$7,5 \mathrm{~mm}$

$8 \mathrm{~mm}$

$7,5 \mathrm{~mm}$

$13,5 \mathrm{~mm}$

$4,5 \mathrm{~mm}$

$3 / 4 \mathrm{Cl} \mathrm{II} \quad 5,5 \mathrm{~mm}$

$3 / 4 \mathrm{Cl} \mathrm{II} \quad 6,5 \mathrm{~mm}$

$3 / 4 \mathrm{Cl} \mathrm{II} \quad 6,5 \mathrm{~mm}$

$3 / 4 \mathrm{Cl} \mathrm{II} \quad 10,5 \mathrm{~mm}$

$3 / 4 \mathrm{CI} \mathrm{II} \quad 4,5 \mathrm{~mm}$

$1 / 2 \mathrm{Cl} \mathrm{II}$

$3 / 4 \mathrm{Cl} \mathrm{II}$

Cl II completa

$3 / 4 \mathrm{Cl} \mathrm{II}$

$1 / 2 \mathrm{Cl} \mathrm{II}$

$3 / 4 \mathrm{Cl} \mathrm{II}$

$3 / 4 \mathrm{Cl} \mathrm{II}$

$3 / 4 \mathrm{CI} \mathrm{II}$

$3 / 4 \mathrm{Cl}$ II

$3 / 4 \mathrm{Cl} \mathrm{II}$

CI II completa

$3 / 4 \mathrm{Cl} \mathrm{II}$

$3 / 4 \mathrm{Cl} \mathrm{II}$
$6,5 \mathrm{~mm}$

$6 \mathrm{~mm}$

$8,5 \mathrm{~mm}$

$7 \mathrm{~mm}$

$5,5 \mathrm{~mm}$

$11 \mathrm{~mm}$

$6,5 \mathrm{~mm}$

$7,5 \mathrm{~mm}$

$5,5 \mathrm{~mm}$

$6,5 \mathrm{~mm}$

$10,5 \mathrm{~mm}$

$8 \mathrm{~mm}$

$4,5 \mathrm{~mm}$

* Considerou-se a avaliação do hemi-arco mais severo. 
APÊNDICE 2 - Valores individuais das grandezas cefalométricas SNA, Co-A e A-Nperp para os pacientes do Grupo Experimental 1 (Jasper Jumper).

\section{Paciente SNA 1 SNA 2 SNA 2-1 Co-A 1 Co-A 2 Co-A 2-1 A-Nperp A-Nperp A-Nperp}

\begin{tabular}{|c|c|c|c|c|c|c|c|c|c|}
\hline & & & & & & & & & \\
\hline A. B. F. S. & 86,8 & 87,2 & 0,40 & 92,6 & 92,4 & $-0,2$ & 4,7 & 6,1 & 1,4 \\
\hline B. N. A. & 82,2 & 78,9 & $-3,30$ & 81,4 & 80 & $-1,4$ & 3,3 & $-1,5$ & $-4,8$ \\
\hline B. P. N. & 85,1 & 82,9 & $-2,20$ & 90,5 & 92,4 & 1,9 & 3,4 & 2,3 & $-1,1$ \\
\hline C. C. Jr. & 78,3 & 75,2 & $-3,10$ & 79,5 & 81,1 & 1,6 & 0,5 & $-1,8$ & $-2,3$ \\
\hline D. P. C. & 81,3 & 81,1 & $-0,20$ & 88,9 & 91,8 & 2,9 & 0,6 & 3 & 2,4 \\
\hline D. L. F. & 90,2 & 89,9 & $-0,30$ & 86 & 87,3 & 1,3 & 7,2 & 8,5 & 1,3 \\
\hline D. R. C. S. & 84,7 & 79,6 & $-5,10$ & 87,6 & 88,2 & 0,6 & 4,2 & 0,4 & $-3,8$ \\
\hline G. C. & 80,8 & 80,3 & $-0,50$ & 86,7 & 84,9 & $-1,8$ & 1,3 & $-1,1$ & $-2,4$ \\
\hline G. B. F. B. & 79,2 & 77,9 & $-1,30$ & 80,8 & 85,4 & 4,6 & $-4,5$ & $-6,5$ & -2 \\
\hline J.R. B. & 83,7 & 85,2 & 1,50 & 90 & 91,6 & 1,6 & 0 & 1,3 & 1,3 \\
\hline J. B. C. & 83,8 & 78,7 & $-5,10$ & 84,5 & 82,7 & $-1,8$ & 1,7 & -7 & $-8,7$ \\
\hline J. T. A. & 84,9 & 85 & 0,10 & 81,1 & 81,5 & 0,4 & 5,3 & 4,8 & $-0,5$ \\
\hline K. F. R. & 82,7 & 82,4 & $-0,30$ & 89,4 & 92,9 & 3,5 & 5,2 & 6,6 & 1,4 \\
\hline L. C. B. S. & 88 & 83,9 & $-4,10$ & 91,8 & 92,7 & 0,9 & 7,4 & 5,1 & $-2,3$ \\
\hline M. H. A. & 85,8 & 80,8 & $-5,00$ & 93,2 & 92,1 & $-1,1$ & 0,4 & $-2,2$ & $-2,6$ \\
\hline M. F. S. & 79,7 & 81,2 & 1,50 & 88 & 90,7 & 2,7 & 1,5 & 2,8 & 1,3 \\
\hline M. M. L. & 81,5 & 79,9 & $-1,60$ & 89,7 & 82,1 & $-7,6$ & $-1,3$ & $-10,1$ & $-8,8$ \\
\hline M. T. M. & 81,8 & 81,7 & $-0,10$ & 76,8 & 76,3 & $-0,5$ & $-1,1$ & $-3,4$ & $-2,3$ \\
\hline M. C. P. & 78 & 78,3 & 0,30 & 85,4 & 85,4 & 0 & $-3,7$ & $-4,1$ & $-0,4$ \\
\hline M. P. P. & 81 & 79,8 & $-1,20$ & 87,9 & 89,5 & 1,6 & $-1,3$ & $-1,1$ & 0,2 \\
\hline P.R. S. & 75,6 & 77,4 & 1,80 & 83,9 & 85,5 & 1,6 & $-5,6$ & $-3,8$ & 1,8 \\
\hline R. C. & 81,5 & 82,8 & 1,30 & 82,7 & 85 & 2,3 & 3,1 & 5,1 & 2 \\
\hline R. F. G. & 83,6 & 81,6 & $-2,00$ & 83 & 83,7 & 0,7 & $-2,9$ & $-4,5$ & $-1,6$ \\
\hline V. F. F. & 85,4 & 83,5 & $-1,90$ & 86,1 & 88,6 & 2,5 & 6,2 & 5,9 & $-0,3$ \\
\hline V. S. & 79 & 78,6 & $-0,40$ & 79,3 & 78,3 & -1 & -2 & $-2,6$ & $-0,6$ \\
\hline
\end{tabular}


APÊNDICE 3 - Valores individuais das grandezas cefalométricas SNB, Co-Gn e Go-Gn para os pacientes do Grupo Experimental 1 (Jasper Jumper).

Paciente SNB 1 SNB 2 SNB 2-1 Co-Gn 1 Co-Gn 2 Co-Gn 2-1 Go-Gn 1 Go-Gn 2 Go-Gn 2-1

$\begin{array}{lccccccccc}\text { A. B. F. S. } & 79,5 & 80,6 & 1,1 & 111,8 & 116,5 & 4,7 & 72,6 & 75,2 & 2,6 \\ \text { B. N. A. } & 77,4 & 76,6 & -0,8 & 106,9 & 109,1 & 2,2 & 70,1 & 73,6 & 3,5 \\ \text { B.P. . } & 79,8 & 79,7 & -0,1 & 111 & 116,9 & 5,9 & 74,6 & 77,4 & 2,8 \\ \text { C. . Jr. } & 74,4 & 74,3 & -0,1 & 100,8 & 106,2 & 5,4 & 65,1 & 69,5 & 4,4 \\ \text { D. P. C. } & 73,2 & 73,6 & 0,4 & 102,7 & 106,3 & 3,6 & 68,2 & 67,6 & -0,6 \\ \text { D. L. F. } & 77,5 & 77,8 & 0,3 & 95,8 & 99,7 & 3,9 & 64,4 & 68,2 & 3,8 \\ \text { D. R. C. S. } & 79,2 & 78 & -1,2 & 107 & 114,5 & 7,5 & 70,9 & 74,5 & 3,6 \\ \text { G. C. } & 75,1 & 76,1 & 1 & 103 & 105,8 & 2,8 & 70,8 & 73,4 & 2,6 \\ \text { G. B. F. B. } & 76,2 & 76,9 & 0,7 & 98,5 & 110,5 & 12 & 65,6 & 76,3 & 10,7 \\ \text { J. R. B. } & 82,6 & 83,3 & 0,7 & 112,4 & 113,6 & 1,2 & 78,7 & 80,4 & 1,7 \\ \text { J.B. C. } & 76,1 & 75,8 & -0,3 & 99,1 & 105,9 & 6,8 & 65,5 & 68,9 & 3,4 \\ \text { J. T. A. } & 82,2 & 82 & -0,2 & 103,8 & 105,2 & 1,4 & 70,1 & 70,9 & 0,8 \\ \text { K. F. R. } & 77,9 & 77,1 & -0,8 & 111,9 & 114,5 & 2,6 & 70,2 & 72,6 & 2,4 \\ \text { L. C. B. S. } & 79,5 & 77,4 & -2,1 & 114,7 & 121 & 6,3 & 75,3 & 79,4 & 4,1 \\ \text { M. H. A. } & 76 & 74,9 & -1,1 & 112,8 & 116,3 & 3,5 & 73,7 & 73,2 & -0,5 \\ \text { M. F. S. } & 73 & 74,5 & 1,5 & 105,6 & 110,8 & 5,2 & 72 & 79 & 7 \\ \text { M. M. L. } & 76,4 & 76,1 & -0,3 & 111,1 & 108,6 & -2,5 & 70 & 73,6 & 3,6 \\ \text { M. T. M. } & 77,9 & 77,7 & -0,2 & 99,2 & 100,8 & 1,6 & 63 & 64 & 1 \\ \text { M. C.P. } & 74,7 & 75 & 0,3 & 106,9 & 110,2 & 3,3 & 69,9 & 73,1 & 3,2 \\ \text { M.P.P. } & 76,1 & 76 & -0,1 & 108,9 & 110,8 & 1,9 & 75,8 & 75,2 & -0,6 \\ \text { P. R. S. } & 73,6 & 75,9 & 2,3 & 107,6 & 113,2 & 5,6 & 74,4 & 74,8 & 0,4 \\ \text { R. C. } & 78 & 77,5 & -0,5 & 107 & 108,4 & 1,4 & 74,7 & 76,3 & 1,6 \\ \text { R. F. G. } & 79,8 & 80 & 0,2 & 110,7 & 116,4 & 5,7 & 70,2 & 74,6 & 4,4 \\ \text { V. F. F. } & 76 & 76 & 0 & 105,1 & 111,4 & 6,3 & 66,4 & 69,8 & 3,4 \\ \text { V.S. } & 78,1 & 79,7 & 1,6 & 103,2 & 106,1 & 2,9 & 70,2 & 72,7 & 2,5\end{array}$


APÊNDICE 4 - Valores individuais das grandezas cefalométricas Co-Go,

P-Nperp e ANB para os pacientes do Grupo Experimental 1 (Jasper Jumper).

Paciente Co-Go 1 Co-Go 2 Co-Go 2-1 P-Nperp P-Nperp P-Nperp ANB 1 ANB 2 ANB 2-1

$\begin{array}{lccccccccc}\text { A. B. F. S. } & 54,9 & 59,4 & 4,5 & -5,5 & -0,1 & 5,4 & 7,3 & 6,6 & -0,7 \\ \text { B. N. A. } & 48,8 & 47,7 & -1,1 & -0,4 & -5,7 & -5,3 & 4,8 & 2,2 & -2,6 \\ \text { B. P. .. } & 52 & 56,3 & 4,3 & -0,1 & 1,9 & 2 & 5,3 & 3,3 & -2 \\ \text { C. C. Jr. } & 53,8 & 55,8 & 2 & -3,4 & -2,8 & 0,6 & 3,9 & 0,9 & -3 \\ \text { D. P. . } & 47,1 & 51,4 & 4,3 & -11,9 & -7 & 4,9 & 8,1 & 7,5 & -0,6 \\ \text { D. L. F. } & 39,8 & 42,3 & 2,5 & -7,3 & -5,4 & 1,9 & 12,7 & 12,1 & -0,6 \\ \text { D. R. C. S. } & 49,9 & 55,1 & 5,2 & -1,5 & -0,2 & 1,3 & 5,5 & 1,6 & -3,9 \\ \text { G. C. } & 48,6 & 50,2 & 1,6 & -6,8 & -8,7 & -1,9 & 5,8 & 4,3 & -1,5 \\ \text { G. B. F. B. } & 47,7 & 51,5 & 3,8 & -8,9 & -9,5 & -0,6 & 3 & 1 & -2 \\ \text { J. R. B. } & 50,1 & 51,2 & 1,1 & 0,2 & 1,2 & 1 & 1,1 & 1,9 & 0,8 \\ \text { J.B. C. } & 51,1 & 56,4 & 5,3 & -8 & -16,2 & -8,2 & 7,7 & 3 & -4,7 \\ \text { J. T. A. } & 46,3 & 47,5 & 1,2 & 6,2 & 4,8 & -1,4 & 2,7 & 3 & 0,3 \\ \text { K. F. R. } & 52,7 & 53,7 & 1 & 1,5 & 2,1 & 0,6 & 4,8 & 5,3 & 0,5 \\ \text { L. C. B. S. } & 50,8 & 53,8 & 3 & -0,6 & -2 & -1,4 & 8,5 & 6,5 & -2 \\ \text { M. H. A. } & 56,4 & 59,7 & 3,3 & -13,6 & -11,9 & 1,7 & 9,8 & 5,9 & -3,9 \\ \text { M. F. S. } & 56,3 & 60,1 & 3,8 & -7,6 & -5,5 & 2,1 & 6,7 & 6,7 & 0 \\ \text { M. M. L. } & 52 & 49,2 & -2,8 & -8,5 & -22 & -13,5 & 5,2 & 3,8 & -1,4 \\ \text { M. T. M. } & 48,5 & 50,5 & 2 & -5,7 & -10,4 & -4,7 & 3,9 & 4 & 0,1 \\ \text { M. C. P. } & 52,2 & 53,5 & 1,3 & -9,3 & -9,6 & -0,3 & 3,3 & 3,3 & 0 \\ \text { M. P. P. } & 52,6 & 52,4 & -0,2 & -9,6 & -6,9 & 2,7 & 5 & 3,8 & -1,2 \\ \text { P. R. S. } & 50,7 & 58,7 & 8 & -8,9 & -3,4 & 5,5 & 1,9 & 1,5 & -0,4 \\ \text { R. C. } & 53,9 & 54,4 & 0,5 & 4,2 & 4,2 & 0 & 3,5 & 5,3 & 1,8 \\ \text { R. F. G. } & 58,1 & 59,9 & 1,8 & -7,3 & -6,4 & 0,9 & 3,7 & 1,5 & -2,2 \\ \text { V. F. F. } & 51,2 & 54,7 & 3,5 & -3,8 & -2,2 & 1,6 & 9,4 & 7,5 & -1,9 \\ \text { V. S. } & 50,4 & 51,5 & 1,1 & -2 & 0,6 & 2,6 & 0,8 & -1,2 & -2\end{array}$


APÊNDICE 5 - Valores individuais das grandezas cefalométricas NAP, Co-A/Co-Gn e Wits para os pacientes do Grupo Experimental 1 (Jasper Jumper).

Paciente NAP 1 NAP 2 NAP 2-1 Co-A/Co- Co-A/Co- Co-A/Co- Wits 1 Wits 2 Wits 2-1

$\begin{array}{lccccccccc}\text { A. B. F. S. } & 15,9 & 12,7 & -3,2 & 82,8 & 79,3 & -3,5 & 3,2 & 0,7 & -2,5 \\ \text { B. N. A. } & 8,2 & 2,9 & -5,3 & 76,1 & 73,4 & -2,7 & -2,2 & -3,5 & -1,3 \\ \text { B. P. N. } & 8,1 & 2,7 & -5,4 & 81,5 & 79 & -2,5 & 1,6 & 1,8 & 0,2 \\ \text { C. C. Jr. } & 5,2 & -0,5 & -5,7 & 78,8 & 76,4 & -2,4 & -1,4 & -3,2 & -1,8 \\ \text { D. P. C. } & 17,5 & 16,9 & -0,6 & 86,6 & 86,3 & -0,3 & 2,1 & 3,3 & 1,2 \\ \text { D. L. F. } & 27 & 26,7 & -0,3 & 89,8 & 87,5 & -2,3 & 5,3 & 7,2 & 1,9 \\ \text { D. R. C. S. } & 11,5 & 1,1 & -10,4 & 81,9 & 77 & -4,9 & 2 & -1,5 & -3,5 \\ \text { G. C. } & 12,3 & 8,6 & -3,7 & 84,1 & 80,3 & -3,8 & 1,9 & -0,7 & -2,6 \\ \text { G. B. F. B. } & 1,3 & -2,7 & -4 & 82,1 & 77,2 & -4,9 & 0,5 & -1,6 & -2,1 \\ \text { J. R. B. } & -0,3 & 1,6 & 1,9 & 80,1 & 80,6 & 0,5 & -1,2 & -1,7 & -0,5 \\ \text { J. B. C. } & 15,6 & 4,1 & -11,5 & 85,2 & 78,1 & -7,1 & 4,1 & -0,8 & -4,9 \\ \text { J. T. A. } & 4,9 & 5,4 & 0,5 & 78,2 & 77,4 & -0,8 & -3,5 & -2,3 & 1,2 \\ \text { K. F. R. } & 9,7 & 11,7 & 2 & 79,8 & 81,2 & 1,4 & -0,5 & 1,2 & 1,7 \\ \text { L. C. B. S. } & 16,4 & 12,3 & -4,1 & 80 & 76,6 & -3,4 & 6,3 & 4,1 & -2,2 \\ \text { M. H. A. } & 15,4 & 7,9 & -7,5 & 82,7 & 79,1 & -3,6 & 5,6 & -2,5 & -8,1 \\ \text { M. F. S. } & 13,2 & 12,4 & -0,8 & 83,4 & 81,8 & -1,6 & 2,2 & 2,7 & 0,5 \\ \text { M. M. L. } & 7,3 & 3,2 & -4,1 & 80,7 & 75,6 & -5,1 & 1,5 & 3,2 & 1,7 \\ \text { M. T. M. } & 4,6 & 4,4 & -0,2 & 77,4 & 75,7 & -1,7 & 0,5 & -1 & -1,5 \\ \text { M. C. P. } & 2,7 & 2 & -0,7 & 79,9 & 77,4 & -2,5 & 3 & 4,2 & 1,2 \\ \text { M.P.P. } & 9,2 & 6,2 & -3 & 80,7 & 80,8 & 0,1 & 2 & 1,6 & -0,4 \\ \text { P. R. S. } & -1,6 & -4,2 & -2,6 & 78 & 75,5 & -2,5 & 0,5 & 0,5 & 0 \\ \text { R. C. } & 1,9 & 6,6 & 4,7 & 77,3 & 78,4 & 1,1 & 2,4 & 1,4 & -1 \\ \text { R. F. G. } & 2,2 & -2,4 & -4,6 & 75 & 71,9 & -3,1 & 3 & 1,4 & -1,6 \\ \text { V. F. F. } & 18,3 & 14,8 & -3,5 & 81,9 & 79,5 & -2,4 & 5,6 & 3,6 & -2 \\ \text { V. S. } & -2,2 & -6,7 & -4,5 & 76,9 & 73,8 & -3,1 & -0,7 & -3,3 & -2,6\end{array}$


APÊNDICE 6 - Valores individuais das grandezas cefalométricas FMA, SN.GoGn e SN.PP para os pacientes do Grupo Experimental 1 (Jasper Jumper).

\section{Paciente FMA 1 FMA 2 FMA 2-1 SN.GoGn SN.GoGn SN.GoGn SN.PP 1 SN.PP 2 SN.PP 2-1}

$\begin{array}{lccccccccc}\text { A. B. F. S. } & 26,1 & 24,2 & -1,9 & 30,4 & 29,7 & -0,7 & 6,5 & 4,4 & -2,1 \\ \text { B. N. A. } & 28,2 & 31,7 & 3,5 & 38,1 & 39,2 & 1,1 & 7,4 & 6,1 & -1,3 \\ \text { B. P. N. } & 21,6 & 20,6 & -1 & 27,8 & 27,5 & -0,3 & 6,9 & 6,7 & -0,2 \\ \text { C. C. Jr. } & 19,2 & 19,5 & 0,3 & 29,1 & 30,1 & 1 & 2,3 & 3,2 & 0,9 \\ \text { D. P. C. } & 30,9 & 27,2 & -3,7 & 36,4 & 35,4 & -1 & 11,8 & 12,4 & 0,6 \\ \text { D. L. F. } & 29,9 & 30,4 & 0,5 & 36 & 37,1 & 1,1 & 6,6 & 7,1 & 0,5 \\ \text { D. R. C. S. } & 25,2 & 25 & -0,2 & 32,4 & 33 & 0,6 & 4,5 & 7,7 & 3,2 \\ \text { G. C. } & 23,8 & 25,9 & 2,1 & 32,1 & 32,4 & 0,3 & 12,1 & 12 & -0,1 \\ \text { G. B. F. B. } & 22,1 & 25,3 & 3,2 & 25,7 & 28,9 & 3,2 & 9,9 & 9,7 & -0,2 \\ \text { J. R. B. } & 21,7 & 21,5 & -0,2 & 25 & 24,9 & -0,1 & 3,1 & 3,7 & 0,6 \\ \text { J. B. . } & 23,1 & 28,1 & 5 & 27,8 & 28,6 & 0,8 & 8,9 & 10,8 & 1,9 \\ \text { J. T. A. } & 23 & 24,1 & 1,1 & 31,6 & 32,2 & 0,6 & 5,8 & 6,5 & 0,7 \\ \text { K. F. R. } & 25,7 & 25,4 & -0,3 & 36 & 36,8 & 0,8 & 10,5 & 12 & 1,5 \\ \text { L. C. B. S. } & 30,4 & 32,6 & 2,2 & 37,5 & 40,8 & 3,3 & 7,5 & 9,1 & 1,6 \\ \text { M. H. A. } & 25 & 25,4 & 0,4 & 28,2 & 30,8 & 2,6 & 4,4 & 6,2 & 1,8 \\ \text { M. F. S. } & 17,8 & 17,1 & -0,7 & 28 & 26,8 & -1,2 & 12,4 & 12,9 & 0,5 \\ \text { M. M. L. } & 29,8 & 37,3 & 7,5 & 34,2 & 35,4 & 1,2 & 5,3 & 5,8 & 0,5 \\ \text { M. T. M. } & 26,9 & 29,2 & 2,3 & 31,6 & 31,5 & -0,1 & 5,9 & 8,6 & 2,7 \\ \text { M. C. P. } & 23,8 & 26,3 & 2,5 & 29,9 & 31,3 & 1,4 & 3,8 & 2,3 & -1,5 \\ \text { M.P.P. } & 25,9 & 24,1 & -1,8 & 30,9 & 31,1 & 0,2 & 8 & 7,7 & -0,3 \\ \text { P. R. S. } & 24,8 & 20,5 & -4,3 & 31,4 & 27,3 & -4,1 & 12,9 & 9,5 & -3,4 \\ \text { R. C. } & 17,2 & 17,9 & 0,7 & 26,9 & 28,3 & 1,4 & 7 & 6 & -1 \\ \text { R. F. G. } & 26,1 & 26,8 & 0,7 & 27,1 & 28,5 & 1,4 & 6,5 & 5,5 & -1 \\ \text { V. F. F. } & 29,4 & 29,6 & 0,2 & 37,4 & 38,5 & 1,1 & 7,9 & 11,7 & 3,8 \\ \text { V.S. } & 20,3 & 20,1 & -0,2 & 26,5 & 26,2 & -0,3 & 7,4 & 7,2 & -0,2\end{array}$


APÊNDICE 7 - Valores individuais das grandezas cefalométricas AFAI, SN.POF e S-Go para os pacientes do Grupo Experimental 1 (Jasper Jumper).

Paciente AFAl 1 AFAl 2 AFAl 2-1 SN.POF SN.POF SN.POF S-Go 1 S-Go 2 S-Go 2-1

$\begin{array}{lccccccccc}\text { A. B. F. S. } & 72,7 & 76,8 & 4,1 & 16,8 & 17,5 & 0,7 & 77,3 & 81,5 & 4,2 \\ \text { B. N. A. } & 62,9 & 67,9 & 5 & 23,2 & 19,9 & -3,3 & 59,8 & 63,2 & 3,4 \\ \text { B.P. .. } & 58,2 & 61,9 & 3,7 & 18,4 & 13,9 & -4,5 & 72,2 & 77,3 & 5,1 \\ \text { C. C. Jr. } & 60,4 & 63,6 & 3,2 & 23,9 & 23,2 & -0,7 & 72,3 & 76,2 & 3,9 \\ \text { D. P. . } & 61,1 & 63 & 1,9 & 28,2 & 23,8 & -4,4 & 64,6 & 68,3 & 3,7 \\ \text { D. L. F. } & 60,2 & 63,6 & 3,4 & 22,6 & 19,6 & -3 & 59 & 62,6 & 3,6 \\ \text { D. R. C. S. } & 62,6 & 67,4 & 4,8 & 18 & 17,6 & -0,4 & 68,6 & 74,9 & 6,3 \\ \text { G. C. } & 59,9 & 62,2 & 2,3 & 23,4 & 23 & -0,4 & 69,8 & 71,3 & 1,5 \\ \text { G. B. F. B. } & 55,5 & 62,8 & 7,3 & 18,4 & 17,2 & -1,2 & 70,5 & 75,9 & 5,4 \\ \text { J. R. B. } & 61,2 & 61,8 & 0,6 & 10,9 & 12,8 & 1,9 & 70,5 & 70,4 & -0,1 \\ \text { J.B. C. } & 58,6 & 63,1 & 4,5 & 20,4 & 19,5 & -0,9 & 66,4 & 73 & 6,6 \\ \text { J. T. A. } & 57,3 & 58 & 0,7 & 18,3 & 17,3 & -1 & 61,6 & 62,9 & 1,3 \\ \text { K. F. R. } & 64,6 & 67,4 & 2,8 & 20,3 & 20,3 & 0 & 67,5 & 68,6 & 1,1 \\ \text { L. C. B. S. } & 66,4 & 72,2 & 5,8 & 14,6 & 16,7 & 2,1 & 67,8 & 71,6 & 3,8 \\ \text { M. H. A. } & 70,7 & 71,8 & 1,1 & 18,9 & 25,5 & 6,6 & 79,4 & 80,5 & 1,1 \\ \text { M. F. S. } & 61,5 & 64,1 & 2,6 & 23,2 & 22,4 & -0,8 & 73,2 & 77,8 & 4,6 \\ \text { M. M. L. } & 64,6 & 71,7 & 7,1 & 20,1 & 16,7 & -3,4 & 70,2 & 75,8 & 5,6 \\ \text { M. T. M. } & 58,4 & 61,1 & 2,7 & 17,9 & 17,9 & 0 & 66,6 & 69,2 & 2,6 \\ \text { M. C.P. } & 64,7 & 69,4 & 4,7 & 16,9 & 13,6 & -3,3 & 74,6 & 77,1 & 2,5 \\ \text { M. P. P. } & 60,6 & 61,2 & 0,6 & 19,9 & 18,1 & -1,8 & 69 & 69,9 & 0,9 \\ \text { P. R. S. } & 57,7 & 63,9 & 6,2 & 19,3 & 16,3 & -3 & 68,9 & 79,6 & 10,7 \\ \text { R. C. } & 57,2 & 61,4 & 4,2 & 13,6 & 18,5 & 4,9 & 68,7 & 70,2 & 1,5 \\ \text { R. F. G. } & 61,9 & 68,9 & 7 & 11,8 & 10,1 & -1,7 & 75,8 & 81,5 & 5,7 \\ \text { V. F. F. } & 67,4 & 69,4 & 2 & 19,2 & 19,9 & 0,7 & 67,2 & 72,1 & 4,9 \\ \text { V.S. } & 58,9 & 61,3 & 2,4 & 14,4 & 15 & 0,6 & 71,9 & 74,6 & 2,7\end{array}$


APÊNDICE 8 - Valores individuais das grandezas cefalométricas 1.PP, 1.NA, 1-NA e 1-ENAperp para os pacientes do Grupo Experimental 1 (Jasper Jumper).

Paciente 1.PP 1 1.PP 2 1.PP 1.NA 1 1.NA 2 1.NA 1 1-NA 1 1-NA 2 1-NA 1 1- 1 1- 1 -

\section{2-1 $2-1$}

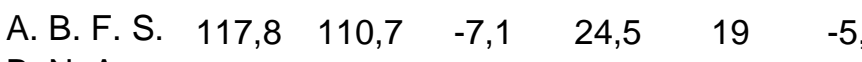

B. N. A.

B. P. N.

C. C. Jr. $\quad 110,4 \quad 105,2 \quad-5,2$

D. P. C. $\quad 115,9 \quad 108,7 \quad-7,2$

D. L. F. $\quad 125,8 \quad 96,8 \quad-29$

D. R. C. S. $98,4 \quad 105,4$

G. C.

G. B. F.

J. R. B.

$117,5112,7$

J. B. C.

J.T. A.

K. F. R.

L. C. B. S.

M. H. A.

M. F. S.

M. M. L.

M. T. M.

M. C. P.

M. P. P.

P. R. S.

R. C.

R. F. G.

V.F.F.

V.S.

$114,6 \quad 118,4$

$109,5 \quad 111$

$110,7 \quad 117,2$

$25 \quad 33,4$

6,5

$-4,8$

4,7

$-1,9$

$121,2 \quad 119,3$

$113,9 \quad 113,4$

$122,3 \quad 108,2$

$-0,5$

$-14,1$

3,6

1,8

$106 \quad 107,8$

$114,3 \quad 107,8$

$108,9 \quad 110,7$

$123,3 \quad 120$

$110,5 \quad 108,8$

$118,1 \quad 112,2$

$111,4 \quad 113,5$

$119,3 \quad 111$,

$\begin{array}{ll}128,7 & 117,3 \\ 106,9 & 102,9\end{array}$

$113,8 \quad 118$,

$22,2 \quad 13,8$

1,8

$-3,3$

$-1,7$

$-5,9$

2,1

$-8,2$

$-11,4$

$\begin{array}{ccc}-4 & 13,5 & 7,6\end{array}$

$4,3 \quad 27,4 \quad 32,3$

$35,7 \quad 29,7$

$28,7 \quad 28,1$

$29,1 \quad 24,7$

$23 \quad 26,6$

$30,8 \quad 22,3$

$38,7 \quad 30,2$
$17,5 \quad 21,4$

$29,8 \quad 26,8$

$22,8 \quad 15,2$

$29 \quad-0,2$

$9,1 \quad 18,1$

$-5,5 \quad 5,3$

$9 \quad-0,2$

8,4

3,9

$-3$

$-7,6$

$-29,2$

7,1

$-3,5$

2,6

1,3

$-1,3$

$-15,3$

6,1

5,1

$-8,4$

2,9

5,3
5,4

2,3

5,3

2,2

4,9
$-0,2$

1,9

6

9,3

5,2

2,9

5,5

$-0,7$

3,7

4,6

3,5

8,4

$-0,6$

$-4,4$

3,6

$-8,5$

$-8,5$

$-5,9$

4,9
$5,4 \quad 5,8$

$7 \quad 5,5$

$49 \quad 42$

$6,4 \quad 2,3$

$9,5 \quad 7,4$

$1,8 \quad-0,2$

5,4
2-1

ENAperp

1
$-0,5$

$-0,5$
$-2,4$

$-1,8$

$-2,9$

$-0,8$

$-0,2$

$-5,6$

$-1,8$

$-3,3$

3,2

$-0,4$

$-6$

$-0,9$

$-3,2$

$-4,7$

$-2,9$

$-2,9$

$-0,5$

$-5,8$

2,8

$-2,5$

0,8

2,6

$-6,1$

$-0,4$
Aperp ENAperp

$-5,4 \quad-4,9$

$-2,2 \quad 0,2$

$-2,5 \quad-0,7$

$-5,4 \quad-2,5$

$-5 \quad-4,2$

$-7,1 \quad-6,9$

$-7,3 \quad-1,7$

$-4,8 \quad-3$

$-4,4 \quad-1,1$

$0,4 \quad-2,8$

$-1,1 \quad-0,7$

$-4,7 \quad 1,3$

$-5,9 \quad-5$

$-4,1 \quad-0,9$

$-5,4 \quad-0,7$

$-3,5 \quad-0,6$

$-5,9 \quad-3$

$-2,9 \quad-2,4$

$-7 \quad-1,2$

$-1,1 \quad-3,9$

$-0,4 \quad 2,1$

$-4,2 \quad-5$

$-1,5 \quad-4,1$

$-6,3 \quad-0,2$ 
APÊNDICE 9 - Valores individuais das grandezas cefalométricas 1-PP, 6-PP e 6-ENAperp para os pacientes do Grupo Experimental 1 (Jasper Jumper).

Paciente 1-PP 1 1-PP 2 1-PP 2-1 6-PP 1 6-PP 2 6-PP 2-1

$\begin{array}{lccccccccc}\text { Paciente } & \text { 1-PP 1 } & \text { 1-PP 2 } & \text { 1-PP 2-1 } & \text { 6-PP 1 } & \text { 6-PP 2 } & \text { 6-PP 2-1 } & \begin{array}{c}\mathbf{6 -} \\ \text { ENAperp }\end{array} & \begin{array}{c}\text { 6- } \\ \text { ENAperp }\end{array} & \begin{array}{c}\mathbf{6 -} \\ \text { ENAperp }\end{array} \\ & & & & & & & \mathbf{1} & \mathbf{2} & \mathbf{2 - 1} \\ \text { A. B. F. S. } & 30,6 & 33,9 & 3,3 & 25,8 & 25,5 & -0,3 & -32 & -34,6 & -2,6 \\ \text { B. N. A. } & 28,6 & 29,7 & 1,1 & 20,9 & 22,3 & 1,4 & -28,6 & -30,9 & -2,3 \\ \text { B.P. N. } & 23,3 & 23,9 & 0,6 & 18,1 & 18,5 & 0,4 & -30,4 & -29,5 & 0,9 \\ \text { C. C. Jr. } & 27,1 & 29,8 & 2,7 & 20,9 & 21,4 & 0,5 & -33,8 & -33,8 & 0 \\ \text { D.P. C. } & 24,7 & 26,4 & 1,7 & 17,6 & 18,8 & 1,2 & -30,4 & -31,4 & -1 \\ \text { D. L. F. } & 25,5 & 28,3 & 2,8 & 17,6 & 19,4 & 1,8 & -33,3 & -30,5 & 2,8 \\ \text { D. R. C. S. } & 30,2 & 30,2 & 0 & 22 & 25,1 & 3,1 & -30,6 & -31 & -0,4 \\ \text { G. C. } & 25,1 & 24,9 & -0,2 & 18,7 & 19,8 & 1,1 & -30,5 & -34,5 & -4 \\ \text { G. B. F. B. } & 23,3 & 25,5 & 2,2 & 19,1 & 22,8 & 3,7 & -30,3 & -29,2 & 1,1 \\ \text { J. R. B. } & 26,9 & 26,7 & -0,2 & 22,7 & 21,5 & -1,2 & -23,8 & -29,3 & -5,5 \\ \text { J. B. C. } & 24,6 & 26,1 & 1,5 & 19,9 & 21,1 & 1,2 & -29,7 & -28,7 & 1 \\ \text { J. T. A. } & 23,4 & 24,6 & 1,2 & 19,1 & 18,8 & -0,3 & -29,6 & -29,5 & 0,1 \\ \text { K. F. R. } & 28,7 & 30,7 & 2 & 25 & 24,4 & -0,6 & -32,1 & -34 & -1,9 \\ \text { L. C. B. S. } & 27,2 & 28,6 & 1,4 & 21,6 & 22,4 & 0,8 & -32,6 & -33,9 & -1,3 \\ \text { M. H. A. } & 33,1 & 33,8 & 0,7 & 22,5 & 21,8 & -0,7 & -35,6 & -35,4 & 0,2 \\ \text { M. F. S. } & 27 & 29,5 & 2,5 & 22,3 & 23,2 & 0,9 & -32 & -31,3 & 0,7 \\ \text { M. M. L. } & 29 & 29,7 & 0,7 & 20,9 & 23,9 & 3 & -31,5 & -33,1 & -1,6 \\ \text { M. T. M. } & 23,2 & 24,7 & 1,5 & 18,5 & 20,5 & 2 & -30,1 & -29,8 & 0,3 \\ \text { M. C. P. } & 27,7 & 29,3 & 1,6 & 22,9 & 23,4 & 0,5 & -32,8 & -34,7 & -1,9 \\ \text { M. P. P. } & 25,4 & 26,4 & 1 & 20,7 & 20,4 & -0,3 & -26,4 & -28,6 & -2,2 \\ \text { P. R. S. } & 25 & 26,9 & 1,9 & 20 & 22,1 & 2,1 & -29,8 & -28,8 & 1 \\ \text { R. C. } & 25,7 & 27,5 & 1,8 & 21,4 & 21,4 & 0 & -27,2 & -31,7 & -4,5 \\ \text { R. F. G. } & 23,5 & 28,5 & 5 & 22,9 & 24,4 & 1,5 & -31,1 & -32,7 & -1,6 \\ \text { V. F. F. } & 28,8 & 29,1 & 0,3 & 21,8 & 23,4 & 1,6 & -36 & -34 & 2 \\ \text { V. S. } & 25,1 & 25 & -0,1 & 20,9 & 21,7 & 0,8 & -26 & -23,6 & 2,4\end{array}$


APÊNDICE 10 - Valores individuais das grandezas cefalométricas IMPA, 1.NB e 1-NB para os pacientes do Grupo Experimental 1 (Jasper Jumper).

Paciente IMPA 1 IMPA 2 IMPA 2-1 1 1.NB 1 1.NB 2 1.NB 2-1 1 1-NB 1 1-NB 2 1-NB 2-1

$\begin{array}{lccccccccc}\text { A. B. F. S. } & 99,8 & 107,8 & 8 & 33,5 & 41,7 & 8,2 & 7,7 & 10,8 & 3,1 \\ \text { B. N. A. } & 91,1 & 96,9 & 5,8 & 28,3 & 34,7 & 6,4 & 5,3 & 8,8 & 3,5 \\ \text { B. P. N. } & 94 & 94,5 & 0,5 & 23,8 & 24,1 & 0,3 & 2,5 & 3,9 & 1,4 \\ \text { C. C. Jr. } & 99,3 & 97 & -2,3 & 25,3 & 23,8 & -1,5 & 2,9 & 3,9 & 1 \\ \text { D. P. C. } & 95 & 104,1 & 9,1 & 28,4 & 36,5 & 8,1 & 5 & 7,4 & 2,4 \\ \text { D. L. F. } & 93,6 & 101,5 & 7,9 & 28,8 & 38,6 & 9,8 & 7,3 & 9,7 & 2,4 \\ \text { D. R. C. S. } & 99,4 & 94,9 & -4,5 & 33,3 & 28,6 & -4,7 & 3 & 2,6 & -0,4 \\ \text { G. . } & 99,5 & 103,6 & 4,1 & 28,8 & 34,1 & 5,3 & 4,3 & 6,3 & 2 \\ \text { G. B. F. B. } & 103,4 & 95,2 & -8,2 & 27,6 & 23,1 & -4,5 & 3,9 & 3,1 & -0,8 \\ \text { J. R. B. } & 98,3 & 104 & 5,7 & 29 & 35 & 6 & 6,2 & 7,7 & 1,5 \\ \text { J. B. C. } & 96,3 & 107,6 & 11,3 & 23,6 & 35,2 & 11,6 & 3,8 & 7,6 & 3,8 \\ \text { J. T. A. } & 84,6 & 88,7 & 4,1 & 21 & 25,3 & 4,3 & 3,3 & 3,1 & -0,2 \\ \text { K. F. R. } & 99,3 & 93,9 & -5,4 & 35,4 & 30,3 & -5,1 & 6,5 & 6,1 & -0,4 \\ \text { L. C. B. S. } & 94,4 & 89 & -5,4 & 33,7 & 29,6 & -4,1 & 6,7 & 8,9 & 2,2 \\ \text { M. H. A. } & 107,6 & 111,2 & 3,6 & 33,3 & 38,6 & 5,3 & 10,3 & 12 & 1,7 \\ \text { M. F. S. } & 124,8 & 119,2 & -5,6 & 47,4 & 42,3 & -5,1 & 8,5 & 7,6 & -0,9 \\ \text { M. M. L. } & 93,6 & 94,2 & 0,6 & 27 & 28,2 & 1,2 & 5,2 & 6,6 & 1,4 \\ \text { M. T. M. } & 94,1 & 100,3 & 6,2 & 25,8 & 31,7 & 5,9 & 4,3 & 8 & 3,7 \\ \text { M. C. P. } & 101,4 & 95,4 & -6 & 28,1 & 24,3 & -3,8 & 3,6 & 4,6 & 1 \\ \text { M. P.P. } & 95,9 & 106,1 & 10,2 & 25,5 & 35,3 & 9,8 & 5,1 & 7,8 & 2,7 \\ \text { P. R. S. } & 97,9 & 101,7 & 3,8 & 25 & 27 & 2 & 2,5 & 3,5 & 1 \\ \text { R. C. } & 106,3 & 105,4 & -0,9 & 33,5 & 33,4 & -0,1 & 5,8 & 6,7 & 0,9 \\ \text { R. F. G. } & 90,5 & 99,6 & 9,1 & 19,8 & 30,4 & 10,6 & 4,1 & 7,5 & 3,4 \\ \text { V. F. F. } & 93,6 & 94 & 0,4 & 29,9 & 31,6 & 1,7 & 7,3 & 8,6 & 1,3 \\ \text { V.S. } & 93,2 & 97,5 & 4,3 & 20,4 & 25,9 & 5,5 & 2,4 & 3,7 & 1,3\end{array}$


APÊNDICE 11 - Valores individuais das grandezas cefalométricas 1-Pogperp, 1-GoMe, 6-Pogperp para os pacientes do Grupo Experimental 1 (Jasper Jumper).

\begin{tabular}{|c|c|c|c|c|c|c|c|c|c|}
\hline Paciente & $\begin{array}{c}1- \\
\text { Pogperp } \\
1\end{array}$ & $\begin{array}{c}1- \\
\text { Pogperp } \\
2\end{array}$ & $\begin{array}{c}1- \\
\text { Pogperp } \\
2-1\end{array}$ & $\begin{array}{c}1- \\
\text { GoMe } \\
1\end{array}$ & $\begin{array}{c}1- \\
\text { GoMe } \\
2\end{array}$ & $\begin{array}{c}1- \\
\text { GoMe } \\
2-1\end{array}$ & $\underset{1}{\text { 6- }} \underset{\text { Pogperp }}{ }$ & $\begin{array}{c}\text { 6- } \\
\text { Pogperp } \\
2\end{array}$ & $\begin{array}{c}\text { 6- } \\
\text { Pogperp } \\
2-1\end{array}$ \\
\hline A. B. F.S. & $-5,2$ & -3 & 2,2 & 45,8 & 45,6 & $-0,2$ & $-28,6$ & $-28,1$ & 0,5 \\
\hline B. N. A. & $-11,4$ & $-7,4$ & 4 & 38,1 & 39,6 & 1,5 & -30 & $-28,9$ & 1,1 \\
\hline B. P. N. & -11 & $-8,8$ & 2,2 & 40,2 & 40,2 & 0 & $-31,5$ & -30 & 1,5 \\
\hline C. C. Jr. & $-6,6$ & $-4,8$ & 1,8 & 35,1 & 34,9 & $-0,2$ & $-32,2$ & $-29,3$ & 2,9 \\
\hline D. P. C. & $-7,6$ & $-4,1$ & 3,5 & 38,9 & 38,2 & $-0,7$ & -28 & $-25,2$ & 2,8 \\
\hline D. L. F. & $-7,3$ & $-3,6$ & 3,7 & 38,4 & 37,1 & $-1,3$ & $-25,6$ & $-23,2$ & 2,4 \\
\hline D. R. C. S. & $-9,3$ & $-10,7$ & $-1,4$ & 35 & 37,4 & 2,4 & $-29,4$ & $-29,3$ & 0,1 \\
\hline G. C. & $-5,1$ & $-4,1$ & 1 & 37,9 & 38 & 0,1 & $-30,5$ & $-29,3$ & 1,2 \\
\hline G. B. F. B. & $-6,4$ & $-9,5$ & $-3,1$ & 35,6 & 37,6 & 2 & $-27,7$ & $-28,3$ & $-0,6$ \\
\hline J.R. B. & $-5,8$ & $-3,8$ & 2 & 40,6 & 39,1 & $-1,5$ & -27 & $-26,3$ & 0,7 \\
\hline J. B. C. & $-5,6$ & $-2,3$ & 3,3 & 38,9 & 40 & 1,1 & $-24,7$ & $-23,2$ & 1,5 \\
\hline J. T. A. & $-9,4$ & $-8,7$ & 0,7 & 34,9 & 33,9 & -1 & $-28,8$ & $-27,8$ & 1 \\
\hline K. F.R. & $-6,9$ & $-6,8$ & 0,1 & 36,1 & 37,7 & 1,6 & $-29,7$ & $-29,3$ & 0,4 \\
\hline L. C. B. S. & $-11,3$ & $-10,2$ & 1,1 & 42,4 & 44 & 1,6 & $-32,6$ & $-32,8$ & $-0,2$ \\
\hline M. H. A. & $-3,6$ & $-1,6$ & 2 & 44,1 & 41 & $-3,1$ & $-29,1$ & $-28,9$ & 0,2 \\
\hline M. F. S. & 0,7 & $-1,9$ & $-2,6$ & 37,3 & 36 & $-1,3$ & -26 & $-25,7$ & 0,3 \\
\hline M. M. L. & $-10,1$ & $-11,9$ & $-1,8$ & 39,3 & 42 & 2,7 & $-31,8$ & -32 & $-0,2$ \\
\hline M. T. M. & $-8,9$ & $-5,9$ & 3 & 37 & 37,3 & 0,3 & $-27,9$ & $-27,5$ & 0,4 \\
\hline M. C. P. & $-8,7$ & $-9,4$ & $-0,7$ & 38,1 & 39,1 & 1 & $-28,3$ & $-29,6$ & $-1,3$ \\
\hline M. P. P. & $-6,2$ & $-3,1$ & 3,1 & 39,6 & 37,4 & $-2,2$ & $-26,6$ & $-25,2$ & 1,4 \\
\hline P. R. S. & $-10,1$ & $-9,5$ & 0,6 & 36,9 & 38 & 1,1 & $-30,8$ & $-31,7$ & $-0,9$ \\
\hline R. C. & $-6,4$ & $-5,7$ & 0,7 & 35,6 & 34,7 & $-0,9$ & $-31,1$ & $-28,3$ & 2,8 \\
\hline R. F. G. & $-11,5$ & $-8,6$ & 2,9 & 41,1 & 41,8 & 0,7 & $-32,4$ & $-32,4$ & 0 \\
\hline V. F. F. & $-8,7$ & $-7,4$ & 1,3 & 41,7 & 41,9 & 0,2 & $-30,3$ & $-29,4$ & 0,9 \\
\hline V. S. & $-8,2$ & $-8,5$ & $-0,3$ & 37,2 & 37,4 & 0,2 & $-29,6$ & $-27,9$ & 1,7 \\
\hline
\end{tabular}


APÊNDICE 12 - Valores individuais das grandezas cefalométricas 6-GoMe, relação molar, TH e TV para os pacientes do Grupo Experimental 1 (Jasper Jumper).

$\begin{array}{lllllllllll}\text { Paciente 6- 6- } & \text { 6- } & \text { Rel. } & \text { Rel. } & \text { Rel. } & \text { TH } 1 & \text { TH } 2 & \text { TH 2-1 } & \text { TV } 1 & \text { TV } 2 & \text { TV 2-1 }\end{array}$ GoMe1 GoMe 2 GoMe mol 1 mol 2 mol

$\begin{array}{lcccccccccccc}\text { A. B. F. S. } & 33,1 & 36,7 & 3,6 & -2,6 & 1,8 & 4,4 & 7,5 & 1,7 & -5,8 & 4,4 & 2,4 & -2 \\ \text { B. N. A. } & 26,4 & 29,4 & 3 & -1,4 & 2,5 & 3,9 & 6 & 2,9 & -3,1 & 5,2 & 0,8 & -4,4 \\ \text { B. P. N. } & 28,5 & 32,6 & 4,1 & -1,4 & 1,8 & 3,2 & 6,6 & 3,4 & -3,2 & 7,5 & 3,3 & -4,2 \\ \text { C. C. Jr. } & 23,6 & 26,5 & 2,9 & -3,1 & 1,5 & 4,6 & 7,2 & 2,6 & -4,6 & 2,7 & 1,8 & -0,9 \\ \text { D. P. C. } & 29,6 & 31,5 & 1,9 & -0,2 & 1,9 & 2,1 & 7,5 & 2,5 & -5 & 5,1 & 2,9 & -2,2 \\ \text { D. L. F. } & 26,3 & 29,7 & 3,4 & -0,6 & 1 & 1,6 & 12,4 & 2,1 & -10,3 & 7,4 & 3,2 & -4,2 \\ \text { D. R. C. S. } & 25,4 & 29,2 & 3,8 & -1 & 1,6 & 2,6 & 4,2 & 2,3 & -1,9 & 4,5 & 1,9 & -2,6 \\ \text { G. C. } & 29,8 & 30,1 & 0,3 & -2,8 & 0,9 & 3,7 & 4,9 & 2,5 & -2,4 & 4,5 & 2 & -2,5 \\ \text { G. B. F. B. } & 27,1 & 30,4 & 3,3 & -1,6 & 1,8 & 3,4 & 5,1 & 2,5 & -2,6 & 5,5 & 1,9 & -3,6 \\ \text { J. R. B. } & 28,6 & 30 & 1,4 & -1,7 & 2,7 & 4,4 & 4,4 & 2,9 & -1,5 & 4,9 & 2,8 & -2,1 \\ \text { J. B. C. } & 28,4 & 33,2 & 4,8 & -1,7 & 2,2 & 3,9 & 10 & 3,5 & -6,5 & 7,6 & 3,6 & -4 \\ \text { J. T. A. } & 25 & 26,8 & 1,8 & -0,4 & 2,5 & 2,9 & 3 & 2,7 & -0,3 & 2,9 & 1,9 & -1 \\ \text { K. F. R. } & 25,7 & 29,1 & 3,4 & 0,3 & 1,7 & 1,4 & 5,6 & 2,6 & -3 & 1 & 2,2 & 1,2 \\ \text { L. C. B. S. } & 28,2 & 32,3 & 4,1 & -0,4 & 2,5 & 2,9 & 4,2 & 2,3 & -1,9 & 5,1 & 1,6 & -3,5 \\ \text { M. H. A. } & 33,8 & 35,7 & 1,9 & -2,5 & 2 & 4,5 & 6 & 2,3 & -3,7 & 8,6 & 3,4 & -5,2 \\ \text { M. F. S. } & 29,9 & 32,6 & 2,7 & -3,3 & 1,5 & 4,8 & 4,8 & 2,5 & -2,3 & 4,2 & 2,1 & -2,1 \\ \text { M. M. L. } & 28,2 & 32 & 3,8 & 0,4 & 2,3 & 1,9 & 4,8 & 2,7 & -2,1 & 4,8 & 2,2 & -2,6 \\ \text { M. T. M. } & 26,4 & 29,7 & 3,3 & -0,1 & 1,6 & 1,7 & 8,4 & 2,4 & -6 & 3,8 & 1,3 & -2,5 \\ \text { M. C. P. } & 28,1 & 30 & 1,9 & -0,3 & 3,1 & 3,4 & 5,7 & 2,7 & -3 & 3,4 & 1,1 & -2,3 \\ \text { M.P.P. } & 28,6 & 29,8 & 1,2 & -2,1 & 1,7 & 3,8 & 8 & 2,6 & -5,4 & 5,4 & 2,2 & -3,2 \\ \text { P. R. S. } & 28,2 & 32,3 & 4,1 & 0,1 & 2,4 & 2,3 & 4,2 & 2,6 & -1,6 & 6 & 1,4 & -4,6 \\ \text { R. C. } & 25,2 & 28,1 & 2,9 & -3,2 & 2,4 & 5,6 & 4,9 & 2,4 & -2,5 & 4,1 & 1,2 & -2,9 \\ \text { R. F. G. } & 27,1 & 31,8 & 4,7 & -1,5 & 3,5 & 5 & 9,6 & 1,9 & -7,7 & 5,1 & 1,9 & -3,2 \\ \text { V. F. F. } & 28,1 & 32 & 3,9 & -2,3 & 2 & 4,3 & 7 & 2 & -5 & 6,1 & 2,4 & -3,7 \\ \text { V. S. } & 28,5 & 31,2 & 2,7 & -1,1 & 2 & 3,1 & 3,9 & 2,1 & -1,8 & 3,8 & 1 & -2,8\end{array}$


APÊNDICE 13 - Valores individuais das idades inicial, final; do tempo de uso do Jasper Jumper, do tempo de tratamento total, e da severidade inicial da má oclusão medida nos modelos de gesso (relação molar*, relação dos caninos*, e sobressaliência) para os pacientes do Grupo Experimental 2 (Bionator).

\begin{tabular}{|c|c|c|c|c|c|c|c|c|c|c|}
\hline Paciente & Gênero & $\begin{array}{l}\text { Idade } \\
\text { inicial }\end{array}$ & $\begin{array}{l}\text { Idade } \\
\text { final }\end{array}$ & $\begin{array}{c}\text { Tempo } \\
\text { de trat. } \\
\text { ortop. }\end{array}$ & $\begin{array}{c}\text { Tempo } \\
\text { de trat. } \\
\text { ortod. }\end{array}$ & $\begin{array}{c}\text { Tempo } \\
\text { entre a } \\
\text { fase ortop. } \\
\text { e ortod. }\end{array}$ & $\begin{array}{l}\text { Tempo de } \\
\text { trat. total }\end{array}$ & Rel. mol & Rel. can. & Sobres. \\
\hline A. F. G. & $\mathrm{F}$ & $12,30 a$ & $14,41 a$ & $0,42 a$ & $0,99 a$ & $0,17 \mathrm{a}$ & $2,11 \mathrm{a}$ & 3/4 Cl II & $3 / 4 \mathrm{Cl} \mathrm{II}$ & $5,5 \mathrm{~mm}$ \\
\hline A. C. L. K. & $\mathrm{F}$ & $12,99 a$ & $15,66 a$ & $1,04 a$ & $0,98 a$ & $0,10 \mathrm{a}$ & $2,67 a$ & Cl II completa & Cl II completa & $6,5 \mathrm{~mm}$ \\
\hline A. L. O. G. & $\mathrm{F}$ & $11,27 \mathrm{a}$ & $13,32 a$ & $1,30 a$ & $0,96 a$ & $-0,22 a$ & $2,05 a$ & CI II completa & $3 / 4 \mathrm{Cl} \mathrm{II}$ & $8,5 \mathrm{~mm}$ \\
\hline B. L. T. G. & $\mathrm{F}$ & $10,82 a$ & $14,79 a$ & $1,00 a$ & $1,50 a$ & $1,43 a$ & $3,97 a$ & $3 / 4 \mathrm{CI} I I$ & $1 / 2 \mathrm{Cl} \mathrm{II}$ & $4,5 \mathrm{~mm}$ \\
\hline C. C.P. & M & $11,29 a$ & $14,64 a$ & $2,21 \mathrm{a}$ & $0,63 a$ & $0,46 a$ & $3,35 a$ & 3/4 CI II & $3 / 4 \mathrm{Cl} I \mathrm{I}$ & $10 \mathrm{~mm}$ \\
\hline C. L. S. S. O. & $M$ & $11,28 a$ & $15,05 a$ & $2,28 a$ & $1,49 a$ & $0,00 \mathrm{a}$ & $3,78 a$ & $3 / 4 \mathrm{Cl} \mathrm{II}$ & $1 / 2 \mathrm{Cl} \mathrm{II}$ & $11,5 \mathrm{~mm}$ \\
\hline C. L. B. & $\mathrm{F}$ & $9,73 a$ & $14,01 \mathrm{a}$ & $1,61 a$ & $1,30 a$ & $1,27 a$ & $4,28 a$ & Cl II completa & 3/4 Cl II & $8 \mathrm{~mm}$ \\
\hline C. S. C. & $M$ & $11,41 a$ & $16,37 a$ & $1,98 a$ & $1,32 \mathrm{a}$ & $1,64 a$ & $4,96 a$ & $1 / 2 \mathrm{CI} \mathrm{II}$ & $1 / 2 \mathrm{Cl} \mathrm{II}$ & $4,5 \mathrm{~mm}$ \\
\hline D. G. B. M. & M & $11,33 a$ & $15,83 a$ & $1,03 a$ & $2,23 a$ & $1,17 \mathrm{a}$ & $4,50 a$ & $3 / 4 \mathrm{Cl} \mathrm{II}$ & $3 / 4 \mathrm{Cl} \mathrm{II}$ & $9 \mathrm{~mm}$ \\
\hline D. A. M. & M & $12,33 a$ & $15,33 a$ & $0,64 a$ & $1,80 a$ & & & Cl II completa & Cl II completa & $15 \mathrm{~mm}$ \\
\hline D. P. S. & $\mathrm{M}$ & $10,17 \mathrm{a}$ & $15,31 a$ & $2,32 a$ & $1,39 a$ & $1,38 a$ & & Cl II completa & $3 / 4 \mathrm{Cl} \mathrm{II}$ & $9 \mathrm{~mm}$ \\
\hline E. M. Z. & M & $9,99 a$ & $15,43 a$ & $1,08 a$ & $3,24 a$ & $1,13 a$ & $5,44 a$ & Cl II completa & $1 / 2 \mathrm{Cl} \mathrm{II}$ & $8,5 \mathrm{~mm}$ \\
\hline F. V. F. & M & $11,21 a$ & $16,63 a$ & $1,63 a$ & $2,68 a$ & $1,12 \mathrm{a}$ & $5,42 a$ & $1 / 2 \mathrm{Cl} \mathrm{II}$ & $1 / 2 \mathrm{Cl} \mathrm{II}$ & $5 \mathrm{~mm}$ \\
\hline F. L. R. & $\mathrm{M}$ & $10,79 a$ & $13,22 a$ & $1,43 a$ & $0,56 a$ & 0,0 & & Cl II completa & Cl II completa & $11 \mathrm{~mm}$ \\
\hline G. C. H. & $\mathrm{F}$ & $11,55 a$ & $12,99 a$ & $1,12 \mathrm{a}$ & $0,92 a$ & $-0,59 a$ & $1,45 a$ & Cl II completa & $3 / 4 \mathrm{Cl} \mathrm{II}$ & $12 \mathrm{~mm}$ \\
\hline G. O. C. & $\mathrm{F}$ & $9,79 a$ & $17,60 \mathrm{a}$ & $2,31 a$ & $2,53 a$ & $1,46 a$ & $7,82 a$ & $1 / 2 \mathrm{CI} \mathrm{II}$ & $1 / 2 \mathrm{Cl} \mathrm{II}$ & $11,5 \mathrm{~mm}$ \\
\hline H. S. M. & M & $12,33 a$ & $17,49 a$ & $1,36 \mathrm{a}$ & $2,87 a$ & & & 3/4 Cl II D & $1 / 2 \mathrm{Cl} \mathrm{II}$ & $6,5 \mathrm{~mm}$ \\
\hline J. G. B. Z. & M & $9,27 a$ & $15,59 a$ & $1,59 a$ & $2,23 a$ & $2,44 a$ & $6,32 a$ & Cl II completa & $3 / 4 \mathrm{Cl} \mathrm{II}$ & $\mathrm{nm}$ \\
\hline J. D. F. F. V. & $\mathrm{F}$ & $14,00 \mathrm{a}$ & $15,52 a$ & $1,38 a$ & $0,69 a$ & $-0,56 a$ & $1,51 \mathrm{a}$ & Cl II completa & 3/4 Cl II & $10,5 \mathrm{~mm}$ \\
\hline M. C. G. & $\mathrm{F}$ & $10,35 a$ & $14,64 a$ & $1,29 a$ & $1,42 a$ & $1,56 a$ & & $1 / 2 \mathrm{Cl} \mathrm{II}$ & $1 / 4 \mathrm{Cl} \mathrm{II}$ & $7 \mathrm{~mm}$ \\
\hline N. C. M. & $\mathrm{F}$ & $12,01 a$ & $14,19 a$ & $0,50 a$ & $1,28 a$ & $0,08 a$ & & $1 / 2 \mathrm{CI} \mathrm{II}$ & $1 / 2 \mathrm{Cl} \mathrm{II}$ & $6 \mathrm{~mm}$ \\
\hline P. F. & $\mathrm{F}$ & $12,28 a$ & $16,14 a$ & $1,21 a$ & $1,98 a$ & $0,16 a$ & $3,85 a$ & $1 / 2 \mathrm{CI}$ II & $1 / 2 \mathrm{Cl} \mathrm{II}$ & $7 \mathrm{~mm}$ \\
\hline P. S. C. T. & $\mathrm{M}$ & $9,84 a$ & $14,84 a$ & $1,24 a$ & $2,73 a$ & $0,98 a$ & $4,99 a$ & 3/4 Cl II & $1 / 2 \mathrm{Cl} \mathrm{II}$ & $10 \mathrm{~mm}$ \\
\hline S. D. O. & $\mathrm{F}$ & $9,62 a$ & $16,59 a$ & $1,35 a$ & $4,76 a$ & $0,86 a$ & & 3/4 Cl II & $3 / 4 \mathrm{Cl} \mathrm{II}$ & $10,5 \mathrm{~mm}$ \\
\hline T. D. F. & $\mathrm{F}$ & $10,84 a$ & $16,40 \mathrm{a}$ & $1,34 a$ & $3,50 a$ & $-0,06 a$ & $5,56 a$ & $1 / 2 \mathrm{Cl} \mathrm{II}$ & Cl II completa & $13 \mathrm{~mm}$ \\
\hline T.P.I & $\mathrm{F}$ & $13,60 a$ & $16,50 \mathrm{a}$ & $1,47 a$ & $0,72 a$ & $0,67 a$ & $2,90 \mathrm{a}$ & Cl II completa & $3 / 4 \mathrm{Cl} \mathrm{II}$ & $9 \mathrm{~mm}$ \\
\hline T. O. & M & $11,68 a$ & $14,43 a$ & $0,63 a$ & $1,67 a$ & $0,06 a$ & $2,75 a$ & $1 / 2 \mathrm{Cl} \mathrm{II}$ & $1 / 2 \mathrm{Cl} \mathrm{II}$ & $9,5 \mathrm{~mm}$ \\
\hline V. D. V. F. & M & $12,73 a$ & $15,20 a$ & $0,67 a$ & $1,33 a$ & $0,12 \mathrm{a}$ & $2,47 a$ & $3 / 4 \mathrm{Cl} \mathrm{II}$ & $3 / 4 \mathrm{Cl} \mathrm{II}$ & $8,5 \mathrm{~mm}$ \\
\hline V. V. & $\mathrm{M}$ & $11,71 a$ & $14,38 a$ & $0,58 a$ & $2,00 a$ & $-1,37 a$ & $2,67 a$ & 1/2 Cl II & $1 / 2 \mathrm{Cl} \mathrm{II}$ & $6,5 \mathrm{~mm}$ \\
\hline W. F. C. R. & $\mathrm{M}$ & $10,82 a$ & $14,52 \mathrm{a}$ & $1,36 a$ & $1,44 a$ & $0,80 a$ & $3,70 a$ & Cl II completa & $3 / 4 \mathrm{Cl} \mathrm{II}$ & $10 \mathrm{~mm}$ \\
\hline
\end{tabular}

OBSERVAÇÃO: o cálculo da idade inicial, idade final e tempo total de tratamento baseou-se nas datas das telerradiografias em norma lateral inicial e final; para calcular o tempo de tratamento ortopédico, tempo de tratamento ortodôntico e tempo entre as fases ortopédica e ortodôntica, utilizou-se as datas e anotações das fichas clínicas.

* Considerou-se a avaliação do hemi-arco mais severo. 
APÊNDICE 14 - Valores individuais das grandezas cefalométricas SNA e Co-A para os pacientes do Grupo Experimental 2 (Bionator).

\section{Paciente SNA1 SNA 2 SNA 2-1 SNA 2-1 \\ anualizada}

A. F. G.

A. C. L. K.

A. L. O. G.

$82,2 \quad 81,2-1,00$

B. L. T. G.

C. C. P

C. L. S. S. O.

C. L. B.

C. S. C.

D. G. B. M

D. A. M.

D.P.S.

E. M. Z.

F. V.F.

F. L. R.

G. C. H.

G. O. C.

H. S. M.

J. G. B. Z.

J. D. F. F. V.

M. C. G.

N. C. M.

P. F.

P. S. C. T.

S. D. O.

T. D. F.

T. P.I

T. O.

V. D. V. F.

V. V.

W. F. C.R. $\begin{array}{lll}77,1 & 77,3 & 0,20\end{array}$

$\begin{array}{lll}85,7 & 84 & -1,70\end{array}$

$86,4 \quad 84,9 \quad-1,50$

$81 \quad 82,2 \quad 1,20$

$80,6 \quad 75,8 \quad-4,80$

$82,5 \quad 81 \quad-1,50$

$83,5 \quad 81,1 \quad-2,40$

$82,5 \quad 85 \quad 2,50$

$79,6 \quad 77,1 \quad-2,50$

$84,8 \quad 83,5 \quad-1,30$

$76,3 \quad 75 \quad-1,30$

$84,9 \quad 83,2 \quad-1,70$

$82,9 \quad 82,8 \quad-0,10$

$85,1 \quad 81,8 \quad-3,30$

$82,7 \quad 83,5 \quad 0,80$

$80,8 \quad 81,8 \quad 1,00$

$80,8 \quad 78,5 \quad-2,30$

$87,4 \quad 86,3$

$80 \quad 79,3$

$77,1 \quad 77,9$

$83,6 \quad 82,2$

$82 \quad 79,4$

$84,2 \quad 83,7$

$82,2 \quad 84,8$

$80,9 \quad 79,8$

$75,8 \quad 77,8$

$84,4 \quad 83,8$

$83,8 \quad 81,5$

83,8

$$
-1,02
$$

0,16

$-1,79$

$-0,81$

0,77

$-2,74$

$-0,76$

$-1,04$

1,20

$-1,80$

$-0,55$

$-0,51$

$-0,68$

$-0,09$

$-4,90$

0,22

0,42

$-0,78$

$-1,57$

$-0,35$

0,79

$-0,78$

$-1,12$

$-0,15$

1,01

$-0,82$

1,57

$-0,52$

$-1,86$

$-0,64$
Co-A 1 Co-A 2 Co-A 2-1

80,3
79,4
86,8
82,8
82,8
81,7

78,8

2,8

$88,6 \quad 1,8$

$88,4 \quad 5,6$

$86,7 \quad 3,9$

$83,9 \quad 2,2$

$85,5 \quad 3,2$

$97,6 \quad 8,9$

$85,7 \quad 5,3$

$89,4 \quad 0,9$

88,6

89,9

91,1

83,7

79,9

85,9

89,4

88,1

89,4

80,3

82

79,4

86,9

81,3

81,3

86,6

83

90,3

88

90,2
Co-A 2-1

anualizada

$-1,53$

2,26

1,89

3,04

2,51

1,25

1,61

3,87

2,54

0,65

0,84

3,09

1,59

3,37

0,30

0,88

3,30

2,76

1,86

$-0,30$

2,27

1,51

1,90

1,76

1,47

$-1,26$

0,86

6,63

3,55

2,91 
APÊNDICE 15 - Valores individuais das grandezas cefalométricas A-Nperp e SNB para os pacientes do Grupo Experimental 2 (Bionator).

Paciente $\begin{array}{ccc}\text { A- } & \text { A- } & \text { A- } \\ \text { Nperp } 1 & \text { Nperp } 2 & \text { Nperp } \\ 2-1\end{array}$

A. F. G.

1,2
-1

A. C. L. K.

A. L. O. G.

B. L. T. G.

C. C.P.

C. L. S. S. O.

C. L. B.

C. S. C.

D. G. B. M.

D. A. M.

D. P. S.

E. M. Z.

F. V. F.

F. L. R.

G. C. H.

G. O. C.

H. S. M.

J. G. B. Z.

J. D. F. F. V.

M. C. G.

N. C. M.

P. F.

P. S. C. T.

S. D. O.

T. D. F.

T. P.I

T. O.

V. D. V. F.

V. V.

W. F. C. R.

$\begin{array}{ll}1,9 & 0,7\end{array}$

$-0,7 \quad 0,3$

$1,5 \quad 0,1$

$2,9 \quad 0,7$

$3,3-1,2$

$-6,2 \quad-0,8$

$-4,6 \quad-0,9$

$0 \quad-2,3$

$1,4 \quad-2,8$

$-4,1$

$-2,3$

$-6,5$

4,7

$-1,5$

$-1,8$

3,5

2,2

$-1,5$

4,9

0,1

0,4

0,9

$-5,2$

3,4

$-2,7$

$-0,9$

$-5,8$

1,2

0,9

1,6 $\underset{2-1}{\text { A-Nperp }}$ SNB 1 anualizada

0,71

0,24

0,11

0,38

$-0,77$

$-0,46$

$-0,45$

$-1,00$

$-1,34$

$-2,51$

$-0,25$

$-0,67$

$-0,95$

$-0,18$

$-2,68$

$-0,22$

1,09

0,07

$-0,71$

0,30

$-1,38$

1,34

$-1,34$

0,71

0,39

1,04

$-2,74$

1,92

2,02

$-0,64$

75,3

$\begin{array}{llll}75,3 & 74,9 & -0,4 & -0,41\end{array}$

$\begin{array}{ll}-1,5 & 1,21\end{array}$

$\begin{array}{llll}78,7 & 80 & 1,3 & 1,37\end{array}$

$81,8 \quad 82,2 \quad 0,4 \quad 0,22$

$76,7 \quad 79,2 \quad 2,5 \quad 1,61$

$78,1 \quad 75,3 \quad-2,8 \quad-1,60$

$\begin{array}{llll}77,4 & 80 & 2,6 & 1,31\end{array}$

$76,3 \quad 75 \quad-1,3 \quad-0,56$

$\begin{array}{llll}75,7 & 80 & 4,3 & 2,06\end{array}$

$71,5 \quad 74,6 \quad 3,1 \quad 2,23$

$\begin{array}{llll}78,3 & 82,8 & 4,5 & 1,89\end{array}$

$72,2 \quad 71,4 \quad-0,8 \quad-0,32$

$77,2 \quad 79,6 \quad 2,4 \quad 0,95$

$\begin{array}{llll}75 & 76,4 & 1,4 & 1,24\end{array}$

$\begin{array}{llll}77,9 & 79,1 & 1,2 & 1,78\end{array}$

$\begin{array}{llll}74,3 & 79,8 & 5,5 & 1,52\end{array}$

$79,4 \quad 83,2 \quad 3,8 \quad 1,59$

$74,1 \quad 74,6 \quad 0,5 \quad 0,17$

$78,9 \quad 79,3 \quad 0,4 \quad 0,57$

$75,9 \quad 77,2 \quad 1,3 \quad 0,65$

$\begin{array}{llll}71,3 & 73,1 & 1,8 & 1,78\end{array}$

$\begin{array}{llll}78,6 & 78,6 & 0 & 0,00\end{array}$

$\begin{array}{llll}73,3 & 74,5 & 1,2 & 0,52\end{array}$

$77,1 \quad 75,6 \quad-1,5 \quad-0,46$

$\begin{array}{llll}76,1 & 80,7 & 4,6 & 1,78\end{array}$

$\begin{array}{llll}74,8 & 75,5 & 0,7 & 0,52\end{array}$

$\begin{array}{llll}69,3 & 71,3 & 2 & 1,57\end{array}$

$\begin{array}{llll}80,5 & 82,5 & 2 & 1,74\end{array}$

$74,5 \quad 74,3 \quad-0,2 \quad-0,16$

$\begin{array}{llll}77 & 78,1 & 1,1 & 0,64\end{array}$ 
APÊNDICE 16 - Valores individuais das grandezas cefalométricas Co-Gn e Go-Gn para os pacientes do Grupo Experimental 2 (Bionator).

\begin{tabular}{|c|c|c|c|c|c|c|c|c|}
\hline Paciente & Co-Gn 1 & Co-Gn 2 & $\begin{array}{c}\text { Co-Gn } \\
2-1\end{array}$ & $\begin{array}{l}\text { Co-Gn 2-1 } \\
\text { anualizada }\end{array}$ & Go-Gn 1 & Go-Gn 2 & $\begin{array}{c}\text { Go-Gn } \\
2-1\end{array}$ & $\begin{array}{l}\text { Go-Gn 2-1 } \\
\text { anualizada }\end{array}$ \\
\hline A. F. G. & 100,6 & 101,4 & 0,8 & 0,82 & 64,4 & 63,6 & $-0,8$ & $-0,82$ \\
\hline A. C. L. K. & 102,2 & 108,7 & 6,5 & 5,25 & 66,8 & 67,6 & 0,8 & 0,65 \\
\hline A. L. O. G. & 98,9 & 104,6 & 5,7 & 5,99 & 67 & 70,5 & 3,5 & 3,68 \\
\hline B. L. T. G. & 103,5 & 111,4 & 7,9 & 4,29 & 69,9 & 76,1 & 6,2 & 3,37 \\
\hline C. C.P. & 102,8 & 108,9 & 6,1 & 3,92 & 68,3 & 71,8 & 3,5 & 2,25 \\
\hline C. L. S. S. O. & 103,4 & 114,6 & 11,2 & 6,39 & 65,9 & 72,2 & 6,3 & 3,59 \\
\hline C. L. B. & 95,7 & 106,8 & 11,1 & 5,59 & 61,4 & 66,8 & 5,4 & 2,72 \\
\hline C. S. C. & 105,4 & 116,1 & 10,7 & 4,65 & 69,1 & 74,1 & 5 & 2,17 \\
\hline D. G. B. M. & 101,1 & 114 & 12,9 & 6,18 & 67,6 & 74,8 & 7,2 & 3,45 \\
\hline D. A. M. & 100,7 & 112,3 & 11,6 & 8,33 & 72,6 & 78,6 & 6 & 4,31 \\
\hline D. P.S. & 100,3 & 114,5 & 14,2 & 5,95 & 71,4 & 82,8 & 11,4 & 4,78 \\
\hline E. M. Z. & 101,1 & 115,7 & 14,6 & 5,78 & 63,4 & 72,5 & 9,1 & 3,60 \\
\hline F. V. F. & 105,9 & 119,1 & 13,2 & 5,25 & 67,5 & 74,5 & 7 & 2,78 \\
\hline F. L. R. & 98 & 104,3 & 6,3 & 5,59 & 66,2 & 69,4 & 3,2 & 2,84 \\
\hline G. C. H. & 93,9 & 100,3 & 6,4 & 9,51 & 63,9 & 67,2 & 3,3 & 4,90 \\
\hline G. O. C. & 97,3 & 107 & 9,7 & 2,67 & 61,7 & 65,7 & 4 & 1,10 \\
\hline H. S. M. & 104,4 & 121,7 & 17,3 & 7,22 & 71,5 & 81,8 & 10,3 & 4,30 \\
\hline J. G. B. Z. & 95 & 110,5 & 15,5 & 5,29 & 60,2 & 73,3 & 13,1 & 4,47 \\
\hline J.D. F. F. V. & 105,2 & 107,1 & 1,9 & 2,71 & 70,4 & 71,3 & 0,9 & 1,28 \\
\hline M. C. G. & 97,7 & 102,3 & 4,6 & 2,31 & 65,6 & 72,2 & 6,6 & 3,32 \\
\hline N. C. M. & 97,2 & 105,1 & 7,9 & 7,81 & 63,3 & 63,7 & 0,4 & 0,40 \\
\hline P. F. & 98,5 & 102,7 & 4,2 & 2,35 & 65,4 & 67,4 & 2 & 1,12 \\
\hline P. S. C. T. & 98,2 & 109,8 & 11,6 & 5,01 & 64,5 & 71,7 & 7,2 & 3,11 \\
\hline S. D. O. & 95,6 & 102,9 & 7,3 & 2,26 & 60,7 & 66,6 & 5,9 & 1,82 \\
\hline T. D. F. & 95,2 & 103,5 & 8,3 & 3,22 & 59,8 & 68,3 & 8,5 & 3,29 \\
\hline T. P.I & 107,1 & 107,7 & 0,6 & 0,45 & 68,1 & 67,3 & $-0,8$ & $-0,59$ \\
\hline T. O. & 100,3 & 101,1 & 0,8 & 0,63 & 68,6 & 69,4 & 0,8 & 0,63 \\
\hline V. D. V.F. & 103,4 & 117,7 & 14,3 & 12,48 & 70,4 & 74,1 & 3,7 & 3,23 \\
\hline V. V. & 95,8 & 104,5 & 8,7 & 7,02 & 61,2 & 66,7 & 5,5 & 4,44 \\
\hline W. F. C. R. & 102,1 & 111,4 & 9,3 & 5,42 & 66,4 & 74,3 & 7,9 & 4,60 \\
\hline
\end{tabular}


APÊNDICE 17 - Valores individuais das grandezas cefalométricas Co-Go e P-Nperp para os pacientes do Grupo Experimental 2 (Bionator).

Paciente Co-Go 1 Co-Go 2 Co-Go

A. F. G.

A. C. L. K.

A. L. O. G.

48,9

51,8

2-1

B. L. T. G.

C. C. P.

C. L. S. S. O.

C. L. B.

C. S. C.

D. G. B. M

D. A. M.

D. P.S.

E. M. Z.

F. V. F.

F. L. R.

G. C. H.

G. O. C.

H. S. M.

J. G. B. Z.

J. D. F. F. V.

M. C. G.

N. C. M.

P. F.

P. S. C. T.

S. D. O.

T. D. F.

T. P.I

T. O.

V. D. V. F.

V. V.

W. F. C. R
47

51,3

46,5

51,9

44,2

47,3

45

49,3

41,4

49,3

49,7

43,4

44,1

45,7

50,3

41,3

46,4

46,5

42,5

48

44,4

43,1

47,8

50,7

42,5

51,6

42,9

45,4
53,8

50,7

53,9

48,6

59

51,3

50,5

52,6

58,4

47,7

56,1

57,4

46,4

47,4

51,5

59,8

45,5

46,8

49,1

51,9

49,4

53

42,7

50,1

52,1

42,1

63,3

45,9

46,2
Co-Go 2-1 P-
anualizada

2,96

5,49

3,57

1,41

1,35

4,05

3,57

1,39

3,64

6,54

2,64

2,69

3,06

2,66

4,90

1,60

3,97

1,43

0,57

1,31

9,29

0,78

3,71

$-0,12$

0,89

1,04

$-0,31$

10,21

2,42

0,47

\section{1
$-9,9$}

$-9,9$

$-0,2$

$-6,5$

0,4

3,2

$-11,4$

$-10,9$

$-9,1$

$-1,5$

$-8,3$

$-8,5$

$-15,3$

0

$-14$

$-8,5$

$-8,2$

$-1$

$-12,2$

$-1,4$

$-5$

$-4,4$

$-8,3$

$-18,2$

$-6,9$

$-13,8$

$-11,1$

$-13$

$-4,9$

$-17,6$

$-6,3$

\section{$\begin{array}{cc} & \\ 2 & \mathbf{2 - 1}\end{array}$}

$-7,7$

2,2

$2,1 \quad 2,3$

$-2,9 \quad 3,6$

$5,7 \quad 5,3$

$2,2 \quad-1$

$-6,8 \quad 4,6$

$-4,8 \quad 6,1$

$-11,2 \quad-2,1$

$-2,7 \quad-1,2$

$-2,8 \quad 5,5$

$0,7 \quad 9,2$

$-16,6$

3,7

$-13,3$

$-5,2$

$-3,7$

10,5

$-6$

$-0,8$

$-1,1$

$-5,4$

$-0,5$

$-17,8$

$-6$

$-10,3$

$-6,2$

$-19,6$

3,4

$-10,5$

$-5,6$

$-1,3$

3,7

0,7

3,3

4,5

11,5

6,2

0,6

3,9

$-1$

7,8

0,4

0,9

3,5

4,9

$-6,6$

8,3

7,1

0,7
P-Nperp 2-1

anualizada

2,25

1,86

3,78

2,88

$-0,64$

2,62

3,07

$-0,91$

$-0,57$

3,95

3,86

$-0,51$

1,47

0,62

4,90

1,24

4,80

2,11

0,86

1,96

$-0,99$

4,37

0,17

0,28

1,36

3,64

$-5,17$

7,24

5,73

0,41 
APÊNDICE 18 - Valores individuais das grandezas cefalométricas ANB e NAP para os pacientes do Grupo Experimental 2 (Bionator).

Paciente ANB 1 ANB 2 ANB 2-1 ANB 2-1
A. F. G.
6,9
6,3
$-0,6$

A. C. L. K. $\quad 1,1$

A. L. O. G.

7

B. L. T. G.

C. C. P.

C. L. S. S. O.

C. L. B.

C. S. C.

D. G. B. M.

D. A. M.

D. P. S.

E. M. Z.

F. V. F.

F. L. R.

G. C. H.

G. O. C.

H. S. M.

J. G. B. Z.

J. D. F. F. V.

M. C. G.

N. C. M.

P. F.

P. S. C. T.

S. D. O.

T. D. F.

T. P.I

T. O.

V. D. V. F.

V. V.

W. F. C. R. anualizada

$-0,61$
$-1,05$
$-3,26$
$-1,09$
$-0,90$
$-1,08$
$-2,01$

NAP 1 NAP 2 NAP 2-1 NAP 2-1

15,1

13,5

$-1,6$

anualizada

$-1,63$

$\begin{array}{llll}14,4 & 8 & -6,4 & -6,73\end{array}$

$\begin{array}{llll}5,2 & -0,7 & -5,9 & -3,20\end{array}$

$\begin{array}{llll}6,6 & 4,8 & -1,8 & -1,16\end{array}$

$\begin{array}{llll}1,6 & -5,4 & -7 & -3,99\end{array}$

$\begin{array}{llll}6,4 & -4,7 & -11,1 & -5,59\end{array}$

$\begin{array}{lllll}-0,43 & 16,3 & 12,2 & -4,1 & -1,78\end{array}$
5,5

$-5,5$

$-6$

4,3

5,6

11,8

2,8

11,8

$-7,5$

3,6

12,6

1,9

7,7

2,7

8,6

13,3

5,7

6,3

9,9

$-1,5$

14,5

$-5,8$

$-16,1$

$-14$

$-3,7$

$-10,8$

$-1,6$

$-9,3$

$-8,5$

$-7,9$

$-8,1$

$-2,3$

$-4,8$

$-2,2$

$-4,3$

$-8,2$

2,3

$-3,7$

$-3,4$

0,4

$-5,2$

$-2,6$

$-4,6$

9,5
$-0,86$

$-4,09$

$-2,43$

$-0,20$

$-1,59$

$-1,33$

$-6,69$

$-1,30$

$-1,13$

$-0,92$

$-2,28$

$-1,00$

$-1,09$

$-0,78$

$-1,55$

11,3

10,6

8

8

16,4

13,4

12,1

20,3

0,4

11,7

14,9

6,7

9,9

7

16,8

0,31

$-0,74$

11

9,4

9,7

9,5

3,7

17,1

14,1

$-2,78$

$-11,56$

$-5,87$

$-1,47$

$-4,29$

$-1,42$

$-13,82$

$-2,34$

$-3,30$

$-2,76$

$-3,28$

$-2,41$

$-2,17$

$-2,41$

$-3,54$

0,71

$-1,43$

$-2,53$

0,31

$-4,54$

$-2,10$

$-1,34$

$-2,68$ 
APÊNDICE 19 - Valores individuais das grandezas cefalométricas Co-A/Co-Gn e Wits para os pacientes do Grupo Experimental 2 (Bionator).

Paciente Co-A/Co- Co-A/Co- Co-A/Co- Co-A/Co- Wits 1 Wits 2 Wits 2-1 Wits 2-1 Gn 1 Gn 2 Gn 2-1 Gn 2-1 anualizada

$\begin{array}{lcccccccc}\text { A. F. G. } & 79,8 & 77,8 & -2 & -2,04 & 1,7 & 4,3 & 2,6 & 2,66 \\ \text { A. C. L. K. } & 77,7 & 75,6 & -2,1 & -1,69 & -2,8 & -1,4 & 1,4 & 1,13 \\ \text { A. L. O. G. } & 87,8 & 84,7 & -3,1 & -3,26 & 3,7 & 0,1 & -3,6 & -3,78 \\ \text { B. L. T. G. } & 80 & 79,4 & -0,6 & -0,33 & 1,2 & 2,2 & 1 & 0,54 \\ \text { C. C. P. } & 80,6 & 79,6 & -1 & -0,64 & 2 & 0,1 & -1,9 & -1,22 \\ \text { C. L. S. S. O. } & 79 & 73,2 & -5,8 & -3,31 & -2,4 & -0,4 & 2 & 1,14 \\ \text { C. L. B. } & 85,9 & 80 & -5,9 & -2,97 & 1,6 & 0,8 & -0,8 & -0,40 \\ \text { C. S. C. } & 84,2 & 84 & -0,2 & -0,09 & 0,4 & 2,2 & 1,8 & 0,78 \\ \text { D. G. B. M. } & 79,6 & 75,2 & -4,4 & -2,11 & 2,1 & 4 & 1,9 & 0,91 \\ \text { D. A. M. } & 87,9 & 79,7 & -8,2 & -5,89 & 7,7 & 5,6 & -2,1 & -1,51 \\ \text { D.P. S. } & 86,3 & 77,4 & -8,9 & -3,73 & 5 & -0,4 & -5,4 & -2,26 \\ \text { E. M. Z. } & 81,3 & 77,7 & -3,6 & -1,43 & 1,5 & 4,5 & 3 & 1,19 \\ \text { F. V. F. } & 82,2 & 76,5 & -5,7 & -2,27 & 2,4 & 0,2 & -2,2 & -0,87 \\ \text { F. L. R. } & 81,6 & 80,2 & -1,4 & -1,24 & -0,7 & -0,3 & 0,4 & 0,35 \\ \text { G. C. H. } & 84,9 & 79,7 & -5,2 & -7,73 & 1,6 & 0,7 & -0,9 & -1,34 \\ \text { G. O. C. } & 84,9 & 80,3 & -4,6 & -1,27 & 1,4 & 0 & -1,4 & -0,39 \\ \text { H. S. M. } & 78,1 & 73,5 & -4,6 & -1,92 & -0,6 & -0,6 & 0 & 0,00 \\ \text { J. G. B. Z. } & 84,2 & 79,8 & -4,4 & -1,50 & 1 & 1,9 & 0,9 & 0,31 \\ \text { J. D. F. F. V. } & 83,8 & 83,5 & -0,3 & -0,43 & 5,8 & 2,8 & -3 & -4,28 \\ \text { M. C. G. } & 82,9 & 78,6 & -4,3 & -2,16 & 3,2 & -1,4 & -4,6 & -2,31 \\ \text { N. C. M. } & 82 & 78 & -4 & -3,95 & 1,3 & 2,4 & 1,1 & 1,09 \\ \text { P. F. } & 77,9 & 77,3 & -0,6 & -0,34 & -0,3 & 1,4 & 1,7 & 0,95 \\ \text { P. S. C. T. } & 84,1 & 79,2 & -4,9 & -2,12 & 1,7 & 2 & 0,3 & 0,13 \\ \text { S. D. O. } & 79 & 79 & 0 & 0,00 & -1,7 & 0,7 & 2,4 & 0,74 \\ \text { T. D. F. } & 81,4 & 78,5 & -2,9 & -1,12 & -0,5 & 2,2 & 2,7 & 1,05 \\ \text { T. P.I } & 82,5 & 80,4 & -2,1 & -1,56 & 2,2 & 1 & -1,2 & -0,89 \\ \text { T. O. } & 81,7 & 82,1 & 0,4 & 0,31 & -0,1 & 2,2 & 2,3 & 1,80 \\ \text { V. D. V. F. } & 80 & 76,7 & -3,3 & -2,88 & 2,3 & 1,3 & -1 & -0,87 \\ \text { V. V. } & 87,3 & 84,2 & -3,1 & -2,50 & 2,7 & 3,5 & 0,8 & 0,65 \\ \text { W. F. C. R. } & 83,5 & 81 & -2,5 & -1,46 & -0,6 & 1,1 & 1,7 & 0,99\end{array}$


APÊNDICE 20 - Valores individuais das grandezas cefalométricas FMA e SN.GoGn para os pacientes do Grupo Experimental 2 (Bionator).

\section{Paciente FMA 1 FMA 2 FMA 2-1}

A. F. G

A. C. L. K

33,3

A. L. O. G

$23,1-22,3$

B. L. T. G

21,7

C. C.P.

816,3

C. L. S. S.

C. L. B. 23,1

24,4

24,9

C. S. C

31,2

D. G. B. M.

D. A. M.

D. P. S

E. M. Z.

F. V. F.

F. L.R.

G. C. H.

G. O. C.

H. S. M.

J. G. B. Z

J.D.F.F. V.

M. C. G.

N. C. M.

P. F.

P. S. C. T.

S. D. O.

T. D. F.

T. P.I

T. O.

V. D. V. F.

V. V.

W. F. C. R.

26,8

$16,7 \quad 14,2$

$24,4 \quad 23$

$30,8 \quad 32$

$26,1 \quad 25,1$

$32,3 \quad 33$

$24,4 \quad 24,3$

$30,7 \quad 29,1$

$20,5 \quad 15,5$

$33,6 \quad 30,1$

27,7

22,9

27,9

$28,8-23,6$

$33,7 \quad 31,7$

$32,8 \quad 36,7$

$30 \quad 28,8$

$29,7 \quad 26,9$

$30,9 \quad 34,7$

19,9

32,5

29,4
16,3

31,7

30,6
FMA 2-1

$-2,6$
$-0,8$
$-0,9$
$-3,5$
1,4
$-0,3$
$-3,2$
2,1

$$
-2,66
$$

$-0,65$

$-0,95$

$-1,90$

0,90

$-0,17$

$-1,61$

0,91

0,29

$-1,80$

$-0,59$

0,48

$-0,40$

0,62

$-0,15$

$-0,44$

$-2,09$

$-1,19$

0,00

$-1,16$

0,30

$-2,91$

$-0,86$

1,21

$-0,47$

$-2,08$

2,98

$-3,14$

$-0,65$

0,70

\section{1}

39,2

33,1

24,5

23,9

34

26,3

26,8

37,5

37,1

24,3

25, 7

37,4

36

36,2

27,5

40,3

27, 2

38,2

33

30,6

41,9

31,3

37,7

38,1

31,2

33,6

41,2

22,7

35,5

36,5
2

38,2

32,4

25,3

22,5

33,2

30,5

23,8

39,2

32,7

20,8

24

39

34,6

36,8

28,6

36,3

24,2

38

33,4

29,3

39,1

29,8

35,6

44,2

27,9

33,8

39,4

21,7

39,1

37,8
2-1

$-1$

$-0,7$

0,8

$-1,4$

$-0,8$

4,2

$-3$

1,7

$-4,4$

$-3,5$

$-1,7$

1,6

$-1,4$

0,6

1,1

$-4$

$-3$

$-0,2$

0,4

$-1,3$

$-2,8$

$-1,5$

$-2,1$

6,1

$-3,3$

0,2

$-1,8$

$-1$

3,6

1,3
SN.GoGn

2-1 anualizada

$-1,02$

$-0,56$

0,84

$-0,76$

$-0,51$

2,39

$-1,51$

0,74

$-2,11$

$-2,51$

$-0,71$

0,63

$-0,56$

0,53

1,63

$-1,10$

$-1,25$

$-0,07$

0,57

$-0,65$

$-2,77$

$-0,84$

$-0,91$

1,89

$-1,28$

0,15

$-1,41$

$-0,87$

2,91

0,76 
APÊNDICE 21 - Valores individuais das grandezas cefalométricas SN.PP e AFAI para os pacientes do Grupo Experimental 2 (Bionator).

Paciente SN.PP 1 SN.PP 2 SN.PP SN.PP 2-1 AFAl 1 AFAl 2 AFAl 2-1 AFAl 2-1

\begin{tabular}{|c|c|c|c|c|c|c|c|c|}
\hline & & & $2-1$ & anualizada & & & & nualiza \\
\hline A. F. G. & 8,7 & 10,8 & 2,1 & 2,14 & 66 & 67,3 & 1,3 & 1,33 \\
\hline A. C. L. K. & 8,1 & 9,5 & 1,4 & 1,13 & 53,9 & 58,3 & 4,4 & 3,55 \\
\hline A. L. O. G. & 7,4 & 8,9 & 1,5 & 1,58 & 52,2 & 55,5 & 3,3 & 3,47 \\
\hline B. L. T. G. & 4,8 & 7,5 & 2,7 & 1,47 & 56,6 & 57,6 & 1 & 0,54 \\
\hline C. C.P. & 9,4 & 7,2 & $-2,2$ & $-1,42$ & 57,8 & 61,6 & 3,8 & 2,44 \\
\hline C. L. S. S. O. & 4,8 & 8,9 & 4,1 & 2,34 & 60,3 & 66,9 & 6,6 & 3,76 \\
\hline C. L. B. & 6,2 & 5,4 & $-0,8$ & $-0,40$ & 50,6 & 54,2 & 3,6 & 1,81 \\
\hline C.S. C. & 10,2 & 12,9 & 2,7 & 1,17 & 63,6 & 71,5 & 7,9 & 3,43 \\
\hline D. G. B. M. & 8,8 & 7,5 & $-1,3$ & $-0,62$ & 61,8 & 70,6 & 8,8 & 4,21 \\
\hline D. A. M. & 7,1 & 8,2 & 1,1 & 0,79 & 55,2 & 58,6 & 3,4 & 2,44 \\
\hline D.P.S. & 3,2 & 2,9 & $-0,3$ & $-0,13$ & 58,9 & 65,2 & 6,3 & 2,64 \\
\hline E. M. Z. & 8,4 & 11,8 & 3,4 & 1,35 & 66,9 & 79 & 12,1 & 4,79 \\
\hline F. V. F. & 11,5 & 11,4 & $-0,1$ & $-0,04$ & 62,4 & 66,6 & 4,2 & 1,67 \\
\hline F. L. R. & 4,3 & 5,9 & 1,6 & 1,42 & 65,2 & 67,4 & 2,2 & 1,95 \\
\hline G. C. H. & 9,5 & 12,3 & 2,8 & 4,16 & 53,6 & 54,6 & 1 & 1,49 \\
\hline G. O. C. & 11 & 9,4 & $-1,6$ & $-0,44$ & 62,6 & 67 & 4,4 & 1,21 \\
\hline H. S. M. & 7,7 & 5,9 & $-1,8$ & $-0,75$ & 57,7 & 66,7 & 9 & 3,76 \\
\hline J. G. B. Z. & 5,8 & 4,6 & $-1,2$ & $-0,41$ & 61,9 & 69,9 & 8 & 2,73 \\
\hline J. D. F. F. V. & 4,7 & 5,6 & 0,9 & 1,28 & 63,2 & 63,7 & 0,5 & 0,71 \\
\hline M. C. G. & 12,5 & 13,3 & 0,8 & 0,40 & 48,8 & 53 & 4,2 & 2,11 \\
\hline N. C. M. & 10,4 & 10,2 & $-0,2$ & $-0,20$ & 55,5 & 60,3 & 4,8 & 4,74 \\
\hline P. F. & 1,5 & 0,9 & $-0,6$ & $-0,34$ & 62,9 & 63,7 & 0,8 & 0,45 \\
\hline P. S. C. T. & 6 & 8,9 & 2,9 & 1,25 & 63,3 & 66,4 & 3,1 & 1,34 \\
\hline S. D. O. & 3,3 & 3,7 & 0,4 & 0,12 & 60,2 & 68,6 & 8,4 & 2,60 \\
\hline T. D. F. & 8,3 & 4 & $-4,3$ & $-1,67$ & 56,5 & 66,6 & 10,1 & 3,91 \\
\hline T. P.I & 11,6 & 12,3 & 0,7 & 0,52 & 59,8 & 60,3 & 0,5 & 0,37 \\
\hline T. O. & 12,1 & 9,6 & $-2,5$ & $-1,96$ & 63,6 & 67,3 & 3,7 & 2,90 \\
\hline V. D. V. F. & 2,9 & 5,7 & 2,8 & 2,44 & 58,9 & 62,3 & 3,4 & 2,97 \\
\hline V. V. & 5,3 & 9,3 & 4 & 3,23 & 61,4 & 65,2 & 3,8 & 3,07 \\
\hline W. F. C. R. & 7,6 & 7,9 & 0,3 & 0,17 & 63,4 & 67,5 & 4,1 & 2,39 \\
\hline
\end{tabular}


APÊNDICE 22 - Valores individuais das grandezas cefalométricas SN.POF e S-Go para os pacientes do Grupo Experimental 2 (Bionator).

\section{Paciente SN.POF 1 SN.POF SN.POF 2 \\ 2-1}

A. F. G.

A. C. L. K.

A. L. O. G.

B. L. T. G

C. C.P.

C. L. S. S. O.

C. L. B.

C. S. C.

D. G. B. M.

D. A. M.

D. P. S.

E. M. Z.

F. V. F.

F. L. R.

G. C. H.

G. O. C.

H. S. M.

J. G. B. Z.

J. D. F. F. V. M. C. G.

N. C. M.

P. F.

P. S. C. T.

S. D. O.

T. D. F.

T. P.I

T. O.

V. D. V. F.

V. V.

W. F. C. R

\begin{abstract}
22,2
\end{abstract}
21,2

15,5

13,4

18

20,1

19

24,4

20,7

19,2

13,9

22,9

21,8

26,5

18,5

26,1

13,7

24

15,8

15,8

27,7

18,6

24,5

25,6

23,6

21,6

30,3

12,1

24,2

23,6
17,9

15,2

18,4

8,2

14,8

15

10,8

22,3

11,1

10

8,3

18,6

15,8

22,2

16,9

15,6

4,8

19

18,5

19,9

20,8

14,6

19,5

24,1

12,5

20,9

24,6

8

20,8

17,7
$-4,3$

$-6$

2,9

$-5,2$

$-3,2$

$-5,1$

$-8,2$

$-2,1$

$-9,6$

$-9,2$

$-5,6$

$-4,3$

$-6$

$-4,3$

$-1,6$

$-10,5$

$-8,9$

$-5$

2,7

4,1

$-6,9$

$-4$

$-5$

$-1,5$

$-11,1$

$-0,7$

$-5,7$

$-4,1$

$-3,4$

$-5,9$
SN.POF

2-1

anualizada

$-4,39$
$-4,84$

3,05

$-2,82$

$-2,06$

$-2,91$

$-4,13$

$-0,91$

$-4,60$

$-6,61$

$-2,35$

$-1,70$

$-2,39$

$-3,81$

$-2,38$

$-2,89$

$-3,72$

$-1,70$

3,85

2,06

$-6,82$

$-2,24$

$-2,16$

$-0,46$

$-4,30$

$-0,52$

$-4,47$

$-3,58$

$-2,74$

$-3,44$
S-Go 1 S-Go 2

63,8

64,3

67,4

62,5

75

63,8

67,1

63,7

71,3

67,3

71

68

62,5

66,3

60

70,7

59,8

65,5

60,5

57,2

68,6

62,1

62,9

63,3

67,4

61,2

77,7

63,7

64

\section{8,2}

70,7

70,7

75,4

68,1

83,2

72,9

77,3

76,6

83,4

76,2

85,2

75,1

67

69,8

70,4

83,4

66,9

67,3

66

66,3

71,1

72,9

65,9

72,1

69,9

65,8

86,3

67,3

68,7
S-Go

anualizada
4,4

8,2

6,4

8

5,6

8,2

9,1

10,2

12,9

12,1

8,9

14,2

7,1

4,5

3,5

10,4

12,7

7,1

1,8

5,5

9,1

2,5

10,8

3

8,8

2,5

4,6

8,6

3,6

4,7
4,49

6,62

6,73

4,34

3,60

4,67

4,58

4,43

6,18

8,69

3,73

5,63

2,82

3,99

5,20

2,87

5,30

2,42

2,57

2,76

9,00

1,40

4,66

0,93

3,41

1,86

3,60

7,50 
APÊNDICE 23 - Valores individuais das grandezas cefalométricas 1.PP e 1.NA para os pacientes do Grupo Experimental 2 (Bionator).

Paciente 1.PP 1 1.PP 2 1.PP 2-1 1.PP 2-1 1.NA 1 1.NA 2 1.NA 2-1 1.NA 2-1

\begin{tabular}{|c|c|c|c|c|c|c|c|c|}
\hline & & & & & & & & \\
\hline A. F. G. & 114,4 & 111,4 & -3 & $-3,06$ & 23,5 & 19,3 & $-4,2$ & $-4,29$ \\
\hline A. C. L. K. & 116,8 & 121,1 & 4,3 & 3,47 & 31,6 & 34,3 & 2,7 & 2,18 \\
\hline A. L. O. G. & 120,6 & 116,4 & $-4,2$ & $-4,42$ & 27,5 & 23,6 & $-3,9$ & $-4,10$ \\
\hline B. L. T. G. & 121,8 & 120,8 & -1 & $-0,54$ & 30,6 & 28,4 & $-2,2$ & $-1,19$ \\
\hline C. C.P. & 117,9 & 119,3 & 1,4 & 0,90 & 27,5 & 30 & 2,5 & 1,61 \\
\hline C. L. S. S. O. & 132,2 & 112,9 & $-19,3$ & $-11,00$ & 46,8 & 28,2 & $-18,6$ & $-10,60$ \\
\hline C. L. B. & 117,6 & 123,8 & 6,2 & 3,12 & 28,9 & 37,4 & 8,5 & 4,28 \\
\hline C. S. C. & 104,7 & 105,4 & 0,7 & 0,30 & 11,1 & 11,4 & 0,3 & 0,13 \\
\hline D. G. B. M. & 125,7 & 114,7 & -11 & $-5,27$ & 34,4 & 22,2 & $-12,2$ & $-5,84$ \\
\hline D. A. M. & 123,5 & 116,4 & $-7,1$ & $-5,10$ & 36,7 & 31,1 & $-5,6$ & $-4,02$ \\
\hline D. P. S. & 119,3 & 119,8 & 0,5 & 0,21 & 31,3 & 33,4 & 2,1 & 0,88 \\
\hline E. M. Z. & 121,2 & 111,2 & -10 & $-3,96$ & 36,5 & 24,4 & $-12,1$ & $-4,79$ \\
\hline F. V. F. & 125,3 & 124,3 & -1 & $-0,40$ & 28,9 & 29,7 & 0,8 & 0,32 \\
\hline F. L. R. & 120,7 & 108,5 & $-12,2$ & $-10,82$ & 33,5 & 19,9 & $-13,6$ & $-12,06$ \\
\hline G. C. H. & 131,6 & 113,7 & $-17,9$ & $-26,60$ & 37 & 19,5 & $-17,5$ & $-26,01$ \\
\hline G. O. C. & 121,6 & 114,7 & $-6,9$ & $-1,90$ & 27,8 & 21,8 & -6 & $-1,65$ \\
\hline H. S. M. & 125,4 & 125 & $-0,4$ & $-0,17$ & 36,9 & 37,3 & 0,4 & 0,17 \\
\hline J. G. B. Z. & 115,2 & 113,2 & -2 & $-0,68$ & 28,6 & 30,2 & 1,6 & 0,55 \\
\hline J.D.F.F. V. & 113,7 & 106 & $-7,7$ & $-10,99$ & 21,5 & 14,2 & $-7,3$ & $-10,42$ \\
\hline M. C. G. & 127,1 & 124,4 & $-2,7$ & $-1,36$ & 34,6 & 31,7 & $-2,9$ & $-1,46$ \\
\hline N. C. M. & 106 & 109,8 & 3,8 & 3,76 & 18,5 & 21,7 & 3,2 & 3,16 \\
\hline P. F. & 109,5 & 107,7 & $-1,8$ & $-1,01$ & 24,3 & 24,5 & 0,2 & 0,11 \\
\hline P. S. C. T. & 117,5 & 114,8 & $-2,7$ & $-1,17$ & 29,6 & 26,4 & $-3,2$ & $-1,38$ \\
\hline S. D. O. & 116,5 & 102,8 & $-13,7$ & $-4,24$ & 28,9 & 15,5 & $-13,4$ & $-4,14$ \\
\hline T. D. F. & 130,8 & 114,9 & $-15,9$ & $-6,16$ & 40,3 & 26 & $-14,3$ & $-5,54$ \\
\hline T.P.I & 114,6 & 106,9 & $-7,7$ & $-5,72$ & 22,1 & 14,8 & $-7,3$ & $-5,42$ \\
\hline Т. O. & 116,2 & 116 & $-0,2$ & $-0,16$ & 28,3 & 28,6 & 0,3 & 0,24 \\
\hline V. D. V.F. & 111,5 & 111,6 & 0,1 & 0,09 & 24,2 & 22,2 & -2 & $-1,74$ \\
\hline V. V. & 113,9 & 101,1 & $-12,8$ & $-10,33$ & 24,8 & 10,3 & $-14,5$ & $-11,70$ \\
\hline W. F. C. R. & 125,7 & 113,7 & -12 & $-6,99$ & 34,4 & 23,1 & $-11,3$ & $-6,58$ \\
\hline
\end{tabular}


APÊNDICE 24 - Valores individuais das grandezas cefalométricas 1-NA e 1-ENAperp para os pacientes do Grupo Experimental 2 (Bionator).

Paciente 1-NA 1 1-NA 2 1-NA 2-1 1-NA 2-1 1-ENAperp 1-ENAperp 1-ENAperp 1-ENAperp 2-1

$\begin{array}{lcccccccc}\text { A. F. G. } & 3,8 & 3,9 & 0,1 & 0,10 & -3,8 & -2,7 & 1,1 & 1,12 \\ \text { A. C. L. K. } & 6,5 & 6,7 & 0,2 & 0,16 & -1,7 & -1,3 & 0,4 & 0,32 \\ \text { A. L. O. G. } & 3,2 & 2,6 & -0,6 & -0,63 & -0,9 & -1,7 & -0,8 & -0,84 \\ \text { B. L. T. G. } & 2,5 & 3,6 & 1,1 & 0,60 & -6,5 & -2,9 & 3,6 & 1,95 \\ \text { C. C. P. } & 4,9 & 5,9 & 1 & 0,64 & -1,9 & -2,7 & -0,8 & -0,51 \\ \text { C. L. S. S. O. } & 11,1 & 7,8 & -3,3 & -1,88 & 1,5 & -0,6 & -2,1 & -1,20 \\ \text { C. L. B. } & 3,6 & 6 & 2,4 & 1,21 & -1,8 & -0,9 & 0,9 & 0,45 \\ \text { C. S. C. } & -0,2 & 0,1 & 0,3 & 0,13 & -4,8 & -5,7 & -0,9 & -0,39 \\ \text { D. G. B. M. } & 6,8 & 3,1 & -3,7 & -1,77 & -0,1 & -6,5 & -6,4 & -3,06 \\ \text { D. A. M. } & 6,2 & 2,9 & -3,3 & -2,37 & -1,8 & -8,3 & -6,5 & -4,67 \\ \text { D. P. S. } & 3,9 & 7,3 & 3,4 & 1,43 & -6,1 & -1,9 & 4,2 & 1,76 \\ \text { E. M. Z. } & 6,4 & 4,4 & -2 & -0,79 & -5,4 & -9,2 & -3,8 & -1,51 \\ \text { F. V. F. } & 4,5 & 6,7 & 2,2 & 0,87 & -0,5 & 1,1 & 1,6 & 0,64 \\ \text { F. L. R. } & 6,8 & 3,4 & -3,4 & -3,02 & -4,8 & -5,9 & -1,1 & -0,98 \\ \text { G. C. H. } & 6,1 & 2,7 & -3,4 & -5,05 & 0,2 & -0,9 & -1,1 & -1,63 \\ \text { G. O. C. } & 5,8 & 6,8 & 1 & 0,28 & -1,3 & -1,3 & 0 & 0,00 \\ \text { H. S. M. } & 7,2 & 8 & 0,8 & 0,33 & 1,9 & -2,3 & -4,2 & -1,75 \\ \text { J. G. B. Z. } & 3,3 & 5,7 & 2,4 & 0,82 & -6,1 & -8,6 & -2,5 & -0,85 \\ \text { J. D. F. F. V. } & 1,8 & -0,8 & -2,6 & -3,71 & -5,9 & -6,7 & -0,8 & -1,14 \\ \text { M. C. G. } & 4,1 & 4,3 & 0,2 & 0,10 & -0,7 & 0,1 & 0,8 & 0,40 \\ \text { N. C. M. } & 2,2 & 2,8 & 0,6 & 0,59 & -6,2 & -6 & 0,2 & 0,20 \\ \text { P. F. } & 3,2 & 3,4 & 0,2 & 0,11 & -7,7 & -7,7 & 0 & 0,00 \\ \text { P. S. C. T. } & 6,3 & 5,3 & -1 & -0,43 & -1,3 & -2,1 & -0,8 & -0,35 \\ \text { S. D. O. } & 5,1 & 0,8 & -4,3 & -1,33 & -4,5 & -8 & -3,5 & -1,08 \\ \text { T. D. F. } & 9,7 & 4,4 & -5,3 & -2,05 & 4,1 & -5,1 & -9,2 & -3,57 \\ \text { T.P.I } & 1,8 & 0,8 & -1 & -0,74 & -5,2 & -6,5 & -1,3 & -0,97 \\ \text { T. O. } & 6,2 & 5,4 & -0,8 & -0,63 & -2,4 & -4 & -1,6 & -1,25 \\ \text { V. D. V. F. } & 6,7 & 3,1 & -3,6 & -3,14 & 1,4 & -3,4 & -4,8 & -4,19 \\ \text { V. V. } & 2,7 & -0,4 & -3,1 & -2,50 & -5,7 & -8,1 & -2,4 & -1,94 \\ \text { W. F. C. R. } & 6,2 & 2,5 & -3,7 & -2,15 & -4 & -7,3 & -3,3 & -1,92 \\ & & & & & & & & \end{array}$


APÊNDICE 25 - Valores individuais das grandezas cefalométricas 1-PP e 6-PP para os pacientes do Grupo Experimental 2 (Bionator).

$\begin{array}{lllllll}\text { Paciente } & \text { 1-PP } 1 & \text { 1-PP } 2 & \text { 1-PP 2-1 } & \text { 1-PP 2-1 } & \text { 6-PP } 1 & 6-P P\end{array} 2$ 6-PP 2-1 6-PP 2-1

$\begin{array}{lcccccccc}\text { A. F. G. } & 25,9 & 26,8 & 0,9 & 0,92 & 21,9 & 21,1 & -0,8 & -0,82 \\ \text { A. C. L. K. } & 23,7 & 25 & 1,3 & 1,05 & 19,4 & 22,6 & 3,2 & 2,58 \\ \text { A. L. O. G. } & 22,4 & 23,3 & 0,9 & 0,95 & 17,3 & 17,9 & 0,6 & 0,63 \\ \text { B. L. T. G. } & 21,8 & 23,1 & 1,3 & 0,71 & 19 & 21,8 & 2,8 & 1,52 \\ \text { C. C. P. } & 24,9 & 25,6 & 0,7 & 0,45 & 19,5 & 19,6 & 0,1 & 0,06 \\ \text { C. L. S. S. O. } & 23,7 & 28,6 & 4,9 & 2,79 & 19,9 & 25,4 & 5,5 & 3,14 \\ \text { C. L. B. } & 21,6 & 22,5 & 0,9 & 0,45 & 16,6 & 19,5 & 2,9 & 1,46 \\ \text { C. S. C. } & 26,7 & 28,4 & 1,7 & 0,74 & 19,8 & 23,2 & 3,4 & 1,48 \\ \text { D. G. B. M. } & 25,7 & 28,7 & 3 & 1,44 & 21 & 25,6 & 4,6 & 2,20 \\ \text { D. A. M. } & 23,9 & 23,6 & -0,3 & -0,22 & 18 & 19,7 & 1,7 & 1,22 \\ \text { D. P. S. } & 25,8 & 26,5 & 0,7 & 0,29 & 20,1 & 22,8 & 2,7 & 1,13 \\ \text { E. M. Z. } & 26,4 & 30,7 & 4,3 & 1,70 & 20 & 26,7 & 6,7 & 2,65 \\ \text { F. V. F. } & 25,4 & 27,7 & 2,3 & 0,91 & 21,1 & 25,4 & 4,3 & 1,71 \\ \text { F. L. R. } & 28,3 & 31,1 & 2,8 & 2,48 & 21,6 & 21,4 & -0,2 & -0,18 \\ \text { G. C. H. } & 22,5 & 24,1 & 1,6 & 2,38 & 18,7 & 20,6 & 1,9 & 2,82 \\ \text { G. O. C. } & 27,4 & 29,9 & 2,5 & 0,69 & 20 & 25,5 & 5,5 & 1,52 \\ \text { H. S. M. } & 25 & 28,3 & 3,3 & 1,38 & 23,1 & 27,2 & 4,1 & 1,71 \\ \text { J. G. B. Z. } & 24,9 & 29,6 & 4,7 & 1,60 & 17 & 21,5 & 4,5 & 1,53 \\ \text { J. D. F. F. V. } & 26,9 & 28,4 & 1,5 & 2,14 & 22,4 & 22,4 & 0 & 0,00 \\ \text { M. C. G. } & 19,1 & 21,2 & 2,1 & 1,05 & 15,2 & 18,4 & 3,2 & 1,61 \\ \text { N. C. M. } & 25,7 & 25,3 & -0,4 & -0,40 & 17,4 & 19,5 & 2,1 & 2,08 \\ \text { P. F. } & 29,6 & 28,2 & -1,4 & -0,78 & 21,1 & 22,2 & 1,1 & 0,62 \\ \text { P. S. C. T. } & 25,1 & 26,9 & 1,8 & 0,78 & 18,2 & 20,9 & 2,7 & 1,17 \\ \text { S. D. O. } & 24,5 & 30,2 & 5,7 & 1,76 & 17,5 & 20,4 & 2,9 & 0,90 \\ \text { T. D. F. } & 24,8 & 28,5 & 3,7 & 1,43 & 20,3 & 23 & 2,7 & 1,05 \\ \text { T. P.I } & 24,6 & 25,5 & 0,9 & 0,67 & 20 & 20,8 & 0,8 & 0,59 \\ \text { T. O. } & 27,2 & 29,5 & 2,3 & 1,80 & 21,4 & 22,1 & 0,7 & 0,55 \\ \text { V. D. V. F. } & 27,6 & 25,1 & -2,5 & -2,18 & 21,1 & 20,7 & -0,4 & -0,35 \\ \text { V. V. } & 24,8 & 27 & 2,2 & 1,78 & 17 & 19,1 & 2,1 & 1,69 \\ \text { W. F. C. R. } & 25,8 & 30,4 & 4,6 & 2,68 & 19,4 & 23,1 & 3,7 & 2,15\end{array}$


APÊNDICE 26 - Valores individuais das grandezas cefalométricas 6-ENAperp e IMPA para os pacientes do Grupo Experimental 2 (Bionator).

Paciente 6-ENAperp 6-ENAperp 6-ENAperp 6-ENAperp IMPA 1 IMPA 2 IMPA IMPA 2-1

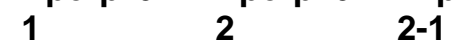

A. F. G.

A. C. L. K.

A. L. O. G.

B. L. T. G.

C. C. P.

C. L. S. S. O.

C. L. B.

C. S. C.

D. G. B. M.

D. A. M.

D.P.S.

E. M. Z.

F. V.F.

F. L. R.

G. C. H.

G. O. C.

H. S. M.

J. G. B. Z.

J. D. F. F. V.

M. C. G.

N. C. M.

P. F.

P. S. C. T.

S. D. O.

T. D. F.

T. P.I

T. O.

V. D. V. F.

V. V.

W. F. C. R.
$-29$

$-27$

$-30,9$

$-35,7$

$-33,9$

$-34,5$

$-29,3$

$-32,3$

$-31,5$

$-35,3$

$-34,5$

$-35,6$

$-33,5$

$-37,2$

$-31,7$

$-36,2$

$-29,1$

$-35,1$

$-34,3$

$-33,1$

$-29,7$

$-35,4$

$-35,6$

$-32,3$

$-27,5$

$-34,8$

$-31,2$

$-30,8$

$-34,2$

$-38,1$

$-28,4$
$-26,9$
$-29,2$
$-31,6$
$-36,5$
$-27,6$
$-28,4$
$-31,5$
$-34,2$
$-34,8$
$-27,4$
$-33,6$
-28
$-37,6$
$-29,4$
-30
-30
$-34,7$
$-33,9$
$-28,2$
$-31,3$
-35
$-31,7$
$-31,1$
$-30,9$
$-34,4$
$-31,2$
$-32,2$
$-35,5$
-37

2-1 anualizada

0,6

0,1

1,7

4,1

$-2,6$

6,9

0,9

0,8

$-2,7$

0,5

7,1

2

5,5

$-0,4$

2,3

6,2

$-0,9$

0,4

0,4

4,9

$-1,6$

0,4

3,9

1,2

$-3,4$

0,4

0

$-1,4$

$-1,3$

1,1

0,61

0,08

1,79

2,23

$-1,67$

3,93

0,45

0,35

$-1,29$

0,36

2,98

0,79

2,19

$-0,35$

3,42

1,71

$-0,38$

0,14

0,57

2,46

$-1,58$

0,22

1,68

0,37

$-1,32$

0,30

0,00

$-1,22$

$-1,05$

0,64
2-1 anualizada

$\begin{array}{cccc}97,2 & 104,9 & 7,7 & 7,86 \\ 84,5 & 90,3 & 5,8 & 4,68 \\ 104,6 & 106,5 & 1,9 & 2,00 \\ 97 & 99,8 & 2,8 & 1,52 \\ 85,2 & 101,8 & 16,6 & 10,68 \\ 93,8 & 102,9 & 9,1 & 5,19 \\ 99,8 & 97,1 & -2,7 & -1,36 \\ 89,9 & 92,5 & 2,6 & 1,13 \\ 97,4 & 88,2 & -9,2 & -4,41 \\ 100,8 & 105,9 & 5,1 & 3,66 \\ 97,1 & 96,5 & -0,6 & -0,25 \\ 96,2 & 96,7 & 0,5 & 0,20 \\ 103,1 & 99,9 & -3,2 & -1,27 \\ 91 & 94,9 & 3,9 & 3,46 \\ 73,8 & 104,5 & 30,7 & 45,63 \\ 99,4 & 104,3 & 4,9 & 1,35 \\ 96,6 & 95,2 & -1,4 & -0,58 \\ 88,5 & 91 & 2,5 & 0,85 \\ 81,6 & 96,8 & 15,2 & 21,69 \\ 92 & 100,7 & 8,7 & 4,37 \\ 84,3 & 100,6 & 16,3 & 16,11 \\ 95,1 & 96,2 & 1,1 & 0,62 \\ 94,5 & 100,3 & 5,8 & 2,50 \\ 78,8 & 99,8 & 21 & 6,49 \\ 97,1 & 98,4 & 1,3 & 0,50 \\ 92,7 & 94,1 & 1,4 & 1,04 \\ 86 & 98 & 12 & 9,40 \\ 101,4 & 95 & -6,4 & -5,58 \\ 89,2 & 99,3 & 10,1 & 8,15 \\ 90 & 92,5 & 2,5 & 1,46\end{array}$


APÊNDICE 27 - Valores individuais das grandezas cefalométricas 1.NB e 1-NB para os pacientes do Grupo Experimental 2 (Bionator).

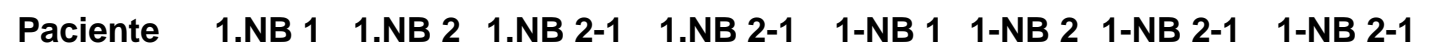

A. F. G. anualizada

$\begin{array}{llllllllr}\text { A. F. G. } & 34,9 & 41,3 & 6,4 & 6,54 & 7,3 & 10,2 & 2,9 & 2,96\end{array}$

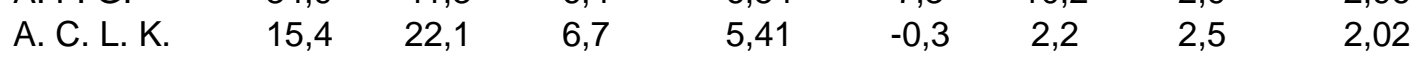

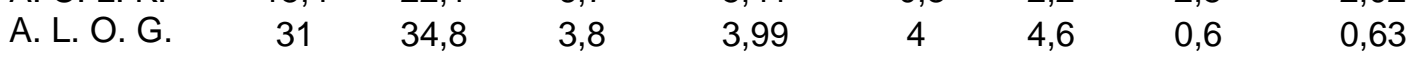

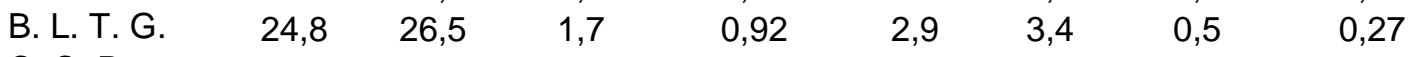

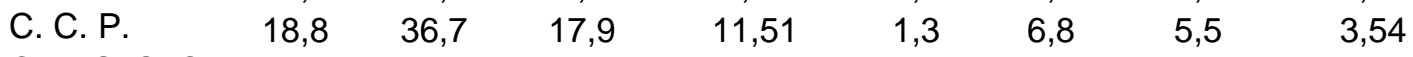

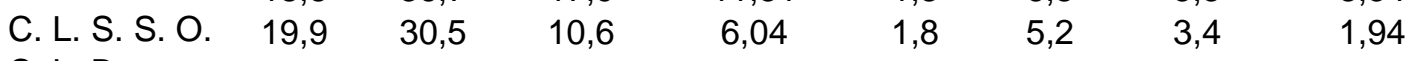

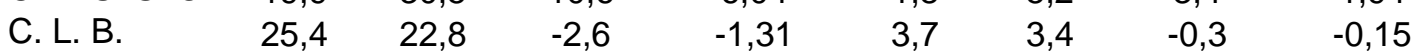

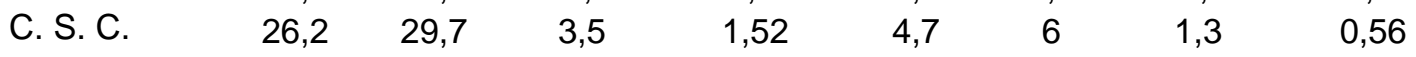

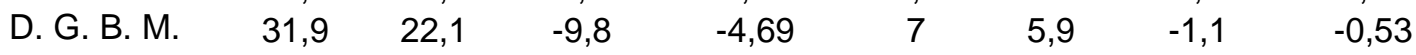

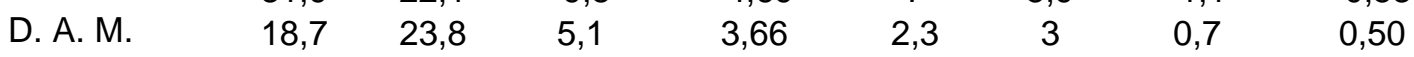

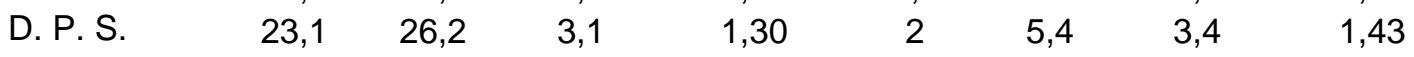

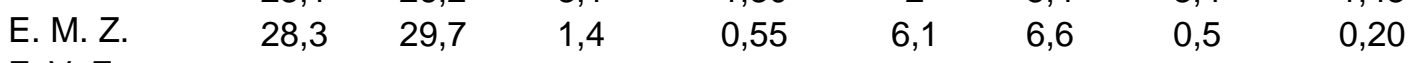

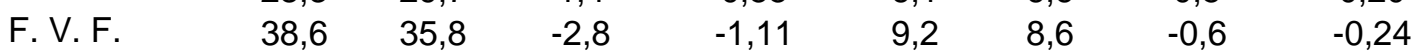

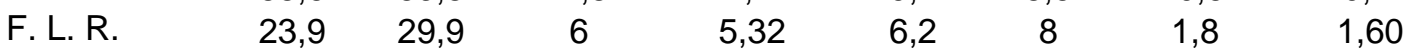

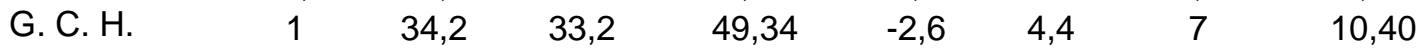

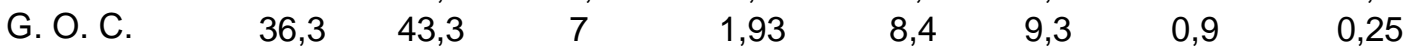

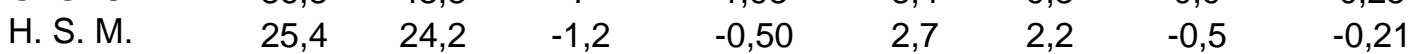

$\begin{array}{llllllll}\text { J. G. B. Z. } \quad 23,5 & 25,6 & 2,1 & 0,72 & 4,7 & 6,6 & 1,9 & 0,65\end{array}$

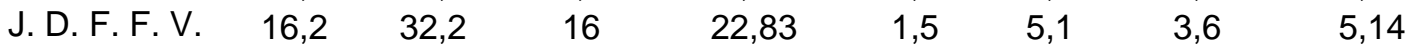

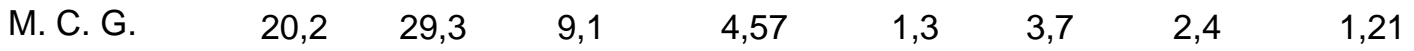

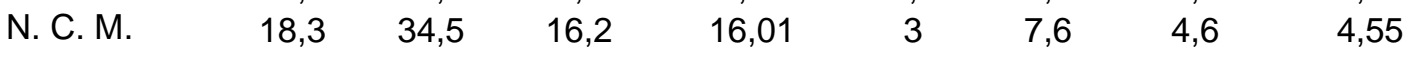

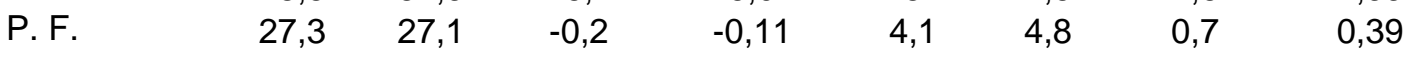

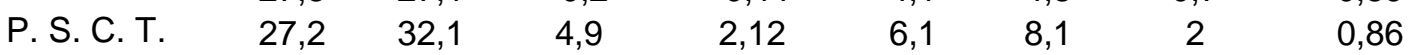

$\begin{array}{lllllllll}\text { S. D. O. } & 15,7 & 41,9 & 26,2 & 8,10 & 2,2 & 10,4 & 8,2 & 2,54\end{array}$

$\begin{array}{lllllllll}\text { T. D. F. } & 26,6 & 30 & 3,4 & 1,32 & 4,6 & 6,7 & 2,1 & 0,81\end{array}$

$\begin{array}{lllllllll}\text { T. P.I } & 24 & 25,8 & 1,8 & 1,34 & 2,1 & 4,4 & 2,3 & 1,71\end{array}$

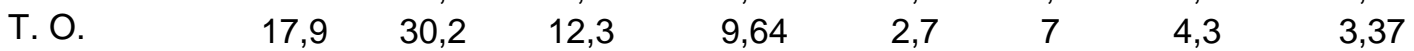

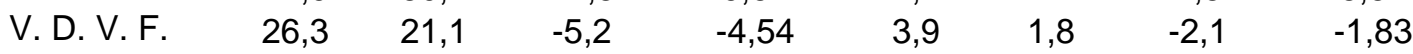

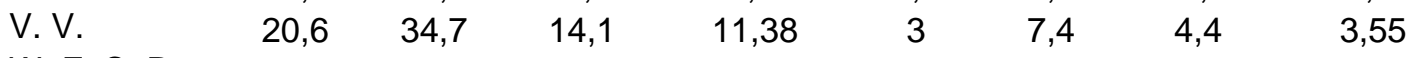

$\begin{array}{lrllllll}\text { W. F. C. R. } \quad 25,5 & 30,1 & 4,6 & 2,68 & 4,1 & 5,5 & 1,4 & 0,82\end{array}$ 
APÊNDICE 28 - Valores individuais das grandezas cefalométricas 1-Pogperp e 1-GoMe para os pacientes do Grupo Experimental 2 (Bionator).

Paciente

$$
\begin{array}{ccc}
1- & 1- & 1- \\
\text { Pogperp } & \text { Pogperp } & \text { Pogperp } \\
\mathbf{2} & \mathbf{2 - 1}
\end{array}
$$

A. C. L. K.

$$
-12,9
$$

$-10,7$

3,5

A. L. O. G.

$-3,8 \quad-3,8$

0

B. L. T. G.

$-8,2$

$-9,8$

$-1,6$

C. C.P.

$-12,4$

$-6,6$

5,8

C. L. S. S. O.

$-9,3$

0,3

C. L. B.

$-7,3$

$-9,6$

$-2,3$

C.S. C.

$-8,5$

$-11,3$

$-2,8$

D. G. B. M

$-9,4$

$-14,5$

$-5,1$

D. A. M

$-8,1$

P.S

$-11,2$

$-9,2$

$-1,1$

$-11,8 \quad-0,6$

$\begin{array}{ll}-7,4 & -12,5\end{array}$

$-5,1$

F.V.F.

$-4,2$

$-7,6$

$-3,4$

F. L. R.

$-9,3$

$-6,7$

2,6

G. C. H.

$-15,2$

G. O. C.

$-4,1$

H. S. M.

$-8$

J. G. B. Z.

$-9$

J.D. F. F. V.

$-13,5$

M. C. G.

$-8,6$

N. C. M.

$-11,9$

P. F.

$-9,8$

P.S. C. T

$-6,4$

S.D. O.

$-14,7$

T.D. F.

$-7,9$

T. P.I

$-11,6$

T. O.

$-13,6$

V.D. V. F.

$-7,8$

$-5$

10,2

$-2,6$

1,5

$-11,3$

$-3,3$

$-11,9$

$-2,9$

$-9,3$

4,2

$-6,4 \quad 2,2$

$-6,6 \quad 5,3$

$-9,9 \quad-0,1$

$-6,9 \quad-0,5$

$-9,3$

$-7,2$

$-8,8$

5,4

0,7

$-9,1$

V. V.

$-11,3$

$-10,7$

2,8

4,5

$-2,9$

W. F. C.R

$-8,9$

$-6,9$

4,4

$-9,9 \quad-1$

\section{1-Pogperp 1-GoMe 1-GoMe 1-GoMe 1-GoMe 2-1 \\ anualizada}

3,57

$\begin{array}{lllll}1,78 & 30,4 & 32,9 & 2,5 & 2,02\end{array}$

$\begin{array}{lllll}0,00 & 33,2 & 33,4 & 0,2 & 0,21\end{array}$

$\begin{array}{lllll}-0,87 & 34,2 & 36,3 & 2,1 & 1,14\end{array}$

$\begin{array}{lllll}3,73 & 35,7 & 38,2 & 2,5 & 1,61\end{array}$

$\begin{array}{lllll}0,17 & 35,3 & 39,5 & 4,2 & 2,39\end{array}$

$\begin{array}{lllll}-1,16 & 33 & 34,8 & 1,8 & 0,91\end{array}$

$\begin{array}{lllll}-1,22 & 39 & 44,1 & 5,1 & 2,22\end{array}$

$\begin{array}{lllll}-2,44 & 38,8 & 42,4 & 3,6 & 1,72\end{array}$

$\begin{array}{lllll}-0,79 & 36,9 & 37,3 & 0,4 & 0,29\end{array}$

$\begin{array}{lllll}-0,25 & 36,4 & 40,8 & 4,4 & 1,84\end{array}$

$\begin{array}{lllll}-2,02 & 41,8 & 47,2 & 5,4 & 2,14\end{array}$

$\begin{array}{lllll}-1,35 & 38,6 & 40,7 & 2,1 & 0,83\end{array}$

$\begin{array}{lllll}2,31 & 38,4 & 37,1 & -1,3 & -1,15\end{array}$

$\begin{array}{lllll}15,16 & 34 & 33,3 & -0,7 & -1,04\end{array}$

$\begin{array}{lllll}0,41 & 37,9 & 40,7 & 2,8 & 0,77\end{array}$

$\begin{array}{lllll}-1,38 & 36,1 & 38,7 & 2,6 & 1,09\end{array}$

$\begin{array}{lllll}-0,99 & 35,1 & 39,5 & 4,4 & 1,50\end{array}$

$\begin{array}{lllll}5,99 & 36,4 & 35,4 & -1 & -1,43\end{array}$

$\begin{array}{lllll}1,11 & 32,2 & 34 & 1,8 & 0,90\end{array}$

$\begin{array}{lllll}5,24 & 32,5 & 34,7 & 2,2 & 2,17\end{array}$

$\begin{array}{lllll}-0,06 & 35,4 & 36 & 0,6 & 0,34\end{array}$

$\begin{array}{lllll}-0,22 & 37,5 & 41,6 & 4,1 & 1,77\end{array}$

$\begin{array}{lllll}1,67 & 33,2 & 39 & 5,8 & 1,79\end{array}$

$\begin{array}{lllll}0,27 & 36,4 & 40 & 3,6 & 1,40\end{array}$

$\begin{array}{lllll}2,08 & 34,5 & 34,5 & 0 & 0,00\end{array}$

$\begin{array}{lllll}3,53 & 36,9 & 39,7 & 2,8 & 2,19\end{array}$

$\begin{array}{lllll}-2,53 & 39 & 40,2 & 1,2 & 1,05\end{array}$

$\begin{array}{lllll}3,55 & 37,9 & 39,2 & 1,3 & 1,05\end{array}$

$\begin{array}{lllll}-0,58 & 36,4 & 36,7 & 0,3 & 0,17\end{array}$ 
APÊNDICE 29 - Valores individuais das grandezas cefalométricas

6-Pogperp e 6-GoMe para os pacientes do Grupo Experimental 2 (Bionator).

\section{Paciente}

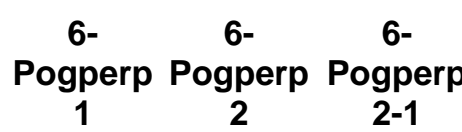

A. F. G.

A. C. L. K.

$-24,7$

A. L. O. G.

$-31,1$

B. L. T. G.

C. C. P.

C. L. S. S. O.

C. L. B.

C. S. C.

D. G. B. M

D. A. M.

D. P. S.

E. M. Z.

F. V.F.

F. L. R.

G. C. H.

G. O. C.

H. S. M.

J. G. B. Z.

J. D. F. F. V

M. C. G.

N. C. M.

P. F.

P. S. C. T.

S. D. O.

T. D. F.

T. P.I

T. O.

V. D. V. F

V. V.

W. F. C. R

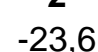

$-29,1$

$-26,1$

$-30,6$

$-32,4$

$-30,7$

$-32,6$

$-29$

$-33,9$

$-29,9$

$-30,2$

$-30,2$

$-29,6$

$-30,1$

$-29,5$

$-23,6$

$-29,5$

$-31,5$

$-29,7$

$-28,8$

$-27$

$-29,8$

$-29,5$

$-26,9$

$-26,2$

$-31,4$

$-27,4$

$-31,5$

$-28,9$

$-33,2$
1,1

2

0,8

0,6

0,4

2,6

$-2,2$

1

$-3,1$

$-0,9$

$-0,8$

$-1,1$

0,3

$-0,6$

1,7

4,3

$-0,4$

$-1,2$

0,9

3,2

0,3

1,8

$-1,2$

2,7

0

1,4

2,8

$-0,5$

$-0,2$

$-1,6$
6-Pogperp

anualizada

1,12
1,61
0,84
0,33

0,26

1,48

$-1,11$

0,43

$-1,48$

$-0,65$

$-0,34$

$-0,44$

0,12

$-0,53$

2,53

1,18

$-0,17$

$-0,41$

1,28

1,61

0,30

1,01

$-0,52$

0,83

0,00

1,04

2,19

$-0,44$

$-0,16$

$-0,93$ $\begin{array}{cccc}\text { 6-GoMe } & 6-\text { GoMe } & 6-\text { GoMe } & 6-\text { GoMe } 2-1 \\ 1 & 2 & 2-1 & \text { anualizada }\end{array}$

$\begin{array}{llll}29,8 & 33,6 & 3,8 & 3,88\end{array}$

$22 \quad 25,2 \quad 3,2 \quad 2,58$

$\begin{array}{llll}25,5 & 29 & 3,5 & 3,68\end{array}$

$24,9 \quad 28,3 \quad 3,4 \quad 1,85$

$\begin{array}{llll}23,5 & 26,5 & 3 & 1,93\end{array}$

$27,8 \quad 31,6 \quad 3,8 \quad 2,17$

$24 \quad 26,1 \quad 2,1 \quad 1,06$

$29,4 \quad 35,7 \quad 6,3 \quad 2,74$

$25,3 \quad 31,5 \quad 6,2 \quad 2,97$

$\begin{array}{llll}26,3 & 31,3 & 5 & 3,59\end{array}$

$25,2 \quad 32,1 \quad 6,9 \quad 2,89$

$30,2 \quad 38,1 \quad 7,9 \quad 3,13$

$\begin{array}{llll}27,1 & 31 & 3,9 & 1,55\end{array}$

$\begin{array}{llll}25 & 28 & 3 & 2,66\end{array}$

$\begin{array}{llll}24 & 26 & 2 & 2,97\end{array}$

$25,3 \quad 29,7 \quad 4,4 \quad 1,21$

$25 \quad 30,6 \quad 5,6 \quad 2,34$

$25,8 \quad 30,9 \quad 5,1 \quad 1,74$

$24,5 \quad 25,8 \quad 1,3 \quad 1,86$

$22,8 \quad 26,2 \quad 3,4 \quad 1,71$

$23,9 \quad 26,7 \quad 2,8 \quad 2,77$

$25,2 \quad 25,4 \quad 0,2 \quad 0,11$

$26,9 \quad 32,5 \quad 5,6 \quad 2,42$

$25 \quad 29,5 \quad 4,5 \quad 1,39$

$\begin{array}{llll}25,4 & 31,4 & 6 & 2,33\end{array}$

$\begin{array}{llll}25,7 & 26,5 & 0,8 & 0,59\end{array}$

$\begin{array}{llll}27,8 & 30,7 & 2,9 & 2,27\end{array}$

$27,1 \quad 33,3 \quad 6,2 \quad 5,41$

$\begin{array}{llll}27,1 & 29,1 & 2 & 1,61\end{array}$

$25,3 \quad 27,6 \quad 2,3 \quad 1,34$ 
APÊNDICE 30 - Valores individuais das grandezas cefalométricas relação molar, TH e TV para os pacientes do Grupo Experimental 2 (Bionator).

Paciente

Rel. Rel. Rel. mol 1 mol 2 mol 2-1

\begin{tabular}{|c|c|c|c|c|}
\hline A. F. G. & $-1,1$ & 1,4 & 2,5 & 2,55 \\
\hline A. C. L. K. & $-2,6$ & 1 & 3,6 & 2,91 \\
\hline A. L. O. G. & $-1,7$ & 2,4 & 4,1 & 4,31 \\
\hline B. L. T. G. & $-0,4$ & 2,6 & 3 & 1,63 \\
\hline C. C.P. & $-0,7$ & 2,8 & 3,5 & 2,25 \\
\hline C. L. S. S. O. & $-0,9$ & 1,1 & 2 & 1,14 \\
\hline C. L. B. & $-2,6$ & $-0,5$ & 2,1 & 1,06 \\
\hline C. S. C. & $-0,3$ & 3,1 & 3,4 & 1,48 \\
\hline D. G. B. M. & -2 & 1,3 & 3,3 & 1,58 \\
\hline D. A. M. & $-2,1$ & 1,8 & 3,9 & 2,80 \\
\hline D. P. S. & -2 & 2,4 & 4,4 & 1,84 \\
\hline E. M. Z. & 0,6 & 1 & 0,4 & 0,16 \\
\hline F. V. F. & $-0,6$ & 2 & 2,6 & 1,03 \\
\hline F. L. R. & $-0,8$ & 3,7 & 4,5 & 3,99 \\
\hline G. C. H. & $-4,2$ & 1,5 & 5,7 & 8,47 \\
\hline G. O. C. & 0,4 & 2,2 & 1,8 & 0,50 \\
\hline H. S. M. & 1,1 & 3,3 & 2,2 & 0,92 \\
\hline J. G. B. Z. & 0,5 & 2 & 1,5 & 0,51 \\
\hline J.D.F.F. V. & $-3,3$ & 1,6 & 4,9 & 6,99 \\
\hline M. C. G. & $-0,8$ & 1,3 & 2,1 & 1,05 \\
\hline N. C. M. & 0,3 & 2,3 & 2 & 1,98 \\
\hline P.F. & $-0,4$ & 2,6 & 3 & 1,68 \\
\hline P. S. C. T. & $-0,2$ & 1,8 & 2 & 0,86 \\
\hline S. D. O. & 0,8 & 3,8 & 3 & 0,93 \\
\hline T. D. F. & $-1,1$ & 2,1 & 3,2 & 1,24 \\
\hline T.P.I & -1 & 1,9 & 2,9 & 2,15 \\
\hline T. O. & $-0,9$ & 0,7 & 1,6 & 1,25 \\
\hline V. D. V. F. & $-0,6$ & 3,7 & 4,3 & 3,75 \\
\hline V. V. & $-1,5$ & 1,9 & 3,4 & 2,74 \\
\hline W. F. C. R. & $-1,4$ & 1,8 & 3,2 & 1,86 \\
\hline
\end{tabular}

Rel. mol TH 1 TH 2 TH 2-1 2-1 anualizada

$\begin{array}{llll}5,1 & 1,8 & -3,3\end{array}$

$8,1 \quad 4,3 \quad-3,8$

$7,1 \quad 3,1 \quad-4$

$4,7 \quad 3,5 \quad-1,2$

$9,2 \quad 3 \quad-6,2$

$12,2 \quad 3,2 \quad-9$

$5 \quad 3,5 \quad-1,5$

$\begin{array}{lll}4,5 & 3,1 & -1,4\end{array}$

$8,2 \quad 3,6 \quad-4,6$

$13,2 \quad 2,9 \quad-10,3$

$8,6 \quad 2,7 \quad-5,9$

$5,3 \quad 3,2 \quad-2,1$

$5,4 \quad 3,3 \quad-2,1$

$9,7 \quad 3,9 \quad-5,8$

$16,5 \quad 1,6 \quad-14,9$

$8 \quad 2,6 \quad-5,4$

$6,1 \quad 4 \quad-2,1$

$6,3 \quad 4,2 \quad-2,1$

$11 \quad 3,3 \quad-7,7$

$7,4 \quad 3,1 \quad-4,3$

$6,4 \quad 1,5 \quad-4,9$

$5 \quad 3,1 \quad-1,9$

$10,6 \quad 3,8 \quad-6,8$

$11,3 \quad 1,6 \quad-9,7$

$11,1 \quad 2,6 \quad-8,5$

$7,4 \quad 2,1 \quad-5,3$

$11,4 \quad 6,2 \quad-5,2$

$7,2 \quad 3,1 \quad-4,1$

$\begin{array}{lll}9,9 & 1,7 & -8,2\end{array}$

$10,6 \quad 3,4 \quad-7,2$
TH 2-1 anualizada

TV 1 TV 2 TV 2-1 TV 2-1

$\begin{array}{lcccc}-3,37 & 1,5 & 0,7 & -0,8 & -0,82 \\ -3,07 & 2,8 & 0,2 & -2,6 & -2,10 \\ -4,20 & 5,4 & 1,7 & -3,7 & -3,89 \\ -0,65 & 2,2 & 2,7 & 0,5 & 0,27 \\ -3,99 & 5,2 & 2,2 & -3 & -1,93 \\ -5,13 & 1,6 & 1,5 & -0,1 & -0,06 \\ -0,76 & 5,8 & 4 & -1,8 & -0,91 \\ -0,61 & 4 & 2,9 & -1,1 & -0,48 \\ -2,20 & 4,2 & 3,3 & -0,9 & -0,43 \\ -7,40 & 9,1 & 4,4 & -4,7 & -3,38 \\ -2,47 & 7,9 & 2,5 & -5,4 & -2,26 \\ -0,83 & 3,6 & 2,3 & -1,3 & -0,51 \\ -0,83 & 1,6 & 1,2 & -0,4 & -0,16 \\ -5,14 & 5,7 & 2 & -3,7 & -3,28 \\ -22,14 & 9,2 & 3,1 & -6,1 & -9,07 \\ -1,49 & 4,2 & 2,1 & -2,1 & -0,58 \\ -0,88 & 4,1 & 1,9 & -2,2 & -0,92 \\ -0,72 & 1,5 & 2 & 0,5 & 0,17 \\ -10,99 & 5,1 & 2,2 & -2,9 & -4,14 \\ -2,16 & 4,8 & 2,7 & -2,1 & -1,05 \\ -4,84 & 6,1 & 0,5 & -5,6 & -5,54 \\ -1,06 & 4,7 & 2,5 & -2,2 & -1,23 \\ -2,94 & 2,1 & 2,5 & 0,4 & 0,17 \\ -3,00 & 2,6 & 1,6 & -1 & -0,31 \\ -3,29 & 7,2 & 2,9 & -4,3 & -1,67 \\ -3,94 & 3,9 & 1,9 & -2 & -1,49 \\ -4,07 & 4,6 & 4,7 & 0,1 & 0,08 \\ -3,58 & 8,4 & 4,3 & -4,1 & -3,58 \\ -6,62 & 7,1 & 3,1 & -4 & -3,23 \\ -4,19 & 3 & 1,5 & -1,5 & -0,87\end{array}$

anualizada 
APÊNDICE 31 - Valores individuais das idades inicial, final; do tempo total de observação, e da severidade inicial da má oclusão medida nos modelos de gesso (relação molar*, relação dos caninos*, e sobressaliência) para os pacientes do Grupo Controle.

\begin{tabular}{|c|c|c|c|c|c|c|c|}
\hline Paciente & Gênero & $\begin{array}{l}\text { Idade } \\
\text { inicial }\end{array}$ & $\begin{array}{l}\text { Idade } \\
\text { final }\end{array}$ & $\begin{array}{l}\text { Tempo total } \\
\text { observ. }\end{array}$ & Rel. mol & Rel. can. & Sobres. \\
\hline M. L. & $M$ & $12,27 a$ & $13,29 a$ & $1,01 a$ & $1 / 2 \mathrm{Cl} \mathrm{II}$ & $1 / 2 \mathrm{Cl} \mathrm{II}$ & $5 \mathrm{~mm}$ \\
\hline F. Z.S. & $\mathrm{F}$ & $12,17 a$ & $14,91 a$ & $2,74 a$ & $1 / 2 \mathrm{Cl} \mathrm{II}$ & $1 / 2 \mathrm{Cl} \mathrm{II}$ & $5 \mathrm{~mm}$ \\
\hline F. Z. & $\mathrm{F}$ & $12,51 a$ & $16,25 a$ & $3,74 a$ & $1 / 2 \mathrm{CI} \mathrm{II}$ & $1 / 2 \mathrm{CI} \mathrm{II}$ & $4,5 \mathrm{~mm}$ \\
\hline A. & $M$ & $12,83 a$ & $19,11 a$ & $6,28 a$ & $3 / 4 \mathrm{Cl} \mathrm{II}$ & $1 / 2 \mathrm{Cl} \mathrm{II}$ & $4 \mathrm{~mm}$ \\
\hline B. A. & $F$ & $11,35 a$ & $13,08 a$ & $1,73 a$ & $1 / 2 \mathrm{Cl} \mathrm{II}$ & $1 / 2 \mathrm{Cl} \mathrm{II}$ & $7 \mathrm{~mm}$ \\
\hline C. M. Jr. & $M$ & $13,00 \mathrm{a}$ & $15,03 a$ & $2,03 a$ & $3 / 4 \mathrm{Cl} \mathrm{II}$ & $1 / 4 \mathrm{Cl} \mathrm{II}$ & $4,5 \mathrm{~mm}$ \\
\hline . A. R. C. M. & M & $13,98 a$ & $14,99 a$ & $1,01 \mathrm{a}$ & 1/4 Cl II & $1 / 4 \mathrm{Cl} \mathrm{II}$ & $4 \mathrm{~mm}$ \\
\hline A. A. C. & $M$ & $12,88 a$ & $14,90 a$ & $2,02 a$ & Cl II completa & $3 / 4 \mathrm{Cl} \mathrm{II}$ & $5 \mathrm{~mm}$ \\
\hline B. & $\mathrm{F}$ & $13,90 a$ & $15,08 a$ & $1,18 a$ & $1 / 2 \mathrm{Cl} \mathrm{II}$ & $1 / 2 \mathrm{Cl} \mathrm{II}$ & $5 \mathrm{~mm}$ \\
\hline 1. G. T. & $M$ & $12,78 a$ & $15,83 a$ & $3,05 a$ & Cl II completa & $3 / 4 \mathrm{Cl} \mathrm{II}$ & $7 \mathrm{~mm}$ \\
\hline М. Н. Т. & $\mathrm{F}$ & $12,31 a$ & $13,66 a$ & $1,35 a$ & $1 / 4 \mathrm{Cl} \mathrm{II}$ & $1 / 2 \mathrm{Cl} \mathrm{II}$ & $5,5 \mathrm{~mm}$ \\
\hline B. B. M. & $\mathrm{F}$ & $11,83 a$ & $12,85 a$ & $1,02 a$ & $1 / 2 \mathrm{CI} \mathrm{II}$ & $1 / 2 \mathrm{Cl} \mathrm{II}$ & $6 \mathrm{~mm}$ \\
\hline B. Jr. & M & $12,88 a$ & $13,82 a$ & $0,94 a$ & 1/4 Cl II & $1 / 2 \mathrm{CI} \mathrm{II}$ & $4 \mathrm{~mm}$ \\
\hline R. B. R. & $\mathrm{F}$ & $11,21 a$ & $12,32 a$ & $1,12 \mathrm{a}$ & Cl II completa & 3/4 Cl II & $9 \mathrm{~mm}$ \\
\hline R. P. F. & $M$ & $13,88 a$ & $15,89 a$ & $2,01 a$ & 1/2 Cl II & $1 / 2 \mathrm{Cl} \mathrm{II}$ & $4,5 \mathrm{~mm}$ \\
\hline ฉ. T. G. & M & $11,82 a$ & $18,40 a$ & $6,58 \mathrm{a}$ & $1 / 2 \mathrm{Cl} \mathrm{II}$ & 3/4 Cl II & $11,5 \mathrm{~mm}$ \\
\hline R. B. A. & M & $13,55 a$ & $14,10 a$ & $0,56 a$ & $1 / 2 \mathrm{Cl} \mathrm{II}$ & $1 / 2 \mathrm{Cl} \mathrm{II}$ & $5 \mathrm{~mm}$ \\
\hline R. R. D. & M & $13,16 a$ & $16,31 a$ & $3,15 a$ & 3/4 Cl II & $1 / 2 \mathrm{Cl} \mathrm{II}$ & $5 \mathrm{~mm}$ \\
\hline R. A. S. S. & $F$ & $12,45 a$ & $13,33 a$ & $0,88 a$ & $1 / 2 \mathrm{Cl} \mathrm{II}$ & CI II completa & $8,5 \mathrm{~mm}$ \\
\hline R. C. & $\mathrm{F}$ & $12,68 a$ & $13,63 a$ & $0,95 a$ & $1 / 4 \mathrm{Cl} \mathrm{II}$ & 1/2 Cl II & $6 \mathrm{~mm}$ \\
\hline Г. S. N. Jr. & M & $12,66 a$ & $15,08 a$ & $2,42 a$ & $3 / 4 \mathrm{Cl} \mathrm{II}$ & $3 / 4 \mathrm{Cl} \mathrm{II}$ & $7,5 \mathrm{~mm}$ \\
\hline I. C. S. C. & $\mathrm{F}$ & $12,66 a$ & $13,70 a$ & $1,04 a$ & $1 / 2 \mathrm{Cl} \mathrm{II}$ & 3/4 Cl II & $5,5 \mathrm{~mm}$ \\
\hline
\end{tabular}

* Considerou-se a avaliação do hemi-arco mais severo. 
APÊNDICE 32 - Valores individuais das grandezas cefalométricas SNA, Co-A

e A-Nperp para os pacientes do Grupo Controle.

\begin{tabular}{lccccccccc} 
Paciente & SNA 1 & SNA 2 & SNA 2-1 & Co-A 1 & Co-A 2 & Co-A 2-1 & \multicolumn{2}{c}{ A-Nperp A-Nperp A-Nperp } \\
B. M. L. & 87,2 & 88,3 & 1,10 & 88,2 & 89,6 & 1,4 & $-1,2$ & $-0,6$ & $\mathbf{2}$ \\
C. F. Z. S. & 88 & 87,1 & $-0,90$ & 84,8 & 84,6 & $-0,2$ & $-0,6$ & $-0,3$ & 0,3 \\
E. F. Z. & 76,4 & 76,8 & 0,40 & 85,4 & 90,2 & 4,8 & -1 & 0,1 & 1,1 \\
E. A. & 85,5 & 84,1 & $-1,40$ & 95,8 & 97,3 & 1,5 & 6 & 6,5 & 0,5 \\
F. B. A. & 82,3 & 82,6 & 0,30 & 87,2 & 90,8 & 3,6 & 4,5 & 5,5 & 1 \\
J. C. M. Jr. & 82,1 & 83,4 & 1,30 & 91,8 & 94,7 & 2,9 & 2,1 & 3,5 & 1,4 \\
J. A. R. C. M. & 82,5 & 81,5 & $-1,00$ & 86 & 88,7 & 2,7 & 1,4 & 1,1 & $-0,3$ \\
J. A. A. C. & 80,8 & 81,9 & 1,10 & 94 & 94,3 & 0,3 & 0,3 & 1 & 0,7 \\
L. B. & 80,7 & 81,2 & 0,50 & 89,5 & 90,8 & 1,3 & 0,5 & 1,8 & 1,3 \\
M. G. T. & 81,5 & 81,7 & 0,20 & 91,1 & 90,4 & $-0,7$ & 2,8 & 1,3 & $-1,5$ \\
M. H. T. & 85,5 & 84,7 & $-0,80$ & 82 & 85,9 & 3,9 & 0,7 & 0 & $-0,7$ \\
P. B. B. M. & 83 & 84,6 & 1,60 & 91 & 93,1 & 2,1 & -1 & 0,2 & 1,2 \\
P. B. Jr. & 77,4 & 76,7 & $-0,70$ & 85,5 & 84,9 & $-0,6$ & 1,5 & 1,3 & $-0,2$ \\
R. B. R. & 76,8 & 76 & $-0,80$ & 82 & 87,5 & 5,5 & $-0,4$ & $-0,3$ & 0,1 \\
R. P. F. & 79,3 & 82,9 & 3,60 & 83,7 & 90,8 & 7,1 & $-2,2$ & 1,2 & 3,4 \\
R. T. G. & 77,3 & 87,9 & 10,60 & 83,5 & 92,1 & 8,6 & $-3,1$ & 9,6 & 12,7 \\
R. B. A. & 80,4 & 80 & $-0,40$ & 92,6 & 91 & $-1,6$ & 2 & 1,7 & $-0,3$ \\
R. R. D. & 86,4 & 89,9 & 3,50 & 80,7 & 90,2 & 9,5 & 0,8 & 6,4 & 5,6 \\
R. A. S. S. & 80 & 79,9 & $-0,10$ & 82,5 & 82,2 & $-0,3$ & $-0,8$ & 0,4 & 1,2 \\
S. R. C. & 81,1 & 80,6 & $-0,50$ & 83,9 & 87,8 & 3,9 & 5,3 & 9,1 & 3,8 \\
T. S. N. Jr. & 81,7 & 81,7 & 0,00 & 90,7 & 90 & $-0,7$ & 1,9 & 0,7 & $-1,2$ \\
T. C. S. C. & 80,5 & 82,6 & 2,10 & 82,4 & 85,2 & 2,8 & $-4,3$ & $-1,4$ & 2,9
\end{tabular}


APÊNDICE 33 - Valores individuais das grandezas cefalométricas SNB, Co-Gn e Go-Gn para os pacientes do Grupo Controle.

Paciente SNB 1 SNB 2 SNB 2-1 Co-Gn 1 Co-Gn 2 Co-Gn 2-1 Go-Gn 1 Go-Gn 2 Go-Gn 2-1

$\begin{array}{lrcccccccc}\text { B. M. L. } & 88,1 & 87,5 & -0,6 & 110,3 & 110,4 & 0,1 & 74,2 & 72,9 & -1,3 \\ \text { C. F. Z. S. } & 82,1 & 83,1 & 1 & 101,7 & 107,6 & 5,9 & 69,6 & 70,6 & 1 \\ \text { E. F. Z. } & 72,4 & 72,1 & -0,3 & 102,3 & 109,1 & 6,8 & 68,4 & 73,1 & 4,7 \\ \text { E. A. } & 79,7 & 78,5 & -1,2 & 115,3 & 118,1 & 2,8 & 75 & 78,6 & 3,6 \\ \text { F. B. A. } & 76,1 & 76,9 & 0,8 & 108,1 & 114,1 & 6 & 69,4 & 76,9 & 7,5 \\ \text { J. C. M. Jr. } & 80 & 79,7 & -0,3 & 115,4 & 118,1 & 2,7 & 75,4 & 79 & 3,6 \\ \text { J. A. R. C. M. } & 80,1 & 79,3 & -0,8 & 107,4 & 111,3 & 3,9 & 70,5 & 73,6 & 3,1 \\ \text { J. A. A. C. } & 75,9 & 77,2 & 1,3 & 114,4 & 116,3 & 1,9 & 74,1 & 77,8 & 3,7 \\ \text { L. B. } & 75,9 & 76,6 & 0,7 & 103,4 & 107,7 & 4,3 & 72,1 & 73,8 & 1,7 \\ \text { M. G. T. } & 75,8 & 75,6 & -0,2 & 110,4 & 111,5 & 1,1 & 71 & 72,9 & 1,9 \\ \text { M. H. T. } & 79,5 & 78,9 & -0,6 & 99,1 & 104,7 & 5,6 & 67,3 & 67,8 & 0,5 \\ \text { P. B. B. M. } & 79,6 & 80,5 & 0,9 & 110,1 & 113,3 & 3,2 & 74,1 & 76,2 & 2,1 \\ \text { P. B. Jr. } & 74,3 & 74 & -0,3 & 108,4 & 110,5 & 2,1 & 69,9 & 72 & 2,1 \\ \text { R. B. R. } & 70,2 & 69,7 & -0,5 & 98,4 & 103,9 & 5,5 & 61,7 & 64,7 & 3 \\ \text { R. P. F. } & 77,6 & 78,1 & 0,5 & 107,5 & 113,9 & 6,4 & 67,5 & 71,3 & 3,8 \\ \text { R. T. G. } & 74,8 & 83,2 & 8,4 & 104 & 121,3 & 17,3 & 68,1 & 73,6 & 5,5 \\ \text { R. B. A. } & 76,1 & 77 & 0,9 & 110,5 & 113,3 & 2,8 & 71,6 & 73,1 & 1,5 \\ \text { R. R. D. } & 80,8 & 85,1 & 4,3 & 99,9 & 114,4 & 14,5 & 68 & 76,1 & 8,1 \\ \text { R. A. S. S. } & 76,2 & 76,3 & 0,1 & 99,8 & 98,3 & -1,5 & 65,4 & 65,1 & -0,3 \\ \text { S. R. C. } & 76,8 & 76,2 & -0,6 & 104,7 & 109,3 & 4,6 & 70,1 & 71,4 & 1,3 \\ \text { T. S. N. Jr. } & 76,5 & 76,9 & 0,4 & 117,7 & 116,5 & -1,2 & 77 & 78,7 & 1,7 \\ \text { T. C. S. C. } & 77,4 & 77,2 & -0,2 & 100,9 & 103,9 & 3 & 64,8 & 67,3 & 2,5\end{array}$


APÊNDICE 34 - Valores individuais das grandezas cefalométricas Co-Go,

P-Nperp e ANB para os pacientes do Grupo Controle.

\section{Paciente Co-Go 1 Co-Go 2 Co-Go 2-1 P-Nperp P-Nperp P-Nperp ANB 1 ANB 2 ANB 2-1}

$\begin{array}{lccccccccc}\text { B. M. L. } & 50 & 52,7 & 2,7 & 1,8 & 1 & -0,8 & -0,9 & 0,8 & 1,7 \\ \text { C. F. Z. S. } & 48,9 & 56,8 & 7,9 & -9,5 & -6,2 & 3,3 & 5,8 & 4 & -1,8 \\ \text { E. F. .. } & 46,5 & 49,5 & 3 & -7,3 & -6,7 & 0,6 & 4 & 4,7 & 0,7 \\ \text { E. A. } & 55,3 & 56,7 & 1,4 & 1,2 & 2,3 & 1,1 & 5,8 & 5,7 & -0,1 \\ \text { F. B. A. } & 51,8 & 50,2 & -1,6 & -1,5 & 0,6 & 2,1 & 6,2 & 5,8 & -0,4 \\ \text { J. C. M. Jr. } & 52,8 & 55,9 & 3,1 & 1 & 1,1 & 0,1 & 2,1 & 3,7 & 1,6 \\ \text { J. A. R. C. M. } & 52,6 & 54,6 & 2 & 0,1 & -0,1 & -0,2 & 2,3 & 2,2 & -0,1 \\ \text { J. A. A. C. } & 55,4 & 54,1 & -1,3 & -5,1 & -2 & 3,1 & 4,9 & 4,7 & -0,2 \\ \text { L. B. } & 43,6 & 47 & 3,4 & -7 & -5,9 & 1,1 & 4,8 & 4,6 & -0,2 \\ \text { M. G. T. } & 53,4 & 53,4 & 0 & -3,4 & -6,2 & -2,8 & 5,7 & 6,1 & 0,4 \\ \text { M. H. T. } & 47,8 & 53,4 & 5,6 & -9,9 & -10,7 & -0,8 & 6 & 5,8 & -0,2 \\ \text { P. B. B. M. } & 49,8 & 52,1 & 2,3 & -6,3 & -4,9 & 1,4 & 3,5 & 4,1 & 0,6 \\ \text { P. B. J. } & 50,5 & 53,8 & 3,3 & -1,2 & -0,5 & 0,7 & 3,1 & 2,7 & -0,4 \\ \text { R. B. R. } & 47,4 & 49,5 & 2,1 & -9 & -8,8 & 0,2 & 6,6 & 6,3 & -0,3 \\ \text { R.P. F. } & 55,5 & 60 & 4,5 & -3,2 & -0,9 & 2,3 & 1,8 & 4,8 & 3 \\ \text { R. T. G. } & 45,9 & 58,9 & 13 & -8,1 & 10,8 & 18,9 & 2,4 & 4,7 & 2,3 \\ \text { R. B. A. } & 50,4 & 53,5 & 3,1 & -3,5 & -1,5 & 2 & 4,3 & 3 & -1,3 \\ \text { R. R. D. } & 44,4 & 54 & 9,6 & -3,9 & 7,4 & 11,3 & 5,7 & 4,8 & -0,9 \\ \text { R. A. S. S. } & 48,5 & 47 & -1,5 & -6,5 & -3,7 & 2,8 & 3,9 & 3,7 & -0,2 \\ \text { S. R. C. } & 52,4 & 54,5 & 2,1 & 3,5 & 9,6 & 6,1 & 4,3 & 4,4 & 0,1 \\ \text { T. S. N. Jr. } & 60,4 & 56,8 & -3,6 & -2,2 & -3 & -0,8 & 5,1 & 4,8 & -0,3 \\ \text { T. C. S. C. } & 48,1 & 50,3 & 2,2 & -10,7 & -9,8 & 0,9 & 3,1 & 5,4 & 2,3\end{array}$


APÊNDICE 35 - Valores individuais das grandezas cefalométricas NAP, Co-A/Co-Gn e Wits para os pacientes do Grupo Controle.

Paciente NAP 1 NAP 2 NAP 2-1 Co-A/Co- Co-A/Co- Co-A/Co- Wits 1 Wits 2 Wits 2-1

$\begin{array}{lccccccccc}\text { B. M. L. } & -5,5 & -3 & 2,5 & 79,9 & 81,1 & 1,2 & -5,1 & -2,7 & 2,4 \\ \text { C. F. Z. S. } & 10,9 & 6,8 & -4,1 & 83,4 & 78,6 & -4,8 & -0,4 & 0,5 & 0,9 \\ \text { E. F. Z. } & 8,1 & 8,6 & 0,5 & 83,5 & 82,7 & -0,8 & 1,6 & 0,8 & -0,8 \\ \text { E. A. } & 11,8 & 11,1 & -0,7 & 83,1 & 82,4 & -0,7 & -0,7 & 0,7 & 1,4 \\ \text { F. B. A. } & 11,9 & 11,1 & -0,8 & 80,7 & 79,6 & -1,1 & 0,1 & 3 & 2,9 \\ \text { J. C. M. Jr. } & 3,4 & 6,2 & 2,8 & 79,6 & 80,2 & 0,6 & -4,7 & 0,8 & 5,5 \\ \text { J. A. R. C. M. } & 3,3 & 2,7 & -0,6 & 80 & 79,7 & -0,3 & -2,3 & -1,8 & 0,5 \\ \text { J. A. A. C. } & 7,2 & 4,7 & -2,5 & 82,1 & 81,1 & -1 & 3,5 & 3,9 & 0,4 \\ \text { L. B. } & 10,8 & 11,4 & 0,6 & 86,6 & 84,3 & -2,3 & 2,9 & 2,9 & 0 \\ \text { M. G. T. } & 10,1 & 10 & -0,1 & 82,5 & 81,1 & -1,4 & 5,4 & 4,3 & -1,1 \\ \text { M. H. T. } & 15,2 & 14,3 & -0,9 & 82,7 & 82 & -0,7 & -3,2 & 0,6 & 3,8 \\ \text { P. B. B. M. } & 5,6 & 6,5 & 0,9 & 82,7 & 82,2 & -0,5 & -1,7 & -1,3 & 0,4 \\ \text { P. B. Jr. } & 4,8 & 3,4 & -1,4 & 78,8 & 76,9 & -1,9 & 0,6 & 4,1 & 3,5 \\ \text { R. B. R. } & 11,4 & 10,5 & -0,9 & 83,4 & 84,2 & 0,8 & -0,4 & 0 & 0,4 \\ \text { R. P. F. } & -1,3 & 3,7 & 5 & 77,9 & 79,7 & 1,8 & -0,4 & 3,6 & 4 \\ \text { R. T. G. } & 3,3 & 8,8 & 5,5 & 80,3 & 75,9 & -4,4 & -1,7 & -3,5 & -1,8 \\ \text { R. B. A. } & 8,8 & 5,5 & -3,3 & 83,8 & 80,3 & -3,5 & -1,2 & -0,6 & 0,6 \\ \text { R. R. D. } & 7,5 & 5,7 & -1,8 & 80,8 & 78,9 & -1,9 & 1,4 & 0,8 & -0,6 \\ \text { R. A. S. S. } & 7,2 & 6,4 & -0,8 & 82,6 & 83,6 & 1 & -2,2 & 1,4 & 3,6 \\ \text { S. R. C. } & 7,7 & 8,5 & 0,8 & 80,1 & 80,3 & 0,2 & 2,6 & 2,2 & -0,4 \\ \text { T. S. N. Jr. } & 6,5 & 4,8 & -1,7 & 77 & 77,3 & 0,3 & 0,9 & 0 & -0,9 \\ \text { T. C. S. C. } & 3,3 & 9 & 5,7 & 81,6 & 82 & 0,4 & 1,4 & 2,7 & 1,3\end{array}$


APÊNDICE 36 - Valores individuais das grandezas cefalométricas FMA, SN.GoGn e SN.PP para os pacientes do Grupo Controle.

Paciente FMA 1 FMA 2 FMA 2-1 SN.GoGn SN.GoGn SN.GoGn SN.PP 1 SN.PP 2 SN.PP 2-1

B. M. L.

$$
19,8
$$

C. F. Z.S

$$
25,6
$$

25,6
26,4

E. F. Z.

22,2

F. B. A.

25,5

J. C. M. Jr. 23,1

J. A. R. C. M. 21,1

J. A. A. C. 23

L. B.

$25,2 \quad 25,7$

$18,4 \quad-1,4$

1

\section{2}

\section{2-1}

M. G. T.

M. H. T.

$24,4 \quad 26,4$

$-3$

18,4

16,7

22,7

26,1

$-0,3$

24,2

36,3

30

35,4

31,2

27,8

30,3

32,6

32,5

P. B. B. M.

$27,5 \quad 26,7$

$25,7 \quad 24,7$

$24,9 \quad 23,7$

P. B. Jr.

$27,9 \quad 26,5$

R. P. F.

$19,1 \quad 18,2$

R. T. G.

$28,2 \quad 22,5$

R. B. A.

$24,4 \quad 24,1$

$26,9 \quad 20,6$

R. R. D.

$24,4 \quad 22$

R. A. S. S.

$17,7 \quad 16,2$

S. R. C.

T. S. N. Jr.

$23 \quad 23,1$

$25,7 \quad 26,6$

$\begin{array}{cr}2 & 32,5 \\ -0,8 & 30,5\end{array}$

$\begin{array}{ll}-1 & 28,9\end{array}$

$-1,2 \quad 37,1$

$-1,4 \quad 38,4$

$-0,9 \quad 25,3$

$-5,7 \quad 36,1$

$-0,3 \quad 33,6$

$\begin{array}{ll}-6,3 & 29,5\end{array}$

$-2,4 \quad 30,7$

$-1,5$

0,1

29,7

31,3

37

29,8

37,8

29,2

28,2

29

34,2

33,3

30,2

27,9

36,6

38

24,4

33

32,9

25,1

29,5

32,5

30,4

$-1,7$

$-1,5$

$-0,9$

6,3

0,7

7,9

9,1

2,4

$-2$

0,4

$-1,3$

1,6

0,8

$-0,3$

$-1$

$-0,5$

$-0,4$

$-0,9$

$-3,1$

$-0,7$

$-4,4$

$-1,2$

2,8

$-0,9$

30,3

1,9

5,1

6,7

12,1

0,8

$$
7,9
$$

1,7

9,9

9,1

5,4

8,1

11,6

$13,1 \quad 11,3$

$11,5 \quad 11,2$

$11,5 \quad 11,1$

$10 \quad 12$

$6,4 \quad 7,3$

$\begin{array}{cc}6,4 & 7,3 \\ 10 & 12,3\end{array}$

$13,9 \quad 14$

$4,1 \quad 5,1$

$8,7 \quad 4,5$

$8,4 \quad 8,7$

$6,5 \quad 3,5$

10,8

11,8

8
5

10,2

4,8

6

5,3

1,6

2

0

0,3

1,4

$-0,5$

$-1,8$

$-0,3$

$-0,4$

2

0,9

2,3

0,1

1

$-4,2$

0,3

$-3$

1

2,2

1 
APÊNDICE 37 - Valores individuais das grandezas cefalométricas AFAI, SN.POF e S-Go para os pacientes do Grupo Controle.

Paciente AFAl 1 AFAl 2 AFAl 2-1 SN.POF SN.POF SN.POF S-Go 1 S-Go 2 S-Go 2-1

$\begin{array}{lccccccccc}\text { B. M. L. } & 56,5 & 54,2 & -2,3 & 9,6 & 10,2 & 0,6 & 70,4 & 70,6 & 0,2 \\ \text { C. F. Z. S. } & 61,1 & 60,7 & -0,4 & 17,8 & 12,9 & -4,9 & 75,8 & 80,2 & 4,4 \\ \text { E. F. Z. } & 61,5 & 63 & 1,5 & 23,2 & 24,3 & 1,1 & 62,2 & 65,1 & 2,9 \\ \text { E. A. } & 63,5 & 67,5 & 4 & 21 & 20 & -1 & 74,6 & 77,4 & 2,8 \\ \text { F. B. A. } & 66,1 & 70,7 & 4,6 & 23,3 & 17,5 & -5,8 & 66,6 & 66,6 & 0 \\ \text { J. C. M. Jr. } & 62,8 & 65,7 & 2,9 & 21,6 & 15,7 & -5,9 & 72,9 & 77,7 & 4,8 \\ \text { J. A. R. . M. } & 54,5 & 57,4 & 2,9 & 18,8 & 19,1 & 0,3 & 70,6 & 74,1 & 3,5 \\ \text { J. A. A. C. } & 60,2 & 62,2 & 2 & 17,6 & 14,5 & -3,1 & 73,4 & 76,8 & 3,4 \\ \text { L. B. } & 56,7 & 59,6 & 2,9 & 18,5 & 16,5 & -2 & 64,1 & 65,6 & 1,5 \\ \text { M. G. T. } & 66,4 & 69 & 2,6 & 15,5 & 16,5 & 1 & 74,6 & 73,9 & -0,7 \\ \text { M. H. T. } & 58,3 & 58,1 & -0,2 & 26,4 & 20,5 & -5,9 & 70,2 & 72,3 & 2,1 \\ \text { P. B. B. M. } & 62,4 & 62,6 & 0,2 & 19,1 & 18,7 & -0,4 & 72,4 & 73,6 & 1,2 \\ \text { P. B. Jr. } & 60,1 & 60 & -0,1 & 19,2 & 14,1 & -5,1 & 64 & 67,1 & 3,1 \\ \text { R. B. R. } & 57,2 & 60,9 & 3,7 & 31,8 & 31,5 & -0,3 & 62,4 & 66,2 & 3,8 \\ \text { R. P. F. } & 61,6 & 66,5 & 4,9 & 15,2 & 13,5 & -1,7 & 75,2 & 81 & 5,8 \\ \text { R. T. G. } & 61,2 & 71 & 9,8 & 22,8 & 17,1 & -5,7 & 67,1 & 77,7 & 10,6 \\ \text { R. B. A. } & 64,9 & 65,5 & 0,6 & 22,2 & 19,5 & -2,7 & 69,7 & 72,5 & 2,8 \\ \text { R. R. D. } & 53,6 & 60,2 & 6,6 & 17,1 & 11,2 & -5,9 & 59,6 & 72,2 & 12,6 \\ \text { R. A. S. S. } & 56,1 & 54,1 & -2 & 24 & 17,7 & -6,3 & 66,6 & 65,5 & -1,1 \\ \text { S. R. C. } & 62,9 & 62,9 & 0 & 15,9 & 17,9 & 2 & 73 & 70,4 & -2,6 \\ \text { T. S. N. Jr. } & 68,6 & 67,6 & -1 & 20,3 & 21,1 & 0,8 & 75,9 & 76 & 0,1 \\ \text { T. C. S. C. } & 59,3 & 61,5 & 2,2 & 14 & 17,1 & 3,1 & 71,1 & 70,5 & -0,6\end{array}$


APÊNDICE 38 - Valores individuais das grandezas cefalométricas 1.PP, 1.NA, 1-NA e 1-ENAperp para os pacientes do Grupo Controle.

\begin{tabular}{|c|c|c|c|c|c|c|c|c|c|c|c|c|}
\hline Paciente & 1.PP 1 & 1.PP 2 & $\begin{array}{c}1 . P P \\
2-1\end{array}$ & 1.NA 1 & 1.NA 2 & $\begin{array}{c}\text { 1.NA } \\
2-1\end{array}$ & 1-NA 1 & 1-NA 2 & $\begin{array}{c}1-N A \\
2-1\end{array}$ & $\begin{array}{c}1- \\
\text { ENAperp } \\
1\end{array}$ & $\begin{array}{c}1- \\
\text { ENAperp } \\
2\end{array}$ & $\begin{array}{c}1- \\
\text { ENAperp } \\
2-1\end{array}$ \\
\hline B. M. L. & 113,3 & 115,5 & 2,2 & 27 & 26,4 & $-0,6$ & 4,4 & 4,5 & 0,1 & $-2,8$ & $-1,5$ & 1,3 \\
\hline C.F.Z.S. & 115,7 & 114,8 & $-0,9$ & 21,4 & 19,9 & $-1,5$ & 1,8 & 4,4 & 2,6 & $-3,1$ & 1,6 & 4,7 \\
\hline E. F. Z. & 95,7 & 96,1 & 0,4 & 11,3 & 9,4 & $-1,9$ & 0,7 & 0,2 & $-0,5$ & $-12,6$ & $-7,7$ & 4,9 \\
\hline E. A. & 106,7 & 103,8 & $-2,9$ & 12 & 10,6 & $-1,4$ & 0,8 & 0,4 & $-0,4$ & $-3,3$ & -4 & $-0,7$ \\
\hline F. B. A. & 111,7 & 114,8 & 3,1 & 24,2 & 26,8 & 2,6 & 4,9 & 5,6 & 0,7 & $-3,9$ & $-3,5$ & 0,4 \\
\hline J. C. M. Jr. & 116,2 & 116,8 & 0,6 & 27,4 & 25,3 & $-2,1$ & 4,8 & 4,4 & $-0,4$ & $-3,2$ & $-1,9$ & 1,3 \\
\hline J. A. R. C. M. & 120,9 & 117,4 & $-3,5$ & 26,4 & 24,4 & -2 & 2,4 & 2,1 & $-0,3$ & $-1,7$ & $-3,6$ & $-1,9$ \\
\hline J. A. A. C. & 103,4 & 99,9 & $-3,5$ & 9,5 & 6,6 & $-2,9$ & $-0,2$ & $-1,5$ & $-1,3$ & $-3,9$ & $-5,7$ & $-1,8$ \\
\hline L. B. & 112,1 & 113,4 & 1,3 & 19,9 & 21 & 1,1 & 2,1 & 1,5 & $-0,6$ & $-1,6$ & $-1,7$ & $-0,1$ \\
\hline M. G. T. & 115,5 & 115 & $-0,5$ & 22,4 & 22,2 & $-0,2$ & 2,7 & 3,3 & 0,6 & $-2,7$ & -3 & $-0,3$ \\
\hline M. H. T. & 121,7 & 119,9 & $-1,8$ & 26,2 & 23,2 & -3 & 3,4 & 3,9 & 0,5 & $-0,1$ & 2,7 & 2,8 \\
\hline P. B. B. M. & 112,4 & 111,8 & $-0,6$ & 22,9 & 20 & $-2,9$ & 4,2 & 4,1 & $-0,1$ & $-4,7$ & $-4,3$ & 0,4 \\
\hline P. B. Jr. & 110,7 & 114,1 & 3,4 & 23,3 & 25,1 & 1,8 & 3,7 & 4,4 & 0,7 & $-3,8$ & $-2,7$ & 1,1 \\
\hline R. B. R. & 116,1 & 115 & $-1,1$ & 25,3 & 25,1 & $-0,2$ & 3,3 & 4,7 & 1,4 & $-4,1$ & $-4,4$ & $-0,3$ \\
\hline R.P.F. & 110 & 107,9 & $-2,1$ & 26,6 & 19,9 & $-6,7$ & 5,8 & 2,5 & $-3,3$ & $-4,1$ & $-4,2$ & $-0,1$ \\
\hline R. T. G. & 115,4 & 119,2 & 3,8 & 29,5 & 26,8 & $-2,7$ & 5,8 & 5,2 & $-0,6$ & $-4,7$ & $-2,5$ & 2,2 \\
\hline R. B. A. & 109,9 & 112,7 & 2,8 & 21,2 & 23,9 & 2,7 & 3 & 5,1 & 2,1 & $-5,3$ & $-3,1$ & 2,2 \\
\hline R. R. D. & 116,2 & 116,6 & 0,4 & 23,2 & 23,2 & 0 & 2,9 & 3,5 & 0,6 & 0,3 & $-0,2$ & $-0,5$ \\
\hline R. A. S. S. & 123,1 & 123,8 & 0,7 & 32,3 & 32 & $-0,3$ & 4,7 & 5,5 & 0,8 & $-0,9$ & $-0,5$ & 0,4 \\
\hline S. R. C. & 110,7 & 114 & 3,3 & 21,6 & 23,3 & 1,7 & 3,3 & 3,1 & $-0,2$ & $-3,8$ & $-2,3$ & 1,5 \\
\hline T. S. N. Jr. & 113,7 & 113,6 & $-0,1$ & 27 & 25,9 & $-1,1$ & 5,1 & 5,4 & 0,3 & $-5,8$ & $-1,3$ & 4,5 \\
\hline Г. C. S. C. & 117,4 & 115,8 & $-1,6$ & 32,1 & 27,9 & $-4,2$ & 6,6 & 3,6 & -3 & $-2,5$ & $-3,8$ & $-1,3$ \\
\hline
\end{tabular}


APÊNDICE 39 - Valores individuais das grandezas cefalométricas 1-PP, 6-PP e 6-ENAperp para os pacientes do Grupo Controle.

Paciente 1-PP 1 1-PP 2 1-PP 2-1 6-PP 1 6-PP 2 6-PP 2-1

B. M. L. $\quad 23,6$

C. F. Z.S. 26,8

E. F. Z. 27,1

E. A.

26,8

F. B. A.

29,4

J. C. M. Jr. $\quad 28,9$

J. A. R. C. M. 22,5

J. A. A. C. 28,1

L. B.

23,8

M. G. T.

26,8

M. H. T.

P. B. B. M.

26

P. B. Jr.

27,6

25,4

R. B. R.

25,8

27,4

R. P. F.

28,9

R. T. G.

30

R. B. A.

$$
30
$$

R. R. D.

22,5

R. A. S. S. 22,8

S. R. C.

26,9

T. S. N. Jr. $\quad 32,2$

24,2

26,4

28,8

28,9

31,4

30,2

24,1

28,1

24,5

28,8

26,2

28,1

24,6

26,3

27,9

28,1

29,7

25

22,4

26,9

32,8

$25,5 \quad 26,2$

$0,6 \quad 19,8$

$-0,4$

1,7

2,1

2

1,3

1,6

0

0,7

2
0,2

0,5

$-0,8$

0,5

0,5

$-0,8$

$-0,3$

2,5

$-0,4$

$0 \quad 22,4$

$0,6 \quad 25,6$

0,7

20
6-

ENAperp ENAperp ENAperp

$\begin{array}{lll}1 & 2 & \mathbf{2}-1\end{array}$

$\begin{array}{lll}-30,1 & -28,9 & 1,2\end{array}$

$\begin{array}{lll}-31 & -27,5 & 3,5\end{array}$

$\begin{array}{lll}-35,3 & -34 & 1,3\end{array}$

$\begin{array}{lll}-30,2 & -29,8 & 0,4\end{array}$

$\begin{array}{lll}-35 & -33,7 & 1,3\end{array}$

$\begin{array}{lll}-34,7 & -33,3 & 1,4\end{array}$

$-30,6 \quad-32,6 \quad-2$

$\begin{array}{lll}-32 & -32,4 & -0,4\end{array}$

$-31,6 \quad-33,1 \quad-1,5$

$-32,5 \quad-34,2 \quad-1,7$

$\begin{array}{lll}-30,7 & -27,6 \quad 3,1\end{array}$

$\begin{array}{lll}-35,6 & -34,8 & 0,8\end{array}$

$\begin{array}{lll}-30,3 & -29,6 & 0,7\end{array}$

$-33,6 \quad-35,8 \quad-2,2$

$\begin{array}{lll}-32,9 & -31,5 & 1,4\end{array}$

$\begin{array}{lll}-33,9 & -32,6 & 1,3\end{array}$

$\begin{array}{lll}-35,9 & -33,5 & 2,4\end{array}$

$-28,3 \quad-29,3 \quad-1$

$\begin{array}{lll}-30,5 & -30,1 & 0,4\end{array}$

$\begin{array}{lll}-32 & -30,8 & 1,2\end{array}$

$\begin{array}{lll}-37 & -32,9 & 4,1\end{array}$

$\begin{array}{lll}-32,8 & -33,8 & -1\end{array}$ 
APÊNDICE 40 - Valores individuais das grandezas cefalométricas IMPA, 1.NB e 1-NB para os pacientes do Grupo Controle.

Paciente IMPA 1 IMPA 2 IMPA 2-1 1 1.NB 1 1.NB 2 1.NB 2-1 1 1-NB 1 1-NB 2 1-NB 2-1

$\begin{array}{llllllllll}\text { B. M. L. } & 92,2 & 90,1 & -2,1 & 21,3 & 16,9 & -4,4 & 0,9 & 0,7 & -0,2\end{array}$

$\begin{array}{lrllllllll}\text { C. F. Z. S. } & 101,9 & 107,8 & 5,9 & 31,1 & 36 & 4,9 & 4,9 & 6,1 & 1,2\end{array}$

$\begin{array}{llllllllll}\text { E. F. Z. } & 92,7 & 90,3 & -2,4 & 24,1 & 21,8 & -2,3 & 2,7 & 3,5 & 0,8\end{array}$

$\begin{array}{llllllllll}\text { E. A. } & 97,5 & 94,7 & -2,8 & 29,7 & 26,2 & -3,5 & 5,3 & 4,9 & -0,4\end{array}$

$\begin{array}{llllllllll}\text { F. B. A. } & 96,5 & 91 & -5,5 & 30,5 & 28,6 & -1,9 & 7,2 & 6,2 & -1\end{array}$

$\begin{array}{lllllllll}\text { J. C. M. Jr. } \quad 97,7 & 96,1 & -1,6 & 30,7 & 27,8 & -2,9 & 5,3 & 5,5 & 0,2\end{array}$

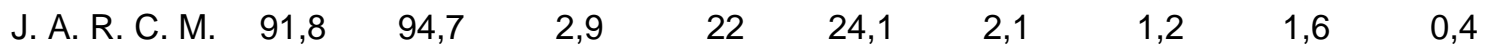

$\begin{array}{llllllllll}\text { J. A. A. C. } & 89,8 & 87 & -2,8 & 18,2 & 15,6 & -2,6 & 2 & 0,6 & -1,4\end{array}$

$\begin{array}{llllllllll}\text { L. B. } & 95,8 & 97,3 & 1,5 & 26,7 & 30,2 & 3,5 & 4 & 5 & 1\end{array}$

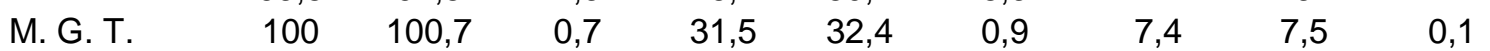

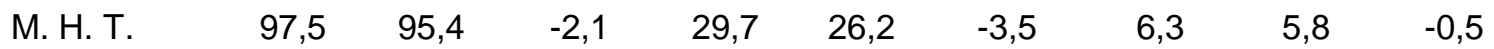

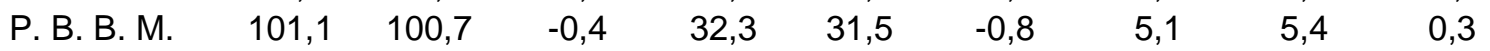

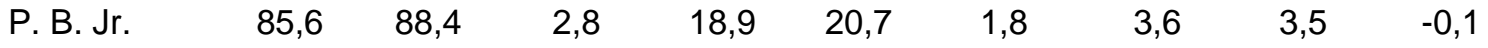

$\begin{array}{llllllllll}\text { R. B. R. } & 99,1 & 100,5 & 1,4 & 30 & 30,4 & 0,4 & 4,2 & 4,6 & 0,4\end{array}$

$\begin{array}{llllllllll}\text { R.P. F. } & 97 & 97,3 & 0,3 & 21,9 & 22 & 0,1 & 2,5 & 2,7 & 0,2\end{array}$

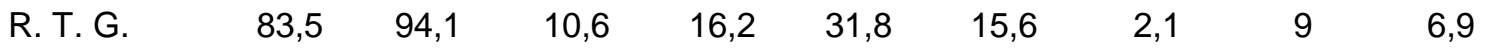

$\begin{array}{llllllllll}\text { R. B. A. } & 95,8 & 98,3 & 2,5 & 27,8 & 31 & 3,2 & 4,3 & 4,1 & -0,2\end{array}$

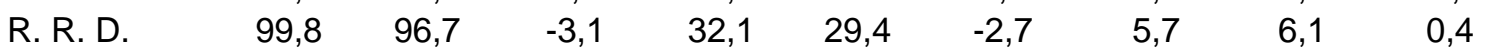

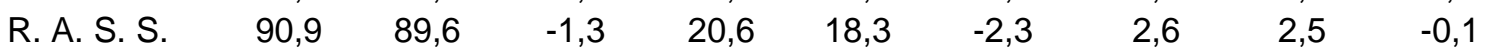

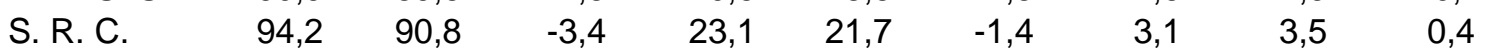

$\begin{array}{lllllllll}\text { T. S. N. Jr. } \quad 94,2 & 96,1 & 1,9 & 23,8 & 25,1 & 1,3 & 4 & 4,4 & 0,4\end{array}$

$\begin{array}{lllllllll}\text { T. C. S. C. } \quad 94,4 & 93,2 & -1,2 & 22,3 & 23 & 0,7 & 3,1 & 3,3 & 0,2\end{array}$ 
APÊNDICE 41 - Valores individuais das grandezas cefalométricas 1-Pogperp, 1-GoMe, 6-Pogperp para os pacientes do Grupo Controle.

$\begin{array}{lccccccccc}\text { Paciente } & \begin{array}{c}\mathbf{1 -} \\ \text { Pogperp }\end{array} & \begin{array}{c}\mathbf{1 -} \\ \text { Pogperp }\end{array} & \begin{array}{c}\mathbf{1 -} \\ \text { Pogperp }\end{array} & \begin{array}{c}\mathbf{1 -} \\ \text { GoMe }\end{array} & \begin{array}{c}\mathbf{1 -} \\ \text { GoMe }\end{array} & \begin{array}{c}\mathbf{1 -} \\ \text { GoMe }\end{array} & \begin{array}{c}\mathbf{6 -} \\ \text { Pogperp }\end{array} & \begin{array}{c}\text { 6- } \\ \text { Pogperp Pogperp }\end{array} \\ \text { B. M. L. } & \mathbf{1} & \mathbf{2} & \mathbf{2 - 1} & \mathbf{1} & \mathbf{2} & \mathbf{2 - 1} & \mathbf{1} & \mathbf{2} & \mathbf{2}-\mathbf{-} \\ \text { C. F. Z. S. } & -9,9 & -10,7 & -0,8 & 33,5 & 34,7 & 1,2 & -31,7 & -33,4 & -1,7 \\ \text { E. F. Z. } & -6 & -5 & 1 & 38,4 & 37,1 & -1,3 & -28,8 & -27,9 & 0,9 \\ \text { E. A. } & -8,1 & -8,5 & -0,4 & 35,4 & 37,7 & 2,3 & -28,3 & -29,7 & -1,4 \\ \text { F. B. A. } & -7,5 & -7,8 & -0,3 & 41,3 & 42,3 & 1 & -28,9 & -29,4 & -0,5 \\ \text { J. C. M. Jr. } & -7,3 & -11,3 & -4 & 41,5 & 44,8 & 3,3 & -29,4 & -31 & -1,6 \\ \text { J. A. R. C. M. } & -6,5 & -7,1 & -0,6 & 35,9 & 39,5 & 3,6 & -33,6 & -31,5 & 2,1 \\ \text { J. A. A. C. } & -11 & -9,5 & -0,2 & 34,9 & 35,6 & 0,7 & -30,6 & -31,6 & -1 \\ \text { L. B. } & -6,6 & -14,2 & -3,2 & 38,6 & 38,3 & -0,3 & -33,6 & -33,3 & 0,3 \\ \text { M. G. T. } & -6,1 & -5,2 & 0,4 & 37,4 & 38 & 0,6 & -28,2 & -29,8 & -1,6 \\ \text { M. H. T. } & -3,8 & -3,8 & 0,3 & 42,2 & 41,4 & -0,8 & -29,1 & -29,2 & -0,1 \\ \text { P. B. B. M. } & -7,1 & -7 & 0,1 & 35,7 & 35,9 & 0,2 & -27,8 & -27,1 & 0,7 \\ \text { P. B. Jr. } & -11,1 & -11,2 & -0,1 & 37,7 & 39 & 1,3 & -30,7 & -30 & 0,7 \\ \text { R. B. R. } & -9 & -8,6 & 0,4 & 35,7 & 35,7 & 0 & -31,4 & -30,1 & 1,3 \\ \text { R. P. F. } & -9,8 & -10,9 & -1,1 & 37,6 & 40,8 & 3,2 & -31,6 & -31,7 & -0,1 \\ \text { R. T. G. } & -11,5 & -8,9 & 2,6 & 35,4 & 42,9 & 7,5 & -30 & -33,2 & -3,2 \\ \text { R. B. A. } & -6,7 & -7,9 & -1,2 & 38,7 & 39,8 & 1,1 & -30,6 & -29,1 & 1,5 \\ \text { R. R. D. } & -7,9 & -9,5 & -1,6 & 33 & 38,2 & 5,2 & -31,5 & -32,9 & -1,4 \\ \text { R. A. S. S. } & -7,8 & -7,5 & 0,3 & 35,3 & 34,9 & -0,4 & -27 & -25,9 & 1,1 \\ \text { S. R. C. } & -8 & -8,7 & -0,7 & 37,1 & 38,7 & 1,6 & -26 & -27,3 & -1,3 \\ \text { T. S. N. Jr. } & -11,2 & -11,3 & -0,1 & 38,3 & 37,7 & -0,6 & -33,7 & -35,1 & -1,4 \\ \text { T. C. S. C. } & -8,8 & -9,7 & -0,9 & 36,7 & 38,4 & 1,7 & -29,4 & -29,8 & -0,4 \\ & & & & & & & & & \end{array}$


APÊNDICE 42 - Valores individuais das grandezas cefalométricas 6-GoMe, relação molar, TH e TV para os pacientes do Grupo Controle.

\begin{tabular}{|c|c|c|c|c|c|c|c|c|c|c|c|c|}
\hline Paciente & $\begin{array}{c}\text { 6- } \\
\text { GoMe1 }\end{array}$ & $\begin{array}{c}\text { 6- } \\
\text { GoMe } 2\end{array}$ & $\begin{array}{c}\text { 6- } \\
\text { GoMe } \\
2-1\end{array}$ & $\begin{array}{l}\text { Rel. } \\
\text { mol } 1\end{array}$ & $\begin{array}{l}\text { Rel. } \\
\text { mol } 2\end{array}$ & $\begin{array}{c}\text { Rel. } \\
\text { mol } \\
2-1\end{array}$ & TH 1 & TH 2 & TH 2-1 & TV 1 & TV 2 & TV 2- \\
\hline B. M. L. & 24,9 & 24,9 & 0 & 1,3 & -2 & $-3,3$ & 2,5 & 4,5 & 2 & 1,4 & 5,7 & 4,3 \\
\hline C. F.Z.S. & 30,5 & 30,9 & 0,4 & $-0,6$ & 1,1 & 1,7 & 4 & 3,5 & $-0,5$ & 5,7 & 3 & $-2,7$ \\
\hline E. F.Z. & 26,9 & 27,8 & 0,9 & $-0,4$ & 0,9 & 1,3 & 2,9 & 2,9 & 0 & 4,5 & 6 & 1,5 \\
\hline E. A. & 31,7 & 32,8 & 1,1 & 0 & $-1,2$ & $-1,2$ & 3,7 & 3,7 & 0 & 5,6 & 5 & $-0,6$ \\
\hline F. B. A. & 28,4 & 29,2 & 0,8 & 1,5 & $-1,5$ & -3 & 5,8 & 7,4 & 1,6 & 5,4 & 6,6 & I,2 \\
\hline J. C. M. Jr. & 26,3 & 28,3 & 2 & 1 & 0,1 & $-0,9$ & 2,6 & 4,2 & 1,6 & 2,1 & 4,6 & 2,5 \\
\hline J. A. R. C. M. & 26,6 & 28,1 & 1,5 & 2 & 2,2 & 0,2 & 4,1 & 3,4 & $-0,7$ & 4,4 & 3,6 & $-0,8$ \\
\hline J. A. A. C. & 28,4 & 28,4 & 0 & $-1,8$ & 0,1 & 1,9 & 4,2 & 4,3 & 0,1 & 9 & 7,5 & $-1,5$ \\
\hline L. B. & 25,1 & 25,4 & 0,3 & 0,9 & 1,9 & 1 & 4 & 2,5 & $-1,5$ & 5,6 & 3,1 & $-2,5$ \\
\hline M. G. T. & 31,4 & 30,7 & $-0,7$ & 0,9 & 1,3 & 0,4 & 3,1 & 4 & 0,9 & 2,6 & 2 & $-0,6$ \\
\hline M. H. T. & 27,1 & 29 & 1,9 & 0,5 & $-0,1$ & $-0,6$ & 4,8 & 5,6 & 0,8 & 4,3 & 4,8 & 0,5 \\
\hline P. B. B. M. & 27,7 & 27,2 & $-0,5$ & 0,8 & 0,8 & 0 & 3,5 & 4,1 & 0,6 & 4,8 & 4,3 & $-0,5$ \\
\hline P. B. Jr. & 27,4 & 27,3 & $-0,1$ & 1,1 & 0,6 & $-0,5$ & 4 & 4,4 & 0,4 & 4,5 & 4,8 & 0,3 \\
\hline R. B. R. & 26,6 & 26 & $-0,6$ & $-0,3$ & 0,2 & 0,5 & 7,1 & 8,2 & 1,1 & 6,9 & 4,6 & $-2,3$ \\
\hline R.P.F. & 28,4 & 32,1 & 3,7 & 0,4 & -1 & $-1,4$ & 5,2 & 5,8 & 0,6 & 5 & 4,2 & $-0,8$ \\
\hline R. T. G. & 25,1 & 32,4 & 7,3 & 2,3 & 2,1 & $-0,2$ & 6,5 & 2,5 & -4 & 5,7 & $-0,6$ & $-6,3$ \\
\hline R. B. A. & 29,1 & 30,4 & 1,3 & 1,8 & 2,7 & 0,9 & 4,5 & 5,2 & 0,7 & 5,3 & 4,9 & $-0,4$ \\
\hline R. R. D. & 23,6 & 28,2 & 4,6 & $-0,2$ & 0,3 & 0,5 & 3,4 & 3,5 & 0,1 & 2,5 & 3 & 0,5 \\
\hline R. A. S. S. & 25,7 & 25,6 & $-0,1$ & 1,8 & 1,4 & $-0,4$ & 6,7 & 7,3 & 0,6 & 3,8 & 5 & 1,2 \\
\hline S. R. C. & 29,5 & 29,6 & 0,1 & 3,2 & 2,6 & $-0,6$ & 5,9 & 5,8 & $-0,1$ & 2,4 & 3,4 & \\
\hline T. S. N. Jr. & 27,1 & 26,6 & $-0,5$ & $-1,7$ & $-1,8$ & $-0,1$ & 8,2 & 7,6 & $-0,6$ & 5,1 & 5 & $-0,1$ \\
\hline T. C.S. C & 26,5 & 27,1 & 0,6 & 0,7 & 0,5 & $-0,2$ & 6,7 & 6,6 & $-0,1$ & 5 & 5,5 & 0,5 \\
\hline
\end{tabular}

